\title{
A GRIPE ESPANHOLA DE 1918
}

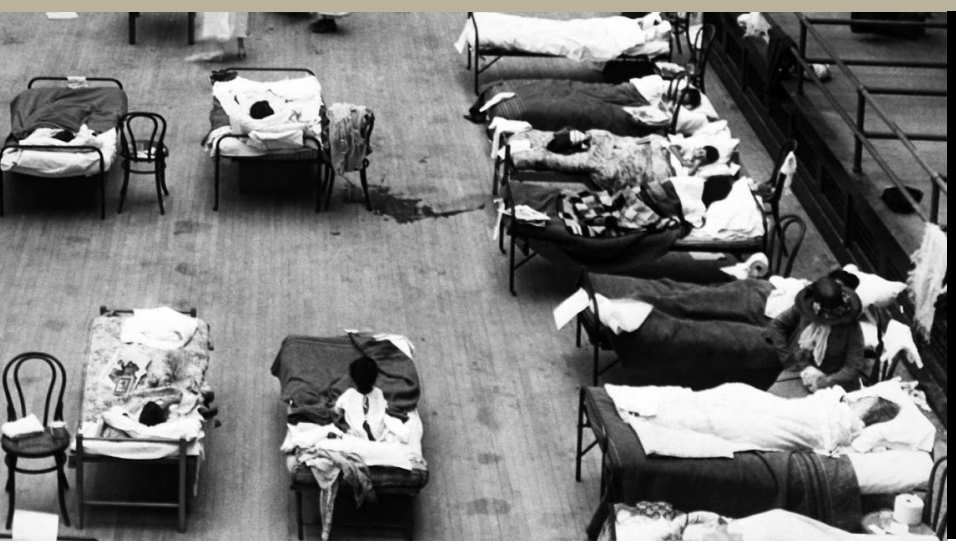

t) casadesarmento

COORD.

ANTERO FERREIRA 
A GRIPE

ESPANHOLA

DE 1918

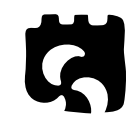

casadesarmento

centro de estudos do património

COORD.

ANTERO FERREIRA 


\title{
FICHA TÉCNICA
}

\author{
TÍTULO \\ A Gripe Espanhola de 1918 \\ COORDENAÇÃO \\ Antero Ferreira
}

\author{
AUTORES \\ Antero Ferreira, Antónia Durán, \\ Aurora Rego, Carlota Santos, \\ Célia Oliveira, Dalton Agostinho, \\ Delminda Rijo, Eunice Relvas, \\ Helena Silva, José Alfredo Faustino, \\ Luís Filipe Vieira, Luís Pimenta Damásio, \\ Manuela Silva, Manuela Ventura, \\ Marcos Mesquita, Maria Isabel Porras Gallo, \\ Maria Norberta Amorim, Mercedes Ramírez Ortega, \\ Milene dos Anjos Fernandes, Odete Paiva, \\ Otília Lage, Rosalina Pisco, Yuri Agostinho
}

\section{CAPA \\ Alexandra Xavier \\ FOTOGRAFIA DA CAPA}

Edward A. "Doc" Rogers, 1873-1960 - Photo by Edward A. "Doc" Rogers. From the Joseph R. Knowland collection at the Oakland History Room, Oakland Public Library.

"Enfermeiros da Cruz Vermelha cuidando de pacientes infectados pelo vírus influenza em Oakland, Califórnia, em 1918."

\section{EDICุÃO}

Casa de Sarmento - Centro de Estudos do Património | UMinho

DESIGN EDITORIAL

Casa de Sarmento e Alexandra Xavier

ISBN:978-989-54723-0-7

DOI: https://doi.org/10.21814/1822.64699

COM O APOIO DE

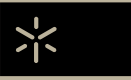


A GRIPE

ESPANHOLA

DE 1918

GUIMARÃES

2020 


\section{Sumário}

Nota de Abertura

Antero Ferreira

Apresentação

Maria Luís da Rocha Pinto

Los efectos de la pandemia de 1918-19 en la lucha contra la gripe en España: el papel de los cambios de percepción del riesgo y la posterior creación de la OMS

Maria Isabel Porras Gallo; Mercedes Ramírez Ortega . . . . . . . . . . .

Aplicação do EpiInfo na análise de dados dos casos notificados da Gripe A (H1N1) em Angola: actuação e experiência

Dalton Ngando José Agostinho; Yuri Agostinho . . . . . . . . . . . . . . .

A Gripe Espanhola no quadro das epidemias históricas da ilha do Faial

Maria Norberta Amorim . . . . . . . . . . . . . . . . . .

A ilha das Flores na rota da gripe espanhola

Luís Filipe Vieira . . . . . . . . . . . . . . . . . . . . . . . 67

O impacto da Gripe Espanhola em Chaves

José Alfredo Faustino . . . . . . . . . . . . . . . . . . . . . . . 8

A gripe no Corpo Expedicionário Português

Helena Silva . . . . . . . . . . . . . . . . . . . . . . 117

Os enterros também se fazem à noite: a pneumónica em Guimarães Antero Ferreira; Célia Oliveira . . . . . . . . . . . . . . . . . . . . . 137

«A epidemia reinante». A Pneumónica no concelho de Lisboa, 1918 Eunice Relvas; Delminda Rijo . . . . . . . . . . . . . . . . . . . . . 161

Impactos da gripe espanhola na região do Alto Minho (Norte de Portugal)

Carlota Santos; Aurora Rego; Manuela Silva; Milene dos Anjos Fernandes

Travar a Doença: reflexão da política de saúde pública e impacto da gripe espanhola em Braga

Marcos Mesquita .. . . . . . . . . . . . . . . . . 21

Evocação da Gripe Pneumónica (1918) em Macedo de Cavaleiros: Uma narrativa ficcional e histórica

Otília Lage 
A "influenza" pneumónica no interior centro do país pelo olhar do jornal A Guarda (1918-1919)

Odete Paiva . . . . . . . . . . . . . . . . . . . . . . . 251

Ecos da Pneumónica na margem sul do Tejo

Manuela Ventura . . . . . . . . . . . . . . . . . . . 267

La Pandemia de Gripe en la Provincia de Badajoz

Antonia Durán ． . . . . . . . . . . . . . . . . . . . 277

Requiem para um modernista: 25 de outubro de 1918

Luís Pimenta Damásio . . . . . . . . . . . . . . . . . . . . . . . . 321

n. Dezembro de 1918. Biografias, Memórias e Histórias de Família

Rosalina Pisco Costa . . . . . . . . . . . . . . . . . 337 


\section{Nota de Abertura}

Esta publicação sobre a "gripe espanhola», a primeira edição da Casa de Sarmento, é um importante marco na história da mais jovem Unidade Diferenciada da Universidade do Minho. Fundada em 2017, suportada num protocolo que a Universidade celebrou com o Município de Guimarães e a Sociedade Martins Sarmento, esta unidade tem como principal missão fortalecer a ligação entre a Universidade e a comunidade, bem como apoiar o desenvolvimento da missão científica e cultural da Sociedade Martins Sarmento. Destaca-se na sua atividade o tratamento, digitalização e divulgação de acervos e o desenvolvimento de projetos de investigação, como é o caso deste conjunto de estudos sobre a «gripe espanhola» de 1918-1919.

A pandemia da «gripe espanhola», ou «pneumónica», irrompe no ano em que termina a I $^{\text {a }}$ Grande Guerra Mundial, em 1918, num contexto de graves dificuldades económicas e sociais. O impacto que teve sobre a mortalidade calcula-se que entre 1918 e 1919 terá provocado a morte a cerca de 50 milhões de pessoas em todo o mundo - ainda hoje constitui uma marca indelével no imaginário coletivo.

Passado um século, a Casa de Sarmento, considerando essencial aprofundar o conhecimento sobre esta pandemia, organizou um encontro científico internacional, que se realizou em Guimarães, na Sociedade Martins Sarmento, entre 25 e 26 de outubro de 2018, em colaboração com a Associação de Demografia Histórica (ADEH), a Associação Portuguesa de Demografia (APD) e o Grupo de Populações e Saúde do CITCEM.

Das jornadas, em que participaram trinta e cinco investigadores, congregando diversas perspetivas, desde a Demografia à História da Saúde, resultou esta publicação, que reúne dezasseis trabalhos que se repartem, fundamentalmente, por três áreas: perspetivas globais sobre a gripe e outras pandemias, estudos de caráter regional e impactos socioculturais da pandemia.

Estamos certos de que este conjunto de estudos será um importante contributo para conhecer melhor uma realidade que só há muito pouco tempo tem acolhido o interesse da comunidade científica e que tem óbvio paralelo com a grave situação epidemiológica que vivemos nos dias de hoje.

Guimarães, 2 de Abril 2020

Antero Ferreira Casa de Sarmento 



\section{Apresentação}

Este livro, resultante das Jornadas de População e Saúde e dedicado à temática "A Gripe Espanhola de 1918", corresponde de forma clara aos objectivos que as Jornadas, que decorreram em Guimarães em outubro de 2018, se propuseram - dar a conhecer sob o ponto de vista local ou regional, uma realidade que nos afectou de uma forma que, passado um século, ainda perdura na memória de parte da população portuguesa. É uma achega importante ao conhecimento da Pneumónica em múltiplas regiões de Portugal e ainda nos traz dois importantes artigos sobre esta temática em Espanha e um outro sobre um método utilizado em Angola para fazer face ao necessário conhecimento da evolução da epidemia de gripe A (H1N1), ocorrida no final da primeira década do século XXI.

Escrevo esta apresentação num momento em que o mundo se debate, de novo, com uma epidemia que, em alguns aspectos, se assemelha ao da Pneumónica de há um século. A leitura deste livro, nos seus diferentes artigos, ao reflectir e aprofundar o conhecimento que temos da epidemia de 1918, quer em alguns aspectos mais gerais (demográficos, socioeconómicos), quer na reacção dos média e dos poderes locais e regionais, mostra-nos, por um lado, o quanto avançamos no controle de epidemias e por outro o quanto as reacções humanas permanecem idênticas.

Não pretendo aqui fazer um resumo dos diferentes artigos do livro, mas tão só chamar a atenção para a importância de que se reveste este conhecimento sobre o passado e para os dias de hoje.

A luta contra a Pneumónica ou Gripe Espanhola, levou muitos países a criarem estruturas que pudessem fazer face à pandemia, com as dificuldades inerentes a um pós- $\mathrm{I}^{\mathrm{a}}$ Guerra Mundial e que, a partir da Liga das Nações ou Sociedade das Nações (1919) terá um primeiro Serviço de Saúde com características internacionais. No entanto, só no pós-II ${ }^{\mathrm{a}}$ Guerra Mundial, com a estruturação das Nações Unidas, é criada, em 1947, a OMS (Organização Mundial de Saúde). É nela que residem hoje as nossas esperanças para um melhor controle e conhecimento das doenças que afectam a humanidade e com um especial papel no que respeita a surtos epidémicos, epidemias ou pandemias. Este processo longo de estruturação de um organismo internacional de saúde começa a surgir após a pandemia da gripe Pneumónica, para a qual, tal como hoje com o Coronavírus (COVID 19), não havia vacina.

A gripe Pneumónica obrigou, quer Portugal, quer Espanha, a montar todo um dispositivo de saúde pública que até aí era inexistente ou muito 
frágil ao nível dos territórios. Em Espanha parece ter sido mesmo o factor desencadeador de um verdadeiro avanço na estrutura de serviços de saúde pública a nível regional que possam estar prevenidos para fazer face a epidemias de doenças contagiosas. O primeiro artigo deste livro, tal como, em parte, o artigo sobre Badajoz são claramente ilustradores deste processo.

Os artigos sobre as diferentes regiões de Portugal, dão-nos um panorama muito interessante sobre o evoluir da gripe, nas suas diferentes vagas, e é possível perceber que sendo quase generalizada no território português a vaga de gripe que explode a partir de Setembro/Outubro e atinge a sua máxima magnitude em Novembro de 1918, é um facto que não foi sentida da mesma forma em todas as regiões abordadas neste livro. As outras vagas, menos intensas, na primavera de 1918 ou na de 1919, nem sempre foram sentidas nas regiões estudadas.

Ao ler estes diferentes artigos, que percorrem algumas das nossas regiões, parece-me claro que Portugal não tinha dispositivos de saúde que pudessem fazer face à epidemia, apesar dos esforços das entidades locais ou regionais e que mesmo a nível nacional foi difícil estruturar uma resposta. Por outro lado, há que ressaltar alguns dos esforços feitos pela sociedade civil, através de comissões de apoio às vítimas. Claras ficam as condições de vida da população em 1918, com Portugal, numa primeira fase ainda a braços com a I ${ }^{\mathrm{a}}$ Guerra e com a carestia por ela provocada, com um surto de tifo exantemático e ainda outro de varíola. Para além disso, a pobreza das populações, não só nas vilas e aldeias, mas também nas nossas maiores cidades - Lisboa e Porto - era uma realidade. Todos estes factores foram potenciadores da grande crise de mortalidade provocada pela Pneumónica.

Torna-se também muito interessante perceber o evoluir das notícias nos jornais. Estes relatos jornalísticos têm características diferentes, não só relativamente à informação prestada sobre o evoluir da epidemia, como também diferenças relativamente às linhas editoriais e políticas a que os mesmos pertenciam.

A partir do artigo sobre Badajoz, vale a pena referir o medo existente nessa província espanhola em relação aos portugueses que aí trabalhavam sazonalmente e cujo contacto os espanhóis não queriam. Em Portugal, a noção era a mesma em relação aos espanhóis. O medo do «outro», e as consequências para a vida social que induz, era forte nesse período, tal como nos dias de hoje.

É óbvio que parece certo que a gripe entrou em Portugal vinda de Espanha, mas a sua designação deve-se, em todo o mundo, ao simples facto de a Espanha não ter entrado na I Guerra e, por isso, não estar a braços com 
os problemas dela resultantes e com algum sigilo que foi mantido em relação à difusão da gripe pelos países envolvidos na guerra, o que fez com que fosse Espanha o primeiro país a relatar nos jornais a existência da epidemia, e daí a designação internacional.

Os dois últimos artigos deste livro têm características um pouco diferentes. Um aborda a pneumónica através da morte de uma das figuras maiores da cultura portuguesa, Amadeu de Souza Cardoso. Torna-se aí claro a forma como a gripe atingiu famílias mesmo da classe alta. O outro, pegando em relatos familiares através da autoetnografia, dá-nos um panorama da gripe na região de Évora.

Este conjunto de artigos aumenta substancialmente o conhecimento que possuíamos da gripe Pneumónica, de investigações anteriores. Têm, contudo, diferentes metodologias de análise, quer dos dados demográficos, sempre que foram tratados, quer das fontes primárias e jornalísticas utilizadas. Esta abordagem é compreensível relativamente a trabalhos apresentados a umas Jornadas abertas à participação dos investigadores interessados nesta problemática. Faz-me, no entanto, pensar o quanto seria importante um projecto de análise estruturado de forma a que todos os resultados fossem comparáveis. Sei das dificuldades de financiamento que, para uma análise da diversidade que esta assumiu, seria necessário. Mas a análise da gripe Pneumónica em territórios com diferentes características demográficas, sociais, económicas e de organização das entidades públicas e da sociedade civil, seria com certeza um contributo importante, não só para o conhecimento do país neste período, como para o presente.

Aveiro, 28 de Fevereiro 2020

Maria Luís Rocha Pinto

UI - GOVCOPP, Universidade de Aveiro 



\title{
LOS EFECTOS DE LA PANDEMIA DE 1918-19 EN LA LUCHA CONTRA LA GRIPE EN ESPAÑA:
}

\author{
EL PAPEL DE LOS CAMBIOS DE PERCEPCIÓN DEL RIESGO Y \\ LA POSTERIOR CREACIÓN DE LA OMS (1918-1969)1
}

\author{
María Isabel Porras Gallo² \\ Mercedes Ramírez Ortega ${ }^{3}$
}

\footnotetext{
1 Trabajo realizado en el marco de los proyectos de investigación financiados por el MINECO/Fondos FEDER (HAR2015-70688-C2-2P) y por la Consejería de Educación (JCCM)/Fondos FEDER (Ref. SBPLY/17/180501/000382), así como de la tesis doctoral de Mercedes Ramírez Ortega titulada La vacunación contra la gripe y el desarrollo de los sistemas de vigilancia en España (1935-2009).

2 Facultad de Medicina de Ciudad Real y Centro Regional de Investigación Biomédica (CRIB). Universidad de Castilla-La Mancha, mariaisabel.porras@uclm.es

3 Facultad de Medicina de Ciudad Real y Centro Regional de Investigación Biomédica (CRIB). Universidad de Castilla-La Mancha, mercedes_ramirez_ortega@hotmail.com
} 



\begin{abstract}
Resumo
La terrible mortalidad de la gripe de 1918-19 impactó durante su desarrollo y más allá de los años inmediatamente posteriores, provocando un cambio en la percepción del riesgo frente a dicha enfermedad y un importante debate sobre sus características, los factores responsables de su magnitud y las medidas de lucha contra ella. Mediante el uso de fuentes archivísticas (OMS, Escuela Nacional de Sanidad e Instituto de Salud Carlos III), fuentes impresas de la OMS, prensa médica y de información general, estudiamos las medidas adoptadas para atender a la situación de emergencia sanitaria generada, las propuestas para corregir las carencias socio-económico-sanitarias presentes en España y lograr su modernización sanitaria para evitar otra pandemia de magnitud similar. Igualmente, analizamos las respuestas ofrecidas en España con la misma finalidad hasta 1969, y el Programa mundial contra la gripe establecido por la OMS en 1947, que incluyó la creación del World Influenza Centre en Londres y la articulación en torno a él de una Red mundial de laboratorios regionales, estableciéndose uno de ellos en España en 1951, poco antes de su incorporación a la OMS. Con ello mostramos los cambios operados en la respuesta frente a las pandemias de gripe de 1957-58 y de 1968-69 en España.
\end{abstract}

Palavras-chave: gripe 1918, OMS, siglo XX, España.

\title{
INTRODUCCIÓN
}

El centenario del desarrollo de la grave pandemia de gripe de 1918-19 se ha acompañado de numerosas iniciativas conmemorativas, como las Jornadas de Populações e Saúde - "A Gripe Espanhola de 1918», celebradas en Guimarães (Portugal), y ha dado lugar a una importante reflexión sobre esta terrible crisis sanitaria desde distintos ámbitos científicos. Como resultado de ello se ha generado una interesante literatura, que está contribuyendo a enriquecer el debate historiográfico existente sobre esta pandemia, que ha tenido un curso no lineal, marcado por fases de «descubrimiento»y «redescubrimiento» acordes con la evolución en las preocupaciones de la sociedad en el siglo ya transcurrido (Phillips, Killingray, 2003: 12-13), la aparición de nuevas pandemias de gripe o de nuevos descubrimientos relacionados con el virus 
de la de 1918-19 y, de modo especial, por el estímulo que supuso la aparición del sida a finales de los ochenta y la conmoción social provocada (Porras Gallo, Davis, 2014: 1-17). A ella han contribuido también las reuniones e iniciativas surgidas con motivo de su ochenta (Phillips, Killingray, 2003) o noventa (Porras Gallo, Davis, 2014) aniversario. Así, los trabajos publicados en los primeros años tras su finalización fueron realizados fundamentalmente por médicos, con muy escasa perspectiva histórica, mientras que los historiadores estuvieron ausentes del debate, incluidos también los historiadores de la medicina, comprensible esto último por haber puesto en jaque esta crisis sanitaria a la ciencia médica del momento, que consideraba «evitables» las enfermedades infecciosas (Porras Gallo, 1994b; 2008). De modo que durante los primeros 40 años tras la pandemia, la historiografía sobre la misma corrió a cargo fundamentalmente de virólogos y epidemiólogos, que trataban de resolver el problema de la etiología de la gripe o anunciaban los nuevos hallazgos, o de explicar su magnitud (Phillips, Killingray, 2003: 14; Porras Gallo, 1994a; 2008), añadiendo en ocasiones cierto dramatismo a sus escritos ante un posible episodio similar, que fue retomado posteriormente en los años noventa y principios del siglo XXI (Porras Gallo, Davis, 2014: 1-17).

Un cambio importante en la historiografía sobre esta pandemia de gripe se produjo en 1976 con la obra Epidemic and Peace del historiador estadounidense Alfred Crosby, que fue seguida de numerosas tesis doctorales en países de varios continentes (EEUU, Canadá, Brasil, Alemania, España, Francia, Gran Bretaña, Suiza, Suecia, Nueva Zelanda, Sudáfrica, Zimbabue y Australia), que aumentaron en número y enfoques en los noventa bajo el impacto del sida. Este conjunto de estudios locales, regionales y urbanos formarían parte de la segunda etapa historiográfica de las quatro establecidas recientemente por el historiador Frédéric Vagneron ${ }^{4}$, y presentan la gripe de 1918-19 como una pandemia universal construida a partir de un mosaico de catástrofes locales, beneficiándose de las aportaciones de la nueva historia social de la medicina y de la salud. Siguiendo a este mismo autor, la tercera etapa estaría integrada por trabajos históricos que, a partir de 1998 y bajo el impacto de la gripe aviar de 1997 y del planteamiento de iniciativas políticas de preparación frente a pandemias, han abordado la gripe de 1918-19 desde distintas perspectivas como una experiencia múltiple, reveladora de las estructuras sociales de las sociedades, de las desigualdades y de la movilización social para llegar a donde los poderes políticos y las élites científicas no lo hacían, pero también relacionando esta crisis sanitaria con la Primera Guerra

4 Para este autor la primera etapa la constituirían todos los estudios sobre la pandemia de gripe de 1918 realizados hasta 1970 (2018: 21-43). 
Mundial. Para Vagneron, la cuarta etapa estaría constituida por los trabajos que ubican el episodio de la pandemia de gripe de 1918-19 en la historia de esta enfermedad desde al menos finales del siglo XIX, y ponen de relieve los desafíos que ha planteado y sigue planteando a la Medicina, a la salud pública y a las personas enfermas (Vagneron, 2018: 21-43). Sin restar validez a la clasificación de la historiografía sobre la gripe de 1918-19 realizada por Fréderic Vagneron, a través del análisis únicamente de una selección de trabajos publicados en francés o inglés, creemos que la complejidad de esta crisis sanitaria ha generado - y sigue generando - una historiografía muy rica, que ha incluido también un análisis del papel desempeñado por la literatura de ficción, los documentales y docudramas, la literatura gráfica juvenil y que está otorgando un destacado lugar a las resonancias socio-culturales de las reacciones y la experiencia pandémica (Porras-Gallo, Davis, 2014). Esta tendencia quedó reflejada también en las Jornadas de Populações e Saúde - «A Gripe Espanhola de 1918» (Guimarães, Portugal) y, muy especialmente, en la reunión celebrada en Frankfurt del 19 al 21 de febrero de 2019, bajo el título «Cultural Histories of the Great Flu Pandemic 1918-1919. Representations and Memories».

En este contexto de reflexión y considerando que la terrible mortalidad producida por la gripe de 1918-19 impactó más allá de los años de su desarrollo y de los inmediatamente posteriores, provocando un cambio en la percepción del riesgo frente a dicha enfermedad, analizamos los efectos de la pandemia de 1918 en la articulación de la lucha contra la gripe en España entre 1918 y 1969, prestando especial atención al papel desempeñado por los cambios de percepción del riesgo frente a dicha enfermedad y al impacto del programa mundial contra la gripe de la OMS en España y de los programas país de dicha agencia internacional. De esta forma se puede advertir el importante debate suscitado durante la pandemia, promovido principalmente por médicos, farmacéuticos, algunas autoridades sanitarias y la población a través de la prensa general, para denunciar el papel de las insuficiencias higiénico-sanitarias de España y de la escasez y carestía de subsistencias y medicamentos en la gravedad alcanzada por la gripe de 1918-19, pero también planteando soluciones para corregir dichas carencias socio-económicosanitarias y efectuar una modernización sanitaria del país, demandada desde finales del siglo XIX. Como se verá, la respuesta de los políticos a las denuncias planteadas fue bastante limitada. El trabajo muestra los proyectos propuestos para conseguir los cambios demandados que no fueron aprobados, pero también las escasas medidas tomadas, cuya materialización se retrasaría en muchos casos hasta finales de los años veinte y treinta del pasado siglo. La 
parte final de la exposición está dedicada a señalar los efectos del programa contra la gripe de la OMS y de algunos de los programas colaborativos de dicha agencia internacional, como el España-25 (E25) entre 1959 y 1969 en la lucha contra esta enfermedad. Ello permite además poner de relieve los cambios operados en la respuesta ofrecida frente a las pandemias de gripe de 1957-58 y de 1968-69.

Para la realización de nuestro trabajo hemos utilizado fuentes archivísticas - del archivo histórico de la OMS (Ginebra, Suiza), del de la Escuela Nacional de Sanidad e Instituto de Salud Carlos III (Madrid, España), fuentes impresas de la OMS, prensa médica y una selección de los principales diarios españoles contemporáneos al período de estudio.

\section{UNA CRISIS SANITARIA EN UN CONTEXTO COMPLICADO}

La pandemia de gripe de 1918-19 estuvo marcada por el desarrollo de la Primera Guerra Mundial y su impacto, tanto en los países que participaron en la contienda como en los que no lo hicieron, como fue el caso de España, que se hallaba además inmersa en una profunda crisis política, económica y social. La inestabilidad política era tan profunda que algunos gobiernos duraron un mes o mes y medio en el bienio de la pandemia. Aunque la actividad comercial exterior aumentó durante los años de la contienda mundial mejorando la macroeconomía española, la población estuvo sometida a muchas penurias, enfrentándose a la escasez y carestía de subsistencias y de medicamentos, que adquirió mayor gravedad durante la pandemia, pero también a unas viviendas insalubres en las que la población se hacinaba (Porras Gallo, 1994a; 1997).

En el ámbito sanitario la situación tampoco era mucho mejor. Nuestro país carecía de una legislación sanitaria moderna y de unas mínimas infraestructuras, que permitieran abordar los problemas de salud conforme a los nuevos principios de la Medicina, que suponía la búsqueda y el aislamiento del germen específico de las enfermedades infecciosas y la inmediata fabricación del suero y la vacuna específicos correspondientes para tratar y prevenirlas (Porras Gallo, 1994a; 1997; 2008). En el caso de la gripe, Richard Pfeiffer propuso en 1892 que el haemophilus influenzae era su agente específico (Théodorides, 1974: 188) y, aunque fue cuestionado ese papel en los primeros años del siglo XX, esa era la doctrina etiológica oficial cuando estalló la pandemia de 1918-19.

Pues bien, en el contexto descrito y con los profesionales sanitarios (médicos, farmacéuticos y veterinarios) en un proceso de reorganización profesional (Porras Gallo, 1994a; 1997; 2009), la gripe hizo su irrupción en Madrid 
en mayo de 1918, alcanzando carácter epidémico hacia mediados de dicho mes, como fue puesto de relieve por la prensa médica y, algo más tarde, por los principales diarios de información general locales y de tirada nacional, en los que fue catalogada como «epidemia benigna» $(A B C, 22$ de mayo de 1918: 7). La benignidad fue señalada igualmente por algunos de los médicos colaboradores habituales de la prensa general, pese a que el número de personas afectadas fue en aumento hasta alcanzar su máximo entre el 27 de mayo y el 10 de junio y los datos de mortalidad mostraron la gravedad de este primer brote en la ciudad de Madrid (Porras Gallo, 1994a; 1997). A pesar de ello las autoridades municipales rápidamente dieron por finalizada la epidemia, situación no admitida por el colectivo médico hasta un mes más tarde (Porras Gallo, 1994a; 1997). Tras el paréntesis del verano la gripe reapareció nuevamente, adquiriendo mayor gravedad que el primer brote en buena parte de España, con algunas excepciones como Madrid. Tras haberse sometido a la censura ejercida por las autoridades políticas sobre la prensa para que ocultaran la magnitud del segundo brote, los principales diarios madrileños y los de tirada nacional decidieron no callar más y denunciar la ocultación que se estaba haciendo a nivel oficial. Justificaban su decisión por el perjuicio que ello entrañaba para la ciudadanía, no sólo por la pérdida de confianza generada por el engaño, sino porque ello implicaba abandonar la defensa de los intereses de la colectividad y restringir la adopción de precauciones ( $E l$ Liberal, 15 de octubre de 1918: 1).

Pues bien, fue precisamente durante el desarrollo del segundo brote epidémico cuando cambió la percepción social del riesgo frente a la gripe ante la intensidad alcanzada por la enfermedad, la gran mortalidad producida, muy especialmente en población adulta joven y sana (20-40 años), y la incapacidad para controlar la epidemia con los recursos empleados habitualmente por la Medicina frente a las tradicionales crisis sanitarias (peste, fiebre amarilla, cólera o la gripe de 1889-90). La alarma y el pánico se adueñaron de la ciudadanía, que además sentía desconfianza frente a las autoridades políticas y la clase médica. Con la colaboración de la prensa, denunció el retraso en la toma de medidas por las autoridades, al igual que había hecho durante el primer brote, y responsabilizó a las malas condiciones socio-económicosanitarias estructurales y coyunturales de España de la gravedad alcanzada por la epidemia (Porras Gallo, 1995). Las páginas de los principales diarios se hicieron eco también de las dudas y dificultades que estaba teniendo la clase médica para enfrentarse a la gripe en 1918 desde el mismo momento de su inicio, que se incrementaron durante el segundo brote (Porras Gallo, 1994a; 1995). 
Al igual que en la mayor parte del mundo, la gripe reapareció por tercera vez en España en la primavera de 1919, relacionada como las dos anteriores con la incorporación y el movimiento de los reclutas, y de la que se hizo eco también la prensa ${ }^{5}$, siendo reconocida explícitamente a primeros de marzo de 1919 en la Real Orden del Ministerio de Gobernación, en la que también se señalaba que «por tercera vez [invadía] casi todos los países de Europa» ${ }^{6}$.

A lo largo de los tres brotes señalados, la gripe provocó unas 270.000 víctimas en España (Echeverri Dávila, 1993), una cifra cercana a las muertes provocadas directamente por la Guerra Civil española en 3 años, lo que da una idea de la gran magnitud que esta pandemia tuvo en España y de la huella que dejó en la sociedad española durante generaciones. Quienes sobrevivieron hicieron frecuentemente un pacto de silencio para tratar de afrontar la terrible experiencia vivida y la pérdida de tantas vidas. Esto explica la ausencia de información durante muchos años sobre esta pandemia, como ocurrió también fuera de nuestro país, pero también la respuesta dada por los profesionales sanitarios (médicos, farmacéuticos y veterinarios) durante su desarrollo y décadas posteriores.

\section{LOS MÉDICOS Y FARMACÉUTICOS ESPAÑOLES ANTE LA PANDEMIA DE GRIPE DE 1918-19}

El aumento de morbilidad a mediados de mayo de 1918 en la ciudad de Madrid, por lo que fue diagnosticado como gripe, generó inquietud entre los médicos, pese al aparente carácter benigno que poseía. Preocupaba que su gran difusión pudiera provocar no sólo la perturbación de la vida normal, sino también la alarma entre la ciudadanía (Arredondo, 1918: 321). Expresión de dicha preocupación fueron los debates registrados en la Real Academia Nacional de Medicina, las principales revistas médicas y la prensa de información general, casi desde el propio inicio, que se repetirían cuando reapareció la epidemia tras el verano (Porras Gallo, 1994a).

Junto a descripciones de lo que estaba ocurriendo, los médicos se interrogaron sobre la enfermedad responsable de la epidemia, realizando rápidamente el diagnóstico clínico de gripe. Sin embargo, como señaló José Codina

\footnotetext{
5 «Barcelona. La epidemia gripal», El Heraldo de Madrid, 16 de febrero de 1919: 3; «La salud en España. Más casos gripales», $A B C, 14$ de febrero de 1919: 17; «La gripe. Reaparición en Córdoba», El Heraldo de Madrid, 2 de marzo de 1919: 2; «Renace la gripe. Médicos para la epidemia», El Sol, 5 de marzo de 1919: 2; «Los reclutas y la gripe», El Socialista, 3481, 18 de febrero de 1919: 1.

6 «Ministerio de la Gobernación. Real Orden Circular». Gaceta de Madrid, 63: 800.
} 
Castellví (1867-1934) en la sesión de la Real Academia Nacional de Medicina del 25 de mayo de 1918, el diagnóstico de una enfermedad infecciosa exigía el apoyo del laboratorio para su confirmación bacteriológica ${ }^{7}$. En este caso, como adelantamos, el laboratorio debía aislar únicamente el bacilo de Pfeiffer en todas las personas afectadas por el cuadro clínico de gripe, pero dicho bacilo no siempre estaba presente, aislándose otras bacterias (estreptococos, neumococos, etc.), solas o constituyendo una asociación bacteriana ${ }^{8}$. Estos resultados del laboratorio y la falta de consenso registrado entre los profesionales sanitarios (fundamentalmente médicos y farmacéuticos ${ }^{9}$ ) cuestionaron el diagnóstico de gripe, crearon confusión y desconfianza, que se trasladó a la ciudadanía y acentuó un aumento de la percepción del riesgo de esta enfermedad, que se vio reforzado por la elevada mortalidad registrada. Y es que, conforme la doctrina bacteriológica, la imposibilidad de aislar y establecer el germen específico de la gripe, impedía contar con un tratamiento y un recurso profiláctico específicos, pero la gravedad de la crisis sanitaria exigía una respuesta (Porras Gallo, 1994a: 311-337; 1997; 2008).

Bajo la presión de las circunstancias los médicos recurrieron al tratamiento empleado en epidemias anteriores, pero también a la administración de sueros ya usados, como el antidiftérico, o los nuevos - antiestreptocócico y antineumocócico - fabricados a partir de los resultados arrojados por la investigación bacteriológica ${ }^{10}$. Pese a ello no se pudo reducir el impacto de-

\footnotetext{
7 Sesión del 25 de mayo de 1918. Anales de la Real Academia Nacional de Medicina, 38: 310-319.

8 Sesión del 1 de junio de 1918. Anales de la Real Academia Nacional de Medicina, 38: 319-333. Sesión del 28 de junio de 1918. Anales de la Real Academia Nacional de Medicina, 38: 374-387. Sesión del 2 de noviembre de 1918. Anales de la Real Academia Nacional de Medicina, 38: 425-430. Sesión del 9 de noviembre de 1918. Anales de la Real Academia Nacional de Medicina, 38: 430-449. Sesión del 2 de marzo de 1919. Anales de la Real Academia Nacional de Medicina, 39: 152-170.

9 Aunque una de las vías propuestas por un sector de la clase farmacéutica para lograr su renovación y una mejor instalación social, era la participación en los debates científicos, junto con los médicos, fueron una minoría de farmacéuticos quienes la siguieron, como Herrero de la Orden, miembro de la Asamblea de Subdelegados de Sanidad o César Chicote (1861-1950), Director del Laboratorio Municipal de Madrid. Este último tuvo un papel mucho más activo, participando en los debates de la Real Academia Nacional de Medicina y preparando una vacuna contra la gripe, o más bien contra sus complicaciones, que ofreció a todos los médicos que lo desearan para su uso (Porras Gallo, 2008; 2009).

10 Sesión del 25 de mayo de 1918. Anales de la Real Academia Nacional de Medicina, 38: 310-319. Sesión del 1 de junio de 1918. Anales de la Real Academia Nacional de Medicina, 38: 319-333. Sesión del 15 de junio de 1918. Anales de la Real Academia Nacional de Medicina, 38: 353-359. Sesión del 26 de octubre de 1918. Anales de la Real Academia Nacional de Medicina, 38: 403-424. Sesión del 23 de noviembre de 1918. Anales de la Real Academia Nacional de Medicina, 38: 511-528.
} 
mográfico, incrementándose inclusive durante el segundo brote. Tampoco se logró reducir su difusión, dada la imposibilidad de fabricar una vacuna específica, pero ello no impidió - como hicieron otros países europeos y los Estados Unidos - la elaboración y aplicación de varias vacunas - mixtas o contra un solo germen de los aislados ${ }^{11}$ - elaboradas generalmente por médicos, pero también por farmacéuticos, como hizo César Chicote (1861-1950) desde la dirección del Laboratorio Municipal de Madrid ${ }^{12}$. Estas vacunas llegaron al final del segundo brote, tuvieron escasos resultados por cuanto carecían de especificidad frente a la gripe y eran únicamente útiles contra las complicaciones respiratorias bacterianas (Porras Gallo, 2008).

Los médicos se sintieron desarmados, abrumados por la gravedad de la pandemia y cuestionados por la ciudadanía, como mostraron los medios de comunicación (Porras Gallo, 1994a; 1995). En estas condiciones y coincidiendo con el momento más grave del segundo brote, un sector importante de la clase médica relacionó la gran magnitud de la gripe de 1918-19 con las carencias existentes a nivel sociosanitario en nuestro país. Se subrayó el negativo impacto de la insuficiente alimentación de la población, de la falta y carestía de subsistencias y medicamentos, de las viviendas insalubres y del hacinamiento en la evolución de la epidemia. La gran mortalidad epidémica se relacionó también con los insuficientes recursos sanitarios existentes y la falta de una legislación sanitaria adecuada a los nuevos tiempos, expresiones ambas del retraso sanitario de España, así como con la escasa y tardía respuesta adoptada por los poderes políticos frente a la gripe de 1918 (Porras Gallo, 1994a: 352-372).

Tras explicar la magnitud de la crisis sanitaria como consecuencias de los factores socio-sanitarios indicados, que permitía evitar admitir el fracaso de la Medicina bacteriológica y salvaba el prestigio de la clase médica, estos profesionales propusieron un conjunto de medidas para evitar nuevas catástrofes similares. Sus propuestas incluían el abaratamiento de los alimentos y los medicamentos, la construcción de viviendas salubres y baratas para mejorar las condiciones higiénico-económicas de la población, pero también la

\footnotetext{
11 Sesión del 28 de junio de 1918. Anales de la Real Academia Nacional de Medicina, 38: 374-387. Sesión del 9 de noviembre de 1918. Anales de la Real Academia Nacional de Medicina, 38: 430-449. Sesión del 12 de noviembre de 1918. Anales de la Real Academia Nacional de Medicina, 38: 449-464. Sesión del 23 de noviembre de 1918. Anales de la Real Academia Nacional de Medicina, 38: 511-528.

12 Recordemos que la primera cátedra de Microbiología, técnica bacteriológica y preparación de sueros medicinales creada en España fue en los estudios de Doctorado de Farmacia en 1900, mientras que la carrera de Medicina no dispuso de una propia sobre este tema hasta 1931 (Mosso Romeo; de la Rosa Jorge, 2019: 127-128).
} 
corrección de las deficiencias sanitarias - organizativas y de infraestructuras - existentes y la ansiada modernización sanitaria del país, con lo que se reforzaría además el papel social de la clase médica, que lograría con ello algunas de sus viejas reivindicaciones profesionales (Porras Gallo, 1994a: 372-398; 1997).

No es objeto de este trabajo detallar dichas propuestas, pero sí queremos mencionar algunas de ellas como expresión del papel que tuvo la gran pandemia de gripe de 1918 en la transformación socio-sanitaria, o más bien en el intento de transformación socio-sanitaria en España, porque muchas medidas no salieron adelante hasta años o décadas más tarde, como ocurrió por ejemplo con la creación de un Ministerio de Sanidad ${ }^{13}$, que no ocurrió hasta 1977, o el establecimiento del seguro de enfermedad o de los seguros sociales, que no se produjo el primero de ellos hasta 1942 y no fue hasta finales de los años sesenta cuando se puede decir que se contó con casi todos los demás. Si con el Ministerio de Sanidad se buscaba dar más importancia a todo lo que tenía que ver con la salud de la población y conseguir una cierta independencia de los continuos vaivenes políticos, con el seguro de enfermedad o los seguros sociales se pretendía corregir las deficiencias socio-económicas y, a la vez, las sanitarias, mejorando también la profilaxis pública de las enfermedades infecciosas (Porras Gallo, 1994b). Sin duda, la propuesta más ambiciosa fue el establecimiento de un completo Plan Nacional de Reforma de la Sanidad, que trató de englobar las medidas ya indicadas y otras muchas más concretas y parciales, que implicaban mejoras en infraestructuras para atender las enfermedades infecciosas, creación de laboratorios bacteriológicos, cambios organizativos, mejoras de la formación y las condiciones de los profesionales sanitarios, etc. Este plan no salió adelante no sólo por su alto coste, sino también por las discrepancias entre distintos sectores de la profesión médica, entre ésta y los farmacéuticos y/o los veterinarios, sobre el reparto de tareas en el nuevo orden sanitario (Porras Gallo, 1994b; 2009).

\section{RESPUESTA DE LAS AUTORIDADES POLÍTICAS Y SANITA- RIAS}

Como hemos adelantado y suele ser habitual en la gestión política de las crisis epidémicas, la respuesta de las autoridades llegó tarde no sólo en el primer brote, sino también en los siguientes. Sus acciones y medidas tuvie-

13 Desde la aprobación de la Instrucción General de Sanidad, los asuntos de Sanidad e Higiene Pública dependían del Ministerio de la Gobernación. Artículo 1 de la Instrucción General de Sanidad. Gaceta de Madrid, 22, 22 de enero de 1904: 273. 
ron fundamentalmente dos finalidades: por un lado, atender a la situación de emergencia existente y, por otro, corregir algunas de las deficiencias estructurales socio-sanitarias para buscar una mejora a largo plazo, respondiendo con ello a algunas de las demandas de los profesionales sanitarios.

Entre las primeras medidas, tranquilizar a la población era una prioridad y recurrir a la ciencia médica ayudaba a ello y ofrecía además una imagen de modernidad. De ahí que se combinaran diferentes medidas. Se reforzó la atención sanitaria domiciliaria y hospitalaria (habilitando nuevos espacios para ingresar a las personas enfermas) y se adoptaron las habituales medidas de Higiene Pública (riego de calles y aceras, limpieza de patios, desinfección de locales, habitaciones, matadero y mercados, cierre centros públicos docentes, etc.). Igualmente, se proporcionaron subsidios a los obreros o comedores de caridad y otras acciones locales puestas en marcha por algunas Sociedades de Socorro Mutuo ${ }^{14}$, se tomaron medidas para tratar de controlar el precio de los medicamentos solicitando la opinión de la Real Academia Nacional de Medicina sobre los recursos terapéuticos y profilácticos contra la gripe y se pidió la declaración jurada de todas las existencias que tenían los farmacéuticos y productores. De igual modo se trató de controlar la calidad de la leche que se vendía, se aprobaron créditos por 2 millones de pesetas para adquirir trigo, medicamentos y otras subsistencias, pero además se llevó a cabo la desinfección de mercancías y viajeros, pese a no reconocérsele valor científico $^{15}$.

Por lo que se refiere al segundo grupo de acciones, con las que se buscaba corregir las deficiencias socio-sanitarias existentes en España, tras intensos debates parlamentarios, se incluyeron algunas mejoras relacionadas con los profesionales sanitarios (médicos y farmacéuticos) y con la infraestructura y la organización sanitarias, pero también con las condiciones de vida de la población (Porras Gallo, 1994a; 1997), de las que no nos ocupamos en este trabajo. Entre las medidas aprobadas que tenían un impacto positivo en el personal sanitario, cabe señalar la aprobación del Reglamento referente a la elaboración y venta de especialidades farmacéuticas ${ }^{16}$ y del relativo a la

\footnotetext{
14 Como ha sido estudiado por Pilar León (2014) para el caso de La Conciliación, Unión Productora, Unión Obrera y Artesanos en la ciudad de Pamplona (España).

15 Sesión del 16 de noviembre de 1918. Anales de la Real Academia de Madrid, 38: 478-479.

16 Real Decreto del Ministerio de la Gobernación del 6 de marzo de 1919 relativo al Reglamento para la elaboración y venta de especialidades farmacéuticas. Gaceta de Madrid, 72, 13 de marzo de 1919: 934-936.
} 
elaboración y venta de sueros y vacunas ${ }^{17}$, la obligación de los ayuntamientos de incluir en sus presupuestos los haberes de los médicos titulares ${ }^{18}$, un Decreto fijando los honorarios de los Inspectores municipales de Sanidad ${ }^{19}$, modificación de los requisitos de las oposiciones al Cuerpo de Inspectores Provinciales de Sanidad y la convocatoria de oposiciones a dicho Cuerpo ${ }^{20}$. Junto a ellas se aprobaron otras que suponían mejoras en la organización e infraestructura sanitarias, como la introducción de cambios en la recogida y el envío de datos estadísticos de morbilidad y mortalidad por enfermedades infecciosas ${ }^{21}$, el establecimiento de laboratorios municipales en las capitales y poblaciones que carecieran de ellos ${ }^{22}$, la adquisición de los terrenos destinados a la construcción del Hospital de epidemias (denominado hospital del Rey u Hospital Nacional de enfermedades infecciosas) ${ }^{23}$, disposiciones generales sobre prevención contra las enfermedades infecciosas ${ }^{24}$, una nueva organización del Ministerio de la Gobernación ${ }^{25}$ y la refundición de los Servicios de Sanidad del Campo en la Inspección General de Sanidad ${ }^{26}$, la reorganización

17 Real Decreto del Ministerio de la Gobernación del 10 de marzo de 1919 relativo al Reglamento para la elaboración y venta de vacunas y sueros. Gaceta de Madrid, 72, 13 de octubre de 1919.

18 Real Orden Circular del Ministerio de la Gobernación relativa a la obligación de los Ayuntamientos de incluir en sus presupuestos los haberes de los médicos titulares. Gaceta de Madrid, 75, 16 de marzo de 1919: 1020.

19 Real Decreto del Ministerio de la Gobernación fijando los honorarios de los Inspectores municipales de Sanidad... Gaceta de Madrid, 269, 26 de septiembre de 1919: 1025-1026.

20 Real Orden del Ministerio de la Gobernación disponiendo que se convoquen oposiciones para el ingreso en el Cuerpo de Inspectores Provinciales de Sanidad. Gaceta de Madrid, 301, 28 de octubre de 1919: 398.

21 Real Orden del Ministerio de la Gobernación del 6 de agosto de 1919 relativa a cambios introducidos en la forma de recoger y enviar los datos estadísticos de morbilidad y de mortalidad por enfermedades infecciosas de cada localidad. Gaceta de Madrid, 219, 7 de agosto de 1919: 459-460.

22 Real Orden del Ministerio de la Gobernación del 3 de octubre de 1919 relativa al establecimiento de laboratorios municipales... Gaceta de Madrid, 278, 5 de octubre de 1919: 57.

23 Real Decreto del Ministerio de Hacienda del 3 de diciembre de 1918 relativo a la adquisición de unos terrenos... Gaceta de Madrid, 337, 3 de diciembre de 1918: 854.

24 Real Decreto del Ministerio de la Gobernación del 10 de enero de 1919 relativo a la prevención de las enfermedades infecciosas. Gaceta de Madrid, 23, 23 de enero de 1919: 308-310.

25 Real Decreto del Ministerio de la Gobernación del 31 de enero de 1919 relativo a la nueva organización sanitaria del Ministerio de la Gobernación. Gaceta de Madrid, 46, 15 de febrero de 1919: 579-581.

26 Real Decreto del Ministerio de la Gobernación disponiendo que queden refundidos en la Inspección General de Sanidad los Servicios de Sanidad del Campo. Gaceta de Madrid, 47, 16 de febrero de 1919: 605 . 
de la Beneficencia y creación de la Dirección General de Beneficencia ${ }^{27}$ y el encargo al INP de la redacción de un proyecto de ley de seguro de paro forzoso ${ }^{28}$.

Además, hubo otras propuestas que no prosperaron, como la aprobación de un completo Plan Nacional de Reforma de la Sanidad, planteado por el Ministro de la Gobernación en el verano de 1919 a la clase médica y la farmacéutica, pero no a los veterinarios. Dicho plan recogía medidas que habrían implicado una verdadera modernización sanitaria de España, por cuanto suponían una gran transformación organizativa de la Sanidad española (como la creación de un Ministerio de Sanidad, por ejemplo) y una importante mejora de sus infraestructuras sanitarias y de la situación de las profesiones sanitarias, que habría dado prácticamente respuesta a todas las demandas realizadas por médicos y farmacéuticos durante la pandemia. Sin embargo, desacuerdos entre distintos sectores médicos y entre éstos y los farmacéuticos y los veterinarios, junto a su alto coste, impidieron su materialización práctica (Porras Gallo, 1994a; 1997: 99).

\section{BAJO EL IMPACTO DE LA PANDEMIA DE 1918-19}

Ahora bien, es importante indicar que la materialización práctica de la mayoría de las medidas que hemos indicado que sí fueron aprobadas para tratar de evitar crisis sanitarias en España tan graves como la pandemia de gripe de 1918-19, se demoró hasta los años veinte y se vio facilitado por el apoyo brindado por la Fundación Rockefeller. En efecto, tras la reinstalación de la Dirección General de Sanidad en 1922 y la firma del acuerdo ese mismo año entre España y la Fundación Rockefeller, que entró en vigor en 1924, bajo la Dictadura de Primo de Rivera, se fundó la Escuela Nacional de Sanidad (Madrid), inspirada en la School of Hygiene and Public Health de la Johns Hopkins University, para proporcionar la demandada formación especializada en Salud Pública a los médicos destinados en la administración sanitaria española. Su actividad no comenzó hasta 1925 (Bernabeu Mestre, 1994; 2009-2010; Barona, Bernabeu Mestre, 2008), el mismo año en que se inauguró el Hospital Nacional de enfermedades infecciosas u Hospital del Rey,

\footnotetext{
27 Real Decreto del Ministerio de la Gobernación relativo a la reorganización de la Beneficencia y a la creación de la Dirección General de Beneficencia. Gaceta de Madrid, 291, 18 de octubre de 1919: 257-259.

28 Real Orden del Ministerio de la Gobernación encargando al Instituto Nacional de Previsión la redacción de un anteproyecto de Ley sobre el seguro de paro forzoso. Gaceta de Madrid, 269, 26 de septiembre de 1919: 1026-1027.
} 
y se promulgó el Reglamento de Sanidad Provincial, que creaba los Institutos Provinciales de Higiene como centros técnicos responsables de la administración sanitaria periférica, bajo la dirección de los Inspectores Provinciales de Sanidad. Con ello se ponían en marcha algunas de las propuestas y demandas realizadas durante la pandemia de gripe de 1918-19 y se pasaba a la denominada por Rodríguez Ocaña como etapa de consolidación de la Salud Pública, que se extendió hasta 1957 (Rodríguez Ocaña, 2001a; 2001b). Esta estapa se vería completada con la creación del Cuerpo de Inspectores Municipales de Sanidad, mediante el Reglamento de Sanidad Municipal de 1926, que les otorgaba cierta autonomía frente a los poderes locales, y fijaba nuevamente la obligación de establecer oficinas municipales de higiene. Sin embargo, una vez más, la materialización práctica de dichas medidas se demoró, no sólo por problemas de financiación sino también por la escasa prioridad política otorgada a la salud, como puso de relieve el Informe elaborado por Charles A. Bayle, experto enviado a España por la Fundación Rockefeller entre diciembre de 1924 y abril de 1926.

El contenido de dicho informe fue responsable de que, en 1927, se propusiera la financiación mancomunada de los Institutos Provinciales de Higiene por los ayuntamientos, para facilitar su desarrollo real y el desempeño de sus funciones, y también de la creación del Servicio Epidemiológico Central, que contó con financiación de la Fundación de Rockefeller. Esta nueva institución y el Hospital del Rey alcanzaron gran protagonismo con motivo de la epidemia de poliomielitis registrada en Madrid y algunas localidades cercanas en otoño de 1929 (Porras Gallo et al., 2013). Es importante resaltar la importancia que la colaboración de la Fundación Rockefeller tuvo en la modernización sanitaria de España, aunque se efectuara lentamente (Rodríguez Ocaña, 2000; Barona, 2015; Weindling 1993; 1995). Este tipo de colaboración de agencias internacionales se repetiría posteriormente durante el periodo franquista.

Además, el Informe de Bayle denunció la escasez de personal sanitario cualificado y de dedicación completa, recomendó la concesión de becas de formación especializada en el extranjero, y apoyo económico para algunas actuaciones concretas (paludismo y anquilostomosis minera). Estas recomendaciones fueron seguidas, beneficiándose así del programa de becas 45 profesionales sanitarios españoles (médicos, enfermeras, matronas, ingenieros) entre 1925 y 1936. Uno de ellos fue Manuel Tapia Martínez (1895-1971), director del Hospital del Rey, y otro fue Laureano Albaladejo García-Berenguer, director del Servicio Epidemiológico Central. Ambos y las instituciones que dirigían, tuvieron una destacada labor durante la epidemia de poliomielitis de 1929 en Madrid, permitiendo una actuación clínica y epidemiológica 
moderna, sustancialmente diferente con respecto al habitual manejo de este tipo de problemas de salud pública, al haberse beneficiado de algunos de los elementos de modernización sanitaria (Porras Gallo et al., 2013).

Paralelamente, fuera de nuestras fronteras, la investigación tendente a aclarar la etiología de la gripe continuó desarrollándose con la esperanza de que ello posibilitaría encontrar finalmente una vacuna específica y eficaz. Con el aislamiento del primer virus de la gripe en 1933 por W. Smith, Ch. Andrewes y P. P. Laidlaw, se impulsó la búsqueda de una vacuna contra la gripe, disponiéndose de las primeras que demostraron eficacia a partir de 1936 en Estados Unidos, Gran Bretaña y la URSS, que fueron probadas principalmente en población militar (Kilbourne, 2011). El fantasma de la gripe de 1918 cobró mayor relevancia durante la II Guerra Mundial. Se temía que se pudiera repetir lo sucedido durante la Gran Guerra, razón por la que se intensificó la inmunización de los militares y se comercializó la primera vacuna en los EEUU (Fiore; Bridges; Cox, 2009). Sin embargo, las esperanzas generadas con las primeras vacunas se empezaron a desvanecer casi inmediatamente ante los fallos en la protección, ligados a la variabilidad antigénica del virus que hoy sabemos es prácticamente continua (Kilbourne, 2011). Esta situación fue una de las razones del establecimiento del Programa contra la gripe por la OMS en 1947 (Ramírez; Porras Gallo, 2014; Porras Gallo; Ramírez, 2017).

Dicho programa se inició con la creación del World Influenza Center en Londres, dirigido por Christopher H. Andrewes, uno de los responsables del aislamiento del primer virus de la gripe, y la articulación de una Red mundial de laboratorios regionales para mejorar el conocimiento y el control de la gripe y evitar una catástrofe similar a la de 1918. Este programa se fue transformando en las décadas siguientes a su puesta en marcha y muy especialmente con las experiencias de las pandemias de gripe de 1957-58 y 1968-69, y, más recientemente, de otras amenazas sanitarias como la gripe aviar (1997), el SARS (2002-2003) o la pandemia de 2009-2010.

\section{EL IMPACTO DE LA ENTRADA DE ESPAÑA EN LA OMS EN LA LUCHA CONTRA LA GRIPE}

El establecimiento de la dictadura franquista en España tras la Guerra Civil supuso su exclusión inicial de los organismos internacionales creados al término de la II Guerra Mundial. Esta situación cambió en 1951, cuando nuestro país fue admitido en la OMS (Ballester Añón, 2016). Con ello comenzó una nueva etapa en la lucha contra la gripe, marcada por la designación del 
laboratorio del Servicio de Virus de la Escuela Nacional de Sanidad, dirigido por Florencio Pérez Gallardo, como nuestro primer Centro nacional de gripe perteneciente a la red de laboratorios regionales de la $\mathrm{OMS}^{29}$, integrada entonces por 57 centros, que se hallaban ubicados en 46 países diferentes.

Esta decisión tuvo gran relevancia para la consolidación futura de la virología en España, pese a que en 1951 las condiciones de dicho laboratorio estaban bastante alejadas de los estándares internacionales y aún España no pertenecía a la OMS ni siquiera había solicitado su ingreso a dicha agencia internacional. Es cierto que en él se aisló el virus de la epidemia de gripe de 1950-51 (Ramírez; Porras, 2014), gracias en buena medida a la experiencia previa alcanzada en el Instituto Nacional de Higiene de Alfonso XIII antes de la Guerra Civil y al relevante papel desempeñado en él por Eduardo Gallardo (Porras Gallo, 2019: 96-98; Báguena Cervellera, 2015: 94-97; Rodríguez Ocaña, 2014).

Sin embargo, no fue hasta finales del periodo franquista y primeros años de la denominada Transición democrática, cuando la institución heredera del Servicio de Virus de la Escuela Nacional de Sanidad alcanzó los estándares internacionales. En ello tuvo mucho que ver las ayudas de la OMS, recibidas mediante los denominados proyectos colaborativos o programas-país entre 1952 y 1975 (Ballester Añón, 2016; Porras Gallo; Ramírez, 2017; Báguena, 2017; Báguena; Mariño, 2017).

Estos proyectos colaborativos, que sumaron un total de 21 para el caso de España, fue una fórmula de carácter técnico administrativo establecida por la OMS para referirse a la prestación de servicios concretos a los países, previa solicitud de sus gobiernos, con el objetivo de introducir mejoras en el ámbito sanitario (Ballester, 2016). Su desarrollo constaba de cuatro etapas bien diferenciadas (OMS, 1958: 170), con una dinámica muy similar a la llevada a cabo en el caso de las ayudas de la Fundación Rockefeller de los años veinte. La primera incluía la visita al país solicitante de un consultor experto de la OMS y la emisión de un informe inicial sobre sus condiciones, el paso siguiente era una evaluación de la situación epidemiológica, que era seguida por la fase de ejecución de las ayudas, conforme las recomendaciones realizadas por el consultor de la OMS. La última etapa consistía en realizar un balance final del programa. Para el tema que nos ocupa, fue relevante el programa denominado España-25 (E25), desarrollado entre 1959-60 y entre 1964-70, dirigido a luchar contra las enfermedades víricas, pero también los

29 Archivo OMS. 12/286/5 Jacket 1. WHO Influenza Centres. Official Designations and Related Correspondence, Carta de Gerardo Clavero del Campo a Brock Chisholm, 21-21951. 
programas siguientes - E1901 (1971-73) y VIR001 (desde 1974) -, que permitieron corregir la mayoría de las deficiencias detectadas por los consultores de la OMS que visitaron España.

Pese a las diversas ayudas de la OMS, la introducción de las mejoras fue paulatina, advirtiéndose un cambio relevante a finales de los años sesenta, en los denominados años del «desarrollismo» del periodo franquista, que resulta bastante visible cuando examinamos las respuestas ofrecidas para luchar contra la gripe, muy especialmente ante dos situaciones concretas: la pandemia de $1957-58$ y la de $1968-69$.

Aunque disponemos de poca información sobre la actuación durante la primera de estas pandemias, que era la primera experiencia desde el establecimiento del Programa de lucha contra la gripe de la OMS, sí hay constancia del interés de las autoridades sanitarias por señalar que se estaban siguiendo las indicaciones de dicho organismo internacional para combatirla (García Orcoyen, 1958), al igual que se hizo con respecto a otros problemas sanitarios presentes en esos momentos en España, como la poliomielitis. También nos consta que, tras la identificación del nuevo virus (H2N2) responsable de la pandemia, se comenzó la fabricación de una vacuna monovalente contra dicho virus, siguiendo las recomendaciones de la OMS, adoptadas en la reunión del 11 de julio de 1957 (WHO, 1957), con la finalidad de que pudiera estar disponible para afrontar el segundo brote de la pandemia, que se desarrolló en el otoño siguiente.

La preparación de dicha vacuna se efectuó en el laboratorio nacional de gripe de la Escuela Nacional de Sanidad, bajo la dirección de Florencio Pérez Gallardo, pero también, y bajo la misma dirección, en el laboratorio privado IBYS (Pérez Gallardo; Ruiz Falcó, 1957), surgido al término de la pandemia de gripe de 1918-19 con el impulso que alcanzó la fabricación de sueros y vacunas para evitar otra situación tan grave. Ahora bien, aunque ambas vacunas se aplicaron, se hizo de modo muy limitado por su escasa disponibilidad (Bravo Unda, 1958). Además, como se había previsto en la reunión de la OMS del 11 de julio de 1957 y suele ser habitual en las pandemias, la nueva vacuna llegó tarde, cuando el brote del otoño estaba en su plenitud (WHO, 1957).

La pandemia de 1957-58 no sólo evidenció las debilidades presentes en el primer laboratorio nacional de gripe de España, sino también en el programa internacional de la OMS para luchar contra esta enfermedad, que reveló la necesidad de incorporar un centro de este tipo en Asia para evitar los importantes retrasos registrados en la identificación del inicio de la pandemia en China, pero también de mejorar la recogida de datos epidemiológicos y 
su difusión. De ahí que se aprobara un nuevo Programa de lucha contra la gripe en 1966, que incluyó entre otras cosas el establecimiento de programas anuales de inmunización de la población más vulnerable, y la incorporación del laboratorio de Singapur a la red de los laboratorios regionales de la OMS.

Por lo que se refiere al caso español, las mejoras llegaron del desarrollo del programa E25 desde 1959, que supuso contar con el asesoramiento de relevantes consultores de la OMS, que señalaron las deficiencias existentes, pero también las vías de mejora del Laboratorio del Virus de Pérez Gallardo de la Escuela Nacional de Sanidad, insistiendo en la necesidad de conceder becas de formación para la especialización del personal sanitario, pero también de construir un nuevo centro, que fuera más apto para las funciones que debía cumplir y para el mejor desarrollo de las vacunas y la consolidación de la virología en España. Esta última petición se plasmó en la construcción del Centro Nacional de Virología y Ecología Sanitarias y del Centro Piloto de vacunación, ambos ubicados en Majadahonda (Madrid), que fueron inaugurados en 1968. De modo que la pandemia de 1968-69 se abordó con estas nuevas instituciones, que suponían un salto cualitativo con respecto a las condiciones en las que se había afrontado la gripe de 1957-58. Sin embargo, el nuevo centro adolecía de personal especializado, que se traducía entre otras cosas en dificultades para realizar el diagnóstico de laboratorio de gripe mediante inmunofluorescencia (Sohier, 1964; Sommerville, 1969). Por el contrario, la fabricación de vacuna contra el virus de la pandemia de 1968-69 alcanzó mayores dimensiones que en 1a anterior pandemia (Wildy, 1970; Porras Gallo; Ramírez Ortega, 2017: 113). La experiencia mundial de la pandemia de 1968-69 motivó nuevos cambios en el abordaje de la gripe y nuevas recomendaciones, entre otras la ampliación de la red de laboratorios de la OMS. En este contexto, en 1968, se propuso el establecimiento del II Centro nacional de gripe en España en el Laboratorio de virus de la Facultad de Medicina de Barcelona, del profesor Agustí Pumarola Busquets ${ }^{30}$.

\section{A MODO DE REFLEXIÓN}

Las páginas precedentes han puesto de relieve el destacado papel que desempeñó la magnitud de la pandemia de gripe de 1918-19 y las circunstancias que la rodearon para provocar un cambio en la percepción social de esta enfermedad y promover una mejora socio-económica en España y su modernización sanitaria. De igual modo hemos visto el impacto, mantenido en el

30 Archivo OMS. 12/286/5 Jacket 1. WHO Influenza Centres. Official Designations and Related Correspondence, Carta de Jesús García Orcoyen a Marcolino Candau, 10-6-1968. 
tiempo, no sólo en nuestro país sino también más allá de nuestras fronteras, que se tradujo en varias medidas, entre ellas la puesta en marcha del Programa de lucha contra la gripe de la OMS de 1947, del que España se benefició poco antes de su entrada en dicho organismo internacional. Esta circunstancia y la posibilidad de acceder a los programas-país de la OMS fueron clave para transformar el abordaje de la gripe durante el período franquista, aunque no se llegaría realmente a los estándares internacionales hasta los años ochenta ya en un contexto democrático. Mediante la Ley General de Sanidad de 1986, se estableció el actual Sistema Nacional de Salud y se otorgó en él un lugar destacado a la medicina de Atención Primaria, que asumió también la profilaxis contra la gripe y resto de enfermedades infecciosas.

\section{Bibliografia}

ARREDONDO, M. (1918). La epidemia reinante. Medicina Social Española, 60, pp. 321326.

BALLESTER AÑÓN, Rosa (2016). España y la Organización Mundial de la Salud en el contexto de la historia de la salud pública internacional (1948-1975). Real Academia de la Medicina de la Comunidad Valenciana, Valencia.

BARONA, Josep Lluis (2015). The Rockefeller Foundation, Public Health and International Diplomacy, 1920-1945. Pickering \& Chatto, London.

BERNABEU MESTRE, Josep (1994). El papel de la Escuela Nacional de Sanidad en el desarrollo de la salud pública en España, 1924-1934. Rev. Sanidad e Higiene Pública, 68 , pp. $65-89$.

BERNABEU MESTRE, Josep (2009-2010). La Escuela Nacional de Sanidad. Eidon Revista de la Fundación Ciencias de la salud, 32, pp. 74-80.

BARONA, Josep Lluis; BERNABEU MESTRE, Josep (2008). La Escuela Nacional de Sanidad de Madrid, in BARONA, Josep Lluis; BERNABEU MESTRE, Josep (org.). El movimiento sanitario internacional y la administración española (1851-1945). Publicacions de la Universitat de València, València, pp. 185-194.

BRAVO UNDA, Gabriel (1957). Algunos comentarios a la epidemia gripal. Medicamenta, 29 (318), pp. 75-77.

FIORE, Anthony E.; BRIDGES, Carolyn B.; COX, Nancy J. (2009). Seasonal Influenza Vaccines, in COMPANS, Richard W.; ORENSTEIN, Walter A. (eds.). Vaccines for Pandemic Influenza. Springer, Heidelberg, pp. 43-82.

KILBOURNE, Edwin D. (2011). A Race with Evolution: A History of Influenza Vaccines, in PLOTKIN, Stanley A. (ed.). History of Vaccine Development. Springer, New York, pp. $137-144$. 
La salud pública en España. Pasividad censurable. El Liberal, 15 de octubre de 1918, 1.

LEÓN SANZ, Pilar (2014). A Collaborative Experience: The Mutual Benefit Societies' Responses to the 1918-1919 Influenza Pandemic in Pamplona, Spain, in PORRAS GALLO, María Isabel; DAVIS, Ryan A. (ed.). The Spanish Influenza Pandemic of 1918-1919. Perspectives from the Iberian Peninsula and the Americas. University of Rochester Press, Rochester, pp. 152-170.

MOSSO ROMEO, María de los Ángeles; DE LA ROSA JORGE, María del Carmen (2019). La primera cátedra de Microbiología en la Universidad española, in CARRASCOSA, Alfonso V.; BÁGUENA, María José (coord.). El desarrollo de la Microbiología en España, vol. I. Fundación Ramón Areces, Madrid, pp. 127-161.

ORGANIZACIÓN MUNDIAL DE LA SALUD (1958). Los diez primeros años de la Organización Mundial de la Salud. OMS, Ginebra.

PORRAS GALLO, María Isabel (1994a). Una ciudad en crisis: la epidemia de gripe de 1918-19 en Madrid. (Tesis doctoral). Facultad de Medicina. Universidad Complutense, Madrid.

PORRAS GALLO, María Isabel (1994b). La lucha contra las enfermedades 'evitables' en España y la pandemia de gripe de 1918-19. Dynamis, 14, pp. 159-183.

PORRAS GALLO, María Isabel (1995). La prensa madrileña de información general ante la epidemia de gripe de 1918-19. Medicina e Historia, 57, pp. 1-15.

PORRAS GALLO, María Isabel (1997). Un reto para la sociedad madrileña: la epidemia de gripe de 1918-1919. Edit. Complutense-CAM, Madrid.

PORRAS GALLO, María Isabel (2008). Sueros y vacunas en la lucha contra la pandemia de gripe de 1918-1919 en España. Asclepio, 60 (2), pp. 261-288.

PORRAS GALLO, María Isabel (2009). Renovación y reorganización profesional en tiempo de crisis: farmacéuticos y veterinarios durante la gripe de 1918-1919 en España. Varia Historia. Revista de História, 25 (42), pp. 477-498.

PORRAS GALLO, María Isabel; DAVIS, Ryan, (2014a). The Spanish Influenza Pandemic of 1918-1919, in PORRAS GALLO, María Isabel; DAVIS, Ryan (eds.). The Spanish Influenza Pandemic of 1918-1919. Perspectives from the Iberian Peninsula and the Americas. University of Rochester Press, Rochester.

PORRAS GALLO, María Isabel; DAVIS, Ryan (2014b). Emerging Perspectives of the Spanish Influenza Pandemic of 1918-19, in PORRAS GALLO, María Isabel; DAVIS, Ryan (eds.). The Spanish Influenza Pandemic of 1918-1919. Perspectives from the Iberian Peninsula and the Americas. University of Rochester Press, Rochester.

PORRAS GALLO, María Isabel; AYARZAGÜENA SANZ, Mariano; DE LAS HERAS SALORD, Jaime; BÁGUENA CERVELLERA, María José (eds.), (2013). El drama de la polio. Un problema social y familiar en la España franquista. Libros de la Catarata, Madrid.

PORRAS GALLO, María Isabel; RAMÍREZ ORTEGA, Mercedes (2017). La lucha contra la gripe en España a través de las relaciones con la OMS (1951-1971), in ZARZOSO, 
Alfons; ARRIZABALAGA, Jon (eds.). Al Servicio de la salud humana: La Historia de la medicina ante los retos del siglo XXI. SEHM-QR5, Ciudad Real, pp. 109-116.

RAMÍREZ, Mercedes; PORRAS GALLO, María-Isabel (2014). La vacunación contra la gripe y sus complicaciones en España (1918-2009), in CAMPOS MARÍN, Ricardo; GONZÁLEZ DE PABLO, Ángel; PORRAS GALLO, María-Isabel; MONTIEL, Luis (eds.). Medicina y poder político. SEHM, Ciudad Real, pp. 191-195.

RODRÍGUEZ OCAÑA, Esteban (2000). La intervención de la Fundación Rockefeller en la creación de la sanidad contemporánea en España. Revista Española de Salud Pública, 74 ( $n^{\mathrm{O}}$ monográfico), pp. 27-34.

RODRÍGUEZ OCAÑA, Esteban (2001a). The Politics of Public Health in the StateManaged Scheme of Healthcare in Spain (1940-1990), in LÖWY, I.; KRIGE, J. (eds.). Images of Disease: Science, Public Policy and Health in Post-war Europe. Office for Official Publications of the European Communities, Luxembourg, pp. 187-210.

RODRÍGUEZ OCAÑA, Esteban (2001b). La salud pública en la España de la primera mitad del siglo XX, in ATENZA FERNÁNDEZ, Juan; MARTÍNEZ PÉREZ, José (coords.). El Centro Secundario de Higiene Rural de Talavera de la Reina y la Sanidad española de su tiempo. Junta de Comunidades de Castilla-La Mancha, Toledo.

SOBRAL, José Manuel; LIMA, María Luisa; CASTRO, Paula; SILVEIRA e SOUSA, Paulo (coord.) (2009). A Pandemia Esquecida: Olhares comparados sobre a pneumónica (1918-19). Imprensa de Ciências Sociais, Lisboa.

SOHIER, Roger (1964). Rapport sur une visite en Espagne, 15-30 Novembre 1964. OMS, 21 p., EUR-ESPAGNE-25.

SOMMERVILLE, R. G. (1969). Report on a visit to Spain, 1-15 December 1968. Epidemiological studies of virus diseases of public health importance. WHO, Copenhagen, EURO, D69, EU39.

THÉODORIDES, Jean (1974). La microbiología médica, in LAÍN ENTRALGO, Pedro (dir.). Historia Universal de la Medicina. Salvat, Barcelona, vol. 6, pp. 175-192.

VAGNERON, Frédéric (2018). La grippe espagnole: une historiographie centenaire revisitée. Ler História, 73, pp. 21-43. Consultado el 03/01/19, en https://journals.openedition.org/lerhistoria/4004

WEINDLING, Paul (1993). Public Health and Political Stabilisation: The Rockefeller Foundation, in Central and Eastern Europe between the Two World Wars. Minerva, 31, pp. 253-267.

WEINDLING, Paul (ed.) (1995). International Health Organizations and Movements, 1918-1939. Cambridge University Press, New York.

WILDY, Peter (1970). Epidemiological studies of virus diseases of public health importance. Report on a visit to Spain, 25-21 September 1970. WHO, Copenhagen, EURO, D71.EU20.

WORLD HEALTH ORGANISATION (1957). Minutes of an Informal Meeting on Influenza. Geneva, 11 July 195\%. Historical Archive of the WHO. 


\section{ApliCaÇÃo do EpiInfo NA ANÁlise DE DADOS DOS CASOS NOTIFICADOS DA Gripe A (H1N1) em Angola: \\ ACTUAÇÃO E EXPERIÊNCIA}

Dalton Ngando José Agostinho ${ }^{1}$

Yuri Manuel Francisco Agostinho

1 Data Manager - Organização Mundial da Saúde - Angola.

2 Professor do Instituto de Superior de Artes - ISART, yanessanguifada@gmail.com 



\begin{abstract}
Resumo
Os autores utilizaram o pacote de programas de computador (Epilnfo3.5.4), para analisar os casos notificados de Gripe A (H1N1) em Angola. Como metodologia fez-se o levantamento dos casos notificados no Centro de Processamento de Dados Epidemiológicos da Direcção Nacional de Saúde Pública de Angola, posteriormente analisou-se a listagem dos casos notificados e a partir deste procedimento, selecionaram-se os casos notificados de Gripe A (H1N1). O resultado mostra que foram notificados em Angola 37 casos positivos de Gripe A (H1N1).
\end{abstract}

Palavras-chave: Epilnfo, Análise de dados, Gripe A (H1N1).

\title{
INTRODUÇÃO
}

Nosso questionamento em senso comum, é que não basta a disponibilidade de programas estatísticos de fácil manuseio para a análise de dados resultantes do processo da vigilância. Contudo, é preciso saber, entre os procedimentos estatísticos de análise de dados, disponíveis em aplicativos computacionais de fácil acesso e manuseio, quais podem ser aplicados tendo-se em vista os pressupostos teóricos formais de tais procedimentos e a origem e natureza dos dados produzidos pelos sistemas de vigilância, (Sanches, 1993: 300). Para o estudo que envolve uma população enorme ou uma amostra significativa, não é aconselhável o processamento manual da informação. Logicamente, surge a necessidade de se encontrar programas para fazer o processamento e análise dos dados, e o EpiInfo é uma saída para o desiderato.

O objectivo deste trabalho é analisar os dados notificados de Gripe A (H1N1) em Angola. Com a ajuda do EpiInfo 3.5.4, pretende-se produzir tabelas e gráficos das ocorrências, que, em geral, são descrições estratificadas por grupos de idade, sexo e locais de ocorrência. 


\section{BREVES CONSIDERAÇÕES SOBRE O EPIINFO}

O EpiInfo foi elaborado através de uma acção conjunta do $\mathrm{CDC}^{3}$ e a $\mathrm{OMS}^{4}$. É caracterizado por uma série de pequenos programas integrados por uma tela de apresentação, (Wagner, 1997: 207). Com o EpiInfo, é possível produzir em poucos minutos uma base de dados, relacionando arquivos, por exemplo, um complexo sistema de vigilância epidemiológica. O EpiInfo é desenvolvido em programação Visual Basic e usa o formato de arquivo Microsoft Access (.mdb) como uma forma de padronizar o banco de dados, tornandoo acessível para outros programas, (Bós, 2012: 14). Embora os dados do EpiInfo sejam armazenados em formato «mdb», outros formatos de arquivos podem ser lidos, analisados, importados ou exportados pelo programa, como, por exemplo, planilhas do Microsoft Excel.

\section{ANÁLISE DE DADOS}

O registo e análise de dados têm sido, desde há muitos séculos, ferramentas fundamentais para o entendimento do universo que nos rodeia. A análise quantitativa de dados é, justamente, a organização e sistematização dos números em categorias com significado. A análise de dados é um procedimento necessário para a prática de muitas profissões, uma vez que ela permite estruturar e organizar a informação.

Qualquer análise de dados deve começar pela análise descritiva de todas as variáveis que pretendemos usar. Observando o resultado dessas análises, podemos identificar possíveis problemas com os dados. A análise descritiva também nos pode orientar na análise dos dados apontando diferenças entre grupos de variáveis que podem comprometer nossos resultados. A análise descritiva, geralmente, faz parte do que chamamos de "primeira tabela», onde descrevemos todas as variáveis que iremos usar na nossa análise. A frequência das variáveis categóricas e médias das variáveis numéricas entre diferentes grupos como, por exemplo, gênero ou raça, ajudam-nos a antecipar os resultados ou a necessidade de uma análise específica. Através da análise de dados, é possível construir modelos que descrevem relações entre variáveis, bem como auxiliar processos de tomada de decisão.

Para este estudo, focaremos a análise de dados de rotina no âmbito da vigilância epidemiológica em saúde pública, visto que, os dados analisados neste trabalho provêm dessa fonte e o seu caráter é estritamente não-amostral

3 Centros de Controle e Prevenção de Doenças dos Estados Unidos.

4 Organização Mundial da Saúde. 
e não-aleatório. Os dados da vigilância em saúde pública são recolhidos através de inúmeras fontes: livro de registo de médicos, laboratórios, hospitais e outros serviços de assistência à saúde. Tradicionalmente, os dados coletados nos sistemas de vigilância em saúde pública são relatados através de tabelas e frequências. Em geral, são descrições estratificadas por grupos de idade, sexo e locais de ocorrência. ${ }^{5}$ A análise de casos e óbitos ao longo do tempo dá-nos a informação necessária para a tomada de decisões, implementação de acções e medidas de saúde pública. Essa análise fornece-nos informações-chave:

- Observar as tendências ao longo do tempo e alertar o pessoal de saúde para os eventos emergentes ou padrões invulgares;

- Agrupar os eventos por áreas geográficas e identificar as de maior risco;

- Caracterizar as variáveis individuais como a idade, o sexo ou a profissão, que podem colocar a pessoa em maior risco de doenças ou eventos;

- Monitorizar e avaliar a qualidade dos programas de saúde pública nos diferentes níveis de gestão do sistema de saúde.

De uma forma geral, a análise dos dados de vigilância de rotina em saúde pública, deverá responder às seguintes questões: ${ }^{6}$

- Foram detectadas algumas doenças prioritárias ou outros eventos preocupantes para a saúde pública durante o período da notificação (por exemplo esta semana)?

- Há suspeitas de epidemias ou eventos de saúde pública invulgares?

- Quantos casos, óbitos ou eventos detectados foram confirmados?

- Onde é que eles ocorreram?

- De que modo se pode comparar a situação observada com anteriores períodos de observação ao longo deste ano?

- Em comparação com o início do período de notificação, o problema está aumentar?

- As tendências são estáveis ou estão a descer ou a subir?

- Os dados de vigilância notificados serão suficientemente representativos da área de abrangência da unidade de notificação?

\footnotetext{
5 Ver secção 3. Manual de vigilância epidemiológica integrada de doenças e resposta. /DNSP/Angola.

6 Idem.
} 
- De todas as unidades que deveriam fazer a notificação, qual a percentagem das que o fizeram de facto?

- Qual o grau de prontidão dos dados recebidos das unidades de notificação?

\section{METODOLOGIA E RESULTADOS}

Os dados analisados neste artigo encontram-se disponíveis na Direcção Nacional de Saúde Pública (DNSP), entidade que nos forneceu uma listagem de casos notificados de Gripe A (H1N1) em Angola. Mediante uma análise global dos dados, fez-se uma limpeza na listagem de casos que se encontravam numa planilha do Excel. Houve, porém, a necessidade de se fazer uma adequação da extensão do arquivo em Excel (xlsx) para o EpiInfo (Data-Formats-Excel 5.0).

O número variado de programas que o pacote EpiInfo contém, permitiu a utilização do pacote «Analyze Data», para analisar a informação. O comando «Frequency» constituiu o principal recurso para a obtenção de resultados neste trabalho. Os resultados obtidos através do EpiInfo são fornecidos em forma de gráficos e tabelas como as que são expostas adiante:

Tab. 1 - Províncias que notificaram casos positivos de Gripe A (H1N1). Angola, 2009-2011.

\begin{tabular}{lrrr}
\hline Província notificadora & Frequency & Percent & Cum Percent \\
\hline Bengo & 2 & 5,4 & 5,4 \\
Huíla & 2 & 5,4 & 10,8 \\
Luanda & 33 & 89,2 & 100,0 \\
Total & 37 & 100,0 & 100,0
\end{tabular}

Fonte: Base de dados da Gripe A (H1N1) do Centro de Processamento de Dados Epidemiológicos.

Tab. 2 - Casos positivos de Gripe A (H1N1) e Nacionalidade. Angola, 2009-2011.

\begin{tabular}{lrrr}
\hline Nacionalidade & Frequency & Percent & Cum Percent \\
\hline Angolana & 31 & 83,8 & 83,8 \\
Brasileira & 3 & 8,1 & 91,9 \\
Peruana & 1 & 2,7 & 94,6 \\
Portuguesa & 2 & 5,4 & 100,0 \\
Total & 37 & 100,0 & 100,0 \\
\hline
\end{tabular}

Fonte: Base de dados da Gripe A (H1N1) do Centro de Processamento de Dados Epidemiológicos. 
Tab. 3 - Casos positivos de Gripe A (H1N1) por sexo. Angola, 2009-2011.

\begin{tabular}{lrrr}
\hline Sexo & Frequency & Percent & Cum Percent \\
\hline Feminino & 20 & 54,1 & 54,1 \\
Masculino & 17 & 45,9 & 100,0 \\
Total & 37 & 100,0 & 100,0 \\
\hline
\end{tabular}

Fonte: Base de dados da Gripe A (H1N1) do Centro de Processamento de Dados Epidemiológicos.

Fig. 1 - Distribuição de subtipos de Gripe. Angola. 2009-2011

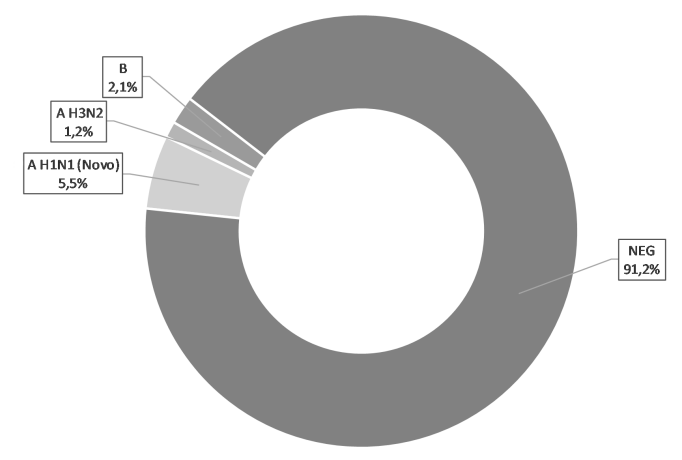

Fonte: Base de dados da Gripe A (H1 N1) do Centro de Processamento de Dados Epidemiológicos.

\section{DISCUSSÃO}

A tabela 1 mostra que foram notificados, em Angola, 37 casos positivos de Gripe A (H1N1). Por ordem de frequência, a província com maior incidência foi a de Luanda, com $89,2 \%$ dos casos, seguindo-se as províncias do Bengo e Huíla, com 5,4\%, respectivamente. A tabela 2 aponta a nacionalidade dos casos confirmados de Gripe A (H1N1): 31 são angolanos e 6 são estrangeiros (Brasil, Peru e Portugal). A tabela 3 evidencia os casos confirmados de Gripe A (H1N1) em funçaõ do sexo: 20 são do sexo feminino e 17 do sexo masculino. E, por último, o gráfico que demonstra a distribuição de subtipos de Gripe, em que os casos positivos de Gripe A (H1N1) corresponderam a 5,5\% do total de casos de síndrome gripal notificados. A análise dos dados notificados de Gripe A (H1N1) da base de dados da DNSP, possibilitou o processamento de um elevado número de variáveis. Este procedimento tornou possível conhecer, em tempo inferior a cinco minutos, o número de casos notificados e positivos de Gripe A (H1N1) em Angola. Se estes dados fossem dissecados manualmente, a tarefa consumiria, no mínimo, algumas horas para serem 
avaliados. A rapidez da análise estatística feita através do EpiInfo é, pois, a principal vantagem da sua utilização. A celeridade das análises estatísticas e o seu baixo custo demonstram a exequibilidade da sua utilização no tratamento de dados, em levantamentos epidemiológicos relacionados com a síndrome gripal.

A nossa experiência no âmbito da epidemia de Gripe A (H1N1) em Angola cingiu-se à gestão de dados epidemiológicos durante a epidemia à escala mundial. O Centro de Processamento de Dados Epidemiológicos (CPDE), da Direcção Nacional de Saúde Pública, foi o local da experiência. A nossa actuação abrangeu os seguintes domínios: criação e organização de bases de dados; análise de dados e produção de relatórios; gestão de arquivo de dados seguros e eficientes para fácil recuperação; integração de dados de diferentes fontes e gestão de uma grande quantidade de dados para indicar tendências e indicadores.

\section{CONCLUSÃO}

De tudo quanto foi descrito conclui-se que o EpiInfo é uma ferramenta vantajosa, face à brevidade da execução das análises estatísticas e ao seu baixo custo. Na era da informática, as potencialidades do uso do EpiInfo no contexto da saúde pública, são bastante relevantes. A utilização desta ferramenta do EpiInfo, pode tornar-se uma maneira eficaz de descobrir e analisar problemas relacionados a saúde, em diferentes contextos. Comandos simples, tais como «abrir», «frequência», «lista», «tabelas» e «gráficos», produzem estatísticas epidemiológicas concretas. O EpiInfo é, assim, uma ferramenta necessária na gestão de dados no âmbito da saúde pública. Durante um surto ou epidemia, auxilia no tratamento dos dados, tornando-os acessíveis a todos intervenientes, facilitando a tomada de decisões. 


\section{Anexo}

Tab. 4 - Casos positivos de Gripe A (H1N1) notificados em Angola

\begin{tabular}{|c|c|c|c|c|c|c|c|c|c|c|c|c|c|}
\hline N. ${ }^{\circ}$ & Nome & $\begin{array}{l}\text { Província } \\
\text { Notificadora }\end{array}$ & Município & $\begin{array}{l}\text { Idade } \\
\text { (Anos) }\end{array}$ & $\begin{array}{l}\text { Idade } \\
\text { (Meses) }\end{array}$ & Sexo & $\begin{array}{l}\text { Data de início } \\
\text { dos sintomas }\end{array}$ & $\begin{array}{l}\text { Data da colheita } \\
\text { das amostras }\end{array}$ & Teste rápido & PCR & Classificação & Nacionalidade & $\begin{array}{l}\text { Proveniência } \\
\text { últimos } 15 \text { dias }\end{array}$ \\
\hline 1 & A.G. & Luanda & Ingombota & 11 & & $\mathrm{~F}$ & $20 / 07 / 2009$ & $04 / 08 / 2009$ & Negativo & Positivo & Confirmado (H1N1) & Angolana & Sem história de viagem \\
\hline 2 & D. V. & Luanda & Ingombota & 41 & & M & $02 / 08 / 2009$ & $05 / 08 / 2009$ & Negativo & Positivo & Confirmado (H1N1) & Angolana & Portugal \\
\hline 3 & A.F. & Luanda & Sambizanga & 38 & & $\mathrm{~F}$ & $09 / 08 / 2009$ & $12 / 08 / 2009$ & Negativo & Positivo & Confirmado (H1N1) & Angolana & Portugal \\
\hline 4 & L.S. & Dengo & Catete & 26 & & M & $08 / 08 / 2009$ & $12 / 08 / 2009$ & Negativo & Positivo & Confirmado (H1N1) & Brasileira & Brasil \\
\hline 5 & C.D.J.M & Dengo & Catete & 15 & & $\mathrm{M}$ & $09 / 08 / 2009$ & $12 / 08 / 2009$ & Negativo & Positivo & Confirmado (H1N1) & Angolana & Sem história de viagem \\
\hline 6 & D.V. & Luanda & Ingombota & 28 & & M & $13 / 08 / 2009$ & $17 / 08 / 2009$ & Negativo & Positivo & Confirmado (H1N1) & Angolana & Inglaterra e Portugal \\
\hline 7 & C.C. & Luanda & Ingombota & 27 & & $\mathrm{~F}$ & $14 / 08 / 2009$ & $17 / 08 / 2009$ & Negativo & Positivo & Confirmado (H1N1) & Angolana & Portugal \\
\hline 8 & V.E.S. & Luanda & Ingombota & 62 & & $\mathrm{~F}$ & $16 / 08 / 2009$ & $17 / 08 / 2009$ & Negativo & Positivo & Confirmado (H1N1) & Angolana & Sem história de viagem \\
\hline 9 & S.R. & Luanda & Ingombota & 26 & & $\mathrm{~F}$ & $16 / 08 / 2009$ & $18 / 08 / 2009$ & Negativo & Positivo & Confirmado (H1N1) & Angolana & Sem história de viagem \\
\hline 10 & F.D.S. & Luanda & Rangel & & 9 & $\mathrm{M}$ & $18 / 08 / 2009$ & $21 / 08 / 2009$ & Negativo & Positivo & Confirmado (H1N1) & Angolana & Sem história de viagem \\
\hline 11 & A.Q. & Luanda & Samba & 28 & & $\mathrm{~F}$ & $19 / 08 / 2009$ & $21 / 08 / 2009$ & Influenza A & Positivo & Confirmado (H1N1) & Angolana & África do Sul \\
\hline 12 & N.N. & Luanda & Ingombota & 44 & & $\mathrm{M}$ & $10 / 08 / 2009$ & $22 / 08 / 2009$ & Influenza A & Positivo & Confirmado (H1N1) & Brasileira & Brasil \\
\hline 13 & A.V. & Luanda & Ingombota & 46 & & $\mathrm{~F}$ & $18 / 08 / 2009$ & $02 / 09 / 2009$ & Influenza A & Positivo & Confirmado (H1N1) & Brasileira & Portugal e Espanha \\
\hline 14 & E.B. & Luanda & Kilamba Kiaxi & 35 & & $\mathrm{M}$ & $28 / 08 / 2009$ & $24 / 08 / 2009$ & Negativo & Positivo & Confirmado (H1N1) & Portuguesa & Portugal \\
\hline 15 & B.C. & Luanda & Ingombota & 55 & & M & $23 / 08 / 2009$ & $24 / 08 / 2009$ & Negativo & Positivo & Confirmado (H1N1) & Peruana & EUA \\
\hline 16 & H.I.S. & Luanda & Maianga & 49 & & $\mathrm{~F}$ & $24 / 08 / 2009$ & $26 / 08 / 2009$ & Negativo & Positivo & Confirmado (H1N1) & Angolana & Sem história de viagem \\
\hline 17 & J.E.C.R. & Luanda & Luanda & 31 & & M & $28 / 08 / 2009$ & $31 / 08 / 2009$ & Influenza A & Positivo & Confirmado (H1N1) & Portuguesa & Portugal \\
\hline 18 & N.G.M. & Luanda & Luanda & 7 & & $\mathrm{~F}$ & $03 / 08 / 2009$ & $04 / 08 / 2009$ & Negativo & Positivo & Confirmado (H1N1) & Angolana & Sem história de viagem \\
\hline 19 & K.A. & Luanda & Ingombota & 32 & & $\mathrm{~F}$ & $03 / 08 / 2009$ & $06 / 08 / 2009$ & Negativo & Positivo & Confirmado (H1N1) & Angolana & Contacto com viajante com gripe \\
\hline 20 & M.C.S & Luanda & Luanda & 35 & & $\mathrm{~F}$ & $20 / 08 / 2009$ & $21 / 08 / 2009$ & Negativo & Positivo & Confirmado (H1N1) & Angolana & Viajou sem mencionar local \\
\hline 21 & W.P. & Luanda & Luanda & 5 & & $\mathrm{~F}$ & $19 / 08 / 2009$ & $21 / 08 / 2009$ & Negativo & Positivo & Confirmado (H1N1) & Angolana & África do Sul \\
\hline 22 & Y.T. & Luanda & Maianga & 9 & & M & $24 / 09 / 2009$ & $24 / 09 / 2009$ & ???? & Positivo & Confirmado (H1N1) & Angolana & Sem história de viagem \\
\hline 23 & P.S.C.M. & Luanda & Maianga & 25 & & $\mathrm{M}$ & $21 / 07 / 2009$ & $26 / 07 / 2009$ & Negativo & Positivo & Confirmado (H1N1) & Angolana & Brasil \\
\hline 24 & A.R. & Luanda & Ingombota & 11 & & $\mathrm{~F}$ & $25 / 07 / 2009$ & $28 / 07 / 2009$ & & Positivo & Confirmado (H1N1) & Angolana & Sem história de viagem \\
\hline 25 & M.M. & Luanda & Maianga & & 9 & M & $01 / 08 / 2009$ & $07 / 08 / 2009$ & & Positivo & Confirmado (H1N1) & Angolana & Sem história de viagem \\
\hline 26 & M.F. & Luanda & Samba & 2 & & $\mathrm{~F}$ & $10 / 08 / 2009$ & $17 / 08 / 2009$ & & Positivo & Confirmado (H1N1) & Angolana & Sem história de viagem \\
\hline 27 & L.A.B.P. & Luanda & Ingombota & & 6 & $\mathrm{~F}$ & $11 / 08 / 2009$ & $12 / 08 / 2009$ & & Positivo & Confirmado (H1N1) & Angolana & Sem história de viagem \\
\hline 28 & L.L. & Luanda & Viana & 1 & & $\mathrm{~F}$ & $10 / 08 / 2009$ & $17 / 08 / 2009$ & & Positivo & Confirmado (H1N1) & Angolana & Sem história de viagem \\
\hline 29 & F.M.G.F. & Luanda & Rangel & 8 & & $\mathrm{~F}$ & $09 / 08 / 2009$ & $12 / 08 / 2009$ & & Positivo & Confirmado (H1N1) & Angolana & Sem história de viagem \\
\hline 30 & M.M. & Luanda & Samba & 1 & & $\mathrm{~m}$ & $09 / 08 / 2009$ & $12 / 08 / 2009$ & & Positivo & Confirmado (H1N1) & Angolana & Sem história de viagem \\
\hline 31 & P.V.C. & Luanda & Maiamga & 1 & & $\mathrm{~F}$ & $07 / 08 / 2009$ & $12 / 08 / 2009$ & & Positivo & Confirmado (H1N1) & Angolana & Sem história de viagem \\
\hline 32 & F.M.F. & Luanda & Viana & 1 & & $\mathrm{M}$ & $24 / 08 / 2009$ & $27 / 08 / 2009$ & & Positivo & Confirmado (H1N1) & Angolana & Sem história de viagem \\
\hline 33 & L.A. & Luanda & Kilamba Kiaxi & 6 & & $\mathrm{~m}$ & $11 / 08 / 2009$ & $26 / 08 / 2009$ & & Positivo & Confirmado (H1N1) & Angolana & Sem história de viagem \\
\hline 34 & J.J.K. & Luanda & Viana & 12 & & $\mathrm{M}$ & $10 / 09 / 2009$ & $16 / 09 / 2009$ & & Positivo & Confirmado (H1N1) & Angolana & Sem história de viagem \\
\hline 35 & D.C. & Huíla & Lubango & 11 & & $\mathrm{M}$ & $10 / 08 / 2009$ & $13 / 08 / 2009$ & & Positivo & Confirmado (H1N1) & Angolana & Sem história de viagem \\
\hline 36 & I.A. & Huíla & Lubango & 10 & & $\mathrm{~F}$ & $12 / 08 / 2009$ & $13 / 08 / 2009$ & & Positivo & Confirmado (H1N1) & Angolana & Sem história de viagem \\
\hline 37 & C.R. & Luanda & Luanda & 61 & & $\mathrm{~F}$ & $29 / 09 / 2009$ & $04 / 10 / 2009$ & & Positivo & Confirmado (H1N1) & Angolana & Reino Unido \\
\hline
\end{tabular}




\section{Bibliografia}

BÓS, Ângelo José Gonçalves (2012). EpiInfoß sem mistérios: um manual prático. EDIPUCRS, Porto Alegre. Acedido a 01/05/2018, em http://www.pucrs.br/edipucrs/

CARDOSO, Yolanda Rebello (2011). Protocolo para a vigilância sentinela nacional da influenza em Angola. Ministério da Saúde de Angola (MINSA).

DNSP (2010). Manual de vigilância epidemiológica integrada de doenças e resposta. Secção de Epidemiologia. Departamento de Higiene e Epidemiologia. Ministério da Saúde de Angola (MINSA).

SANCHES, Odécio (1993). Análise rotineira de dados de Vigilância em Saúde Pública: que procedimentos estatísticos utilizar?. Rev. Saúde Pública, 27 (4), pp. 300-304. Acedido a 01/05/2018, em http://www.scielo.br/pdf/rsp/v27n4/10.pdf

WAGNER, MB (1997). O programa EpiInfo e a avaliação do estado nutricional. Jornal de Pediatria, vol. 73 , no 4, pp. 207-208. Acedido a 01/05/2018, em http://www.jped.com.br/conteudo/97-73-04-207/port.pdf 


\section{A Gripe Espanhola no QUADro DAS EPIDEMIAS HISTÓRICAS DA ILHA DO FAIAL}

Maria Norberta Amorim ${ }^{1}$

1 Investigadora do CITCEM|FLUP - Grupo de Populações e Saúde, mnsbamorim@gmail.com 



\begin{abstract}
Resumo
Pelo tráfico aéreo, desde as últimas décadas do século $X X$, qualquer ilha açoriana liga-se, várias vezes por semana, a um exterior sucessivamente alargado, sem qualquer entrave à eventual circulação de epidemias. Em períodos anteriores, em que apenas se contavam as ligações por mar, a entrada de epidemias podia acontecer de forma desfasada, afetando diretamente as zonas portuárias e preservando frequentemente zonas rurais mais afastadas.

No caso da ilha do Faial, com um excelente porto de mar, verificamos que a gripe espanhola entrou na ilha com incidência marcada apenas no mês que decorre de 27 de novembro a 27 de dezembro de 1918, não tomado as proporções de grande crise.

Utilizámos para esse estudo registos de óbito da Conservatória do Registo Civil da Horta, de janeiro de 1913 a dezembro de 1923, já disponibilizados ao público, enquadrando 1918 nos cinco anos anteriores e posteriores, com aplicação da metodologia de Livi-Bacci e Del Panta para tais casos.

Estando os registos paroquiais anteriores a 1911 disponíveis on line, tivemos curiosidade em saber como a ilha do Faial, apesar do porto da Horta se abrir desde cedo ao tráfico intercontinental, lidou historicamente com epidemias de crise. A exploração sistemática dos registos de óbitos, freguesia a freguesia, fez-nos concluir que apenas no século XIX, com entradas de epidemias de varíola, a instabilidade da morte esteve mais presente, comprometendo o crescimento da população, já afetado por uma intensa emigração. No século XVIII, apenas duas epidemias generalizadas se instalaram, particularmente gravosas em algumas freguesias, a de $1704 / 5$ e a de 1746 , mas que não chegaram a comprometer o intenso crescimento das últimas décadas do século XVIII e primeiras do XIX.
\end{abstract}

Palavras-chave: registos de óbito, ilha, epidemias, gripe espanhola.

\title{
INTRODUÇÃO
}

Considerando as ilhas como extraordinários laboratórios para a análise demográfica, desde há muitos anos que venho explorando a ilha do Pico, alargando depois a investigação à ilha do Faial, ao Corvo, e, mais recentemente, às Flores, as quatro ilhas que integravam o ex-distrito da Horta do arquipélago dos Açores. 


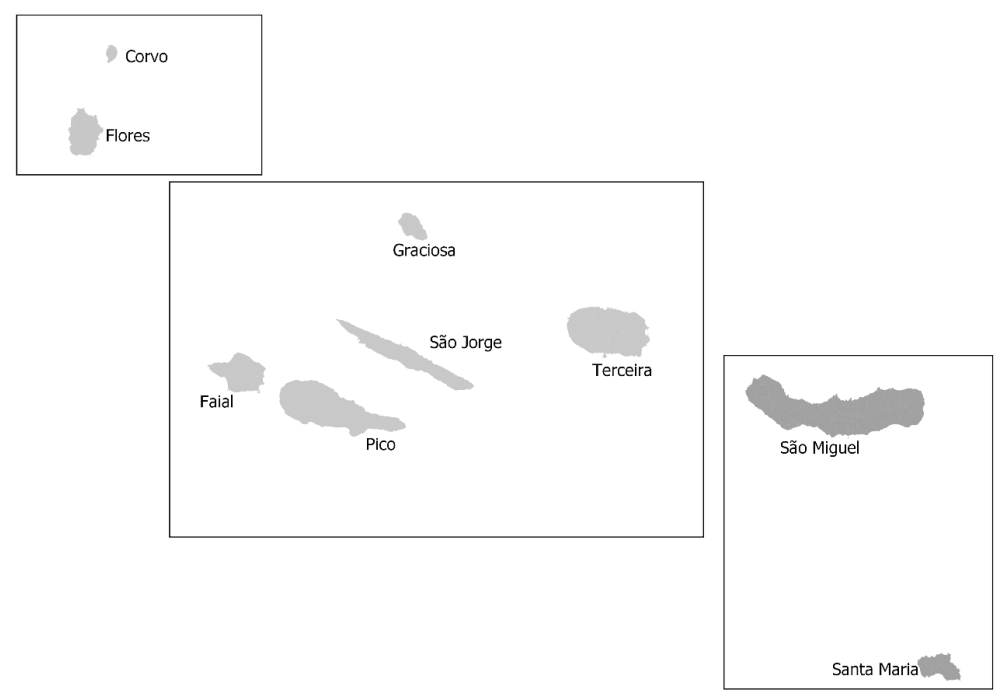

Fig. 1 - Arquipélago dos Açores

Além da pequena base de dados genealógica já publicada sobre a única paróquia da ilha do Corvo e de uma outra em construção sobre as Flores, a envolver no momento vários investigadores, dispomos de uma base de dados demográfico-genealógica que integra as 30 paróquias do Pico e Faial, mas em fases diferentes de sistematização. Decorrentes dessas bases, algumas dezenas de trabalhos já foram publicados sobre o Pico e sobre a cidade da Horta, no Faial, de três autoras do nosso Grupo (Amorim, Mesquita, Santos). Neste momento, aplicamo-nos sobre as paróquias rurais da ilha do Faial, que, na maior parte dos casos, nos oferecem, pela antiguidade e sistematicidade dos seus registos, favoráveis condições de análise.

Nesse sentido, respondendo ao desafio lançado por Antero Ferreira para uma abordagem à gripe espanhola, propomo-nos focar o seu eventual impacto no Faial, avançando depois sobre a problemática que envolve a identificação das crises epidémicas na mesma ilha, a partir de séries paroquiais de longa duração.

\section{FONTES E METODOLOGIAS}

No caso português, o registo civil inicia-se em abril de 1911. Para período anterior, está a ser disponibilizada on line a informação paroquial sobre 
atos vitais. Para os Açores, toda essa informação está acessível há alguns anos no site da Direção Regional da Cultura.

No Faial, uma ilha com um único concelho, o Conservador do Registo Civil já enviou para o Arquivo da Horta informação a entrar pela segunda metade do século XX sobre casamentos e óbitos.

Assim, para avaliar sobre o reflexo da gripe espanhola de 1918 na ilha do Faial e só dispondo, para o período, da série de óbitos, apliquei a metodologia proposta em 1977 por Livi-Bacci e Del Panta para tais casos (1977: 401405). Tracei a evolução anual dos óbitos entre janeiro de 1913 e dezembro de 1923, enquadrando 1918 nos cinco anos anteriores e nos cinco posteriores. Para cálculo da média de óbitos, de aproximação ao comportamento normal, subtraí os dois anos com maior volume e os dois anos de menor volume de ocorrências. Essa média figura como referência para medir a intensidade da crise esperada. A análise da sazonalidade normal e da sazonalidade da crise, a idade dos defuntos, a sua distribuição geográfica pelas comunidades da ilha e informações sobre causas de morte, serão outros indicadores a perseguir.

Se, no caso da gripe espanhola, partíamos de uma crise identificada, procurando os registos que nos poderão elucidar sobre o seu efeito na ilha, para as epidemias anteriores ao século XX, partimos das fontes paroquiais para identificar eventuais crises.

Até março de 1911, trabalhamos as séries paroquiais de óbitos de 12 das 13 freguesias faialenses. Não foi considerada a freguesia dos Flamengos, por lacunas significativas nos séculos XVII e XVIII e evidente sub-registo de atos ainda no século XIX.

Embora a reconstituição paroquial esteja em fase desigual de tratamento, fizemos a contagem de todos os óbitos ainda não inseridos na base de dados, podendo já dispor na mesma base de dados das séries de batizados relativas aos séculos XVII e XVIII e parte do XIX. Beneficiamos do facto de haver registo de mortalidade infantil tendencialmente sistemático desde o início da observação para cada freguesia.

A identificação das principais crises históricas pode beneficiar assim das vantagens de uma comparação entre paróquias, de uma comparação entre as séries de óbitos e as de batizados, observando os anos em que os primeiros se sobrepõem aos segundos, podendo ainda acompanhar-se, pela evolução dos nascimentos nos anos posteriores às crises, o seu impacto na renovação das gerações. A sazonalidade das crises, a idade dos defuntos e eventuais indicações sobre causas de morte dos próprios párocos, são outros indicadores a considerar. 


\section{DESENVOLVIMENTO}

\section{A gripe espanhola de 1918 na ilha do Faial}

A observação do gráfico (Fig. 2) evidencia de imediato a pouca gravidade na morte, em 1918, na ilha do Faial. Se, usando a metodologia atrás referida, considerarmos que a média anual de óbitos, subtraindo os dois anos mais gravosos e os dois mais favoráveis, é de 434 nos 11 anos que decorrem entre 1913 e 1924, os 582 óbitos identificados em 1918, não chegam a atingir $50 \%$ a mais do volume considerado normal, patamar que, a atingir-se, indicaria uma pequena crise na classificação de Livi-Bacci e Del Panta.

Fig. 2 - Evolução dos óbitos no Faial entre 1913 e 1923

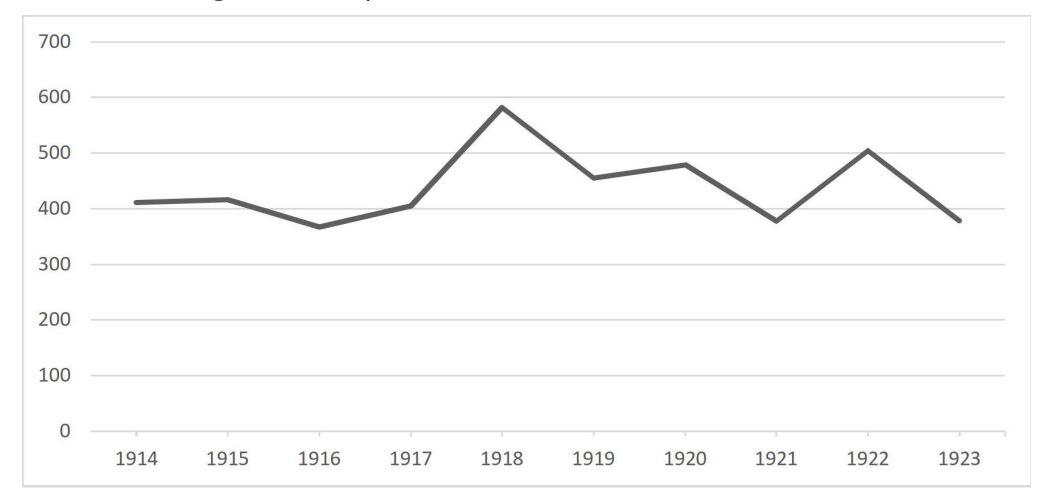

Sem outros indicadores, pela contagem anual dos óbitos, poderíamos interrogar-nos se a gripe espanhola entrou de facto na ilha do Faial.

A incidência dos óbitos entre 27 de novembro e 27 de dezembro de 1918, com algum prolongamento até 2 de fevereiro de 1919, apontando-se em grande parte dos casos como causa de morte, gripe, pneumonia, bronco-pneumonia, pneumonia gripal, e até peste pneumónica, esclarece qualquer dúvida.

Dado que as mortes identificadas por gripe ou pneumonia se intercalam entre novembro de 1918 e fevereiro do ano seguinte (um caso de pneumonia de 5 de setembro de 1918 não nos parece enquadrar-se na epidemia), para avaliar a distribuição mensal, considerámos os dois anos em causa. Seguindo procedimento corrente, reduzimos os eventos de cada um dos 24 meses a números proporcionais, dividindo primeiro os efetivos mensais pelo número de dias do mês (para fevereiro a divisão foi feita por 28,25 ) e fazendo corresponder o somatório desses valores a 2.400 (100 vezes 24 meses). 
Pelo gráfico, reparamos que a incidência da epidemia, embora intensa, foi muito curta, localizando-se no mês de dezembro com curtas franjas nos meses adjacentes. Nesse mês, as mortes sobrepuseram-se quatro vezes e meia à média dos dois anos.

Na medida em que só para a zona urbana e freguesias contíguas de Feteira e Flamengos e, mais esporadicamente, para Castelo Branco, havia assistência médica, a identificação da causa de morte por gripe cobre apenas uma parte da totalidade dos óbitos ocorridos entre 27 de novembro de 1918 e 2 de fevereiro de 1919. Na circunstância, 84 óbitos num total de 218.

Fig. 3 - Sazonalidade da gripe espanhola na Ilha do Faial

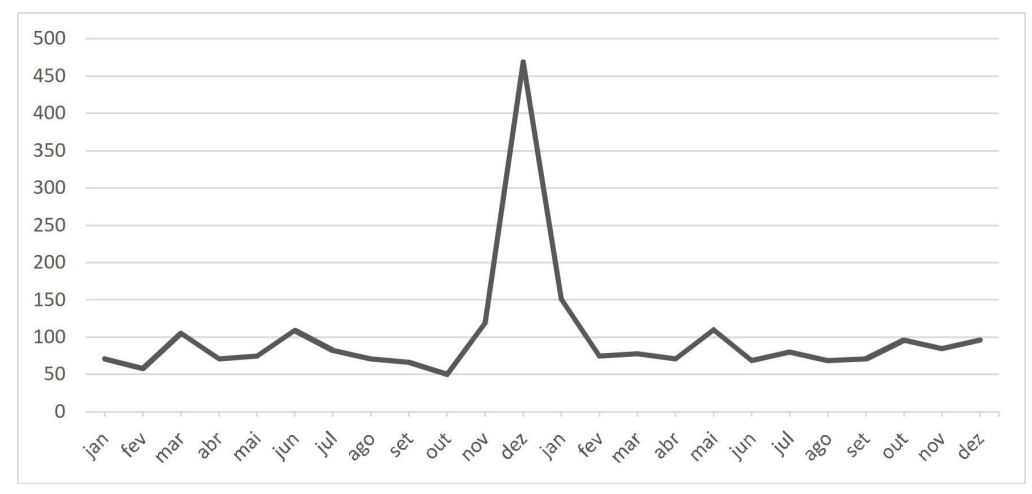

A distribuição dessas 84 mortes por sexos e grupos etários mostra grandes assimetrias, que não sabemos serem reais. Eventualmente, a causa de morte poderia ser mais frequentemente apontada no caso dos homens.

Tab. 1 - Distribuição dos óbitos por gripe espanhola por sexos e grupos etários

\begin{tabular}{lrrrr}
\hline Grupos de Idades & Homens & Mulheres & Total & Total (\%) \\
\hline $0-4$ & 3 & 2 & 5 & $6 \%$ \\
$5-14$ & 0 & 2 & 2 & $2 \%$ \\
$15-39$ & 41 & 12 & 53 & $63 \%$ \\
$40-64$ & 9 & 6 & 15 & $18 \%$ \\
65 e mais & 5 & 4 & 9 & $11 \%$ \\
Todas as idades & 58 & 26 & 84 & $100 \%$ \\
\hline
\end{tabular}

De facto, são identificados 58 casos de morte pela epidemia entre os homens e apenas 26 entre as mulheres. Embora a pneumónica afetasse todas as idades, o grupo etário mais atingido foi o dos 15 aos 39 anos com $63 \%$ das 
ocorrências conhecidas, seguido de longe pelo grupo dos 40 aos 64 anos, com apenas $18 \%$ dos casos.

Não sabemos como foi introduzida a epidemia na ilha. O óbito de um tripulante de um barco atracado no porto da Horta data só de 4 de dezembro, mas, além das comunicações entre ilhas, a cidade abria o seu porto ao trânsito intercontinental, sendo de admitir a aceleração do movimento portuário no imediato pós-guerra.

\section{As epidemias históricas}

O início do registo de óbitos não se processa ao mesmo tempo em cada uma das freguesias da ilha, sendo o caso mais gravoso de perda de informação o da Feteira, com registos sistemáticos de óbitos apenas a partir de 1799. Por outro lado, a freguesia do Salão foi apenas criada em 1730, por desdobramento dos Cedros, e a antiga freguesia da Praia do Norte, arrasada pelo vulcão de 1672, viu o seu espaço integrado, como lugar, na freguesia do Capelo, voltando a ser freguesia apenas em 1840.

Dadas as caraterísticas conhecidas das crises de mortalidade antes e depois do século XIX e também porque o levantamento dos batizados das diferentes freguesias se processou para os séculos XVII e XVIII, mas está ainda em curso em algumas delas para o século seguinte, optámos por dividir a informação em dois períodos:

- O primeiro período envolve os séculos XVII e XVIII, comparando-se batizados e óbitos para nove espaços: as três freguesias urbanas de Matriz, Angústias e Conceição, e as freguesias rurais de Castelo Branco, Capelo, Cedros e Salão (estas duas integradas), Ribeirinha, Pedro Miguel, Praia do Almoxarife.

- Num segundo período, entre 1800 e 1910, apresentamos apenas as curvas de óbitos, neste caso para 11 espaços correspondentes às diferentes freguesias, com exceção de Capelo e Paria do Norte que se mantêm integradas. Como vimos, as séries dos Flamengos padecem de sub-registo. 
Fig. 4 - Ilha do Faial

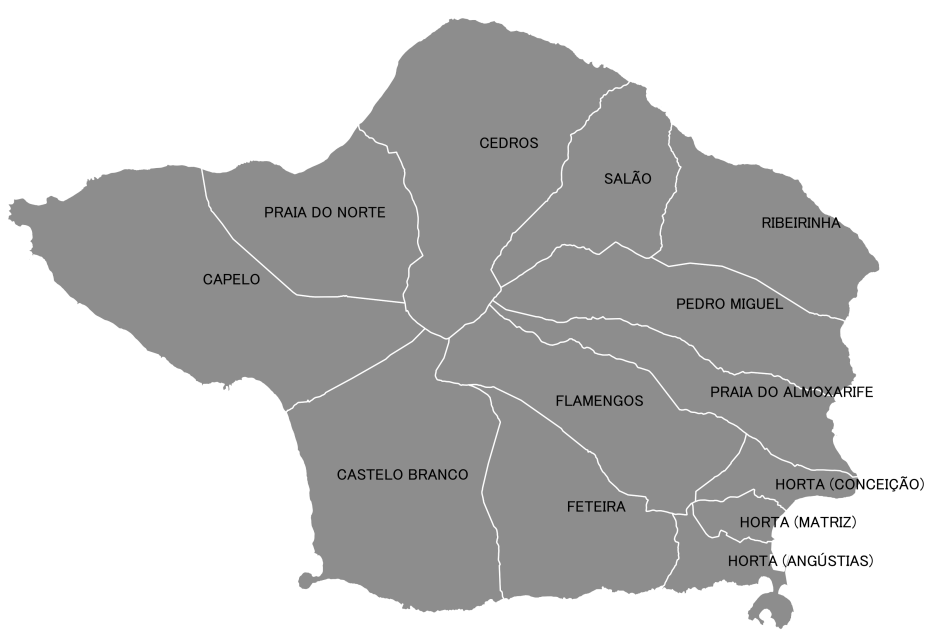

\subsection{Crises de mortalidade identificadas nos séculos XVII e XVIII}

Comparando a evolução dos batizados e óbitos para os séculos XVII e XVIII em cada freguesia e entre as diferentes freguesias, apenas duas grandes crises sobressaem na observação: a de 1705, que já se deteta na zona urbana em 1704, e a de 1746. Alguma sobremortalidade generalizada é detetada para os anos de 1714 e 1773/1774, mas com a dimensão de pequenas crises.

Fig. 5 - Evolução dos batizados e óbitos. Séculos XVII e XVIII (Cedros)

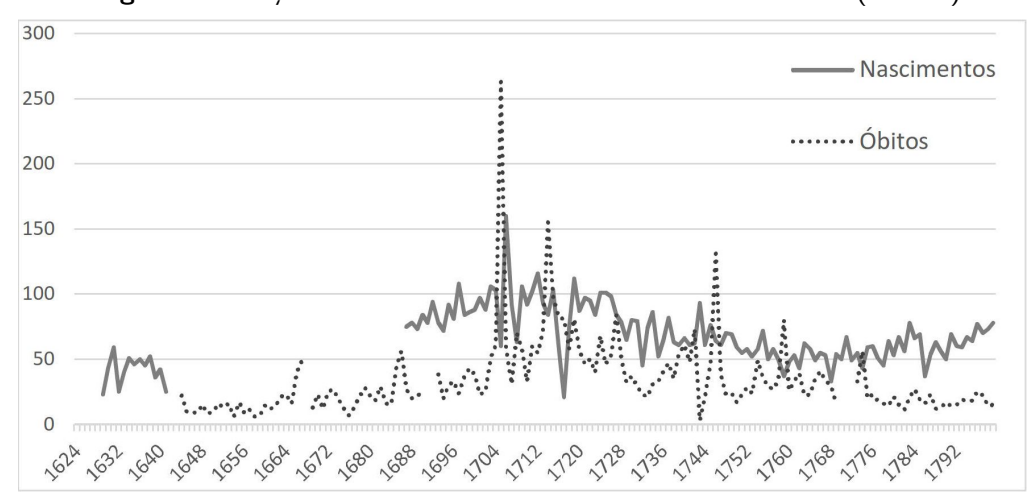


Fig. 6 - Evolução dos batizados e óbitos. Séculos XVII e XVIII (Capelo)

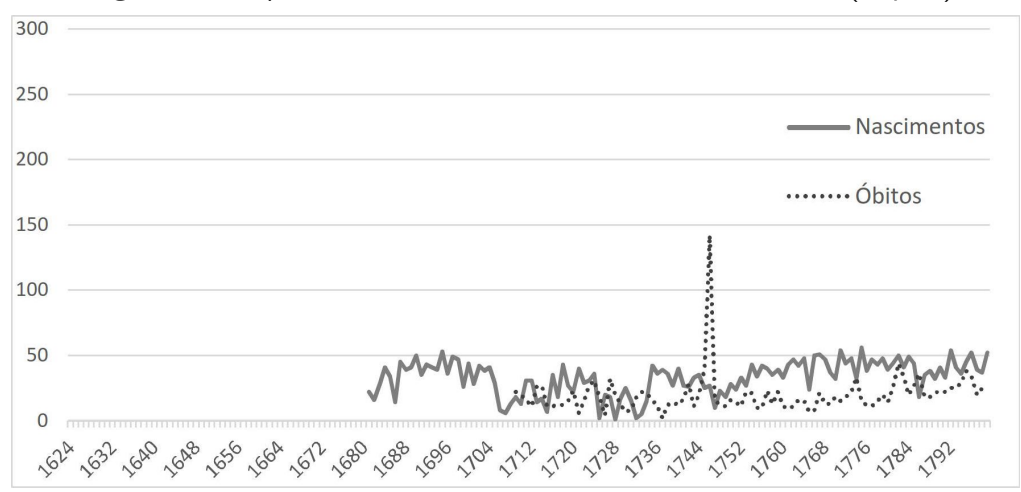

Fig. 7 - Evolução dos batizados e óbitos. Séculos XVII e XVIII (Castelo Branco)

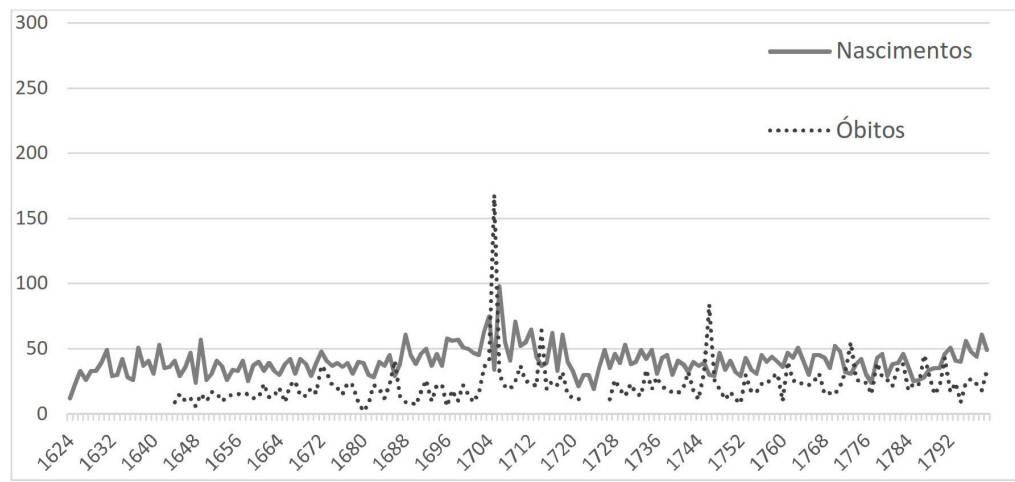

Fig. 8 - Evolução dos batizados e óbitos (Praia do Almoxarife)

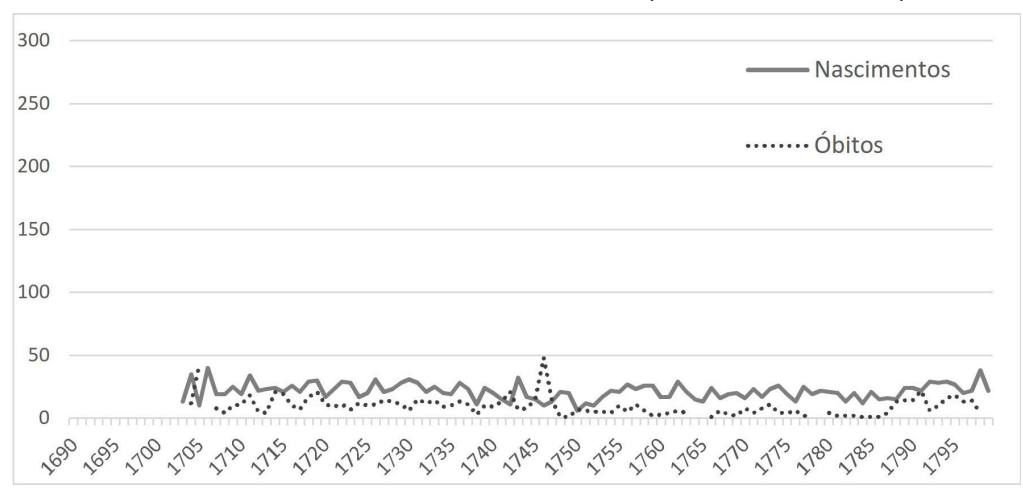


Fig. 9 - Evolução dos batizados e óbitos (Pedro Miguel)

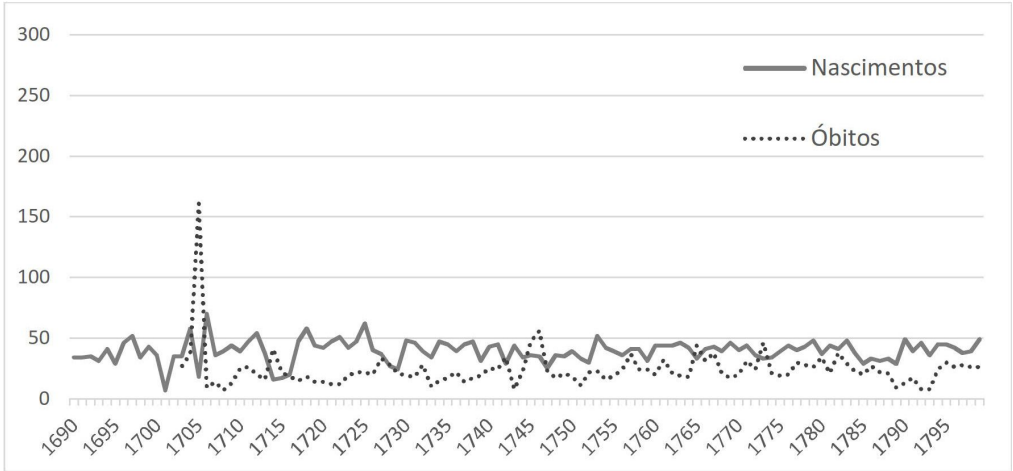

Fig. 10 - Evolução dos batizados e óbitos (Ribeirinha)

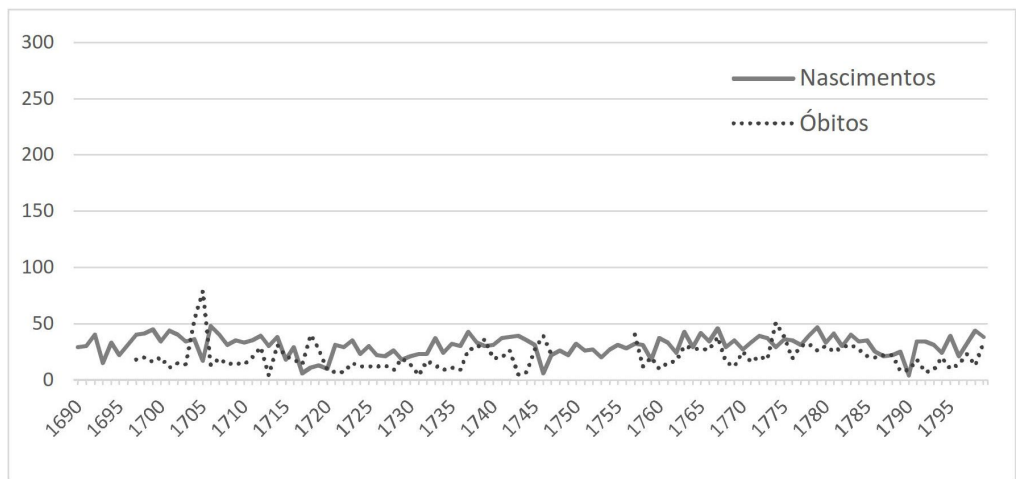

Fig. 11 - Evolução dos batizados e óbitos (Horta - Angústias)

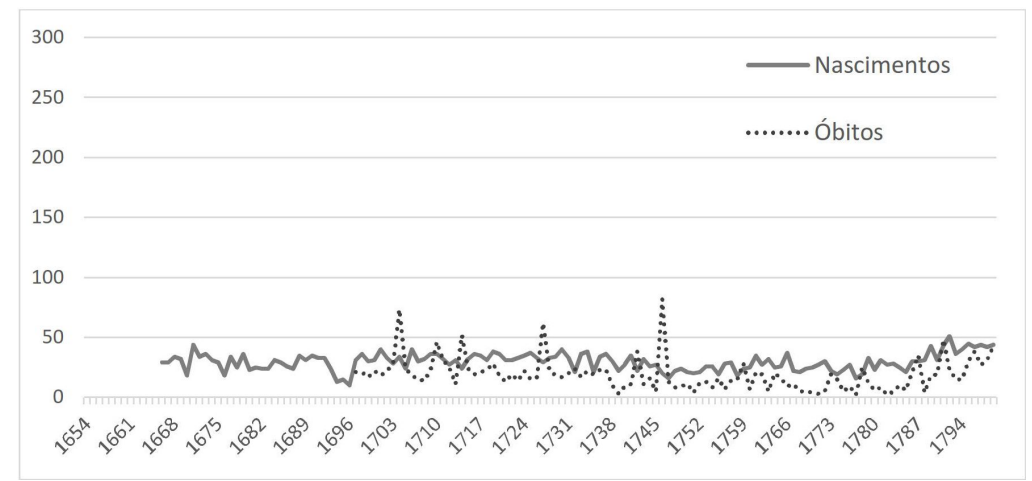


Fig. 12 - Evolução dos batizados e óbitos (Horta - Conceição)

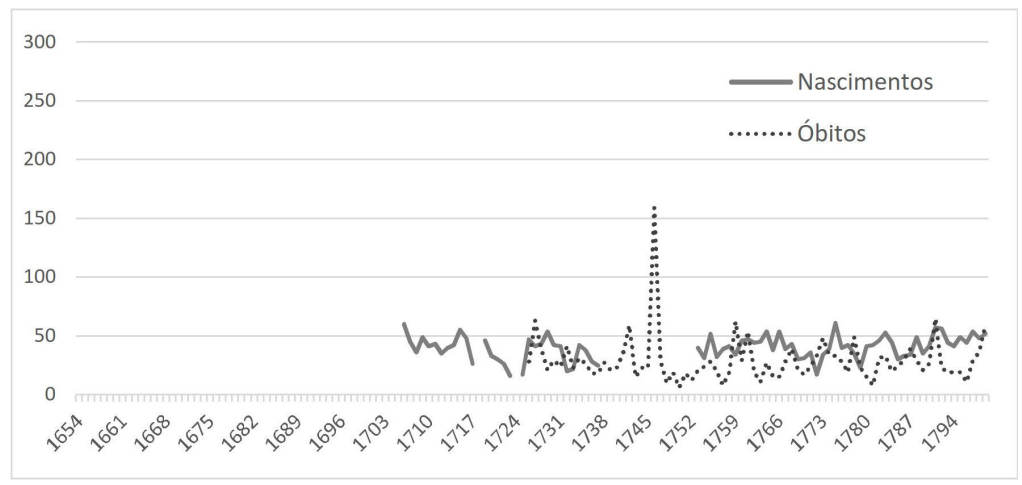

Fig. 13 - Evolução dos batizados e óbitos (Horta - Matriz)

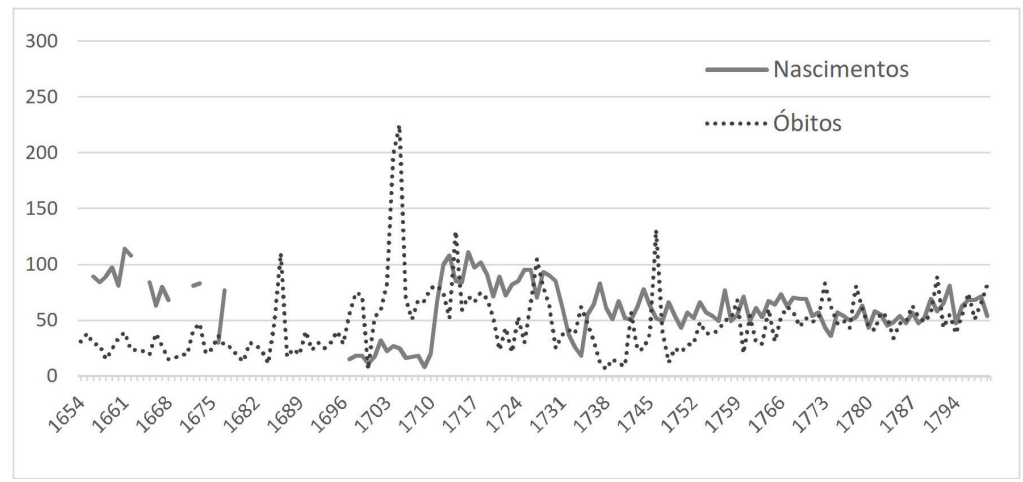

\subsection{A crise de $1704 / 1705$}

Entre 1704 e 1705 desencadeia-se uma grande crise, se considerarmos a classificação de Livi-Bacci e Del Panta. Na generalidade das paróquias em que a observação se torna possível mais que quadruplica o volume normal de óbitos.

Observámos a sazonalidade da crise para as freguesias rurais com registos mais antigos, Castelo Branco, Cedros, Ribeirinha e Pedro Miguel, entre setembro de 1704 e novembro de 1705, meses enquadrantes que apresentam comportamento normal.

Verifica-se que na Ribeirinha, em novembro de 1704, já se contam valores de óbitos superiores à média, atingindo-se o pico em dezembro seguinte. Já em junho de 1705 a curva tende a normalizar. Na freguesia contígua dePedro Miguel, no sul da ilha, a subida da curva dá-se no mês de dezembro, atingindo o máximo em janeiro e fevereiro seguintes, decrescendo depois rapidamente. No caso das 
Fig. 14 - Sazonalidade da crise de 1704/1705 (Castelo Branco, Cedros, Ribeirinha e Pedro Miguel)

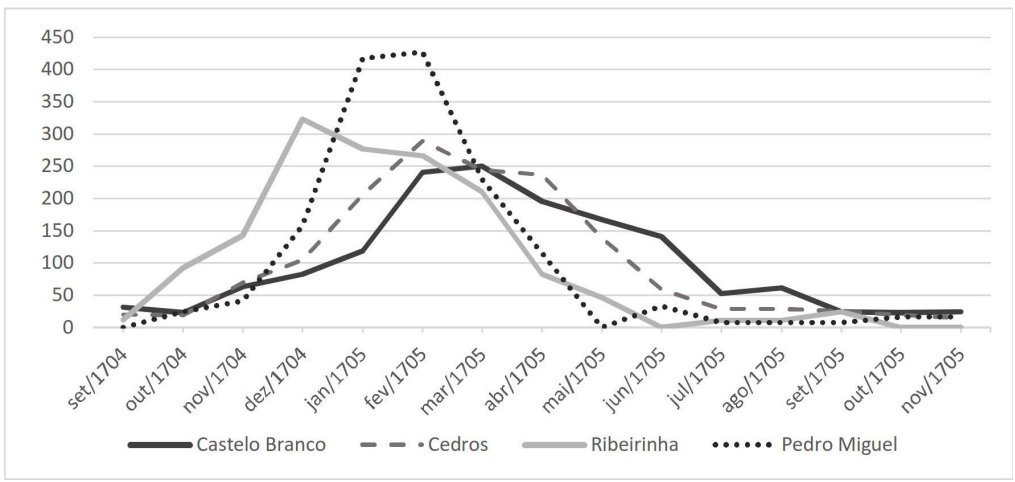

grandes freguesias de Castelo Branco e Cedros os pontos mais altos da curva colocam-se em fevereiro e março, mantendo-se nível elevado ainda em maio.

Aproveitando o cuidado dos párocos de Castelo Branco em registarem a idade dos defuntos, distribuímos os falecidos nessa freguesia por sexos e grupos de idades para todo o ano de 1705 (apenas para quatro casos, três do sexo masculino e um do feminino, não foi apontada idade). Os resultados são surpreendentes.

Tab. 2 - Distribuição da idade dos defuntos em 1705 (Castelo Branco)

\begin{tabular}{lrrrr}
\hline Grupos de Idades & Homens & Mulheres & Total & Total (\%) \\
\hline $0-4$ & 12 & 6 & 18 & 10 \\
$5-14$ & 6 & 4 & 10 & 6 \\
$15-39$ & 16 & 22 & 38 & 22 \\
$40-64$ & 30 & 46 & 76 & 43 \\
65 e mais & 10 & 6 & 16 & 9 \\
Todas as idades & 74 & 84 & 178 & 100 \\
\hline
\end{tabular}

Os indivíduos com menos de 40 anos foram menos afetados do que os mais velhos, colocando-se a média de idades ao óbito para o sexo masculino e feminino, nos 37,8 e nos 40,8 respetivamente. O trabalho microanalítico impõe-se. À partida não podemos descartar a hipótese de algum sub-registo de óbito de menores.

Admitimos que se tratasse de uma epidemia de tifo, que não afetou particularmente crianças e jovens. No entanto, a violência da crise é retratada pelo pároco que deixou de dar a extrema-unção aos moribundos a partir do início de junho por não haver óleos sagrados na freguesia nem em toda a ilha. As covas abriram-se no adro da igreja e, num dos casos, numa mesma 
cova, foram enterrados cinco cadáveres, um homem, duas mulheres e duas crianças, sendo corrente, no auge da crise, o enterramento numa mesma cova de dois defuntos.

Os registos de óbitos da vizinha ilha do Pico são em geral mais tardios, mas da informação que dispomos, 1705 é também nessa ilha um ano de crise. Ano de crise que afeta várias regiões do Continente ${ }^{2}$.

\subsection{A crise de 1746}

Segundo António Lourenço da Silveira Macedo na sua História das Quatro Ilhas que formam o Distrito da Horta (1781), as inundações de 1744

desolaram estas ilhas ocasionando uma esterilidade geral nos campos resultando daí a fome que em 1746 em todas elas se sentiu, mas em maior grau na ilha do Pico, onde o povo recorreu a socas e raízes para manter a vida e faltando-lhe esse mesmo mísero alimento emigrou para as mais ilhas, e com preferência para o Faial, agravando a crise que já aqui se sofria, valendo contudo de muitos uma porção de tremoço que ainda havia que o povo curtiu para se alimentar e ultimamente recorreu a socas e raízes, resultando desse alimento nocivo mortíferas doenças que dizimaram a população.

Publicou-se neste ano um alvará régio convidando os casais que quisessem emigrar para o Brasil franqueando-lhes o governo navios e dando-lhes lá terrenos para cultivarem. Alistaram-se 230 casais de todas estas ilhas com suas famílias que completaram 1.600 pessoas.

Fig. 15 - Sazonalidade da crise de 1746 (Conceição, Paria do Almoxarife e Capelo)

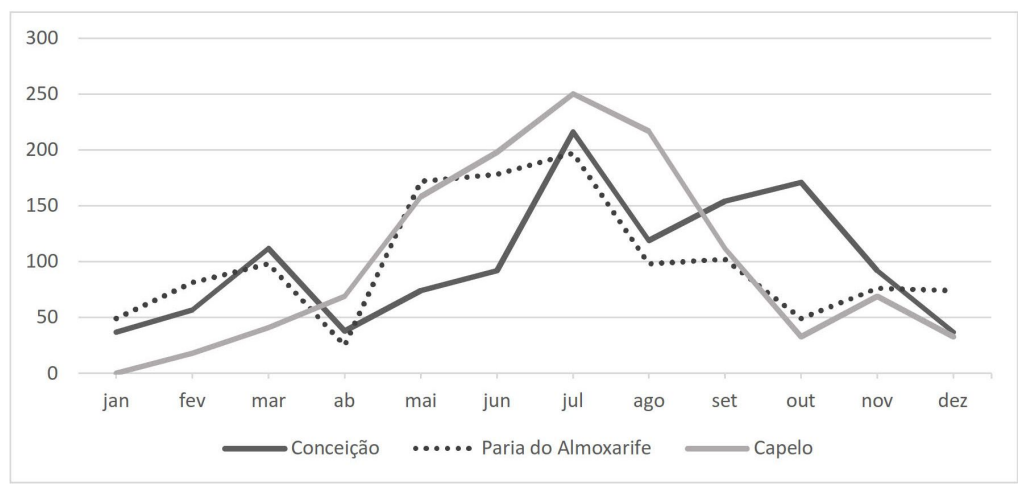

2 Veja-se o trabalho de Hermínia Barbosa sobre as crises de mortalidade (Cadernos NEPS, 2001) e que eu própria detetei nos meus trabalhos sobre Guimarães (1987) e sobre o Nordeste Transmontano (1983). 
Vimos, pela representação gráfica comparada, que nem todas as freguesias faialenses foram afetadas da mesma forma pela epidemia de 1746 . Particularmente gravosa foi a epidemia para a freguesia urbana da Conceição, para Praia do Almoxarife e Capelo.

Em qualquer dessas freguesias, verificamos que a crise se centra no ano de 1746, com o seu pico em julho. A subida dá-se a partir de abril e em setembro já tende para a normalidade nas freguesias rurais, mantendo-se oscilações na freguesia urbana.

Para avaliar da distribuição etária dos defuntos no ano de 1746 observámos a freguesia do Capelo, onde a epidemia foi particularmente gravosa e há registo sistemático da idade dos defuntos.

Verificamos, também neste caso, que mais de metade dos indivíduos falecidos tinham 40 e mais anos, embora a mortalidade infanto-juvenil se veja agravada relativamente à observação sobre Castelo Branco na epidemia de 1704/1705. A médias de idades dos defuntos foi, neste caso, de 32,1, para o sexo masculino, e 37,1, para o feminino.

Tab. 3 - Distribuição da idade dos defuntos em 1746 (Capelo)

\begin{tabular}{lrrrr}
\hline Grupos de Idades & Homens & Mulheres & Total & Total (\%) \\
\hline $0-4$ & 20 & 15 & 35 & 25 \\
$5-14$ & 11 & 6 & 17 & 12 \\
$15-39$ & 12 & 5 & 17 & 12 \\
$40-64$ & 27 & 27 & 54 & 38 \\
65 e mais & 8 & 10 & 18 & 13 \\
Todas as idades & 78 & 63 & 141 & 100 \\
\hline
\end{tabular}




\subsection{As crises do século XIX}

Fig. 16 - Evolução dos batizados e óbitos. 1800-1910 (Cedros)

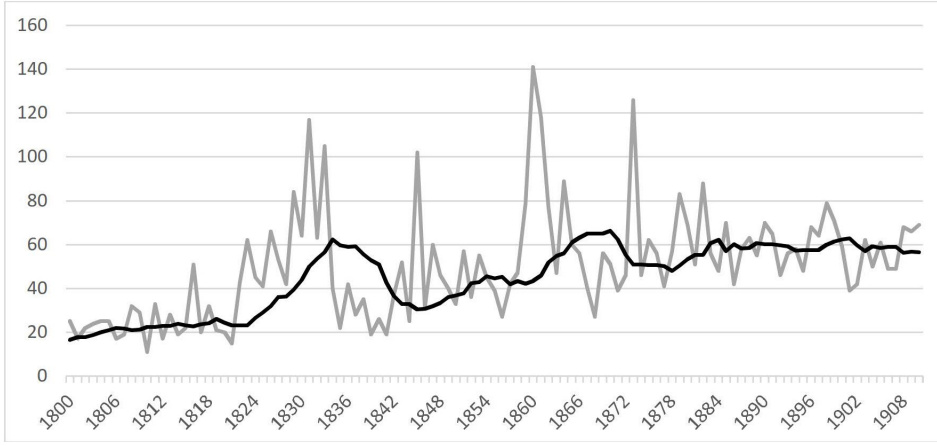

Fig. 17 - Evolução dos batizados e óbitos. 1800-1910 (Capelo e Praia Norte)

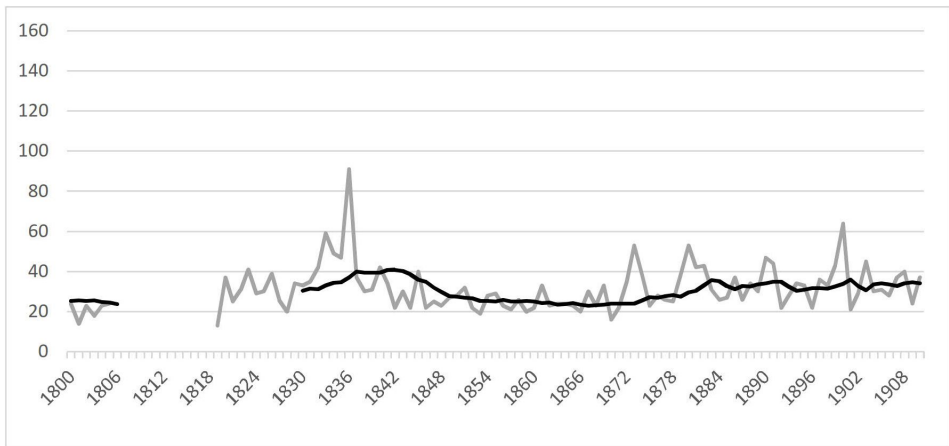

Fig. 18 - Evolução dos batizados e óbitos. 1800-1910 (Castelo Branco)

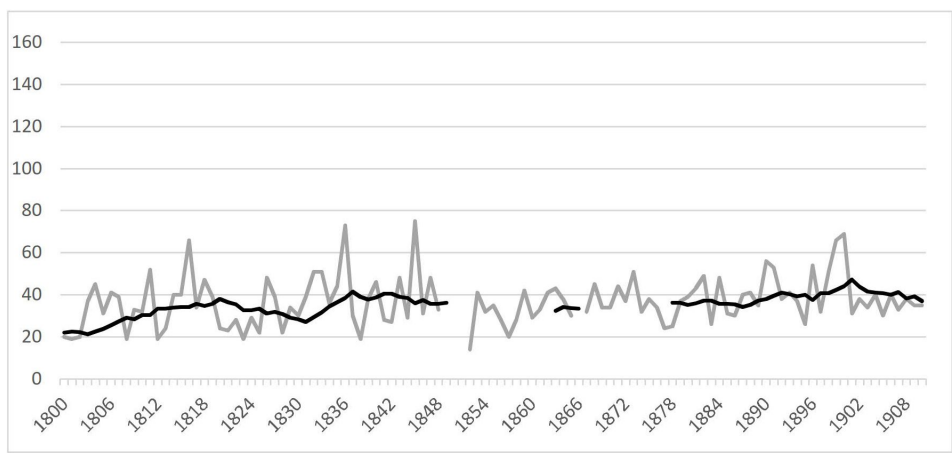


A GRIPE ESPANHOLA NO QUADRO DAS EPIDEMIAS históRICAS DA IlHA DO FAIAL

Fig. 19 - Evolução dos batizados e óbitos. 1800-1910 (Feteira)

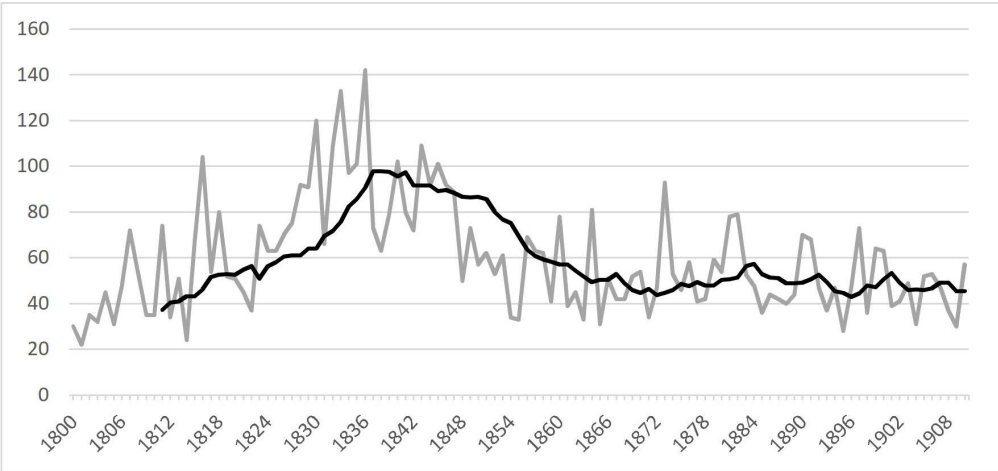

Fig. 20 - Evolução dos batizados e óbitos. 1800-1910 (Salão)

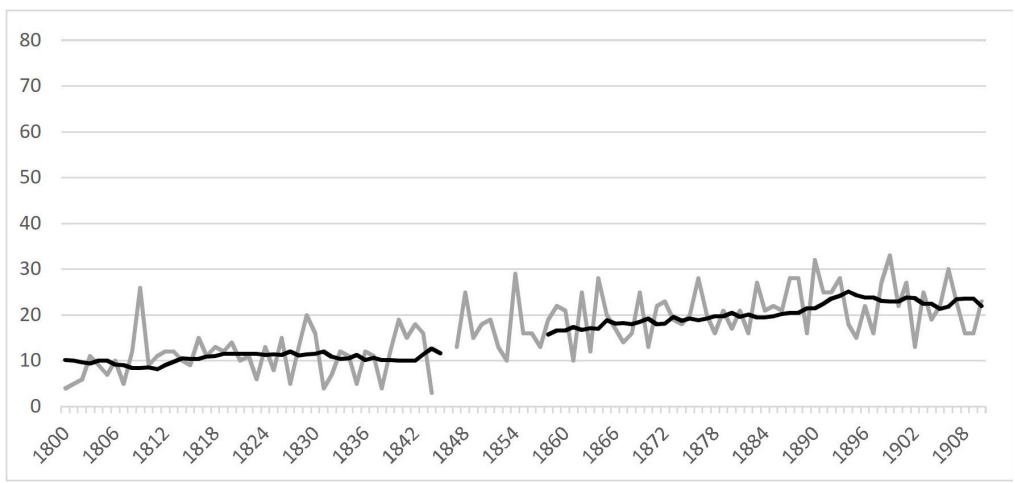

Fig. 21 - Evolução dos batizados e óbitos. 1800-1910 (Ribeirinha)

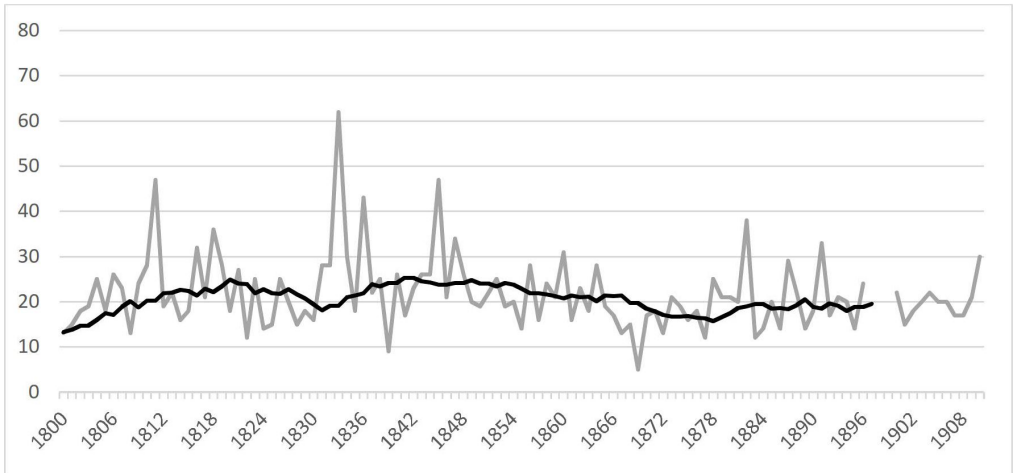


A Gripe Espanhola de 1918

Fig. 22 - Evolução dos batizados e óbitos. 1800-1910 (Pedro Miguel)

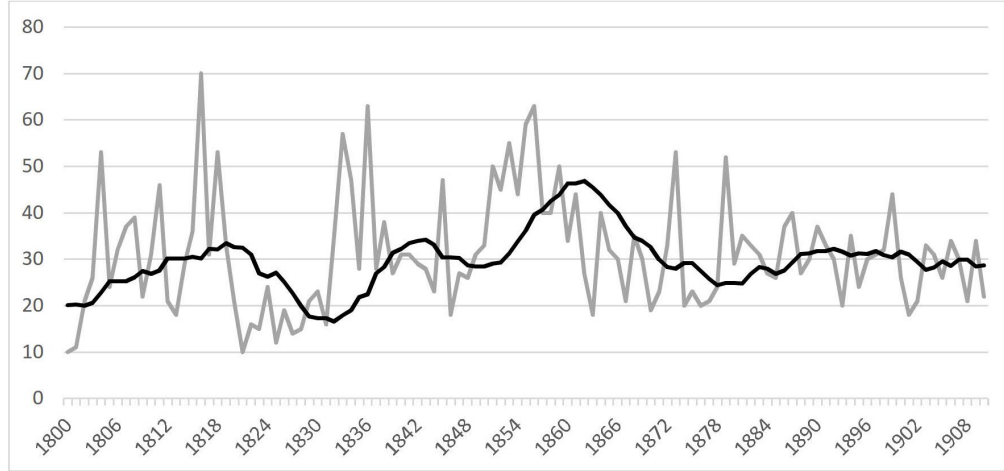

Fig. 23 - Evolução dos batizados e óbitos. 1800-1810 (Praia do Almoxarife)

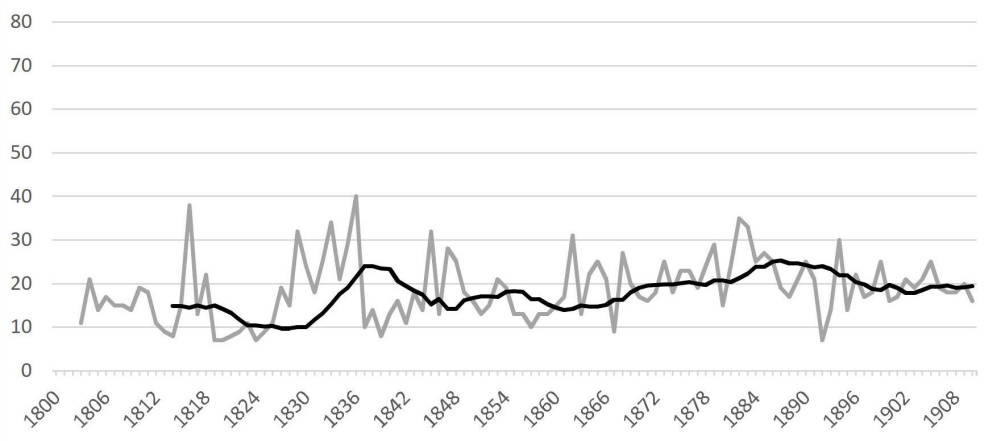

Fig. 24 - Evolução dos batizados e óbitos. 1800-1910 (Horta - Conceição)

120

100

80

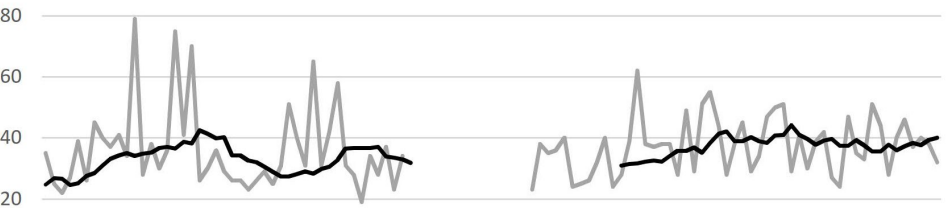

0

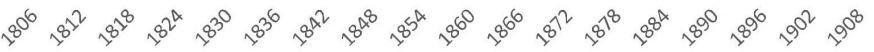

62 
Fig. 25 - Evolução dos batizados e óbitos. 1800-1910 (Horta - Matriz)

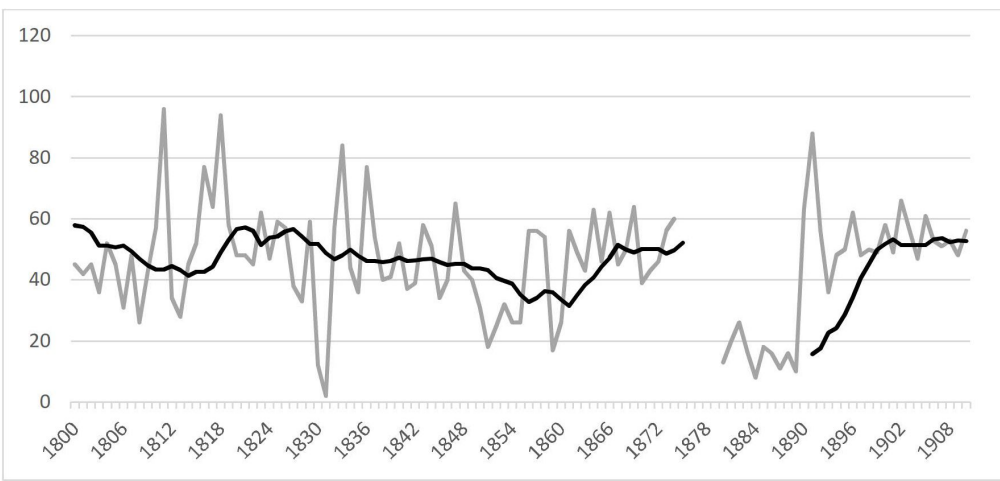

Fig. 26 - Evolução dos batizados e óbitos. 1800-1910 (Horta - Angústias)

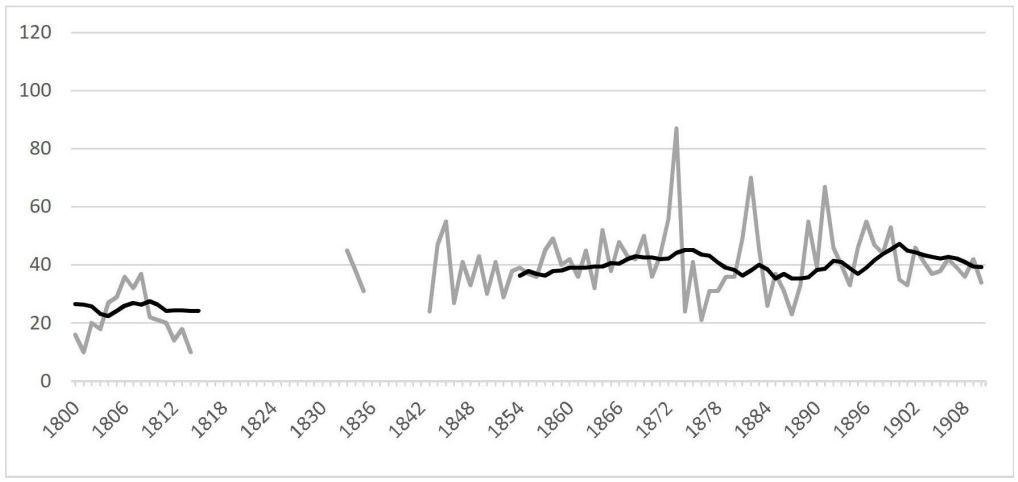

Pese embora a existência de períodos lacunares, particularmente na zona urbana, verificamos ao longo do século XIX uma relativa instabilidade da morte à volta dos valores da média móvel modificada de 11 anos, sem, no entanto, atingir os níveis das duas grandes epidemias do século anterior.

Pela observação já feita sobre o Pico, esperaríamos encontrar sobremortalidade devida a varíola nos anos de 1811, 1816, 1836, 1845 e 1873, principalmente. Tal de facto acontece, particularmente no caso das epidemias de 1816, 1836 e 1873.

Para uma análise mais próxima de uma epidemia de varíola, incidimos sobre a última maior epidemia anterior aos avanços da vacinação, a de 1873 na freguesia rural mais populosa, os Cedros. Verificámos a sazonalidade da crise e depois sobre a idade dos defuntos nos meses de maior mortalidade. 
Fig. 27 - Sazonalidade da crise de 1873 (Cedros)

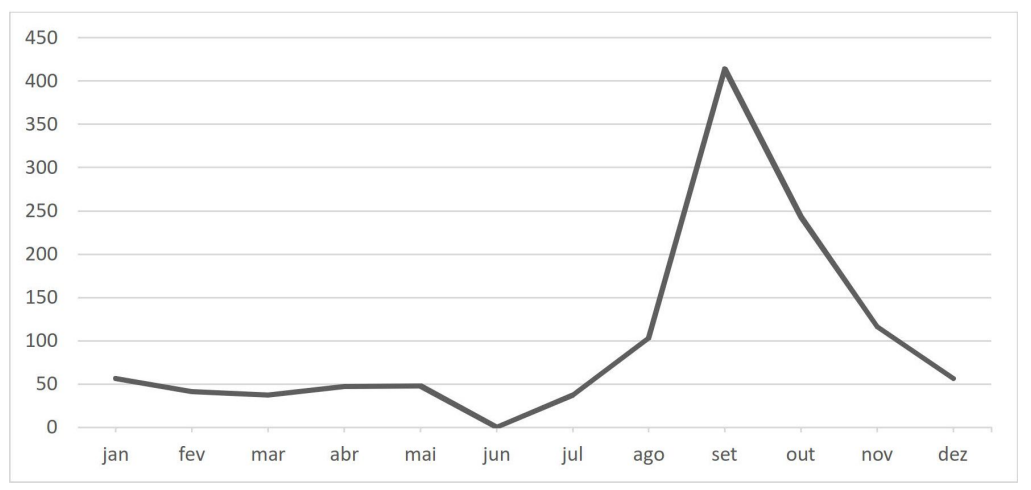

Encontramos sobremortalidade a partir do mês de agosto, atingindo o pico em setembro. Prolongando-se ainda pelo mês seguinte, não tendo já significado em dezembro.

Verificamos que $71 \%$ dos falecidos tinham menos de 10 anos, com maior incidência nas crianças de um a dois anos, a apontar para as crises anteriores a imunizar a população de maior idade.

Tab. 4 - Distribuição da idade dos defuntos entre agosto e novembro de 1873 (Cedros)

\begin{tabular}{lrrrr}
\hline Grupos de Idades & Homens & Mulheres & Total & Total (\%) \\
\hline $0-1$ & 10 & 10 & 20 & 21 \\
$1-2$ & 12 & 9 & 21 & 22 \\
$3-4$ & 13 & 3 & 16 & 16 \\
$5-9$ & 8 & 4 & 12 & 12 \\
$10-19$ & 5 & 5 & 10 & 10 \\
20 e mais & 9 & 9 & 18 & 19 \\
Todas as idades & 57 & 40 & 97 & 100 \\
\hline
\end{tabular}

\section{NOTAS FINAIS}

Uma ilha como o Faial não estava imune às epidemias. Desde cedo, o porto da Horta se abria ao trânsito intercontinental e os contágios podiam processar-se. Admitimos, no entanto, que as comunidades rurais da ilha, antes do século XIX, mantivessem relativo isolamento.

Nos séculos XVII e XVIII, a considerar os valores da idade ao óbito, a esperança de vida na ilha, à semelhança do que acontecia no Pico, colocar-seia num patamar muito favorável. Apenas duas grandes crises de mortalidade 
se destacam: a de 1704/5 e a de 1746. Essas crises, apesar de muito violentas, ao poupar crianças e adolescentes, não tiraram a capacidade de recuperação rápida às populações. No século XIX, a varíola introduz um quadro diferente: surtos frequentes a afetar a população ainda imune ao contágio, as crianças particularmente, penalizaram mais fortemente a renovação das gerações.

A gripe espanhola entrou na ilha tardiamente, com uma incidência marcada apenas no mês que decorre de 27 de novembro a 27 de dezembro de 1918, não tomando proporções de grande crise.

Resta-nos o desafio de microanalisar, para as comunidades rurais da ilha, os comportamentos demográficos dos últimos quatro séculos, podendo admitir-se, a partir deste trabalho, que no Faial, como já se observou no Pico, a esperança de vida tenha atingido valores não expetáveis para o Antigo Regime demográfico europeu.

\section{Bibliografia}

AMORIM,MariaNorberta(1987). Guimarães 1580-1819. Estudo demográfico. INIC,Lisboa.

AMORIM, Maria Norberta (1992). Evolução Demográfica de três Paróquias do Sul do Pico. Instituto de Ciências Sociais, Universidade do Minho.

AMORIM, Maria Norberta (2004). O Pico (séculos XVIII a XX). A Ilha açoriana mais poupada pela morte. Revista de Demografia Histórica, XXII, II, 2004, pp. 53-84.

AMORIM, Maria Norberta (2016). O Pico. A Abordagem de uma ilha. Vol I-As Famílias. Tomo IX, As Famílias de Santa Luzia nos finais do século XIX. CITCEM, Desafios da Montanha CRL, Porto.

BANDEIRA, Mário Leston (1996). Demografia e Modernidade. Família e Transição Demográfica em Portugal. Imprensa Nacional Casa da Moeda, Lisboa.

BARBOSA, Maria Hermínia Vieira (2001). Crises de Mortalidade em Portugal desde meados do Século XVI até ao início do século XX. Cadernos NEPS, Guimarães.

DEL PANTA, L.; LIVI-BACCI, M. (1977). Chronologie, Intensité et Diffusion des Crises de Mortalité en Italie: 1600-1850. POPULATION. I.N.E.D., Paris.

LIVI-BACCI, Massimo (1987). Poblacion y alimentacion. Editorial Ariel, Barcelona.

MACEDO, António Lourenço da Silveira (1981). História das Quatro Ilhas que formam o Distrito da Horta, Volume III, (reimpressão fac-similada da edição de 1871). S.R.E.C., D.R.A.C., Região Autónoma dos Açores.

MESQUITA, Maria Hermínia (1988). Evolução Demográfica na Criação Velha: paróquia do Sul do Pico (1801-1993). Direção Regional da Cultura, Açores.

SANTOS; Carlota (2008). Biodemografia do Concelho da Madalena.NEPS, Câmara Municipal da Madalena. 



\title{
A IlHa Das Flores na Rota DA Gripe EsPanhola
}

\author{
Luís Filipe Nóia Gomes Vieira ${ }^{1}$
}

$\overline{1}$ CITCEM|FLUP - Grupo de Populações e Saúde, luisfilipevieira@sapo.pt 



\begin{abstract}
Resumo
A llha das Flores fica situada na extremidade poente do arquipélago dos Açores, com uma área de $143 \mathrm{~km}^{2}$. A sua posição geostratégica facilitou a emigração para os Estados Unidos da América (EUA) durante a última metade do séc. XIX e primeiras décadas do século seguinte.

Entre 1915 e 1925 a ilha obteve um saldo fisiológico positivo, apesar do embate da pandemia. Somente no ano de 1920 o número de mortes superou os nascimentos. A grande regressão demográfica, verificada entre 1864 e 1920, foi uma consequência da emigração para os Estados Unidos da América.

A escassez de transportes, agravada pela I Guerra Mundial, condicionou a chegada da gripe espanhola. Somente no ano de 1920, em Abril, a população sofreu o flagelo desembarcado do navio Funchal. A primeira morte foi registada a 3 de Maio e nos dias seguintes apareceu em Santa Cruz, Ponta Delgada, Lomba e Lajes. Cedros, Fajãzinha e Mosteiro receberam-na uma a duas semanas depois, porque ficam mais distantes dos primeiros centros de contágio. Manifestou-se de forma exuberante e breve durante um mês.
\end{abstract}

Palavras-chave: Ilha das Flores, pneumónica, gripe, Demografia.

\title{
1. O ESPAÇO E AS GENTES - UMA DEMOGRAFIA EM CRISE
}

A Ilha das Flores, última fronteira de Portugal, fica situada na extremidade poente do arquipélago dos Açores, com uma área de $143 \mathrm{~km}^{2}$, dividida em dois concelhos de dimensão aproximada, Santa Cruz e Lajes, e 11 freguesias, pertencendo Ponta Delgada, Cedros, Santa Cruz e Caveira ao primeiro; Lomba, Fazenda das Lajes, Lajes, Lajedo, Mosteiro, Fajãzinha e Fajã Grande ao segundo concelho.

O clima temperado marítimo faz com que o Inverno e o Verão sejam amenos e facilita a agricultura e a pecuária. Os cereais, leguminosas e tubérculos foram a base da alimentação. A agricultura intensiva, praticada em pequenas courelas, susceptível de alterar a produtividade por causa da imprevisibili- 
dade climatérica, sempre provocou problemas na garantia da subsistência. A produção era destinada ao consumo próprio e só o excedente era lançado no mercado.

O relevo acidentado da ilha foi sempre um entrave às deslocações em terra. Recordemos que a estrada só ligou a vila de Santa Cruz à Fazenda de Santa Cruz, lugar desta mesma freguesia, em 1948, aos Cedros em 1955 e a Ponta Delgada, última freguesia do Norte, em 1966 (Gomes, 2003). A Ilha das Flores: da redescoberta à actualidade (Subsídios para a sua História). Câmara Municipal das Lajes das Flores, Lajes das Flores.. As duas vilas só ficaram ligadas por estrada em 1954 (Gomes, 2003). A dificuldade de deslocação em terra foi superada com o transporte marítimo de pessoas e bens.

A importância geostratégica das Flores assume um peso muitas vezes superior à dimensão e riqueza do seu território. Durante todo o período da navegação à vela, por força da imposição do regime de ventos e correntes no Atlântico Norte, aquela ilha tornou-se um relevante ponto de apoio para as rotas de torna viagem. A confluência de gentes vindas das mais variadas zonas do planeta constituía uma ameaça permanente de entrada de epidemias. O controlo sanitário feito pelo guarda-mor de saúde foi a mais importante medida para minimizar a exposição dos habitantes à acção devastadora das doenças.

Fig. 1 - Evolução da população das Flores 1789-2011

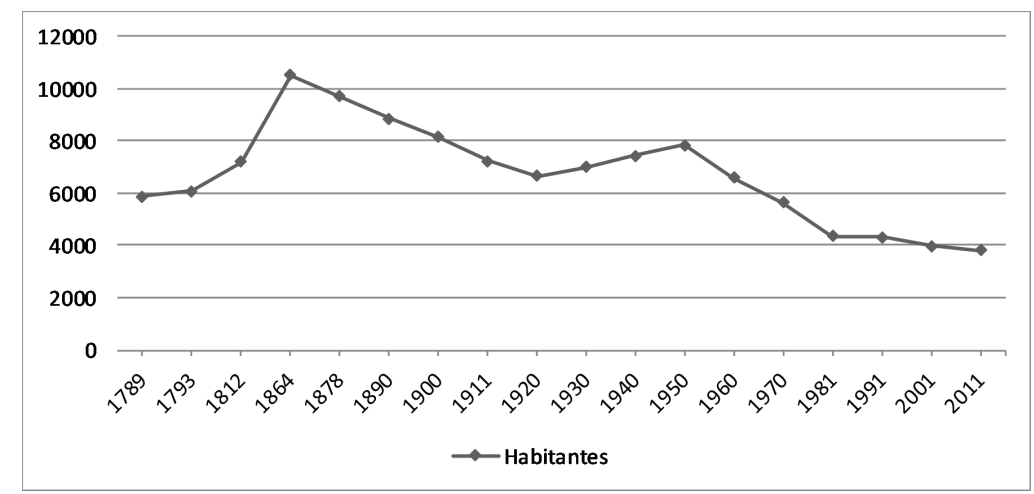

Fonte: Biblioteca Pública e Arquivo Regional Luís da Silva Ribeiro, Capitania Geral, Mapas da população, llhas de São Jorge, Graciosa, Flores e Corvo 1789-1827. Censos da População Portuguesa 1864-2011.

A incapacidade das Flores de sustentar os seus habitantes atirou boa parte dos jovens para o convés das barcas da emigração, que, de forma inexorável, iam drenando os mais novos, atraídos pelas riquezas imaginadas do 
outro lado do Atlântico. A população das Flores correspondia a cerca de $6 \%$ da população do distrito da Horta, mas contribuiu com contingentes migratórios em percentagens muito mais elevadas relativamente ao peso da sua população. Por exemplo, em 1896, forneceu $24,5 \%$ dos emigrantes legais do distrito e um terço em 1897 (Vieira, 2012).

A emigração ilegal teria um peso enorme, mas ainda não foi devidamente estudada.

A pujança demográfica vivida desde o século XVIII até à década de 60 do século XIX, passando de quase 6.000 habitantes para 10.500, não teve seguimento na última metade de Novecentos. Com efeito, em 1864, foi atingido o pico de habitantes na Ilha das Flores, para seguidamente se entrar numa rota descendente que hoje atinge valores alarmantes. Desse ano até 1920, há uma contracção demográfica enorme que representa uma perda de cerca de $40 \%$ dos habitantes que rumaram aos Estados Unidos da América (EUA). Entre os anos 20 e 50 do século passado, verificamos uma retoma de algum significado, traduzida num aumento de 1.188 indivíduos, provocada por leis americanas restritivas da emigração. A inversão da tendência descendente não era vista desde 1864 e ainda mais significativa se torna porque reequilibrou a diferença que havia entre sexos com grande desvantagem para os homens. As décadas de 60 a 80 trazem de volta o despovoamento através de nova onda migratória, favorecida pelo relançamento económico americano do pós-guerra e o abrandamento das leis da emigração. Aqui avulta a intervenção do jovem senador John Kennedy, eleito pelo Estado de Massachusetts, onde reside numerosa comunidade açoriana, que fez aprovar o Kennedy Azorean Refugee Act, de 1958, para responder à crise sísmica do vulcão dos Capelinhos, reabrindo as portas a novas partidas. O advento da autonomia política e administrativa dos Açores, em 1976, trouxe uma melhoria considerável das condições de vida, que se reflectiu numa forte desaceleração da emigração, sem, contudo, alterar o sentido descendente de despovoamento dos Açores e das Flores, em particular. Separando os números por concelhos, o decréscimo é idêntico para ambos, apenas se alterando a partir de 1960 as Lajes perde o título de concelho mais populoso para Santa Cruz.

\section{O IMPACTO DA PNEUMÓNICA NA ILHA DAS FLORES}

No período compreendido entre 1915 e 1925, apesar do embate da pneumónica, as Flores logrou um saldo fisiológico positivo de 349 indivíduos. O crescimento é sustentado pelo vigor natal de Santa Cruz, que apresenta um comportamento oposto ao das Lajes. Enquanto o primeiro concelho apenas 
teve um ano de saldo fisiológico negativo, precisamente em 1920, quando morreram mais sete pessoas do que aquelas que nasceram, e contabiliza saldos muito favoráveis em 1916, 1918, 1921 e 1922, com valores de 50 nascimentos ou superiores e nos restantes anos saldos positivos superiores às duas dezenas, o segundo concelho teve um saldo negativo de 46 indivíduos, logrando anos positivos somente em 1916, 1918, 1922 e 1925, num total de 25 baptizados, contra os valores negativos de 71 indivíduos obtidos em 1917, 1919, 1920, 1921 e 1923.

Tab. 1 - Saldo fisiológico dos concelhos de Santa Cruz e Lajes das Flores 1915-1925

\begin{tabular}{lrrrrrr}
\hline & \multicolumn{2}{c}{ Concelho de Santa Cruz } & \multicolumn{3}{c}{ Concelho das Lajes } \\
\hline Anos & Nascimentos & Óbitos & $\begin{array}{c}\text { Saldo } \\
\text { Fisiológico }\end{array}$ & Nascimentos & Óbitos & $\begin{array}{c}\text { Saldo } \\
\text { Fisiológico }\end{array}$ \\
\hline 1915 & 113 & 76 & 37 & 42 & 42 & 0 \\
1916 & 120 & 53 & 67 & 53 & 49 & 4 \\
1917 & 107 & 86 & 21 & 39 & 50 & -11 \\
1918 & 100 & 49 & 51 & 24 & 21 & 3 \\
1919 & 96 & 68 & 28 & 36 & 51 & -15 \\
1920 & 106 & 113 & -7 & 39 & 75 & -36 \\
1921 & 106 & 53 & 53 & 30 & 36 & -6 \\
1922 & 113 & 63 & 50 & 34 & 28 & 6 \\
1923 & 102 & 78 & 24 & 31 & 34 & -3 \\
1924 & 109 & 63 & 46 & 29 & 29 & 0 \\
1925 & 95 & 70 & 25 & 31 & 19 & 12 \\
\hline Total & 1167 & 772 & 395 & 388 & 434 & -46 \\
\hline \multicolumn{7}{c}{} \\
\hline
\end{tabular}

O saldo fisiológico demonstra que foi a emigração o principal factor de decréscimo populacional e não a pneumónica.

Da análise do movimento de nascimentos e óbitos ressalta à vista uma mortalidade anormal em 1920, único momento em que os nascimentos não são maioritários sobre as mortes. Importa, então, explicar o ano fatídico que representa quase uma duplicação da média anual de óbitos e acresce em mais do dobro as defunções ocorridas em 1918, 1922, 1924 e 1925. Se excluirmos 1917, os restantes anos revelam oscilações pouco sensíveis da curva de mortalidade. A insularidade, agravada com as dificuldades nos transportes, provocadas pela I Grande Guerra, tornou as Flores um caso singular de progressão da epidemia. A gripe espanhola veio no Funchal, navio que ligava as ilhas ao continente e que ancorou nas Flores a 15 de Abril de 1920, desembarcando 64 passageiros, pois foi o único navio a escalar a ilha durante o primeiro semestre do ano. Havia médico a bordo, o guarda-mor de saúde visitou o paquete, a carta de saúde estava limpa e foi dada livre prática. Não

2 Estes valores dizem apenas respeito às freguesias das Lajes, Lomba, Mosteiro e Fajãzinha porque não encontramos documentação relativa às outras freguesias para os anos em estudo. 
cremos que o vírus tenha chegado na viagem anterior, ocorrida um mês antes, considerando que o período de incubação da doença é relativamente curto e o primeiro óbito foi declarado a 3 de Maio.

Fig. 2 - Nascimentos e óbitos na llha das Flores, 1915-1925 3

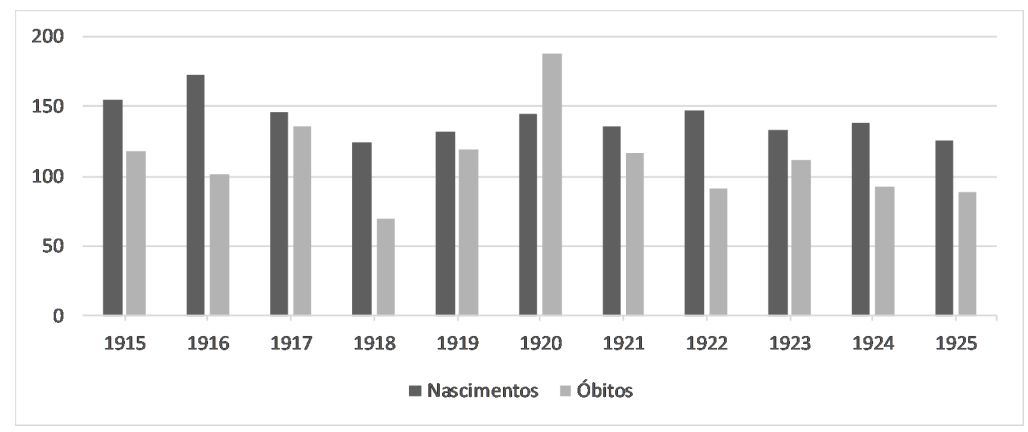

Fonte: Arquivo Paroquial da Ouvidoria da Ilha das Flores.

Não sabemos onde os contaminados embarcaram, porque o navio saía de Lisboa e, ao longo de 10 dias, fazia o percurso pela Madeira e restantes ilhas dos Açores. A falta de estudos sobre o tema para o arquipélago impede-nos de tentar formular uma hipótese. No ano de 1920 não encontramos notícia da pandemia em Portugal continental, nem em S. Miguel, que haviam sido fustigados nos anos de 1918 e 1919 (Monteiro, 2006).

3 Estes valores dizem apenas respeito às freguesias das Lajes, Lomba, Mosteiro e Fajãzinha, porque não encontramos documentação relativa às outras freguesias para os anos em estudo. 
Fig. 3 - Ilha das Flores

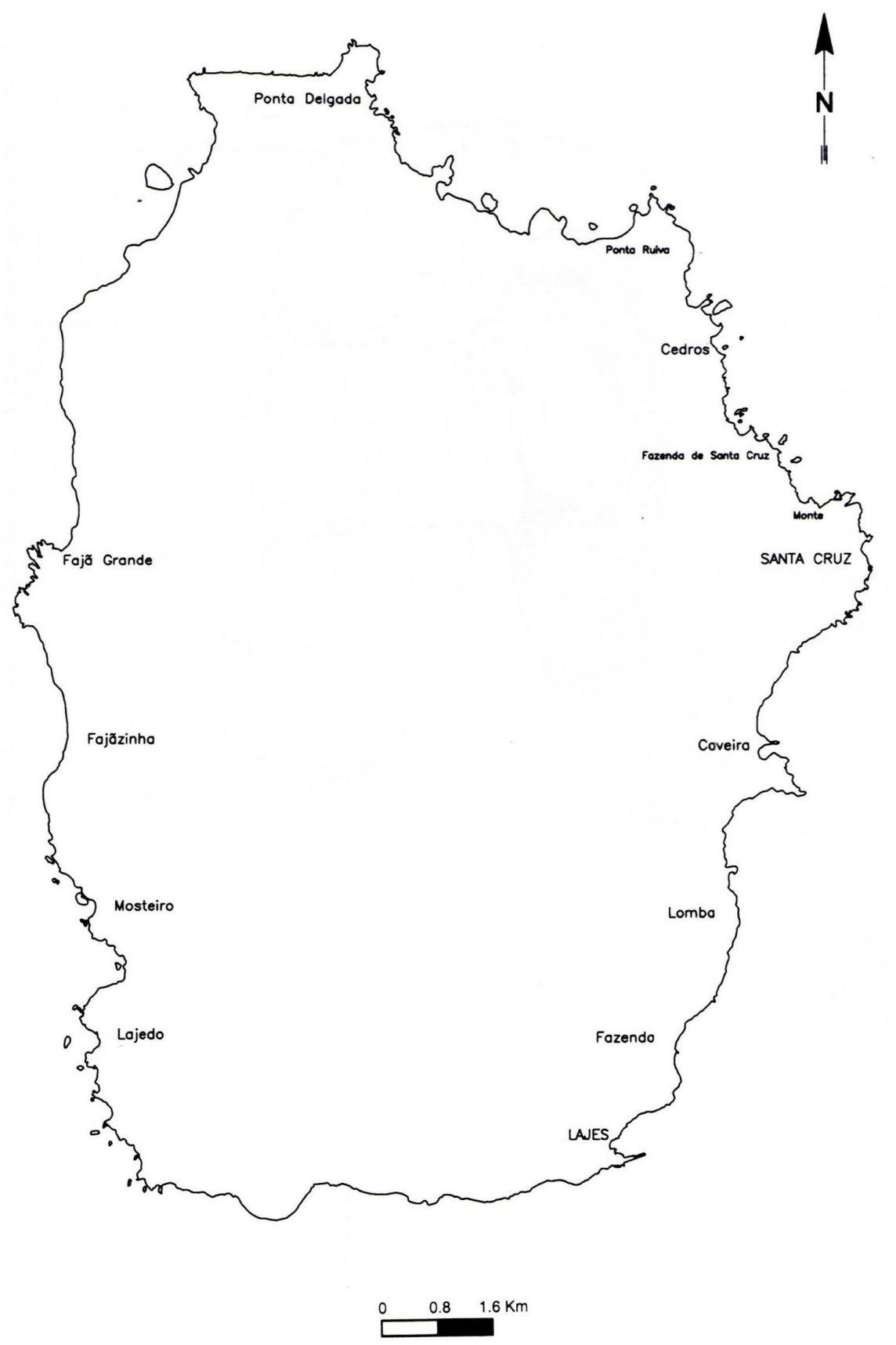

Fonte: Divisão de Topografia, Desenho e Cartografia - SRHE. 


\subsection{O comportamento das populações face à pandemia - concelho de Santa Cruz}

Fig. 4 - Óbitos da freguesia de Ponta Delgada 1915-1925

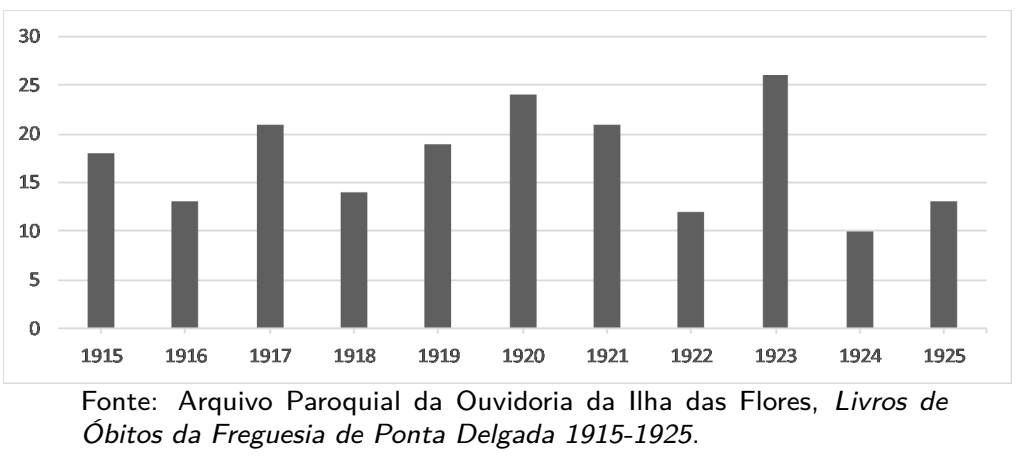

Com o condicionamento da navegação provocado pela I Grande Guerra, viveu-se praticamente daquilo que a terra dava. O organismo humano estaria, em muitos casos, depauperado e foi campo fértil para a instalação e progressão do vírus da gripe.

A freguesia de Ponta Delgada, no extremo Norte do concelho, situada a $21 \mathrm{~km}$ de Santa Cruz, praticamente fazia todas as deslocações de barco, porque o caminho era mau e longo. Embora não haja uma causa de morte indicada para os óbitos, o seu ritmo dos óbitos no mês de Maio é muito diferente dos restantes meses. Começa com uma defunção, a que se seguem duas no dia seguinte, outra a 5 e 7, e a 9 mais duas. Há repetições das ruas de residência e nunca houve mais do que um óbito diário, nem sequer em dias consecutivos, nos anos estudados. Fica o saldo de 7 mortes. Apesar da gripe, este não foi o ano com o maior número de mortes, 1923 ultrapassa-o e 1917 e 1921 quase o igualam.

Os Cedros, freguesia situada a $7 \mathrm{~km}$ da sede do concelho, mas sem estrada de ligação eficaz, apresenta um comportamento semelhante ao de Ponta Delgada: 1920 não foi o ano de maior mortalidade, esse recorde foi batido em 1916. Em 1925 morreram tantas pessoas como no ano da gripe e 1917 só ficou a dois enterramentos. Os anos de 1918, 1922 e 1924 foram anos de mortalidade moderada (Fig. 5). 
Fig. 5 - Óbitos da freguesia dos Cedros, 1915-1925

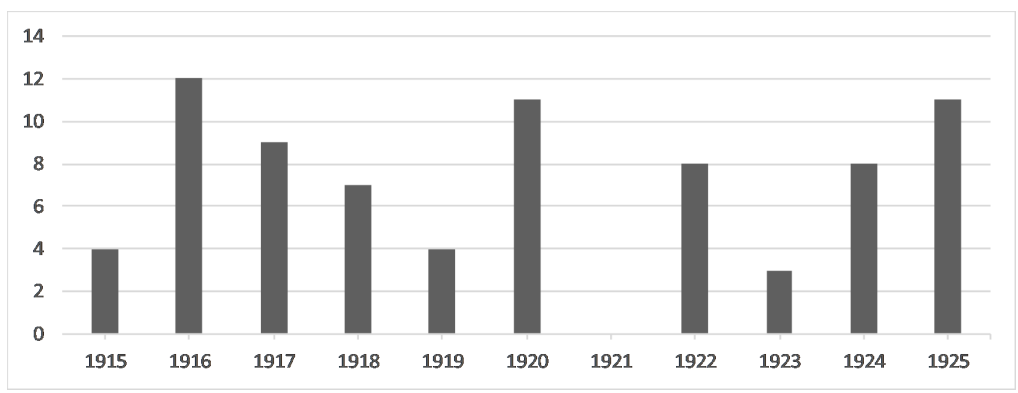

Fonte: Arquivo Paroquial da Ouvidoria da Ilha das Flores, Livros de Óbitos da Freguesia dos Cedros, 1915-1925.

Fig. 6 - Óbitos da freguesia da Caveira, 1915-1925

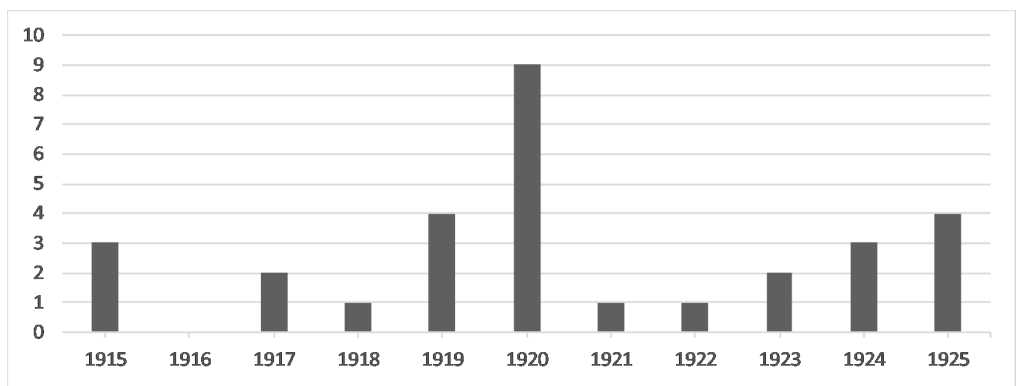

Fonte: Arquivo Paroquial da Ouvidoria da llha das Flores, Livros de Óbitos da Freguesia da Caveira, 1915-1925.

Fig. 7 - Óbitos da freguesia de Santa Cruz das Flores, 1915-1925

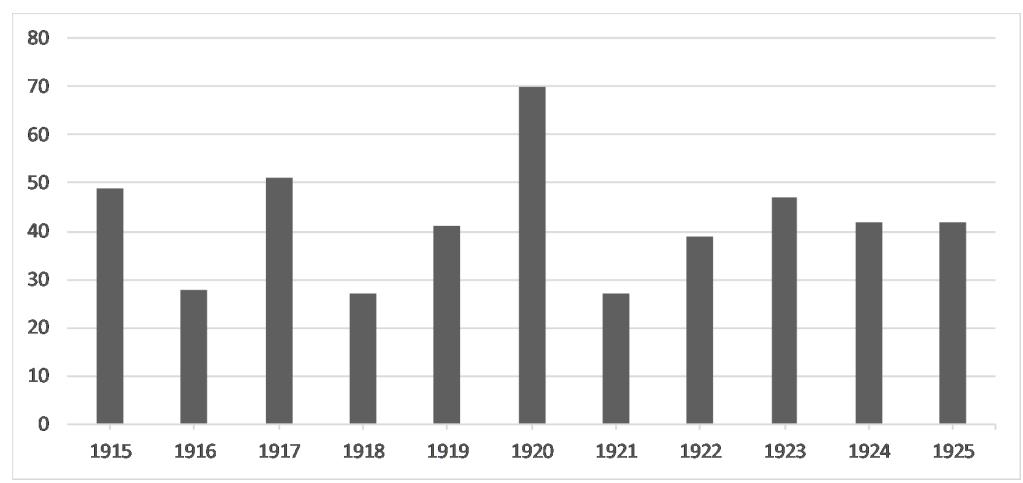

Fonte: Arquivo Paroquial da Ouvidoria da llha das Flores, Livros de Óbitos da Freguesia de Santa Cruz, 1915-1925. 
Sem a indicação da causa de morte, é novamente o número e a densidade dos óbitos que nos revelam a chegada da maleita, um pouco mais tarde do que nas restantes freguesias do concelho. Aqui, temos a primeira morte a 8 de Maio, com repetições a 10, 14, 18 e 28. Os três últimos casos aconteceram no Miradouro. No mês seguinte, a doença desapareceu.

A Caveira atesta, de forma inequívoca, a passagem da pandemia com mais do dobro dos óbitos em 1920 face a 1919 e 1925. Os restantes anos apresentam valores muito baixos. Dos nove decessos verificados em 1920, quatro aconteceram no mês de Maio, tantos quantos haviam ocorrido nos piores anos do decénio em estudo. Voltamos a encontrar repetições de mortes na mesma vizinhança: dois foram na Rua da Igreja e dois na Rua do Sul. Tem a primeira causa de morte por gripe, indicada nas Flores, a 3 de Maio.

Em Santa Cruz, 1920 destaca-se pela elevada mortalidade. Vejamos em pormenor o ano: metade das defunções anuais ocorreram no mês de Maio. Dessas, 31 tiveram a gripe como causa declarada e 30 não tiveram causa de morte atribuída, mas certamente que a pandemia esteve na origem de muitas delas.

Os primeiros óbitos por gripe surgem em localidades limítrofes da vila, a 4 e 5 Maio. Atingem o núcleo central a 8, nas Ruas de Santa Catarina e das Flores, depois sobem para a Rua de Santo Espírito, ao mesmo tempo que se propagam pelas restantes ruas da sede do município. Desde os primeiros dias que encontramos repetições de mortes na mesma rua, verificando também a morte de pai e filho, aquele com 55 anos e este com 13. Podemos dizer que a pandemia praticamente atacou por igual os dois sexos: 14 homens e 17 mulheres. Considerando que a maioria das mulheres eram domésticas e os homens agricultores, são também estes grupos profissionais que encabeçam a lista de mortes: quatro domésticas, doze agricultores, dois proprietários, dois marítimos, uma costureira e sete crianças.

Distribuindo a mortalidade por escalões etários, encontramos uma curva em forma de W, querendo isto dizer que o grupo, à partida, melhor preparado fisicamente para resistir à doença, os adultos dos 20 aos 40 anos, também foi ceifado impiedosamente pela gripe espanhola. As idades extremas são sempre presas fáceis da pandemia: morreram sete crianças até aos 10 anos, sete adultos dos 20 aos 40 anos e outros tantos no grupo de 70 para cima. Uma divisão matematicamente igualitária. De alguma importância é o escalão dos 50 aos 69 anos já que faleceram seis pessoas. Este surto tinha a particularidade de criar nos adultos jovens os casos mais complicados e cobrar um elevado número de vidas. Álvaro Sequeira (2001: 56), com as devidas reservas, indica a possibilidade do vírus de 1918 e da pandemia de 1890 terem alguns antigénios 
comuns que proporcionaram uma imunidade parcial aos idosos de 1918 que tivessem sido contaminados em 1890. Não releva a diferenciação entre sexos. Temos que ter cuidado com as conclusões, porque é pequeno o universo de mortes identificadas com causa gripal.

Fig. 8 - Distribuição diária dos óbitos por gripe na freguesia de Santa Cruz das Flores, em Maio de 1920

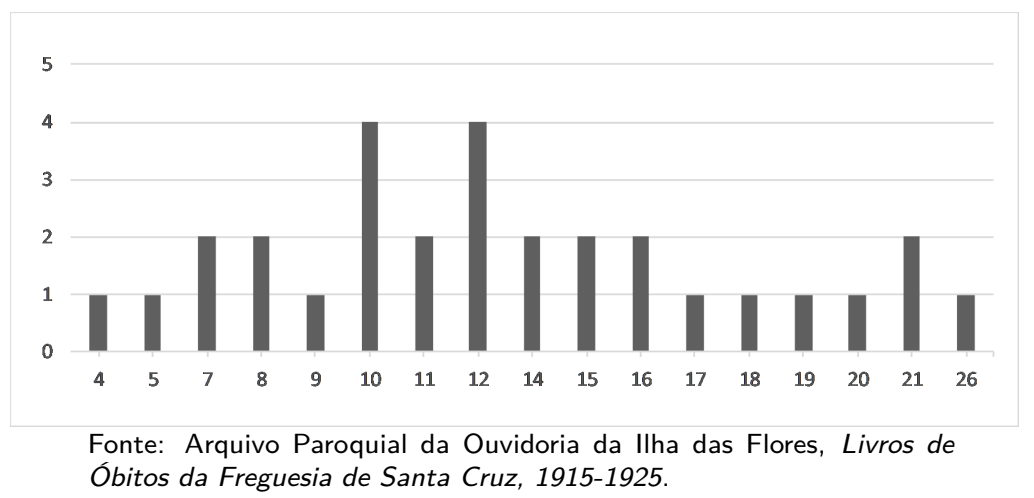

Mais uma vez, encontramos uma situação epidemiológica explosiva, com a contaminação a propagar-se de forma vertiginosa e com os falecimentos a sucederem-se diariamente. Entre 10 e 12 de Maio foram feitos quatro enterramentos diários e em outros dias, dois e três. Foi assustador não só o número de baixas, como a frequência diária com que ocorria: entre 8 e 21 de Maio, só não morreu gente no dia 13. O flagelo durou cerca de um mês.

\subsection{O comportamento das populações face à pandemia - concelho das Lajes}

Entremos no concelho das Lajes pela freguesia mais a Norte e mais próxima do concelho de Santa Cruz, a Lomba. As condições socio-económicas em nada divergiam da outra parte das Flores. A carência e dificuldade de subsistências eram iguais.

Aqui teremos que ser ainda mais cuidadosos na reflexão a fazer, porque nos faltam livros de três freguesias, sendo duas de bastante expressão demográfica à escala local.

O ano de 1920 volta a não ser aquele que tem maior mortalidade, com efeito é ultrapassado por 1919 e igualado por 1915. Os anos mais favoráveis à vida foram os de 1924 e 1918. 
Fig. 9 - Óbitos da freguesia da Lomba, 1915-1924

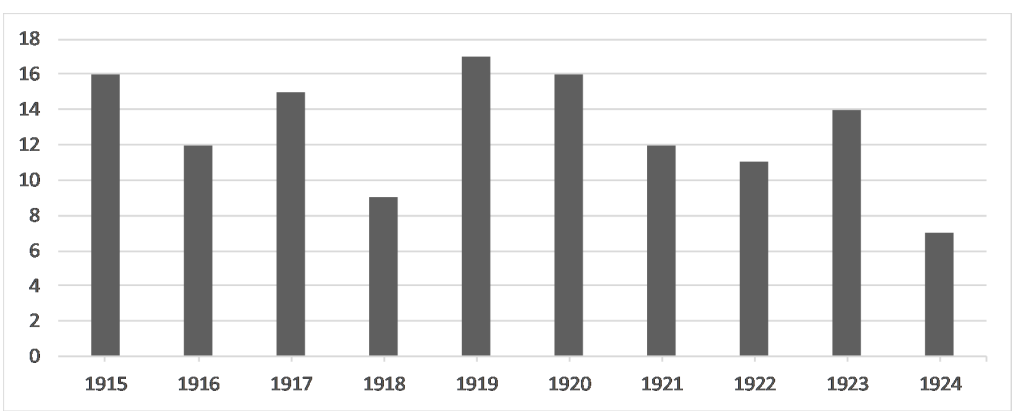

Fonte: Arquivo Paroquial da Ouvidoria da llha das Flores, Livros de Óbitos da Freguesia da Lomba, 1915-1925.

Faleceram 11 mulheres e cinco homens. Esta diferença pode ser explicada pelo desequilíbrio estrutural entre sexos, que se conhece ser, desde as últimas décadas do século XIX, favorável às mulheres. Ocorreram quase tantas defunções na última semana de Abril quanto as ocorridas na primeira semana de Maio, com a diferença que, neste mês, morre um agricultor de 29 anos e uma criança de 5 meses, que encaixam no padrão de mortalidade da pneumónica, que lavrou durante uma semana. As mortes ocorrem nos primeiro, segundo, terceiro e sexto dias do mês e equivalem a um terço dos óbitos do ano.

Na leitura das freguesias, feita de Norte para Sul, saltamos a sede do concelho por ser um universo maior e propiciador de tirar algumas conclusões, tal como fizemos na análise de Santa Cruz.

Fig. 10 - Óbitos da freguesia do Mosteiro, 1915-1920

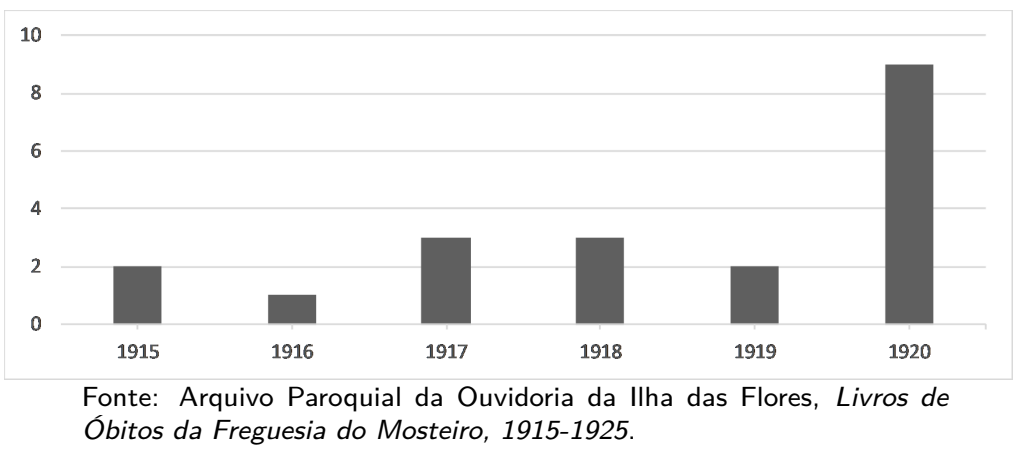

O Mosteiro é a freguesia que melhor reflecte o impacto brutal da gripe ao revelar 1920 com o triplo dos óbitos ocorridos face a 1917 e 1918. Por ficar longe da sede dos dois concelhos e pior servida de vias de comunicação, teve 
o primeiro óbito a 19 de Maio, quase três semanas passadas sobre a primeira ocorrência. Seguem-se novas vítimas em 21, 22, 24 e 26 desse mês, tendo-se registado neste último dia duas mortes. É de novo a cadência rápida e fugaz que ressalta da observação dos dados: uma semana foi suficiente para cobrar o seu tributo à vida.

Passemos agora à Fajãzinha, outro aglomerado populacional da costa Oeste.

Fig. 11 - Óbitos da freguesia da Fajãzinha, 1915-1924

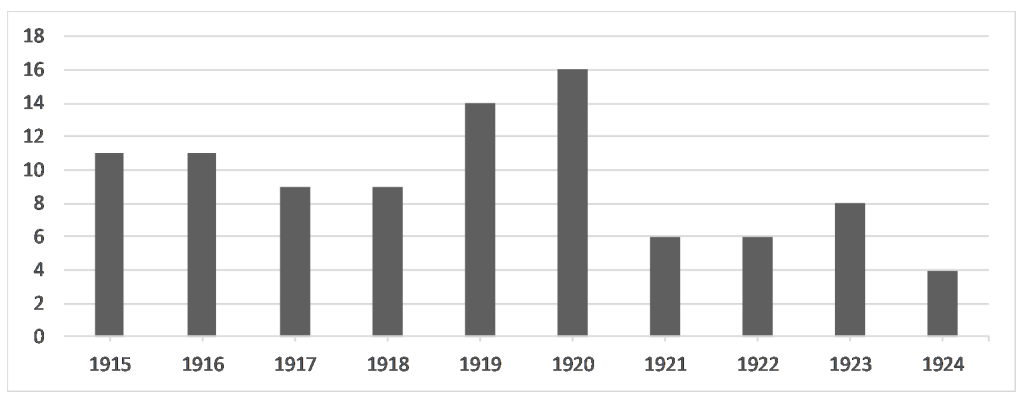

Fonte: Arquivo Paroquial da Ouvidoria da llha das Flores, Livros de Óbitos da Freguesia da Fajãzinha, 1915-1925.

Foi 1920 o ano mais mortífero do período em análise, superiorizando-se apenas ao ano anterior em dois indivíduos. Nova freguesia longe das sedes dos concelhos, à época ficaria quase à mesma distância de cada uma delas, pelo que recebe com atraso a ingrata visita, entre 13 e 27 de Maio, ou 3 de Junho se quisermos alargar um pouco mais a sua possível permanência. O facto do óbito de Junho pertencer a uma doméstica de 44 anos leva-nos a pensar que possa ser a última vítima do flagelo. São dez defunções que ocorrem a um ritmo diário, correspondendo a quase dois terços dos finados do ano.

Deixamos para o fim a sede do município por ter um universo demográfico mais alargado e mais susceptível de encontrar tendências.

A vila das Lajes foi vincadamente marcada pela morte, como é evidente na figura 12. De facto, 1920 foi o ano mais mortífero, destacando-se de todos os outros.

Somos de opinião que, também nesta freguesia, a doença começou a martirizar a população em Maio, em período semelhante ao de Santa Cruz e de Caveira, pois encontramos falecimentos em dias seguidos - 1, 2, 4, 5, 6 até dia 25-, com várias defunções diárias e um recorde de quatro uma semana após o registo da eclosão da epidemia. Quase metade dos falecimentos do ano ocorreram neste mês: 23 vítimas eram octogenários ou tinham idade 
Fig. 12 - Óbitos da freguesia das Lajes das Flores, 1915-1925

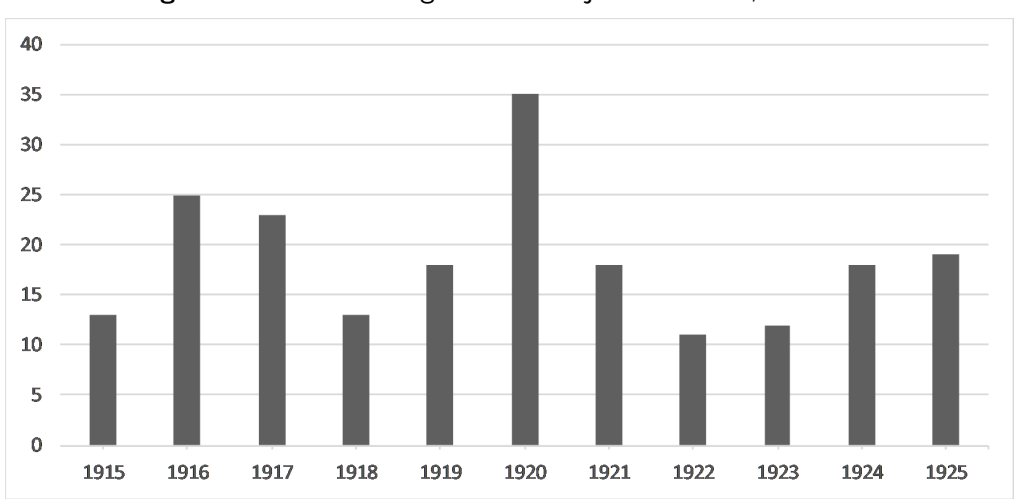

Fonte: Arquivo Paroquial da Ouvidoria da llha das Flores, Livros de Óbitos da Freguesia das Lajes, 1915-1925.

superior, oito eram sexagenários e septuagenários, pereceram cinco jovens dos 10 anos 19, enquanto os restantes grupos apresentam valores de uma ou duas unidades. Ao nível das profissões, também predominam largamente os agricultores e as domésticas. Neste universo, as crianças e os jovens adultos foram relativamente poupados, em comparação com o que se passou em Santa Cruz, e os velhos mais penalizados.

Tudo leva a crer que houve um aparecimento repentino e simultâneo da pandemia em vários locais. Sem causa de morte identificada, é certo, o que nos obriga a ser prudentes, mas numa cadência inusitada, encontramos mortes em Ponta Delgada, nos primeiros dois dias de Maio, na Caveira a primeira morte por gripe é identificada a 3 de Maio, em Santa Cruz a 4, na Lomba sem causa confirmada, encontramos movimentos de mortalidade anormais também nos primeiros dias do mesmo mês, verificando-se idêntica situação nas Lajes. Os Cedros, no concelho de Santa Cruz, Fajãzinha e Mosteiro, no concelho das Lajes, apresentam indícios de uma contaminação mais tardia, sobretudo as duas últimas freguesias, com os primeiros casos a deflagrarem por volta de meados do mês.

\section{CAUSAS DE MORTE NO CONCELHO DE SANTA CRUZ DAS FLORES (1915-1925)}

A falta de preocupação em registar as causas de morte faz com que a amostra não seja tão alargada como gostaríamos. No concelho das Lajes, não temos elementos; no de Santa Cruz, apenas possuímos para as freguesias da 
Tab. 2 - Causas de morte em Santa Cruz das Flores (Maio de 1920)

\begin{tabular}{lr}
\hline Causa de Morte & N. \\
\hline Resfriamento & 1 \\
Não preenchida & 15 \\
Gripe & 31 \\
Debilidade senil & 2 \\
Gastroenterite & 3 \\
Lesão orgânica do coração & 1 \\
\hline Total & $\mathbf{5 3}$
\end{tabular}

Fonte: Arquivo Paroquial da Ouvidoria da llha das Flores, Livros de Óbitos de 1915-1925.

Caveira e Santa Cruz, raramente para Cedros e Ponta Delgada, o que talvez seja explicado pela distância do médico e dificuldade de transportes, sendo muitas vezes a autoridade administrativa a atestar o óbito, confirmando-o como resultado de causa natural.

Vamos retirar das nossas preocupações os $40 \%$ de indivíduos cuja causa mortis não foi referida e focar a nossa atenção naqueles que têm o motivo atestado por um médico. A velhice é a primeira e mais constante causa de morte (98 indivíduos), seguida da dupla gastroenterite e enterite (72 indivíduos e uma incidência muito grande na população infantil), da gripe (57 indivíduos, sendo 37 em 1920 e desses 31 faleceram em Maio) e a doença cardíaca (44 indivíduos). Menos expressivas são: a debilidade congénita, 19 indivíduos que não foram capazes de sobreviver aos primeiros dias de vida; importante pela incidência única no ano de 1917 foi a tosse convulsa, a que somamos a coqueluche, por serem sinónimas, e que juntas mataram 14 crianças e jovens; a pneumonia com 11 mortes; hemorragia cerebral com oito e mal de Bright com nove completam a lista das doenças mais significativas. Existe ainda uma infindável lista de causas com valores pouco significativos. Para o fim deixamos a tuberculose pulmonar, que não tendo um quantitativo muito alto, rouba a vida a 21 indivíduos, quase dois por ano, mas que assombra o quotidiano das gentes com uma persistência constante. A medicina não dispunha de antibióticos e o aparecimento da doença correspondia a uma efectiva sentença de morte. Crescemos nos anos 70 a ouvir falar desta doença com um sentimento muito grande de terror ainda patente na comunidade, apesar da disponibilidade de terapêuticas eficazes, que tornaram a tuberculose numa doença curável, sem grande incómodo para o doente. Lembramos a frequente evocação e eterna gratidão à alma do tio emigrado na América, que, nos primeiros anos da década de 50, enviou as injecções 
aplicadas à nossa prima adolescente que lhe salvaram a vida. Como se vê, em meados do século XX, os antibióticos não eram facilmente adquiridos na Ilha das Flores.

Se descermos ao nível da microanálise e concentrarmos a atenção no mês de Maio de 1920, concluímos que a pandemia provocou 31 vitimas mortais, seguida da gastroenterite (3), da debilidade senil (2) e do resfriamento e lesão orgânica do coração (1), respectivamente. Continuamos sem informação para 15 óbitos.

\section{CONCLUSÃO}

A Ilha das Flores vinha a sofrer uma sangria de população desde 1864 provocada, por uma forte emigração com destino à América e não por qualquer alteração do comportamento demográfico. O impacto da pandemia no efectivo populacional é insignificante, porque o saldo fisiológico negativo de 1920 pouco passa dos 40 indivíduos.

A pneumónica chegou às Flores com dois anos de atraso, tendo-se registado somente uma curta incidência em Maio, mês em que se concentrou o contágio. Parece ter havido um conjunto de focos infeciosos que, praticamente ao mesmo tempo, irrompem em Ponta Delgada, Santa Cruz, Caveira, Lomba e Lajes. Dos 64 passageiros desembarcados, havia gente portadora do vírus com residência pelo menos nalgumas dessas freguesias e os contactos comerciais, sociais e familiares produziram o resto. As freguesias da costa Oeste, mais distantes das vilas, conheceram a doença cerca de duas semanas mais tarde. A dificuldade de comunicações com o exterior e a difícil deslocação no interior da própria ilha criaram tempos de propagação diferentes.

Identificamos a sua marca pelo número anormal de finados por comparação com os nascimentos, pois é o único ano do período estudado em que há mais óbitos do que nascimentos. A insularidade, sem dúvida, retardou a chegada do vírus. Apesar da sua elevada mortalidade, nalgumas freguesias não foi a principal causa de morte, existindo outros anos mais mortíferos. Atingiu sobretudo crianças, o grupo etário entre os 20 e os 40 anos e idosos.

Detectamos três causas de morte principais: velhice, doenças do aparelho digestivo - que atingem sobretudo crianças-, e doenças infeciosas que aparecem com especial violência num momento determinado. A gripe, em Maio de 1920, e a tosse convulsa, na Primavera de 1917, são disso exemplo. Menos exuberante nos números, mas assustadoramente presente, era a tuberculose pulmonar, que cobrava vidas todos os anos e para a qual não havia ainda cura disponível. 
Persistiu na memória colectiva, por muitos anos, o temor da gripe que em Maio aterrorizou os florentinos. Mais de metade dos óbitos de 1920 ocorreu nesse mês e mais de metade daqueles que faleceram nesse mês foram vítimas confirmadas da pandemia. Por toda a ilha a morte atingiu diariamente as comunidades.

\section{Bibiografia}

\section{Fontes manuscritas}

Arquivo da Ouvidoria Paroquial da Ilha das Flores. Livros de Registos de Óbitos 1915-1925.

\section{Fontes Impressas}

GOMES, Francisco António Nunes Pimentel (2003). A Ilha das Flores: da redescoberta à actualidade (Subsídios para a sua História). Câmara Municipal das Lajes das Flores, Lajes das Flores.

MONTEIRO, Albertino José Ribeiro (2006). Crises de mortalidade em Ponta Delgada no $1^{\mathrm{o}}$ quartel do séc. XX. Revista Arquipélago - História, $2^{\mathrm{a}}$ série, 9.

SEQUEIRA, Álvaro (2001). A pneumónica. Revista Medicina Interna, vol. 8, n⿳⺈ 1, pp. 49-55. Acedido a 16/09/2018, em https://www.spmi.pt/revista/vol08/ch7_v8n1jan 2001.pdf

VIEIRA, Luís Filipe Nóia Gomes (2012). O Concelho de Santa Cruz das Flores (1890-1920) Entre a Estagnação e o Progresso. Policopiado (Dissertação apresentada à Universidade dos Açores para obtenção do grau de Mestre em Património, Museologia e Desenvolvimento, sob a orientação do Professor Doutor Carlos Alberto da Costa Cordeiro). Universidade dos Açores, Ponta Delgada. 


\section{O Impacto da Pneumónica em Chaves}

José Alfredo P. Faustino ${ }^{1}$

$\overline{\text { Investigador do CITCEM|FLUP }}$ - Grupo de Populações e Saúde, alfredo.faustino@sapo.pt 



\begin{abstract}
Resumo
A Pneumónica, que afetara dramaticamente milhares de pessoas no mundo, em 1918, também não poupou os flavienses, a região e o país, provocando, num curto espaço de tempo, uma verdadeira razia demográfica, com graves consequências sociais e económicas. De origem ainda dúbia, a gripe instalou-se em Chaves, durante a $2^{\text {a }}$ vaga, maioritariamente nos meses de outubro e novembro. A sua disseminação foi potenciada por uma conjuntura particularmente vulnerável, consequente da permanente instabilidade política e social, da insuficiência de subsistências e da carestia dos géneros alimentares, associadas a condições higiénicas e médico-sanitárias incapazes de dominar a epidemia. Ignoravam-se as eficazes práticas imunizantes e também não existiam os medicamentos preventivos, uma vez que a doença só viria a conhecer-se mais tarde. As principais vítimas foram os adultos jovens, dos 20 aos 40 anos de idade, e não, como seria de esperar, os mais fracos e vulneráveis, as crianças e os idosos. Entre géneros, foram as mulheres que pagaram maior tributo à morte. O saldo obituário foi elevadíssimo, constituindo uma das maiores sobremortalidades que se abateram sobre Chaves, só comparável à da crise demográfica de 1855.
\end{abstract}

Palavras-chave: pneumónica, gripe espanhola, crise demográfica de 1918, Chaves.

\title{
INTRODUÇÃO
}

No outono de 1918, Chaves viveu um clima de medo e de terror por causa da gripe pneumónica ${ }^{2}$, que aqui se instalou, a par de outras doenças, como o tifo exantemático e a varíola. Uma situação idêntica à que ocorria noutras regiões do país, o que levara Ricardo Jorge a considerar aquele ano «de má nota para os fastos epidemiológicos $\rangle^{3}$. Na verdade, o tempo era de crise,

\footnotetext{
2 Também designada, entre nós, por «gripe espanhola» por ter sido a imprensa espanhola a primeira a noticiar a existência desta epidemia. Assim aconteceu porque a Espanha se conservava neutral no conflito da Primeira Guerra Mundial, quando os países beligerantes mantinham os meios de comunicação censurados para não terem repercussões negativas nas populações e, sobretudo, entre as tropas, com a divulgação do número de mortos.

3 Relatório apresentado ao Conselho Superior de Higiene em sessão de 1918, acrescentando que «ainda mal entrava de quebrar o tabardilho que de memória de homem se não alastrara
} 
tendo como pano de fundo a interminável Guerra Europeia, a duradoura carência de subsistências, a consequente carestia de vida e uma contínua instabilidade política.

A origem geográfica desta epidemia permanece ainda incerta. Poderá ter tido origem num acampamento militar no Kansas, nos Estados Unidos da América, durante o mês de março, e trazida para a Europa pelos soldados do Corpo Expedicionário Americano, difundindo-se, posteriormente, a partir dos portos de desembarque de Bordéus e Brest. Há, no entanto, outras explicações que situam a sua origem na Ásia ou mesmo na Europa. Entre estas, destaca-se a que defende a sua disseminação a partir da base militar de Étaples, na costa norte de França, introduzida possivelmente por soldados contagiados do sudeste asiático, que vieram auxiliar os franceses entre 1916 e 1918 .

Seja como for, a guerra, com a concentração de milhões de soldados, criou condições favoráveis ao desenvolvimento de estirpes mais agressivas do vírus da influenza $a^{4}$ e estimulou a sua propagação à escala global, com efeitos tremendamente devastadores, somando mais mortos do que toda a Primeira Grande Guerra. Depois de, em abril, a terrível gripe ter atingido a França, propagou-se furiosamente durante o mês de maio aos países do Norte da Europa, Mediterrâneo e Norte de África, para no mês de junho se estender a todo o globo. Estima-se que fez mais de 50 milhões de mortos ${ }^{5}$. A sua morbilidade era tão rápida que matava os doentes em apenas dois ou três dias depois de manifestarem sintomas bronco-pulmonares e hemorrágicos, de forma semelhante ao que ocorrera por toda a Europa nos anos de 1889 e de 1890, situação que levou Ricardo Jorge a afirmar, face à incapacidade da Medicina responder eficazmente ao contágio difusivo da gripe pneumónica, «que nada há por hora que [a] precate e defenda», acrescentando, com alguma amargura, «há que suportá-lo sem mais, e se já na vida civil as baixas nos elementos ativos da indústria e do comércio chegam a causar um real prejuízo à vida económica, nos arraiais da guerra o acervo das baixas pode ser tal que inutilize um exército transitoriamente para as operações de campanha» (1918: 125-6). Não se enganou. Tal como os exércitos aliados, as tropas

assim entre nós, e já soprava de Espanha a ameaça dum flagelo, o mais contagiante de todos, a querer repetir a ruidosa intrusão de há trinta anos» (Jorge, 1918: 121).

4 Designada de influenza, porque no passado se pensava que as epidemias apareciam devido à influência dos astros. O seu vírus, então desconhecido, só foi isolado em 1933 por Wilson Smith e seus colaboradores.

5 Não há um valor preciso do número óbitos, porém, estudos recentes reveem o número de mortos em alta. 
alemãs foram, igualmente, fustigadas pela influenza, contribuindo, assim, para acelerar o final do conflito.

Em Portugal, o surto epidémico entra na segunda quinzena de maio, proveniente de Espanha, possivelmente através da fronteira alentejana ${ }^{6}$, atingindo severamente o país de Norte a Sul, fazendo, de acordo com as estatísticas oficiais, 55.780 mortos em 1918 e 3.097 em 1919. Leston Bandeira vai mais longe, estimando que esse valor terá ultrapassado as 100 mil almas, concretamente 114.836, sendo 53.038 óbitos masculinos e 61.798 femininos (2009: 138).

O flagelo desenvolveu-se em duas vagas: a primeira, entre maio e finais de julho, mais branda e de características benignas, mantendo-se em situação mais ou menos controlada; a segunda, entre agosto e dezembro, incomparavelmente mais agressiva, com efeitos terrivelmente mais devastadores.

Foi durante esta segunda vaga que, nos finais de setembro, a epidemia se instalou em Chaves, possivelmente proveniente de Vila Nova de Gaia e do Porto, onde a gripe havia lavrado com certa intensidade nos finais do mês de agosto e inícios do mês seguinte, irradiando, a partir daí, para o noroeste peninsular ${ }^{7} \mathrm{e}$, por ambas as margens do Douro, até às terras do interior transmontano e zonas fronteiriças, acompanhando, provavelmente, as deslocações dos passageiros dos caminhos-de-ferro, frequentemente usados naquela altura por inúmeros viajantes, incluindo os militares, como fora amplamente noticiado pelo jornais da época. As romarias, as feiras e as vindimas, que se realizavam neste período do ano, facilitaram igualmente a propagação da doença.

De acordo com o jornal $A$ Capital de 6 de outubro, a pneumónica só chegou a Lisboa nos começos desse mês, com o regresso de milhares de veraneantes à sua residência habitual, atacando metade da população da cidade.

\footnotetext{
6 Ricardo Jorge esclarece que nos finais de maio de 1918, segundo as autoridades consulares portuguesas em Espanha e sanitárias da fronteira, «que a moléstia se fechou em arco desde Tui, no Minho, a Aiamonte, no Guadiana», acrescentado que, por essa ocasião, já se espraiava na raia em Badajoz e Ciudad Rodrigo, trazida pelo regresso dos trabalhadores rurais, alastrando no início de junho a outros lugares fronteiriços de Terrugem (Elvas) e Assumar (Arronches). Por essa altura, em Vila Viçosa o mal já tocara um quinto da população, e no dia 10 de junho instalara-se no Porto, designadamente no Aljube, onde se registaram 18 casos, e no dia seguinte na prisão de Monsanto, contabilizando-se 50 doentes, e na secção dos mutilados da guerra do Instituto Médico-pedagógico da Casa Pia, em Lisboa. Aqui, entre junho e julho, a epidemia ceifara mais de 400 vítimas por semana. No final do mês, o surto epidémico já se espalhara a todo o país, desde o Minho e Trás-os-Montes ao Algarve (Jorge, 1918: 121-122).

7 Em 26 de setembro, o jornal semanário O Espozendense, no seu n⿳ํㅜ 595 , noticiava que grassava «com intensidade n'este concelho a gripe pneumónica, tendo-se dado já alguns óbitos».
} 
Ainda segundo o mesmo diário, as autoridades sanitárias foram incapazes de tomar as providências necessárias que impedissem a sua propagação. Só no início de outubro, a Direção-Geral de Saúde tomou algumas medidas profiláticas que, infelizmente, se tornaram incapazes de suster o seu avanço. Foi por esta altura que o governo nomeou o Dr. Ricardo Jorge para Diretor-Geral de Saúde, uma autoridade esclarecida em assuntos epidemiológicos e de saúde pública, que não poupou esforços para controlar e vencer a doença, apesar de não contar com suficientes recursos humanos, financeiros e materiais. Por sua vez, a Medicina mostrava-se incapaz de lidar com a gripe, por desconhecer a sua etiologia. Como afirmava Ricardo Jorge «práticas imunizantes não se conhece nenhuma; drogas preventivas não existem», aconselhando «quando o mal vier, cama, dieta, tisanas e médico» (Jorge, 1918: 130).

Na luta contra a epidemia, as determinações da Direção-Geral de Saúde eram implementadas nos distritos pelos delegados de saúde e nos municípios pelos subdelegados, apoiados nos administradores do concelho. Entre as medidas urgentes, aconselhava-se a hospitalização dos doentes, a organização de brigadas sanitárias e comissões de socorro e, para evitar a propagação da epidemia, proibiu-se a realização de eventos que concentrassem grande número de pessoas, como as feiras e as romarias, obrigou-se ao encerramento de escolas e tea-tros, a vigilância das estações de comboio e a limpeza e desinfeção das ruas. Porém, todas estas medidas não foram suficientes para impedir a marcha da epidemia, causadora de milhares de mortos por todo o país.

Para o estudo do impacto desta epidemia em Chaves, privilegiámos como fontes documentais o registo das inumações dos falecidos, os extratos de óbito do Registo Civil, as atas das sessões camarárias, os registos de correspondência da Câmara, os recenseamentos e os jornais da época. Foi pena que o jornal O Flaviense tivesse suspendido a sua publicação em 3 de setembro de 1916 e que a nova edição de $O$ Republicano, de António Granjo, estivesse ativo apenas num pequeno período, de abril a julho de 1918, de que resultou ficarmos privados de um interessante acervo documental.

\section{O espaço geográfico e a população}

Para compreendermos melhor os efeitos da gripe pneumónica começámos, antes de mais, por conhecer sucintamente o território e a sua população nos começos do século XX, não circunscrevendo a nossa análise à vila de Chaves e ao seu concelho, mas, sempre que possível, procurando alargá-la à região e ao país. 
Chaves é uma cidade transmontana, situada a $12 \mathrm{Km}$ da Galiza, provida, à altura, de um importante dinamismo económico, político e militar. Era sede de um concelho de $548,7 \mathrm{~km}^{2}$, repartido por 45 freguesias, com 36.745 habitantes, dos quais 6.851 viviam em Chaves, segundo o censo de 31 de dezembro de 1920, assumindo-se, deste modo, como centro urbano e concelhio mais populoso do que Vila Real, sua rival e capital de distrito, mercê, entre outros fatores, da sua generosa veiga, atravessada pelo rio Tâmega, uma das mais férteis do país, e da forte presença militar, bem como do seu vigoroso dinamismo comercial. O desenvolvimento das vias de comunicação conferiulhe, igualmente, uma posição estratégica em relação aos concelhos confinantes de Valpaços, Vila Pouca, Ribeira de Pena, Boticas e Montalegre, bem assim como à região do Minho e às terras da Galiza, dinamizando importantes fluxos de pessoas e bens (Figura 1).

Fig. 1 - Localização de Chaves e do seu concelho

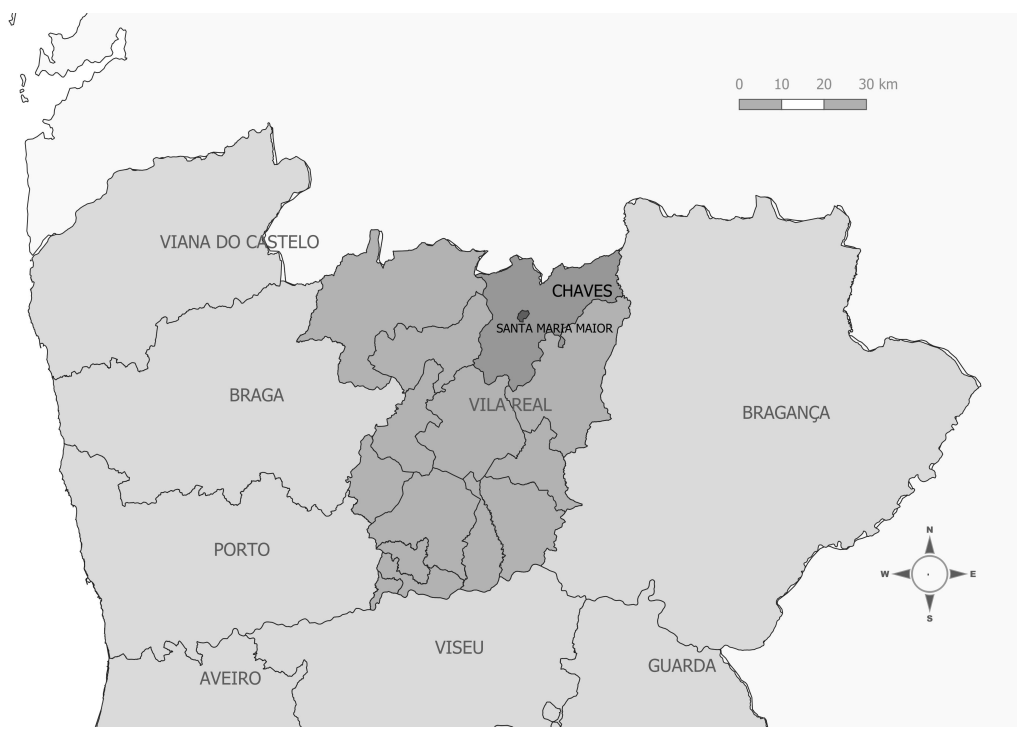

Fonte: CAOP (2011). Elaboração: Casa de Sarmento - UMinho.

Apesar desse dinamismo, o final do século XIX e as primeiras décadas do século XX, até ao início da década de 1930, apresentam um abatimento populacional, como nos mostra a Tabela 1, sobretudo entre 1890 e 1900, possivelmente em consequência do desfalque do surto emigratório. Por sua vez, no período intercensitário de 1911 a 1920, atravessado pela pneumónica, a taxa de crescimento, segundo o censo, foi ligeiramente positiva em $0,05 \%$, 
de que resultou um aumento, de apenas 31 pessoas, seguindo-se-lhe uma forte recuperação até cerca de 1960 .

Tab. 1 - Evolução da população de Chaves e ritmos de crescimento anual médio (1864-1960)

\begin{tabular}{lrrrr}
\hline Censo & População & $\begin{array}{c}\text { Índice } \\
\text { (base } \mathbf{1 8 6 4})\end{array}$ & $\begin{array}{r}\text { Taxa de crescimento } \\
\text { (\%) }\end{array}$ \\
\hline $\mathbf{1 8 6 4}$ & 5.612 & 100 & - \\
$\mathbf{1 8 7 8}$ & 5.539 & 87 & $-0,09$ \\
$\mathbf{1 8 9 0}$ & 7.730 & 121 & 3,30 \\
$\mathbf{1 9 0 0}$ & 6.463 & 101 & $-1,64$ \\
$\mathbf{1 9 1 1}$ & 6.820 & 107 & 0,50 \\
$\mathbf{1 9 2 0}$ & 6.851 & 107 & 0,05 \\
$\mathbf{1 9 3 0}$ & 7.804 & 122 & 1,39 \\
$\mathbf{1 9 4 0}$ & 9.501 & 149 & 2,17 \\
$\mathbf{1 9 5 0}$ & 12.239 & 192 & 2,88 \\
$\mathbf{1 9 6 0}$ & 12.490 & 196 & 0,21 \\
\hline
\end{tabular}

Fonte: Recenseamentos Gerais da População, INE.

Para uma melhor compreensão da evolução da população de Chaves, construímos um gráfico (Fig. 2) que compara as taxas de crescimento médio anual da população de Chaves, do concelho e do país, entre 1864 e 1930.

A sua observação permite-nos concluir, desde logo, que as taxas de crescimento do país foram sempre positivas, mesmo no período intercensitário de 1911 a 1920, cuja taxa de crescimento foi, apenas, de 0,14\%. Se admitirmos que o surto emigratório diminuíra durante a Primeira Guerra Mundial, poderemos avaliar melhor os efeitos devastadores da gripe pneumónica de 1918.

Diferentemente, Chaves e o seu concelho, no período em análise, não exibem ritmos constantes de crescimento populacional, apresentando, mesmo assim, taxas que oscilam entre um máximo de 3,30\% e um mínimo de -1,64\% na Vila e entre 1,63\% e -1,04\% no concelho, respetivamente, nos períodos intercensitários de 1878 a 1890 e de 1890 a 1900. Verifica-se, assim, pelo recenseamento de 1890, que a população de Chaves e do seu concelho aumentou 2.191 e 6.833 efetivos, respetivamente. Já o censo seguinte, de 1900, registou uma diminuição de 1.267 pessoas na Vila e de 4.321 no seu concelho, em consequência, possivelmente, de uma forte torrente migratória que afetara toda a região. A diminuição verificou-se, igualmente, a nível do distrito, 
Fig. 2 - Evolução comparativa das taxas de crescimento médio anual da população (Chaves, Concelho e Portugal)

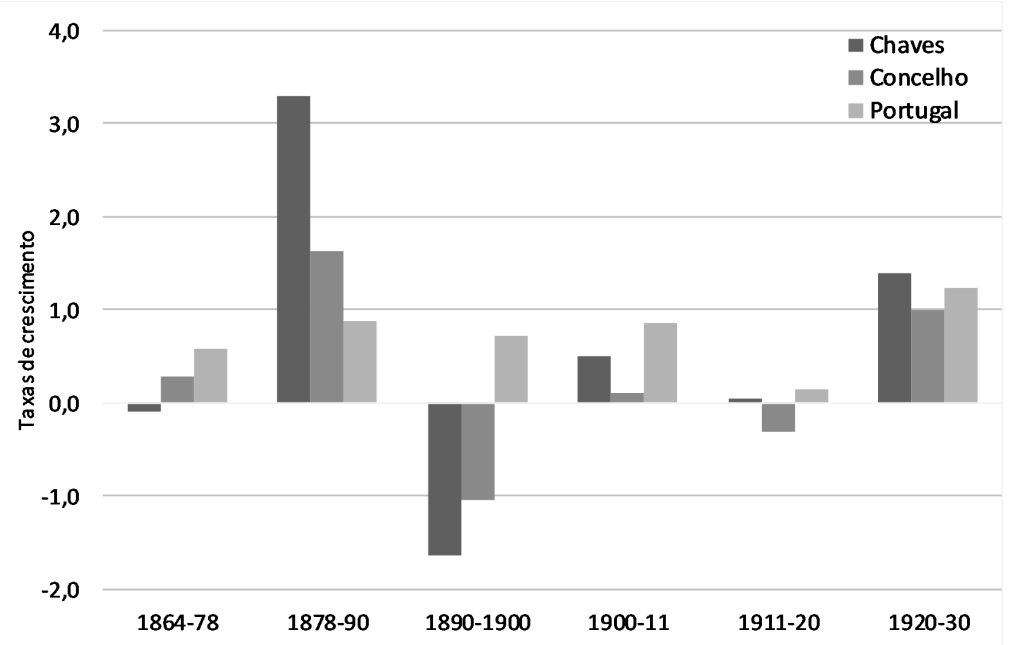

Fonte: Recenseamentos Gerais da População, INE.

traduzida numa taxa de crescimento anémica de apenas $0,35 \%$, segundo o censo de $1900^{8}$.

Até 1920, o crescimento foi muito débil, sobretudo na segunda década do século, tanto para Chaves (0,05\%), como para o seu concelho $(-0,31 \%)$, à semelhança do país $(0,14 \%)$, como resultado de um quadro negativo sobejamente conhecido, marcado pela instabilidade política, associada a uma profunda crise socioeconómica, ao persistente desfalque emigratório, à participação de Portugal na $1^{\text {a }}$ Guerra Mundial e, finalmente, aos surtos epidémicos, sobretudo da gripe espanhola, que assumira tamanha virulência nos distritos de Vila Real e Bragança, que atingira taxas mortuárias de 52,1 e 49,2, respetivamente, no ano de 1918, quando a média do país se situou nos 39,6 por mil habitantes (Machado, 1957: 191).

Após este período de abatimento demográfico, a recuperação da população conheceu um ritmo de crescimento excecional, designadamente no período de 1920 a 1930, com taxas de 1,39\% em Chaves, de 1,0\% no concelho e de $1,24 \%$ no país.

Em síntese, podemos concluir que a gripe encontrou uma população já debilitada, de crescimento anémico, fruto da carência dos principais bens essenciais, como cereais, batata, açúcar, azeite e petróleo, tendo surgido por

8 Veja-se a propósito Machado, 1957: 46. 
todo lado os celeiros municipais e as sopas dos pobres. À fragilidade económica associou-se a pobreza e a miséria, bem como a falta de cuidados de higiene pública e privada, que mais não fizeram do que facilitar a disseminação do surto epidémico. Por sua vez, a Medicina mostrou-se incapaz de debelar os efeitos da gripe. Esta precária situação foi ainda agravada pelos efeitos da Grande Guerra que, para além de subtrair braços ao sector produtivo, dificultou a comercialização dos géneros alimentares, e, pelas constantes migrações militares, facilitara a rápida propagação do vírus da influenza, transformando a vida das populações de então num verdadeiro calvário.

\section{A pneumónica e a crise demográfica}

Portugal era um país rural e pobre, estruturalmente insuficiente em subsistências e com condições higiénicas e médico-sanitárias deficientes, incapazes, na altura, de dominar a pneumónica. Além disso, sofreu a escassez de recursos humanos e económicos, agravados por uma constante instabilidade política e social, consequentes da instauração do regime republicano e da participação de Portugal na Primeira Guerra Mundial. Na verdade, estamos perante uma conjuntura negativa, que nos aproxima do quotidiano do Antigo Regime, onde pontuavam os flagelos da guerra, a crise de subsistências e as epidemias. Uma trilogia sinistra que constitui o terceiro cenário da tipologia de J. Dupâquier para o estudo das crises de mortalidade, onde estes fatores estão intimamente concatenados num processo dialético (1979: 336), considerando-se a epidemia como o elemento constitutivo de toda a crise, manifestando-se, por vezes, em curtos espaços de tempo, com desmedida brusquidão.

A abordagem demográfica da sobremortalidade ocorrida em 1918 não está isenta de escolhos, a começar pelo acesso às fontes. Para o presente estudo servimo-nos de dados recolhidos do livro de inumações da vila de Chaves, existente no Arquivo Municipal de Chaves, e dos livros de extratos do registo de óbitos do Registo Civil, disponíveis no Arquivo distrital de Vila Real, como antes foi referido. Estes documentos dão-nos a conhecer a identificação dos defuntos, data e local dos óbitos, mas nada nos dizem sobre as causas de morte. Também as declarações de óbito, disponibilizadas apenas para o concelho de Vila Pouca, nada revelaram de útil nesse sentido, ao atribuir as causas dos óbitos a «doença desconhecida» ou «morte desconhecida».

Em termos metodológicos socorremo-nos da metodologia desenvolvida por J. Dupâquier (1979: 83-112), como se das populações tradicionais se tratasse, procurando avaliar a intensidade e natureza da crise e, bem assim, 
o impacto que a pneumónica tivera nos demais comportamentos demográficos e na evolução da população desta Vila e do seu concelho.

Posto isto, e não pretendendo aqui fazer uma inusitada discussão das metodologias propostas para o estudo das crises de mortalidade ${ }^{9}$, privilegiámos, como já se referiu, a desenvolvida por J. Dupâquier, que, apesar das suas limitações e inconvenientes, designadamente na utilização do ano civil por referência, em que os índices de mortalidade podem ser afetados pelos valores dos anos mais próximos, pela simplicidade e rapidez nos cálculos, por ser a que, presentemente, melhor serve o estabelecimento de uma cronologia das crises e porque um bom número de estudos segue atualmente esta linha metodológica, permitindo-nos fazer comparações mais consistentes com outras regiões do país.

Começámos, assim, por utilizar o livro dos registos das inumações de Chaves, que nos permitiu analisar com bastante segurança a evolução do volume de óbitos ocorridos na Vila, por naturalidade, sexo e idade, ainda que esta, em certos casos, seja omissa e, noutros, imprecisa. Com base nos dados recolhidos, construímos o gráfico (Fig. 3) que nos mostra a evolução das curvas obituárias dos menores de sete anos e da mortalidade adulta, entre 1911 e 1930.

Da sua análise, verificamos que a morte irrompera virulentamente no ano de 1918, provocando, num curto espaço de tempo, um aumento inusitado de óbitos, sobretudo de adultos, ainda que tenhamos de reconhecer que nem todos os falecidos foram vítimas da pneumónica, mas também de outras doenças infecto-contagiosas que aqui, como no resto do país, se fizeram sentir, como a varíola, o tifo e a tysica pulmonar. Seja como for, o pico de mortalidade ocorreu durante o ano de 1918, atingindo a população flaviense

\footnotetext{
9 Para Pierre Goubert (1960) bastaria que o número anual de óbitos ultrapassasse o dobro da média dos anos normais, sendo tanto mais grave quanto mais elevado fosse o número de mortes, traduzindo-se no triplo, quádruplo ou mais, em relação à média anual. Mais tarde, várias outras metodologias foram apresentadas para medir a intensidade das crises demográficas partindo das variações de mortalidade. Entre elas, destacamos as metodologias desenvolvidas por Lorenzo Del Panta e Massimo Livi-Bacci e a usada por J. Dupâquier. Os primeiros seguem uma metodologia cujos valores de referência são calculados através de um sistema de médias móveis de onze anos, dos quais são excluídos os dois valores máximos e os dois mínimos, considerando-se anos de crise aqueles cujo número de óbitos ultrapasse $50 \%$ face à média móvel e uma grande crise quando esse número a quadruplica. Por sua vez, J. Dupâquier desenvolveu igualmente um método baseado no volume anual de óbitos e na média aritmética dos dez anos enquadrantes do acidente de sobremortalidade, mas introduz o desvio padrão para minorar as flutuações aleatórias dos valores observados, resultando a fórmula seguinte: $I=(\boldsymbol{D}-M) / E$, sendo I a intensidade da crise, sendo as crises classificadas de acordo com os valores do I (intensidade), em crise menor (1-2), crise média (2-4), crise forte (4-8), crise maior (8-16), super crise (16-32) e catástrofe (superior a 32).
} 
com uma intensidade sem par em todos os anos observados. É bem verdade que, ao longo desta vintena de anos, a curva obituária infantojuvenil se mostrou mais nervosa do que a descrita pela mortalidade adulta, com elevações nos anos de 1913, 1916 e 1927, mas em nenhum destes com a intensidade de 1918.

Fig. 3 - Evolução dos óbitos em Chaves (1911-1930)

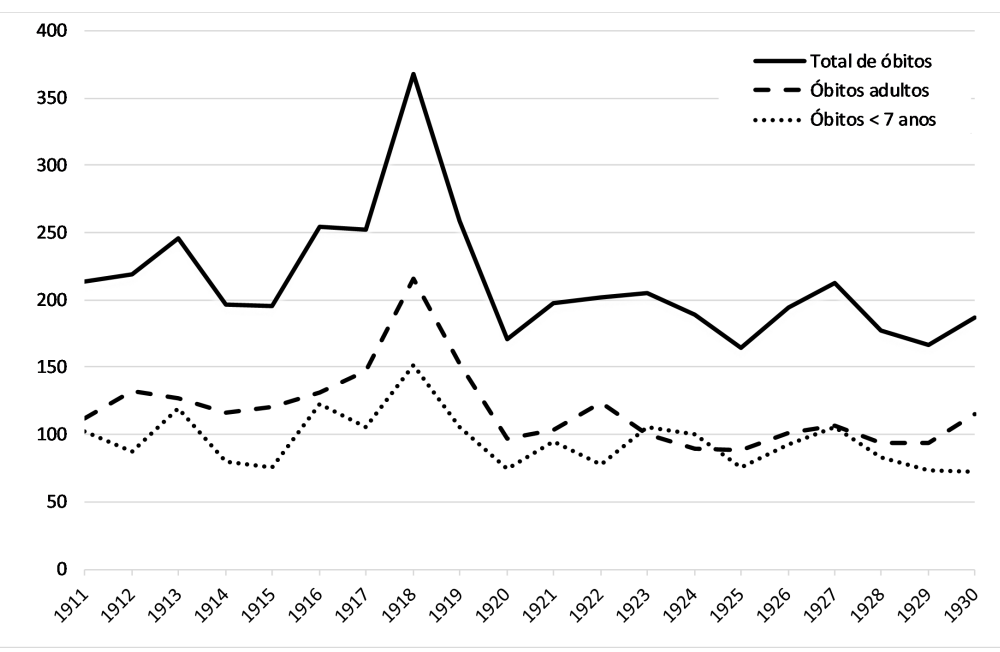

Fonte: AMC - Livro de inumações de Chaves.

Feitos os cálculos a esta brutal subida obituária da população total, de acordo com os instrumentos de análise da metodologia de Dupâquier, concluímos que estamos perante uma crise geral forte, de magnitude 3 e de intensidade 4,9. Todavia, a mortalidade infantojuvenil ficou-se apenas pela intensidade de 3,2 e magnitude de 2, precedida de uma pequena crise de sobremortalidade, ocorrida no ano de 1916, com a intensidade de 1,05 e de magnitude 1. Já a mortalidade adulta elevou-se a 5,03, dando a perceber uma diferencial incidência da epidemia na estrutura etária da população flaviense, como veremos mais adiante.

Revela-se-nos, assim, como uma das maiores crises demográficas ocorridas em Chaves, tendo apenas par na de 1855, de intensidade 5,9, segundo a mesma metodologia, consequente da terrível epidemia de cholera morbus que lavrara virulentamente no mês de outubro.

Da totalidade dos óbitos de 1918, isolámos os ocorridos semanalmente entre a segunda metade de setembro e finais de novembro, por se considerar que foi durante este período que a segunda vaga da gripe de influenza se fez sentir na região. 
Fig. 4 - Frequência semanal dos óbitos na Vila e no concelho de Chaves (de setembro a novembro de 1918)

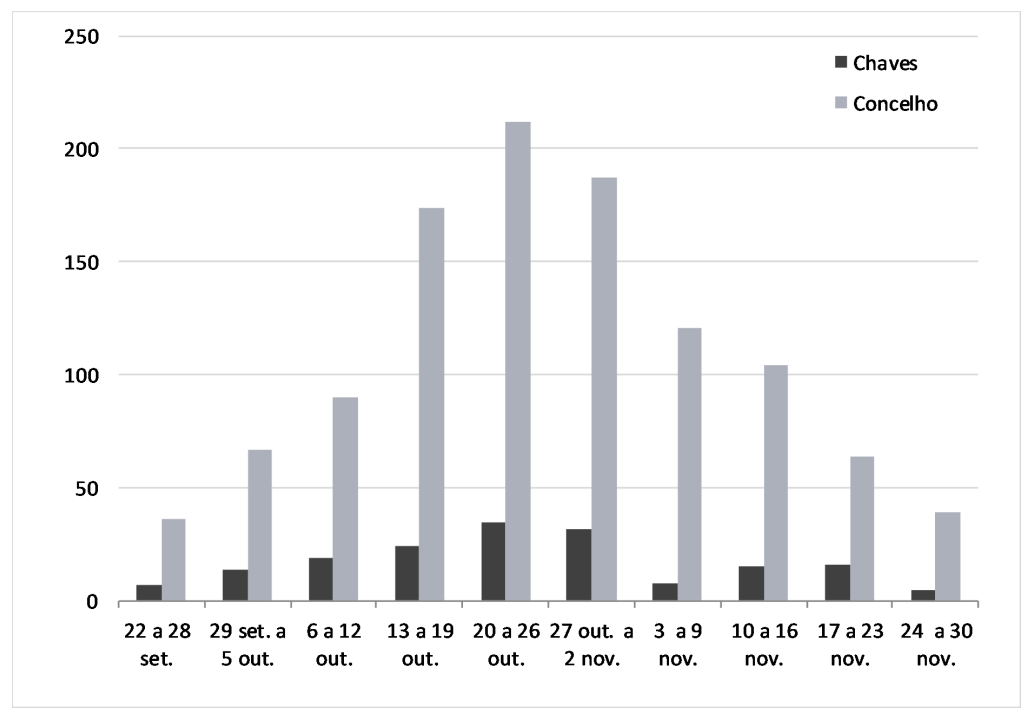

Fonte: ADVRL - Livros de extratos de óbito do Registo Civil.

Considerando o gráfico da frequência semanal dos óbitos registados na Vila e no concelho (Fig. 4), verificamos, desde logo, que a maior incidência da mortalidade concentrou-se sobretudo entre meados de outubro e meados de novembro, evidenciando uma lógica de curta duração que caracterizou esta epidemia, sendo de admitir que a quase totalidade dos óbitos provocados ocorreu, grosso modo, num pequeno período de um mês e meio, sobretudo nas três semanas que vão de 13 de outubro a 2 de novembro, tanto em Chaves como no seu concelho. Todavia, durante este período, o surto manifestou-se de forma irregular na Vila, alternando semanas de grande virulência com outras de menor intensidade, sendo exemplo disso a quebra acentuada para 8 óbitos na primeira semana de novembro, seguida dum repique nas duas semanas subsequentes, com 15 e 16 falecimentos registados, respetivamente. Constatamos também que a última semana de setembro trouxe um número crescente de ocorrências, mas foi na penúltima semana outubro, de 20 a 26, que a epidemia mais vidas ceifou neste concelho, somando 212 óbitos. As semanas vizinhas, precedente e seguinte, apresentam valores assaz elevados, com 174 e 187 casos, respetivamente. Nas seguintes, os valores declinam progressivamente até à última semana do mês de novembro, descendo para 39 falecimentos, próximos dos valores médios verificados nas restantes semanas do ano, anunciando, desta maneira, a extinção da epidemia na região. 
Comparando a evolução do movimento dos óbitos em vários concelhos do Alto Tâmega (Fig. 5), verificamos, como esperado, a notória coincidência de uma subida brusca da mortalidade nos meses de outubro e novembro, com o acme no primeiro mês, indicando-nos, para essas circunscrições, a cronologia do impacto obituário da pneumónica.

Fig. 5 - Evolução comparada dos óbitos em diferentes concelhos do Alto Tâmega (1918-1919)

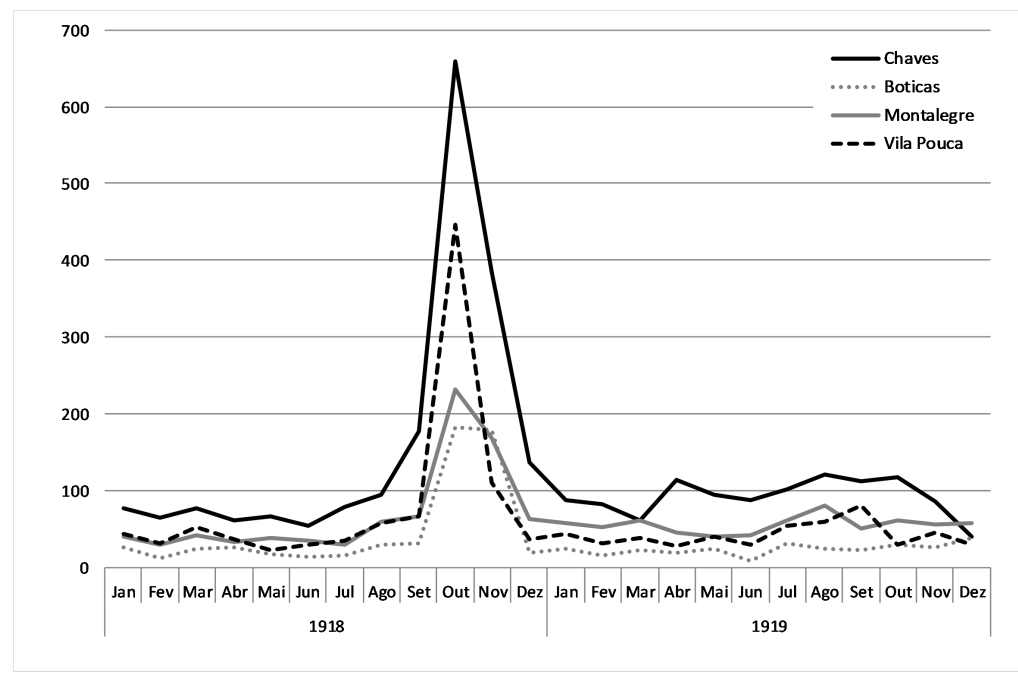

Fonte: ADVR - Livro de óbitos do registo Civil.

Olhando isoladamente a linha obituária do concelho de Boticas, constatamos que aqui, diferentemente do que ocorrera nos demais concelhos, a gripe lavrava ainda com grande virulência no mês de novembro. Isto mesmo é confirmado pelo quinzenário Ecos de Boticas, de 1 dezembro, que noticiava que já nos princípios de outubro a gripe infetava mais de 300 pessoas só na Vila, acrescentando que «a malina que vitimou o pobre e o rico, o limpo e o surrento, [e] reinou por espaço de um mês na cabeça do concelho e continua por várias freguesias» ${ }^{10}$.

Para uma melhor compreensão do fenómeno, elaboramos um gráfico com base na frequência semanal dos óbitos, em percentagens (Fig. 6), que traduz a disseminação da epidemia no tempo, nos mesmos concelhos.

Comparando os resultados obtidos, podemos observar que o movimento semanal dos falecimentos, para o período observado, revela idêntica evolução nos concelhos de Chaves e Montalegre, com maior ocorrência de casos na

$\overline{10}$ Veja-se o jornal «Ecos de Boticas», no 23 , de 1 de dezembro de 1918. 
semana que se inicia no dia 20 de outubro e um progressivo abrandamento até finais de novembro.

Fig. 6 - Frequência semanal dos óbitos em diferentes concelhos do Alto Tâmega (Outono de 1918)

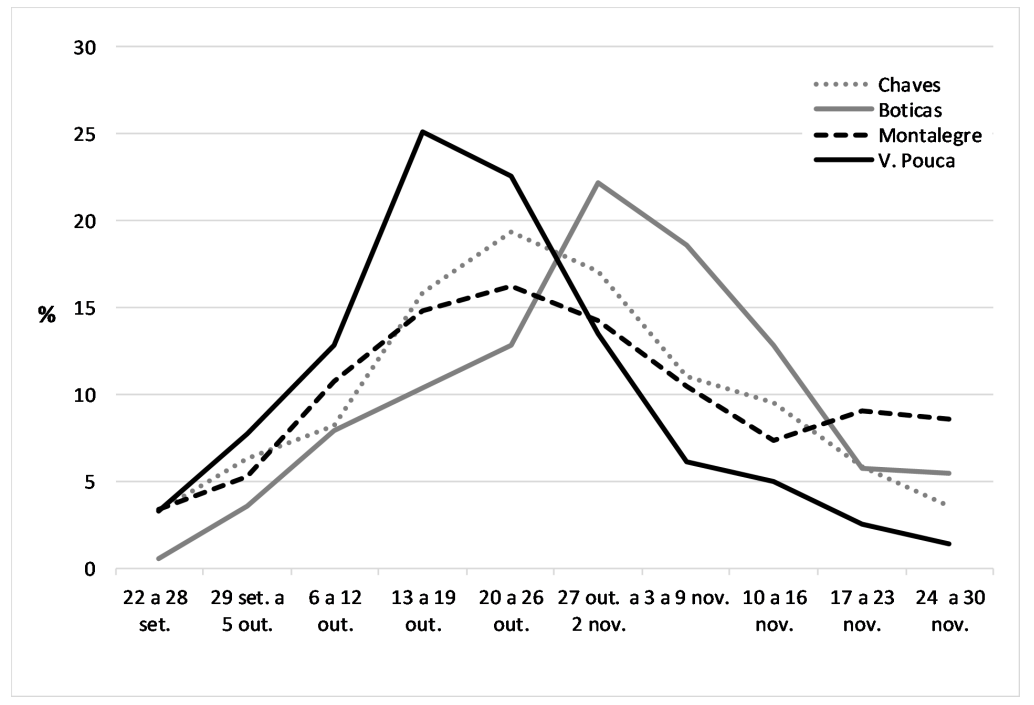

Fonte: ADVRL - Livros de extratos de óbitos do Registo Civil.

Por sua vez, em Vila Pouca, concelho situado mais a sul, a maior concentração de falecimentos ocorreu em meados de outubro, na semana de 13 a 19, não sendo despiciendo o volume de óbitos registado na semana seguinte, parecendo indiciar o trajeto de propagação do surto epidémico de sul para norte.

Já o concelho de Boticas, mais isolado que os anteriores, é abrasado pela gripe mais tardiamente, na semana de 27 de outubro a 2 de novembro, diminuindo progressivamente de intensidade até final do mês de novembro, para se extinguir nos começos do mês seguinte, a fazer fé no jornal Ecos de Boticas, de 15 de dezembro, que noticia a partida do médico David d'Albuquerque Rocha, que viera ajudar a combater a pneumónica no concelho, por não haver médico algum que o servisse ${ }^{11}$.

Terminada a pneumónica, surgiu a varíola, na vila de Boticas e em algumas aldeias do seu concelho, tendo-se incentivado a vacinação das populações, como forma de combatê-la.

No que respeita à influência da pneumónica na estrutura populacional da Vila, podemos observar que, de acordo com o gráfico (Fig. 7), a mortalidade

$\overline{11}$ Cf. Jornal Ecos de Boticas, no ${ }^{\circ}$, de 15 de dezembro de 1918. 
afetou muito a população adulta nos períodos considerados, ao contrário do habitual, em que dizimava mais as crianças e os velhos. Pensa-se que os mais idosos, sempre muito frágeis, teriam adquirido uma certa imunidade ao vírus da Influenza A (H1N1) por terem estado expostos a um vírus aparentado A (H2N2) da pandemia gripal de 1890.

Fig. 7 - Comparativo da repartição dos óbitos de Chaves (por grupos de idade)

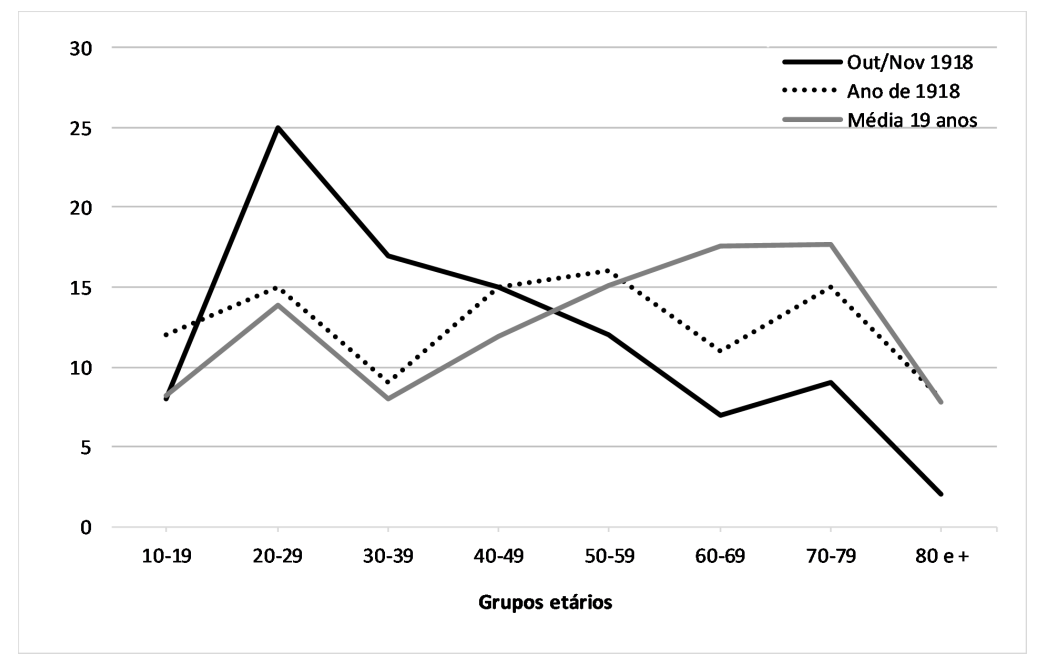

Fonte: AMC - Livro de inumações de Chaves.

Podemos, ainda, verificar que os grupos etários mais atingidos pela mortalidade gripal, nos meses de outubro e novembro, foram os adultos jovens com idades entre os 20 os 40 anos, justamente os que, em princípio, deveriam ter mais capacidade de resistir. De forma diferente, as linhas obituárias pertencentes aos restantes meses do ano de 1918 e à média dos dezanove anos enquadrantes elevam-se particularmente nas idades mais avançadas, correspondendo ao que podemos considerar o modelo normal da mortalidade adulta.

Considerando-se a diferenciação por género, é, em geral, o masculino o mais atingido, devido à sua maior exposição ao contágio durante as suas atividades quotidianas. Todavia, no concelho de Chaves, como nos demais concelhos que nos servem de comparação (Fig. 8), não foi bem assim: o sexo feminino foi mais afetado pela pneumónica que o masculino, possivelmente pelo facto de o vírus da gripe atacar mais as mulheres adultas jovens, sobretudo as grávidas. Assim, tomando-se por base o cálculo da relação de masculinidade ao óbito, ou seja, o número de homens falecidos por cada 100 
mulheres, nos meses de outubro e novembro, verificamos que foram as mulheres a pagar de forma bem notória um maior tributo à morte, em todos os concelhos, à exceção da vila de Chaves, em que houve um maior número de óbitos masculinos, sobretudo nas semanas em que a gripe pneumónica mais se atiçou, possivelmente como consequência da forte presença militar, dos viandantes de negócios e dos pobres pedintes.

Fig. 8 - Comparativo do índice de masculinidade na Vila de Chaves e em diferentes concelhos do Alto Tâmega (semanas)

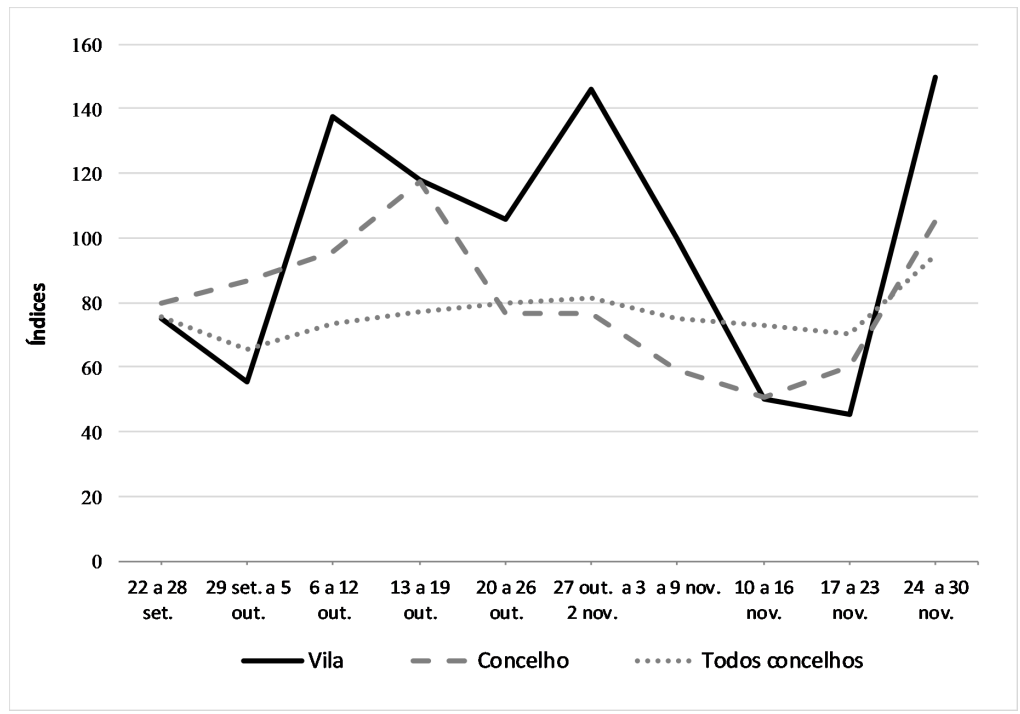

Fonte: ADVRL - Livros de extratos de óbitos do Registo Civil.

Podemos, assim, concluir que, no meio rural, onde a mobilidade é menor, as mulheres foram mais atingidas pela epidemia, como demonstra o quadro seguinte:

Tab. 2 - Frequência dos óbitos em Chaves e em diferentes concelhos do Alto Tâmega (entre 22 de setembro e 30 de novembro)

\begin{tabular}{lrrrrrrrrrr}
\hline População & \multicolumn{2}{c}{ Vila } & \multicolumn{2}{c}{ Chaves } & \multicolumn{2}{c}{ Boticas } & \multicolumn{2}{c}{ Montalegre } & \multicolumn{2}{r}{ Vila Pouca } \\
\hline & N & \% & N & \% & N & \% & N & \% & N & \% \\
\hline Homens & 86 & 49,1 & 483 & 44,1 & 171 & 46,7 & 180 & 42,9 & 265 & 46,3 \\
Mulheres & 89 & 50,9 & 613 & 55,9 & 195 & 53,3 & 240 & 57,1 & 320 & 54,7 \\
Total & 175 & 100 & 1096 & 100 & 366 & 100 & 420 & 100 & 585 & 100 \\
\hline
\end{tabular}

Fonte: ADVRL - Livros de óbitos do Registo Civil.

Segundo os dados apresentados, confirma-se que, durante este período, morreu um número mais elevado de mulheres, obtendo o valor mais alto no 
concelho de Montalegre onde atingira $57,1 \%$ de todos os falecidos, seguido do concelho de Chaves, com 55,9\%. Importa salientar que os valores encontrados na vila de Chaves de 49,1\% de óbitos masculinos, são em grande parte de militares e de mendigos, como atrás já referimos.

Dos falecidos na vila de Chaves, uma boa parte finou no Hospital da Santa Casa da Misericórdia, particularmente os mais pobres. Na verdade, dos 108 adultos falecidos durante este período, 22 morreram naquele hospital, $77 \%$ dos quais no curto espaço de tempo de um mês, entre meados de outubro e meados novembro. A maioria eram homens (16), solteiros (13), com idades compreendidas entre os 14 e os 75 anos. O maior número dos falecidos situase na faixa etária dos 20 aos 40 anos, com 11 casos registados. Conhecemos a naturalidade, destes pobres sem nada de seu: seis eram da Vila e três do concelho, sendo os restantes de várias terras do país, entre outras, de Valpaços (3), da Régua (1), de Cabeceiras de Basto (1), de Guimarães (1) e até da Madeira (1).

Por sua vez, no Hospital Militar da Vila faleceram, durante este período, somente 5 militares de baixa patente, dois solteiros e três casados, com idades entre os 22 e os 42 anos, sendo 1 do concelho e 4 de outras naturalidades.

Consideremos agora a capacidade de reação da população concelhia à crise demográfica de 1918, isto é, a forma como a mortalidade influenciou os comportamentos da nupcialidade e da natalidade, durante esse período. Para isso, construímos as séries de óbitos, de casamentos e de nascimentos para um período de 36 meses, como podemos observar no seguinte gráfico:

A sua análise permite-nos observar que a subida brusca do número de falecimentos acarretou consigo uma quebra do volume de nascimentos e de casamentos, numa lógica de experiência histórica, no dizer de Livi-Bacci, cujo ciclo nascimento-casamento-morte se desenrola de acordo com os mecanismos demográficos de «um sistema homeoestático de autorregulação assente no controlo da nupcialidade», tal como J. Dupâquier tão bem observara para as sociedades europeias do Antigo Regime. Assim, o cômputo de casamentos começou a diminuir a partir de junho, descendo, de 19 para cerca de 12 enlaces matrimoniais mensais até abril do ano imediato, seguida de uma vigorosa recuperação para cerca de 27 matrimónios mensais, fruto da animação do mercado matrimonial, quer dos solteiros quer dos viúvos que pretendem refazer os seus lares após um período de viuvez. Por sua vez, a recuperação dos casamentos acarretou a retoma dos nascimentos. Constata-se, assim, que, durante a crise, os registos de nascimentos baixaram até agosto de 1919, de cerca de 117 para 88 crianças, em média, voltando a elevar-se para valores ligeiramente superiores aos verificados antes da crise. Assim aconteceu porque 
Fig. 9 - Evolução comparativa da frequência dos nascimentos, casamentos e óbitos, no concelho de Chaves (1918-1920)

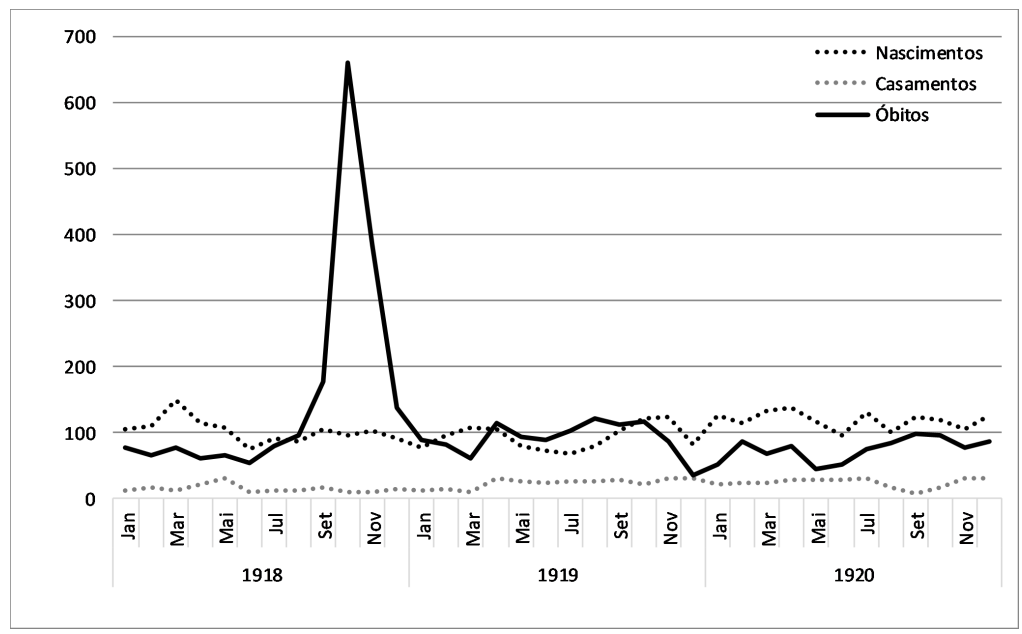

Fonte: ADVRL - Livros paroquiais do Registo Civil.

a pandemia afetara predominantemente a população em idade de procriação, entre os 20 e os 40 anos, sobretudo as mulheres.

Se observarmos a população de Chaves, por sexo e grupos de idade, segundo os dados dos censos de 1911 e 1920 (Fig. 10), constata-se, desde logo, um maior volume de efetivos do sexo feminino em ambos os censos, sobretudo nos grupos etários dos 20 aos 45 anos.

Verifica-se, também, uma diminuição de crianças nos dois primeiros níveis etários, até aos dez anos de idade, sobretudo no grupo dos 0 aos 5 anos, em ambos os sexos, face ao anterior recenseamento de 1911, possivelmente devido à sobremortalidade de 1918 e consequente baixa de natalidade. Observamos, igualmente, uma redução dos adultos do sexo masculino com idades compreendidas entre os 25 e os 45 anos, sobretudo dos 25 aos 30 anos, em ambos os recenseamentos, ainda que ligeiramente menor no censo de 1920 . A razão desta situação encontra-se no surto emigratório que atravessou a população masculina a partir de 1890 e na sobremortalidade adulta ocorrida em 1918. A redução desta população jovem é responsável, igualmente, pela diminuição da natalidade, por afetar os grupos de idade com maior fecundidade.

Analisando conjuntamente o volume da população e de fogos, segundo os censos de 1911 e 1920 (Tab. 3), constata-se, grosso modo, que, durante este período intercensitário, houve uma diminuição do número de pessoas e, também, de agregados familiares em todos os concelhos que vimos ana- 
Fig. 10 - Pirâmide etária do concelho de Chaves (1911 e 1920)

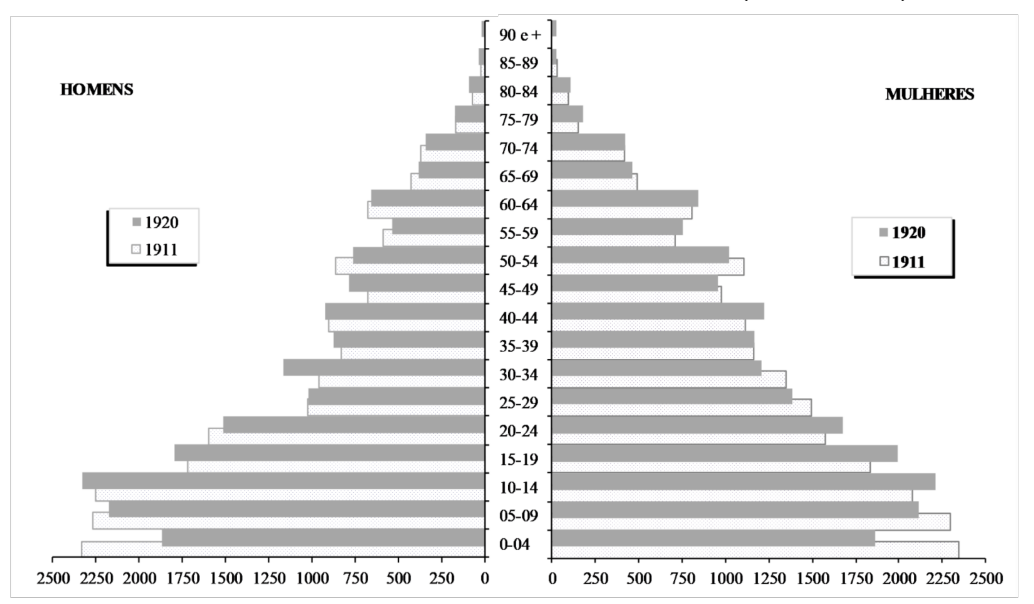

Fonte: Recenseamentos Gerais da População, INE.

lisando, à exceção da população na vila de Chaves que nos apresenta um ligeiro aumento de 22 efetivos, correspondendo a um crescimento de $0,32 \%$. Já quanto à evolução dos fogos, Chaves acompanha a tendência de quebra global, com menos 51 unidades, um decréscimo de 3,27\%. Esta situação traduz claramente uma maior perda de fogos que de indivíduos, ao arrepio do que habitualmente ocorre, pois, como é sabido, o agregado doméstico é a célula mais estável dentro do quadro social, variando menos que a sua população.

Tab. 3 - População e fogos em Chaves, seu concelho e em diferentes concelhos do Alto Tâmega (censos de 1911 e 1920)

\begin{tabular}{|c|c|c|c|c|c|c|c|c|c|c|}
\hline \multirow{3}{*}{ Circunscrições } & \multirow{3}{*}{ Pop. } & \multirow{3}{*}{$\begin{array}{r}1911 \\
\text { Fogos }\end{array}$} & \multirow{3}{*}{$P /$ fogo } & \multirow{3}{*}{ Pop. } & \multirow{3}{*}{$\begin{array}{r}1920 \\
\text { Fogos }\end{array}$} & \multirow{3}{*}{$\mathrm{P} /$ fogo } & \multicolumn{4}{|c|}{ Diferença 1920-1911 } \\
\hline & & & & & & & \multicolumn{2}{|c|}{ População } & \multicolumn{2}{|c|}{ Fogos } \\
\hline & & & & & & & $\mathbf{N}$ & $\%$ & $\mathbf{N}$ & $\%$ \\
\hline$\overline{\text { Vila }}$ & 6.820 & 1.558 & 4,4 & 6.842 & 1.507 & 4,5 & 22 & 0,32 & -51 & $\overline{-3.27}$ \\
\hline Chaves* & 31.014 & 7.752 & 4,0 & 29902 & 7.500 & 4,0 & -1.112 & -3.59 & -252 & $-3,25$ \\
\hline Boticas & 10.937 & 2.485 & 4,4 & 10.338 & 2.440 & 4,2 & -599 & $-5,48$ & -45 & $-1,81$ \\
\hline Montalegre & 22.066 & 4.917 & 4,5 & 20.065 & 4.584 & 4,4 & -2.001 & $-9,07$ & -333 & -6.77 \\
\hline Ribeira de Pena & 10.261 & 2.451 & 4,2 & 10.019 & 2.369 & 4,2 & -242 & -2.36 & -82 & $-3,35$ \\
\hline Vila Pouca & 17.496 & 4.098 & 4,3 & 17.113 & 3.931 & 4,4 & -383 & $-2,19$ & -167 & $-4,08$ \\
\hline
\end{tabular}

Fonte: Recenseamentos Gerais da População, INE.

Entre todos os concelhos, o de Montalegre é o que mais perde no decurso deste período intercensitário, tanto em termos absolutos como percentuais, diminuindo 2.001 pessoas e 333 fogos, correspondendo a uma redução de $9,07 \%$ e $6,77 \%$, respetivamente. Seguem-se os concelhos de Boticas, com um abatimento de 5,48\% de efetivos e de 1,81\% de fogos, e de Vila Pouca, 
com uma redução de $2,19 \%$ de pessoas e de 4,08\% de agregados familiares. Constata-se, assim, que a perda de população nem sempre se reflete de igual modo na redução do número de agregados domésticos. Como é sabido, diferentemente do movimento emigratório, que normalmente subtrai indivíduos aos agregados domésticos, as epidemias, como a da influenza, pelo seu vigoroso contágio dentro dos agregados familiares, manifestam-se não só por uma diminuição de pessoas por fogo, como pelo decréscimo do número de agregados familiares. Mais, este surto epidémico pode, como tantos outros, ter conduzido a uma reorganização da composição familiar, aumentando o número de pessoas da parentela. Porém, só o recurso a uma metodologia de reconstituição familiar em cada paróquia nos permitiria estabelecer, com alguma segurança, uma relação consistente entre a ação da epidemia e a dimensão do agregado doméstico.

\section{As respostas da sociedade e das autoridades públicas}

Na nossa região, a epidemia foi precedida de outras doenças, como o tifo exantemático, a varíola e a tuberculose, e veio a coexistir, por vezes, com estas. É isso mesmo que nos dizem as fontes. Assim, o jornal A Capital, no seu número 2.907, em 23 de setembro, sobre a vizinha terra de Mirandela, diz-nos que «Há, na Vila, diversas doenças de carácter epidémico. A febre hespanhola é uma d'elas, mas há ainda o typho - ou febre tyfhoide, não sabemos bem - a dysentria, etc. Morrem por dia umas 8 pessoas, em média», revestindo uma situação verdadeiramente dramática.

Já nos finais de fevereiro de 1918, perante o avanço do surto epidémico de tifo exantemático, o presidente da Comissão Administrativa da Câmara de Chaves, Dr. Francisco Igrejas, incumbiu os médicos da Vila ${ }^{12}$ de elaborarem um plano «com as medidas necessárias e convenientes» para enfrentar a dita epidemia, disponibilizando, para o efeito, dois ou três contos. Logo no primeiro de março, em sessão extraordinária, o corpo clínico apresentou um extenso e rigoroso relatório, dividido em três capítulos, seguindo as medidas tradicionais de controlo epidemiológico:

12 Segundo a ata da Comissão Administrativa da Câmara Municipal, de 26 de fevereiro, além dos membros da Vereação, estiveram presentes nesta sessão o Administrador do Conselho, coronel António Bernardes Gomes, e os seguintes médicos: José Montalvão Machado, António José Mota Campos, Adalberto Teixeira, Júlio Martins, Francisco Vasques Astorga, António Augusto Lobo e Leopoldo de Lima Barreto Coelho. AMC - Livro de Atas da Câmara Municipal de Chaves - 1917/1918, ata da sessão extraordinária de 26 de fevereiro de 1918. 
1. Empregar todas as diligências possíveis para que o tifo exantemático que agora grassa no Porto e noutras localidades não transponha as raias do nosso concelho;

2. Tornar desde já o meio de Chaves e do seu concelho um meio impróprio para a doença grassar com intensidade, caso ela invada esta região;

3. Estudar o meio de tratar os doentes que apareçam, de modo que a doença se não dissemine.

Do primeiro capítulo, entre as medidas propostas pelo corpo clínico, salienta-se a de mandar para Vidago «um agente da autoridade administrativa para tomar nota de todas as pessoas que desembarquem no comboio e que se destinam a este concelho», comunicando depois ao Sr. Administrador os seus nomes, localidade de onde vêm e para onde vão residir, ficando estas obrigadas a apresentarem-se diariamente nos primeiros dez dias ao subdelegado de saúde ou ao regedor da freguesia, caso se dirigissem para a Vila ou para alguma aldeia do concelho.

Relativamente ao segundo grupo de medidas, estas, entre outras recomendações, impunham evitar a entrada na Vila aos andrajosos e mendigos. Aos que aqui se encontravam, mandava-os lavar, despiolhar e desinfetar, bem como às suas roupas, proibindo-se-lhes a prática da mendicidade. Aconselham, ainda, a criação de um posto para desinfeção hebdomentária dos vagabundos da Vila e de suas vestimentas. Ainda neste campo, incitam a Câmara a cumprir as posturas municipais e os regulamentos de saúde.

Nos dias seguintes, o presidente da Câmara ocupou-se em dar cumprimento ao plano traçado pelo corpo clínico, participando às várias instituições as providências que deviam tomar para combater a propagação do tifo exantemático, como esta que enviara ao reitor do Liceu de Chaves, para que obrigasse os «alunos do sexo masculino a cortarem o cabelo rente e os do sexo feminino a trazer a cabeça no maior estado de limpeza, proibindo os que assim não fizerem a frequência na escola» ${ }^{13}$, medidas que foram igualmente extensivas ao ensino particular, apesar de se associar esta doença aos meios mais pobres e indigentes. Mandou ainda proceder «à lavagem das mantas, substituição de enxergas dos presos e mais, lavar e desinfetar a cadeia civil», por constituir um perigo para o desenvolvimento do tifo exantemático.

O terceiro conjunto de medidas, no âmbito da saúde pública e da profilaxia, determinava que «logo que apareça neste concelho algum indivíduo com sintomas de tifo exantemático» deve informar-se o subdelegado de saúde, que ordenará ou não a sua hospitalização. Para esse fim, a Câmara solicitou

13 AMC - Copiador de Cartas da Câmara Municipal de Chaves (1917/1918), Livro no ${ }^{\circ}$ 11, ofício de 6 de março de 1918, s/p. 
a cedência do prédio dos Bombeiros Voluntários para aí instalar um eventual hospital, para cujo apetrechamento pedira empréstimo de camas e de roupas aos Regimentos de Infantaria 19 e de Cavalaria 6 e à Santa Casa da Misericórdia.

Do mesmo modo, a fim de enfraquecer e debelar a epidemia, a Vereação Camarária providenciou a aquisição de dez barricas de cloreto de cal, duas barricas de sulfato de cobre, quatrocentos litros de álcool desnaturado, quinhentos litros de essência de terebintina, cem litros de petróleo e outros tantos de azeite, para utilizar pelos serviços camarários nas visitas domiciliárias, na desinfeção das habitações e no despiolhamento e tratamento das roupas.

Associada à epidemia de tifo exantemático medrou, entre outras doenças, a varíola, como atrás se referiu. Disso deu conhecimento o médico do partido de Vidago, Dr. Artur Fernandes, em 10 de maio, informando a Câmara que ali «grassava uma epidemia de varíola e por isso pedia que se lhe enviassem vinte tubos de vacina antivariólica» ${ }^{14}$. Mas, como em setembro esta ainda continuasse instalada no concelho, o subdelegado de saúde oficiou à Câmara, informando-a de que:

nesta Vila e em algumas localidades deste concelho grassa a epidemia de varíola com grande intensidade, tornando-se de absoluta necessidade intensificar a vacina e para isso julgo que se deve estabelecer a vacinação permanente com postos em diferentes localidades e por tanto rogava que para desempenhar tão árduo trabalho seja nomeado um médico para assim poderem dar cumprimento $^{15}$.

Esta situação levou a Vereação Camarária, em sessão de 2 de outubro, a nomear interinamente o Dr. Adalberto Teixeira para exercer Medicina em Oura, e, face às informações recebidas, pediu ao governador civil que, com a maior brevidade, enviasse alguns desinfetantes, vacinas e outros medicamentos para combater as epidemias da varíola e da gripe pneumónica que grassavam no concelho ${ }^{16}$. Alarmado pelas notícias, compareceu propositadamente naquela reunião o Sr. Administrador do Concelho, coronel António Bernardes Gomes, dizendo que lhe constava «que a epidemia da gripe pneumónica grassava já com grande intensidade no nosso concelho e por isso lembrava à câmara a necessidade urgente de se tomarem as possíveis providencias no

14 AMC - Livro de Atas da Câmara Municipal de Chaves - 1918/1919, ata de 15 de maio de 1918.

15 AMC - Livro de Atas da Câmara Municipal de Chaves - 1918/1919, ata de 2 de outubro de 1918.

16 Idem. 
sentido de a combater ${ }^{17}$, levando ao cancelamento da feira anual, que se realizava no final do mês de outubro, e de outras feiras, enquanto a epidemia lavrasse no concelho, para evitar o contágio.

Já, em 16 de setembro, face às assustadoras notícias de que a pneumónica já fizera no distrito e até na Vila algumas vítimas, o Administrador pedira à Vereação Camarária «maior rigor no serviço de limpeza e higiene e que se providenciasse para que fossem removidos os focos de infecção» ${ }^{18}$. Além destes, havia naturalmente outros fatores que facilitavam a propagação da doença que há muito urgia resolver, como a falta de água potável, o inexistente sistema de esgotos e as más condições de alojamento.

A fazer fé nas atas das sessões camarárias e no registo de correspondência, as autoridades sanitárias do país, pensando possivelmente no caráter benigno da primeira vaga da gripe e perdidos em questões estéreis e bizantinas, como refere o jornal $A$ Capital, de 6 de outubro, pouco terão feito para evitar a propagação do flagelo. Somente no dia 4 desse mês, quando o mal se havia instalado do Minho ao Algarve, a Secretaria de Estado do Trabalho, que tutelava a Direção-Geral de Saúde Pública, promulga uma portaria ${ }^{19}$ com as primeiras instruções profiláticas, que infelizmente vieram a revelar-se ineficientes, a saber: obrigatoriedade dos médicos informarem a DGS de todos os casos conhecidos de pneumónica; controlo das migrações; criação de hospitais improvisados; abastecimento das farmácias com quinino, cafeína, óleo canforado, etc.; mobilização dos médicos, mesmo os reformados, e, por fim, apelos à população para a formação de «comissões de socorro».

Por novo decreto de 4 de outubro, proibia-se a saída de todas as drogas medicamentosas, devido ao estado sanitário, reconhecendo-se que a epidemia se encontrava disseminada por todo o país. Só por essa altura a Direção-Geral de Saúde esboçou um programa de resposta à influenza baseado nas tradicionais medidas epidemiológicas ${ }^{20}$, tendo o governo começado por nomear o Dr. Ricardo Jorge para Comissário Contra a Gripe que, entre as primeiras medidas tomadas, proibiu as visitas aos hospitais e anulou a abertura das aulas. Para suprir a falta de médicos, registou-se a devolução à clínica civil

\footnotetext{
17 Idem.

18 Idem.

19 Veja-se a Portaria de 2 de outubro. Diário do Governo, II série, no 233, pp. 32553256, de 4 de outubro de 1918. A Direção-Geral de Saúde era o órgão de cúpula de saúde e higiene públicas, sendo coadjuvado pelos delegados e subdelegados de saúde, a nível distrital e concelhio, respetivamente. Além destes, eram igualmente autoridades sanitárias os governadores civis dos distritos e os administradores do concelho, ambos de nomeação governamental.

20 Cf. Decreto $\mathrm{n}^{\mathrm{o}} 4.872$, de 7 de outubro. Diário do Governo, I série, no ${ }^{\mathrm{o}} 218$, p. 1755, de 7 de outubro de 1918 .
} 
dos médicos afetos à vida militar, o regresso ao serviço de médicos que já se haviam reformado e a mobilização dos estudantes finalistas de Medicina, os designados quintanistas. Fazia ainda parte destas medidas a requisição de veículos automóveis particulares para o serviço médico-sanitário, a distribuição de géneros alimentares, como o pão e o açúcar, e dos remédios recomendados, como o quinino e outras drogas. A complementar este conjunto de determinações, criaram-se comissões de socorro para recolher dádivas e exercer beneficência, como ocorrera aqui em Chaves e também em Boticas ${ }^{21}$. Tomaram-se medidas para acalmar a população, proibindo o toque dos sinos e das campainhas nos acompanhamentos fúnebres, à semelhança do que aqui se fizera durante a epidemia de cholera morbus, em 1855.

Recomendava-se aos doentes, para além de ficarem em casa, em repouso, na cama, uma dieta ligeira, a toma de aspirinas, quinino ou salicilato de sódio, um purgante salino de sulfato de sódio e xarope de benzoato de sódio e acetato de amónio para a tosse. Aconselhava-se, ainda, para evitar a gripe, cuidados higiénicos do nariz e da garganta, como instilação nasal de gotas e os gargarejos.

No pino da gripe na região, o governador civil do distrito, antevendo inúmeras dificuldades no apoio médico, recomendava, por ofício expedido em 17 de outubro, a esta e às demais Câmaras do distrito «que mandem apresentar ao serviço os Subdelegados de saúde e os facultativos municipais que se encontrem no gozo de licença, logo que se manifeste a gripe no concelho», não vá algum deles solicitar licença alargada, como fizera o médico facultativo de Vidago, Dr. Artur Fernandes. Felizmente fora substituído, a tempo, pelo Dr. Adalberto Teixeira.

Por essa altura, o deputado Eurico Cameira, secretário de Sidónio Pais, quis saber, por telegrama de 18 de outubro, o estado da epidemia no concelho de Chaves, oferecendo os seus préstimos no caso de esta se manifestar. Aproveitando o ensejo, o presidente da Vereação pediu «que lhe enviasse urgentemente medicamentos, especialmente mostarda, benzoato de soda, acetato de amónio, creolina, cloreto de cal e auxílio pecuniário», uma vez que a gripe já alastrara por todo concelho. Sem delongas, o influente político providenciou o despacho dos medicamentos solicitados e de um subsídio de oitocentos

\footnotetext{
21 Aqui, foi criada a Associação Social de Chaves que, a partir de 10 de novembro de 1918, assegurou a designada «sopa dos pobres» a cerca de 90 mendigos. AMC - Livro de Atas da Câmara Municipal de Chaves - 1918/1919, ata de 13 de novembro de 1918. Por sua vez, o jornal Ecos de Boticas, replicando outros jornais, como o Diário de Notícias, procedeu a uma recolha de fundos, destinando uma parte para a solidariedade aos mais necessitados e a outra a ser entregue à administração concelhia para aquisição de medicamentos para os mais precisados.
} 
escudos, pedindo, apenas, que fosse informado «dia a dia do estado sanitário» da Vila, a fim de prover o necessário «para que o povo de Chaves sofra o menos possível». Esta situação levou a Câmara, de tendência sidonista, a manifestar-lhe o seu reconhecimento, em reunião de 30 de outubro, pelo auxílio demonstrado ${ }^{22}$.

Todavia, pelos documentos analisados, verifica-se que a Vereação Camarária de Frederico Igrejas, curiosamente a mesma que mandara elaborar um rigoroso plano para combater o tifo exantemático, diferentemente do que então fizera, teve uma ação bastante limitada. Não temos nota de que a Câmara providenciasse a implementação de novas medidas profiláticas que evitassem a propagação da epidemia ou a criação de um eventual hospital para isolamento dos doentes influenziados. Se admitirmos que as autoridades públicas concelhias não desvalorizaram o terrífico surto epidémico, somos levados a pensar que o plano de resposta pouco teria variado em relação ao desenhado nos começos de março, quer quanto à utilização das redes de apoio médico e administrativo, quer quanto ao uso dos conhecimentos e das medidas profiláticas.

Já os clínicos de Chaves terão manifestado a mesma dedicação e afinco que outrora demonstraram no combate à epidemia de tifo exantemático, o que levou a Câmara, na sessão de 30 outubro, a manifestar-lhes o seu reconhecimento, exarando em ata o seguinte voto público de louvor a todos eles, especialmente aos doutores António Firmo de Azevedo Antas, do lugar de Oura, e Júlio Martins, a residir nesta Vila:

que não se limitando apenas ao cumprimento dos seus deveres profissionais têm praticado atos de verdadeira filantropia e benemerência, o primeiro, distribuindo gratuitamente leite aos doentes e outros géneros que vão sobrando no seu Hotel Salus, em Vidago, a preços muito inferiores aos praticados nos mercados comuns, e o segundo, socorrendo pecuniariamente alguns dos pobres a quem presta a melhor assistência ${ }^{23}$.

Deste louvor ficou de fora o facultativo municipal de Vidago, Dr. Artur Fernandes, por em plena epidemia ter apresentado a sua demissão, dizendose doente e ausente da região, alegando que na sua área a doença já teria desaparecido ${ }^{24}$.

Paralelamente às medidas tomadas pelas autoridades sanitárias e administrativas, circulava um bom conjunto de conselhos e «mezinhas» caseiras

\footnotetext{
$\overline{22}$ AMC - Livro de Atas da Câmara Municipal de Chaves - 1918/1919, ata de 30 de outubro de 1918.

23 Idem.

24 Idem.
} 
que, através de diversos meios, iam influenciando as práticas das populações, associando, por vezes, o diagnóstico à sua prevenção e tratamento. São exemplo disso as várias sugestões publicadas nos jornais, que vão alterando os comportamentos sociais e outras formas de sociabilidade e de tratamento pessoal.

Alvitrava-se, como arma mais comum para contrariar o contágio do mal, o isolamento das pessoas, tendo em conta que as diversas doenças haviam fragilizado o estado sanitário das populações, gerando um elevado número de enfermiços crónicos, como os tuberculosos e os bronquíticos, fazendo jus ao velho ditado popular de que muita gente junta não se salva. Daí:

Deve-se fugir do contacto de pessoas doentes e ter principalmente uma boa alimentação, evitando os excessos de qualquer natureza e procurar defendermonos do frio e das mudanças de temperatura. Ao mesmo tempo é aconselhada, mas com menos eficácia, a desinfeção da boca e da face ${ }^{25}$.

Aconselhavam-se, igualmente, a limpeza das ruas e os defumadouros no exterior e interior das habitações, com ramos de pinheiro, eucalipto, rosmaninho, associando-lhes, sempre que possível, um pouco de incenso. Porém, todas estas medidas não foram suficientes para impedir os terríveis efeitos da epidemia, que causara, como vimos, uma pesada memória.

$\overline{25}$ Jornal «Ecos de Boticas», no 22 , de 7 de novembro de 1918. 


\section{CONSIDERAÇÕES FINAIS}

A pandemia de influenza de 1918 vitimou milhões de indivíduos em todo o mundo. Em Portugal foi além do esperado, atacando dramaticamente todo o país, num elevadíssimo número de pessoas, provocando uma autêntica razia demográfica estimada em mais de 60 mil pessoas num curto espaço de tempo. A doença instalara-se em Chaves a partir dos finais do mês de setembro e só veio a recuar a partir dos meados de novembro. Durante este tempo, a epidemia fez dezenas de óbitos, sobretudo entre os adultos jovens, com o acme no mês de outubro, tanto na Vila como no concelho, constituindo uma das maiores crises de mortalidade conhecidas em Chaves, semelhante à que ocorrera em 1855. É bem verdade, que alguns destes óbitos estão associados a outras doenças que lavravam na mesma altura endemicamente, tais como a tuberculose, o tifo exantemático e a varíola, mas sem expressão significativa na curva obituária deste período.

Ao contrário da primeira vaga gripal, de características benignas, a segunda onda da gripe pneumónica manifestou-se de forma mais virulenta e com maior poder difusivo. A sua disseminação foi ainda facilitada pela conjuntura particularmente penosa do país, devido à pobreza, falta de subsistências e consequente carestia dos géneros alimentares, associada a uma permanente instabilidade política e social. Acresce que as medidas higiénicas e médico-sanitárias foram incapazes de dominar a epidemia. Porquanto, não podemos compreender os efeitos da pneumónica desligada da difícil realidade histórica que atravessava a Nação naquela época, profundamente marcada pelo conflito da Primeira Guerra Mundial e do governo presidencialista de Sidónio Pais, pelo que os recursos a despender eram inevitavelmente limitados. Além disso, ignoravam-se as práticas imunizantes mais eficazes e os medicamentos preventivos também não existiam, uma vez que a natureza da doença só viria a ser conhecida mais tarde. Por isso, entre as medidas mais comuns, aconselhava-se evitar os grandes ajuntamentos, como as romarias e as feiras, isolar os doentes e, face à incapacidade dos serviços de saúde e de assistência, observar as práticas clássicas de higiene pessoal e pública, como as lavagens do nariz e da boca e a limpeza e desinfeção das casas e das ruas.

O combate à epidemia foi dirigido pela Direção-Geral de Saúde, com o apoio dos delegados de saúde, em cada distrito, e dos subdelegados, nos concelhos, contando estes com o auxílio dos administradores e das câmaras municipais. Aqui, em Chaves, de acordo com a documentação consultada, a ação das autoridades públicas foi diminuta no âmbito da saúde pública e das medidas profiláticas, possivelmente por terem relativizado os efeitos da 
epidemia, em consequência da natureza benigna da primeira vaga e da sua coexistência com outras doenças, como a varíola e o tifo exantemático.

\section{Fontes}

ADVRL. Livro de declaração de óbito de Vila Pouca (1918), n.o 8.

ADVRL. Livros de extratos de assentos de casamento de Chaves (1918, 1919 e 1920), n. ${ }^{\circ} \mathrm{s}$ 8,9 e 10.

ADVRL. Livros de extratos de assentos de nascimento de Chaves (1918, 1919 e 1920), n. ${ }^{\circ} \mathrm{s}$ $11,12,13,14,15$ e 16.

ADVRL. Livros de extratos de assentos de óbito de Boticas (1918, 1919 e 1920), n. ${ }^{\circ}$ s 8, 9 e 10 .

ADVRL. Livros de extratos de assentos de óbito de Chaves (1918, 1919 e 1920), n. ${ }^{\circ} \mathrm{s} 10,11$ e 12 .

ADVRL. Livros de extratos de assentos de óbito de Montalegre (1918, 1919 e 1920), n. ${ }^{\circ} \mathrm{s} 8$, 9 e 10.

ADVRL. Livros de extratos de assentos de óbito de Ribeira de Pena (1918, 1919 e 1920), n. ${ }^{\circ}$ s 9,10 e 11 .

ADVRL. Livros dos assentos de óbito de Vila Pouca (1918, 1919 e 1920), n..$^{\circ} \mathrm{s} 8$ e 9, 10 e 11.

AMC. Copiador de Cartas da Câmara Municipal de Chaves (1917/18). Livro no 11 , cota 1.417 .

AMC. Livros de inumações de Chaves (1911-1941).

AMC. Livro de atas da Câmara Municipal de Chaves (1917/18).

AMC. Livro de atas da Câmara Municipal de Chaves (1918/19).

ASCMC. Livro de movimento de doentes do Hospital da Santa Casa da Misericórdia de Chaves e Boticas (1918/32), no 222.

BMB. Jornal «Ecos de Boticas», de 1 de dezembro de 1918, nำ 23.

BMB. Jornal «Ecos de Boticas», de 15 de dezembro de 1918, no 24.

BMB. Jornal «Ecos de Boticas», de 18 de outubro de 1918, no 21.

BMB. Jornal «Ecos de Boticas», de 18 de setembro de 1918, nํำ 19.

BMB. Jornal «Ecos de Boticas», de 7 de novembro de 1918, no 22.

INE. Censo da População de Portugal no $1^{o}$ de dezembro de 1911. Lisboa: Imprensa Nacional. 
INE. Censo da População de Portugal no $1^{o}$ de dezembro de 1920. Lisboa: Imprensa Nacional.

INE. Censo da População do Reino de Portugal no $1^{o}$ de dezembro de 1900. Lisboa: Imprensa Nacional.

Jornal «A Capital», de 23 de setembro de 1918, ano $9^{\circ}$, $\mathrm{n}^{\mathrm{o}} 2.907$.

Jornal «A Capital», de 6 de outubro de 1918, ano $9^{\circ}$, nํㅡ 2.919 .

Jornal «O Espozendense», de 26 de setembro de 1918, nํㅜ 595.

\section{Bibliografia}

AMORIM, Maria Norberta (1992). Evolução demográfica de três paróquias do Sul do Pico (1680-1980). Instituto de Ciências Sociais da Universidade do Minho, Braga.

BANDEIRA, Mário Leston (1996). Demografia e Modernidade. Família e Transição Demográfica em Portugal. Imprensa Nacional - Casa da Moeda, Lisboa.

BANDEIRA, Mário Leston (2009). A Sobremortalidade de 1918 em Portugal: análise demográfica, in SOBRAL, José Manuel; LIMA, Maria Luísa; CASTRO, Paula; SOUSA, Paulo Silveira (org.). A pandemia Esquecida. Olhares comparados sobre a pneumónica 1918-1919. ICS/Instituto de Ciências Sociais da Universidade de Lisboa, Lisboa.

DUPÂQUIER, Jacques (1979). «Commentaire», in CHARBONNEAU, Hubert; LAROSE, André (eds.). The great mortalities: methodological studies of demographic crises in the past. Étude méthodologique des crises démographiques du passé: Les grandes mortalités. Ordina Éditions, Liège, pp. 333-336.

DUPÂQUIER, Jacques (1979). L'analyse statistique des crises de mortalité, in CHARBONNEAU, Hubert; LAROSE, André (eds.). The great mortalities methodological studies of demographic crises in the past. Étude méthodologique des crises démographiques du passé: Les grandes mortalités. Ordina Éditions, Liège, pp. 81-112.

DUPÂQUIER, Jacques (1984). Demografia Histórica e História Social, in Marcílio, Maria Luiza (org.). População e Sociedade. Evolução das sociedades pré-industriais. Vozes, Petrópolis, pp. 25-46.

HENRY, Louis (1988). Técnicas de Análise em Demografia Histórica. Tradução portuguesa de J. Manuel Nazareth. Gradiva, Lisboa.

JORGE, Ricardo (1918). A nova Incursão peninsular da Influenza. Relatório apresentado ao Conselho Superior de Higiene em sessão de 18 de junho de 1918.

LEMOS, Maximiano de (1991). História da Medicina em Portugal, vol. II, $2^{\text {a }}$ edição. D. Quixote-Ordem dos Médicos, Lisboa.

LIVI-BACCI, Massimo (1984). Crises de mortalidade: definição, métodos de cálculo, análise das consequências, in Marcílio, Maria Luiza (org.). População e Sociedade. Evolução das sociedades pré-industriais. Vozes, Petrópolis, pp. 69-109. 
MACHADO, José Timóteo Montalvão (1957). Como nascem e morrem os portugueses. Estudo demográfico. Gomes \& Rodrigues Editores, Lisboa.

MACHADO, Júlio Montalvão (1994). Crónica da Vila Velha de Chaves. Edição da Câmara Municipal de Chaves, Chaves.

MACHADO, Júlio Montalvão (1998). A República em Chaves. Edição do Grupo Cultural Aquae Flaviae, Chaves.

MARQUES, Oliveira (1986). História de Portugal, vol. III, $3^{\text {a }}$ edição. Pala Editores, Lisboa .

MEUVRET, Jean (1946). Les crises de subsistances et la démographie de la France d'Ancien Régime. Population, vol. 1, nº 4, pp. 643-650.

MOREIRA, Maria João Guardado (1994). Vida e Morte no Concelho de Idanha-a-Nova. Estudo Demográfico - Século XVIII. Livros Horizonte, Lisboa.

NAZARETH, J. Manuel (1988). Princípios e Métodos de Análise da Demografia Portuguesa. Editorial Presença, Lisboa.

PÉREZ MOREDA, Vicente (1980). Las crisis de mortalidad en la España interior. Siglos XVI-XIX. Siglo Veintiuno, Madrid.

RODRIGUES, Teresa (1990). Crises de mortalidade em Lisboa, Séculos XVI e XVII. Livros Horizonte, Lisboa.

RODRIGUES, Teresa Ferreira (coord.) (2009). História da População Portuguesa. Edições Afrontamento/CEPESE, Porto.

SANTOS, Carlota Maria (2007). Incidência da mortalidade no concelho da Madalena (Ilha do Pico - Açores) de 1670 a 1970. Actas do I Congresso Internacional de História da Universidade do Minho, 3. Núcleo de Estudos Históricos, Braga, pp. 559-583.

SOBRAL, José Manuel; LIMA, Maria Luísa; CASTRO, Paula; SOUSA, Paulo Silveira (org.) (2009). A Pandemia Esquecida. Olhares comparados sobre a pneumónica 19181919. ICS/Instituto de Ciências Sociais da Universidade de Lisboa, Lisboa.

SERRÃO, Joaquim Veríssimo (1989). História de Portugal. (1910-1926), vol. XI. Editorial Verbo, Lisboa.

SERRÃO, Joaquim Veríssimo (1990). História de Portugal. (1910-1926), vol. XII. Editorial Verbo, Lisboa. 



\section{A GRIPE PNEUMÓNICA NO CORPO ExPEDicionário Português}

Helena da Silva ${ }^{1}$

1 Investigadora FCT (IF/00631/2014/CP1221/CT0004) com o projecto Medical and Healthcare services in the First World War: the case of the Portuguese soldiers during and after the Great War (1914-1960) no IHC-NOVA-FCSH, helenadasilva@fcsh.unl.pt 



\begin{abstract}
Resumo
O último ano da Grande Guerra (1914-1918) ficou marcado pela pandemia de gripe pneumónica, que afectou a população civil e militar. A violência e a longevidade do conflito tiveram um impacto directo na saúde dos militares. As sucessivas vagas de gripe agravaram este cenário, afectando os militares exaustos e enfraquecidos. Neste artigo, pretende-se abordar a pandemia de gripe em contexto militar, nomeadamente no Corpo Expedicionário Português (França), e conhecer algumas das medidas de profilaxia adoptadas pelas autoridades militares portuguesas no terreno, que seguiram orientações internacionais. Graças à Comissão de Vigilância Interaliada e às suas reuniões regulares foi possível trocar informações sobre a pandemia e adoptar medidas comuns. Paralelamente, tentaremos avaliar o impacto da gripe nas forças militares portuguesas partindo de relatos da época e estatísticas oficiais, cruzando com contagens dos registos de entradas de estruturas de saúde. Por último, tentaremos estabelecer uma comparação com o exército britânico, onde a mortalidade foi bem mais elevada.
\end{abstract}

Palavras-chave: Primeira Guerra Mundial, influenza, Comissão de Vigilância Interaliada, profilaxia.

A pandemia de «gripe espanhola», pneumónica ou influenza marcou o último ano da Grande Guerra (1914-1918) tendo afectado as populações civis tal como militares. Neste artigo, abordaremos a pandemia de gripe em contexto militar, nomeadamente no Corpo Expedicionário Português (CEP), que desde Janeiro de 1917 tinha sido enviado para a França, deixando de fora o teatro de guerra africano. Recorde-se que, desde 1914, Portugal tinha reforçado o envio de tropas para Angola e Moçambique, numa tentativa de assegurar as suas colónias. Na sequência da tomada dos navios alemães em águas portuguesas, a Alemanha declarou a guerra a Portugal a 9 de Março de 1916, o que levou ao envio de tropas para a frente europeia, nomeadamente para o Norte da França (Afonso, Gomes, 2013; Telo, Sousa, 2016).

A violência e a longevidade do conflito tiveram um impacto directo na saúde dos militares. As sucessivas vagas de gripe agravaram este cenário, afectando os militares exaustos e enfraquecidos. Neste artigo, veremos algumas 
das medidas de profilaxia adoptadas pelas autoridades militares portuguesas no terreno, que seguiram orientações internacionais. Partindo da análise das actas das reuniões da Comissão de Vigilância Interaliada, referentes ao período da pandemia de gripe, veremos como este órgão permitiu trocar informações entre os diferentes países membros e adoptar medidas comuns. Tentaremos perceber, através de dados disponíveis no Arquivo Histórico Militar (PT AHM) e no Arquivo da Cruz Vermelha Portuguesa (ACVP), qual o impacto da gripe nas forças militares portuguesas. Para tal, recorremos a uma documentação variada, como relatos da época, e a estatísticas oficiais do CEP, que cruzamos com contagens efectuadas aos registos de entradas de várias estruturas de saúde. Contudo, esta análise impõe um conjunto de limites, deixando algumas questões em aberto, como a comparação com o impacto da gripe no exército britânico.

Apesar da historiografia portuguesa já ter abordado o tema da gripe pneumónica em vários aspectos, como a mortalidade e as respostas do Estado e da sociedade civil (Frada, 2005), as consequências demográficas e socioeconómicas no caso do Algarve (Girão, 2003), ou ainda a memória da gripe, as suas representações e as respostas à epidemia (Sobral et al., 2009a; 2009b; 2014), o contexto militar tem ficado de fora da maioria dos estudos. Apesar do centenário da Grande Guerra ter permitido a publicação de inúmeros novos trabalhos que não poderemos citar aqui, também os 100 anos da gripe pneumónica têm suscitado algum interesse (Nunes, et al., 2018), deixando, contudo, de lado este tema, salvo algumas excepções (Silva, Pereira e Bandeira, 2019). Aliás, na introdução ao dossier «Revisitar a Pneumónica de 1918-1919», da revista Ler História, é salientado este facto e o interesse em estudar os efeitos da gripe nas tropas portuguesas, nos campos de batalha da Grande Guerra (Abreu, Serrão, 2018).

Este vazio na historiografia portuguesa é surpreendente, sobretudo tendo em conta a relação intrínseca entre a Primeira Guerra Mundial e a pandemia de gripe pneumónica. Veja-se, por exemplo, a origem do vírus, que ainda é motivo de debate. As hipóteses mais plausíveis apontam uma possível origem num campo militar do Kansas (Estados Unidos), outros estudos mencionam os campos militares no sul da Inglaterra e no Norte da França, mas há ainda a hipótese de uma origem asiática, tendo o vírus chegado à Europa com os trabalhadores chineses usados como mão-de-obra na Grande Guerra (Killingray, 2009; Rasmussen, 2014).

A única certeza é que o conflito mundial contribuiu para a propagação da doença, quer através da concentração de homens em determinados espaços, quer pela sua circulação com a mobilização, desmobilização e ainda as 
licenças. Ricardo Jorge, referindo-se ao caso português e aos avanços da segunda vaga de norte para sul, escreveu «os vai-vens de tropas continuaram a contribuir para a sementeira da infecção (...); à epidemia das casernas sucedeu a epidemia na cidade» (Jorge, 1919a: 313). Por último, a pandemia de gripe acompanhou as fases finais do conflito. Isto é, a primeira vaga, na Primavera de 1918, coincide com a última ofensiva alemã e a chegada das tropas americanas à Europa; a segunda vaga, no Outono de 1918, corresponde à progressão final da guerra e ao armistício; e a terceira vaga no Inverno-Primavera de 1918-1919, coincide com a desmobilização das tropas (Rasmussen, 2014).

\section{A GRIPE NAS TROPAS EM BREST}

Comecemos pelo caso de Brest (Fig. 1), que foi o porto de desembarque das tropas portuguesas (e americanas) em França, vindas por via marítima. Esta cidade foi, aliás, apontada por alguns historiadores como um dos locais na Europa onde surgiram os primeiros casos de gripe. Foi ali que se

Fig. 1 - A França durante a Grande Guerra e o sector português (quadrilátero)

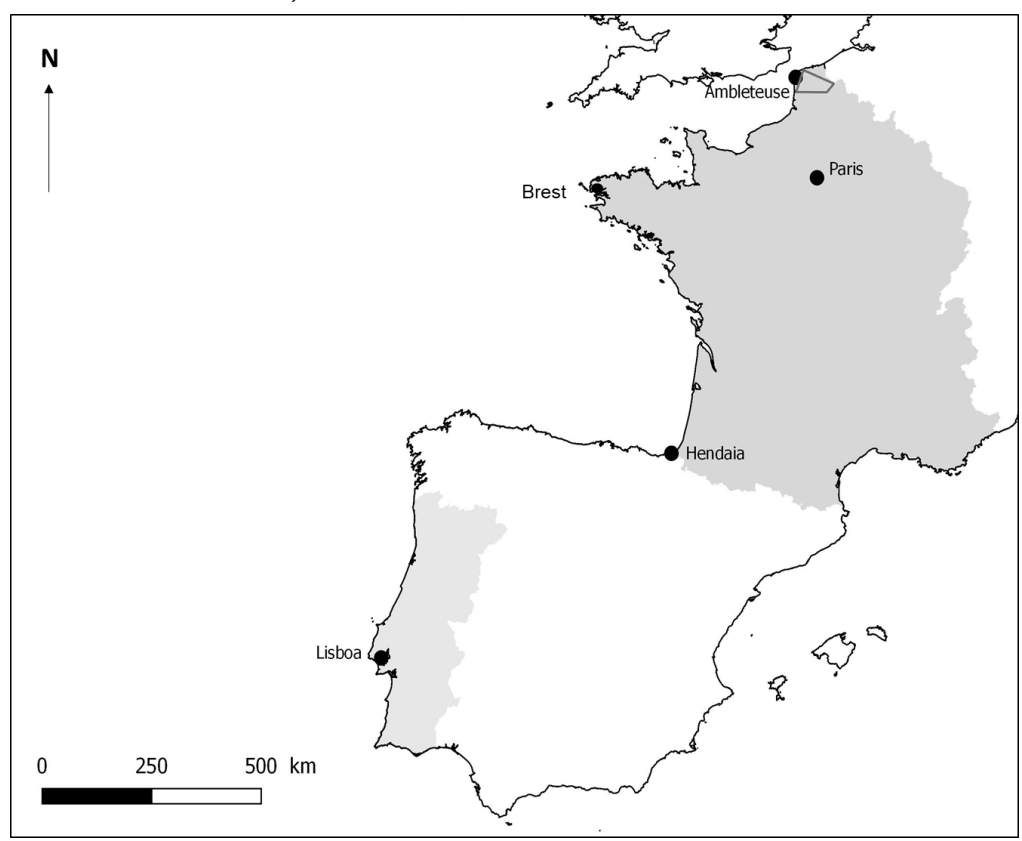

Fonte: Mapa livre de direitos. 
reuniu regularmente a Comissão de Vigilância Interaliada (Commission de Vigilance Interalliée). Esta terá sido uma das várias comissões que surgiram no contexto da Primeira Guerra para partilhar informações, saberes e experiências entre os aliados, como a Comissão Sanitária Interaliada, não esquecendo também as diferentes conferências sobre cirurgia de guerra ou ainda sobre a reeducação dos mutilados (Rasmussen, 2016).

A Comissão de Vigilância tinha um presidente e entre sete a oito membros, sendo um deles secretário. Esta incluía representantes dos serviços de saúde militares do Reino Unido, dos Estados Unidos, de Portugal e da França, bem como representantes civis como o Director do Serviço de Higiene da cidade de Brest. Estes apresentavam o estado de saúde das tropas, abordavam possíveis epidemias e, nesse caso, discutiam a adopção de medidas sanitárias. A pandemia de gripe foi, assim, um dos temas centrais das reuniões em finais de 1918. Nestas reuniões, o médico José de Sousa Guimarães representou Portugal, tendo sido louvado pelo «esforço e inteligência» com que participou nas reuniões, que lhe valeram também elogios dos colegas estrangeiros ${ }^{2}$.

Reunimos os dados estatísticos apresentados nas actas das reuniões desta comissão relativos aos casos de gripe. Em primeiro lugar, convém referir que o Reino Unido tinha um número reduzido de tropas estacionadas em Brest e, por isso, não apresenta qualquer caso. Entre Abril e Setembro de 1918, houve um reduzido número de casos entre as tropas portuguesas em Brest, nomeadamente 16 num efectivo de 400 homens, não havendo qualquer morte a declarar. Isto é, $4 \%$ das tropas portuguesas em Brest sofreram de gripe, na primeira vaga, que foi menos mortífera ${ }^{3}$.

Como é possível verificar na Figura 2, na segunda vaga, o número de casos entre as tropas portuguesas foi extremamente reduzido $(0,4 \%$ ou $24 / 6.033$ casos), sobretudo quando comparado com os números americanos e franceses. Como é óbvio, em vez destes números absolutos, seria interessante conhecer a proporção dos casos em relação ao número de militares. Infelizmente, não foi possível obter estes dados. Contudo, é visível um pico nos inícios de Outubro, que afecta sobretudo os americanos e que, quando começa a reduzir, observa-se um aumento entre as tropas portuguesas. Por último, é ainda observável a terceira vaga. Contudo, a fonte não menciona a mortalidade por gripe $^{4}$.

$2 \quad$ Boletim individual de José de Sousa Guimarães, PT AHM DIV 1-35A-1-07-2151, disponível em https://arqhist. exercito.pt/details?id=127546, consultado em 19/09/2018.

3 Procès-verbaux de la Commission de Vigilance Interalliée, PT AHM DIV 1-35-727-9.

4 Idem. 
Fig. 2 - Casos de gripe assinalados nas tropas em Brest

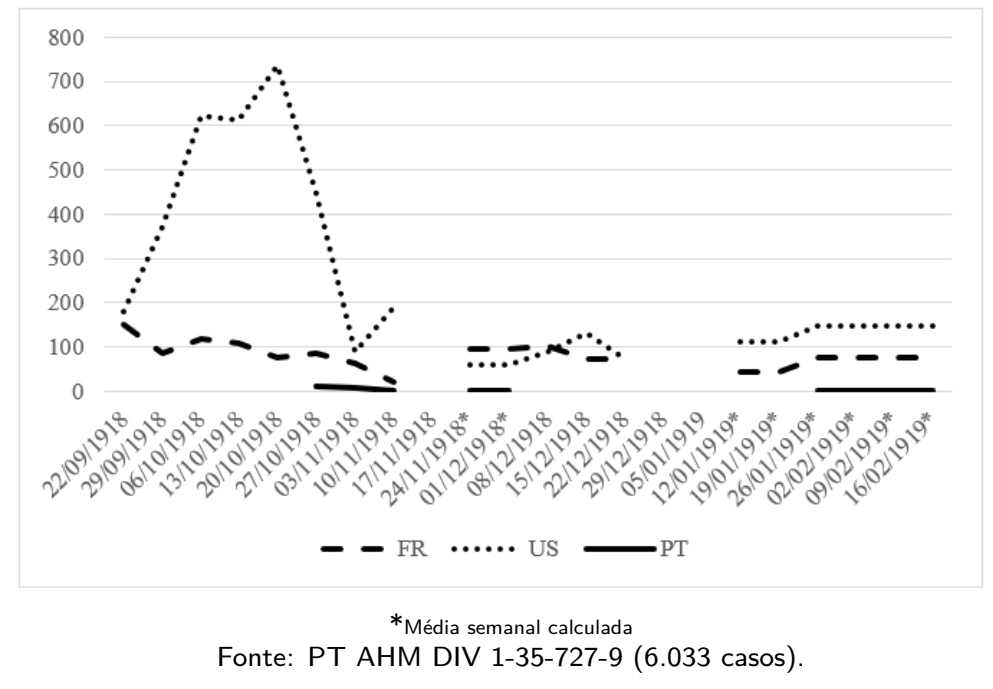

Quanto às medidas de profilaxia discutidas nas reuniões, coube ao representante americano defender medidas mais severas, bem como a sua imposição à população civil. Estas medidas incluíam a quarentena, o encerramento das salas de espectáculos, de cafés e de restaurantes, sendo que estas eram então contestadas por serem pouco eficazes face à violência do vírus. Já o representante português, José de Sousa Guimarães, defendeu nomeadamente a declaração obrigatória dos casos de gripe, com sanções em caso de não declaração, e consequente desinfecção dos locais contaminados e isolação entre uma a dez noites. Tal como alguns dos seus colegas, Sousa Guimarães defendeu o encerramento temporário dos estabelecimentos públicos, como locais de espectáculo, escolas e igrejas, bem como o isolamento dos doentes de gripe num local específico ${ }^{5}$.

Contudo, muitas das medidas discutidas não chegaram a ser implementadas ou foram-no de forma parcial, isto é, apenas aplicadas a determinado exército. Por exemplo, as tropas portuguesas não foram proibidas de frequentar locais de espectáculo como as americanas. Nas diferentes discussões, a medida que mais consenso reuniu foi o isolamento dos casos de gripe desde os primeiros sintomas. Assim, quando em finais de Novembro surgiu um caso

5 Procès-verbal de la Séance du 16 septembre 1918. Commission de Vigilance Interalliée, PT AHM DIV 1-35-727-9. 
de gripe entre os portugueses, este foi imediatamente dirigido ao Hospital Principal da Marinha em Brest ${ }^{6}$.

\section{MEDIDAS DE PROFILAXIA ADOPTADAS NA FLANDRES}

Mais a norte, na Flandres, segundo o diário de campanha da Ambulância n. ${ }^{\mathrm{o}}$ 4, a 15 de Junho de 1918 surgiam os primeiros casos de gripe. «Desenvolveu-se neste Estacionamento uma epidemia gripal, derivada, segundo opinião clinica, aos abaixamentos bruscos de temperatura. Registou um grande numero de casos epidémicos nas praças da formação.» ${ }^{7}$. Se esta primeira vaga foi vista como uma gripe banal, a segunda levou à implementação de medidas de profilaxia excepcionais.

Estas medidas foram, na realidade, baseadas no relatório redigido pelo Dr. Fernand Bezançon, que foi apresentado e aprovado a 15 de Outubro de 1918 pela Academia de Medicina de Paris. O relatório continha uma dezena de páginas e fora redigido a pedido do subsecretário de Estado dos Serviços Franceses de Saúde Militar, o Dr. Louis Mourier ${ }^{8}$.

O Dr. Lúcio Nunes, chefe de saúde do CEP, partindo das conclusões deste relatório, elaborou, dez dias depois, um documento de uma página com as principais medidas a adoptar contra a gripe. Primeiro, era necessário evitar o contacto com doentes contaminados e seguir uma rigorosa assepsia da boca e da rinofaringe. Depois, aconselhava a evitar locais fechados, como teatros e cinemas, bem como os transportes públicos. Assim, estas medidas eram menos restritivas, pois defendiam que estes espaços deveriam continuar a funcionar, desde que fossem alvo de uma limpeza rigorosa.

Em caso de gripe, deveria proceder-se ao isolamento, separando esses doentes dos feridos e gazeados, bem como os casos simples dos graves, e evacuando os convalescentes. As visitas eram proibidas para os engripados, que deveriam ser tratados por um pessoal específico, que não se ocuparia de outros doentes, para evitar ser agente de transmissão do vírus. À semelhança do que era feito nos hospitais americanos, o uso de máscaras deveria ser generalizado. O último ponto refere que se deveria tratar no local os doentes

${ }_{6}$ Procès-verbal de la Séance du 2 décembre 1918. Commission de Vigilance Interalliée, PT AHM DIV 1-35-727-9.

7 Diário de campanha - Ambulância 4, PT AHM DIV 1-35-0370.

8 Académie nationale de médecine (1918). Rapport II - Sur la prophylaxie de la grippe, in Bulletin de l'Académie nationale de médecine, 3ème série, Tome LXXX, Masson, Paris, 317-327, disponível em https://gallica.bnf.fr/ark:/12148/bpt6k408741x/ (consultado em 21/09/2018). 
de gripe e evitar deslocá-los; em caso de evacuação, deveriam ser usados transportes específicos que seriam desinfectados ${ }^{9}$.

Um outro documento refere que cabia aos oficiais médicos das unidades e das formações instruir os militares a desinfectar o nariz, a boca e a garganta. O ideal seria efectuar gargarejos e lavagens com água salgada tépida na medida de uma colher de chá de sal para um litro de água. Mas poderia ainda ser utilizado «quaisquer $[$ sic] desinfectantes que possam haver ao seu alcance» $^{10}$.

Hoje, é complexo avaliar se estas medidas foram adoptadas na totalidade, ou até se houve oposição de médicos, oficiais ou praças ${ }^{11}$. Tudo indica que terão sido parcialmente respeitadas em meio hospitalar. Centremo-nos em Ambleteuse (Fig. 1), a base das tropas portuguesas em França, onde se encontravam várias estruturas hospitalares de retaguarda, nomeadamente um hospital da Cruz Vermelha Portuguesa e dois hospitais militares portugueses (Silva, 2018; Marques, 2008).

No hospital da Cruz Vermelha, foi preparada uma enfermaria de isolamento para doentes com sintomas da «epidemia mundial», em finais de $\mathrm{Ou}-$ tubro $^{12}$. Nos inícios de Novembro, o Hospital da Base n. ${ }^{\circ} 1$ tinha uma enfermaria com várias salas para os casos de gripe, incluindo uma para isolar doze doentes graves. Alguns dias depois, foi aberta uma outra enfermaria apenas para a gripe provavelmente em resposta ao número de $\operatorname{casos}^{13}$. Aquando da terceira vaga, logo em inícios de Maio de 1919 e «tendo-se manifestado com intensidade e caracter grave a gripe n'esta zona», eram novamente propostas medidas que, uma vez mais, incluíam evitar aglomerações em cafés e saídas injustificadas dos acantonamentos, uma limpeza, duas vezes ao dia, das vias respiratórias superiores com água salgada tépida, bem como uma lavagem das mãos e do rosto antes das refeições e das idas às casas de banho, e ainda evitar alimentos crus e beber apenas água dos depósitos. Outras recomendações incluíam evitar resfriamentos e trabalhos cansativos sobretudo de noite,

\footnotetext{
$9 \quad$ Instruções de Profilaxia Geral contra a Gripe ou Influenza Epidémica, Ordem do Quartel General da Base n. ${ }^{\circ} 301$ de 28/10/1918, Arquivo da Cruz Vermelha Portuguesa (ACVP) Pasta $1^{\mathrm{a}}$ Guerra Mundial Ambleteuse $2^{\mathrm{o}}$ volume.

10 Instruções sobre hygiene e profilaxia anti-grippal pelo Comandante do Serviço de Saúde do CEP, 31/10/1918, PT AHM DIV 1-35-208-1.

11 Segundo o historiador Leo van Bergen, nem todos os médicos e oficiais, e muito menos as praças, estavam interessados em respeitar as medidas higiénicas impostas durante a guerra, não se referindo ao caso específico da gripe (Bergen, 2014).

12 Carta de Luís Bettencourt para o Presidente da Sociedade Portuguesa da Cruz Vermelha em Lisboa, 31/10/1918, ACVP - Pasta $1^{\text {a }}$ Guerra Mundial Ambleteuse $2^{\mathrm{o}}$ volume.

13 Ordem n..$^{\circ} 220$ de 03/11/1918 e ordem n. ${ }^{\circ} 228$ de 12/11/1918, Ordens de Serviço do Hospital de Base n. ${ }^{\circ}$ 1, PT AHM DIV 1-35-0674.
} 
a ventilação das barracas e limpeza dos acantonamentos e a desinfecção das roupas dos doentes de gripe. Em caso de sintomas, deveriam ser rapidamente admitidos no Hospital da Base n. ${ }^{\circ} 1$ que ainda estava em funcionamento ${ }^{14}$.

Durante a epidemia, foi também ordenada a limpeza dos soalhos com soluto de cresol uma ou duas vezes ao dia e o recurso a fumigações em todas as salas com cânfora em pó e ácido fénico puro, nos acantonamentos e hospitais ${ }^{15}$.

Ainda sobre as medidas tomadas, no Arquivo Histórico Militar encontrámos exemplares de um documento do CEP intitulado A gripe - que se deve fazer para não a ter? da autoria do tenente médico miliciano Vasco Verdial e do capitão de cavalaria Júlio de Moura Borges. Este contém cinco pontos simples: abrir as janelas e as portas das casas, casernas e refeitórios; evitar aglomerações de pessoas em cafés, cinemas e teatros; ir ao médico quando surgirem os primeiros sintomas, a saber, dores de cabeça fortes, febres e constipação; fazer exercícios ao ar livre; e por último, a habitual lavagem do nariz e da boca duas vezes ao dia com água salgada. Desconhecemos como este documento foi utilizado, divulgado e claro, se as tropas seguiram ou não estes pontos $^{16}$.

\section{AS TROPAS PORTUGUESAS FORAM POUCO DIZIMADAS?}

Oficialmente, «as tropas portuguesas da Flandres foram pouco dizimadas pela influenza» ${ }^{17}$ (Jorge, 1919b: 22), segundo declaração do próprio Ricardo Jorge apontando, na primeira vaga, um morto num efectivo de 40.000 homens e, na segunda vaga, 37 mortos até finais de Dezembro, num efectivo de 30.000 homens. Estes números, que são inferiores aos oficiais, foram compilados durante mês e meio por António Vieira Barradas, médico responsável pela estatística médica do $\mathrm{CEP}^{18}$. Isto porque Ricardo Jorge lhe tinha colocado um conjunto de questões, como «Que formas torácicas se observaram? Pesquizas bacteriológicas? (...) A epidemia grassou com intensidade egual

\footnotetext{
14 Ordem n. ${ }^{\circ} 61$ de 02/03/1919, Ordens de Serviço do Hospital de Base n. ${ }^{\circ}$ 1, PT AHM DIV 1-35-0674.

15 Ordem n. 73 de 14/03/1919, Ordens do Quartel General da Base, ACVP - Pasta $1^{\text {a }}$ Guerra Mundial Ambleteuse $2^{\circ}$ volume.

16 A gripe - que se deve fazer para não a ter?, PT AHM DIV 1-35-1412-04; PT AHM DIV 1-35-0674.

17 Os números apresentados por Jorge eram um quarto menores do que os oficiais.

18 Boletim individual de António Vieira Barradas, PT AHM DIV 1-35A-1-05-1422, disponível em https://arqhist.exercito.pt/details?id=123967 (consultado em 19/09/2018).
} 
[sic] ou menos que nas tropas inglesas?», e tinha, assim, pedido todos os dados possíveis sobre a epidemia e os militares portugueses ${ }^{19}$.

O próprio Barradas concluiu que a gripe teve um «eco não muito acentuado» e um balanço menos pesado entre os militares portugueses, comparativamente aos exércitos britânico e belga. Segundo ele, a primeira vaga, entre Abril e Agosto, foi quase sem mortalidade e, como dava três dias de incapacidade, muitos homens não chegaram sequer a baixar aos hospitais. Já na segunda vaga, Barradas referiu centenas de baixas, fazendo-se sentir a mortalidade. Assim, mencionou que, entre Outubro e Dezembro de 1918, deram-se 107 baixas no Hospital da Base n. 1 e 452 no Hospital de Sangue n. ${ }^{\circ}{ }^{20}$. Segundo Barradas, foi neste Hospital de Sangue e na Ambulância n. ${ }^{\circ} 4$ que se atingiu a maior mortalidade, sem avançar mais informações (Barradas, 1920). Segundo o Coronel médico Álvaro Martins, a Ambulância n. ${ }^{\circ} 4$ recebeu em Novembro um grande número de doentes devido à «grande epidemia gripal», tendo contabilizado até Dezembro um quarto de doentes com gripe, isto é, 585 homens (Martins, 1936: 121-122). Contudo, as informações são limitadas e desconhecemos como foram feitas as contagens.

António Barradas mencionou, numa carta de Maio de 1919, que estava a terminar um artigo sobre a gripe no CEP e que até o tinha mostrado a Ricardo Jorge ${ }^{21}$. Infelizmente, e apesar das tentativas, não conseguimos encontrar esse artigo, quer nos arquivos, quer nas publicações periódicas da especialidade. Assim, apenas sabemos que este contabilizou, até 31 de Março de 1919, 51 óbitos em terras francesas por gripe, que é o número oficial de vítimas de gripe pneumónica no CEP. Isto significa que, entre Janeiro de 1917 e Março de 1919, esta foi a segunda causa de morte por doença ou acidente das tropas portuguesas, sendo a primeira a tuberculose (Fig. 3). Ou seja, um em cada oito portugueses que morreram por doença em França, morreram de gripe. Podemos também verificar que este número é relativamente próximo dos mortos por gases. No geral, o número de óbitos por gripe corresponde a cerca de $3,4 \%$ do total de mortes contabilizadas até Março de $1919^{22}$, segundo estatísticas do $\mathrm{CEP}$, sendo efectivamente um número que parece reduzido no contexto da guerra.

19 Carta de Ricardo Jorge para António Barradas, 29/01/1919, PT AHM DIV 1-35-141204.

20 Carta de António Barradas a António de Azevedo, 01/04/1919, PT AHM DIV 1-351401-09.

21 Carta de António Barradas, 22/05/1919, PT AHM DIV 1-35-1412-01.

22 De referir que o número de mortos no CEP será superior aos 1507 casos aqui mencionados, de acordo com outras fontes como PT AHM DIV 1-35-1401-09. 
Fig. 3 - Causas de morte do CEP (1917-1919))

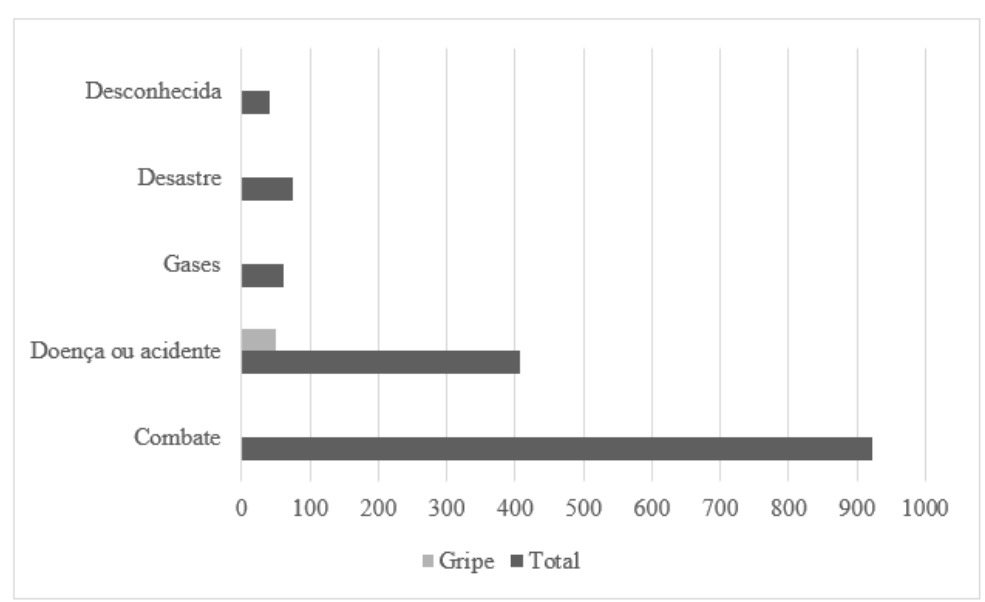

Fonte: Causas de morte no CEP, PT AHM DIV 1-35-1412-01 (1.507 casos em 31/3/1919).

Numa tentativa de analisar de forma mais aprofundada os casos de gripe no Hospital da Base n. ${ }^{\circ} 1$ (HB1), recorremos aos dados fornecidos pelo serviço de estatística do CEP, entre Março e Dezembro de $1918^{23}$, e aos dados que conseguimos recolher e tratar relativamente aos doentes hospitalizados entre finais de Janeiro e Junho de 1919, quando era a única estrutura hospitalar da retaguarda ainda em funcionamento em França. A estes juntámos os registos das entradas no Hospital da Cruz Vermelha Portuguesa (HCVP), que contabilizámos entre Abril de 1918 e Janeiro de 1919 (período de funcionamento desta estrutura $)^{24}$. A Figura 4 representa a evolução das entradas por gripe (praças e oficiais), revelando bem os picos da epidemia de gripe, nomeadamente em Junho e Novembro de 1918 e em Fevereiro de 1919. Assim, contabilizámos um total de 1048 entradas por gripe nestes dois hospitais, correspondendo a $11 \%$ do total das entradas. Se discriminarmos por estrutura, o Hospital da Base n. ${ }^{\circ} 1$ recebeu 935 doentes de gripe (842 em 1918 e 93 em 1919), correspondendo a 10,7\% do total de entradas, enquanto que o Hospital da Cruz Vermelha recebeu 113 doentes de gripe, isto é, 15\% das entradas deveram-se à gripe.

\footnotetext{
23 De referir que estes dados não mencionam se são relativos apenas às praças ou também aos oficiais.

24 Estatística médica Hospital de Base n. ${ }^{\circ}$ 1, PT AHM DIV 1-35-1401-03; Relações de oficiais e praças hospitalizados no Hospital de Base n. 1 , PT AHM DIV 1-35-0675-04;
} 
Fig. 4 - Entradas por gripe no Hospital da Base n. ${ }^{\circ} 1$ e no Hospital da Cruz Vermelha

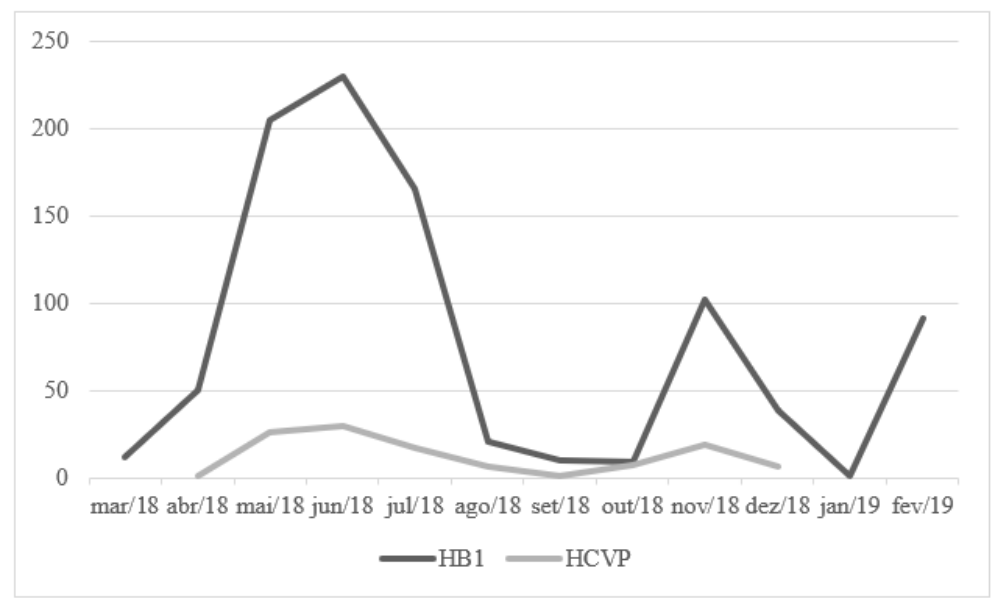

Fonte: Estatística médica Hospital de Base n. 1, PT AHM DIV 135-1401-03; Relações de oficiais e praças hospitalizados no Hospital

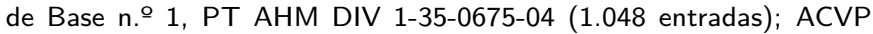
Ambleteuse Livro de Oficiais em tratamento; ACVP Ambleteuse Livro de Praças de pré em tratamento.

Destas 1.048 entradas, assinalaram-se 11 óbitos, uma percentagem bastante reduzida. Em média, um em cada cem doentes de gripe, nestas instituições, acabou por falecer. Se analisarmos a mortalidade por gripe em relação ao número total de óbitos (85), a gripe representa 12,9\%. Como revela a Figura 5 , a mortalidade por gripe foi superior no Hospital da Base n. $\stackrel{\circ}{ }$ 1 em 1919, comparativamente a 1918, destacando-se igualmente o Hospital da Cruz Vermelha.

Contudo, estas fontes e consequentes contagens podem ser facilmente postas em causa, nomeadamente quanto à denominação da causa de hospitalização, bem como de morte. Relativamente às estatísticas do CEP, desconhecemos o que é registado como gripe e tendo em conta que existem outros campos para bronquites e pneumonias, entre outras doenças respiratórias, pressupomos que as possíveis complicações ligadas à gripe pneumónica não foram contabilizadas como gripe. Convém ainda afirmar que estas doenças existiram antes da epidemia e tendo apenas os valores totais, corremos o risco de incluir óbitos que ocorreram antes da epidemia. De igual modo, quando vemos os livros de entradas dos hospitais, verificamos uma multiplicação de

ACVP Ambleteuse Livro de Oficiais em tratamento; ACVP Ambleteuse Livro de Praças de pré em tratamento. 
Fig. 5 - Entradas e óbitos por gripe em relação aos totais

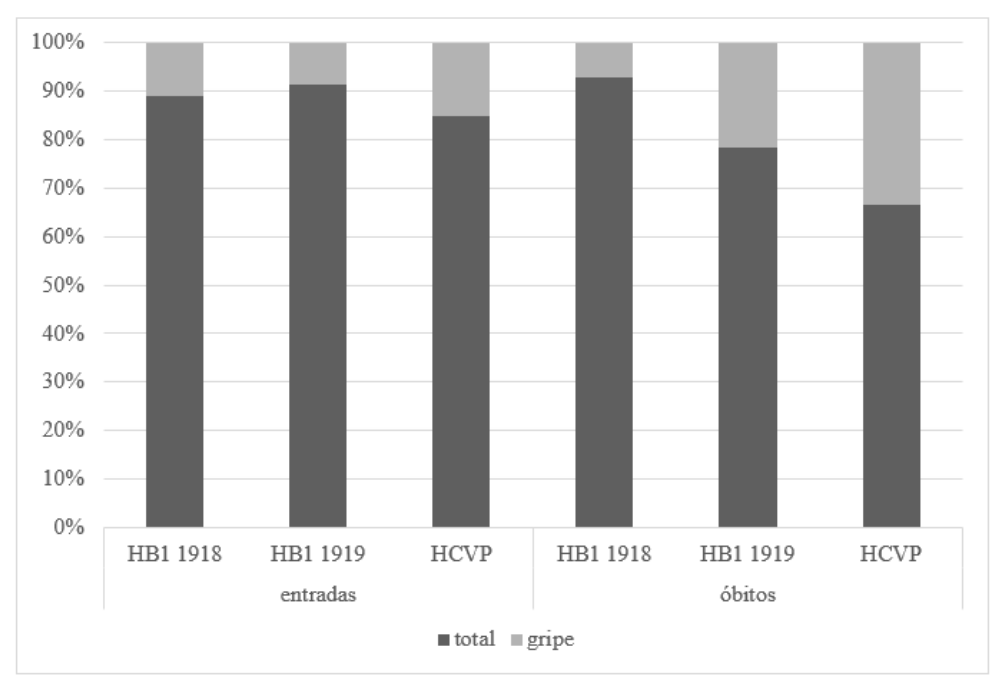

Fonte: Estatística médica Hospital de Base nํㅜ 1, PT AHM DIV 1-351401-03; Relações de oficiais e praças hospitalizados no Hospital de Base no 1, PT AHM DIV 1-35-0675-04; ACVP Ambleteuse Livro de Oficiais em tratamento; ACVP Ambleteuse Livro de Praças de pré em tratamento ( 9.444 entradas; 85 óbitos).

denominações («bronco-pneumonia gripal», «influenza», «congestão pulmonar»), o que dificulta a análise e nos leva a questionar como os serviços de estatística calcularam os mortos por gripe. Constatámos ainda que, consoante as fontes, a causa de entrada no hospital e a causa de morte eram também diferentes. Por exemplo, «astenia, gripe, pneumonia» no momento da entrada e «bronco-pneumonia» como causa de morte.

A título de exemplo, vejamos a situação no Hospital de Sangue n. ${ }^{\circ} 8$, mais na frente de combate. Se seleccionarmos o período entre Março de 1918 e Janeiro de 1919, contabilizámos um total de 4.124 entradas, apenas de praças. Destas, 554 devem-se à «gripe», 25 à «influenza» e 72 surgem assinaladas como gripe juntamente com outra doença. A estas, podemos ainda acrescentar doenças não identificadas, bem como «bronquites», com 299 entradas (incluindo bronquite e outras doenças), ou «febres» ${ }^{25}$.

Sabemos ainda que apenas em Março de 1919 foi pedido pelos serviços de estatística do CEP que houvesse um cuidado com as baixas e as mortes por

25 Registo de entradas de praças Hospital de Sangue n. ${ }^{\circ}$ 8, 29/04/1917 a 03/11/1918, PT AHM DIV 1-35-1797-02; Hospital de Sangue n.o 8 Praças, 03/11/1918 a 28/01/1919, PT AHM DIV 1-35-1796. 
«motivo da epidemia gripal». Assim, pedia-se que estes casos fossem assinalados com o número 7 da tabela nosológica, como «Influenza», incluindo depois entre parêntesis, «a forma clinica ou a complicação que motivou a morte», dando como exemplo bronco-pneumonia e congestão pulmonar. Acrescentando que, tendo havido «um acréscimo de numero de mortos por bronchopneumonia $[s i c][\ldots]$, é licito suspeitar que alguns d'estes casos devessem ser levados em conta do activo da epidemia gripal, não sendo possível traçar uma estatística fidedigna senão houver o máximo rigor em descriminar cuidadosamente os casos atribuíveis à influenza, dos que o não devam ser.» ${ }^{26}$, resumindo bem a situação com a qual nos temos deparado.

Assim, uma possível comparação com o caso das tropas britânicas (incluindo, então, as tropas canadianas, australianas e neozelandesas), sector partilhado com as tropas portuguesas, torna-se bastante complexa. Graças a um resumo estatístico efectuado pelos serviços britânicos entre Outubro de 1918 e Março 1919, isto é, durante quase meio ano, contabilizaram-se mais de 100 mil casos de influenza, que resultaram em mais de 3.000 mortes e $3 \%$ de taxa de mortalidade (Fig. 6). Com contagens semanais, é possível ver a segunda e a terceira vaga da pandemia.

Fig. 6 - A gripe nas tropas britânicas

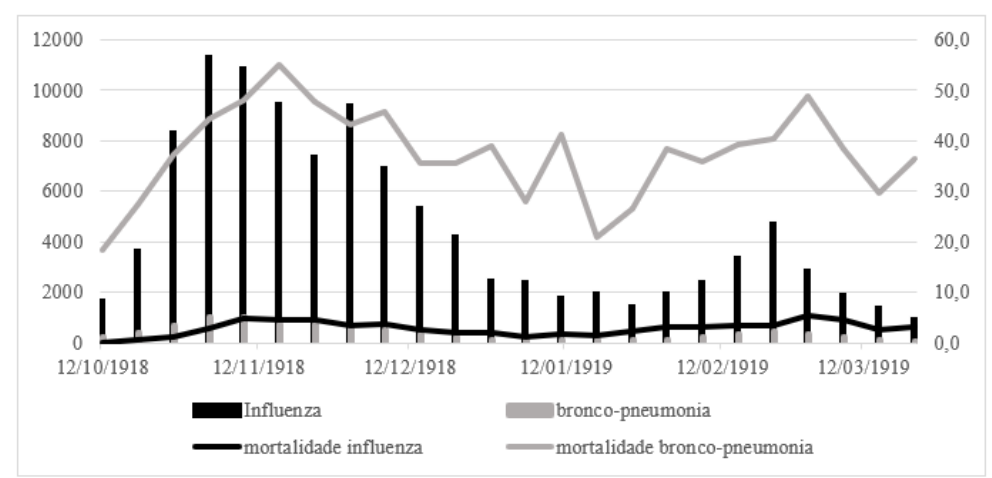

Fonte: Influenza and broncho-pneumonia, British only, PT AHM DIV 1-35-1412-01 (116.353 casos; 7.065 óbitos).

As contagens incluem ainda a bronco-pneumonia que, apesar de ter um número de casos inferior, tem uma taxa de mortalidade muito superior à da influenza. O mesmo documento acaba por somar as duas enfermidades

26 Ordem n. ${ }^{\circ} 75$ de 15/03/1919, Ordens de Serviço do Hospital de Base n. ${ }^{\circ}$ 1, PT AHM DIV 1-35-0674. 
para chegar ao total de 116.353 casos e 7.065 óbitos, ou seja, uma taxa de mortalidade de $6,07 \%^{27}$.

Neste momento, é praticamente impossível estabelecer uma comparação entre a situação da epidemia de gripe nas tropas portuguesas e britânicas, pois desconhecemos se os casos de bronco-pneumonia foram tidos em conta na estatística do CEP. Por outro lado, faltam números concretos, nomeadamente o número total de casos de gripe e de bronco-pneumonia, para calcular as taxas de mortalidade e comparar com as de outros exércitos.

\section{CONSIDERAÇÕES FINAIS}

Esta análise permitiu constatar que, durante a pandemia de gripe pneumónica, as medidas de profilaxia impostas às tropas portuguesas eram semelhantes às impostas a outros exércitos, em parte graças aos contactos com equipas médicas dos países aliados. Contudo, não sabemos se as medidas foram respeitadas na totalidade ou parcialmente pelas tropas.

Apesar de as fontes oficiais declararem que a gripe teve um impacto reduzido nas tropas lusas, muito provavelmente diminuto em relação às tropas britânicas, sem que haja qualquer explicação para tal situação, é muito provável que essas fontes não contabilizem o total dos casos de gripe e consequentes complicações respiratórias que, na maioria dos casos, eram a causa de morte. Como vimos, as causas de morte variavam de fonte para fonte, o que impede apurar dados concretos quanto ao número de vítimas da gripe, correndo o risco de obter números dispares e de cair em generalizações ao incluir todos os casos de infecções respiratórias, como bronquites, broncopneumonias, pneumonias, gripes, influenza, tuberculose, etc. Sem dúvida que, neste caso, o número de óbitos por gripe pneumónica no CEP iria aumentar de forma exponencial, exagerando talvez a realidade.

O ideal seria efectuar um minucioso levantamento de todos os óbitos, respectivas causas e datas para tentar seleccionar apenas possíveis mortes por gripe e por infecções respiratórias entre Junho de 1918 e Abril de 1919. E, num segundo momento, se possível, cruzar estes dados com os livros de registo de entradas nos hospitais e ambulâncias em França para apurar os que faziam menção à epidemia de gripe. Sem dúvida que é um trabalho importante, contudo moroso, e que fica por efectuar.

No entanto, não devemos esquecer que, apesar do diminuto número de mortes no CEP, a gripe terá sido a segunda doença que mais mortes cau-

$\overline{27}$ Influenza and broncho-pneumonia, British only, PT AHM DIV 1-35-1412-01. 
sou entre os militares portugueses em França, não obstante as medidas de profilaxia excepcionais tomadas no seguimento do que era decretado internacionalmente. 


\section{Fontes}

A gripe - que se deve fazer para não a ter?, PT AHM DIV 1-35-1412-04.

ACVP, Ambleteuse Livro de Oficiais em tratamento.

ACVP, Ambleteuse Livro de Praças de pré em tratamento.

Académie nationale de médecine (1918). Rapport II - sur la prophylaxie de la grippe. Bulletin de l'Académie nationale de médecine, 3ème série, Tome LXXX, Masson, Paris, 317-327, disponível em https://gallica.bnf.fr/ark:/12148/bpt6k408741x/ (consultado em 21/09/2018).

Boletim individual de António Vieira Barradas, PT AHM DIV 1-35A-1-05-1422, disponível em https://arqhist . exercito.pt/details?id=123967 (consultado em 19/09/2018).

Boletim individual de José de Sousa Guimarães, PT AHM-DIV-1-35A-1-07-2151, disponível em https://arqhist. exercito.pt/details?id=127546 (consultado em 19/09/2018).

Carta de António Barradas a António de Azevedo, 01/04/1919, PT AHM DIV 1-35-1401-09.

Carta de António Barradas, 22/05/1919, PT AHM DIV 1-35-1412-01.

Carta de Luís Bettencourt para o Presidente da Sociedade Portuguesa da Cruz Vermelha em Lisboa, 31/10/1918, ACVP - Pasta $1^{\mathrm{a}}$ Guerra Mundial Ambleteuse, $2^{\mathrm{o}}$ volume.

Carta de Ricardo Jorge para António Barradas, 29/01/1919, PT AHM DIV1/35/1412/04.

Causas de morte no CEP, PT AHM DIV 1-35-1412-01.

Diário de campanha - Ambulância 4, PT AHM DIV 1-35-0370.

Hospital de Sangue n. ${ }^{\circ}$ Praças, 03/11/1918 a 28/01/1919, PT AHM DIV 1-35-1796.

Influenza and broncho-pneumonia, British only, PT AHM DIV 1-35-1412-01.

Instruções de Profilaxia Geral contra a Gripe ou Influenza Epidémica, Ordem do Quartel General da Base n. ${ }^{\circ} 301$ de 28/10/1918, ACVP - Pasta $1^{\text {a }}$ Guerra Mundial Ambleteuse, $2^{\text {o }}$ volume.

Instruções sobre hygiene e profilaxia anti-grippal pelo Comandante do Serviço de Saúde do CEP, 31/10/1918, PT AHM DIV 1-35-208-1.

Ordens de Serviço do Hospital de Base n. ${ }^{\circ}$ 1, PT AHM DIV 1-35-0674.

Procès-verbaux de la Commission de Vigilance Interalliée, PT AHM DIV 1-35-727-09.

Estatística Médica Hospital de Base n. ํ 1, PT AHM DIV 1-35-1401-03. 
Registo de entradas de praças Hospital de Sangue n.. 8, 29/04/1917 a 03/11/1918, PT AHM DIV 1-35-1797-02.

Relações de oficiais e praças hospitalizados no Hospital de Base $\mathrm{n}^{\mathrm{o}}$ 1, PT AHM DIV 1-350675-04.

\section{Bibliografia}

ABREU, Laurinda; SERRÃO, José Vicente (2018). Revisitar a pneumónica de 1918-1919: introdução. Ler História [Online], 73. DOI: 10.4000/lerhistoria.3944.

AFONSO, Aniceto; GOMES, Carlos de Matos (2013). Portugal e a Grande Guerra 19141918. Verso da História, Vila do Conde.

BARRADAS, António (1920). Service de santé portugais pendant la guerre. La Presse médicale, n. ${ }^{\circ}$ 4, Volume d'annexes, pp. 55-58. Disponível em http://www.biusante.par isdescartes.fr/histmed/medica/cote?100000x1920xannexes (consultado em $27 / 05 / 2015)$.

BERGEN, Leo van (2014). Military Medicine, in WINTER, Jay (ed.). The Cambridge History of the First World War, vol. III. Cambridge University Press, Cambridge, pp. 287309.

FRADA, João (2005). A gripe pneumónica em Portugal continental 1918: estudo socioeconómico e epidemiológico com particular análise do concelho de Leiria. Sete Caminhos, Lisboa.

GIRÃO, Paulo (2003). A pneumónica no Algarve (1918). Caleidoscópio, Casal de Cambra.

JORGE, Ricardo (1919a). A gripe. Portugal Médico, vol. V, n.ํ5, pp. 309-318.

JORGE, Ricardo (1919b). La Grippe. Rapport préliminaire présenté à la Commission Sanitaire des Pays Alliés, dans sa session de mars 1919. Imprimerie Nationale, Lisbonne.

KILLINGRAY, David (2009). A pandemia de gripe de 1918-1919: causas, evolução e consequências, in SOBRAL, José Manuel, et al. (org.). A pandemia esquecida: olhares comparados sobre a pneumónica, 1918-1919. ICS, Lisboa, pp. 41-61.

MARQUES, Isabel Pestana (2008). Das Trincheiras com Saudade, a Vida Quotidiana dos Militares Portugueses na Primeira Guerra Mundial. A Esfera dos Livros, Lisboa.

MARTINS, Álvaro (1936). As tropas do $1^{\circ}$ Grupo de Companhias de Saúde, em França, na Grande Guerra (1917-1919). Imprensa Beleza, Lisboa.

NUNES, Baltazar; SILVA, Susana; RODRIGUES, Ana; ROQUETTE, Rita; BATISTA, Inês; REBELO DE ANDRADE, Helena (2018). The 1918-1919 Influenza Pandemic in Portugal: A Regional Analysis of Death Impact. American Journal of Epidemiology, 187(12), pp. 2541-2549. Em DOI:10.1093/aje/kwy164

RASMUSSEN, Anne (2014). The Spanish flu, in WINTER, Jay (ed.). The Cambridge History of the First World War. Cambridge University Press, Cambridge, pp. 334-357. 
RASMUSSEN, Anne (2016). Documenter la santé en guerre : l'Internationale sanitaire interalliée, 1915-1919. Bulletin de l'Institut Pierre Renouvin, 2 , n 44, pp. 103-118. Disponível em https://www.cairn.info/revue-bulletin-de-l-institut-pierrereno uvin-2016-2-page-103.htm, (consultado em 21/09/2018).

SILVA, Helena da (2018). O Hospital da Cruz Vermelha Portuguesa na Flandres, in LOUSADA, Abílio Pires e ROCHA, Jorge Silva (coord.). Portugal na $1^{\underline{a}}$ Guerra Mundial. Uma História Militar Concisa. CPHM, Lisboa, pp. 495-517.

SILVA, Helena da; PEREIRA, Rui M.; BANDEIRA, Filomena (coord.) (2019). Centenário da Gripe Pneumónica. A pandemia em retrospectiva. Portugal 1918-1919. IGAS, Lisboa.

SOBRAL, José Manuel; LIMA, Maria Luísa; CASTRO, Paulo; SOUSA, Paulo Silveira e (org.) (2009a). A pandemia esquecida: olhares comparados sobre a pneumónica, 1918-1919. ICS, Lisboa.

SOBRAL, José Manuel; LIMA, Maria Luísa; SOUSA, Paulo Silveira e; CASTRO, Paula (2009b). Perante a Pneumônica: a epidemia e as respostas das autoridades de saúde pública e dos agentes políticos em Portugal (1918-1919). VARIA HISTORIA, vol. 25, n.o 42, pp. 377402.

SOBRAL, José Manuel; LIMA, Maria Luísa; SOUSA, Paulo Silveira e (2014). And to Make Things Worse, the Flu. The Spanish Influenza in a Revolutionary Portugal, in PORRASGALLO, María-Isabel and DAVIS, Ryan A. (ed.). The Spanish Influenza Pandemic of 1918-1919. Perspectives from the Iberian Peninsula and the Americas. University of Rochester Press, Rochester, pp. 75-92.

TELO, António José; SOUSA, Pedro Marquês de (2016). O CEP. Os Militares Sacrificados pela Má Política. Fronteira do Caos, Porto. 


\title{
OS ENTERROS TAMBÉM SE FAZEM À NOITE: A PNEUMÓNICA EM GUIMARÃES
}

\author{
Antero Ferreira ${ }^{1}$
}

Célia Oliveira ${ }^{2}$

1 Casa de Sarmento e CITCEM|FLUP - Grupo de Populações e Saúde, aferreira@csarmento.uminho.pt

2 Casa de Sarmento, coliveira@csarmento.uminho.pt 



\begin{abstract}
Resumo
A Gripe Espanhola de 1918 foi um episódio que ficou inscrito no nosso imaginário coletivo. Através da análise das entradas de doentes no Hospital da Santa Casa da Misericórdia de Guimarães, do registo de enterramentos no cemitério municipal e de relatos da imprensa da época, procuramos neste trabalho quantificar o impacto desta pandemia na cidade de Guimarães.
\end{abstract}

Palavras-chave: pneumónica, gripe, mortalidade, assistência.

\title{
1. INTRODUÇÃO
}

Apresentada como «A pandemia esquecida» (Sobral; Lima; Castro; e Sousa, 2009) ou o «último episódio de crise de mortalidade típica de sociedade de Antigo Regime demográfico» (Rodrigues, 2008: 465), a gripe espanhola foi um episódio que ficou inscrito no nosso imaginário coletivo. Quando se conversa sobre este tema, são inúmeros os que recordam relatos trágicos do impacto da epidemia nas suas famílias.

Para nós, que estudamos o fenómeno numa perspetiva demográfica, esta pandemia exerce uma particular atração pois, por um lado, pelo período e contexto em que surgiu, teve proporções só imagináveis nos tempos modernos, com intensos e rápidos contactos entre todos os continentes, mas, por outro lado, ocorreu num período em que a medicina não tinha ainda ferramentas adequadas para a combater. Cruzam-se nesta epidemia características de um novo mundo que se anuncia, com um mundo tradicional que progressivamente vai saindo de cena.

Motivou-nos também a leitura da imprensa da época. Os relatos da epidemia, entre o drama e a tragédia, a divulgação de informações com caráter 
científico, a tentativa de apresentar informações objetivas, traçam-nos uma perspetiva riquíssima da realidade social, proporcionando-nos informações sobre o quotidiano que farão corar de inveja os investigadores de épocas mais recuadas.

Motivou-nos ainda o estudo da doença, particularmente das causas de morte, num período em que os avanços da medicina moderna estão, progressivamente, a mudar o paradigma da mortalidade.

Finalmente, queríamos aproveitar esta oportunidade para quantificar e analisar o impacto desta pandemia em Guimarães.

\section{FONTES E METODOLOGIA}

O objetivo que traçamos conduziu-nos a procurar fontes que nos permitissem identificar as doenças de que padeciam os vimaranenses e o impacto que tinham na mortalidade. Pensamos, por essa razão, recorrer aos registos do principal hospital da cidade, o Hospital da Santa Casa da Misericórdia ${ }^{3}$. Para este trabalho, recolheram-se os dados relativos ao movimento hospitalar, designadamente as entradas, altas e óbitos, assim como o número de doentes existentes nas enfermarias. Estudaram-se, igualmente, os registos de internamentos do Hospital, respeitantes a doentes de ambos os sexos, onde constam, entre outras informações, a identificação dos mesmos (idade, estado civil, profissão, residência), a(s) doença(s) de que padeciam, o resultado do tratamento recebido e o respetivo período de internamento. Por forma a ter uma perceção do perfil e capacidade assistencial do Hospital, consultou-se também o seu inventário de bens móveis e utensílios.

No arquivo da Santa Casa da Misericórdia, consultou-se ainda a correspondência expedida e os livros de atas da Assembleia Geral e da Mesa por nos parecer fundamental conhecer as suas deliberações no sentido de assegurar o cumprimento da missão de benemerência da instituição.

No Arquivo Municipal Alfredo Pimenta, por outro lado, analisaram-se as atas da vereação da Câmara Municipal de Guimarães e a correspondência recebida e expedida, assim como o registo de enterramentos no Cemitério Municipal da Atouguia.

Finalmente, recorreu-se à imprensa local.

A informação recolhida foi organizada em duas bases de dados: uma para os doentes do Hospital e que conta com 7420 indivíduos; e a outra para os enterramentos no cemitério municipal e que incorpora 2625 registos. Os

3 Agradecemos à Santa Casa da Misericórdia a generosa amabilidade com que nos recebeu e facilitou a consulta do seu arquivo. 
diagnósticos foram sistematizados de acordo com a Classificação de Causas de Mortalidade (Mestre et al., 2003) e as ocupações profissionais organizadas com recurso à HISCO - Historical Internacional Standard Classification of Occupations (Leeuwen et al., 2002) e à SOCPO - Social Power Scheme (Putte \& Miles, 2005).

\section{O HOSPITAL DA SANTA CASA DA MISERICÓRDIA DE GUIMARÃES NO INÍCIO DO SÉCULO XX}

O padre António Caldas, nos seus apontamentos sobre Guimarães, publicados em 1881, menciona a existência de quatro hospitais na cidade: o hospital da Santa Casa da Misericórdia; o hospital de São Dâmaso; o hospital da Ordem Terceira de São Francisco; e o hospital da Ordem Terceira de São Domingos (1996: 387-394). Neste conjunto de casas de saúde, destaca o estabelecimento da Santa Casa da Misericórdia, devido à localização, dimensão e condições higiénicas do seu edifício, mas também à organização do serviço interno e qualidade dos cuidados prestados aos doentes. Por esta altura, o hospital da Santa Casa, que acolhia o maior número de enfermos, possui já «quatro magníficas enfermarias além de outras vastas dependências, tudo nas melhores condições de limpeza e asseio» (Caldas, 1996: 388).

Mas porque a Santa Casa da Misericórdia acalentava o desejo de «possuir um hospital que rivalizasse com os melhores do reino» (Caldas, 1996: 388 ), nunca deixou de investir em sucessivos melhoramentos, quer ao nível do edificado, quer ao nível da assistência médica e farmacêutica. Assim se explica a admiração e os elogios proferidos por D. Manuel II durante a visita ao hospital, em 1908, tendo mesmo comentado «[q]uem dera em Lisboa um hospital assim bem montado como este» (O Comércio de Guimarães, $\mathrm{n}^{\mathrm{o}}$ 2314). Um corpo clínico especializado e provedores interessados em garantir os melhores cuidados de saúde à população serão determinantes no desenvolvimento do hospital como um instrumento terapêutico.

O combate às várias doenças endémicas que, a partir de 1914, se conjugam com a guerra e a fome, vai originar uma maior preocupação com o funcionamento do hospital. Era cada vez mais importante reforçar a higiene hospitalar e, por isso, implementam-se horários de visita mais rigorosos ${ }^{4}$, assim como assegurar a correta organização interna dos espaços e respetivos serviços. Cada dependência é dotada de recheio próprio (leitos, mobiliário, têxteis, louças, faqueiro, vidros, etc.), supervisionado e inventariado pela

4 ASCMG, L. 540, fl. 143. 
diretora do hospital, e a sua atividade obedece ao regulamento geral da instituição ou, em casos especiais, a um regulamento específico ${ }^{5}$.

Com o desenvolvimento dos surtos epidémicos de 1918 e 1919, designadamente o tifo exantemático e, sobretudo, a gripe espanhola, aumenta a apreensão no hospital por não se acharem reunidas as condições para se proceder ao indispensável isolamento dos epidemiados. Em 1918, o hospital dispunha, efetivamente, de sete enfermarias gerais para o tratamento de crianças e adultos de ambos os sexos e ainda de quartos particulares. Estava também equipado com sala de operações, casa de banhos, banco, sala da aceitação, cozinha, despensa, rouparia e sala do engomado ${ }^{6}$. No entanto, não possuía os pavilhões de isolamento que o Conselho Médico, presidido pelo Dr. Joaquim José de Meira, solicitava há já algum tempo: «O isolamento das doenças contagiosas e infeciosas, que é um dos mais graves problemas a que é preciso atender-se num hospital, não pode razoavelmente efetuar-se sem que se lhe destinem instalações apropriadas» ${ }^{7}$.

À medida que se multiplicam os doentes com gripe que chegam ao hospital, maior é a pressão sobre o corpo clínico, composto por quatro médicos efetivos (2 cirurgiões) e dois substitutos, o encarregado da farmácia e o pessoal assistente ${ }^{8}$. Também os mesários da Santa Casa se apercebem que, perante a quebra geral de rendimentos, os subsídios do Estado e os recorrentes empréstimos ao capital da instituição não serão suficientes para cobrir as despesas crescentes com as hospitalizações, consultas, curativos e medicamentos, e evitar a rutura dos serviços hospitalares ${ }^{9}$. Torna-se, por isso, indispensável a reabertura do hospital privativo de Santa Luzia, a unidade de isolamento que a Administração do concelho instalara no edifício das Escolas Centrais e geria com recurso à caridade dos vimaranenses. Cumpre-se, assim, uma das disposições emitidas pela Direção Geral de Saúde, chefiada por Ricardo Jorge: «Para os casos graves, sobretudo quando peca o domicílio e faltam os recursos, está indicada a hospitalização que satisfaz à dupla indicação do tratamento e do isolamento. É a arma mais eficaz de que dispomos para a atenuação do flagelo. Onde haja hospital, é aproveitá-lo para os epidemiados; onde o não haja ou não chegue, institua-se onde possa ser, requisitando a autoridade administrativa o prédio apropriado nos termos legais, assim como camas e roupas. Obtenha-se das corporações locais a sua

\footnotetext{
ASCMG, L. 110, fl. 10v.

6 ASCMG, L. 110, fls. 10v-20.

7 ASCMG, L. I, fl. 57v.

8 ASCMG, L. 540, fls. $184 \mathrm{v}-186$.

9 ASCMG, L. 27, fls. 36v-37.
} 
cooperação pessoal e material; o subsídio restante será solicitado pelas vias competentes.» (Jorge, 1918: 154).

\subsection{Caracterização do público que frequenta o hospital}

Num artigo publicado em 1884, na Revista de Guimarães, o médico Joaquim José de Meira refere que das 378 pessoas que faleceram em Guimarães, no ano de 1883, havia 45 indivíduos que, embora tenham falecido no Hospital da Misericórdia, não residiam na cidade e que atraídos «[...] das aldêas e outros concelhos mais ou menos distantes pela fácil admissão e bom tratamento do hospital da Misericórdia, aqui vêm falecer, sem terem contrahido n'este meio a doença que lhes causou a morte.» (Meira, 1884: 134).

Em 1907, João de Meira, médico, filho do Joaquim José de Meira, apresenta a sua tese de licenciatura à Escola Médico-Cirúrgica do Porto, intitulada o Concelho de Guimarães. No capítulo Nosographia apresenta, com extraordinário rigor e detalhe, um conjunto de indicadores sobre o estado de saúde da população do concelho e cidade de Guimarães. Relativamente ao Hospital, verificamos que, em 1904, foram hospitalizados 2.588 doentes (1.258 do sexo masculino e 1.338 do sexo feminino), dos quais $30 \%$ eram da cidade, 63\% do concelho e 7\% de fora do concelho (Meira, 1907: 133). A análise da distribuição dos doentes por meses e idades permite verificar que são os adultos, entre os 16 e os 50 anos, os principais frequentadores do hospital. A percentagem de doentes com idade inferior a 10 anos é reduzidíssima, apesar de ser a idade que apresenta a mais elevada taxa de mortalidade (entre 1896 e 1905, João de Meira (1907: 130) calcula uma taxa de mortalidade, nas idades dos 0 aos 4 anos, de $223,2 \%$ para o sexo masculino e de $199,1 \%$ para o sexo feminino).

Calcula que, em 1904, faleceram no hospital 121 doentes, repartidos do seguinte modo: 47 da cidade de Guimarães, 69 do concelho e 5 de fora do concelho. Recorrendo aos dados do cemitério municipal, verifica que faleceram, no mesmo ano, 383 doentes em Guimarães (Meira, 1907: 147) ${ }^{10}$.

Analisa as doenças mais frequentes, interessando-nos para o objetivo deste trabalho, as notas que apresenta sobre a gripe: «é uma doença vulgar, mas felizmente quasi inofensiva. Em 1904, só no Hospital da Misercórdia, trataram-se de grippe 117 pessoas, sendo 76 do sexo masculino e 41 do feminino, sem um unico obito. E em toda a cidade, no mesmo período, faleceram d'ella 6 individuos. [Estes] [...] eram ou de uma idade ainda fragil por pouco

$\overline{10}$ A este número de óbitos retira 74 que não residem na cidade, calculando assim a mortalidade urbana em 309 óbitos. 
adiantada, ou já vacillante pelo peso do anos. Entre os 20 e os 50 ninguem morreu de grippe» (Meira, 1907: 137).

No levantamento de dados que efetuamos, entre os anos de 1914 e 1921, são muitas as semelhanças que encontramos com o quadro traçado por João de Meira, excetuando o número de doentes admitidos no hospital que, surpreendentemente, é significativamente inferior, com uma média de 1.766 doentes/ano (Tabela 1).

Tab. 1 - Hospital da Misericórdia. Movimento de doentes (1914-1921)

\begin{tabular}{rrrrrrr}
\hline Ano & \multicolumn{2}{c}{ Masculino } & \multicolumn{2}{c}{ Feminino } & \multicolumn{2}{c}{ Total } \\
\hline & Doentes & Óbitos & Doentes & Óbitos & Doentes & Óbitos \\
\hline 1914 & 764 & 45 & 1097 & 59 & 1861 & 104 \\
1915 & 850 & 65 & 1164 & 76 & 2014 & 141 \\
1916 & 816 & 58 & 1100 & 68 & 1916 & 126 \\
1917 & 890 & 89 & 1050 & 93 & 1940 & 182 \\
1918 & 986 & 105 & 1129 & 121 & 2115 & 226 \\
1919 & 1045 & 129 & 1188 & 122 & 2233 & 251 \\
1920 & 546 & 67 & 588 & 74 & 1134 & 141 \\
1921 & 437 & 46 & 480 & 59 & 917 & 105 \\
\hline
\end{tabular}

Fonte: Elaboração própria a partir dos registos de entradas e saídas de doentes.

Tal como Meira já tinha assinalado, mantém-se a tendência para uma maior procura do hospital pelo sexo feminino ${ }^{11}$. Também o número de óbitos se aproxima dos valores apresentados por Meira, com uma média de 159 óbitos/ano.

Analisando o movimento mensal entre 1914 e 1917, constatamos que é durante o verão que se verifica maior afluência ao hospital. O mês de dezembro, por sua vez, é o que regista menores entradas, facto também assinalado por Meira, quando referia que «Dezembro d'entre os mezes, se não o menos rico em doenças, o mais pobre em doentes hospitalizados. Em grande parte concorrem para este resultado as festas do Natal, que só passam fóra de casa aquelles que de todo em todo não podem regressar a ella nesses dias» (Meira, 1907: 132).

No que respeita ao perfil etário dos doentes entrados no Hospital da Misericórdia, verificamos que são muito reduzidas as admissões de crianças até aos cinco anos de idade, quase sempre internadas por companhia, junto

\footnotetext{
11 Apesar de variações pontuais, esta tendência estará provavelmente relacionada com a relação de masculinidade da população vimaranense que, em 1911, por exemplo, era de 87,6 homens para 100 mulheres.
} 
Fig. 1 - Entradas no Hospital (1917-1921)

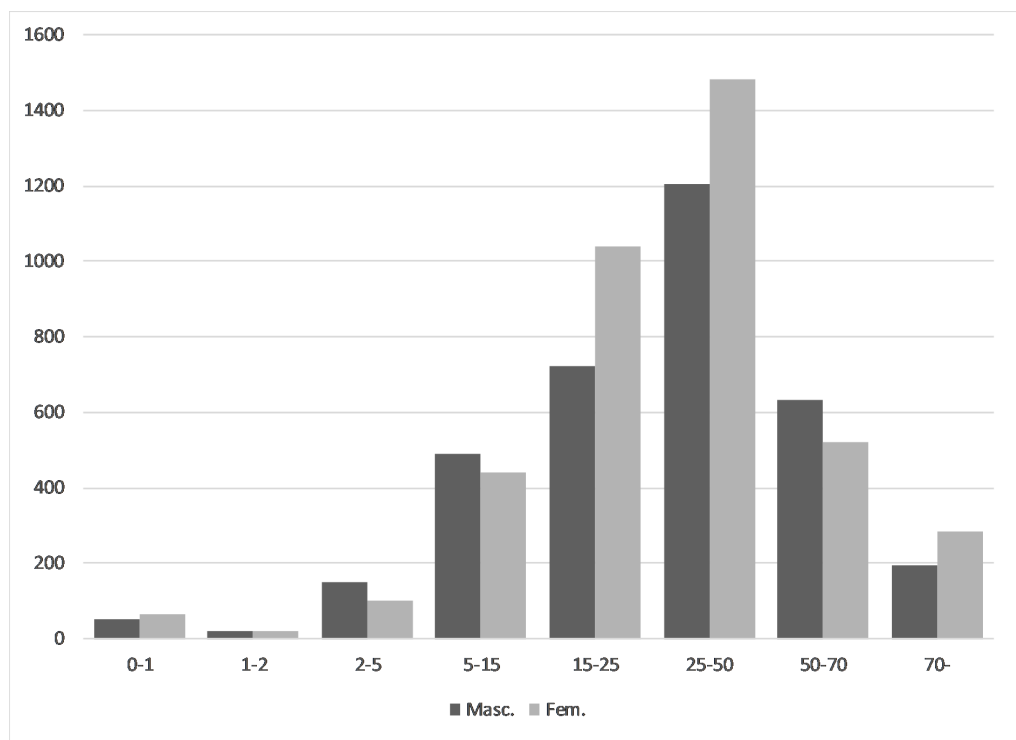

Fonte: Elaboração própria a partir dos registos de entradas e saídas de doentes.

com as suas mães que se encontravam doentes. A maior parte das admissões correspondia, claramente, aos adultos em idade laboral e aos idosos (Fig. 1).

Continuando a traçar o perfil dos pacientes que recorriam ao hospital, procuramos avaliar o seu o nível social através do único indicador que dispúnhamos: a sua ocupação profissional. Para ultrapassarmos o problema da enorme variabilidade de designações, procedemos à sua codificação de acordo com o sistema $\mathrm{HISCO}^{12}$, traduzindo posteriormente os resultados na escala social SOCPO (Social Power) ${ }^{13}$ (ver Quadro 2). Segundo os seus autores, esta classificação combina o poder económico - utilizando as dimensões da especialização, trabalho por conta própria e autoridade - e o poder cultural representado pela distinção entre trabalho manual e não manual, bem como pelos títulos sociais (pure status) ${ }^{14}$ (Putte; Miles, 2005: 75).

Desta classificação ficaram afastados 958 indivíduos cuja ocupação não tem correspondência na escala SOCPO, como é o caso das domésticas e dos indivíduos sem ocupação conhecida. Estes últimos, pela sua situação de fragilidade, poderão ser adicionados, sem dúvida, nos níveis sociais mais baixos

\footnotetext{
$\overline{12}$ HISCO (Leeuwen, Maas e Miles, 2002).

13 SOCPO (Putte; Miles, 2005).

14 Pure Status é um nível da classificação de STATUS associado ao sistema HISCO, correspondendo aos valores 51-Nobreza e 52-Títulos de prestígio.
} 
(cerca de 60\% têm mais de 50 anos). Já no caso das «domésticas», só estabelecendo uma relação com o nível social do marido poderíamos arriscar uma hipótese de classificação. Dos restantes 1016 indivíduos de que se desconhece a ocupação, $98 \%$ têm menos de 15 anos.

Tab. 2 - Nível social dos doentes entrados no Hospital da Misericórdia (1914-1921)

\begin{tabular}{lrr}
\hline Nível SOCPO (Social Power) & N & $\mathbf{\%}$ \\
\hline 5 - Elite & 29 & 0,39 \\
4.1 - Classe média & 281 & 3,79 \\
4.2 - Classe Média (agricultores) & 160 & 2,16 \\
3 - Trabalhadores especializados & 927 & 12,49 \\
2 - Trabalhadores semiespecializados & 588 & 7,92 \\
1 - Trabalhadores não especializados & 3461 & 46,64 \\
\hline Total & $\mathbf{5 4 4 6}$ & $\mathbf{7 3 , 4 0}$ \\
\hline & & \\
\hline Ocupação (S/ Classificação SOCPO) & $\mathbf{N}$ & $\mathbf{\%}$ \\
\hline Doméstica & 802 & 10,80 \\
Nenhuma (Sem ocupação) & 149 & 2,00 \\
Indeterminada & 7 & 0,09 \\
\hline Total & $\mathbf{9 5 8}$ & $\mathbf{1 2 , 9 1}$ \\
\hline & $\mathbf{1 0 1 6}$ & $\mathbf{1 3 , 6 9}$ \\
\hline S/ indicação de ocupação
\end{tabular}

Fonte: Elaboração própria a partir dos registos de entradas e saídas de doentes.

De qualquer modo, através da análise da Tabela 2 comprova-se que o hospital é frequentado principalmente pelas pessoas de menor estatuto social. Note-se que as três primeiras classes da SOCPO reunidas totalizam somente $6 \%$ dos doentes que recorreram ao hospital.

Finalmente, debruçamo-nos sobre a origem geográfica dos doentes, concluindo que predominam os doentes oriundos do concelho (97\%), dos quais cerca 30\% residem nos limites da cidade de Guimarães. Cruzando a origem dos doentes com o seu nível social (SOCPO), verificamos que para quase todos os níveis ( 1 a 4), a percentagem de doentes oriundos de fora do concelho varia entre os $15 \%$ e os $23 \%$, enquanto que para o nível 5 , contabilizamos $42 \%$ dos doentes exteriores ao concelho. 


\section{A GRIPE PNEUMÓNICA ATRAVÉS DOS REGISTOS HOS- PITALARES}

\subsection{O movimento de doentes}

Fig. 2 - Entradas de doentes no Hospital da Misericórdia (1914-1921)

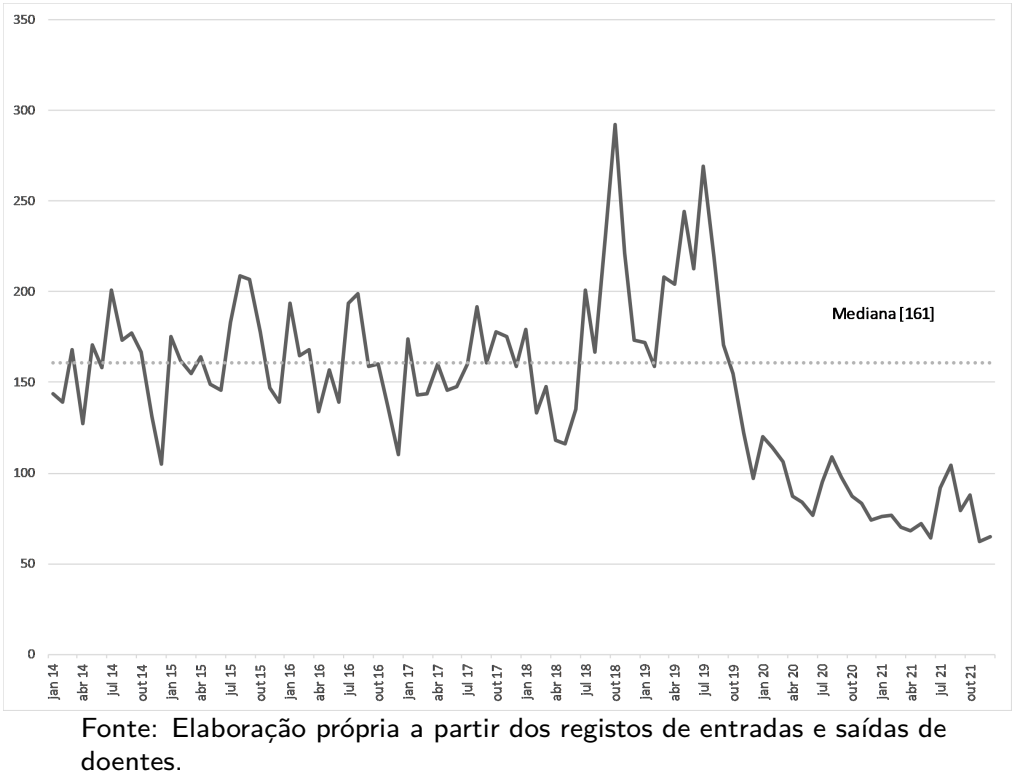

Analisando o ritmo mensal de entradas de doentes entre 1914 e 1921 (Figura 2), pudemos observar um período de relativa regularidade até meados do ano de 1918, a que corresponde uma média de 161 admissões por mês. A este período, sucedem-se dois picos de entradas de doentes, o primeiro mais curto e mais intenso, entre setembro e novembro de 1918, e o segundo, de menor intensidade, mas com maior duração, entre fevereiro e outubro de 1919 .

A partir de 1920, constata-se uma contínua descida das entradas no hospital. Este movimento não se relaciona com qualquer melhoria extraordinária da condição sanitária da população vimaranense, mas sim com uma decisão da Santa Casa da Misericórdia de Guimarães que, a braços com enormes dificuldades financeiras, resolveu, a 27 de Agosto de 1919, que por causa da carência absoluta de recursos «[...] se limitasse a 100 o número de doentes hospitalizados, [...] e depois, a 70 (20 de Fevereiro de 1920), embora 
podendo aceitar-se mais 5 em caso de gravidade [...] e abreviar o tempo de internamento» (Conceição, 2016: 87).

Aliás, já em setembro de 1918, em ofício do Provedor da Santa Casa enviado ao Governo, se referia que: «[...] em virtude da epidemia que grassa neste concelho, tendo-se dado caso no Hospital de tifo exantemático, de broncopneumonias e de febres infeciosas, do crescendo pavoroso dos preços dos géneros de consumo, de medicamentos e de tudo o mais que é indispensável para os serviços de assistência, solicita um subsídio de dez mil escudos para ajuda do custeio das despesas hospitalares e da farmácia, a fim de evitar a redução dos serviços de assistência, por falta de recursos. O que seria uma calamidade no tempo presente.» (Conceição, 2016: 86).

Procedeu-se, de seguida, à análise exaustiva das causas que conduziram ao internamento de cada um dos doentes, num total de 7.420, entre os anos de 1917 a 1920. Perante a enorme diversidade de diagnósticos e para efeito de sistematização, classificamos as diversas enfermidades de acordo com a proposta desenvolvida por Bernabéu Mestre (2003), baseada, por sua vez, nos estudos de McKeown. Os diferentes tipos de doenças foram organizados em três grandes grupos: doenças infeciosas, doenças não infeciosas e doenças mal definidas e, de seguida, desagregados em diferentes tipologias consoante o mecanismo de transmissão e os órgãos afetados.

O resultado da aplicação desta classificação à base de dados de entradas no Hospital da Misericórdia de Guimarães está expresso no gráfico seguinte, onde observamos que, apesar de algumas flutuações, existe uma relativa regularidade nos diferentes tipos de doenças até agosto de 1918. A partir do mês de setembro, se as entradas por doenças não infeciosas mantêm a mesma tendência, o mesmo não se pode dizer das doenças infeciosas, que têm uma subida abrupta em outubro, só recuperando os valores normais em dezembro, para subir novamente entre março e setembro de 1919, embora com valores significativamente inferiores. Os valores das doenças mal definidas são residuais, apresentando alguma subida entre setembro de 1918 e setembro de 1919, o que poderá estar relacionado com o movimento que acabamos de descrever para as doenças infeciosas (Figura 3). Fica assim claro que a oscilação que tínhamos detetado na entrada de doentes no hospital se deveu à erupção de fenómenos epidémicos.

Aumentando o nível de detalhe, poderemos apresentar as principais doenças infeciosas que afetaram a população vimaranense neste período. Nesta classificação, estas doenças estão subdivididas em função do seu mecanismo de transmissão, apresentando-se do seguinte modo: 1.1. Doenças infeciosas transmitidas por água e alimentos; 1.2. Doenças infeciosas transmitidas pelo 
Fig. 3 - Entradas no Hospital

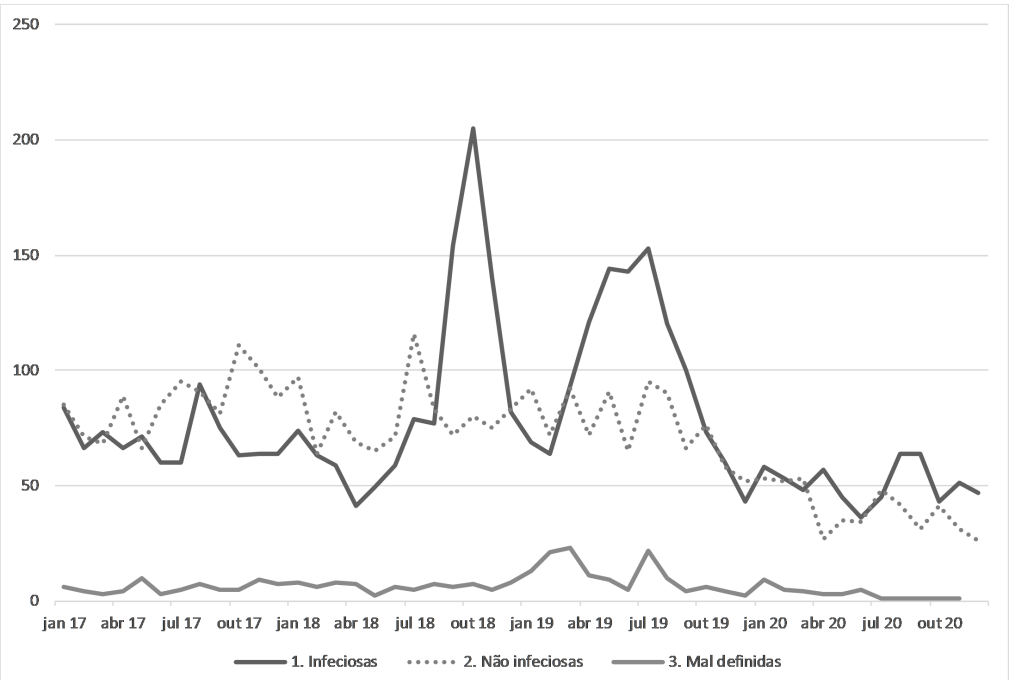

Fonte: Elaboração própria a partir dos registos de entradas e saídas de doentes.

ar; 1.3. Doenças infeciosas transmitidas por vetores; 1.4. Outras doenças infeciosas.

A gripe, a doença infeciosa que nos interessa para este trabalho, inserese no grupo «1.2. Transmitidas pelo Ar». Salientamos que os diagnósticos apresentados nas fontes não são sempre inequívocos na identificação da doença, surgindo diversos tipos de designação, como: gripe, broncopneumonia gripal, pneumonia gripal, gripe pneumónica, gripe toráxica, influenza, etc.

Por outro lado, como aliás refere João Frada (2005: 110), «[...] outras patologias consequentes ou concomitantes terão sido responsáveis, em especial, as provenientes das habituais alterações desencadeadas pelo vírus a nível das defesas e dos mecanismos orgânicos locais». O mesmo autor destaca ainda o aumento da taxa de mortalidade por doença desconhecida para o mesmo período, como consequência da desorganização provocada pela marcha da epidemia. Tendo em conta estas considerações, decidimos classificar como gripe todo e qualquer diagnóstico que referisse as expressões «gripe», «influenza» e «pneumónica», mesmo que se tratasse de um diagnóstico duplo, como por exemplo, «broncopneumonia e gripe».

No período que estudamos (1917-1920), manifesta-se uma enorme variedade de doenças infeciosas, ${ }^{15}$ mas só algumas apresentam valores que vale

$\overline{15}$ A lista completa das doenças encontradas pode ser consultada em apêndice. 
a pena destacar (ver Tabela 3). Trata-se da varíola, da gripe, das infeções intestinais e das infeções na pele, cuja evolução no período podemos observar na Figura 4.

Tab. 3 - Principais doenças infeciosas registadas nas entradas do Hospital da Misericórdia (1914-1921)

\begin{tabular}{lrrrr}
\hline & $\mathbf{1 9 1 7}$ & $\mathbf{1 9 1 8}$ & $\mathbf{1 9 1 9}$ & $\mathbf{1 9 2 0}$ \\
\hline Varíola & 1 & 2 & 307 & 5 \\
Gripe & 81 & 379 & 168 & 70 \\
Tuberculose & 150 & 125 & 116 & 81 \\
Infeções intestinais & 112 & 81 & 131 & 97 \\
Infeções na pele & 90 & 103 & 100 & 17 \\
\hline Soma & $\mathbf{4 3 4}$ & $\mathbf{6 9 0}$ & $\mathbf{8 2 2}$ & $\mathbf{2 7 0}$ \\
\hline Total (Infeciosas) & $\mathbf{8 4 0}$ & $\mathbf{1 0 8 2}$ & $\mathbf{1 1 8 3}$ & $\mathbf{6 1 1}$ \\
\hline
\end{tabular}

Fonte: Elaboração própria a partir dos registos de entradas e saídas de doentes.

Se a tuberculose, as infeções intestinais e infeções na pele mantêm níveis semelhantes ao longo do período em análise, a gripe, em 1918 e 1919, e a varíola, em 1919, assumiram valores extraordinários. Em 1918, no caso da gripe, tomando como base os valores de 1917 e 1920, o número de doentes teve um aumento superior a $470 \%$, concentrado em três meses (setembro, outubro e novembro). O ano de 1919, por sua vez, não tendo um pico tão extraordinário como o de 1918, concentra na gripe e na varíola 475 doentes, a que se soma um aumento significativo das infeções intestinais. O impacto destas doenças distribui-se por um período mais longo, de fevereiro a outubro de 1919, o que, somado ao drama de 1918, criou na comunidade um ambiente de alarme social, com grande eco na imprensa local.

\subsection{A Epidemia de Gripe de 1918}

As primeiras referências à epidemia da gripe na imprensa vimaranense datam de 29 de junho. Informava o periódico O Comércio de Guimarães ${ }^{16}$ que se encontravam em observação no Hospital da Misericórdia o Dr. Alberto Ribeiro de Faria, clínico das Taipas, a esposa e o filho. No dia 2 de julho, o mesmo jornal informa que «[...] continua melhorando, com o que muito folgamos, o snr. dr. Alberto Ribeiro de Faria, que tem estado, bem como um seu filhinho, no Hospital da Misericórdia, atacado de grippe infecciosa. A

$\overline{16}$ HSMS - O Comércio de Guimarães, n. o 3239, 29.06.1918, p. 2. 
Fig. 4 - Entradas no Hospital. Doenças infecciosas

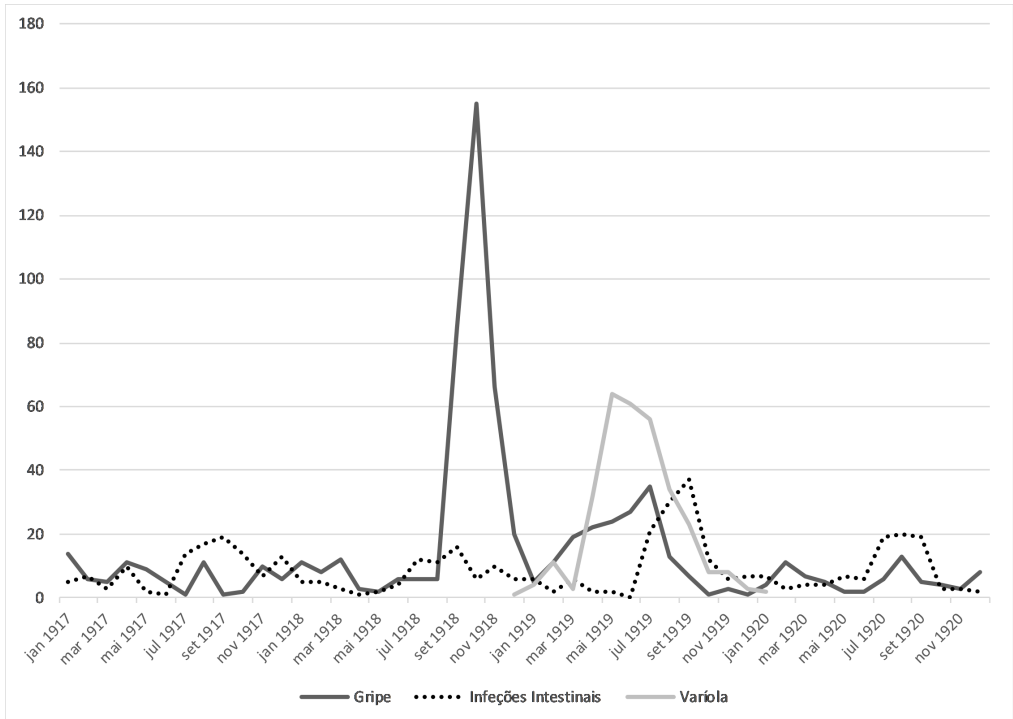

Fonte: Elaboração própria a partir dos registos de entradas e saídas de doentes.

propósito: dissemos em o ultimo número que igualmente se achava enferma a dedicada Esposa do distincto clínico, o que, felizmente, não é verdade» ${ }^{17}$. Consultada a base de dados de entradas de doentes, verificamos que o Dr. Alberto Ribeiro de Faria, com 42 anos, acompanhado do filho, João Alberto Ribeiro de Faria, com 6, tinha dado entrada no hospital no dia 25 de junho de 1918. Ao pai tinha sido diagnosticada gripe e febre paratifoide, ao filho, simplesmente, gripe. O filho teve alta, curado, em 11 de julho de 1918 e o pai, também curado, dez dias depois, em 21 de julho.

A 24 de setembro surge, pela primeira vez, uma referência inequívoca: $O$ Comércio de Guimarães ${ }^{18}$ informa-nos que se encontra gravemente enfermo com a gripe pneumónica o filho do negociante José Joaquim Vieira de Castro. Quatro dias depois, declara que «Grassa com grande intensidade uma doença a que chamam grippe bronco-pneumónica. [...] Essa terrível epidemia chegou também, já, até nós. Encontram-se muitas pessoas atacadas, e, em o Hospital da Santa Casa da Misericórdia, deram entrada alguns soldados d'infantaria 20. Há casas aonde se acham atacadas 8 pessoas, algumas das quais se

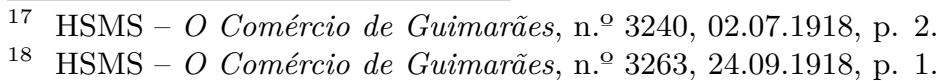


encontram em estado grave. Tem havido, já, alguns óbitos. Estamos pois a contas com os três peores flagellos: a peste, a fome, a guerra». ${ }^{19}$

Fig. 5 - Doentes internados com gripe no Hospital da Misericórdia

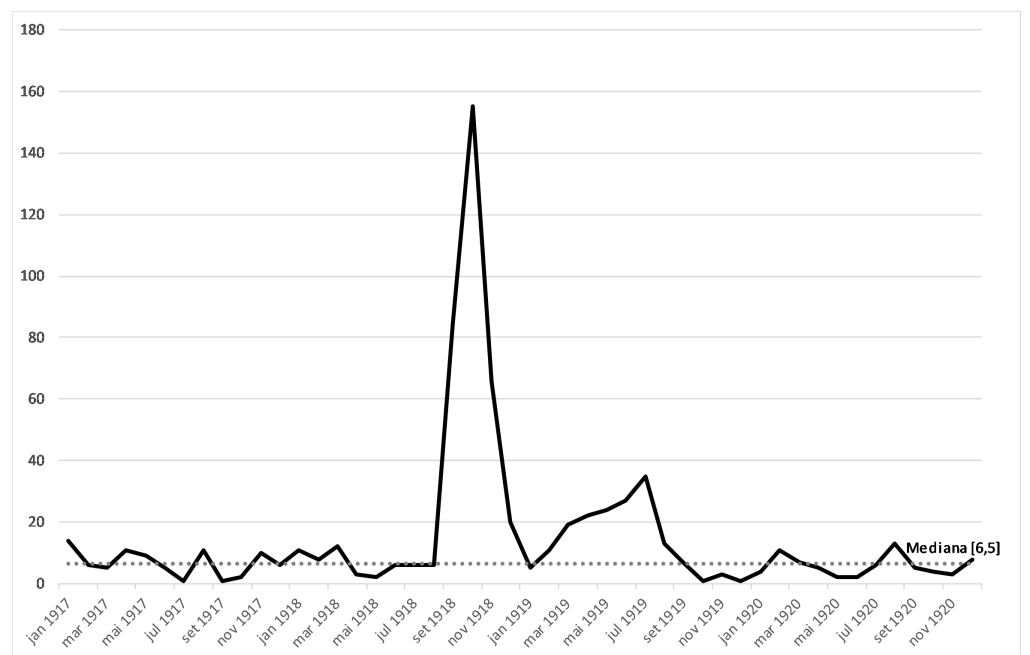

Fonte: Elaboração própria a partir dos registos de entradas e saídas de doentes.

Os registos de entradas do hospital permitem-nos acompanhar diariamente a evolução da epidemia, identificando a sua eclosão explosiva e posterior enfraquecimento (Figura 5). Sendo certo que o valor da mediana nos indica que, em metade do período analisado (janeiro de 1917 a dezembro de 1920), os valores de entradas no hospital não ultrapassam os 6,5 doentes/mês, analisando os dados com mais detalhe, verificamos que $90 \%$ da distribuição não ultrapassa o valor de 25 doentes/mês. Existem somente cinco meses atípicos (outliers), com valores extremos: no ano de 1918, setembro com 84 doentes, outubro com 155 e novembro com 66; em 1919, junho com 27 doentes e julho com 35 (Tabela 4).

Conseguimos, assim, traçar com facilidade a evolução da epidemia de gripe que, tendo início na segunda quinzena de setembro, atingiu o seu acme em outubro, mês em que entraram no Hospital da Misericórdia 155 doentes com diagnóstico de gripe. Só na última semana deste mês é que se começa a apreciar uma descida do número de doentes internados. A imprensa vimaranense ia dando conta desta evolução, apercebendo-se da diminuição da virulência da epidemia, que pareceu desaparecer durante o mês de dezembro. Em notícia de 26 de outubro, O Comércio de Guimarães informava que «Pa-

19 HSMS - O Comércio de Guimarães, n. ํ 3264, 28.09.1918, p. 2. 
Tab. 4 - Sobremorbilidade (meses com mais de 25 doentes)

\begin{tabular}{lrr}
\hline Período & Doentes & Sobremorbilidade (\%) \\
\hline set/18 & 84 & 236 \\
out/18 & 155 & 520 \\
nov/18 & 66 & 264 \\
jun/19 & 27 & 8 \\
jul/19 & 35 & 40 \\
\hline
\end{tabular}

Fonte: Elaboração própria a partir dos registos de entradas e saídas de doentes.

rece que tende a declinar um pouco a marcha da grippe pneumonica n'esta cidade e concelho. Há ainda diariamente bastantes casos e muita miséria, estando os hospitaes completamente cheios de doentes e convalescentes $[\ldots]{ }^{20}$. Mais tarde, em 1 de dezembro, o Gil Vicente adiantava que se encontrava «[...] quasi totalmente debellada a epidemia bronco pneumónica, que durante uma temporada dizimou milhares de vidas, levando o lucto e a miséria a muitos lares». ${ }^{21}$

Durante o ano de 1919, em Guimarães, houve ainda alguns casos de pneumónica, mas sem a virulência do episódio de 1918. O número médio de doentes internados por semana foi de quatro, tendo atingido o valor máximo de 12, na terceira semana de julho.

Chegados a este ponto, interrogamo-nos sobre a representatividade dos resultados que obtemos a partir das entradas no Hospital. Se, por um lado, através desta informação podemos acompanhar o movimento da epidemia, por outro lado, tememos não obter uma visão completa da dimensão da população afetada. De facto, como já referimos, nem todos os vimaranenses acorriam ao hospital quando se encontravam doentes.

Percorrendo as notícias dos jornais da época, apercebemo-nos que quando se identifica pelo nome um doente ou uma família, está-se a dar a conhecer à comunidade que alguns dos seus membros mais notáveis estão doentes ou faleceram. Cruzando estas informações nominativas com a base de dados dos doentes hospitalizados, verificamos que a maior parte nunca chegou a dar entrada no hospital.

Notemos, por exemplo, o caso da família de Alberto Ferreira Guimarães, guarda-livros, e de D. Maria da Conceição Miranda, professora. Alda de Barros, a filha mais velha do casal, com 20 anos, prestes a concluir o curso para o magistério primário, entrou no hospital a 24 de julho e faleceu no dia

20 HSMS - O Comércio de Guimarães, n. ㅇ 3272, 26.10.1918, p. 2.

21 HSMS - Gil Vicente, n. ${ }^{\circ}$ 7, 01.12.1918, p. 3. 
seguinte, vítima de um antraz maligno. Segundo a imprensa, teria contraído a doença quando beijou a irmã Dulce, de 12 anos, no leito de morte. A 13 de agosto é noticiado que tinha falecido, com apenas 15 anos, o empregado comercial Alberto Ferreira, irmão de Alda e Dulce. Em menos de um mês estes pais perderam três filhos. Não querendo especular sobre o diagnóstico ou causas da doença, interessa-nos apenas salientar que nesta sucessão de eventos dramáticos numa mesma família, apenas um doente, a Alda, recorreu aos serviços do hospital.

Numa outra perspetiva, os mesmos periódicos alertam-nos para o facto de que, por incapacidade ou por uma questão de mentalidade, há muitos indivíduos que não recorrem aos serviços do hospital. A 12 de outubro, $O$ Comércio de Guimarães informa-nos que «Na cidade, [...] há bastantes casos, mas parece que tendem a declinar, embora os óbitos tenham sido também numerosos. Nas freguezias ruraes, o mal tem alastrado immenso, havendo freguesias que quasi vêem desaparecer os homens e mulheres relativamente vigorosos e fortes. A todo o momento vemos atravessar a cidade carros de bois conduzindo doentes aos hospitaes, não fallando n'aquelles que se tratam em sua casa $\rangle^{22}$.

Para avaliarmos a representatividade da amostra recolhida no livro de registo de entradas do Hospital, decidimos analisar, para o mesmo período, os livros de registo de enterramentos do cemitério municipal. Verificamos que neste cemitério são sepultados indivíduos de todo o concelho, com maior representatividade das freguesias urbanas da cidade de Guimarães. De facto, enquanto que as freguesias da Oliveira, S. Paio e S. Sebastião não dispunham de outro cemitério, as famílias das restantes freguesias periféricas, Creixomil, Azurém, Urgezes ou Fermentões, poderiam optar por sepultar os seus mortos nos cemitérios paroquiais.

A Figura 6 dá-nos uma perspetiva da evolução dos enterramentos no cemitério municipal, sento evidente uma grande semelhança com as tendências que já tínhamos assinalado quando analisamos o movimento hospitalar. A representação da mediana das duas variáveis, ao indicar-nos que em metade do período analisado os valores não ultrapassam os 15 óbitos/mês no hospital e os 52 enterramentos/mês no cemitério, permite-nos visualizar o que representou a sobremortalidade nos meses de setembro a dezembro de 1918 . Na Tabela 5, calculando a diferença entre a mediana e o número de óbitos, medimos o impacto que esta epidemia teve na população vimaranense, particularmente no mês de outubro, em que se contabilizou, quer no hospital, quer no cemitério, um crescimento dos óbitos de cerca de $280 \%$.

$\overline{22}$ HSMS - O Comércio de Guimarães, n. o $3268,12.10 .1918$, p. 2. 
Fig. 6 - Movimento hospitalar vs enterramentos no cemitério

250

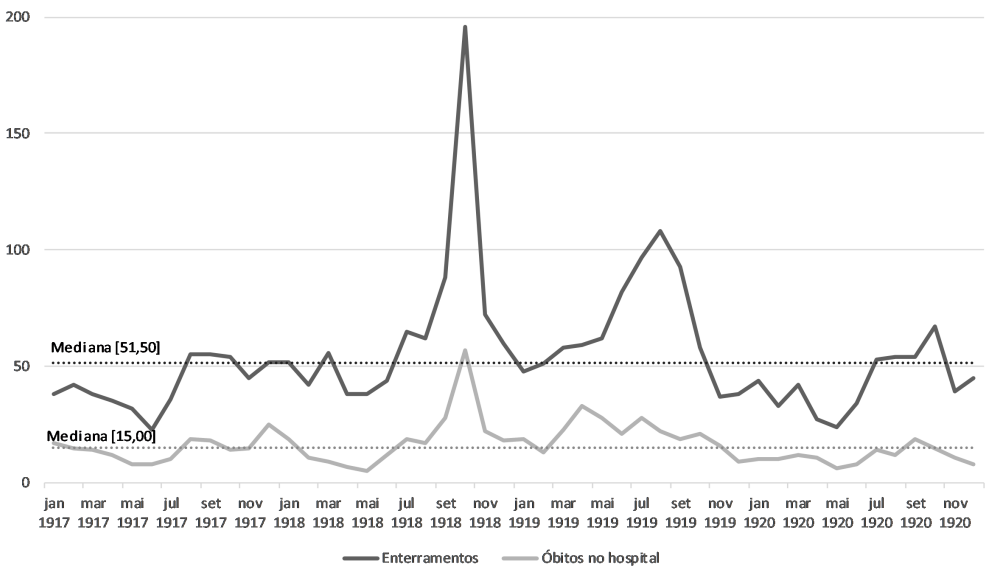

Fonte: Elaboração própria a partir dos registos de entradas e saídas de doentes.

Tab. 5 - Análise da sobremortalidade (setembro a dezembro de 1918)

\begin{tabular}{lrrrrrr}
\hline \multirow{2}{*}{ Mês } & \multicolumn{3}{c}{ Enterramentos no cemitério } & \multicolumn{2}{c}{ Óbitos no Hospital } \\
& $\mathrm{N}$ & Mediana & Sobremortalidade & $\mathrm{N}$ & Mediana & Sobremortalidade \\
Setembro & 88 & 51,60 & $70 \%$ & 28 & 15 & $87 \%$ \\
Outubro & 196 & 51,60 & $279 \%$ & 57 & 15 & $280 \%$ \\
Novembro & 72 & 51,60 & $39 \%$ & 22 & 15 & $47 \%$ \\
Dezembro & 60 & 51,60 & $16 \%$ & 18 & 15 & $20 \%$ \\
\hline
\end{tabular}

Fonte: Elaboração própria a partir dos registos de entradas e saídas de doentes.

Regressando à análise da Figura 6, existem ainda alguns aspetos que merecem uma análise mais detalhada. Em primeiro lugar, como interpretar a enorme diferença entre o número de enterramentos no cemitério e os óbitos registados no hospital? Poderá esta diferença estar relacionada com o movimento dos outros hospitais na cidade? Sabemos que existiam mais três hospitais em Guimarães, o Hospital de S. Francisco, o Hospital de S. Domingos e o Hospital Militar. Dos 2.625 enterramentos realizados entre 1917 e 1920, 30\% eram doentes do Hospital da Misericórdia, 3\% do Hospital de S. Domingos e $4 \%$ do Hospital de S. Francisco. A análise da média de idades dos doentes oriundos destes dois últimos hospitais ajuda-nos a traçar um quadro do seu público. Enquanto que a idade média dos doentes do Hospital da Misericórdia é de 40,7, a idade média dos doentes dos outros hospitais é de 64,4 e de 56,6, respetivamente. Estes valores parecem indicar que estes dois 
hospitais, de dimensão muito inferior ao da Misericórdia, teriam um público mais idoso, provavelmente os asilados lá residentes. Temos ainda notícia da existência de um Hospital Militar, mas não conseguimos encontrar informação sobre o número de doentes internados. De qualquer modo, sabemos que alguns militares foram acompanhados no Hospital da Misericórdia.

Com números ainda mais reduzidos, na ordem dos 2,5\%, temos ainda notícia de que, durante o ano de 1918, as Escolas Centrais da Rua de Santa Luzia foram convertidas em hospital provisório. Tinha como principal função, garantir o isolamento dos doentes atacados pelo tifo, tendo recebido por isso a designação de «Hospital dos Tifosos». A partir de setembro, começou a receber os doentes da pneumónica. Infelizmente, para a realização deste trabalho, não foi possível consultar os registos deste hospital, pelo que só indiretamente, através dos órgãos municipais, das atas da Santa Casa da Misericórdia de Guimarães e da imprensa pudemos ter uma pálida impressão da sua atividade.

De qualquer modo, tem especial significado o facto de que dos 2.625 indivíduos sepultados no cemitério, cerca de 50\% (1.330) não tinha qualquer indicação sobre o hospital ou o médico que os assistiu, o que muito provavelmente significa que faleceram sem acompanhamento médico.

Se analisarmos o perfil etário dos indivíduos sepultados, poderemos encontrar algumas pistas para o esclarecimento deste comportamento. Dos 1.330 indivíduos que terão falecido sem acompanhamento médico, 58\% (777) tinha menos de 5 anos, metade dos quais morreram durante o primeiro ano de vida. Concluímos, portanto, que são acima de tudo as crianças, principalmente no primeiro ano de vida, o grupo responsável pela diferença que encontramos entre o volume dos óbitos hospitalares e o dos enterramentos. Esta conclusão é reforçada se recordarmos que, ao analisar o público do hospital (ver Figura 1), já tínhamos evidenciado o reduzido número de doentes internados com menos de 5 anos de idade, e que, por outro lado, na sociedade portuguesa de inícios do século XX era ainda enorme o peso da mortalidade infantil ${ }^{23}$.

Chegados a este ponto, tendo determinado através do número de enterramentos o período e a dimensão da sobremortalidade provocada pela gripe, procuraremos agora analisar a evolução dos enterramentos por grupos de idades, tentando determinar o impacto da gripe.

«No início do século XX por cada 1.000 nascimentos morriam 134 crianças antes de completar um ano de idade. Este valor culmina entre 1917-1918, atingindo 164\%o» (Rodrigues, 2008: 426). 
Fig. 7 - Enterramentos no cemitério (grupos de idades)

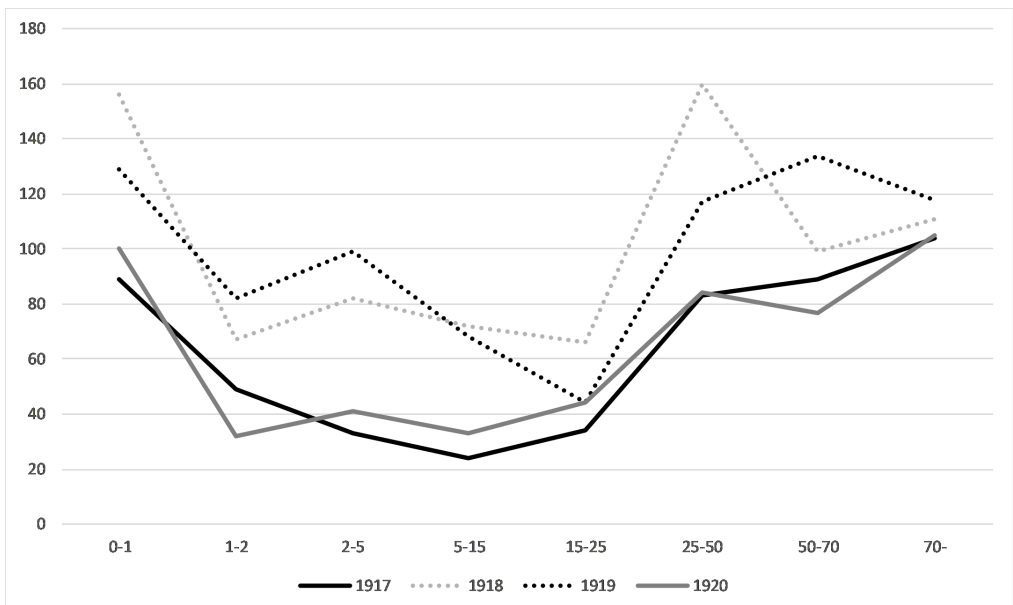

Fonte: Elaboração própria a partir dos registos de entradas e saídas de doentes.

Através da Figura 7, podemos verificar que no ano de 1918, comparativamente com 1917 ou 1920, houve um grande aumento do número de óbitos, que praticamente duplicou em todos os grupos de idades, com exceção dos adultos com mais de 50 anos, em que o aumento foi mais ligeiro.

O ano de 1919 foi também um ano penalizador para a população vimaranense, com valores superiores aos habituais em quase todas as idades, com particular incidência nos primeiros anos de vida.

\section{NOTAS FINAIS}

Em jeito de conclusão, assinalamos que a gripe espanhola terá atingido a cidade de Guimarães na segunda quinzena de setembro de 1918, provocando uma elevada sobremorbilidade que se revelou através do enorme aumento dos internamentos no Hospital da Santa Casa da Misericórdia, o principal hospital da cidade onde, até ao início de dezembro de 1918, foram internados 305 doentes com gripe, mais 290 do que o que seria espectável. A epidemia teve o seu acme em outubro, mês em que o número de doentes internados com gripe no hospital ultrapassou 23 vezes o que era habitual em anos anteriores. Este aumento do número de doentes teve reflexo no número de óbitos que, no mesmo período, considerando unicamente os enterramentos no cemitério da cidade de Guimarães, teve um aumento de $384 \%$. 


\section{Bibliografia}

BERNABEU-MESTRE, J.; FARIÑAS, D. R.; GIMENO, A. S.; GONZÁLEZ, E. R. (2003). El análisis histórico de la mortalidad por causas. Problemas y soluciones. Revista de Demografía Histórica, XXI (I), pp. 167-193.

CALDAS, A. J. F. (1996, [1881]). Guimarães. Apontamentos para a sua história. Câmara Municipal de Guimarães / Sociedade Martins Sarmento, Guimarães.

CONCEIÇÃO, F. (2016). A Santa Casa da Misericórdia de Guimarães: perspectiva histórica. Em 500 anos - Santa Casa da Misericórdia de Guimarães. Santa Casa da Misericórdia de Guimarães, Guimarães.

FRADA, J. (2005). A Gripe Pneumónica em Portugal Continental-1918. Estudo socioeconómico e epidemiológico. Setecaminhos, Lisboa.

JORGE, Ricardo (1918). Instruções da Direcção Geral de Saúde de 29 de Setembro de 1918 aprovadas por portaria da Secretaria do Trabalho, in Instituto de Higiene Dr. Ricardo Jorge (1936). Arquivos do Instituto Central de Higiene, vol. II - Secção de Higiene.

LEEUWEN, M. H. D.; MAAS, I. ; MILES, A. (2002). HISCO: Historical international standard classification of occupations. Leuven University Press, Leuven. Obtido de http: //library.wur.nl/WebQuery/clc/1656817

MEIRA, João de (1907). O concelho de Guimarães. Typographia a vapor da Empresa Guedes, Porto. Obtido de https://repositorio-aberto.up.pt/bitstream/10216/17406

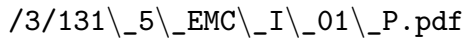

MEIRA, Joaquim de (1884). Higiene Local. Revista de Guimarães, 1 (3), pp. 130-135.

PUTTE, B. V. D.; MILES, A. (2005). A Social Classification Scheme for Historical Occupational Data. Historical Methods: A Journal of Quantitative and Interdisciplinary History, 38 (2), pp. 61-94. https://doi.org/10.3200/HMTS.38.2.61-94

RODRIGUES, Teresa (2008). História da população portuguesa. Das longas permanências à conquista da modernidade. CEPESE / Edições Afrontamento, Porto.

SOBRAL, J. M.; LIMA, M. L.; CASTRO, P.; SOUSA, P. S. (eds.) (2009). A Pandemia esquecida. Olhares comparados sobre a pneumónica (1918-1919). ICS, Lisboa.

\section{Fontes:}

\section{Arquivo da Santa Casa da Misericórdia de Guimarães [ASCMG]:}

Registo do Movimento Hospitalar. (1914 a 1918), cota: 1.2.4.19; (1918 a 1923), cota 1.2.4.20.

Registo de Entradas e Saídas de Doentes de «Medicina» no Hospital - Homens. (1916 a 1918), cota 1.1.3.3; (1918 a 1922), cota 1.1.3.2. 
Registo de Entradas e Saídas de Doentes de «Medicina» no Hospital - Mulheres. (1914 a 1917), cota 1.1.5.3; (1917 a 1919), cota 1.1.4.1; (1919 a 1924), cota 1.1.5.4.

Inventário do Hospital da Santa Casa da Misericórdia de Guimarães (1897 a 1929), Livro n.o 110, cota A-2-47.

Livro de Atas da Mesa. (1917-1920), n. ํ 27, cota A-1-24.

Livro de Atas da Assembleia Geral. (1889-1940), n. ${ }^{\circ}$ 1, cota 1.3.1.23.

Cópia do manuscrito da correspondência expedida. (1913-1918) Livro N. ํ 540, cota B-1-63.

\section{Arquivo Municipal Alfredo Pimenta[AMAP]:}

Livros de Enterramentos no Cemitério da Atouguia. (1916-1917), cota 10-9-14-15; (1917-1918), cota 10-9-14-14; (1918-1919), cota 10-9-14-13; (1919-1921), cota 10-9-14-8.

\section{Hemeroteca da Sociedade Martins Sarmento (HSMS):}

O Comércio de Guimarães (1918; 1919).

Gil Vicente (1918). 



\section{«A epidemia reinante». \\ A pneumónica no concelho de Lisboa, 1918}

Eunice Relvas ${ }^{1}$

Delminda Rijo ${ }^{2}$

1 GEO-CML e IHC-NOVA-FCSH, eunicerelvas@gmail.com

2 GEO-CML e CITCEM|FLUP, delminda.rijo@cm-lisboa.pt 



\begin{abstract}
Resumo
Este artigo tem por objetivo estudar a grande pandemia gripal de 1918 no conceIho de Lisboa. À omnipresença da fome e da guerra unia-se o pânico da peste e da morte, numa verdadeira sentença apocalíptica. Este trabalho analisa a génese, duração e efeitos da pneumónica na urbe. Examina as medidas profiláticas e as disposições do governo central e local perante esta doença, através da investigação nos registos oficiais (relatórios, assentamentos de óbitos, atas das sessões do município, etc.) e na imprensa da época. Nas páginas dos periódicos perpassa a presença da doença, confirmando o seu impacto avassalador, numa visão diferente e complementar do discurso público.

Este estudo traça o quadro funesto da pneumónica na capital da República Portuguesa. Uma gripe que, contra as conclusões e discursos da época, não atingiu equitativamente a população de Lisboa, mas penalizou e provocou maior mortandade (em termos absolutos) nas zonas ribeirinhas, a ocidente e oriente, em freguesias demograficamente representadas pela supremacia da pequena burguesia e do operariado - manifestação da existência de uma geografia social desta pandemia gripal.
\end{abstract}

Palavras-chave: pneumónica, gripe, Lisboa, mortalidade, poder local.

No outono de 1918, os lisboetas experienciaram uma verdadeira sentença apocalíptica, quando à fome e à guerra se associou o pânico da epidemia e da morte. A vivência na cidade modificou-se e as ruas ficaram desertas, apesar de os teatros, os animatógrafos e os recentes night-clubs continuarem abertos durante a pandemia ${ }^{3}$. As repercussões da pandemia agudizaramse quando, devido à doença entre os seus funcionários, a Companhia Carris reduziu e suprimiu carreiras de elétricos; a Companhia dos Telefones solicitou

\footnotetext{
3 Encontrámos uma notícia sobre o encerramento do teatro Ginásio, de 17 a 19 de outubro, por alguns artistas estarem epidemiados, tendo sido substituídos por outros atores. Ver A Capital, 20-10-1918, 2. Ao folhear a imprensa, no auge da pneumónica, observamos que alguns anúncios de teatros faziam questão de informar o público que as salas eram desinfetadas no final do espetáculo, decerto procurando transmitir segurança aos seus espetadores quanto à prevenção do contágio.
} 
aos seus subscritores que limitassem as chamadas telefónicas ao indispensável; alguns serviços de Repartições públicas decorreram com alguma lentidão; se encerraram estações de comboios e houve atrasos na distribuição postal e no serviço telegráfico ${ }^{4}$.

Contudo, a presença da doença no quotidiano dos lisboetas não constituía uma novidade. Existiam doenças endémicas como a tuberculose ${ }^{5}$, o tifo exantemático e a febre tifoide. Uma epidemia de varíola coexistiu e sobreviveu à gripe, originando uma campanha de vacinação antivariólica ${ }^{6}$. Apesar desta convivência frequente com gravíssimas moléstias, neste ano, a grande mortandade foi motivada pela pneumónica. Das três ondas da epidemia, registadas de meados de 1918 até inícios do ano seguinte, a mais mortífera foi a segunda, que cursou no último trimestre de 1918; será esta que analisaremos neste trabalho. A primeira vaga da pneumónica em Lisboa, benigna, aconteceu entre finais de maio e meados de junho. Uma notícia do seu reaparecimento surgiu no Diário de Notícias, informando os seus leitores que, cerca do dia 19 de setembro, ocorreram, num quartel da Guarnição Militar de Lisboa, os primeiros casos da doença, principiando em praças oriundos de Bragança e de outros locais do Norte ${ }^{7}$, confirmando que, no caso da capital, a movimentação de soldados esteve na sua génese.

Porém, à facilidade e à rápida propagação do contágio na urbe não são estranhos outros fatores diversos: a mobilidade dos seus habitantes, que regressavam das férias estivais; a vida da generalidade da população na fronteira da sobrevivência; a escassez de mantimentos para alimentar os convalescentes (leite, galinhas para fazer um caldo, ovos, etc.); as «bichas» junto aos estabelecimentos comerciais, ao frio e à chuva, para comprar as subsistências; a ausência de higiene pessoal e insalubridade das habitações e da própria cidade; a insipiência dos serviços de saúde e sanitários e, por último, a incapacidade da medicina para combater uma doença que confundia os clínicos.

\section{A SOBREMORTALIDADE NA CAPITAL}

Na nossa análise, à exceção de quando é indicado, a observação é indistinta por sexos e escalão etário, considerando-se os óbitos declarados por

4 Cf. Diário de Notícias, 16-10-1918, 2; Ibidem, 22-10-1918, 2; Ibid., 29-10-1918, 1.

5 Desde finais do século XIX que a mortalidade por tuberculose, nas classes pobres, era elevada na capital. Ver Ilustração Portugueza, 29-08-1910, 262-264.

6 Cf. Almeida, 2014: 698-701 e 704; A Capital, 19-01-1917, 1; Ibid., 10-12-1918, 1; Lisboa, 1920, 9 e 21.

7 Diário de Notícias, 29-09-1918, 1. 
gripe entre outubro e dezembro de 1918, excluindo os grupos de forasteiros e indivíduos de domicílio desconhecido (181 mortos). Metodologicamente, a distribuição da mortalidade, em articulação com a variação relativa à população dos censos de 1911 e 1920, foi compartimentada por freguesias, agrupadas nos quatro bairros administrativos da capital, conferindo assim maior clareza à leitura do impacto da epidemia.

A pandemia gripal de 1918 foi uma verdadeira hecatombe que, em Portugal, causou largas dezenas de milhares de mortos (Sobral, 2009). Na cidade de Lisboa, o total de óbitos atribuídos somente à gripe ascendeu aos 3.692, tendo penalizado mais o sexo masculino (1.913) do que o feminino (1.779). A segunda vaga epidémica foi a mais letal deixando, só no mês de outubro, um rasto de 2.486 mortes, acompanhando o diferencial por género referido. As primeiras hospitalizações da segunda vaga epidémica ocorreram a 24 de setembro e o foco inicial, segundo a notícia atrás referida, terá surgido no quartel de Infantaria do Corpo de Tropas da Guarnição, na Junqueira, inserido na área que viria a registar maior mortalidade, o $4 .^{\circ}$ bairro administrativo, daí alastrando por toda a cidade com extrema virulência. A 10 de novembro, sucedeu-se uma quebra expressiva até à sua extinção, declarada pelo diretor dos Hospitais Civis de Lisboa (HCL), a 11 de dezembro ${ }^{8}$.

No concelho de Lisboa, como no país, o indicador da mortalidade foi largamente influenciado pela ocorrência da gripe pneumónica. De facto, as taxas brutas de mortalidade para Portugal, no triénio de 1917 a 1919, expressam valores de 22,4\%o (1917), uma subida abrupta para os 41,32\%o (1918), seguindo-se um decréscimo acentuado para os $24,86 \%(1919)^{9}$. Os números específicos do distrito de Lisboa apresentam uma variação proporcional equivalente: $23,42 \%$ em 1917, 41,84\% em 1918 e 24,40\% em 1919 ${ }^{10}$. Não obstante o cenário, os dados veiculados pela comunicação social da época mantiveramse aquém das estimativas da mortalidade, apenas o vespertino A Capital se aproximou dos dados oficiais ao calcular, em fevereiro do ano seguinte, que «só em Lisboa andou por umas 4.000 vítimas» ${ }^{11}$.

Numa escala diferenciada, representada na Tabela 1, a observação dos dados isolados de óbitos declarados devido a gripe no concelho reproduz o mesmo movimento: em 1917, cerca de 1\% das causas de morte na cidade de Lisboa, ascendendo quase aos $22 \%$ em 1918 e decrescendo para os $4 \%$ em $1919^{12}$. Quando agregamos os números de mortes causadas por infeções

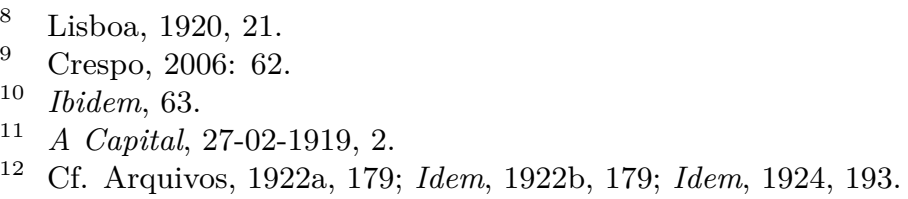


Tab. 1 - Total de óbitos no concelho de Lisboa (1917-1919), morte por Gripe e «Outras doenças do aparelho respiratório»

\begin{tabular}{lrrrrr}
\hline \multirow{2}{*}{ Anos } & Óbitos & \multicolumn{2}{c}{ Gripe $^{(\mathbf{a})}$} & \multicolumn{2}{c}{ Outras doenças } \\
& & Óbitos & $\%$ & Óbitos & $\%$ \\
\hline $\mathbf{1 9 1 7}$ & 11.528 & 120 & 1,04 & 3.178 & 27,56 \\
$\mathbf{1 9 1 8}$ & 17.071 & 3.692 & 21,62 & 4.508 & 26,40 \\
$\mathbf{1 9 1 9}$ & 12.197 & 509 & 4,16 & 3.497 & 28,60 \\
\hline
\end{tabular}

secundárias ou patologias preexistentes à infeção gripal, o número de óbitos mais que duplica, indo muito além dos dados oficiais. São, por isso, elucidativos os números evidenciados pela variável «outras doenças do aparelho respiratório», apesar da elevação mais discreta da mortalidade no grupo de doenças que convencionámos agrupar neste quadro específico (tuberculose dos pulmões, bronquite aguda, pneumonia e doenças ignoradas) e uma flutuação menos notória dada a tendência elevada transversal aos três anos. De facto, estas eram as doenças que, regularmente, mais vítimas causavam, sobretudo a tuberculose e a pneumonia, e que terão sido exacerbadas no quadro epidémico em estudo. A epidemia de 1918 provocou mortes que foram declaradas como óbitos causados por broncopneumonias, pneumonias, outras doenças do aparelho respiratório ou como «doenças ignoradas ou mal definidas», variáveis que subiram exponencialmente em todos os bairros da cidade.

Delimitando o evento para maior clareza e coadjuvando-o com a Figura 1, que representa os valores da mortalidade nos meses de outubro de 1918 e no homólogo de 1917, se colocarmos a ênfase, por exemplo, no $4 .^{\circ}$ bairro, o mais sacrificado pela epidemia, constatamos também a elevação transversal de todas as patologias representadas. Em 1917, a bronquite aguda vitimou 28 pessoas enquanto que a pneumonia vitimou 15 , disparando o número de vítimas, em 1918, para os 82 e os 53, respetivamente, quase quadruplicando no caso da pneumonia. Obtêm-se resultados análogos quando a observação contempla os meses que demarcaram a grande vaga do outono de 1918, com a subida brusca de todas as variáveis no mês de outubro, confirmando que estamos perante um ciclo de mortalidade extraordinária.

A colação dos números no plano territorial permite divisar que todos os bairros da cidade foram afetados, mas não de forma equitativa, sendo esta afirmação mais evidente com a observação por freguesias - teria a densidade demográfica pesado substancialmente na ocorrência da mortalidade ou outros fatores foram determinantes? 
Fig. 1 - Comparação do $\mathrm{n} .{ }^{\circ}$ de óbitos por causas selecionadas em outubro de 1917-outubro de 1918 / Bairros de Lisboa

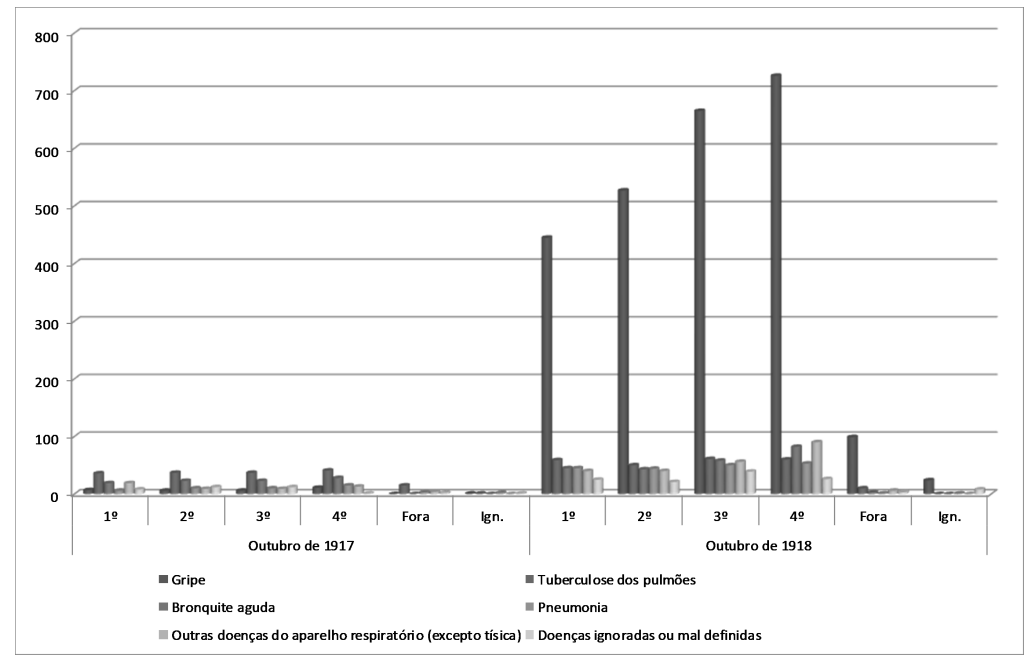

Fonte: Boletim Mensal de Estatística Demográfico-Sanitária da Cidade de Lisboa, 1917-1918.

A cintura industrial e a pobreza foram denominadores comuns, embora não exclusivos, na trajetória da pandemia. Sem dúvida que a alimentação deficiente (Frada, 1989), a debilidade orgânica também muito relacionada com as condições de higiene, quer individual quer coletiva, propiciaram maior suscetibilidade dos organismos ao contágio por contacto físico direto e por via aérea. Uma carta de Ricardo Jorge, comissário geral do governo no combate à pandemia, publicada no Diário de Notícias e reimpressa noutro jornal, falava da miséria de Lisboa e da sua relação com a pneumónica ${ }^{13}$. O mesmo declarou outro protagonista na luta contra a epidemia, Lobo Alves, diretor dos HCL, que escreveu: «Pelos meus próprios olhos eu tenho verificado que não poucos dos hospitalizados desde que a epidemia se declarou sofrem mais das dolorosas consequências da miséria que propriamente da doença dominante ${ }^{14}$. De facto, na análise da informação estatística da mortalidade avultam as freguesias com população mais carenciada, com piores condições de habitação e, embora não se esgotando nessa atividade laboral, com grande empregabilidade na indústria, como veremos de seguida.

Tomando como ponto de partida a Tabela 2 - que reproduz o impacto da epidemia por freguesias agrupadas nos quatro bairros administrativos e a

\footnotetext{
13 A Capital, 17-10-1918, 1.

14 Ibidem.
} 
variação relativa à população total das mesmas, segundo os censos de $1911 \mathrm{e}$ 1920 - verifica-se que o 1. bairro, o mais central e com população heterogénea, foi o menos atingido pela mortalidade da pandemia gripal. Destacam-se as freguesias mais orientais: Santa Engrácia, com mais habitantes, assinalou 176 mortos, o maior número de óbitos; sendo seguida pela freguesia limítrofe do Beato, com 138 óbitos, marcada por assinalável atividade fabril e presença do operariado; e os Olivais, um lugar com características rurais, no limite concelhio oriental da urbe, contabilizou 113 mortes. No 2. ${ }^{\circ}$ bairro, sobressaem as freguesias de S. Jorge de Arroios, Anjos e Pena, todas com algumas características sociais e habitacionais similares, como o predomínio de uma população de estratos sociais baixos e contextos habitacionais precários, em que se contabilizaram 174, 162 e 103 óbitos, respetivamente. Observamos um cenário menos óbvio no $3 .^{\circ}$ bairro, em que a freguesia com o número de óbitos mais elevado foi S. Sebastião da Pedreira, com 269 mortos, que se distinguia pela heterogeneidade económico-social, habitacional e arquitetónica, e onde se localizavam as Avenidas Novas com as suas residências de negociantes e capitalistas. Distanciando-se desta, a segunda freguesia mais penalizada foi a de Santos, com 127 óbitos, um espaço muito associado à atividade piscatória, fabril e à venda ambulante. O efeito da epidemia no 4. ${ }^{\circ}$ bairro, no extremo ocidental ribeirinho, representou $31 \%$ do total de óbitos do concelho, ditando a morte de 1.107 pessoas, surgindo no topo a freguesia de Santa Isabel, que em números absolutos assinalou 408 mortos, seguida de Alcântara, com 235, ambas com forte presença de população pequeno burguesa e operariado, e Belém, no limite ocidental do concelho, a mais penalizada em números relativos, representando os seus 220 óbitos mais de $1 \%$ da população da freguesia. 
Tab. 2 - Impacto da gripe pneumónica de 1918 (por freguesias) e variação relativa à população total (censos de 1911 e 1920)(a)

\begin{tabular}{|c|c|c|c|c|c|}
\hline \multirow[b]{2}{*}{ Freguesias } & \multirow{2}{*}{$\begin{array}{l}\text { Óbitos } \\
\text { Gripe } \\
(1918)\end{array}$} & \multirow{2}{*}{$\begin{array}{c}\text { População } \\
\text { Lisboa } \\
(1911)\end{array}$} & \multicolumn{3}{|c|}{ População } \\
\hline & & & $\%$ & $\begin{array}{c}\text { Lisboa } \\
(1920)\end{array}$ & $\%$ \\
\hline Santa Engrácia (Monte Pedral) & 176 & 23.542 & 0,75 & 28.036 & 0,63 \\
\hline Beato António & 138 & 17.198 & 0,80 & 14.739 & 0,94 \\
\hline Olivais & 113 & 9.590 & 1,18 & 13.202 & 0,86 \\
\hline Socorro & 64 & 9.630 & 0,66 & 9.308 & 0,69 \\
\hline S. Vicente (Escolas Gerais) & 47 & 8.581 & 0,55 & 9.384 & 0,50 \\
\hline Sé e S. João da Praça & 37 & 6.364 & 0,58 & 5.663 & 0,65 \\
\hline S. Tiago & 32 & 3.245 & 0,99 & 2.999 & 1,07 \\
\hline S. Cristóvão e S. Lourenço & 28 & 7.016 & 0,40 & 6.688 & 0,42 \\
\hline Santo Estevão & 24 & 5.971 & 0,40 & 5.695 & 0,42 \\
\hline S. Miguel & 24 & 3.690 & 0,65 & 3.826 & 0,63 \\
\hline Santa Cruz do Castelo & 19 & 2.569 & 0,74 & 2.699 & 0,70 \\
\hline Santo André & 17 & 4.115 & 0,41 & 4.746 & 0,36 \\
\hline Total 1. ${ }^{\circ}$ bairro administrativo & 719 & 129.571 & 0,55 & 138.758 & 0,52 \\
\hline S. Jorge de Arroios & 174 & 21.127 & 0,82 & 33.619 & 0,52 \\
\hline Anjos & 162 & 28.060 & 0,58 & 31.773 & 0,51 \\
\hline Pena & 103 & 12.482 & 0,83 & 13.674 & 0,75 \\
\hline Penha de França ${ }^{(c)}$ & 61 & 0 & 0,00 & 15.106 & 0,40 \\
\hline S. José & 58 & 10.351 & 0,56 & 10.878 & 0,53 \\
\hline Encarnação & 56 & 9.841 & 0,57 & 10.177 & 0,55 \\
\hline Sacramento & 33 & 5.019 & 0,66 & 4.549 & 0,73 \\
\hline Santa Justa (Restauradores) & 32 & 6.977 & 0,46 & 5.492 & 0,58 \\
\hline S. Nicolau & 27 & 4.106 & 0,66 & 3.019 & 0,89 \\
\hline Mártires & 16 & 2.679 & 0,60 & 2.496 & 0,64 \\
\hline Conceição & 9 & 2.816 & 0,32 & 1.860 & 0,48 \\
\hline S. Julião & 8 & 3.848 & 0,21 & 2.619 & 0,31 \\
\hline Madalena & 6 & 2.269 & 0,26 & 1.547 & 0,39 \\
\hline Total 2. ${ }^{\circ}$ bairro administrativo & 745 & 81.515 & 0,91 & 105.036 & 0,71 \\
\hline S. Sebastião da Pedreira & 269 & 23.182 & 1,16 & 46.194 & 0,58 \\
\hline Santos & 127 & 21.930 & 0,58 & 23.270 & 0,55 \\
\hline Santa Catarina & 85 & 12.791 & 0,66 & 13.916 & 0,61 \\
\hline Mercês & 79 & 12.735 & 0,62 & 12.633 & 0,63 \\
\hline Benfica & 74 & 5.694 & 1,30 & 8.132 & 0,91 \\
\hline Coração de Jesus (Camões) & 69 & 12.414 & 0,56 & 18.581 & 0,37 \\
\hline S. Paulo (Marquês de Pombal) & 46 & 7.782 & 0,59 & 6.877 & 0,67 \\
\hline Charneca & 43 & 1.266 & 3,40 & 1.487 & 2,89 \\
\hline Lumiar & 42 & 2.857 & 1,47 & 4.312 & 0,97 \\
\hline S. Mamede & 40 & 8.684 & 0,46 & 8.613 & 0,46 \\
\hline Carnide & 34 & 1.489 & 2,28 & 2.462 & 1,38 \\
\hline Campo Grande & 31 & 3.006 & 1,03 & 6.852 & 0,45 \\
\hline Ameixoeira & 1 & 531 & 0,19 & 455 & 0,22 \\
\hline Total 3. ${ }^{\circ}$ bairro administrativo & 940 & 114.361 & 0,82 & 153.784 & 0,61 \\
\hline Santa Isabel & 408 & 41.437 & 0,98 & 50.046 & 0,82 \\
\hline Alcântara & 235 & 26.404 & 0,89 & 30.841 & 0,76 \\
\hline Belém & 220 & 14.528 & 1,51 & 16.706 & 1,32 \\
\hline Ajuda & 153 & 14.119 & 1,08 & 20.117 & 0,76 \\
\hline Lapa & 91 & 13.334 & 0,68 & 14.236 & 0,64 \\
\hline Total $4 .^{\circ}$ bairro administrativo & 1.107 & 109.822 & 1,01 & 131.946 & 0,84 \\
\hline Total cidade de Lisboa & 3.511 & 435.269 & $\mathbf{0 , 8 1}$ & 529.524 & 0,66 \\
\hline
\end{tabular}

(a) Inclui os óbitos de forasteiros e de domicílio desconhecido.

Fonte: Estatísticas do Movimento Fisiológico da População de Portugal, 1917-1919. 
Numa análise atenta à relação entre o número de óbitos e a população das diferentes freguesias (censo de 1911), constata-se que as menos urbanizadas, com características rurais (excetuando S. Sebastião da Pedreira), foram as que registaram maior ascensão relativa de mortalidade, por ordem decrescente: Charneca $(3,40 \%)$, Carnide $(2,28 \%)$, Belém $(1,51 \%)$, Benfica $(1,30 \%)$, Lumiar (1,47\%), Olivais (1,18\%), Ajuda (1,08\%) e Campo Grande $(1,03 \%)$. Em comum, o facto de na época serem afastadas do centro da cidade, constituindo em alguns casos os limites concelhios, e, por isso, com maior dificuldade no acesso a cuidados médico-sanitários e aos hospitais. Esta circunstância vai ao encontro do que constatámos nos números da hospitalização - a acessibilidade viária e a proximidade territorial quase que organizaram o afluxo dos beneficiários da terapêutica hospitalar, com ingresso mais frequente dos moradores do $2 .^{\circ}$ bairro administrativo. Na verdade, esta dinâmica foi observada noutros contextos, como o estudado por Carlos Mourato Crespo nos concelhos de Loures, Mafra e Vila Franca de Xira, em que as assimetrias relacionadas com o isolamento das populações, as acessibilidades precárias e a insuficiência de médicos e de terapêuticas ditaram as taxas de mortalidade $^{15}$.

Desdizendo o relatório do diretor dos HCL, que concluiu que «a epidemia invadiu por igual toda a cidade, espalhando-se rapidamente e sem predilecção de zonas, pesando do mesmo modo em toda ela o número de mortos» ${ }^{16}$, observamos que, em números absolutos, à exceção da freguesia de S. Sebastião da Pedreira, o percurso mais letal da pandemia de 1918 revelou-se numa cintura transversal e circundante aos bairros centrais (Anexo Fig. 2), unindo as zonas industriais ribeirinhas, entre o ocidente e o oriente. Esta perpassou com maior severidade o território de freguesias onde predominavam o operariado e os estivadores do porto de Lisboa (ocupados na descarga do carvão e mercadorias), que eram, identicamente, áreas por excelência de venda ambulante, de pequeno comércio e com intensa circulação de pessoas e bens e, claro, onde a população carenciada, a insalubridade e as más condições habitacionais eram notas persistentes.

15 Crespo, 2006: 71.

16 Lisboa, 1920, 4. 


\section{O COMBATE OFICIAL À PANDEMIA PELO GOVERNO CEN- TRAL}

Ao nível governamental, logo nos primeiros dias, e de forma mais enérgica com o gradual agravamento da situação, sucederam-se as medidas oficiais: proibição da saída do país de medicamentos ${ }^{17}$; alargamento do horário das Repartições de Registo Civil ${ }^{18}$ e das farmácias ${ }^{19}$; requisição de automóveis militares e particulares para o serviço médico ${ }^{20}$; mobilização de clínicos militares e dos quintanistas de medicina ${ }^{21}$; encerramento dos estabelecimentos de educação ${ }^{22}$, etc. Na Secretaria de Estado das Finanças, foram abertos vários créditos extraordinários ${ }^{23}$, de 16 de setembro a 16 de novembro de 1918, para combater a pneumónica e outras epidemias, no valor total de 1.065.000\$00. Para além disso, uma das primeiras iniciativas de Sidónio Pais foi a criação, a 21 de outubro, de uma Comissão Central de Socorros às Vítimas da Epidemia ${ }^{24}$.

Além destas ações de âmbito nacional, no caso da cidade de Lisboa, destacamos outras medidas, como as relativas à assistência hospitalar. Neste tempo, estavam em funcionamento os hospitais civis de S. José, do Rego e de D. Estefânia, que tiveram de estabelecer enfermarias destinadas aos doentes da pneumónica. Além disso, o número elevado de doentes originou a abertura de três hospitais provisórios, exclusivos e de isolamento, para estes enfermos: o hospital de Arroios, que estava encerrado e reabriu de 4 de outubro a 15 de dezembro; o hospital das Trinas, no antigo convento, de 9 de outubro a 28 de novembro e enfermarias no Liceu Camões, de 11 de outubro a novembro. Para além destes, num hospital na rua da Junqueira, da Cruz Vermelha Portuguesa, foi instituída uma enfermaria com o mesmo fim ${ }^{25}$. Igualmente,

17 Decreto n. ${ }^{\circ} 4.871$, de 5 de outubro de 1918.

18 Portaria n. ${ }^{\circ}$ 1.566, de 23 de outubro de 1918, publicada no Diário do Governo, 217, 2510-1918. Revogada pela Portaria n. ${ }^{\mathrm{o}}$ 1595, de 16 de novembro de 1918. Ibidem, 250, 18-111918.

19 No dia 12 de outubro, Ricardo Jorge regulamentou o novo horário destes estabelecimentos. Todas as farmácias deveriam estar abertas das $8 \mathrm{~h}$ às $23 \mathrm{~h}$, suprimindo-se o descanso dominical; e as de serviço noturno estariam abertas até à 1 hora. Ver Diário de Notícias, $12-$ $10-1918,1$.

20 Circular da Direção Geral de Saúde, assinada por Ricardo Jorge. ANTT-ADL, 18361990, doc. avulso.

21 Cf. Diário de Notícias, 04-10-1918, 1; Ibid., 26-10-1918, 1.

22 Ibidem, 03-10-1918, 1.

23 Cf. Portugal, 1953, 186 e segs.

24 A Capital, 21-10-1918, 2.

25 Diário de Notícias, 02-10-1918, 2; Ibidem, 03-10-1918, 1; Ibid., 11-10-1918, 1; Lisboa, 1920,15 e 47. 
os hospitais militares da Estrela e de Campolide, mais o hospital da Marinha tiveram enfermarias de epidemiados.

Ainda durante o mês de outubro, a mortalidade excecional, indiferenciada por causa de morte, somou 4.682 óbitos (2.376 Homens/2.306 Mulheres), incluindo os forasteiros e pessoas com domicílio incerto. Apenas 27,8\% (1.302) faleceram em hospitais e outras instituições (816 H/486 M), ocorrendo a maioria dos óbitos em casa (3.380). Se outros elementos não existissem, a sistematização dos números da hospitalização, na segunda vaga epidémica, é indicadora da conturbação vivenciada e que temos vindo a relatar. O dia 17 de outubro registou o maior número de internados, 3.804 de ambos os $\operatorname{sexos}^{26}$. Em todo o período da pandemia assistiram-se 4.817 doentes nos HCL, 600 vindos de fora da cidade $(12,5 \%)$, com uma taxa de alta hospitalar de $72,3 \%$ (3.484) e uma taxa de mortalidade de doentes internados de $27,7 \%$ $(1.333 \text { óbitos })^{27}$.

No entanto, dos 3.484 internados com alta hospitalar há um ligeiro predomínio dos residentes no $2 .^{\circ}$ bairro administrativo. Embora fosse o de menor densidade populacional, a proximidade e acesso às unidades hospitalares (S. José, Rego, D. Estefânia e, também, ao Liceu Camões) explicarão esse volume, uma vez que também foi o bairro com o número ligeiramente mais elevado de óbitos em internamento hospitalar, 309 de um total de 1.333 (754 H/579 M). Quanto ao estado civil dos falecidos nestas unidades, predominam os solteiros (870), com clara superioridade do sexo masculino (509 H/361 M), seguidos dos casados (324), também maioritariamente homens (185 H/139 $\mathrm{M})$, e menor impacto nos viúvos (70), imperando neste caso o género feminino $(21 \mathrm{H} / 49 \mathrm{M})^{28}$.

O pico epidémico com mortalidade mais elevada ocorreu no dia 21, com 142 óbitos por gripe, número que, quando somado às mortes causadas em consequência da infeção primária ou agravamento das patologias preexistentes já referidas (tuberculose pulmonar, bronquite aguda, pneumonia, outras doenças do aparelho respiratório e doenças ignoradas ou mal definidas), ascendeu aos 176 mortos $^{29}$. A dura realidade destes números traduziu-se no dia mais trágico em Lisboa, em que o total de mortos foi de 236 indivíduos, dos quais 122 homens, tendo a maioria falecido em casa (177). Só nesse dia, e apenas no cemitério do Alto de S. João, foram enterrados 156 cadáveres $^{30}$. Ironicamente, a edição do Diário de Notícias publicava uma nota oficiosa,

\footnotetext{
26 ANTT-HSJ, 1913-1927.

27 Lisboa, 1920, 4.

28 ANTT-HSJ, 1918.

29 Higiene, 1919, 10-11.

30 Lisboa, 1918a, 181-186.
} 
segundo a qual «As entradas nos hospitais baixaram em toda esta semana relativamente à semana anterior: tem quebrado o ímpeto epidémico» ${ }^{31}$.

A conjuntura caótica foi exacerbada com a questão do enterramento dos mortos. A aglomeração de cadáveres em estado de decomposição na morgue dos hospitais tinha ocasionado, a 15 de outubro, a ordem de serviço n. ${ }^{\circ} 390$ do diretor geral dos HCL, que determinava que não haveria condescendências para as famílias que não levantassem os seus mortos em 24 horas, ordenando que se envie «no dia imediato os cadáveres para o cemitério no carro mortuário dos hospitais, com destino a serem enterrados na vala comum» ${ }^{32}$. A urgência no enterramento, já sem o decoro do vestuário, apenas embrulhados em serapilheiras, impôs o recurso da vala comum, que foi o destino de 627 falecidos em unidades hospitalares, na maioria homens $(348)^{33}$.

\section{A INTERVENÇÃO DO MUNICÍPIO DE LISBOA}

A Câmara Municipal de Lisboa empreendeu diversas medidas profiláticas, sanitárias e de apoio aos mais pobres. O Serviço de Limpeza e Regas efetuou lavagens diárias das ruas e desinfeções ${ }^{34}$ repetidas nos bairros populosos e, sobretudo, nos mais insalubres da cidade, desde 4 de outubro. Como alguns funcionários deste serviço municipal foram atingidos pela pneumónica, a partir do dia 24, os trabalhadores que se mantiveram ao serviço passaram a trabalhar mais 4 horas por dia ${ }^{35}$. Apesar destas medidas, na imprensa, a censura ao Município foi recorrente e abundante, criticando-se a ausência de ações de profilaxia e desinfeção durante a pandemia.

Para prevenir o contágio, a edilidade, entre outras ações, proibiu os mercados provisórios que funcionavam ao ar livre ${ }^{36}$ e oficiou à Carris para aparafusar as janelas dos carros elétricos e abrir os ventiladores superiores ${ }^{37}$; imple-

\footnotetext{
31 Diário de Notícias, 21-10-1918, 1.

32 Lisboa, 1920, 14. Muitas pessoas não conseguiam enterrar os seus familiares por falta do bilhete de óbito das conservatórias e, igualmente, de esquifes e de carretas.

33 Ibidem, 17.

34 Se bem que a imprensa denunciasse que eram pouco eficazes, porque após a colocação, à tarde, de cloreto nas valetas da cidade, de noite os varredores tiravam-no, juntando-o ao lixo. Ver, por exemplo, o Diário de Notícias, 22-10-1918, 1.

35 Lisboa, 1940, 719.

36 Ibidem, 694.

37 A 14 de outubro o executivo camarário enviou um ofício à Carris para que esta norma vigorasse desde o dia seguinte até 15 de abril de 1919. Até esta data, o encerramento das janelas era efetuado de 1 de novembro a 1 de março. Ver Ibid., 695; Lisboa, 1922, 175. Em 7 de novembro o município estendeu as medidas aplicadas aos elevadores da cidade. Lisboa, 1940, 750-751.
} 
mentou medidas de solidariedade, como por exemplo, a doação de $1.000 \$ 00$ ao diretor dos HCL, para assistência aos convalescentes com alta hospitalar ${ }^{38}$; determinou que, desde 6 de outubro, dois «coupés» dos bombeiros municipais conduzissem para os hospitais os epidemiados de Campolide, Terramotos e Beato (zonas insalubres e pobres da capital) ${ }^{39}$; e, por fim, atribuiu abonos aos empregados que tivessem estado enfermos devido à pneumónica ${ }^{40}$.

A sua obra mais apreciável foi, sem sombra de dúvida, a respeitante aos sepultamentos. O cemitério do Alto de São João, era o mais extenso e que servia a maior área da cidade $^{41}$. De acordo com a imprensa, no dia 20 de outubro, até às 18 horas, foram lá sepultados 131 cadáveres, ficando um em depósito, trabalho que deixou os mais de 14 coveiros extenuados e alguns doentes ${ }^{42}$. Antes de 11 do referido mês, a municipalidade tinha aprovado o prolongamento dos enterramentos até às 18 horas e, ao contrário do sucedido em outros municípios nacionais, não houve enterramentos noturnos ${ }^{43}$. A situação nos cemitérios da capital ficou normalizada a 24 de outubro. A existência de cadáveres insepultos, nos cemitérios ou casas de particulares, foi atribuída pelo município e pelos jornais ao facto das conservatórias não facultarem os bilhetes de enterramento ${ }^{44}$.

A Câmara Municipal combateu a falta de terrenos para sepulturas com a realização das inumações em terrenos anexos aos cemitérios, ordenando o sepultamento de mortos em cemitérios que não eram os regulamentados para a sua área de residência e a tomada de decisões urgentes, como a aquisição de terrenos em Chelas e no Alto do Pina ou a abertura, no cemitério dos Prazeres, de uma vala comum destinada a receber os cadáveres dos falecidos

\footnotetext{
38 Ibidem, 713.

39 Diário de Notícias, 07-10-1918, 1.

40 Aprovado em sessão de Câmara de 3 de abril de 1919. Lisboa, 1922, 171.

41 Fora aprovado em agosto de 1918 o Regulamento dos cemitérios municipais de Lisboa, que convencionava para o grande cemitério oriental do Alto de São João os falecidos nos 1. $\stackrel{\mathrm{o}}{ }, 2 .^{\mathrm{o}}$ e $3 .^{\circ}$ bairros de Lisboa; o cemitério dos Olivais para o $1 .^{\circ}$ e o $2 .^{\circ}$ bairros; os cemitérios de Benfica e Lumiar para o $3 .^{\circ}$ bairro e o $4 .^{\circ}$ era servido pelos cemitérios dos Prazeres e da Ajuda. Ver Lisboa, 1918b.

42 Diário de Notícias, 21-10-1918, 1.

43 No dia 21 de outubro um vereador lisbonense apresentou uma proposta nesse sentido que foi chumbada pelos seus colegas edis. Lisboa, 1940, 714 .

44 Cf. Diário de Notícias, 11-10-1918, 1; Lisboa, 1940, 718 e 714; Diário de Notícias, 21-10-1918, 1. Desde o dia 8 de outubro que os pedidos de milhares de impressos (mais de 2.700) para admissão de doentes nos hospitais e certidões de óbito chegavam em catadupa ao Governo Civil de Lisboa. Eram solicitados pelas administrações dos bairros da capital, conservatórias do registo civil e até por esquadras da Polícia Cívica, destinados aos subdelegados de saúde para formalização do processo burocrático do internamento ou do óbito. Vejase ANTT-ADL, 1836-1990, doc. avulsos.
} 
no Hospital das Trinas, atendendo ao pedido do diretor dos $\mathrm{HCL}^{45}$. A 28 de outubro, uma nota oficiosa informava que na capital tinham diminuído as entradas hospitalares e os enterramentos nos cemitérios ${ }^{46}$ e, no dia seguinte, outra nota fazia o seguinte balanço: "As entradas dos epidemiados nos hospitais que no dia 16 do corrente atingiram o máximo de 233 , vieram descendo progressivamente, sendo nos dois ultimos dias em número de 87 e 85 . O total diário dos enterramentos teve como maximo 259 , decaindo depois» ${ }^{47}$. A mesma nota recomendava, ainda, a celeridade nos funerais por forma a evitar a retenção domiciliária dos cadáveres.

O dia 21 de outubro foi decisivo na intervenção da administração da cidade face à letalidade do flagelo epidémico sobre as populações mais carenciadas. Nessa data, a municipalidade patenteou a sua solidariedade para com os paupérrimos através da aprovação do fabrico de caixões nas oficinas do Município. Estes eram fornecidos pelo preço do custo aos sujeitos que exibissem um atestado de pobreza, medida que combatia a falta e a inflação de féretros (no dia 24 seria sancionada a sua gratuitidade para os indigentes $)^{48}$. Não esqueçamos que a gravidade da situação originou a ordem do diretor dos HCL para sepultamento na vala comum dos mortos para os quais os familiares não providenciassem o funeral 24 horas após o óbito, que já referimos anteriormente.

Concluindo, uma avaliação genérica da atuação municipal lisbonense revela uma preocupação com a epidemia e uma gestão imediata das dificuldades ao nível sanitário, se bem que insuficiente e, muitas vezes, em resposta a críticas da imprensa. Porém, não nos esqueçamos que, apesar de ser a edilidade da capital da República, terá enfrentado as dificuldades comuns a outros municípios nacionais ${ }^{49}$ - insalubridade das habitações, falta de higiene pessoal e familiar, o hábito dos seus habitantes deitarem lixo nas vias públicas e a falta de recursos humanos e financeiros.

Ainda a nível local, fica por apresentar o importante papel desempenhado pela sociedade civil lisbonense, por exemplo, através de doações monetárias e da assistência aos epidemiados, e por outras instituições, como a Cruz Vermelha, os escoteiros e as associações mutualistas. Fundamental foi também o empenho da Igreja, que olhou para a doença como um castigo divino, mas combateu-a de diversas formas: com ações religiosas para acabar

\footnotetext{
$\overline{45}$ Cf. Lisboa, 1920, 19; Idem, 1940, 714, 787, 794 e 714-715.

46 Diário de Notícias, 28-10-1918, 1.

47 Ibid., 29-10-1918, 1.

48 Lisboa, 1940, 713-714 e 718.

49 A atuação dos municípios algarvios, por exemplo, conheceu dificuldades similares. Cf. Girão, 2009: 120-121.
} 
com a pandemia (procissões, missas, expiação, penitências), com a divulgação de medidas profiláticas na missa e, por último, através da atividade desenvolvida pela Associação das Senhoras de Caridade.

\section{CONCLUSÃO}

Traçámos o quadro trágico da pneumónica na capital. Todos os esforços experimentados pelos poderes oficiais e iniciativas da sociedade civil revelaram-se infrutíferos para debelar a epidemia. A pobreza, a desnutrição e as débeis condições higiénico-sanitárias existentes em Lisboa favoreceram a propagação desta enfermidade. A escassez de recursos humanos, financeiros e materiais influenciou a aplicação de medidas de prevenção, tratamento e apoio às vítimas, a nível central e local. Para além disso, as contingências da medicina e a falta de medicamentos dificultaram o tratamento dos epidémicos. A pandemia findou a sua caminhada quando a natureza o definiu.

Em poucos meses, com muito vigor em outubro e abrandando até dezembro, a epidemia - aliando-se a outras doenças do foro respiratório e pulmonar que habitualmente mais vítimas causavam - espalhou a morte pelos quatro bairros da cidade, «ferindo» indiscriminadamente todo o tipo de indivíduos e famílias, conquanto mais os homens que as mulheres. Mas também é certo que os menos poupados viviam, sobretudo, nos bairros a ocidente e oriente, mais industrializados, e em contextos sociais e habitacionais mais precários. Eram também estes, os que mais longe distavam dos hospitais, nos limites concelhios, onde era mais difícil ou mesmo inacessível a condução de doentes e até a atuação humanitária, assaz frequente nos bairros centrais.

No seu momento mais intenso, na primeira quinzena de outubro, imperou o caos na capital. Terá sido aterradora a omnipresença da morte quando muitos cadáveres foram conduzidos, amontoados em carroças e tapados com trapos ou serapilheira, para as valas comuns dos cemitérios. Neste outono fatídico, com enterramentos de urgência devido à aglomeração de cadáveres em decomposição nas morgues dos hospitais e em casas particulares, a dignidade na morte esteve ausente de Lisboa. 


\section{Fontes}

ANTT-Arquivo Distrital de Lisboa, (1836-1990). Governo Civil, Gestão de Informação e Documentação, Organização e Recuperação, pasta 106 e doc. avulsos.

ANTT-Hospital de São José, (1913-1927). Comissão médica dos hospitais. Registo de actas, Liv. 6222.

ANTT-Hospital de São José, (1918). Registo da estatística do movimento da população doente, Liv. 3089.

ARQUIVOS, Instituto Central de Higiene (1922a). Estatística do Movimento Fisiológico da População de Portugal de 1917. Lisboa, Imprensa Nacional.

ARQUIVOS, Instituto Central de Higiene (1922b). Estatística do Movimento Fisiológico da População de Portugal de 1918. Imprensa Nacional, Lisboa.

ARQUIVOS, Instituto Central de Higiene (1924). Estatística do Movimento Fisiológico da População de Portugal de 1919. Imprensa Nacional, Lisboa.

HIGIENE, Instituto Central de (1918). Boletim mensal de estatística demográfico-sanitária, mês de Outubro de 191\%. Imprensa Nacional, Lisboa.

HIGIENE, Instituto Central de (1919). Boletim mensal de estatística demográfico-sanitária, mês de Outubro de 1918. Imprensa Nacional, Lisboa.

LISBOA, Câmara Municipal de (1918a). Registo de Enterramentos [14 de ago. a 24 de out.], v. 2,68 .

LISBOA, Câmara Municipal de (1918b). Regulamento dos cemitérios municipais de Lisboa [Agosto de 1918]. [S.l.: s.n.].

LISBOA, Câmara Municipal de (1922). Actas das Sessões da Comissão Administrativa da $C M$ de 1919. Imprensa Nacional, Lisboa.

LISBOA, Câmara Municipal de (1940). Actas das sessões da CML. Comissão executiva e comissão administrativa. Ano de 1918. Oficinas Gráficas da CML, Lisboa.

LISBOA, Hospitais Civis de (1920). Relatórios e notícias sobre a epidemia de gripe pneumónica. Suplemento ao Boletim de 1918. Imprensa Nacional, Lisboa.

PORTUGAL, Ministério das Finanças. Direcção Geral de Estatística (1913). Censo da População de Portugal. No $1 .^{\circ}$ de Dezembro de 1911. Imprensa Nacional, Lisboa.

PORTUGAL, Direcção Geral de Estatística (1923). Censo da População de Portugal. Dezembro de 1920. Imprensa Nacional, Lisboa.

PORTUGAL, Direcção Geral de Saúde (1953). Boletim dos Serviço Sanitários, 6 e 7. Leis, decretos e portarias desde 1 de Janeiro de 1911 a 31 de Dezembro de 1925. Imprensa Nacional, Lisboa. 


\section{Publicações periódicas}

A Capital.

Diário de Notícias.

Diário do Governo. Série I.

Ilustração Portugueza.

\section{Bibliografia}

ALMEIDA, Maria Antónia Pires de (2014). As epidemias nas notícias em Portugal: cólera, peste, tifo, gripe e varíola, 1854-1918. História, Ciências, Saúde-Manguinhos, vol. 21 (2), pp. 687-708.

CRESPO, Carlos João Mourato (2006). A gripe pneumónica nos concelhos de Loures, Mafra e Vila Franca de Xira. Um estudo sociodemográfico. [Tese de mestrado em História Local e Regional]. [FL-UL], Lisboa.

FRADA, João José Cúcio (1989). A pneumónica de 1918 numa perspectiva médica, económica e social. Provas de Aptidão Pedagógica e Capacidade Científica apresentadas na Faculdade de Medicina da Universidade de Lisboa. Policopiado, Lisboa.

GIRÃO, Paulo Jorge Marques (2009). A gripe pneumónica no Algarve, in SOBRAL, José Manuel; LIMA, Maria Luísa; CASTRO, Paula; SOUSA, Paulo Silveira e (org.). A pandemia esquecida. Olhares comparados sobre a pneumónica 1918-1919. ICS, Lisboa, pp. 107-130.

SOBRAL, José Manuel; LIMA, Maria Luísa; CASTRO, Paula; SOUSA, Paulo Silveira e (org.) (2009). A Pandemia Esquecida. Olhares comparados sobre a pneumónica 1918-1919. ICS, Lisboa. 


\section{Anexo}

Fig. 2 - Óbitos por gripe e freguesias de Lisboa, outubro a dezembro de 1918

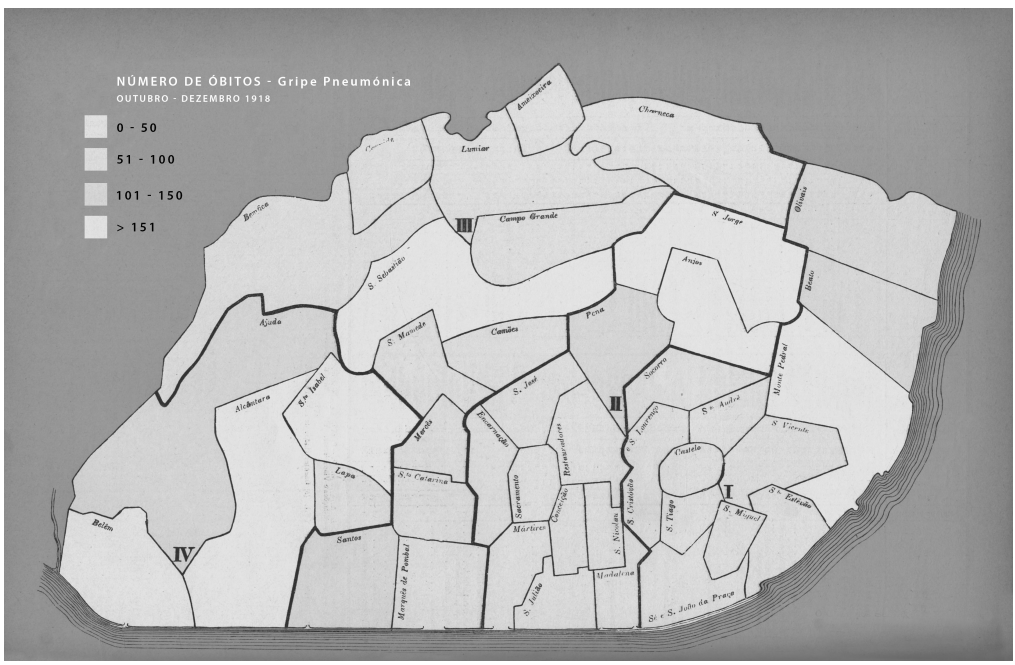

Fonte: Infogravura, CML-DMC-DPC-GEO, 2018. 



\title{
IMPACTOS DA GRIPE ESPANHOLA NA Região do Alto Minho (Norte de PorTugal)
}

\author{
Carlota Santos ${ }^{1}$
}

Aurora Botão Rego ${ }^{2}$

Manuela Silva ${ }^{3}$

Milene dos Anjos Fernandes ${ }^{4}$

\footnotetext{
1 CITCEM|FLUP; CECS - Universidade do Minho, csantos@ics.uminho.pt 2 CITCEM|FLUP - Grupo de Populações e Saúde, aurorarego@gmail.com

3 CITCEM|FLUP - Grupo de Populações e Saúde, mmtfs_125@sapo.pt

4 CITCEM|FLUP - Grupo de Populações e Saúde, milene_feriange@hotmail.com
} 



\begin{abstract}
Resumo
A dimensão e os efeitos da pandemia de gripe, que grassou entre a população portuguesa a partir de 1918, carecem ainda de aprofundamento sobretudo na perspetiva regional. O presente artigo visa analisar os contextos e as consequências do fenómeno em quatro municípios da região do Alto Minho - Viana do Castelo (nas suas 2 freguesias urbanas), Caminha (19 freguesias), Vila Nova de Cerveira (15 freguesias) e Paredes de Coura (21 freguesias) - integrados no distrito de Viana do Castelo e localizados na área geográfica que estabelece fronteira com a Galiza. Considerando esta proximidade, mas também a clivagem entre meio urbano e rural ou a especificidade das comunidades marítimas relativamente à restante população, pretendemos analisar eventuais comportamentos diferenciais observados durante o período de maior exposição à epidemia ${ }^{5}$.
\end{abstract}

Palavras-chave: gripe espanhola, pneumónica, influenza, Alto Minho.

\title{
Introdução
}

No plano administrativo, a região portuguesa do Alto Minho corresponde ao atual distrito de Viana do Castelo (Figura 1) onde, para este estudo, privilegiámos quatro municípios (Caminha, Vila Nova de Cerveira, Paredes de Coura e a área urbana de Viana do Castelo) no sentido de avaliar os impactos produzidos pela gripe pneumónica que, tendo alastrado por todo o país no ano de 1918, atingiu as populações nacionais em cronologia e intensidade diferenciadas.

No sentido de uma análise comparativa a nível regional, considerámos relevante destacar dois fatores que teriam decisivamente condicionado diferentes graus de exposição à epidemia: por um lado, o maior ou menor isola-

5 O levantamento e análise de dados relativos a Viana do Castelo, Caminha e Vila Nova de Cerveira, foram desenvolvidos por Aurora Rego e Manuela Silva. O levantamento e análise de dados relativos a Paredes de Coura foram desenvolvidos por Carlota Santos e Milene Fernandes. 
Fig. 1 - Localização dos municípios do distrito de Viana do Castelo

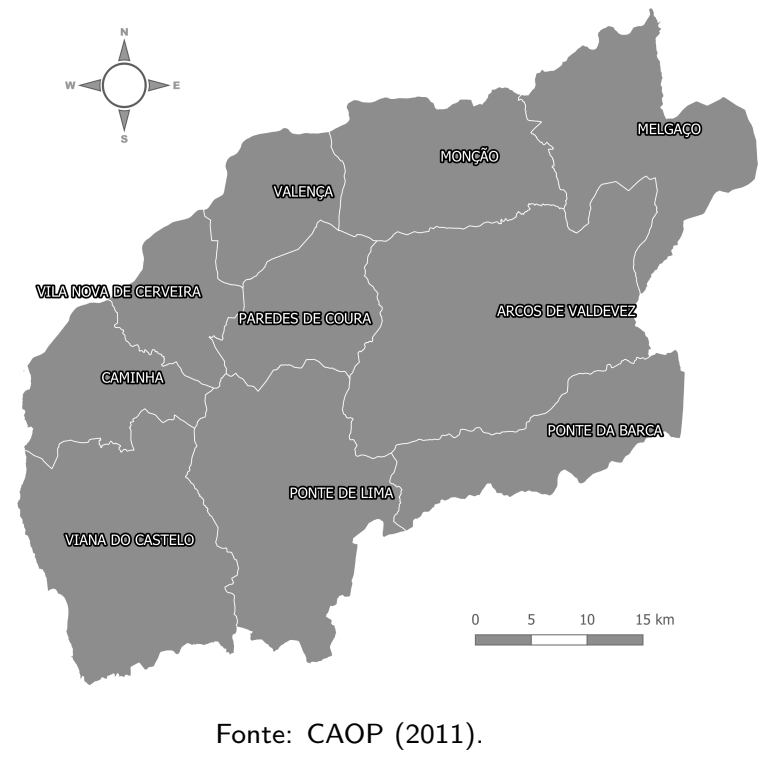

mento geográfico de cada município e, por outro lado, a significativa presença de comunidades marítimas na orla litoral que, pela sua mobilidade laboral em grande parte direcionada para os portos da Galiza espanhola, sempre mantiveram um estreito e permanente contacto com essa área que viria a ser um dos principais focos transmissores do vírus além fronteira.

Os registos de óbito constituíram a fonte principal para o estudo do fenómeno nos quatro territórios, entre 1914 e 1920, enquadrando-se centralmente o ano pandémico de 1918 para efeitos de análise. Para os municípios de Caminha e de Vila Nova de Cerveira foram também explorados os registos paroquiais de nascimentos que proporcionaram a observação dos saldos fisiológicos nestas comunidades. Por outro lado, a informação disponibilizada pelos recenseamentos nacionais portugueses (INE), produzidos entre 1864 e 1940, permitiu desenhar a evolução das populações e estimar os efeitos depressivos causados pela epidemia no ano de 1920.

Foram ainda consultadas diversas fontes para contextualização da análise quantitativa: fundos assistenciais das Misericórdias de Viana do Castelo, Caminha e V. N. Cerveira; fundos administrativos dos concelhos de Caminha e de V. N. Cerveira; imprensa local - A Aurora do Lima (Viana do Castelo); Correio de Caminha (Caminha); Echos de Cerveira (V. N. Cerveira) e A Voz de Coura (Paredes de Coura). 


\section{CARACTERIZAÇÃO DOS MUNICÍPIOS, EVOLUÇÃO PO- PULACIONAL E CONTEXTO SOCIOECONÓMICO}

Na impossibilidade de analisar as 41 freguesias que integravam então o concelho de Viana do Castelo, incidimos a análise na cidade de Viana do Castelo, de secular vocação marítima e piscatória, incluindo duas grandes freguesias urbanas - Monserrate e Santa Maria Maior.

No concelho de Caminha, muito diversificado geograficamente, coexistem freguesias de forte atividade marítima e ribeirinha e outras comunidades mais interiorizadas e serranas cuja economia assentava primordialmente na agricultura de subsistência e na pastorícia.

No concelho de V.N. Cerveira, a atividade de pesca fluvial, juntamente com a atividade de barcagem ao longo do curso do rio Minho e entre as margens portuguesas e galegas contribuíram para a afirmação da sua identidade até aos inícios do século XX.

O concelho vizinho de Paredes de Coura é considerado o celeiro do Minho, «(...) como lhe chamam, pela abundante produção de cereais, em que predomina o milho maiz» (Cunha, 1979: 26). A sua superfície ronda os 13.000 hectares, distribuídos numa área predominantemente montanhosa, cuja fertilidade das terras é assegurada pela rede hidrográfica que parte do rio Coura.

Quatro rios de dimensão variável - Lima, Minho, Âncora e Coura atravessam os municípios em observação. Ao longo dos séculos, estes rios estabeleceram fronteiras político-administrativas importantes, condicionaram a morfologia dos territórios e determinaram o maior ou menor grau de interioridade das freguesias. As serras de Arga, Boulhosa, Chã das Pipas e um extensa cordilheira que se estende até à zona de fronteira com a Galiza espanhola, com mais de 800 metros de altitude, condicionaram a fixação das populações e a sua evolução, conduzindo ao isolamento das comunidades mais afastadas do litoral.

Procedemos à análise da evolução da população nos quatro territórios com recurso aos recenseamentos nacionais entre 1864 e 1940, de forma a enquadrarmos os efeitos da pandemia da gripe espanhola.

A observação da Figura 2 revela que a evolução populacional positiva geral foi interrompida em 1890 em três espaços, com exceção para a Viana do Castelo. A causa da recessão verificada em 1890 parece estar relacionada com a incidência da gripe russa que deflagrou entre 1879 e inícios do ano seguinte (Frada, 2005: 87). 
Fig. 2 - Evolução da população

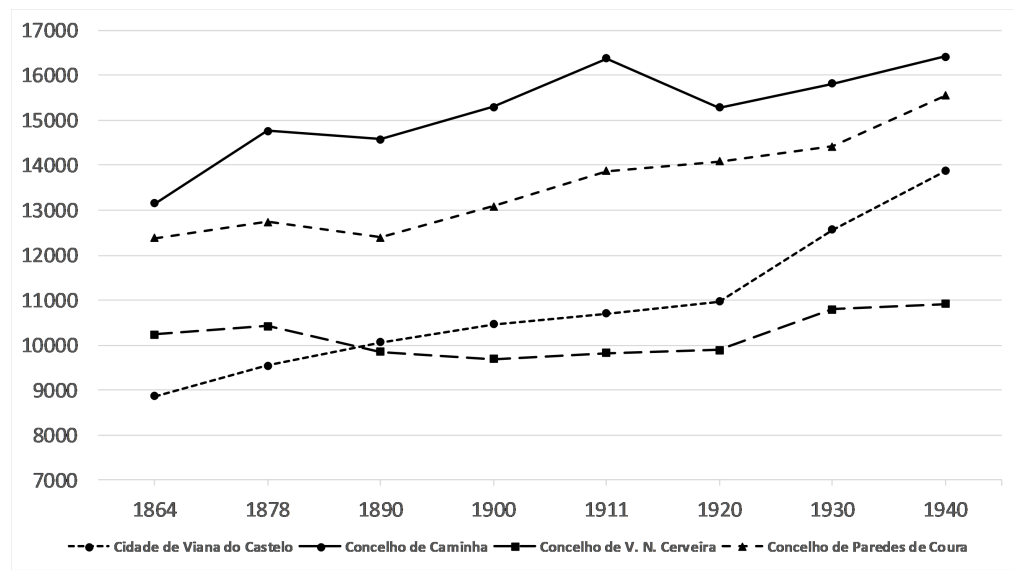

Fonte: Recenseamentos nacionais portugueses, INE.

De 1890 até 1911, a tendência prevalecente foi de franco crescimento demográfico, com exceção para a estagnação populacional verificada no concelho de V. N. Cerveira. No entanto, entre 1911 e 1920, a apatia populacional torna-se evidente: na cidade de Viana do Castelo contaram-se somente mais 1402 habitantes numa década, no concelho de Caminha mais 119, no concelho de V. N. Cerveira mais 63 e no concelho de Paredes de Coura 202. Será somente a partir do recenseamento de 1930 que se virá a observar um claro relançamento do crescimento populacional nos quatro espaços em análise.

Os dados apresentados nas Figuras 3 e 4 permitem concluir que, entre 1911 e 1920, os saldos fisiológicos nos dois concelhos analisados foram negativos no ano de 1918. Surtos larvares epidémicos nos anos seguintes, em particular na primavera de 1919, acrescidos ainda de surtos de febre tifoide, determinaram um quadro de recessão demográfica.

Com o início da I Grande Guerra, o contexto socioeconómico e político vigente modificou-se dramaticamente em Portugal, país periférico, isolado e pobre de recursos. Os bens de primeira necessidade sofreram uma inflação sem precedentes, especialmente a partir da entrada de Portugal no conflito bélico em 1916. 
Fig. 3 - Saldo fisiológico no concelho de Caminha

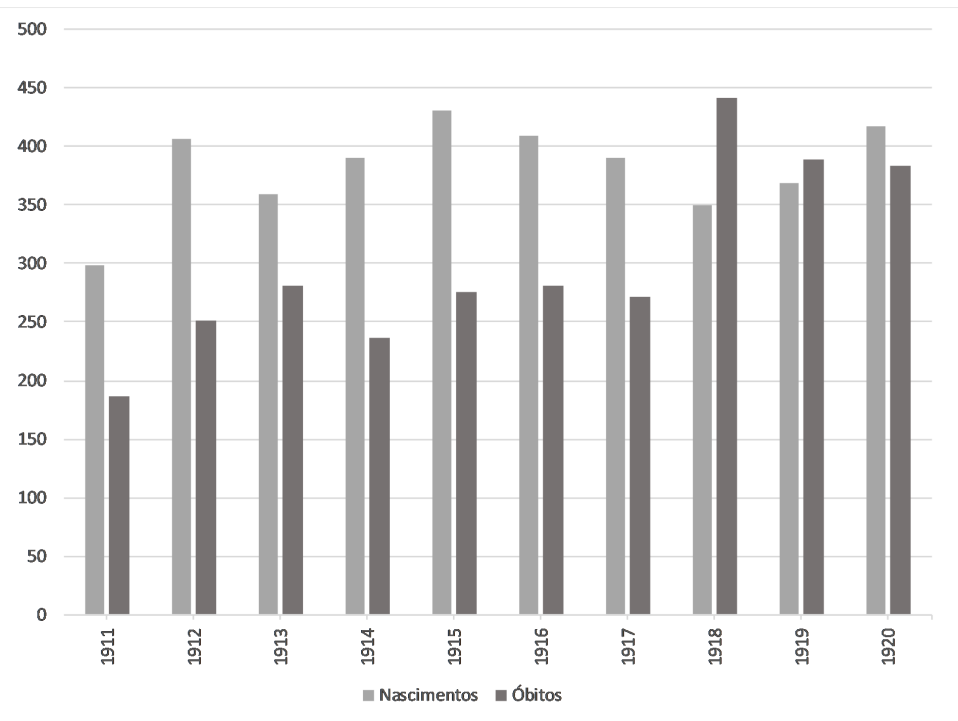

Fonte: Registos paroquiais do concelho de Caminha.

Fig. 4 - Saldo fisiológico no concelho de V. N. Cerveira

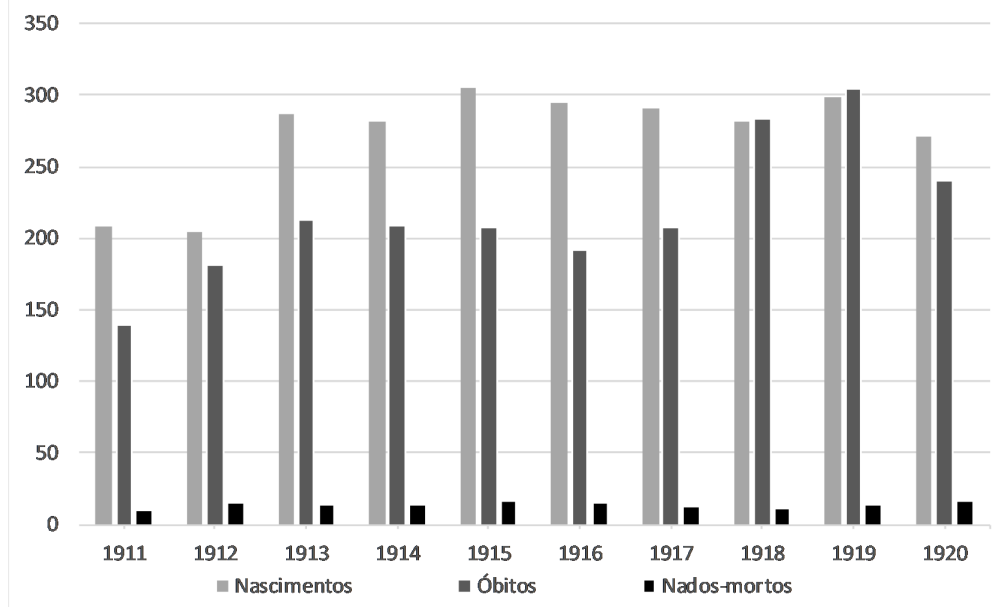

Fonte: Registos paroquiais do concelho de V. N. Cerveira. 
Analisemos a evolução dos preços médios anuais dos bens de primeira necessidade no concelho de V.N. Cerveira entre 1911 e 1922 (Figura 5).Tomando como exemplo o milho (base da alimentação do povo nortenho), o seu preço médio, que, até 1915 , rondava os $\$ 500-\$ 600$ reis por alqueire (medida de 20 litros), aumentou para $\$ 820$ em 1916, $1 \$ 590$ em 1918, $4 \$ 630$ em 1920 , atingindo os $7 \$ 110$ reis em 1922 . Idêntico cenário foi encontrado para o concelho de Caminha (Rego, 2015: 353-356).

Fig. 5 - Bens de primeira necessidade e inflação dos preços

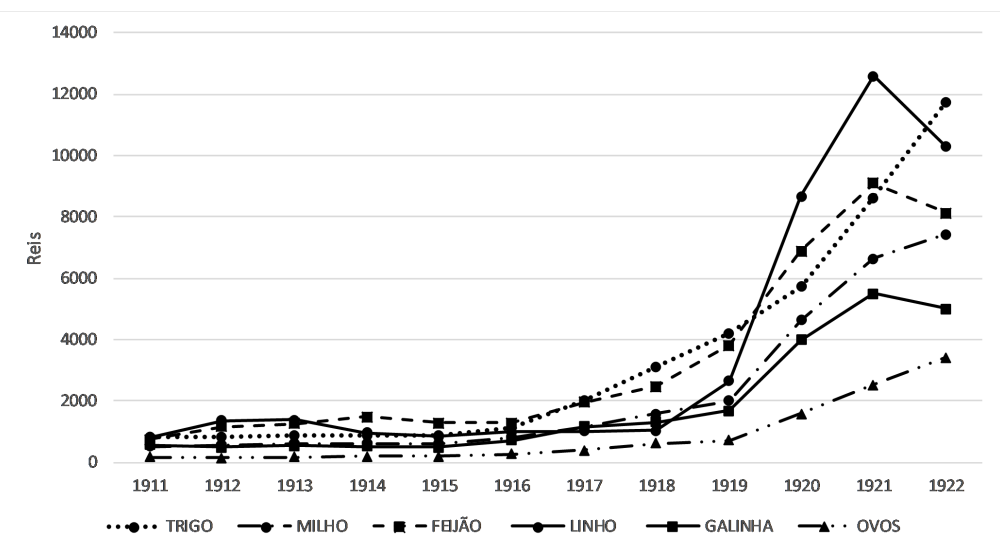

Fonte: AMVNC, Tabela dos preços dos cereais.

Esta inflação assombrosa era agravada pelo açambarcamento das subsistências e pelo contrabando para fora dos limites do concelho e do país, através das ligações existentes entre o rio Minho e a Galiza. Outros fatores explicam esta inflação. Em 1918, a produção de cereais tinha sofrido perturbações, devido à estiagem que se fez sentir no distrito de Viana do Castelo, da qual imprensa regional nos fez eco ${ }^{6}$.

É de realçar os níveis de analfabetismo existentes no Recenseamento Nacional de 1920: na cidade de Viana do Castelo 47,57\%; no concelho de Caminha 58,16\%; no concelho de V. N. Cerveira $69,39 \%$ e no concelho de Paredes de Coura 75,81\%. A falta de informação geral sobre a alimentação, higiene, salubridade ou medidas sanitárias e profiláticas a adotar na prevenção de contágios e doenças, maximizava os riscos durante a eclosão de crises epidémicas.

\footnotetext{
6 A Diocese de Braga sugere que todos os párocos sob sua jurisdição efetuem preces ad pretendam pluviam de forma a obter chuva da misericórdia divina e minimizar o ano de seca em curso, prejudicial à agricultura. Jornal Echos de Cerveira, no ${ }^{\circ}$ 119, 23/06/1918.
} 


\section{INCIDÊNCIA DA GRIPE ESPANHOLA NA CIDADE DE VIANA DO CASTELO}

A urbe vianense é composta por duas freguesias. Na freguesia de Monserrate, concentravam-se, entre outras, as populações ribeirinhas e militares, nomeadamente em arruamentos mais próximos da doca e da ribeira e ainda do Castelo de Santiago da Barra e aquartelamentos anexos. Na freguesia de Santa Maria Maior encontravam-se, principalmente, serviços e comércio, tendo como polo dinamizador a Praça da República.

Compulsada a informação proveniente dos assentos de óbito das duas paróquias, agregámos o conjunto total dos óbitos entre 1916 e 1920.

Fig. 6 - Movimento de óbitos na cidade de Viana do Castelo

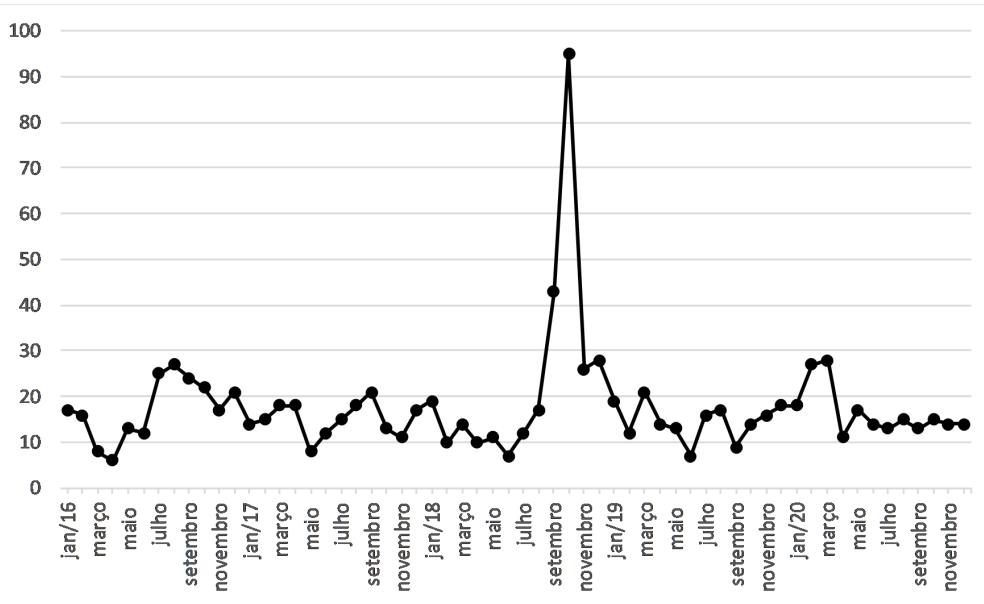

Fonte: Registos paroquiais de óbitos de Viana do Castelo.

A análise da Figura 6 revela que o ano de 1918 se destaca claramente dos demais anos, sendo de evidenciar que o pico de mortalidade se centrou no mês de outubro, embora com início no mês de setembro e queda nos dois meses subsequentes ${ }^{7}$.

Que indivíduos foram mais expostos à gripe espanhola em Viana do Castelo? Para respondermos a esta questão, isolámos os indivíduos que faleceram durante os meses de crise pandémica. A Figura 7 demonstra que a faixa etária dos recém-nascidos até aos 23 meses foi a mais afetada $(27 \%)$, seguindo-se o grupo de adultos robustos entre os 20 e os 39 anos (24\%) e o

$7 \quad$ No Hospital da Misericórdia já tinham dado entrada doentes com gripe durante o mês de setembro. ADVCT Fundo da Misericórdia de Viana do Castelo, Cotas 3.24.5.9, 3.26.3.10, 3.26.3.17, 3.26.3.21. 3.26.3.22. 
grupo dos 2 aos 19 anos (21\%), ou seja, 72\% dos óbitos referem-se a indivíduos até aos 39 anos de idade.

Fig. 7 - Óbitos segundo os grupos de idade

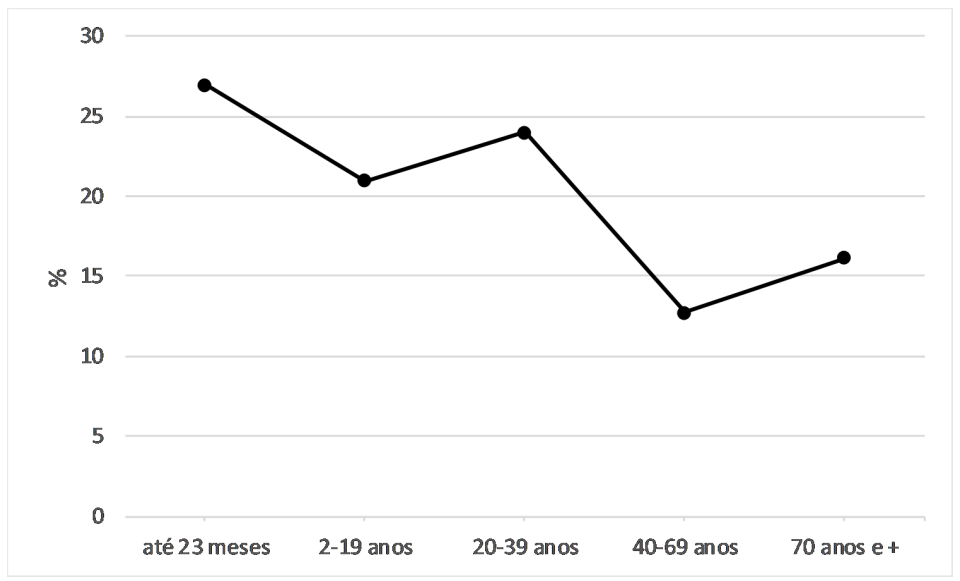

Fonte: Registos paroquiais de óbitos de Viana do Castelo.

Fig. 8 - Idade média ao óbito durante a crise pandémica

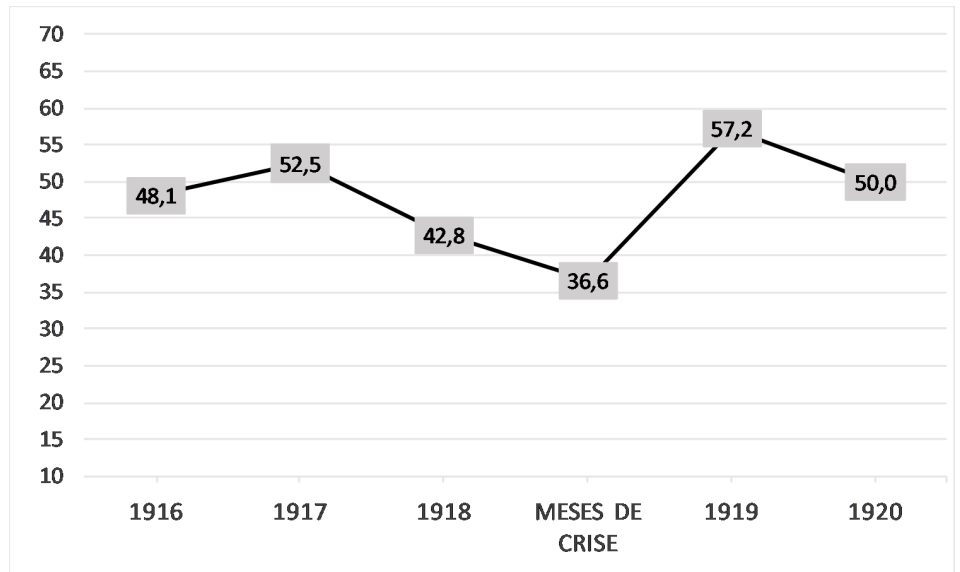

Fonte: Registos paroquiais de óbitos de Viana do Castelo.

Na Figura 8 encontram-se os resultados da análise das idades médias anuais ao óbito entre 1916 e 1920, como também durante o período de crise pandémica (setembro-dezembro de 1918). Concluímos inequivocamente que a descida da média de idades ao óbito para 36,56 anos durante a pandemia 
comprova a juventude da maioria das vítimas, comportamento análogo ao encontrado noutros estudos (Frada, 2005: 114).

A particularidade de esta pandemia ter atingido as camadas mais jovens da população vem sendo atribuída a duas causas - a imunização das faixas etárias mais velhas devido à pandemia de origem viral idêntica - a gripe russa - que deflagrou em 1889/1890 (Frada, 2005: 87) e que poderá estar também na origem da interrupção do crescimento demográfico de 1890 (vide Fig. 2). A segunda causa relaciona-se com a própria juventude dos organismos e pela sua debilidade face à fome que grassava na região. A disseminação do vírus da gripe tornou-se muito mais veloz, produzindo vítimas mais jovens (Sousa, Castro, Lima, Sobral, 2008: 478).

Em Monserrate, as áreas de residência registadas ao óbito durante os meses de crise foram, na sua maioria, as zonas habitadas por famílias de marítimos e militares e os eixos principais de passagem. As profissões mais mencionadas foram pescadores, marinheiros, peixeiras, militares, guardas, empregados de comércio ou domésticas.

Já em Santa Maria Maior, foi na Rua da Bandeira onde faleceu grande parte dos indivíduos, seguindo-se artérias e eixos privilegiados de entrada e saída da cidade, mas também áreas de estabelecimentos comerciais ou serviços. Notem-se os riscos associados à localização do Hospital da Misericórdia, em pleno centro da cidade, na esquina com a Rua da Bandeira, nomeadamente pela constante circulação de peões, entrada e saída de doentes, falecidos e pessoal médico, tornando-se num possível foco de disseminação da pandemia. Domésticas, empregados de balcão, jornaleiros, oficiais da construção, ferroviários, militares, médicos, farmacêuticos, por exemplo, foram as profissões mais abundantemente registadas ao óbito, ocupações mais sujeitas à exposição viral.

A análise da documentação do Hospital da Misericórdia de Viana do Castelo revela um movimento semelhante ao paroquial, como se pode concluir pela observação da Figura 9. Entre 1912 e 1932, o ano de 1918 perfila-se claramente acima da média. De igual modo, o movimento sazonal ao óbito nesse mesmo ano, indica que entre janeiro e setembro a média foi de 0-6 óbitos/mês, enquanto que, em outubro do mesmo ano, ascendeu a 29 vítimas. A idade média dos falecidos foi igualmente baixa (33,42 anos) e, à semelhança do observado na cidade, $66,9 \%$ eram indivíduos do sexo feminino.

Durante este período a origem dos doentes diversificou-se. Entraram doentes de todo o concelho e o seu alcance atingiu a Ribeira-Lima, com doentes internados dos concelhos do interior, como Arcos de Valdevez ou 
Fig. 9 - Movimento de óbitos no Hospital da Misericórdia de Viana do Castelo

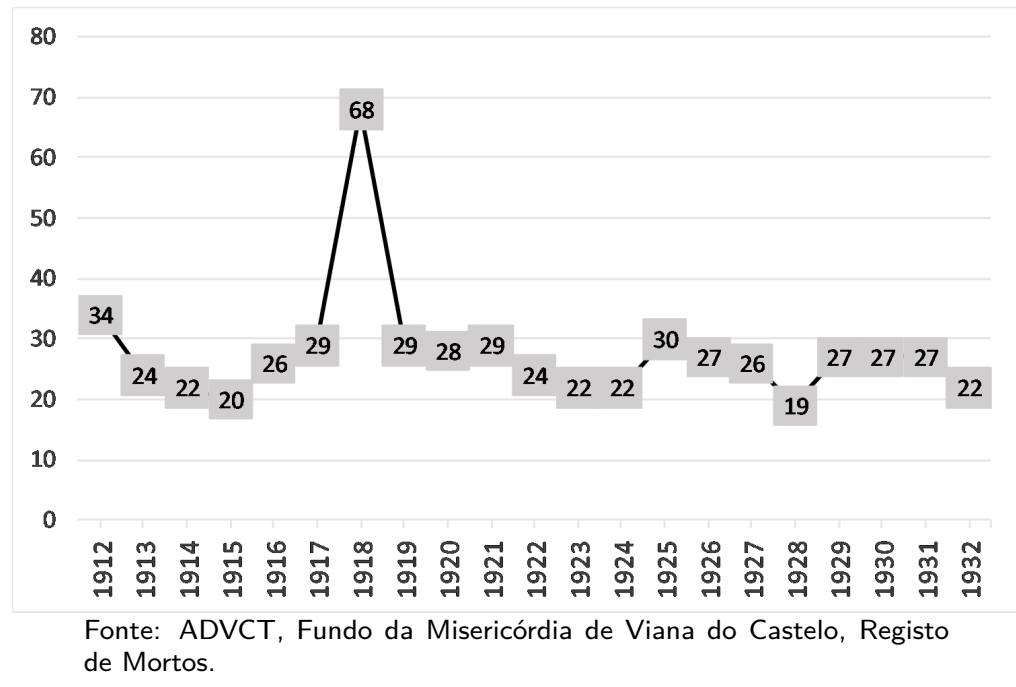

Ponte de Lima. As poucas profissões encontradas referem-se a jornaleiros, criadas de servir e mendigos.

Consultámos o Jornal Aurora do Lima que evidenciou a dramática conjuntura da época ${ }^{8}$, revelando uma variedade extraordinária de temáticas abordadas em simultâneo, como a guerra, a mobilidade de militares, Sidónio Pais, censura, greves, falta de subsistências, fome, mendicidade e pneumónica.

A crise de subsistências era avassaladora. As medidas tomadas pelo Governador Civil de Viana do Castelo, no sentido de organizar celeiros municipais para abastecer as populações, foram amplamente divulgadas, mas também criticadas. Por Decreto-Lei de 20 de abril de 1918, os lavradores eram obrigados a manifestar a sua produção de cereais oito dias depois da colheita. Retirada a quantia necessária à família, deviam entregar o remanescente ao respetivo celeiro. No entanto, a lei era impossível de cumprir, pois as colheitas pautavam-se por ciclos próprios e faseados ao longo do ano, condicionadas pelas chuvas. Os cronistas clamavam pela equidade da distribuição do pão no Alto Minho através da implementação de celeiros paroquiais e aos quais todos teriam acesso. Uma vez que os celeiros municipais centralizavam os bens, as populações das paróquias mais afastadas já encontravam o milho esgotado quando chegavam à cidade. Escrevia um cronista que «(...) o po-

8 BMVCT, Jornal A Aurora do Lima, 1918. 
bre é sempre o que paga mais caro porque não tem senão o que ganha dia a dia $(. ..) \gg$. Os organismos debilitados facilitaram a ação da gripe espanhola.

A mendicidade tornou-se endémica, especialmente a infantil. Pode ler-se «O espetáculo mais deprimente de uma sociedade é, sem dúvida, a mendicidade de menores pelas ruas (...) innocentes creaturinhas a quem os paes, pela fome, obrigam a esmolar (...)». Os asilos estavam cheios, não existiam albergues para menores. Este fenómeno agravou-se com a pandemia, errando pela cidade numerosos órfãos. Na edição de 13 de dezembro, o jornal já comunicava ter sido criado um Orfanato para «(...) os menores que a última epidemia deixou ao desamparo (...). Abriga já 20 crianças de ambos os sexos e estão ainda sendo recolhidas, em diferentes pontos do districto, outras a quem a desgraça feriu $(\ldots) »$.

\section{INCIDÊNCIA DA GRIPE ESPANHOLA NO CONCELHO DE CAMINHA}

O território do concelho de Caminha pode dividir-se em quatro áreas distintas: a frente litoral e da ribeira Minho, o Vale do Âncora, o Vale do Coura e as freguesias da serra d'Arga, quase isoladas, devido à falta de acessos. Os Vales do Âncora e do Coura formam uma segunda linha de povoações, mais defendidas do mar.

Fig. 10 - Movimento de óbitos no concelho de Caminha - 1916-1920

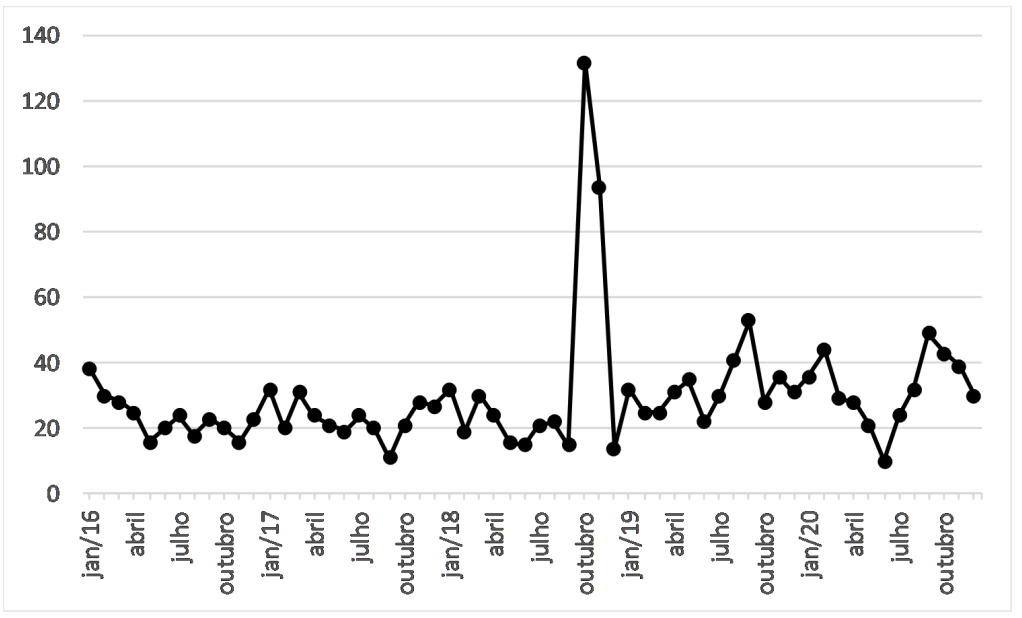

Fonte: Registos paroquiais de óbitos de Caminha. 
Procedemos à análise do movimento de óbitos nas 19 freguesias do concelho de Caminha ${ }^{9}$ (Figura 10). O ano de 1918 e, especialmente, os meses de outubro e novembro, evidenciam a ação da gripe espanhola. Em dezembro, a regressão é clara. Ainda que, como nos demais territórios, existam alguns óbitos não relacionados com a pandemia, um pico de mortalidade de tal dimensão não deixa lugar a dúvidas quanto à morbilidade pandémica.

Fig. 11 - Óbitos segundo os grupos de idade

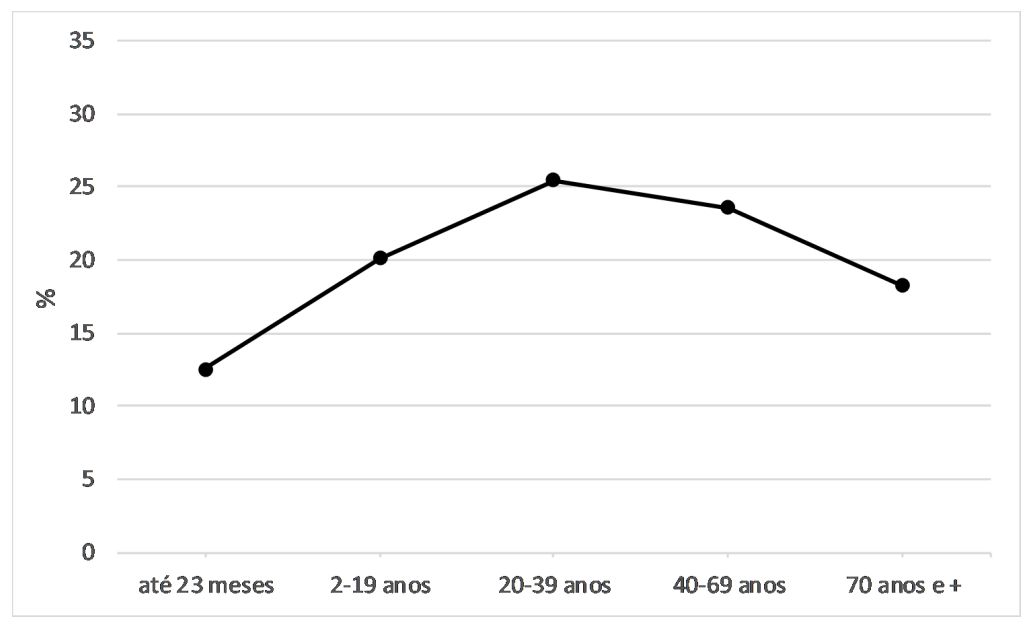

Fonte: Registos paroquiais de óbitos de Caminha.

Efetuado o levantamento dos indivíduos falecidos durante a crise pandémica e respetivas idades médias, obtivemos os dados que se encontram nas Figuras 11 e 12 . O grupo de idades mais afetado localiza-se na faixa etária dos 20 aos 39 anos de idades (25,5\%). Desde a infância até aos 39 anos contabiliza-se um total de cerca de $60 \%$.

A observação das idades médias ao óbito entre 1916 e 1920 revela que foi durante a crise de gripe que se observou a média mais baixa. Se em 1916 esta se cifrava nos 55,5 anos, no ano de 1918 desceu para 47,3 anos e, durante a crise, para 36,1 anos.

A geografia da gripe espanhola no concelho de Caminha mostra que esta afetou, numa primeira vaga, as freguesias do litoral - Vila Praia de Âncora, Moledo, Cristelo, Caminha e Seixas -, cavalgando depois, em finais de outubro e inícios de novembro, para os vales interiores. Alheias à gripe pneumónica devido ao seu isolamento geográfico, ficaram as três freguesias da Serra d'Arga, Vile e Azevedo, de dimensão diminuta. As duas freguesias mais

9 Consulte-se REGO, 2015: 331-368, sobre a pneumónica no concelho de Caminha. 
Fig. 12 - Idade média ao óbito durante a crise pandémica

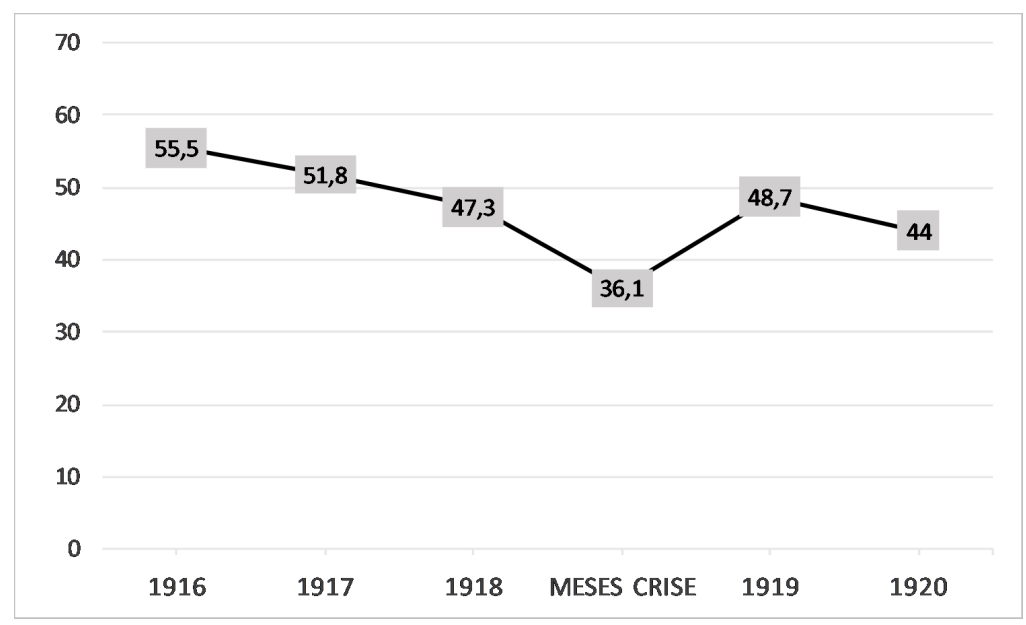

Fonte: Registos paroquiais de óbitos de Caminha.

fustigadas pela pandemia - Vila Praia de Âncora e Seixas - correspondem às duas maiores comunidades piscatórias.

No caso particular de Vila Praia de Âncora (paróquia reconstituída segundo a metodologia de Amorim (1991) por Rego (2013)), a sua praia de banhos era frequentada por elites oriundas dos principais centros urbanos, como Lisboa, Porto, Braga, Guimarães, e pelas comunidades dos concelhos interiores altominhotos. A época de banhos iniciava-se em agosto, quando chegava o primeiro conjunto de frequentadores, terminando em finais de outubro, quando se retirava o segundo conjunto e cujos banhos eram pautados pelo ciclo das colheitas. Vários estudos indicam que a segunda onda da gripe espanhola entrou nos arredores do Porto em agosto de 1918 (Dias, 1919: 4950). Assim, não é de estranhar que Vila Praia de Âncora se transformasse num dos principais focos de contágio e disseminação. De facto, vários jovens pescadores locais, banhistas e criadagem faleceram a partir 8 de setembro, sem causa aparente. A 3 de outubro, o jornal Notícias de Caminha regista já o início da pandemia, a ida e vinda de soldados da Grande Guerra, a par da saída de banhistas da Praia d'Âncora, num contexto geral de contágio em expansão.

Analisado o Movimento deEntrada de Doentes no Hospital da Misericórdia de Caminha (Figura 13) verificamos que os meses de outubro e novembro de 1918 se destacam claramente de todo o conjunto. Se nos anos enquadrantes o número de doentes girava entre 80-90, em 1918 atingiu os 157. 
Fig. 13 - Movimento de Entradas de Doentes no Hospital da Misericórdia de Caminha

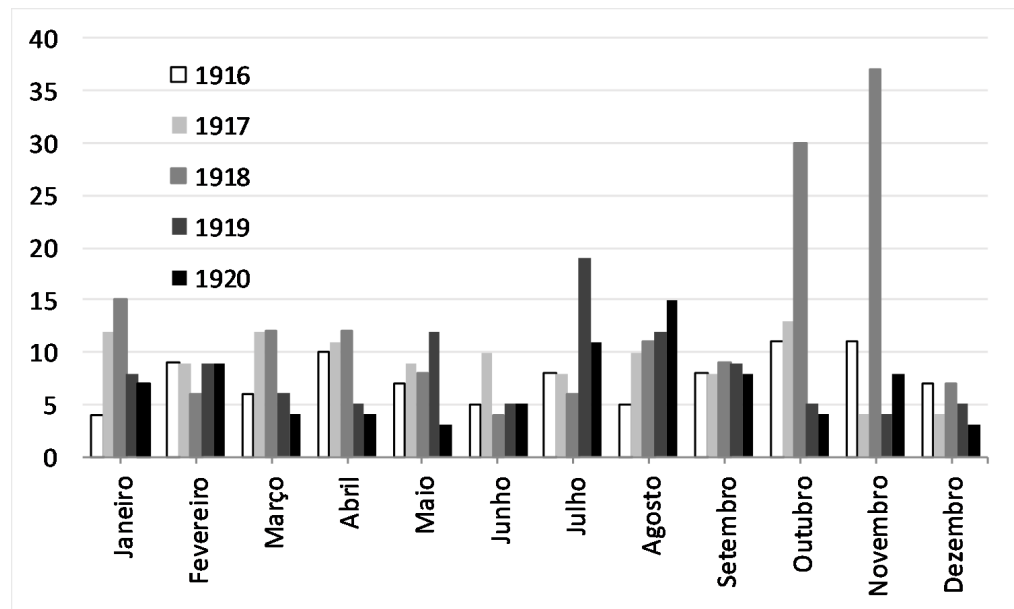

Fonte: ADVCT, Misericórdia de Caminha, Livros de entradas de doentes.

Na Misericórdia de Caminha, o primeiro doente registado com gripe foi um marinheiro, internado já no dia 1 de setembro. Passou-se um mês e, em 4 de outubro, a pandemia já se encontrava descontrolada, pois, a partir dessa data, só deram entrada exclusivamente doentes com gripe. As ocupações registadas indicam que os profissionais ligados ao mar e ao rio (marinheiros, grumetes, fogueiros, barqueiros, pescadores, remadores) foram atingidos em primeiro lugar e em maior número $(37,88 \%)$, mercê de um maior contacto com outros locais. Seguiu-se um conjunto contaminado de domésticas, jornaleiras e criadas $(47 \%)$.

Selecionando os meses de outubro e novembro observamos que os doentes epidemiados apresentavam uma média de idades baixa (31,64 anos). Note-se que nos livros de entrada de doentes não se encontram menores de 6 anos, registando-se somente uma criança de 7 anos e jovens com idades iguais ou superiores a 11 anos. Devido à precocidade do contágio e à exiguidade das instalações, o setor masculino registou $59,15 \%$ da ocupação hospitalar.

De destacar que, durante o ano de 1918, não foi registado na Misericórdia nenhum doente com tifo ou varíola, epidemias que poderiam interferir na análise desta fonte. Já no ano de 1919, identificámos sete doentes atacados com gripe, entre fevereiro e agosto, três doentes com tifo e um com varíola; em 1920, cinco doentes com gripe e cinco com tifo. Concluímos, pelo exemplo desta instituição hospitalar, a nula interferência de outros agentes contagiosos durante a ocorrência do pico pandémico no concelho de Caminha. 
Esta asserção ficou comprovada pela intensa troca de telegramas a partir de 8 de outubro de 1918, entre o Provedor da Misericórdia, Manuel Alves Pinto, e o Presidente da República, Sidónio Pais, oriundo de Caminha. A braços com uma pandemia que não foi tomada em atenção no tempo devido, o Provedor informava, ao longo dos dois meses catastróficos, sobre o alastramento da pandemia no concelho e o terror da população, solicitando assim a vinda de médicos, subsídios para montagem de hospitais provisórios e envio de medicamentos ou de substâncias de desinfeção ${ }^{10}$.

A maioria das vítimas que tombaram durante a pandemia pertencia a camadas populacionais mais desfavorecidas, onde os índices de alimentação, salubridade e higiene habitacional eram mais baixos e as famílias numerosas $^{11}$.

Segundo as orientações da Direção Geral de Saúde, os seus delegados concelhios deveriam preencher o mapa de Movimento Fisiológico anual, onde constariam todos os óbitos e respetivas causas. No ano de 1918, torna-se evidente o descuido na anotação ou desconhecimento das causas da grande maioria dos falecimentos. No concelho de Viana do Castelo, desconhecemse as causas de 65,91\% dos óbitos; em Caminha, de 11,79\% dos casos; em V. N. Cerveira, de $59,11 \%$ e em Paredes de Coura, de $76,32 \%$, catalogadas como outras doenças ou doenças ignoradas ou mal definidas. Tomando como exemplo o concelho de Caminha, no documento foram registados 167 óbitos de gripe, um de tifo e um de varíola.

A Câmara Municipal de Caminha solicitou às elites locais que se organizassem para auxiliar «os pobres epidemiados e suas famílias» ${ }^{12}$. Através do Relatório de Trabalhos da Comissão torna-se possível compreender a sua ação junto das famílias atacadas pela pandemia. A filantropia adquiriu diversas facetas, como, por exemplo, a cedência por particulares de meios de transporte para doentes ou a sopa económica do 5 de Dezembro. Nas freguesias mais afastadas, onde a ação médica não chegava, eram os párocos que acudiam os doentes em visitas domiciliárias, distribuindo medicamentos e conselhos. Uma Delegação da Cruz Vermelha foi instalada em Vila Praia de Âncora.

10 ADVCT, Fundo da Misericórdia de Caminha, Correspondência expedida, cota 7.36.2.36. 11 «Éramos 14 irmãos, muito pobrezinhos; e vivíamos com a nossa mãe (...) O nosso pai tinha ido para o Brasil. Nesse tempo havia na nossa casa apenas 3 camas para 15 pessoas: uma cama ficava para a mãe com 4 raparigas, noutra cama, 6 raparigas mais pequenas (...) e na outra dormia eu e mais 3 irmãos. Pois adoecemos 6 com a pneumónica (...)» (Rodrigues, 1970: 9-15).

12 AMC, Comissão angariadora de donativos. Relatório dos seus trabalhos desde 15 de Outubro de 1918 a 14 de Dezembro do mesmo ano, Cota 1.21.3.7-15. 
Os cronistas das diferentes freguesias do jornal Correio de Caminha estiveram, desde o início, atentos ao fenómeno da «nova moléstia que já tem feito algumas víctimas». Anunciada a pandemia em 3 de outubro, os cronistas vão descrevendo o seu alastramento. Os nomes das vítimas vão sendo sucessivamente elencados e, na sua fase de rescaldo, elaboram listas de mortos por freguesia. Ao longo do período de crise, não faltam alusões ao contexto pandémico já referido: fome e subsistências, focos de imundície pública e atividades insalubres (como a seca do patelo ${ }^{13}$ a céu aberto), medidas profiláticas (como a queima de eucaliptos para purificar o ar), grande mobilidade de militares, elevada mortalidade de crianças e existência de órfãos sem rede familiar, cerimónias religiosas dedicadas, na sua maioria, a S. Sebastião, patrono da trilogia da miséria.

\section{INCIDÊNCIA DA GRIPE ESPANHOLA NO CONCELHO DE VILA NOVA DE CERVEIRA}

Para além do papel defensivo do concelho de V. N. Cerveira e das atividades piscatória fluvial e de barcagem, existiam freguesias interiores de forte pendor agrícola, destacando-se algumas, como Sopo ou Gondarém, que possuíam escolas famosas de pedraria.

Fig. 14 - Movimento de óbitos no concelho de Vila Nova de Cerveira

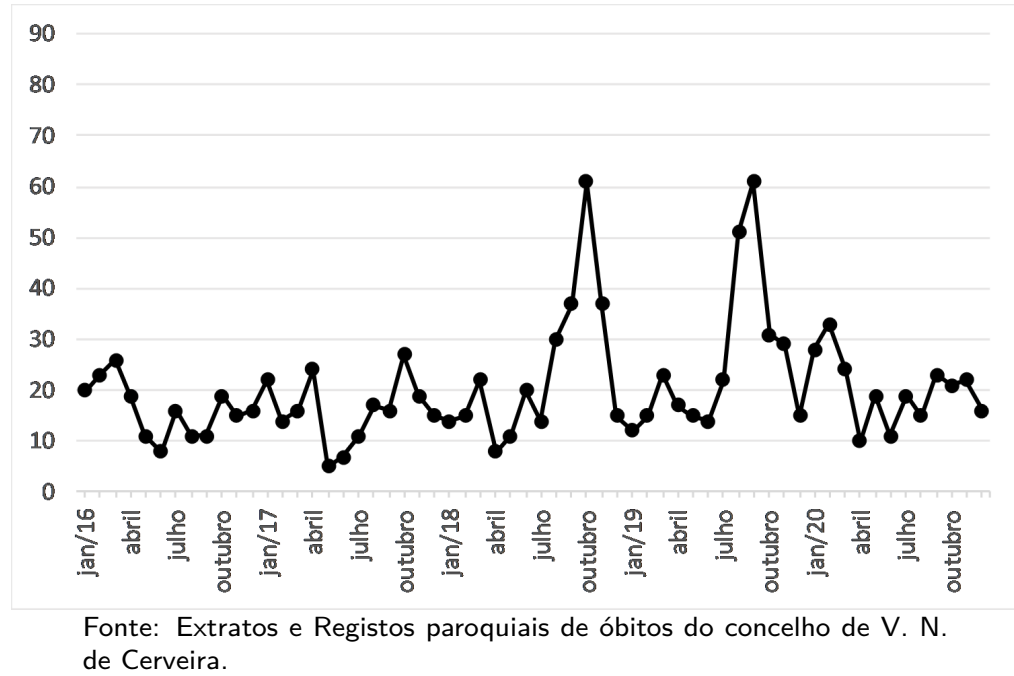

\footnotetext{
13 Patelo: caranguejo pequeno não comestível que, depois de seco, era utilizado como adubo para as terras.
} 
Fig. 15 - Óbitos segundo os grupos de idade

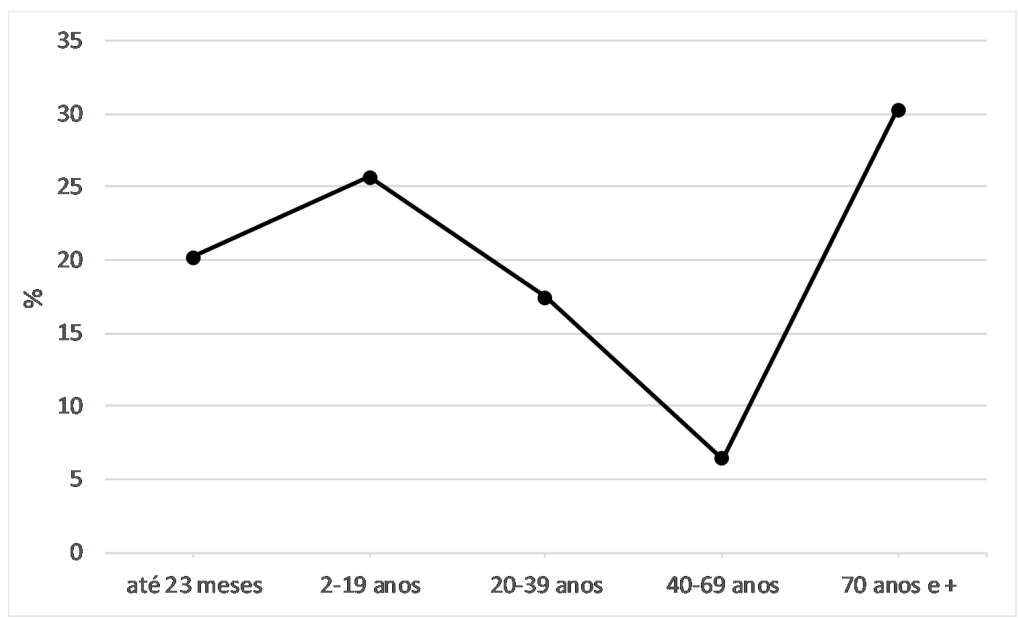

Fonte: Extratos e registos paroquiais de óbitos de V. N. de Cerveira.

O levantamento dos óbitos neste concelho foi efetuado através do cruzamento dos extratos de óbito com os registos paroquiais. O seu movimento (Figura 14) revela que existiram, entre 1916 e 1920, dois picos significativos de mortalidade. O pico de 1918 corresponde à pandemia da gripe e o de 1919, segundo o jornal Echos de Cerveira, a um importante surto de tifo exantemático $^{14}$. A eclosão da pneumónica teve início já em agosto, atingindo o seu auge no mês de outubro. Somente em novembro a pandemia começou a regredir.

Calculados os grupos de idades afetados pela gripe espanhola no concelho de V. N. Cerveira (Figura 15), concluímos que foram as faixas etárias das crianças menores de 23 meses $(20,18 \%)$, dos jovens até aos 19 anos $(25,69 \%)$ e dos adultos até aos 39 anos (17,43\%), as mais atingidas. A Figura 16 revela que, durante o período de crise pandémica (agosto-novembro), a idade média ao óbito desceu para os 35,5 anos, por comparação com os anos enquadrantes, com valores, respetivamente, de 57,4 e 45,7 anos.

Do território cerveirense, a sede concelhia, a freguesia central do território (Candemil) e a freguesia de Sopo (com grande mobilidade de trabalhadores) foram os espaços mais afetados pela pandemia. Com média intensidade, podemos referir todo o núcleo de paróquias que rodeiam V. N. Cerveira e,

14 AMVNC, Jornal Echos de Cerveira, no 172,10 de agosto de 1919. Alastra neste concelho a peste, e grande numero de baixas tem produzido já, achando-se varias pessoas doentes e outras queixando-se bastante de dores no ventre, onde a moléstia parece começar por atacalas. 
Fig. 16 - Idade média ao óbito durante a crise pandémica

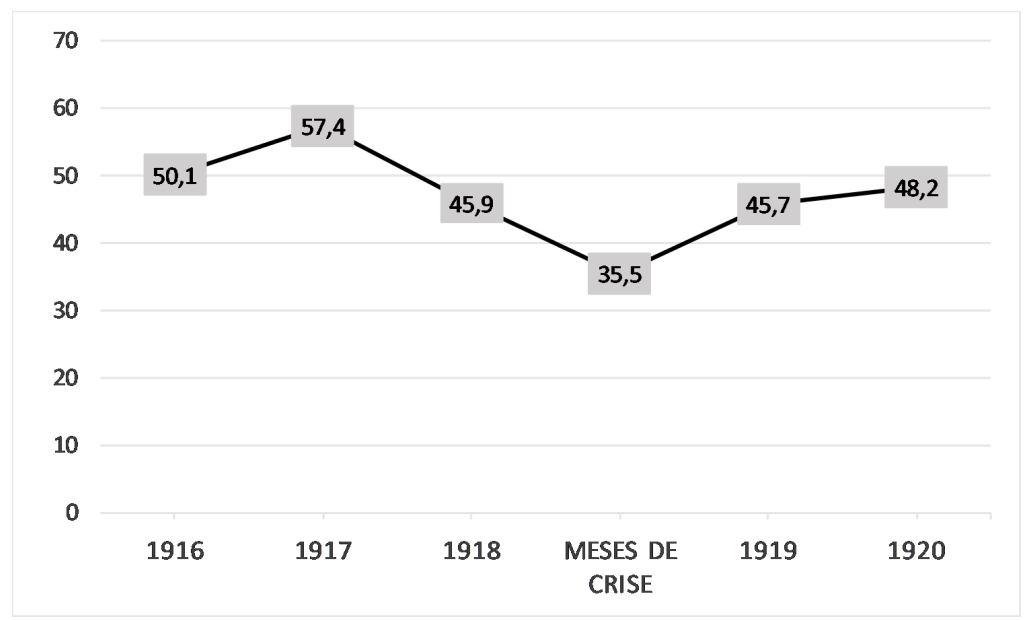

Fonte: Extratos e registos paroquiais de óbitos de V. N. de Cerveira.

de baixa ou nenhuma intensidade, as pequenas paróquias mais afastadas e isoladas.

A informação proveniente da documentação municipal, cruzada com os conteúdos do jornal local ${ }^{15}$ revela, no seu conjunto, o cenário dramático vivido neste concelho. Com a seca prolongada no ano de 1918, a produção agrícola de cereais foi ruinosa, nem escapando a ela as fruteiras. Adivinhava-se fome e, apesar das ordens dadas pelo Administrador do Concelho aos lavradores no sentido de, conforme os termos legais, entregarem os excedentes para o celeiro municipal, elas não foram cumpridas na generalidade. Em vão se procurava controlar a laboração e produção dos moinhos, implementar o manifesto da mostarda e linhaça ou a tabelagem dos preços dos bens essenciais. O celeiro foi por várias vezes fechado por falta de grão e reorganizado. A aplicação de multas aos produtores devido ao açambarcamento de cereais, especulação de preços, escoamento de farinhas e de gado para fora do concelho e para a Galiza, foram uma constante ao longo do período pandémico. Perante a falta de subsistências, a população recorria à prática da caça ilegal para dar de comer às famílias. Matadouros, armazéns e lojas diversas foram assaltados várias vezes. A segurança pública era praticamente inexistente, uma vez que só existia uma praça para todo o concelho e esta se lamentava que a Câmara

15 AMVNC, Fundo da Misericórdia; Comissão Executiva: Correspondência recebida e Expedida (Cotas 1.22.6.3-2, 1.31.2-2, 1.32.1.1-7, 1.32.1.1-3, 1.52.5.11, 1.52.4.3, 1.52.6.22, 1.53.5.3); Tabelas de Cereais (cotas 1.29.6.1-1, 1.34.4.1); Atas das Sessões (cotas 1.1.2.20, 1.1.2.21); Jornal Echos de Cerveira, anos de 1918-1919. 
só havia guarnecido (à falta de petróleo) uma vela de estearina, por noite, para o quartel, insuficiente para manter a ordem noturna.

A distribuição de bens, numa primeira fase, foi fortemente criticada, devido à arbitrariedade na entrega às diferentes freguesias, em particular, do açúcar para medicamentos aos epidemiados. Esta situação ocasionou vários desacatos em diferentes freguesias. No caso da freguesia de Candemil (a segunda mais afetada), a 2 de setembro existiam já 33 fogos com doentes em número variável (entre 2 a 9 familiares).

Numa segunda fase, foram afixados e lidos nas igrejas editais para a entrega de senhas de consumo e guias de trânsito, cujos termos não eram compreendidos pela maioria dos regedores e da população em geral, apesar da imprensa regional informar, em dimensão apreciável e, desde a primeira hora, da pandemia que se aproximava e se expandia.

Em plena fase de expansão - inícios de outubro - foram cancelados eventos que propiciassem a aglomeração de pessoas, tais como inspeções militares e atividades religiosas, decretando-se o imediato encerramento das escolas a 10 de outubro. O número de comboios em circulação diminuiu, ocasionando reclamações nos vários concelhos.

Em 12 de setembro, o barqueiro foi impedido de atracar em terras galegas, devido à gravidade da gripe nas margens portuguesas, encerrando os serviços de transporte a 28 do mesmo mês. O jornal Echos de Cerveira já tinha advertido para esta eventualidade:

Consta-nos que agora quem quizer passar para Hespanha há de apresentar-se engravatado. Dizem mais que é por causa da epidemia que por cá grassa. Ahi teem os snrs. medicos: havendo epidemia, gravata ao pescoço e ... cura certa. Já se póde, pois, visitar os «limpos galegos».

Porém, quando a 12 de novembro retrocedia a intensidade gripal em V. N. Cerveira, a Administração do Concelho pedia providências ao Governador Civil para que agora não deixasse entrar indivíduos da Galiza, onde grassava fortemente a gripe.

Ao que tudo indica, foi o jornal Echos de Cerveira que primeiro comunicou a aproximação da pandemia. Foi também pioneiro quando, no dia 20 de outubro, apresentou um extenso artigo que estabelecia comparações entre a pandemia atual e a pandemia de 1889-1890. No dia 1 de setembro, pode ler-se: «Grassa n'esta villa e concelho uma terrível epidemia que já tem feito algumas victimas». Pouco depois, noutro artigo:

Uma doença mysteriosa e traiçoeira que por ahi chamam vulgarmente "gripepneumonica», mas que deixa logar a duvidas cruéis pelos seus variados symptomas e pelos seus estragos muitas vezes quasi fulminantes, invadiu a maior 
parte do nosso paiz, fazendo victimas aos milhares. Quasi que não há domicilio nas cidades e aldeias que não tenha sido acommettido por essa moléstia estranha e indefinida que diariamente ceifa tantas pessoas no vigor da existência.

Como principais causas da precocidade da incidência da pneumónica neste concelho, podemos destacar: a constante ida e vinda de militares da Grande Guerra, o frequente estacionamento de tropas em passagens regulares entre os quartéis de Viana do Castelo e de Valença (incluindo doentes para tratamento nos hospitais militares) ${ }^{16}$, a desorganização das instituições (que ocasionou, em plena pandemia, exonerações e eleições de chefias, por exemplo), a existência de apenas dois médicos para todo o concelho, bem como a proximidade com a fronteira galega.

\section{INCIDÊNCIA DA GRIPE ESPANHOLA NO CONCELHO DE PAREDES DE COURA}

O concelho de Paredes de Coura ocupa geograficamente uma posição central no distrito de Viana do Castelo. Confina a norte com o concelho de Monção, a noroeste com o de Valença, a sul com o de Ponte de Lima, a leste com o de Arcos de Valdevez e a oeste com o de Vila Nova de Cerveira. No plano administrativo, o território municipal agrega 21 freguesias distribuídas pelos vales e encostas dos seus montes, atravessados pela rede hidrográfica que parte do rio Coura e se multiplica em afluentes, ribeiros, regatos e fontes (Figura 17).

Em 1909, Narcizo Alves da Cunha informava que «(...) o clima, frio no Inverno, é benéfico e saudável (...)» e que «(...) moléstias endémicas de carácter grave, não têm aparecido senão as febres tifoides em 1856 que não ultrapassaram os limites da freguesia de Formariz; e uma vez ou outra, a varíola que, em geral, não tem feito estragos sensíveis (...)» (Cunha, 1979: 27).

Por outro lado, dos poucos casos de tuberculose identificados até ao início do século XX, o maior número teria sido contraído fora da localidade por indivíduos que daí «(...) saíam e depois regressavam, contaminados, ao seio das suas famílias $(\ldots){ }^{17}$.

\footnotetext{
16 «A pandemia foi identificada pela primeira vez em acampamentos de treinos de militares, no Kansas, EUA. A deslocação de tropas para a Europa teria propiciado o seu contágio. Mais recentemente, foram apontadas outras origens possíveis em contexto da guerra» (GEORGE, (s/d): 5).

17 AMPC, Jornal A Voz de Coura, 1905-05-13, citado por (Cunha, 1979: 27)
} 
Fig. 17 - Mapa do concelho de Paredes de Coura

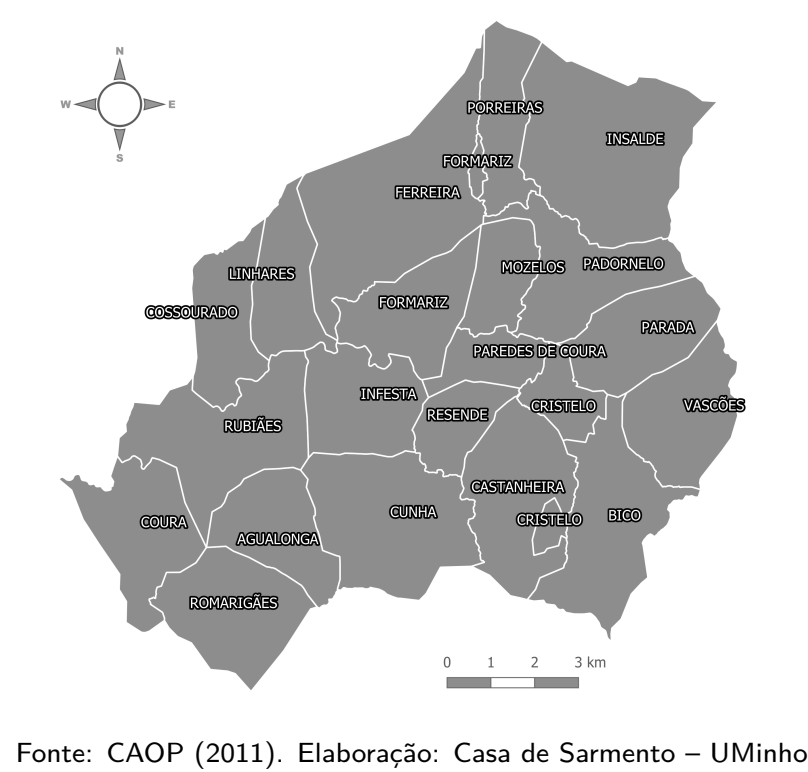

A análise do ciclo da gripe pneumónica neste município assentou, essencialmente, nos dados fornecidos pelos registos paroquiais de óbito, produzidos em cada uma das suas freguesias entre os anos de 1916 e 1920. Para a contextualização dos impactos causados pela epidemia, e sendo desconhecida para este período qualquer documentação sobre a evolução do fenómeno, emanada quer do Hospital da Misericórdia quer da Câmara municipal, recorremos às sucessivas informações veiculadas pela imprensa local em cruzamento com os resultados estatísticos obtidos através das fontes paroquiais.

O movimento anual dos óbitos observado ao longo de um quinquénio (Figura 18) revela claramente uma excecional elevação do volume de mortes nos meses de outubro e novembro de 1918, correspondendo aos momentos mais gravosos e de propagação generalizada.

Conforme noticiado a 5 de outubro desse ano pelo jornal local $A$ Voz de Coura, a gripe viral já se expandia em todo o norte do país, registando-se apenas alguns casos no concelho de Paredes de Coura. A explicação para esta entrada mais tardia terá seguramente resultado do grande isolamento das suas populações, geograficamente afastadas da orla litoral onde as comunidades marítimas que aí residiam se encontravam particularmente expostas a contágio, induzido pela mobilidade profissional dos homens do mar que exi- 
Fig. 18 - Movimento de óbitos no concelho de Paredes de Coura

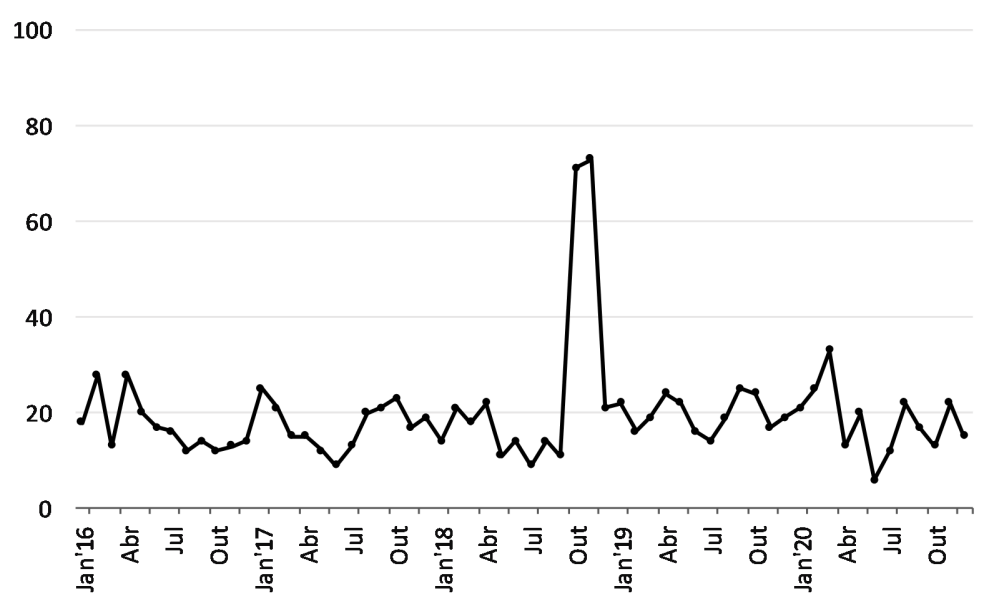

Fonte: Registos paroquiais de óbitos de Paredes de Coura.

gia permanentes contactos com as localidades costeiras da vizinha Espanha, um dos principais focos de propagação da epidemia na região.

Uma notícia do mesmo jornal, publicada em 26 de outubro, referia então que $«(. .$.$) a epidemia continua atirando com uns para a cama e com outros$ para o coval. Os casos aumentam e os óbitos são diários. Luta-se com a falta de médicos e medicamentos. A mortalidade pelas aldeias tem sido maior devido talvez ao pouco cuidado e falta de limpeza (...)». Informava também que, nesta data, as «(...) freguesias mais atacadas são Paredes Mozelos, Padornelo, Vascões, Parada, Bico, Rubiães e Ferreira (...)» ${ }^{18}$.

Após o pico de gripe, que culminou no mês de novembro, seria noticiado em 7 de dezembro, que «(...) a nossa terra com ser salubre, padeceu, e muito, com o flagelo: freguesias houve em que as vitimas foram a esmo. Agora a maldita vai-se e fica-se a gente a recordar tanto e tanto vulto amigo levado naqueles dias negros da epidemia $(. ..) »^{19}$. Ainda assim, o mesmo jornal viria a informar em 28 de dezembro ${ }^{20}$ que a epidemia continuava a atingir duas paróquias do concelho (Cunha e Cossourado), ainda que com menor intensidade. Estas são duas freguesias periféricas, a primeira confinando com

\footnotetext{
18 Jornal A Voz de Coura, 1918-10-26, citado por Narciso C. Alves Cunha (1979: 28).

19 AMPC, Jornal A Voz de Coura, 1918-12-07.

20 AMPC, Jornal A Voz de Coura, 1918-12-28.
} 
o concelho de Ponte de Lima, e a segunda situada nos limites dos concelhos de Valença e Vila Nova de Cerveira.

Fig. 19 - Óbitos segundo os grupos de idade

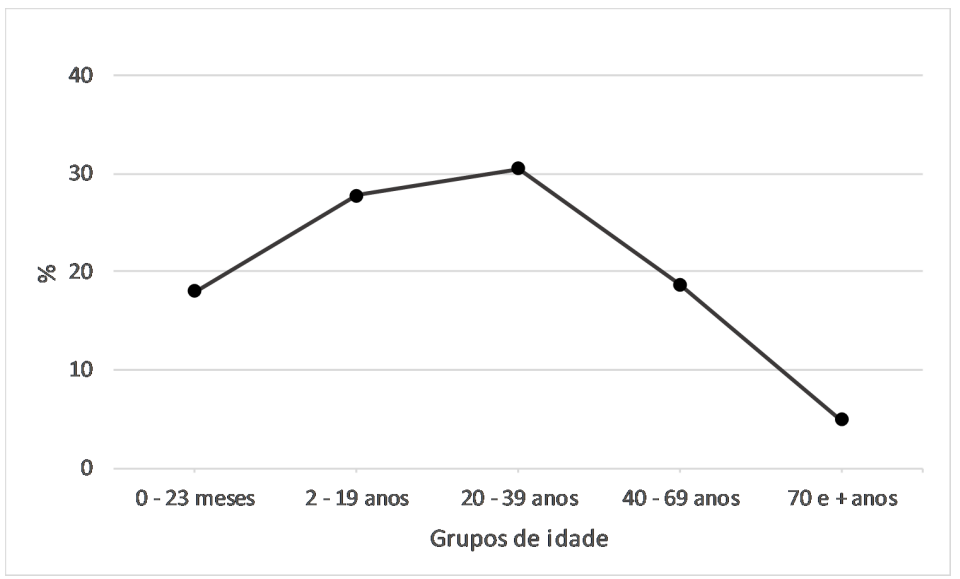

Fonte: Registos paroquiais de óbitos de Paredes de Coura.

Fig. 20 - Idade média ao óbito durante a crise pandémica

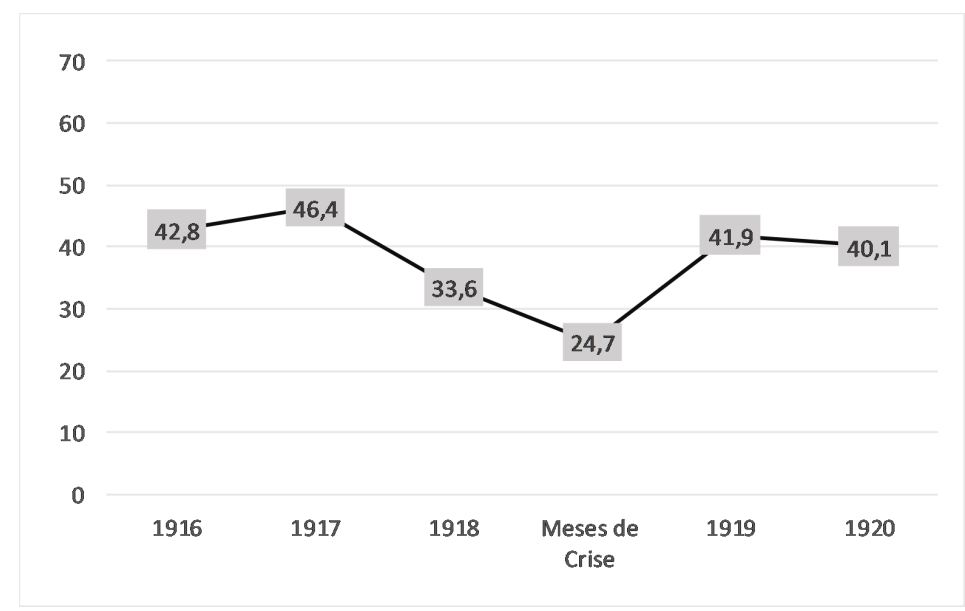

Fonte: Registos paroquiais de óbitos de Paredes de Coura.

Visando avaliar o impacto da mortalidade causada pela gripe pneumónica nos diferentes grupos de idade, isolámos os casos de indivíduos que faleceram no conjunto das freguesias do concelho durante os meses de crise. Os resultados obtidos, expressos na Figura 19, indicam que a faixa etária mais atingida teria sido a dos adultos com idades compreendidas entre os 
20 e os 39 anos (30,5\%), seguida de perto pelo grupo de crianças e jovens adultos com idades entre os 2 e os 19 anos (27,6\%). Por outro lado, o peso relativo de mortes registadas durante a fase crítica de incidência viral assumiu valores muito próximos no grupo de recém-nascidos e crianças até aos 23 meses $(18,2 \%)$ e no de adultos com idades entre 40 e 69 anos $(18,8 \%)$, correspondendo estes dois últimos grupos a uma percentagem acumulada de $37 \%$. Para esta distribuição teria decisivamente contribuído a permanente exposição a contágio que prevalecia no seio dos agregados domésticos, induzida por deficientes condições de habitabilidade e higiene que maximizavam, na generalidade das famílias, os riscos de contaminação junto dos elementos mais jovens.

A título ilustrativo e com base no cruzamento da informação retirada dos registos de óbito com as notícias que foram publicadas no jornal A Voz de Coura durante os meses de crise, retiramos os seguintes casos:

- Em 13 de outubro de 1918, faleceram, na freguesia de Infesta, Porfírio Barbosa, solteiro, de 28 anos, e Rosa Cândida Silva, solteira, de 13 anos, ambos irmãos e lhos de Custódio Barbosa e Francisca Luísa Silva.

- Ainda neste mês, em que a gripe alastrou com grande intensidade, faleceram três filhos de Manuel Barreiro e de Antónia Rodrigues no espaço de quatro dias: Delm Barreiro, de 3 anos, António Barreiro, de 5 anos e Rosa Rodrigues Barreiro, de 18 anos de idade.

- Carolina Rosa, mãe solteira, residente na freguesia de Paredes, viu falecer em 27 de novembro a sua filha Maria das Dores, de 4 anos de idade e, no dia seguinte, o seu filho Domingos da Rocha, de 7 anos.

Como seria previsível neste contexto depressivo, a idade média ao óbito calculada para o conjunto das freguesias do concelho durante os meses de crise (Figura 20) acusou uma queda significativa, caindo até aos 24,7 anos, por influência da intensa mortalidade registada na população com idade inferior a 40 anos. Esta tendência foi igualmente assinalada nos restantes territórios em análise, correspondendo a idades médias ao óbito que variaram entre 36,6 anos na cidade de Viana do Castelo, 36,1 anos em Caminha e 35,5 anos em Vila Nova de Cerveira, valores que seguramente refletem a especificidade das respetivas estruturas populacionais. 


\section{NOTAS FINAIS}

A pandemia manifestou-se primeiramente no concelho ribeirinho de $\mathrm{V}$. N. de Cerveira, já durante o mês de agosto, com uma intensidade média. No mês seguinte, já assumia o mesmo grau na cidade de Viana do Castelo e registava-se também no concelho de Caminha. Durante o mês de outubro, apresentou intensidade forte nos quatro territórios, decaindo durante o mês de novembro, à exceção do concelho de Paredes de Coura, onde a sua intensidade se prolongou até final desse mês. Durante o mês de dezembro os efeitos da gripe tenderam a extinguir-se nos quatro municípios.

A pandemia alastrou-se das frentes marítima e ribeirinha para a região interior atingindo mais tardiamente as populações de Paredes de Coura. Verificámos igualmente que, no concelho de Caminha, a epidemia cavalgou das freguesias do litoral para as freguesias de segunda linha dos vales do Âncora e do Coura, deixando incólumes as freguesias serranas e mais isoladas. No concelho de V. N. de Cerveira o seu epicentro registou-se na sede concelhia, virada à Galiza. De qualquer forma, seja no meio urbano seja no meio rural, a gripe atingiu os quatro territórios analisados, chegando, porém, mais tardiamente às zonas rurais interiores.

Comparando a incidência dos óbitos segundo os grupos de idade, tornase evidente a semelhança de comportamentos em todos os territórios, isto é, uma forte incidência nos recém-nascidos até aos 23 meses e nas faixas etárias seguintes até aos 39 anos. A forte mortalidade registada entre as faixas etárias jovens e entre famílias em reprodução conduziu necessariamente à descida das taxas de natalidade e de fertilidade, que justificam a estagnação populacional no aludido Recenseamento de 1920.

Podemos concluir que a pandemia da gripe espanhola se abateu, de forma geral, sobre uma população faminta, maioritariamente analfabeta, nela se destacando as famílias numerosas que viviam em condições de habitabilidade, higiene e salubridade precárias. Quando as instâncias burocráticas de saúde reagiram, a pandemia encontrava-se já fora de controlo. 


\section{Fontes manuscritas:}

\section{Cidade de Viana do Castelo}

Cartórios Paroquiais, Registos paroquiais de óbitos.

ADVCT, Fundo da Misericórdia de Viana do Castelo, Livro dos Mortos.

\section{Concelho de Caminha}

Cartórios Paroquiais, Registos paroquiais de batismos e de óbitos.

ADVCT, Fundo da Misericórdia de Caminha: Livros de entradas de doentes; Correspondência expedida.

AMC, Comissão angariadora de donativos, Relatório dos seus trabalhos desde 15 de Outubro de 1918 a 14 de Dezembro do mesmo ano.

\section{Concelho de Vila Nova de Cerveira}

Cartórios Paroquiais, Registos paroquiais de batismos e de óbitos.

AMVNC, Atas das Sessões da Câmara; Administração do Concelho; Tabelas dos preços de Cereais.

AMVNC, Fundo da Misericórdia; Comissão Executiva: Correspondência recebida e Expedida.

\section{Concelho de Paredes de Coura}

AMPCR, Registos paroquiais de óbitos de Paredes de Coura (1916-1918), consultados no Arquivo Municipal de Paredes de Coura mediante empréstimo dos párocos das freguesias do concelho.

\section{Fontes impressas:}

AMPCR, Colecção de jornais de Paredes de Coura.

A Aurora do Lima (1918). Biblioteca Municipal de Viana do Castelo.

Correio de Caminha (1918). Coleção particular.

Echos de Cerveira (1918-1919). Coleção particular.

INE, Recenseamentos nacionais portugueses. 


\section{Bibliografia}

AMORIM, Maria Norberta (1991). Uma metodologia de Reconstituição de Paróquias desenvolvida sobre registos paroquiais portugueses. Boletín de la Asociación de Demografía Histórica, IX, 1, pp. 7-25.

CUNHA, Narcizo C. Alves (1979). No Alto Minho Paredes de Coura. Câmara Municipal de Paredes de Coura.

DIAS, Domingos José (1919). A Pandemia Gripal. Tese de Doutoramento, Faculdade de Medicina do Porto. Ed. Autor, V. N. de Famalicão.

GEORGE, Francisco (s/d). A Pneumónica. Acedido a 23/02/219, em http://www.dossie rdelutas.pt/category/textos-do-autor

FRADA, João (2005). A Gripe Pneumónica em Portugal Continental - 1918. Sete Caminhos.

FRADA, João (2010). Pandemias de gripe A (H1N1) em Portugal, 1918-2009. Ecos e cismas do passado no presente. Edições Clinfontur, Lisboa.

REGO, Aurora Botão (2013). De Santa Marinha de Gontinhães a Vila Praia de Âncora (1624-1924). Demografia, Sociedade e Família. Junta de Freguesia de V.P. Âncora, Vila Praia de Âncora.

REGO, Aurora Botão (2015). Impacto da pneumónica no concelho de Caminha, in Pereira et alli (coord.). A Grande Guerra (1914-1918): Problemáticas e Representações. Citcem, Faculdade de Letras da Universidade do Porto, Porto.

RODRIGUES, Alexandre H. S. (1978). Traços biográficos do Dr. Luís Inocêncio Ramos Pereira e de seu Pai José Bento Ramos Pereira. Gráfica da Casa dos Rapazes, Viana do Castelo.

SOUSA, Paulo Silveira e; CASTRO, Paula; LIMA, Maria Luísa; SOBRAL, José Manuel (2008). Responder à epidemia: estado e sociedade civil no combate à gripe pneumónica (19181919). Revista da História das Ideias, 29, pp. 469-500. Acedido a 23/02/2019, em http s://doi.org./10.14195/2183-8925\_29\_17 



\section{O PAPEl DA AdministraçÃo LocAl PERANTE A GRIPE EsPANHOLA:}

AS AUTORIDADES DE BRAGA EM ACÇÃO (1918-1919)

Marcos Filipe da Costa Mesquita ${ }^{1}$

1 marcos91meskita@gmail.com 



\begin{abstract}
Resumo
A epidemia da gripe espanhola assolou o mundo, Portugal, e, a nível local, a cidade de Braga. O presente artigo pretende demonstrar, em linhas gerais, como a administração local bracarense reagiu e actuou perante a epidemia da pneumónica, à luz da noção de saúde pública e das políticas sanitárias implementadas pela burocracia de Estado.
\end{abstract}

Palavras-chave: administração, saúde pública, higienismo, epidemias.

\title{
INTRODUÇÃO
}

No ano de 1918, o mundo conheceu a epidemia da gripe pneumónica, que vitimou milhares de pessoas. Portugal não foi excepção. Neste trabalho, procura-se verificar a nível local, na cidade de Braga, como as autoridades conseguiram combater esta epidemia, isto é, no contacto mais próximo com a população. Porém, Braga não conheceu apenas a gripe pneumónica, debateuse ainda com outros flagelos, nomeadamente o tifo exantemático (1918-19) e a varíola (1919). A reacção das autoridades demonstra a capacidade que um país tem para, de maneira colectiva, realizar esforços, envolver e mobilizar meios e recursos para fazer face a tais flagelos. Contudo, como se verá, o desempenho das autoridades em Braga assemelha-se ao manifestado em tantas outras localidades, em que as medidas de combate não passaram de recomendações que pouca eficácia tiveram para conter o mal, deixando a população entregue a si própria. 


\section{A CONSTRUÇÃO DA SANIDADE: REFLEXÃO DA NORMA SOCIAL E COMPORTAMENTAL OPERADA PELO ESTADO}

A consciência do o corpo e de que este é perecível traduz-se uma percepção pertencente à racionalidade humana. Por isso, o ser humano começou a considerar a forma de atingir um equilíbrio, isto é, de tornar o seu corpo são. Porém, é preciso, antes de tudo, separar dois elementos que dizem respeito à saúde dos indivíduos: por um lado, políticas de saúde pública, sendo estas relativas à higiene, ou seja, toda a concepção de ideias ligadas à sanidade, à qualidade de tornar o indivíduo são através de medidas médicas preventivas num dado prazo (curto, médio ou longo); por outro lado, a assistência na saúde, a qual está associada aos cuidados do indivíduo quando este já está numa fase de doença, pretendendo recuperá-lo ou acompanhá-lo até à sua morte. No período em estudo, o ano de 1918, ainda prevalece uma assistência na saúde de cariz caritativo, herdada do século XIX e que se prolonga no século XX, vocacionada para cuidar dos doentes pobres e indigentes (Lopes, 1998: 433-434; Campos, 2000: 406; Sobral et al., 2009: 66). A assistência hospitalar estava entregue, sobretudo, às Misericórdias e a outras instituições filantrópicas, evidenciando o alheamento do Estado na prestação de cuidados de saúde médicos, além dos preventivos (Sobral et al., 2009: 66).

A bibliografia da especialidade tem vindo a clarificar o modo como o sano (tempo verbal) se tornou uma preocupação da consciência colectiva das sociedades em matéria de saúde, a qual influenciou e controlou a esfera privada da vida, criando condições para um estado de boa saúde. Pelo que não é um assunto novo. Mas, contudo, convém sempre tecer as ideias de força que a mesma elucida. É possível constatar, antes de mais, que a consciência da saúde é uma construção histórica com raízes ainda muito ténues, associadas à «revolução» da ciência e à sua difusão pela Europa das Luzes (Chaunu, 1985). Por exemplo, João Cosme recorda dois médicos, respectivamente, António Ribeiro Sanches, que, no século XVIII, disserta sobre a importância da "conservação dos povos», propondo um modelo de organização espacial das cidades e a respectiva limpeza (Cf. Cosme, 2014: 47), e José Pinheiro de Freitas, que,no século XIX, XIX, propõe a instituição de uma polícia médica (Cosme, 2014: 48). Ambos refletiram sobre a regeneração do indivíduo, verificando que a sua saúde beneficiaria muito mais se se constituíssem meios capazes de a assegurar como um bem comum. Outros autores desenvolveram as mesmas premissas e conseguiram ir mais longe, nomeadamente José Gouveia Osório e Ricardo Jorge, os quais (e principalmente este último) arquitectaram, através de modelos científicos, os princípios que a so- 
ciedade portuguesa deveria seguir para criar uma saúde pública baseada nas políticas sanitárias ou de higiene (Alves e Carneiro, 2014: 29-40).

Este ideal de saúde pública aparece na sociedade contemporânea mais associado à esfera colectiva do que à privada, tornando-se «um cuidado social afigurado pelo Estado» (Neves, 2010: 21). Esta apropriação é uma herança histórica que foi evoluindo ao longo de séculos e que permitiu implementar normas de medicina preventiva que foram sendo testadas, como, por exemplo, a disseminação de vacinas, a proibição dos enterramentos nas igrejas, a fiscalização sanitária em diversos estabelecimentos (comerciais, industriais), inspecções, vigilância, limpezas das ruas, salubridade dos edifícios, entre outras (Alves; Carneiro, 2011: 34 e 44; Lopes, 1998: 434; Almeida, 2017: 70; Campos, 2000: 406). Esta construção só pôde ter viabilidade prática através da força de lei, da sistematização do Direito. Ao Estado, coube, cada vez mais, atribuir determinadas funções (Bourdieu, 2014: 248-249), tal como a certificação médica, em que, para desenvolver a prática da medicina, era necessário adquirir determinados conhecimentos, ratificados e concedidos por uma organização superior (Alves; Carneiro, 2011: 34), ou a produção medicamentosa, em que o Estado passa a gerir, regulamentar e vigiar os moldes em que a sua produção deveria ser feita (Sousa et al., 2014: 11-26).

À medida que o Estado Moderno alargou a sistematização através da universalização e norma prefigurados no Direito, com a acumulação de capital social e ascensão dos médicos associada aos avanços científico-tecnológicos da Ciência, a noção de saúde pública torna-se o corolário da afirmação do Estado enquanto entidade abstracta capaz de gerir a sociedade. A saúde politizou-se e passou a encarar a população como um objecto de estudo, tendo em vista a transformação da biologia humana, utilizando para isso as novas práticas científicas que começavam a institucionalizar-se (Alves e Carneiro, 2011: 40-42; Hobsbawm, 2001: 284-287). Como avança Jorge Fernandes Alves e Mariana Carneiro, ao Estado, em nome da medicina e na sobreposição do colectivo sobre o individual, compete:

(...) disciplinar o corpo social, codificar conceitos e práticas na área da saúde pública, instituir a organização burocrática», no sentido weberiano, para atingir eficiência e afirmar a superioridade técnico-científica, centralizando a autoridade e definindo regras claras através de legislação com a qual se controla o sistema, que deverá ser dotado financeiramente para garantir os diversos tipos de encargos (Alves; Carneiro, 2014: 27). 


\section{DISCURSO HIGIENISTA E PREOCUPAÇÃO COM A SAÚDE PÚBLICA EM BRAGA}

Se se traçar um quadro geral da saúde pública de Braga, em 1918, verifica-se que havia situações problemáticas ao nível das políticas públicas e higienização, atuando a Câmara Municipal como podia dentro dos seus parcos recursos(Echos do Minho, 13 de Agosto de 1918: 2). Estes eram transversais às epidemias do tifo exantemático e da pneumónica. Durante o período do tifo exantemático, o bairro de Guadalupe e a prisão eram casos que preocupavam tanto o Delegado de Saúde como o Administrador da Câmara Municipal, uma vez que eram locais propícios à germinação e proliferação de epidemias. O Delegado de Saúde, ao caracterizar o bairro de Guadalupe, salienta mesmo as «condições anti-hygienicas e porque é um ponto assás vulneravel á epedemia» (Echos do Minho, 13 de Agosto de 1918: 2).

Durante o mês de Outubro, Vicente Braga alude e difunde a consciência da «Saúde Pública» como um problema colectivo, para além de salientar as carências da administração política em matéria de sanidade da cidade:

Nós não temos saneamento; a limpeza municipal deixa muito a desejar, havendo ruas onde raras vezes passa a vassoura e para onde creaturas ignorantes do mal que podem causar lançam toda a sorte detrictos; casas ha, onde as fossas sao outros tantos focos epidemicos, pela sua pessima construcção, e onde os canos de exgoto, por falta de isolamento conveniente, exhalam um cheiro pestilento; dentro da cidade, e a dois passos dos predios, ainda se véem cortelhos de suínos; e a lavagem da via publica, nos dias ardentes de estio, é feita de modo a deixar muito a desejar (Commercio do Minho, 20 de Outubro de 1918: 1).

Além de destacar a incapacidade da administração municipal em criar estruturas eficazes para eliminar a insalubridade da cidade, Vicente Braga faz também observações com um sentido profiláctico. Em primeiro lugar, apela à observação, por parte da população, das medidas emanadas pelas autoridades, de maneira a irem ao encontro da saúde pública, num sentido de dever colectivo, independentemente da classe social. Expõe o comportamento sistemático de lançar detritos para o espaço público, pelo perigo que representam. Por fim, sendo mais objectivo, insiste no cuidado da «hygiene particular» como sendo um dever público:

Se a hora que passa, apavoreia, cumpra cada um o seu dever, velando pela hygiene particular e contribuindo com a sua quota de esforço para que não seja descurada a hygiene publica (Commercio do Minho, 20 de Outubro de 1918: $1)$.

Em suma, embora estas duas epidemias tenham diferentes formas de proliferação, o certo é que, tanto durante o período do tifo como no período 
da pneumónica, as bases para uma boa higiene pública faltavam em Braga e a Administração pouco poderia oferecer de melhor, visto que os apoios financeiros eram escassos (Echos do Minho, 13 de Agosto de 1918: 2). Além do mais, verifica-se que as práticas da higiene não estavam enraizadas na população, o que criava um círculo vicioso. As autoridades não tinham meios para combater as variadas formas de proliferação de doenças e os próprios comportamentos da população não eram permeáveis às determinações da autoridade neste domínio. Com efeito, os hábitos da população eram um obstáculo à implementação e normalização das medidas sanitárias propostas pelas autoridades, ainda que diminutas, como afirma o administrador da Câmara:

Que a respeito de limpeza na cidade reconhece que ainda falta tambem, que se lhe não importa ver as ruas com a erva crescer. O que lhe repulsa é ver detrictos por toda a parte e especialmente por saber culpados os proprios moradores negligentes. Que todos nós, municipes, devíamos ser a policia do nosso visinho, obrigando nos mutuamente á mais estricta observancia da hygiene; limpando as fronteiras das nossas casas, impulsionando se assim a limpeza geral. E que nós os bracarenses, como afinal todos os portuguezes, só sabems criticar e nada mais (Echos do Minho, 13 de Agosto de 1918: 2).

Perante o flagelo da gripe, as carências em matéria de saúde pública originam apelos constantes. No início de Outubro, quando a gripe ainda não oferecia motivos para preocupações de maior em Braga, apelava-se à acção das autoridades de maneira a conter a epidemia logo no seu início (Echos do Minho, 3 de Outubro de 1918: 2). Num primeiro momento, e apesar da inoperância das autoridades responsáveis, vão surgindo elogios no combate à gripe, caracterizando-se as medidas adotadas como «acertadas e beneficas». No entanto, estas medidas não são eficazes, pois a epidemia «vae seguindo impavidamente a sua marcha assoladora» (Echos do Minho, 13 de Outubro de 1918: 2$)^{2}$.

2 Apesar de não haver mais dados que possam ratificar e clarificar a situação sanitária da cidade e restante concelho de Braga, não deixa de ser necessário fazer uma advertência. Vicente Braga escreve o seu artigo de opinião no jornal Commercio do Minho, dando o quadro de fundo já referido. O jornal Echos do Minho, apesar de considerar a pneumónica como um flagelo, é mais contido. Em suma, esta diferença das observações sobre a gripe pode estar relacionada com a defesa da conjuntura política da época em Portugal. Como se sabe, neste ano, Portugal estava sob a presidência de Sidónio Pais, em que este reformulou a acção e estrutura da República e aproximou-se de alguns sectores da sociedade até aí colocados à margem como, por exemplo, a Igreja Católica (Ramos, 2001). O jornal Echos do Minho era um periódico católico, regionalista, sidonista e monárquico (Lemos e Vargues, 2006: 323) e, quando noticia uma acta da Câmara Municipal, verifica-se que a administração camarária é afecta à conjuntura política (Echos do Minho, 20 de Outubro de 1918: 1). Com efeito, poderá ficar mais clara esta atitude perante a acção das autoridades. 


\section{A EVOLUÇÃO E INSERÇÃO DA PNEUMÓNICA}

Existem três vagas de propagação epidémica: a primeira, mediando entre os meses de Março-Junho, com mortalidade baixa, benigna e rápida proliferação; a segunda medeia entre Agosto e Dezembro, a mais mortífera das três vagas e de maior propagação, com maior mortalidade nos meses de Outubro e Novembro; e, finalmente, a terceira, que vai desde os inícios do ano de 1919 até, sensivelmente, Maio, sendo já pouco mortífera (Porras Gallo, 1996: 77-78; Killingray, 2009: 45-46; Sobral et al., 2009: 70-71).

A epidemia da gripe não foi um caso isolado. Na época grassaram outras enfermidades contagiosas, tais como o tifo exantemático, a varíola, a febre tifóide e a disenteria (Sobral et al., 2009: 66), como já foi anteriormente adiantado. Em Braga, a situação não foi diferente, no entanto, antes e depois da pneumónica, as doenças que mais se destacavam eram o tifo exantemático e a varíola. No ano de 1918, a primeira liderou o quadro de moléstias até Setembro, recomeçando em 1919 juntamente com a varíola (Commercio do Minho, 6/03/1919: 1; 27/03/1919: 1; Echos do Minho, 15/01/1919: 1; 19/01/1919: 2 ). DDeste modo, os meses de Outubro e Novembro foram os meses de maior incidência epidémica, à semelhança de outras regiões como, por exemplo, o Algarve, em que estes também foram os meses de maior actividade gripal (Girão, 2003: 60-61).

\section{OS PRIMEIROS CONTACTOS COM A PNEUMÓNICA}

Quando o mês de Outubro caiu sobre Braga, o sentimento vivenciado não reflectiu a preocupação que esta epidemia deveria suscitar. Por outras palavras, não se apresentou à população, mesmo nas notícias dos jornais, com o carácter altamente contagioso e mortífero que já ostentava noutras localidades, como em Guimarães, por exemplo, onde o cenário se mostrava, pelo contrário, bastante mais aterrador (Echos do Minho, 3 de Outubro de 1918: 2 e 5 de Outubro de 1918: 3). Apesar de, neste período do ano, o poder central já ter tomado medidas com força de lei, visto que a pneumónica vitimava massivamente a população (Sobral et al., 2009: 77), Braga a tudo assistia passivamente. Esta inactividade poderá ser explicada não pelo facto da epidemia ainda não assumir contornos letais, mas pela falta de cuidados individuais de saúde:

Comquanto benignamente, tem por aqui grassado, como aliás em muitas terras do paiz, a broncopneumonia. E dizemos benignamente porque poucos casos fataes tem havido a lastimar, e esses mesmos, segundo nos dizem, por falta 
de cuidado ou de necessárias precauções, logo desde o começo da doença ou então por complicações internas (Echos do Minho, 3 de Outubro de 1918: 2).

Apesar de, no início do mês, não haver uma preocupação geral, o facto é que rapidamente a conjuntura da epidemia se modificou por completo, assemelhando-se ao flagelo que já se manifestava noutros pontos do país $($ Echos do Minho, 10 de Outubro de 1918: 2; 13 de Outubro de 1918: 2; Commercio do Minho, 13 de Outubro de 1918: 2). Com efeito, o final Outubro já se mostrou bastante desanimador e a passagem da gripe criou uma imagem desoladora através da massificação da morte, deixando marcas demográficas observáveis:

Continuam sendo numerosíssimos os casos da gripe bronco-pneumonica, tanto n'esta cidade como nas aldeias, sendo tambem muito elevada a mortalidade. Desde 1 do corrente registaram-se no cemiterio 260 enterramentos (Commercio do $\mathrm{Mi}$ nho, 27 de Outubro de 1918: 2).

No mês de Novembro, contudo, o cenário já se mostrava mais promissor, com a pneumónica a começar a dar tréguas e os serviços a funcionarem normalmente (Commercio do Minho, 7 de Novembro de 1918: 1). Salientase, a título de exemplo, a abertura das escolas e colégios, os quais estavam fechados desde o início de Outubro (Commercio do Minho, 3 de Outubro de 1918: 1; Echos do Minho, 4 de Outubro de 1918: 1) - em que as proibições à sua abertura começam a ser levantadas devido ao estado de diminuição gripal (Arquivo Distrital de Braga (ADB), Epidemias, Cota $\mathrm{n}^{\mathrm{o}} 1$ a 6: Cota $\mathrm{n}^{\mathrm{o}}$ 5; Commercio do Minho, 7 de Novembro de 1918: 1).

\section{A ACÇÃo DAS AUTORIDADES E A RELAÇÃO COM A PO- PULAÇÃO}

As autoridades administrativas bracarenses não tiveram uma acção diferente da adotada noutros pontos do país, como o Algarve e Lisboa (Girão, 2003: 82-83; Sobral et al., 2009: 86). Ao nível distrital, o Governador Civil, no início de Outubro, apressou-se a apresentar um edital onde reconhecia o carácter mortífero da epidemia, prontificando-se a agilizar a obtenção de automóveis para a mobilização dos médicos e deslocação dos epidemiados - essa requisição era forçada e os proprietários poderiam ser considerados «delinquentes» se se recusassem a cedê-los (Echos do Minho, 13 de Outubro de 1918: 2)-, e a proibir quaisquer eventos que resultassem na aglomeração de pessoas, como as feiras e romarias (Echos do Minho, 8 de Outubro de 1918: 2; Commercio do Minho, 10 de Outubro de 1918: 2). Além do mais, o uso dos automóveis também serviu para deslocar os doentes afectados com a 
gripe (Commercio do Minho, 17 de Outubro de 1918: 2). Juntamente com o Delegado de Saúde, percorreu o distrito com o intuito de verificar o grau de intensidade da pneumónica e fornecer bens consumíveis, tais como açúcar e arroz, medicamentos e roupas (Echos do Minho, 8 de Outubro de 1918: 2; 10 de Outubro de 1918: 2; 11 de Outubro de 1918: 1).

A crise de subsistências vivenciada em Portugal afectava o fornecimento equilibrado de géneros alimentícios como o açúcar, que não chegava para suprimir as necessidades dos doentes. Veja-se, a título de exemplo, uma carta enviada ao Governador Civil de Braga pelo Presidente da Junta de Freguesia de Este (São Pedro) a pedir o fornecimento de açúcar, visto que já havia acabado naquela região, dando conta que o fornecimento se mostrou diminuto, sendo necessário mais açúcar para acudir aos restantes doentes (ADB, Correspondência Geral: anos 1918-1919, 1582316905, pasta 23, folha 16774).

A resposta pública não ficou por aqui: o hospital de tifosos ou do Espírito Santo foi adaptado/improvisado para receber os epidemiados da gripe ${ }^{3}$ (Commercio do Minho, 13 de Outubro de 1918: 2; Sobral et al., 2009: 78-80); suprimiu-se o descanso semanal nas farmácias, ficando abertas em vários pontos da cidade de maneira a fornecerem os medicamentos necessários, dadas «as condições anormaes da saude publica» (Echos do Minho, 20 de Outubro de 1918: 2; 23 de Outubro de 1918: 1); mobilizaram-se enfermeiros militares para auxiliarem no hospital de São Marcos, visto que era recorrente os profissionais adoecerem por se encontrarem em contacto directo com os epidemiados (Commercio do Minho, 13 de Outubro de 1918: 2; 17 de Outubro de 1918: 2; Echos do Minho, 20 de Outubro de 1918: 2; Girão, 2003: 83).

Em alguns casos, as autoridades bracarenses implementaram medidas sanitárias coercivas. Os editais disseminados pelos periódicos davam conta, por exemplo, da obrigatoriedade de «todos os proprietários de hotéis, cafés, restaurantes, casas de pasto, tabernas e outros quaisquer pontos de reuniões a lavarem e desenfectarem os seus estabelecimentos, bem como retretes» (Echos do Minho, 12 de Outubro de 1918: 1), evidenciando-se a absoluta necessidade de uma mudança de comportamentos perante pneumónica, de maneira a

\footnotetext{
3 A adaptação deste hospital para receber os doentes afectados pela pneumónica demonstra a necessidade que as autoridades tiveram de agilizar os meios que tinham ao seu alcance para o combate à epidemia. Todavia, um estudo aprofundado acerca deste hospital poderá dar mais informação sobre os procedimentos levados a cabo para o tratamento dos doentes com a gripe, visto que a sua estrutura estava vocacionada para o tratamento dos infectados pelo tifo exantemático. Assim permanecerá a dúvida se o hospital estaria preparado para receber os doentes infectados pela pneumónica.
} 
combatê-la. Contudo, falta verificar se tais práticas foram atendidas e se se efectuou a respectiva inspecção de controlo.

Em termos de medidas concretas como forma de contenção da propagação da gripe, não se foi mais longe do que evitar a «impureza e viciação» do ar (Echos do Minho, 12 de Outubro de 1918: 2), recomendações que eram indicadas à população de forma generalizada em todo o país(Sobral et al., 2009: 77). A Câmara Municipal mobilizou as corporações de Bombeiros Municipais e Voluntários para procederem à lavagem das ruas e mandou queimar ramagens de eucalipto e pinheiro nos locais públicos(Echos do Minho, 12 de Outubro de 1918: 2; 13 de Outubro de 1918: 2; Commercio do Minho, 13 de Outubro de 1918: 2; 17 de Outubro de 1918: 2). O Delegado de Saúde também reforçou a importância destas práticas e ainda aconselhou a não varrer os detritos domésticos para o exterior, efectuando-se em alternativa uma limpeza com um pano húmido ou embebido em cloreto de cal ou creolina (Echos do Minho, 12 de Outubro de 1918: 2). . Também recomendou que os afectados pela gripe se dirigissem ao hospital do Espírito Santo, de maneira a serem tratados (Echos do Minho, 12 de Outubro de 1918: 2; Commercio do Minho, 13 de Outubro de 1918: 2).

\section{SOCIEDADE E RELIGIÃO}

Em 1918, a prestação de cuidados de saúde em Portugal era ainda bastante incipiente. Quando a pneumónica proliferou, os epidemiados foram socorridos, principalmente, através da beneficência de associações e de subscrições públicas(Girão, 2003: 111). ). Em Braga, houve subscrições lançadas pelo Governador Civil e pela Igreja Católica (Echos do Minho, 31 de Outubro de 1918: 2; 3 de Novembro de 1918: 2).

Tal como em todo o país, a Igreja Católica foi a principal propulsionadora de subscrições para ajudar as vítimas (Commercio do Minho, 31 de Outubro de 1918: 1; Girão, 2003: 111-112). A sua estrutura institucional permitiu mobilizar vários meios, destacando-se a importância dos párocos, na medida em que se encontravam mais próximos da população e tinham maior contacto com os doentes (Echos do Minho, 27 de Outubro de 1918: 2; Commercio do Minho, 31 de Outubro de 1918: 2).

O Arcebispo apelou à oração como remédio perante o flagelo (Echos do Minho, 5 de Outubro de 1918: 1; 10 de Outubro de 1918: 1), pois esta prática era a forma mais eficaz de maneira a ultrapassar a conjuntura que a população estava a experienciar. 
Especialmente as nossas orações se dirigem n'este momento a Deus, a fim de que cesse a epidemia dominante, consequência de tantos erros e crimes, castigo de tantos desvarios, punição de tantos pecados.

Todos se devem compenetrar d'esta verdade, para que, unidos no mesmo espirito de fé, as suas orações possam attrahir sobre nós a misericordia divina (Echos do Minho, 26 de Outubro de 1918: 1).

Incitou ainda ao ajuntamento público, pois a oração só ganharia a sua amplitude no refúgio e massificado espaço sagrado das Igrejas, medida que projectou para três dias (Echos do Minho, 5 de Outubro de 1918: 1).Também foi prática dos párocos acorrerem aos fiéis quando estes se encontravam doentes, sendo, em muitos casos, os seus principais assistentes na falta dos médicos (Echos do Minho, 5 de Outubro de 1918: 1; Girão, 2003: 112; Sobral et al., 2009: 304).

É neste contexto da gripe pneumónica que a Igreja recupera o papel social que havia perdido durante a I República (Sobral et al., 2009: 294). $\mathrm{O}$ apelo à oração e ao ajuntamento são formas de retemperar o sentimento devocional, albergando num ideal de união e espiritualismo uma recompensa comum, a qual só seria permitida pelas «preces publicas» (Echos do Minho, 5 de Outubro de 1918: 1; Sobral et al., 2009: 304). A Igreja apresentavase como o último recurso, um abrigo, a única entidade capaz de acudir à população. Esta instituição não desmerecia a medicina, mas oferecia o reverso da moeda, afirmando que a ciência não era a principal nem a única forma de salvação, que não era somente o médico a curar a doença e que esta se superava através do culto:

Nas horas de afflicção, como as que traz uma doença, doas necessidades sentem o afflictos: a assistencia do medico, para atalhar, se é possível, a marcha do mal; e a assistencia do padre, para socegar as consciencias, o que é um poderosos auxiliar da medicina, o unico remedio, para o espirito, quando a medicina desespera de salvar o corpo (Echos do Minho, 23 de Outubro de 1918: 1).

\section{NOTA CONCLUSIVA}

A Gripe Pneumónica foi um facto consumado em todo o mundo. Pode-se mesmo avançar que a linha que separa a sua propagação às escalas internacional, nacional e local são bastante ténues. Por onde passou, a epidemia causou sempre recuos demográficos. A matéria de estudo deste trabalho não se enquadrou na compreensão das flutuações demográficas. A sua intensão foi trazer à luz da história local, a projecção da epidemia na opinião pública, mais propriamente, o trabalho desenvolvido pelas autoridades no combate à 
mesma. Desta feita, foi possível constatar a inexistência de um sistema de saúde, por um lado, capaz de dar suporte médico aos enfermos e, por outro lado, de um sistema jurídico ou uma agência capaz de coordenar os trabalhos de contenção perante um fenómeno deste género. As acções tiveram, por isso, um cariz meramente caritativo. Assim, este trabalho serve de mote para aprofundar mais estudos relacionados com esta conjuntura em específico. Em primeiro lugar, seria pertinente estudar os orçamentos da câmara e descortinar até que ponto os serviços administrativos, em termos gerais, estavam preocupados com a progressiva necessidade de implementar medidas de higiene pública na cidade. Por exemplo, verificar a permanência de práticas de criação de animais no espaço urbano, as quais punham em risco a saúde pública. Exemplo que, como foi possível observar, na época causou preocupação, na medida em que essas práticas poderiam constituir um foco de variadas epidemias. A somar a isto, seria também interessante realizar um estudo sobre as instituições hospitalares bracarenses, desde a sua organização interna até à sua implementação na comunidade. Neste caso, importaria inventariar os recursos humanos, analisar a organização de serviços e recursos financeiros, assim como o apoio concedido aos doentes, entre outros aspectos. 


\section{Fontes}

\section{Fontes Manuscritas}

Arquivo Distrital de Braga, Correspondência Geral: anos 1918-1919, 15823-16905; Pasta 23; Folha 16774.

ADB, Epidemia; Cota $n^{\circ} 1$ a 6 ; Cota $n^{\circ} 5$.

\section{Fontes Impressas}

Echos do Minho, «Vida de Braga; Camara Municipal», 13 de Agosto de 1918: 2.

Echos do Minho, «Vida de Braga; A bronco-pneumonia», 3 de Outubro de 1918: 2.

Echos do Minho, «Correspondencia; Guimarães», 3 de Outubro de 1918: 2.

Echos do Minho, «Vida de Braga; Collegios de Braga», 4 de Outubro de 1918: 1.

Echos do Minho, «Circular», 5 de Outubro de 1918: 1.

Echos do Minho, «Correspondencia; Guimarães», 5 de Outubro de 1918: 1.

Echos do Minho, «Vida de Braga; A gripe pneumonica», 8 de Outubro de 1918: 2.

Echos do Minho, «A gripe pneumonica», 10 de Outubro de 1918: 2.

Echos do Minho, «Vida de Braga; Grippe pneumonica», 11 de Outubro de 1918: 1.

Echos do Minho, «Vida de Braga; Medidas sanitarias» 12 de Outubro de 1918: 1.

Echos do Minho, «A bronco-pneumonia» 12 de Outubro de 1918: 2.

Echos do Minho, «Vida de Braga; A bronco-pneumonia», 13 de Outubro de 1918: 2.

Echos do Minho, «Vida de Braga; Camara Municipal», 15 de Outubro de 1918: 3.

Echos do Minho, «Vida de Braga; Hospitaes de Braga», 20 de Outubro de 1918: 2.

Echos do Minho, «Padres e medicos/ Para lêr e fazer circular», 23 de Outubro de 1918: 1.

Echos do Minho, «A epidemia reinante», 26 de Outubro de 1918: 1.

Echos do Minho, «Vida de Braga; Assistencia ás victimas da epidemia», 27 de Outubro de 1918: 2.

Echos do Minho, «Vida de Braga; A favor dos epidemiados», 31 de Outubro de 1918: 2.

Echos do Minho, «A favor dos epidemiados», 3 de Novembro de 1918: 2. 
Commercio do Minho, «A Epidemia; Medidas de precaução», 3 de Outubro de 1918: 1.

Commercio do Minho, «A epidemia», 10 de Outubro de 1918: 2.

Commercio do Minho, «A epidemia», 13 de Outubro de 1918: 2.

Commercio do Minho, «A epidemia», 17 de Outubro de 1918: 2.

Commercio do Minho, «A epidemia», 20 de Outubro de 1918: 1.

Commercio do Minho, «A epidemia; Socorros», 31 de Outubro de 1918: 1-2.

Commercio do Minho, «A Epidemia; Seu decrescimento», 7 de Novembro de 1918: 1.

Commercio do Minho, «Saude publica», 6 de Março de 1919: 1.

\section{Bibliografia}

ALVES, Jorge Fernandes; CARNEIRO, Marinha (2011). A Saúde Pública em Portugal. Alguns delineamentos administrativos (da Monarquia à Ditadura Militar), in FERREIRA, Fátima Moura; MENDES, Francisco Azevedo; CAPELA, José Viriato (coord.) (2011). Justiça na Res Publica (Sécs. XIX e XX). Direitos Individuais e Defesa da Sociedade, vol. 2. CITCEM - Centro de Investigação Transdisciplinar «Cultura, Espaço e Memória», Braga, pp. 33-50.

ALVES, Jorge Fernandes; CARNEIRO, Marinha (2014). Saúde Pública e Política do «Código Sanitário» ao regulamento geral de 1901. CEM. Cultura, Espaço e Memória, 5, pp. $27-43$.

BOURDIEU, Pierre (2014). O Poder Simbólico. Edições 70, Lisboa.

CAMPOS, António Correia de (2000). Saúde Pública, in BARRETO, António; MÓNICA, Maria Filomena (coord.) (2000). Dicionário de História de Portugal. Livraria Figueirinhas, Porto, pp. 405-406.

CHAUNU, Pierre (1995). A Civilização da Europa das Luzes. Editorial Estampa, Lisboa.

COSME, João (2014). A Consciência Sanitária em Portugal nos Séculos XVIII-XIX. CEM. Cultura, Espaço e Memória, 5, pp. 45-62.

GIRÃO, Paulo (2003). A Pneumónica no Algarve. Caleidoscópio, Casal de Cambra.

HOBSBAWM, Eric (2001). A Era das Revoluções. Editorial Presença, Lisboa.

KILLINGRAY, David (2009). A pandemia da gripe de 1918-1919: causas, evolução e consequências, in SOBRAL, José Manuel; LIMA, Maria Luísa; CASTRO, Paula; SOUSA, Paulo Silveira (org.). A Pandemia Esquecida: olhares comparados sobre a pneumónica, 1918-1919. Imprensa de Ciências Sociais, Lisboa, pp. 41-62.

LEMOS, Mário Matos; VARGUES, Isabel Nobre (2006). Jornais Diários Portugueses do Século XX: um dicionário. Ariadne Editora, Coimbra. 
LOPES, Maria Antónia (1998). Os Pobres e a Assistência Pública, in MATTOSO, José (dir.). História de Portugal. O Liberalismo, vol. V. Editorial Estampa, Lisboa, pp. 427-437.

NEVES, Lia Raquel Lopes das (2010). A Saúde como Autêntico Problema de Saúde Pública. Dissertação de Mestrado apresentada à Universidade de Coimbra, Coimbra.

PORRAS GALLO, María Isabel (1996). Las Repercusiones de la Pandemia de Gripe de 191819 en la Mortalidad de la Ciudad de Madrid. Boletin de la Asociación de Demografia Histórica, XVI, 1, pp. 75-116.

RAMOS, Rui (coord.), (2001). A Segunda Fundação, in MATTOSO, José (dir.). História de Portugal, vol. VI. Editorial Estampa, Lisboa.

SOBRAL, José Manuel; SOUSA, Paulo Silveira; CASTRO, Paula; LIMA, Maria Luísa (2009). A Igreja e a pneumónica: auto-retrato e interpretações, in SOBRAL, José Manuel; LIMA, Maria Luísa; CASTRO, Paula; SOUSA, Paulo Silveira (org.) (2009). A Pandemia Esquecida: olhares comparados sobre a pneumónica, 1918-1919. Imprensa de Ciências Sociais, Lisboa, pp. 291-312.

SOBRAL, José Manuel; SOUSA, Paulo Silveira; LIMA, Maria Luísa; CASTRO, Paula (2009). Perante a pneumónica: a pandemia e as respostas das autoridades de saúde pública e dos agentes políticos em Portugal, in SOBRAL, José Manuel; LIMA, Maria Luísa; CASTRO, Paula; SOUSA, Paulo Silveira (org.). A Pandemia Esquecida: olhares comparados sobre a pneumónica, 1918-1919. Imprensa de Ciências Sociais, Lisboa, pp. 63-92.

SOUSA, Micaela Figueira de; PITA, João Rui; PEREIRA, Ana Leonor (2014). Farmácia e Medicamentos em Portugal em Meados do Século XX. O papel da comissão reguladora dos produtos químicos e farmacêuticos (1940). CEM. Cultura, Espaço e Memória, 5, p. $11-26$. 


\section{Evocação da Gripe Pneumónica (1918) em Macedo de Cavaleiros:}

NARRATIVA Ficcional E HistóRICA Otília Lage $^{1}$ 



\begin{abstract}
Resumo
A gripe pneumónica ou Gripe Espanhola, por ter vindo de Espanha pela fronteira alentejana, pandemia mortífera associada à I Guerra Mundial, vitimou quase 50 milhões de pessoas no mundo e mais de 50.000 pessoas em Portugal. Logo esquecida, perdurou difusa no imaginário das populações, húmus sócio-cultural que alimenta o romance "Um tiro na Bruma», de Manuel Cardoso (2007), que aborda a pneumónica em Macedo de Cavaleiros, concelho do Nordeste Transmontano. Este romance histórico-policial é mobilizado como fonte literária e documental, que se analisa na fronteira da História e Ficção, através das «Representações Sociais», cruzando narrativa literária, matéria histórica e científica e dados factuais, numa abordagem às manifestações e impactos desta epidemia letal nesse município central do Nordeste Transmontano.
\end{abstract}

Palavras-chave: Gripe Pneumónica (1918), Macedo de Cavaleiros, Nordeste Transmontano, Representações sociais.

\title{
1. A PNEUMÓNICA OU GRIPE ESPANHOLA NA HISTÓRIA, NA CIÊNCIA E NA LITERATURA
}

Há um século, a gripe pneumónica de 1918, conhecida em Portugal como a «Pneumónica» ou a «Espanhola», por ter chegado aqui a partir de Espanha pela fronteira alentejana (Vila Viçosa), pandemia de origem geográfica desconhecida, extremamente maligna e das mais mortíferas de sempre, à qual não terá sido alheio o drama da I Guerra Mundial ${ }^{2}$, vitimou entre 50.000 a 70.000 pessoas no nosso país e quase 50 milhões de pessoas em todo o mundo, tendo causado «em poucos meses, mais do dobro de mortos que a própria

2 Para Alfred Crosby, isto ficou a dever-se ao facto de ter sido a imprensa espanhola (a Espanha era neutral) a primeira a revelar a existência da doença, pois os países beligerantes tinham a imprensa censurada e, só tardiamente, deram conhecimento público da situação. (Sequeira, 2001). 
guerra tinha feito em quatro anos, e um terço do que a peste em seis séculos!» (Sequeira, 2001).

A pandemia de 1918, um dos anos mais trágicos na história da humanidade $^{3}$, inicia um novo período na epidemiologia da gripe, que passou a ser uma das causas de maior morbilidade e de mortalidade na Europa Ocidental. A gripe ou influenza (pois acreditava-se que aparecia por influência dos astros) é uma doença respiratória aguda, provocada por um vírus isolado no homem em 1933... Tem um quadro clínico de febre, mialgias, cefaleias (Sequeira, 2001) e outras afecções, sendo a complicação mais grave a pneumonia primária, a influenza, levando muitas vezes à morte em 24 ou 48 horas por dificuldade respiratória aguda. A tecnologia moderna, com progressos espetaculares no campo da virulogia, da biologia molecular e da genética, tornou possível o estudo de partes do vírus responsável pela catastrófica pandemia de 1918 (Sequeira, 2001) ${ }^{4}$.

Desta calamidade que dizimou famílias inteiras e, particularmente, adultos jovens, também em Trás-os-Montes e, em particular, nas 63 freguesias e aldeias do concelho de Macedo de Cavaleiros (o município mais jovem e de maior centralidade do Nordeste Transmontano $)^{5}$, se faz eco muito impressivo no referido romance histórico-policial, Um Tiro na Bruma (2007), ao longo de 6 dos seus 23 capítulos $^{6}$. Esta narrativa literária da gripe pneumónica assenta em fontes escritas e orais, testemunhos, depoimentos e memórias familiares, textos científicos e históricos e notícias de jornais, um conjunto diversificado de documentos reunidos em aturada pesquisa histórica e científica, como se pode comprovar pelo extenso e criterioso arquivo pessoal, diário da investigação realizada para a criação ficcional, que documenta e contextualiza esta calamidade pública, marcada por numerosos casos fatais e «estado de emergência» em todo o país ${ }^{7}$. Pode encontrar-se ainda neste dossier, para além de numerosos dados e informações diversas sobre o concelho de Macedo de Cavaleiros, em que «grassa com intensidade a gripe pneumónica, havendo mais de 300 pessoas atacadas ${ }^{8}$, referências concretas, em notícias de imprensa da época, ao que se passava então noutros concelhos do Nordeste Transmontano.

3 Destaca-se entre outros antecedentes desta mortífera pneumónica, outra grave pandemia de gripe com origem na Sibéria, que afectou em fins de 1889, entre 15 a $70 \%$ da população mundial, tendo vitimado metade da população lisboeta.

4 O interesse pelo seu estudo reactivou-se a partir de 1997 em vários países do mundo.

5 Ver Anexo I: «Macedo de Cavaleiros - Centralidade geográfica e elementos demográficos».

6 Capítulos XIII a XIX, p. 146-229.

7 Dossier de arquivo do escritor Manuel Cardoso, suporte documental de apoio à construção histórica do romance, que nos foi generosamente facultada pelo seu autor.

8 «D.N.», 15-10-1918; correspondência de 6 de Outubro. 
Por exemplo, em Carrazeda de Ansiães «não há pão, açúcar, leite, arroz» e «há pessoas a morrer à fome», tendo-se registado «126 mortos num mês» ${ }^{9}$; em Mogadouro, onde «o estado moral era muito baixo», com «10 mortos por dia» ${ }^{10}$; ou também em Alfândega da Fé, «com mais de 10 casos de óbitos diários» ${ }^{11}$.

\subsection{O alastrar da «pneumónica» em Portugal}

Em Maio de 1918, a gripe dissemina-se por todo o país com o regresso dos trabalhadores sazonais alentejanos vindos de Badajoz e de Olivença, peregrinações e ligações rápidas entre Madrid, Lisboa e Porto. Foi um surto breve, com uma mortalidade de 6,6 por 100.000, ultrapassado em Julho, não encarado muito a sério, apesar da apreensão de parte da comunidade médica. Em fins de Agosto, vários casos de pneumonia fulminante (Gaia) alarmaram a população, que julgava ser peste pneumónica, mas as autoridades sanitárias dizem ser uma forma altamente mortal de influenza, desconhecendo porém as medidas para a combater. Era o início da «segunda onda». Nesta altura (princípios de Setembro), a Comissão Sanitária dos Países Aliados, cujo delegado em Portugal era o Dr. Ricardo Jorge (então professor da Faculdade de Medicina, Director Geral de Saúde Publica e delegado no Comité do Oficio Internacional de Higiene Pública), anuncia que o mesmo fenómeno estava a acontecer noutros pontos da Europa, sobretudo entre os soldados. Quando foram atingidas as grandes cidades, as populações entraram em pânico, pois a gripe estendeu-se a todo o Norte do país, levada principalmente pelos soldados com licença para regressar às suas terras. Com as feiras, romarias e vindimas, comuns nessa altura do ano, muitas populações e trabalhadores deslocavam-se de umas regiões para outras, sendo também outra via de disseminação da doença as deslocações para as termas ou estâncias balneares dos estratos sociais mais privilegiados.

Desde os fins de Setembro que os jornais davam notícias de uma «epidemia que zomba da medicina» (A Capital, 25-9-1918), mas já havia populações dizimadas em várias comunidades nortenhas, onde, ao contrário do habitual, os casos mais graves e mortais atingia a população jovem, caso que se encontra ainda pouco estudado.

\footnotetext{
9 «D.N.», 11-10-1918.

10 «D.N.», 25-9-1918.

11 «D.N.», 29-10-1918; correspondência de 21 de Outubro.
} 


\subsection{A Pandemia gripal segundo o Dr. Ricardo Jorge}

Este relatório sanitário de saúde e higiene pública (Jorge, 1919: 1-35) ${ }^{12}$ foi antecedido de artigos, notas, comunicados e mais dois relatórios do mesmo médico, professor da Faculdade de Medicina e detentor de outros cargos: «A influenza, nova incursão peninsular» (apresentado ao Conselho Superior de Higiene em 18 Junho 1918) e «A influenza e a febre dos Papatazes» (JullhoAgosto 1918), que foram reproduzidos de imediato em Portugal, na imprensa quotidiana e jornais de Medicina. Desenvolve-se em 3 grandes tópicos: Epidemiologia, Natureza e Complicações e Profilaxia.

Debelada a epidemia da Pneumónica nos inícios de 1919, esta tragédia imensa que pareceu votada a um esquecimento generalizado, apesar do avanço da tecnologia ter permitido estudar algumas das características do vírus da influenza espanhola de 1918, perdurou, porém, difusa e sofrida, na memória e no renascer de novos medos dos povos e nas histórias e memórias das populações.

Daí que se nos imponha uma observação transdisciplinar, assente numa tentativa de análise plurifacetada, construída no cruzamento da matéria histórica, científica e literária.

\section{DA HISTÓRIA E DA LITERATURA}

Assim, para uma leitura conceptual, reflexiva e complementar sobre esta pandemia mortífera dos inícios do séc. XX, que se tenta aqui e agora esboçar, optou-se pelo romance histórico, uma das mais ricas tradições e um dos mais cultivados géneros da ficção portuguesa, originalmente de estética romântica, mas cuja evolução o tornaria objecto de reabilitação contemporânea, de que é exemplo o romance histórico e policial pós-moderno aqui escolhido para estudo, porque nele se reescreve e historia o passado centenário deste acontecimento populacional, valorizando perspectivas em geral ocultas na história oficial.

Atendendo à evolução interdisciplinar recente de novas práticas historiográficas e partindo da premissa que o romance histórico «não é outra coisa que uma constante interrogação dos tempos passados, em nome dos problemas, das curiosidades, e também das inquietações e angústias com que nos rodeia e cerca o tempo presente... », reflecte-se sobre a história como ficção

12 Ver resumo em Anexo II. 
e a ficção como história, com Saramago, Prémio Nobel da Literatura (1999) $(\text { Saramago, 2000 })^{13}$.

A História não é outra coisa que uma constante interrogação dos tempos passados, em nome dos problemas, das curiosidades, e também das inquietações e angústias com que nos rodeia e cerca o tempo presente. (...) assim, História e Ficção seriam expressões da mesma inquietação dos seres humanos, os quais (...) teimam em procurar, na impalpável névoa do tempo, um passado que constantemente se lhes escapa e que hoje, talvez mais do que nunca, quereriam integrar no presente que ainda são.

Desde finais do século XX, a partir de novas aproximações teóricometodo-lógicas, muitos historiadores (Bosi, Hayden Whaite e La Capra, Ginzburg, Chartier...) debateram e debatem as fronteiras polémicas e complexas entre História e Literatura (Barbato, 2014: 94-102), designadamente para melhorar e completar o entendimento e compreensão das identidades e das memórias sociais e, em definitivo, dos acontecimentos e momentos históricos. A própria história já assumiu que o passado, nos modos como «realmente aconteceu», é, senão impossível, pelo menos incompleto. E é essa incompletude da verdade, não a sua ausência, que aliada ao facto de que a história, ao passar pela narrativa e pela escrita como literatura, se torna suficiente para sair do seu campo especial, só seu, por não se poder ignorar a contaminação daí resultante.

Sendo hoje inquestionável a importância da Literatura enquanto «analyseur» para o conhecimento da História e a sua estreita relação para se alcançar explicações mais completas em ambos os campos, procurar-se-á identificar e perceber aqui quer inter-relações entre as respectivas narrativas e sua contribuição para «iluminar» este momento histórico e a inscrição nele da sociedade rural transmontana, quer o impacto da criação literária no comportamento e pensamento dos diversos grupos sociais convocados. Tenta-se apreender mais do passado através da narração dramatizada que nos é proporcionada pela criação literária, a qual não é só um produto cultural, mas também um evento histórico a estudar nas suas múltiplas variáveis - demográficas, económicas, sociais, culturais e ideológicas -, que permitem conhecer como se moldam comportamentos e identidades, e compreender melhor «representações» e sociedade.

$\overline{13} \mathrm{O}$ escritor refere-se aqui à obra «O Mediterrâneo» do historiador francês Fernand Braudel, que cita. 


\subsection{Sobre a gripe pneumónica em Trás-os-Montes: cruzando olhares ficcionais e dados factuais}

Do húmus cultural entretecido no imaginário histórico e social, se alimentaram algumas criações literárias como por exemplo, entre nós, o romance «Um tiro na Bruma», de Manuel Cardoso (2007), que se desenrola no Nordeste Transmontano, em especial, num dos seus concelhos mais jovens e centrais, Macedo de Cavaleiros, no qual se entrecruzam discurso literário e narrativa factual, devidamente ancorados num significativo arquivo pessoal de numerosas fontes, documentos e bibliografia de natureza histórica e científica $^{14}$.

\subsection{A Gripe de 1918 em Macedo de Cavaleiros no romance Um tiro na bruma (2007)}

Aí, perpassam com verosimilhança representações sociais e culturais do súbito e avassalador surto da pneumónica, do ambiente de grande morbilidade do aglomerado populacional local, dos meios clínicos e higiénicos de combate, da generalização súbita dos casos de doença e mortes, e de uma ambiência geral de dor, consternação e impotência colectivas de que foi único refúgio a crença e religiosidade popular, assim se percepcionando imediatas repercussões demográficas, sociais e culturais desta pandemia.

Ao cruzar esta narrativa literária sobre a pneumónica com outras fontes históricas - registos de óbitos das localidades de Macedo de Cavaleiros, aí mencionadas como as mais afectadas (Vale de Prados, Castelãos, Grijó, Vilarinho de Agrochão, etc.), e notícias de imprensa - procura-se, no campo da história cultural e social, ensaiar uma análise na perspectiva transdisciplinar entre literatura e história, nas suas especificidades próprias, através das noções teórico-metodológicas de «representações» colectivas e identidades sociais (Chartier, 1988) inscritas nos textos ou produzidas pelos indivíduos.

As representações do mundo social assim construídas, embora aspirem à universalidade de um diagnóstico fundado na razão, são sempre determinadas pelos interesses de grupo que as forjam. (...) As percepções do social não são de forma alguma discursos neutros: produzem estratégias e práticas (sociais, escolares, políticas)... para os próprios indivíduos, as suas escolhas e condutas.

\footnotetext{
14 Consultar Anexo II: descrição sucinta do dossier de arquivo do escritor Manuel Cardoso, suporte documental de apoio à construção histórica do romance, que nos foi generosamente facultado pelo seu autor.

15 Sopa de Letras, Março de 2007, ISBN: 9789728708269, http://www.principia.pt/epa ges/960704007.sf/pt_PT/?ObjectPath=/Shops/960704007/Products/103020024
} 
(...) As lutas de representações têm tanta importância como as lutas económicas para compreender os mecanismos pelos quais um grupo impõe, ou tenta impor, a sua concepção do mundo social, os valores que são seus, e o seu domínio. Ocupar-se dos conflitos de classificações ou de delimitações não é, portanto, afastarse do social - como julgou uma história de vistas demasiado curtas -, muito pelo contrário, consiste em localizar os pontos de afrontamento tanto mais decisivos quanto menos imediatamente materiais (Chartier, 1988: 17).

Foi por este dispositivo analítico que se orientou a leitura dos fragmentos literários alusivos ao impacto social da pneumónica e suas representações na inscrição do tempo num dado espaço da representação, com vista a uma compreensão mais por dentro do vivido no decurso desta histórica «trilogia mórbida» - miséria, guerra e morte - do «ano negro de 1918».

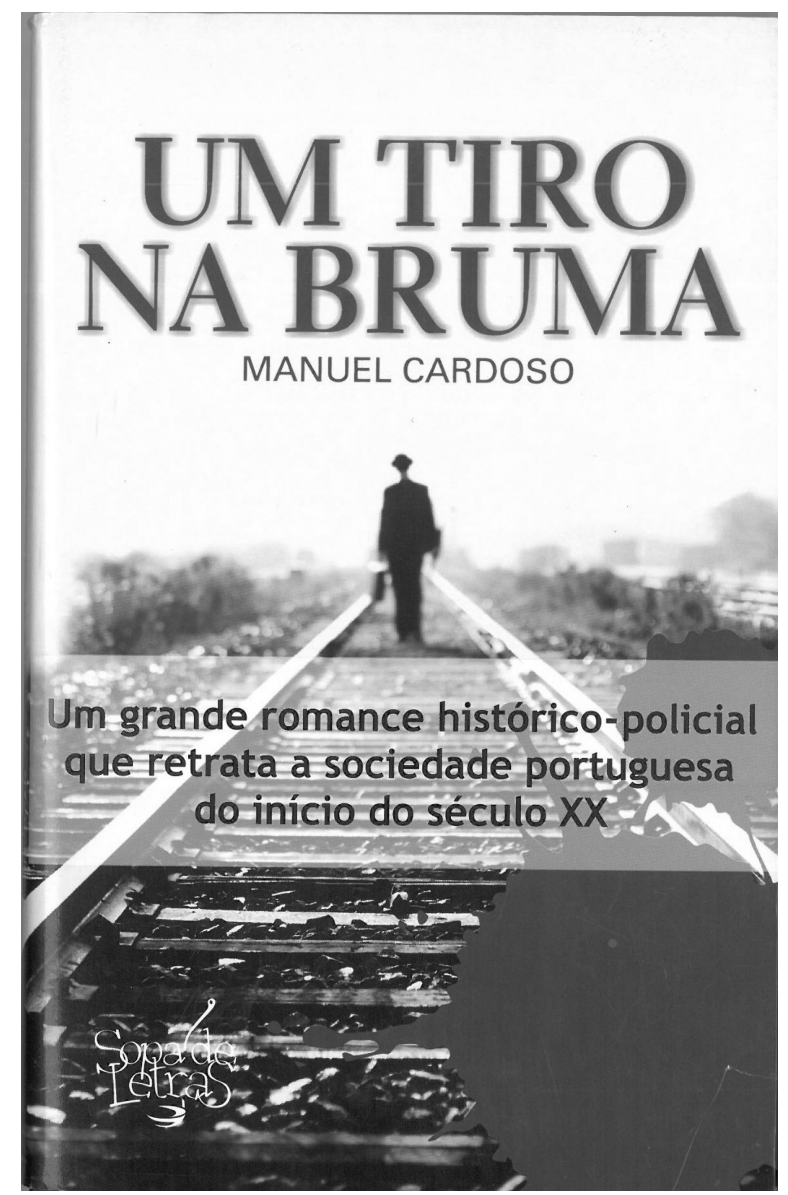

Fig. 1 - Um tiro na bruma $(2007)^{15}$ 
A trama romanesca sustenta-se numa tessitura de documentos, testemunhos, memórias individuais e colectivas, factos e segredos familiares, ambientes de miséria e episódios diários locais, historicamente contextualizados no panorama nacional da Primeira República, com seus golpes, contra-golpes e conflitos político-partidários, culminando na adesão local de certos núcleos de Trás-os-Montes à «Monarquia do Norte» de Paiva Couceiro e na morte de Sidónio Pais, sem deixar de ter por amplo referente à escala internacional a I Guerra Mundial (1914-1918) e a entrada e participação de Portugal no grande conflito bélico.

O cenário deste «romance histórico-policial» situa-se num elevado número de freguesias e aldeias recônditas do concelho de Macedo de Cavaleiros, cuja população global registou, no período em observação, a perda de 2.541 habitantes (de 20.917, em 1911, passou para 18.376, em 1920), uma súbita e enorme baixa provocada pela drástica mortalidade e acentuada quebra de natalidade, a qual só foi recuperada ao longo das seis décadas seguintes ${ }^{16}$.

Os quadros seguintes relativos ao concelho de Macedo de Cavaleiros em matéria de óbitos em geral associados à gripe pneumónica, permitem uma observação mais concreta e detalhada das elevadas taxas de morbilidade e mortalidade desta epidemia, que duplicaram em relação aos anos intermédios, num crescendo verificado a partir de Agosto e concentrado nos meses de Setembro, Outubro e Novembro de 1918.

Tab. 1 - Óbitos no concelho de Macedo de Cavaleiros (1917-1920)

\begin{tabular}{rr}
\cline { 2 - 3 } Anos & Óbitos \\
\cline { 2 - 3 } 1917 & 582 \\
1918 & 1.122 \\
1919 & 528 \\
Fonte: Livros do & Registo Civil de Macedo de Cavaleiros.
\end{tabular}

\footnotetext{
$\overline{16}$ A quebra populacional registada recentemente, acompanha a desertificação acentuada das terras do interior, verificada sobretudo a partir dos anos 1990, devido a factores diversos.

17 Aparecem designações como «moléstia ignorada», «moléstia desconhecida», «doença ignorada».
} 
Fig. 2 - Óbitos por gripe no concelho de Macedo de Cavaleiros (19171918)

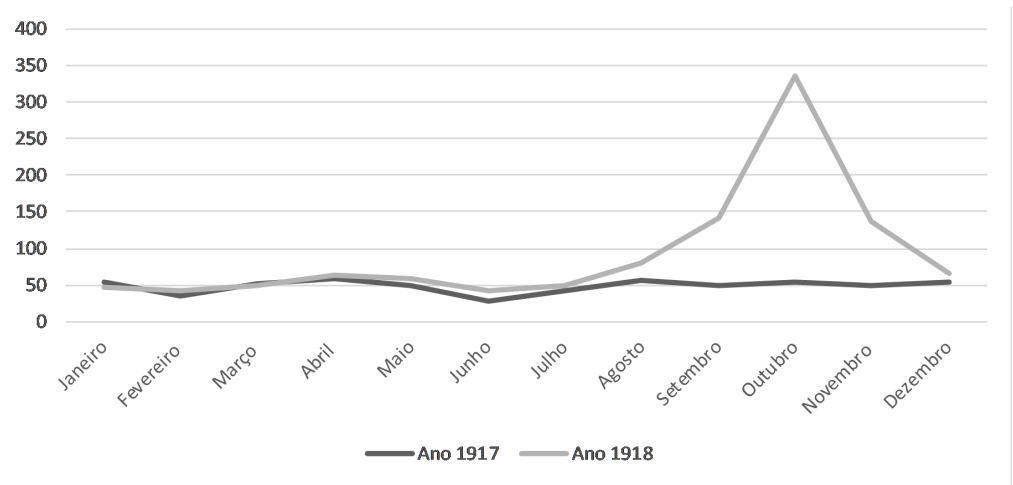

Fonte: Livros do Registo Civil de Macedo de Cavaleiros.

Tab. 2 - Óbitos por gripe em 63 localidades do concelho de Macedo de Cavaleiros $(1918)^{17}$

\begin{tabular}{|c|c|c|c|}
\hline Meses & Ano 1917 & Ano 1918 & $\begin{array}{c}\text { Povoações com maior } \\
\text { mortalidade e no } \\
\text { de óbitos em } 1918\end{array}$ \\
\hline Janeiro & 54 & 47 & 1. Macedo de Cavaleiros (68) \\
\hline Fevereiro & 36 & 42 & 2. Grijó (44) \\
\hline Março & 52 & 50 & 3. Talhinhas (42) \\
\hline Abril & 58 & 64 & 3. Chacim (42) \\
\hline Maio & 50 & 58 & 3. Talhas (42) \\
\hline Junho & 28 & 42 & 4. Castelãos (40) \\
\hline Julho & 43 & 50 & 5. Vale de Prados (16) \\
\hline Agosto & 56 & 80 & \\
\hline Setembro & 48 & 142 & $2^{\mathrm{a}}$ vaga de gripe \\
\hline Outubro & 54 & 336 & Set., Out., Nov. $=614$ mortes \\
\hline Novembro & 49 & 136 & \\
\hline Dezembro & 54 & 65 & \\
\hline Totais & 582 & 1.122 & \\
\hline
\end{tabular}

Fonte: Livros do Registo Civil de Macedo de Cavaleiros. 
A este propósito, leia-se o seguinte trecho do romance em análise, no qual se aflora ficcionalmente a preocupação documental, à época latente, com o crescendo de doentes e mortos provocados pela "gripe pneumónica», nos meses mais críticos, por influência contagiosa de migrações populacionais e ambiência social e cultural generalizada de penúria e indigência.

[...] Setembro era um mês de mexer com muita gente. Das vindimas do Douro vinham para cá jornaleiros e para cá regressavam os que daqui tinham ido. Vinham também os romeiros das festas... havia sempre uma pequena multidão de indigentes e pedintes que se iam arrastando por aqui e por ali... Andavam sempre a pé de um lado para o outro... a arrastar a doença, a tentar fugir da morte e da fome... Os jornaleiros e gentes de outros mesteres andavam de jeito diferente, porte orgulhoso, passo mais decidido... E havia os ciganos... juntavamse todos nas feiras e romarias... Só que neste fim de verão... Estavam a vir para um... enorme coval de enterrar mortos. O doutor Amadeu dera-se conta disso já desde Agosto. Por curiosidade científica e por insistência da Junta Central de Higiene, ia tomando nota dos casos de doentes que havia. Num caderno de folhas de papel almaço... inscrevia os seus casos e os que tinha conhecimento pelos colegas e ainda todos os que, sem observação certa, chegavam até si por «ouvir dizer». Tinha também uma folha para os óbitos, os que sabia de fonte segura pelo registo civil e os que lhe chegavam aos ouvidos pelas mais variadas fontes. Aldeia por aldeia, dia a dia. Fazia somas por semanas, por vezes corrigidas à posteriori sempre para cima e que lhe forneciam... uma visão de evolução. Os seus números poderiam pecar sempre por defeito nunca por excesso. Como tal, se a coisa estivesse a ficar preta no papel, seria porque a realidade estaria negríssima! [...](Cardoso, 2007: 189-190).

Quem assim fazia estes registos era o personagem central deste romance, o médico Amadeu Cardoso (1873-1946), casado com uma descendente dos Morgados Oliveira de Macedo ${ }^{18}$, avô paterno do escritor ${ }^{19}$, o qual era, na altura da pneumónica, o subdelegado de saúde de Macedo de Cavaleiros, a quem «competia assistir aos expostos, às amas e aos pobres»(Cardoso, 2007: 146). Pela actuação clínica e humana deste médico, autêntico João Semana, que na altura da pneumónica assistia aos «doentes que passavam largamente das centenas e registava os mortos que subiam das duas dezenas em todo o concelho»(Cardoso, 2007: 194), acorrendo aos sítios mais miseráveis, primeiro sózinho e logo depois acompanhado do padre com a extrema santa unção para os moribundos, vai-se acompanhando o sofrimento e pavor crescente das populações - «aves lúgubres a voar de preto»(Cardoso, 2007: 204) - afectadas pela pandemia nas suas duas vagas ou ciclos: «uma primeira,

\footnotetext{
18 Ver esquema genealógico dos Morgados de Macedo (Cardoso, 2007: 13)

19 O escritor, médico veterinário, natural e residente em Macedo de Cavaleiros, foi Professor da Escola Superior Agraria do IPB, e é autor de vários textos científicos na sua área de especialidade e ainda do livro de contos Quartzo (Coimbra, Quarteto, 2000).
} 
entre Maio e finais de Julho, mais branda, em que a epidemia se manteve em situação mais ou menos controlada, a que sucedeu um segundo ciclo, entre Agosto e Dezembro, terrivelmente dramático, assumindo efeitos verdadeiramente devastadores»(Rollo, 2008).

As dimensões referidas tornam-se ainda mais operantes para o entendimento da importância desta narrativa literária, de grande valor documental, sobre a «trilogia mórbida» do «ano negro de 1918», delineada no romance histórico analisado, com noções e informações sócio-históricas, epidemiológicas e cientificas precisas.

\section{CONSIDERAÇÕES FINAIS}

O corpus ficcional analisado em função das representações sociais relativas ao deflagrar e evoluir da Gripe Pneumónica ou Espanhola de 1918, selecionado no romance histórico e policial «Um Tiro na Bruma» (2007), de Manuel Cardoso, capítulos relativos à ocorrência no concelho de Macedo desta trágica pandemia gripal, aí bem contextualizada e ancorada em grandes acontecimentos históricos da época (Grande Guerra, Primeira Republica...), foi complementarmente esclarecido, ao nível da matéria histórica, pelo dossier de arquivo do escritor deste romance ${ }^{20}$, autêntica radiografia da sua escrita minuciosa, do ponto de vista histórico-cientifico. Tudo isto contribui para conferir a esta fonte de natureza literária um elevado valor documental.

2. Quanto à premissa analítica da interrelação entre história e literatura, pode verificar-se que o diálogo entre estes dois domínios contribui para uma compreensão potencialmente mais rica e pormenorizada deste relevante acontecimento da história das populações anónimas e de uma sociedade rural, observada em particular, permitindo aprender historicamente mais sobre o passado através das narrativas ficcionadas e dramatizadas que a literatura nos proporciona. Porém, subjacente a este entendimento, duas perguntas continuam a subsistir: a) quanto da matéria histórica se reflecte no campo da literatura?; b) como a sociedade configura a percepção da história?(Rodríguez Garrido, 2015: 423-436).

A resposta depende quer da dimensão, reconstituição e qualidade histórica dos textos literários, quer da qualidade da narrativa e escrita literária dos textos históricos e, naturalmente, também do impacto que a literatura pode ter no pensamento e comportamentos dos diversos grupos sociais. As leituras a partir da literatura podem moldar o conhecimento da história e da

$\overline{20}$ Descrição sumária do dossier de arquivo - Anexo II. 
forma como vemos o mundo. O conhecimento e o estudo da literatura são, pois, importantes para o conhecimento da História, na medida em que permitem entender como se moldam comportamentos e identidades individuais e colectivas e se reconstituem memórias e materiais de memória relevantes para a reconstituição histórica. Ambas as disciplinas podem e devem mobilizar suas estreitas e intrincadas relações com vista a explicações mais ricas e densas de acontecimentos históricos relevantes como este. O enfoque privilegiado possibilita observar este cataclismo populacional nacional, de escala mundial, a uma luz histórica e socialmente mais vasta e polifacetada graças ao cruzamento de uma diversidade de fontes, perspectivas e variáveis que concorrem para aumentar e aprofundar o conhecimento histórico-social da Pneumónica de 1918 e suas repercussões no nordeste transmontano, região a este nível menos estudada, quer «no tempo dos lugares» quer no «tempo nacional», diferenciados mas complementares.

\section{Bibliografia}

AMARAL, Marques R. (1996). Abordagem Clínica da Gripe. Pathos, no 9, Out.

ANDRADE, M. Helena Rebelo de (1996). História das Grandes Pandemias de Gripe. Pathos, $\mathrm{n}^{\mathrm{o}}$ 9, Out.

BAKHTIN, M. (2003). Estética da criação verbal. Martins Fontes, São Paulo.

Barbato, Luís Fernando Tosta (2014). História e Literatura: considerações a respeito de um eterno dilema. Revista Espaço Académico, no 158, Jul. 2014, pp. 94-102. Disponível em http://www . periodicos.uem.br/ojs/index.php/EspacoAcademico/article/viewFi le/22762/13207

CARDOSO, Manuel (2007). Um Tiro na Bruma: romance histórico-policial. Sopa de Letras.

CHARTIER, Roger (1988). A história Cultural: entre práticas e representações. Difel, Lisboa.

JORGE, Ricardo (1919). La Grippe: Rapport préliminaire présenté à la Comission Sanitaire des Pays Alliés, dans sa session de Mars 1919. Imprimerie Nationale, Lisbonne, pp. 1-35.

ROCHA, João César de Castro (org.) (2011). Roger Chartier - a força das representações: história e fição. Argos, Chapecó. Disponivel em https://issuu.com/argoseditora /docs/trecho_cortesia_roger_chartier

ROLLO, Maria Fernanda (2008). 1918: Pneumónica ou a gripe espanhola. Revista Ingenium, n. ${ }^{\circ}$ 105, Maio/Junho. 
SARAmAGO, José (2000). A História como ficção, a ficção como história. Revista de Ciências Humanas, 27, 9.

SEQUEIRA, Álvaro (2001). A pneumónica: Spanish influenza. Medicina interna, vol. 8, n. ${ }^{\circ}$ 1.

TRINDADE, Luís (1998). A Morte Anunciada. Revista História, Nov.

\section{FONTES}

Arquivos do Instituto Central de Higiene. Estatística do Movimento Fisiológico da População de Portugal. Ano de 1917.

Arquivos do Instituto Central de Higiene. Estatística do Movimento Fisiológico da População de Portugal. Ano de 1918.

Arquivos do Instituto Central de Higiene. Estatística do Movimento Fisiológico da População de Portugal. Ano de 1919.

Arquivos do Registo Civil de Macedo de Cavaleiros. Anos: 1917, 1918, 1919, 1920.

«Diário de Noticias». Ano 1918. 


\section{ANEXOS}

\section{Anexo I}

\section{Macedo de Cavaleiros: centralidade geográfica e demografia}
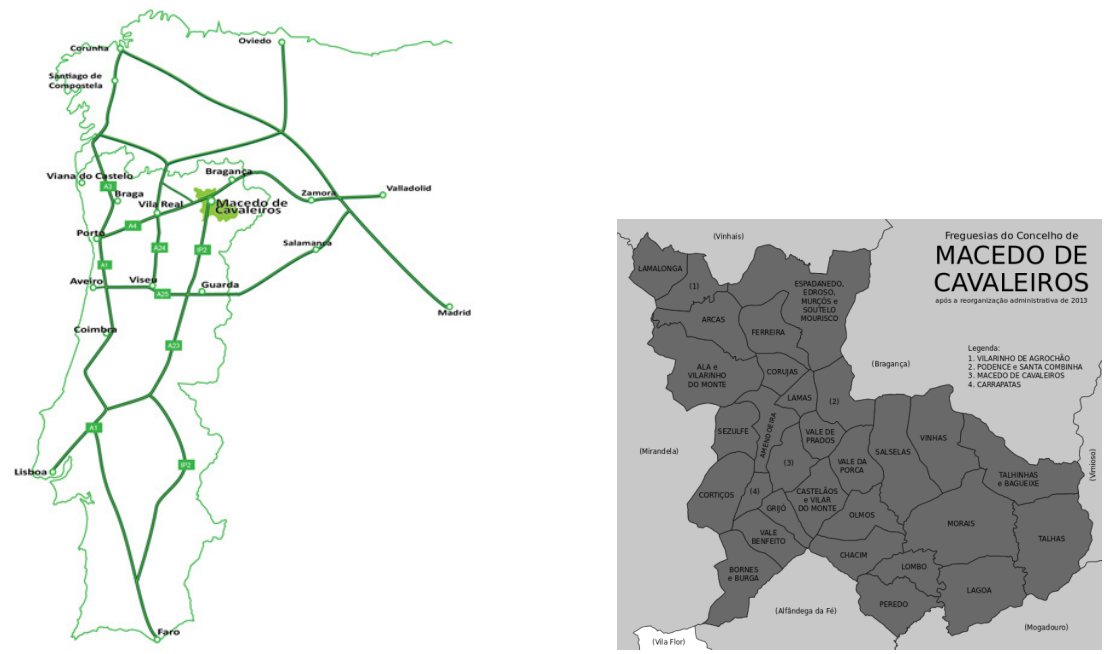

Macedo de Cavaleiros é o concelho mais jovem do Nordeste Transmontano, onde ocupa posição central, sendo assim apelidado de «coração do Nordeste». Com uma área de $699 \mathrm{~km}^{2}$, faz fronteira com 7 concelhos vizinhos. Nasceu apenas em 1853, quando a sua sede não ultrapassava, ainda, a categoria de aldeia. Por mercê de D. Luís I, haveria de receber o título de Vila, 10 anos após a constituição do novo concelho. Hoje é constituído por 67 localidades, agregadas em 30 freguesias ou 4 uniões de freguesias e conta com uma população de 15.776 habitantes (2011).

A centralidade geográfica de Macedo de Cavaleiros, cidade muito próxima, por ligações internas, da grande parte das localidades do Nordeste Transmontano, e as novas acessibilidades rodoviárias (A4 e IP2) colocamna estrategicamente posicionada, relativamente ao norte do país e ao espaço europeu ${ }^{21}$.

Embora o concelho registe quase 16.000 habitantes (Censos 2011), a ela acorre com frequência uma população de cerca de 300.000 indivíduos que, vizinhos de Macedo de Cavaleiros ou de localidades próximas portuguesas e espanholas de menor dimensão, escolhe esta cidade para assistir a eventos de maior relevância, fazer compras, etc. ${ }^{22}$

\footnotetext{
21 https://www.cm-macedodecavaleiros.pt/pages/330

22 https://www.cm-macedodecavaleiros.pt/pages/332
} 


\section{Macedo de Cavaleiros - Evolução da população (1864-2011)}

\begin{tabular}{rrrrrrrrrrrrrrrr}
\hline 10 & \multicolumn{10}{c}{ Número de habitantes } \\
\hline $\mathbf{1 8 6 4}$ & $\mathbf{1 8 7 8}$ & $\mathbf{1 8 9 0}$ & $\mathbf{1 9 0 0}$ & $\mathbf{1 9 1 1}$ & $\mathbf{1 9 2 0}$ & $\mathbf{1 9 3 0}$ & $\mathbf{1 9 4 0}$ & $\mathbf{1 9 5 0}$ & $\mathbf{1 9 6 0}$ & $\mathbf{1 9 7 0}$ & $\mathbf{1 9 8 1}$ & $\mathbf{1 9 9 1}$ & $\mathbf{2 0 0 1}$ & $\mathbf{2 0 1 1}$ \\
\hline 16.653 & 17.901 & 18.825 & 19.200 & 20.917 & 18.376 & 19.781 & 22.765 & 25.204 & 26.199 & 22.173 & 21.608 & 18.930 & 17.449 & 15.776 \\
\hline
\end{tabular}

Obs: Número de habitantes que tinham residência oficial neste concelho à data em que os censos se realizaram. De 1900 a 1950 os dados referem-se à população presente no concelho à data em que eles se realizaram. Daí que se registem algumas diferenças relativamente à designada população residente.

\begin{tabular}{lrrrrrrrrrrrr}
\hline \multicolumn{11}{c}{ Número de habitantes por grupo etário } \\
\hline Idade & $\mathbf{1 9 0 0}$ & $\mathbf{1 9 1 1}$ & $\mathbf{1 9 2 0}$ & $\mathbf{1 9 3 0}$ & $\mathbf{1 9 4 0}$ & $\mathbf{1 9 5 0}$ & $\mathbf{1 9 6 0}$ & $\mathbf{1 9 7 0}$ & $\mathbf{1 9 8 1}$ & $\mathbf{1 9 9 1}$ & $\mathbf{2 0 0 1}$ & $\mathbf{2 0 1 1}$ \\
\hline $\mathbf{0 - 1 4}$ & 6.178 & 7.495 & 6.309 & 6.875 & 8.064 & 8.567 & 9.145 & 7.345 & 6.118 & 4.008 & 2.512 & 1.848 \\
$\mathbf{1 5 - 2 4}$ & 3.597 & 3.338 & 3.184 & 3.574 & 3.927 & 4.603 & 4.486 & 3.620 & 3.898 & 3.176 & 2.467 & 1.561 \\
$\mathbf{2 5 - 6 4}$ & 8.625 & 8.912 & 7.695 & 8.038 & 9.257 & 10.335 & 10.876 & 9.095 & 8.860 & 8.715 & 8.557 & 7.932 \\
$\mathbf{0} \mathbf{~ o u ~}>\mathbf{6 5}$ & 880 & 1.152 & 1.077 & 1.322 & 1.456 & 1.614 & 1.692 & 2.165 & 2.732 & 3.031 & 3.913 & 4.435 \\
\hline
\end{tabular}

\section{Anexo II \\ Dossier documental de Manuel Cardoso «Um Tiro Na Bruma» (2007)}

\section{Apontamentos, notas, entrevistas, testemunhos e bibliografia his- tórica e cientifica}

\begin{tabular}{lll}
\hline Descrição/ Referências & Observações & Sínteses \\
\hline Informações sobre objectos e & - Pedaço de granada & Bandeira hasteada no Registo Civil de \\
peças de valor histórico, & retorcido; - Fragmento de & Macedo de Cavaleiros e aí queimada \\
propriedade familiar do & bandeira da República de & por monárquicos amotinados em \\
escritor. & cetim vermelho. & 6/10/1911. Reimplantação da \\
& & Monarquia do Norte por Paiva \\
& Couceiro. \\
\hline
\end{tabular}

Fotografias da época.

Porto, 12 de Janeiro a 1 de

Fevereiro de 1919.

Varias fotografias de época, postais, selos, impressos da Monarquia e Junta GoverImagens diversificadas de hospitais de sangue e de enfermagem, de tropas em nativa, emissão de notas.

Estarreja, de movimentações republicanas e contra revolucionárias no Porto, 13 de Fev. 1919, primeiras prisões de monárquicos. . . 


\begin{tabular}{|c|c|c|}
\hline Descrição/ Referências & Observações & Sínteses \\
\hline $\begin{array}{l}\text { Lista manuscrita ( } 5 \text { p.) de } \\
\text { notas relativas a depoimen- } \\
\text { tos e testemunhos de con- } \\
\text { siderados réus - participa- } \\
\text { ções individuais em mani- } \\
\text { festações republicanas. }\end{array}$ & & \\
\hline
\end{tabular}

Inúmeras notas manuscritas sobre temas diversos.
Informações e dados retirados de jornais, revistas, entrevistas e depoimentos sobre factos políticos, militares, sociais e sanitários da época.

\begin{abstract}
Apontamentos e notas diversas sobre a vida quotidiana à época no país e em Trás-os-Montes e entrevistas realizadas a idosos com mais de 80 anos alusivas a figuras tornadas personagens do romance.
\end{abstract}

Vocabulário, vestuário, alimentação, Linha e comboio do Tua, vagonetas, mercadorias transportadas, correios, coretos, guardas, etc.

Restauração da Monarquia no Norte de Portugal, 19 de Janeiro a 13 de Fevereiro de 1919: A aç̧ão da Cruz Vermelha. Lisboa, Agosto 1920, p. 63-139.

Diário da Junta Governativa do Reino de Portugal. Porto: 19 de Janeiro de 1919.

Restauração da Monarquia. Colecção de Affonso Dornellas.

Proclamação. Tipografia Lusitana, Mario Antonio Leitão, Rua da Picaria, 7, Porto.

Sobre o Porto! Viva a República! [Proclamação].
Um exemplar de muitas

das proclamações da Mo-

narquia à época.
Um exemplar das múltiplas proclamações da Republica espalhadas por aeroplanos sobre o Porto (Colecção de Affonso Dornellas).

José Pessanha - Para a Autobiografia política.

História... episódio do movimento monárquico em 1919. Porto: Tipografia Progresso, 1919, 60 p. 


\begin{tabular}{|c|c|c|}
\hline Descrição/ Referências & Observações & Sínteses \\
\hline $\begin{array}{l}\text { João Baptista Vilares - } \\
\text { Para a história da Trau- } \\
\text { litania: um voluntário da } \\
\text { República na defesa de } M i \text { - } \\
\text { randela. Póvoa de Varzim: } \\
\text { Tipografia «O Progresso», } \\
\text { 1924, } 55 \text { p. }\end{array}$ & $\begin{array}{l}\text { Varias páginas deste livro } \\
\text { encontram-se sublinhadas } \\
\text { e anotadas pelo escritor M. } \\
\text { Cardoso. }\end{array}$ & $\begin{array}{l}\text { Livro com duas fotografias de época de } \\
\text { Mirandela «vila heroica» } 1919 \text {, e dedi- } \\
\text { catória «à memoria de meu irmão, Eu- } \\
\text { génio das Neves Vilar». }\end{array}$ \\
\hline $\begin{array}{l}\text { Couceiro, o capitão Phan- } \\
\text { tasia - A incursão das Bei- } \\
\text { ras. (p. 53-82). }\end{array}$ & $\begin{array}{l}\text { Referências várias a Ma- } \\
\text { cedo de Cavaleiros. }\end{array}$ & \\
\hline $\begin{array}{l}\text { Notas e referências biblio- } \\
\text { gráficas manuscritas sobre } \\
\text { a I Guerra Mundial (1910 } \\
\text { e 1911) e Primeira Repu- } \\
\text { blica. }\end{array}$ & $\begin{array}{l}\text { Acontecimentos principais } \\
\text { referentes à implantação da } \\
\text { República. }\end{array}$ & \\
\hline $\begin{array}{l}\text { Notas síntese de noticias } \\
\text { sobre a gripe publicadas no } \\
\text { «Diário de Noticias» entre } \\
14-1-1918 \text { e } 29-10-1918 .\end{array}$ & $\begin{array}{l}\text { Conjunto diversificado de } \\
\text { elementos para um «diário } \\
\text { da gripe de } 1918 » \text {, Mar.-Out. }\end{array}$ & $\begin{array}{l}\text { - Em finais de Abril e Maio a morta- } \\
\text { lidade é alta (sarampo, diarreias, brôn- } \\
\text { quios); morrem mendigos, indigentes e } \\
\text { ficam filhos sem pais. } \\
\text { - DN, Junho «a gripe infeciosa». «do- } \\
\text { ença espanhola», passa em } 3 \text { dias de } \\
\text { «doença da moda», "nada de medos } \\
\text { nem de receios» a noticias alarmantes } \\
\text { de grande numero de doentes, empresas } \\
\text { e escolas que encerram portas porque a } \\
\text { maioria está doente, etc. } \\
\text { - DN 19/6 Relatório do Director Geral } \\
\text { de Saúde, Dr. Ricardo Jorge ao Con- } \\
\text { selho Superior de Higiene - recomenda- } \\
\text { ções gerais: não é útil o isolamento dos } \\
\text { doentes que devem tomar ar livre; evi- } \\
\text { tar atmosferas fechadas e arejar recin- } \\
\text { tos; deixar de visitar doentes e de cum- } \\
\text { primentar por beijo e aperto de mão } \\
\text {;quando o mal vier cama, tisanas, die- } \\
\text { tas e médico nada de drogar-se por sua } \\
\text { conta nem com purgas nem com gro- } \\
\text { gues. } \\
\text { - DN, Julho. }\end{array}$ \\
\hline $\begin{array}{l}\text { Relação manuscrita de óbi- } \\
\text { tos em Banrezes entre } 1863 \\
\text { e } 5-2-1908 \text { com anotações } \\
\text { de dados biográficos indi- } \\
\text { viduais e sobre locais de } \\
\text { enterramento (igreja paro- } \\
\text { quial, Capela de N } \mathrm{S}^{\mathrm{a}} \text { do } \\
\text { Rosário e cemitérios públi- } \\
\text { cos). }\end{array}$ & & $\begin{array}{l}\text { Referência a uma epidemia em Setem- } \\
\text { bro de } 1874 \text { em V.P. em que morreram } \\
37 \text { pessoas num ano, sendo } 29 \text { dessas } \\
\text { mortes registadas nos meses de Setem- } \\
\text { bro, Outubro e Novembro. }\end{array}$ \\
\hline
\end{tabular}




\begin{tabular}{|c|c|c|}
\hline Descrição/ Referências & Observações & Sínteses \\
\hline $\begin{array}{l}\text { COSTA, António Luís Pinto } \\
\text { de. Higiene e Saúde em } \\
\text { Trás-os-Montes. } \\
\text { «Brigantia», Vol. X, n. }{ }^{\circ} 4 \text {, } \\
1990 .\end{array}$ & & $\begin{array}{l}\text { Câmaras de Vila Real e Bragança } \\
\text { possuíam pulverizadores e } \\
\text { formalisadores que lançavam vapores } \\
\text { de formol nas ruas e carroças que } \\
\text { diariamente recolhiam em barricas } \\
\text { despejos domésticos, como medidas de } \\
\text { higiene pública. Limpeza geral de } \\
\text { piolhos que se julgavam transmissores } \\
\text { da epidemia; produção nas boticas de } \\
\text { fármacos, os «manipulados». } \\
\text { Havia um grande número de } \\
\text { nados-mortos (4.07\%) e de nascidos } \\
\text { deformados que morriam à nascença. }\end{array}$ \\
\hline
\end{tabular}




\begin{tabular}{|c|c|}
\hline Descrição/ Referências & Sínteses \\
\hline $\begin{array}{l}\text { JORGE, Ricardo. La } \\
\text { Grippe: Rapport préliminaire } \\
\text { présenté à la Comission } \\
\text { Sanitaire des Pays Alliés, } \\
\text { dans sa session de Mars } \\
\text { 1919. Lisbonne: Imprimerie } \\
\text { Nationale, 1919, p. 1-35. }\end{array}$ & 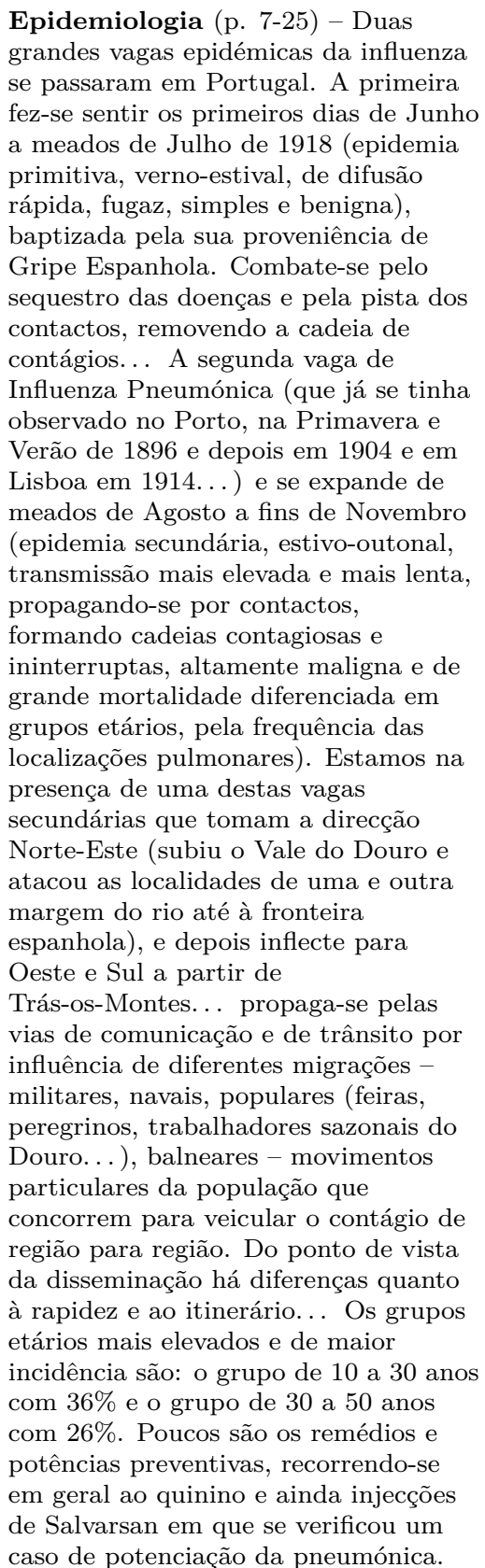 \\
\hline
\end{tabular}




\begin{tabular}{|c|c|c|}
\hline Descrição/ Referências & Observações & Sínteses \\
\hline & & $\begin{array}{l}\text { Natureza e complicações (p. } 22 \text { a } \\
30 \text { ) - A influenza em Portugal assumiu } \\
\text { sobretudo três formas clínicas: a } \\
\text { simples, a hipertóxica e a pneumónica, } \\
\text { com a seguinte sintomatologia: } \\
\text { tendência hemorrágica acentuada, } \\
\text { expectoração abundante, hemoptises, } \\
\text { mortes femininas acentuadas, } \\
\text { tendência para abortos seguidos de } \\
\text { morte determinando baixas de } \\
\text { natalidade, e formas pulmonares } \\
\text { variadas. O estado pneumónico fixa-se } \\
\text { em geral nos primeiros dias da } \\
\text { infecção. } \\
\text { Profilaxia (p. 34-35) - Conferiu-se à } \\
\text { autoridade sanitária a faculdade de } \\
\text { requisitar imóveis para os adaptar ao } \\
\text { isolamento dos afectados e } \\
\text { hospitalização do casos graves. A } \\
\text { profilaxia individual é tão pobre como } \\
\text { a colectiva (falta de hospitais e } \\
\text { esgotamento de todos os recursos } \\
\text { mesmo nos grandes centros). As } \\
\text { lavagens frequentes do nariz e da } \\
\text { garganta com água salgada, mentolada } \\
\text { ou oxigenada eram recomendações } \\
\text { correntes de eficácia não comprovada e } \\
\text { a prevenção mecânica (uso de } \\
\text { máscaras) não bem aceite. O recurso a } \\
\text { médicos de todas as idades, mesmo os } \\
\text { aposentados e os mais jovens, alunos } \\
\text { de } 5 \text { o ano de Medicina foi muito } \\
\text { frequente. Também se fazia a } \\
\text { distribuição de géneros e suplementos } \\
\text { alimentares (pão, açucar.. ), quinino, } \\
\text { farinha de linhaça, e outras drogas. } \\
\text { Repartiam-se socorros em dinheiro aos } \\
\text { indigentes e criavam-se comissões de } \\
\text { socorros pra recolha de donativos e } \\
\text { beneficência.» }\end{array}$ \\
\hline
\end{tabular}

JORGE, Ricardo. Le

Typhus Exanthématique

à Porto (1917-1919):

Communication faite

au Comité International

d'Higiène Publique dans sa session d'Ocotobre, 1919.

Lisbonne: Imprimierie

Nationale, 1920.

VALDEZ AGUILLAR, Rafael. Pandemia de gripe. «Elementos», Vol. IX, n.응 47, Sep.-Nov. 2002, 37 p.
História longa das gripes no mundo e características clinicas da gripe pneumónica de 1918. 


\begin{tabular}{lll}
\hline Descrição/ Referências & Observações & Sínteses \\
\hline «Euro Surveillance», vol. & Numero Spécial sur la \\
3, n. ${ }^{\circ}$ 3, Mar 1998. & Grippe A (H5N1) de Hong \\
& Kong (1997-1998). \\
\hline $\begin{array}{l}\text { Kyrie Eleison. In «Catho- } \\
\text { lic Enciclopedie». }\end{array}$ & [texto electrónico] \\
\hline Missale Romanum... & [Excertos] pág. 115-121 e \\
$\begin{array}{l}\text { Missae Defunctorum... } \\
\text { Absolutio super tumulum. }\end{array}$ & p. 130-133. \\
\hline
\end{tabular}





\section{A GRIPE PNEUMÓNICA DE 1918 NO INTERIOR CENTRO DE PORTUGAL: UM OLHAR SOBRE O DISTRITO DA GUARDA}

Odete Paiva ${ }^{1}$ 



\begin{abstract}
Resumo
O artigo propõe o estudo da gripe pneumónica de 1918 no distrito da Guarda, através da leitura do periódico $A$ Guarda, um dos mais lidos na região, verificando o impacto da epidemia na população, num período atravessado por condições matriciais: a guerra, a fome e a doença. Com a imprensa censurada nalguns países beligerantes, como Portugal, os dados disponíveis da Delegação de Saúde da Guarda e subdelegações respetivas foram adjuvantes e permitiram um esboço de triangulação dos resultados que apontam para o início da gripe em junho de 1918, e o acume em outubro do mesmo ano, sendo o concelho do Sabugal, vasta circunscrição administrativa com freguesias a fazer fronteira com Espanha, o mais fustigado. A resposta das autoridades regionais encontra-se vertida, por exemplo, numa notícia de outubro de 1918 do jornal A Guarda, relatando a preocupação dos representantes distritais com a saúde das populações, deslocando-se ao Sabugal várias vezes, acompanhados de médicos. A Igreja, através do bispo da diocese, foi outro canal interventivo, como fica patente na provisão episcopal de outubro de 1918.
\end{abstract}

Palavras-chave: pneumónica, 1918, distrito da Guarda, Portugal.

\title{
INTRODUÇÃO
}

Iniciado o século XX, com a publicação em Portugal do Regulamento Geral da Saúde Pública, o poder central pretendeu estabelecer um protocolo entre o frágil orçamento público e os cuidados de saúde à população. $\mathrm{O}$ ano de 1918 foi o seu laboratório de experimentação por excelência, com o tifo exantemático, a varíola e a gripe pneumónica a atacar.

A tríade guerra, fome e doença ressuscitou no ano de 1918, invadindo muitas regiões da Europa, incluindo Portugal. Se a guerra emergira quatro anos antes e a fome a foi acompanhando, a doença fechou o polígono da catástrofe. Conhecida entre nós também por «hespanhola», ao longo dos 
ciclos que tomou, fez muitas vítimas, provocando um clima de «estado de sítio».

Estimando-se em 20 milhões de mortes a nível mundial, o continente europeu colheu uma proporção assinalável, registando-se em Portugal, cerca de 60.500 mortes, distribuídas por três vagas consecutivas entre junho de 1918 e março de 1918.

No final de 1917, surgiu o primeiro momento epidémico, com picos entre junho e agosto do ano seguinte, que voltaram a eclodir entre outubro e novembro. A epidemia ia grassando assimetricamente pelo país, com quebras demográficas maiores nalgumas zonas.

Entre as medidas do poder central conta-se a criação do Comissariado do Governo presidido por Ricardo Jorge, a quem foram cometidas funções como a reformulação dos serviços médicos tendentes a apoiar a população a nível de cuidados de saúde, dispensa de medicamentos e informação.

Como se verá, a sociedade civil assumiu um papel de cooperação, por exemplo, com a formação de comissões de socorro locais, a que não foi alheio o apelo de Ricardo Jorge, em setembro de 1918, após a declaração de 16 de outubro desse ano, do estado de sítio $^{2}$.

\section{O DISTRITO DA GUARDA}

Nas várias regiões do país, as autoridades locais iam respondendo, face aos recursos e prioridades, ao problema de saúde, que vestia complementos, de que destacamos a carestia de vida e a escassez alimentar, como aconteceu na cidade da Guarda e no seu distrito. O periódico A Guarda, que seguimos de perto, dá-nos um panorama local, quando informa que a terrível epidemia que, em junho de 1918, andou pelo país com o nome de «hespanhola», retornou no período seguinte e com caráter muito grave nalgumas regiões, entre as quais a da Guarda.

O jornal, com correspondentes nas Beiras, noticiou pela primeira vez a epidemia em junho de 1918 e retomou o tema em finais de setembro, aludindo à conjuntura difícil, salientando a crise das subsistências e as «revoluções» como alguns dos «perigos» em que o país estava mergulhado.

Em inícios de outubro de 1918, sob o título Epidemia, surgiu um pequeno artigo, onde o autor, após referir que em quase todo o país grassava a gripe, se detinha no distrito da Guarda, relatando que o concelho mais atacado era o do Sabugal, onde as autoridades do distrito se haviam deslocado

2 Decreto n. ${ }^{\circ}$ 4.891, 12 de outubro de 1918; Diário do Governo, I Série, n. ${ }^{\circ}$ 223, suplemento, pp. 1.791-2. 
por várias vezes, acompanhadas de um clínico «distinto», no sentido de debelar a «terrível doença». Dava-nos conta das medidas necessárias para evitar a propagação da epidemia, entre elas, a proibição de transferência de militares, o adiamento da abertura das aulas e a realização do serviço de exames, bem como de feiras e romarias. Paralelamente, chamava a atenção para as normas gerais como a beneficiação e a higienização. "Cuidados com a limpeza das povoações e das casas, e a desinfecção até onde os casos o exijam e as circunstancias o permitam. Como profilaxia individual o uso de gargarejos, mentolados ou salgados». O isolamento dos doentes, uma boa alimentação, o evitar excessos de qualquer natureza, como o frio, mas também mudanças de temperatura, eram igualmente ressaltados.

Em convergência com estas medidas, o Governo Civil da Guarda proibiu a realização da feira de S. Francisco que ocorria anualmente a 4 de outubro.

Se a pneumónica lançava os seus braços mortíferos na região e as notícias dos óbitos, principalmente de «adultos jovens» de famílias mais consideradas, era uma realidade ${ }^{3}$, o tifo continuava a matar, como ia noticiando o jornal.

Com a crónica presente em todos os números do semanário sob o título «À janela do meu quarto», variando de subtítulo, destacamos uma análise de finais de setembro de 1918, sobre «A epidemia - abertura das aulas». O autor, após se interrogar se seria castigo de Deus, focando-se no repicar constante a finados, chamava a atenção para o contraditório de alguns enterros serem de valorosos soldados que não sucumbiram na guerra e foram derrotados pela gripe. E continuava a sua reflexão, traçando um quadro de um país sem alegria, onde perpassavam sombras, «ou buscando um medico, ou procurando uma receita, ou procurando um enterro (...)». E detinha-se no mal que os excessos provocavam, recorrendo aos escritos de Heródoto, quando o autor abordava a grande fortuna de Polycrates ${ }^{4}$, terminando por escrever que «a epidemia pode ser o toque de clarim, que faça accordar a nação inteira».

A higiene da cidade era alvo de atenção do semanário, por exemplo, a 12 outubro de 1918, e conquanto elogiasse o papel das autoridades sanitárias nos meios empregues para que a epidemia não invadisse a zona urbana, «com a gravidade de tantas outras terras», apontava o dardo à limpeza das «bocas de lobo» e das valetas, por onde corriam águas imundas, bem como à dos edifícios públicos, locais propícios a «ajuntamentos», não esquecendo a saúde dos seus funcionários.

3 Este critério tinha a ver com razões editoriais, pois a maioria dos que morria formava uma massa anónima.

4 Governante de Samos, detentor de grande poder e riqueza, parecia desafiar a fortuna, pelo êxito que alcançava em todos os empreendimentos, até chegar o dia em que, pelo sofrimento, teve consciência das suas ações e falibilidade, e nesse mesmo dia morreu. 
Este periódico do interior ia informando os leitores da situação da epidemia no país, relatando o seu alastramento e desigual ataque regional e enfatizando o facto de as estatísticas hospitalares de Lisboa mostrarem um decréscimo de mortes, cifrando-o em 10\%, chamando a atenção para a relatividade dos dados baseados nos «internados nos hospitais, visto que a maior parte da população civil se cura ou morre em casa».

Duas medidas governamentais foram sublinhadas nas suas páginas em outubro de 1918: a nomeação de um alto-comissário para «estudar a maneira mais facil de se atacar a doença» e a publicação de um decreto «convocando todos os aspirantes a medicos milicianos do $3 .^{\circ}$ grupo de companhias de saúde».

Ainda no mês mais agudo, proibida a saída do território nacional das «drogas medicamentoras», era fundamental que o jornal difundisse uma selecção de remédios que pudesse ajudar os epidemiados e divulgasse medidas simples a aplicar nas circunstâncias. A supressão de cumprimentos (apertos de mão e beijos entre as senhoras) difundida em vários jornais, de que $A$ Guarda se fazia eco, seria mais uma forma de minimizar a propagação da epidemia.

A 26 de outubro de 1918, o semanário publicava na íntegra uma provisão emitida pelo bispo da Guarda, de 16 desse mês, onde o prelado, após considerar a gravidade da conjuntura, incentivava os fiéis à oração e à penitência e exortava à caridade cristã, pedia aos sacerdotes que divulgassem e explicassem nas suas freguesias o conteúdo da mesma, que incluía as «instrucções» de um «medico muito distincto», recomendando-lhes que também eles fizessem uso de todos aqueles meios higiénicos e preventivos, sobretudo quando fossem à casa dos enfermos, lembrando a falta de clero que se fazia sentir. Dado o interesse deste documento, passamos a analisá-lo com mais detalhe.

Nas zonas mais recônditas do país era muito difícil prestar assistência médica à população, com maior acuidade nas circunstâncias de uma epidemia, como foi o caso em apreço. D. José Alves Matoso, bispo da Guarda, homem ilustrado mostrou estar atento à circunstância e, num documento sintomático da sua preocupação, revela-nos o quanto a igreja se mostrou esclarecida e interventiva no distrito da Guarda. A provisão episcopal a que nos estamos referindo foi divulgada por diversos canais, sendo um deles os párocos e os capelães que a deviam ler e explicar na missa imediata à sua receção, e o outro, o veículo da imprensa. Podemos dividir o documento em 3 partes: a primeira, em que o prelado descreve a situação do distrito e aponta para a intervenção divina; a segunda, que incide nos meios preventivos e a terceira, 
Fig. 1 - Provisão de episcopal de D. José Alves Matoso

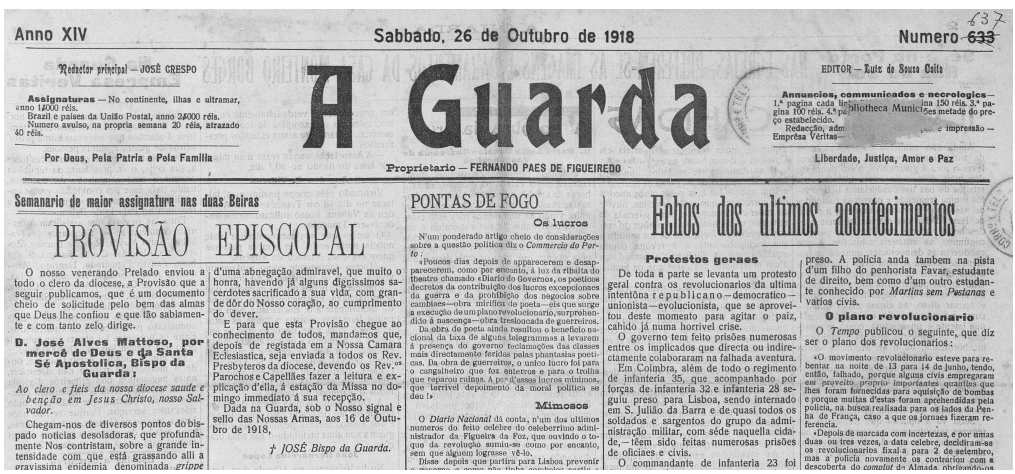

Fonte: Jornal A Guarda de 26 de outubro de 1918, p. 1.

no modo de ajuda ao doente após instalada a gripe. É importante deter-nos nas primeiras palavras do prelado que transcrevemos:

Chegam-nos de diversas partes do bispado noticias desoladoras que profundamente Nos contristam, sobre a grande intensidade com que está grassando ali a gravíssima epidemia denominada grippe pneumónica, sendo já muito elevado o número dos casos fataes, sobretudo Sabugal e Penamacor.

Descrita a situação de emergência, o dignitário pede a intercessão de Deus e de Nossa Senhora e exorta os fiéis do seu bispado a acompanhá-lo nesse desiderato, reconhecendo as culpas, mas também a forma de as remir, como a oração, o cumprimento das virtudes cristãs e dos sacramentos da penitência e da eucaristia, como modos mais eficazes de Deus acabar com esses males e calamidades «que duramente nos affligem, levando o lucto a inúmeras famílias deixando na viuvez e orphandade tantas e tantos infelizes». $\mathrm{O}$ apelo à caridade é outra linha de força desta parte inicial, sabido que em muitas casas não existia sequer o básico.

Antes de o prelado entrar na exposição das medidas do foro médico, indicadas por um médico avalizado, recomenda aos sacerdotes que, além do preceituado pelo dever do seu munus, que cooperem com as autoridades e divulguem as instruções contidas na sua disposição.

Passamos aos meios preventivos que constam de vários pontos, que transcrevemos e depois comentaremos:

1. Evitar pôr-se em contacto com doentes, e, portanto, a não ser por motivo de dever, não entrar nos quartos onde elles estejam.

2. Evitar a acção de temperaturas extremas, calor ou frio; e, como a estação é fria, agasalhar-se convenientemente. 
3. Evitar fadigas, assim como quaesquer outros excessos, incluindo os de bebidas alcoólicas, que só podem ser usadas muito moderadamente; e, havendo suspeitas de que não sejam puras as aguas potáveis, convem purificalas pela fervura.

4. Limpeza do corpo, roupas, casas e povoações.

5. Trazer, pois, muito bem lavadas as mãos e o rosto com água e sabonete ou sabão, tendo o cuidado de o fazer sobretudo antes das refeições.

6. Depois de lavar as mãos, mergulha-las em uma solução de sublimado $(\ldots)^{5}$.

7. Para a desinfecção da bôcca e pharynge (garganta) usar: Thymol... 0,5 gramas, álcool... 4,0 gramas, borato de soda... 10,0 gramas, agua destillada... 95,0 gramas, na porção de 1 colher de sopa em 4 colheres de agua para bochechar e gargarejar, ou fenosatil... 4 gramas, álcool... 250 gramas, tintura de benjoim... XXX gramas, na porção de 1 colher de café em 1 copo de agua tépida para bochechar e gargarejar.

8. Para as fossas nasais: terpinol e gomegol a XX gotas, fenosatil... 0,6 grammas, bálsamo do Peru... 2,0 grammas; vaselina... 40,0 grammas ${ }^{6}$.

9. Para os olhos: oxieyanêto de mercúrio... 0,01 grammas, sal commum... 0,70 grammas, agua destillada... 50,0 gramas. Para banhar os olhos com 4 ou 6 gotas.

10. A desinfecção das roupas de linho ou algodão far-se-há pela barrela, ou ainda pela simples passagem a ferro depois de humedecidas. No caso de terem servido a doentes, convem mergulhar tudo em um soluto de sublimado.

11. Particularmente aos que lidarem com doentes, convem o uso diario de uma ou duas hóstias de sulfato ou de chlufhdrato de quinina, com 0,2 grammas cada uma.

12. Conservem-se no maior grau de açeio as egrejas e capellas; e para desinfecção dos pavimentos use-se a solução de sublimado indicada.

13. Pode além disto, queimar-se alcatrão dentro d'ellas, e arejá-las muito bem, mas o essencial é o açeio e a passagem a panno com soluto de sublimado.

\section{Remédios depois do ataque da doença}

1. Deve chamar-se o medico onde e quando seja possível para prescrever a medicação necessária.

2. Entretanto recolhe-se desde logo o doente á cama e use de chás sudoríferos, especialmente de flor de borragem e de todos revulsivos, como são sinapismos ou mostarda applicados no peito e nas costas. Melhor será ainda a tintura de iodo applicada differentes vezes também no peito e nas costas.

5 A fórmula constava de 1 grama de sublimado corrosivo, 1 colher de sal comum e 1 litro de água, sendo indicado que, conquanto fosse muito bom, era venenoso, devendo constar esta indicação no rótulo da garrafa.

6 A pomada poderá ser preparada só com terpinol e gomegol. 
3. Na falta destes remédios envolvam-se o peito e as costas em flanela ou lã e appliquem-se por cima pannos molhados com água bem quente e frequentemente renovados.

Façamos algumas considerações acerca deste documento episcopal, no que concerne às medidas preventivas e curativas da doença, começando pelas primeiras. Pese embora o mérito da provisão, os conselhos seriam praticamente inexequíveis para a maioria da população, com meios exíguos, onde quase tudo faltava. Quanto aos remédios, começamos logo pelo recurso ao facultativo, o que igualmente se revelava inatingível para o comum do beirão, quer pelo custo, quer pela falta de acessibilidades à maioria das localidades desse vasto território e também pelo número diminuto de médicos disponíveis. Contudo, a iniciativa teve o grande mérito de dar a conhecer medidas que, conquanto muitas não pudessem ser postas em prática, como dissemos, alertavam e informavam a população.

A desigual distribuição regional de meios afetos à epidemia era especialmente tratada, como em finais de outubro, em que se comparava a capital a uma senhoria e a província a uma criada ${ }^{7}$ e se chamava a atenção para o urgente uso de medidas profiláticas e para a distribuição de pão. Os exemplos eram fortes, como o fornecimento de açúcar às farmácias, em Lisboa, a fim de não faltar para medicamentos, a prescrição pelo médico de receitas de remédios e de alimentos para os doentes pobres, o pagamento das despesas com desinfecções, transporte de doentes, hospitalização, enterros, «tudo por conta do Estado», mas só na capital ${ }^{8}$.

Em alinhamento com a catastrófica situação, iam surgindo no semanário, no mês de outubro, a par do necrotério densamente povoado de mortes de adultos jovens, notícias como a de finais desse mês, dando conta do óbito, num paquete vindo de África, de 199 passageiros, dos 952 embarcados, a maioria pertencente a soldados e graduados que regressavam da missão nesse continente. Ricardo Jorge também retém a catástrofe, referindo-se a ela em março de 1919, no relatório apresentado à comissão sanitária dos países aliados (Jorge, 1919: 23-24), dando conta desses óbitos e de mais 11, que morreram depois do desembarque, relatando que o vapor Moçambique saíra do porto de Lourenço Marques a 12 de setembro de 1918, transportando militares do corpo expedicionário que regressavam ao continente, com escala

\footnotetext{
7 Atente-se no que se escreve na revista $A$ medicina contemporânea, n. ${ }^{\circ} 41$ de 13-X-1918, no artigo «Epidemias reinantes», p. 326, onde se diz que em Lisboa o número de casos diminuíra e a virulência era menor, conquanto em várias partes da província fosse de molde a afligir as populações, citado por Maria Rita Lino Garnel (2009: 221-235)

8 Não podemos deixar de chamar à atenção para a matriz política deste suporte noticioso, antitético ao governo de ideário republicano.
} 
na cidade do Cabo em 1 de outubro, onde a pneumónica se fazia sentir e o contágio se gerou.

Retomando o nível local, ainda a propósito da limpeza da cidade, $A$ Guarda inseria uma carta recebida no apogeu da epidemia, em outubro de 1918, onde se descrevia o estado de várias ruas e se chamava a atenção, em particular para a freguesia de S. Vicente ${ }^{9}$, em estado calamitoso de higiene, cujas consequências poderiam inverter o quadro relativamente benévolo da epidemia na localidade, imputando-se a responsabilidade às autoridades «(...) que descuram a limpeza e saneamento».

A esperança na ciência ao serviço da descoberta de um medicamento que pudesse curar esta gripe foi outro tema tratado nas colunas do semanário $A$ Guarda, em novembro de 1918, como a invenção do médico militar italiano Luigi Mille e a do francês Dr. Dujarie de la Rivière, usando sangue extraído das veias do enfermo, «aplicando injecções subcutâneas de sorum obtido com esse sangue».

O papel do sacerdote na epidemia que invadia o país era descrito como de grande intervenção, já pela assistência abnegada e próxima, qual enfermeiro dos pobres, mormente nas freguesias do «interior profundo», já como «confortador dos tristes enlutados» e angariador de esmolas, a exemplo do padre de Vila Fernando, organizador de uma comissão para socorrer os pobres epidemiados.

Evitar o pânico entre a população terá sido uma das razões para a publicação de uma nota oficiosa à imprensa do subdelegado de saúde da Guarda, no primeiro de novembro, baseada em dados de um inquérito domiciliário por si promovido, para apurar «a situação sanitária da cidade». Nela informou que, desde o início da epidemia até 31 de outubro, se tinham registado 302 casos, o que representava aproximadamente $5 \%$ da população calculada, havendo-se curado 185 pessoas, encontrando-se 104 a convalescer ou em tratamento, e registando-se 13 mortos, incluídas 4 crianças menores de 3 anos. Concluía que a mortalidade global encontrada (4\%) se podia considerar reduzida, comparada com a mínima (10\%) que era apontada para fora de Portugal.

$\mathrm{Na}$ conjuntura que o país atravessava, o fornecimento de mostarda e de linhaça era imprescindível e urgia ser tabelado e organizada a sua distribuição na capital e no resto do país, estipulando-se pelas autoridades competentes o preço em Lisboa de 480 réis por quilo de linhaça e $3 \$ 000$ réis por quilo de mostarda, acrescentando-se o valor do transporte para fora de Lisboa.

$\overline{9}$ A sua principal artéria é medieval, com casas juntas. 
Os sinais de que a gripe estava a decrescer eram dados por indícios como a autorização da retoma do horário normal das farmácias e do abaixamento do receituário.

Reflete um articulista do semanário A Guarda, em crónica de fundo de 8 de novembro de 1918, sobre o número significativo de óbitos que a estatística oficial continha, enfatizando a sua percentagem considerável, sobretudo com vinte e trinta anos, isto é, os novos, os fortes, os sadios, os primeiros a morrer, parecendo juntar o rubro sangue destes ao rubro sol outonal.

$\mathrm{O}$ mês de novembro foi denso em «festas de penitência» pelas duas Beiras, pedindo-se a clemência divina e, em muitas freguesias, invocando S. Sebastião, advogado da peste.

O desânimo parecia apoderar-se das populações deste interior, como nos relata o correspondente de Celorico da Beira, numa notícia escrita a 1 de novembro, que reportava uma situação na localidade, com muitas vítimas mortais e um auditório diminuto na missa desse dia, por quase todos os que não haviam perecido se encontrarem no «leito soffrendo terriveis dores». Os homens, quais sombras, estampada no rosto a tristeza, pareciam vaguear nas ruas com passos incertos, tal o estado daquela gente.

A epidemia «adejava a sua asa sinistra», mas, paralelamente, o fim da guerra com a assinatura do armistício e a vitória dos aliados temperava um pouco este clima pesado de dor.

Não se tendo publicado durante três meses e ressurgindo em abril de 1919, neste mês, o periódico registou na primeira página uma pequena local, onde de forma irónica deu a notícia desse silenciamento forçado e destacou nesse número mortes de figuras locais.

Terminada a guerra, extirpada a pneumonia, imperava a questão das subsistências, e na Guarda os géneros estavam «mais caros do que noutra qualquer cidade», segundo se noticia a 9 de agosto de 1919. Sem a função equilibradora do celeiro público, entretanto extinto, fazia-se notar a subida abrupta dos preços, como do trigo que se pagava a 400 réis, praticando-se em Portalegre a metade do preço. O aumento estendia-se aos outros produtos de primeira necessidade, como os ovos e a carne, sugerindo-se a criação de um talho regulador. A carestia constituía «o tormento das donas de casa e o pesadelo dos chefes de família» e, aventava o articulista, que a solução estaria em baratear a vida, dando pão aos operários e moralizando as finanças, incutindo confiança aos burgueses.

Títulos como «açambarcadores», «receita para fazer fortuna» e similares eram recorrentes entre finais de setembro e meados de novembro de $1919^{10}$.

$\overline{10}$ Veja-se, por exemplo, o periódico de 27-9 e o de 15-11 desse ano. 
Fig. 2 - Receita para fazer fortuna

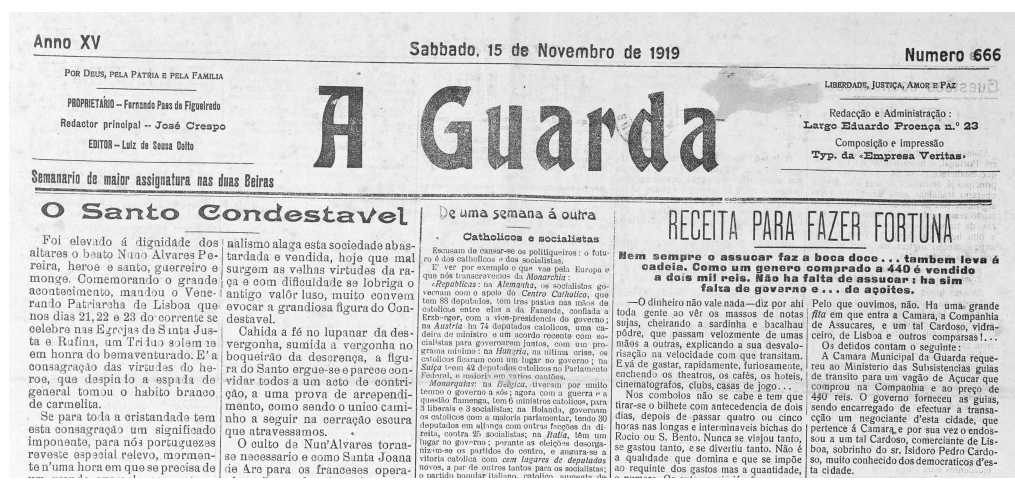

Fonte: Jornal A Guarda de 11 de novembro de 1918.

A fim de termos informações oficiais, consultámos o fundo da Delegação de Saúde da Guarda que, embora depauperado em fontes, nos respondeu a certas questões, como a carência de médicos, a transferência de verbas dos fundos públicos para ajuda aos epidemiados pobres via subdelegados de saúde das sedes concelhias, algum apoio presencial das autoridades civis, como do governador civil (acompanhado do delegado de saúde), o incentivo à constituição de comissões locais e o envio de açúcar para algumas subdelegações de saúde.

Atentemos nalguma da correspondência da Delegação de Saúde da Guarda. A 4 de julho de 1918, o delegado de saúde da Guarda enviou um ofício ao subdelegado de saúde de Foz Côa, respondendo a uma preocupação que este colocou sobre a falta de médicos ${ }^{11}$, aludindo à possibilidade de o concelho ser atacado pela influenza ou pelo tifo, referindo «(...) se quisermos desde já prevenir tais hipóteses para todos os concelhos precisaríamos do dobro dos médicos que existem no pays e no front (...)», adiantando-lhe haver concelhos com um só médico e outros sem nenhum. A 27 de setembro de 1918, o delegado de saúde da Guarda enviou um ofício ao subdelegado de saúde do Sabugal, onde incluía que «(...) para as despesas mais urgentes e até que possa enviar mais fundos, remeto a V. ${ }^{\mathrm{a}} \mathrm{Ex} \cdot{ }^{\mathrm{a}}$ o incluso cheque de $150 \$ 00$ para despesas a fazer com a epidemia que grassa nesse concelho». E, logo a 7 de outubro, lhe remeteu novo cheque, no valor de $394 \$ 00$, e ainda em medicamentos $100 \$ 00$, pois a epidemia era galopante.

$\overline{11}$ No jornal A Guarda de 26-10-1918, fala-se na mobilização de quintanistas de medicina. 
Fig. 3 - Boletim mensal $n . \stackrel{0}{3}$ de moléstias infeciosas de setembro de $1918^{12}$

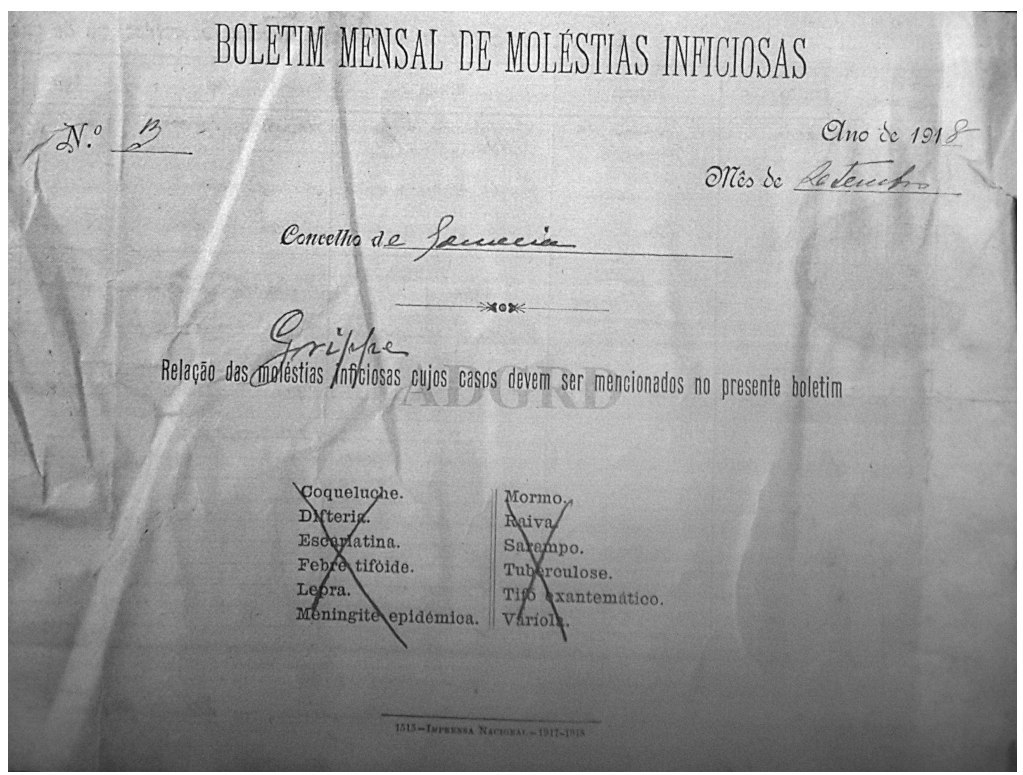

As verbas para despesas com doentes pobres, medicamentos, desinfetantes e dietas iam chegando aos concelhos do distrito, mas vamos concentrar-nos no do Sabugal, onde a gripe pneumónica era mais aguda, como salientou a provisão episcopal de D. José Alves Matoso, de início de outubro de 1918. O ofício enviado a 9 de outubro pelo delegado de saúde da Guarda ao facultativo municipal Dr. António José Gomes é pregnante, atentemos:

Recebi o officio de V. ${ }^{\text {a }}$ Ex. ${ }^{\text {a }}$ com data de 7 do corrente que dei ao Sr. Subdelegado de Saúde (...) para propor as medidas mais adaptadas ao combate da epidemia. No entanto devo dizer a V. ${ }^{a}$ Ex. ${ }^{a}$ que na freguesia de Benespera como em todas as outras freguesias quando grassar a doença deve organizar-se Comissões que possam adquirir donativos e receber e administrar o subsídio que o Governo pensar por intermédio da Delegação, ou melhor da Sub-delegação de Saúde.

Decorrido cerca de um mês, a 8 de novembro de 1918, o delegado de saúde da Guarda devolveu uma fatura, que lhe havia sido enviada para pagamento pelo subdelegado, respeitante a um táxi em que o Governador Civil e o representante da Delegação de Saúde do Distrito se deslocaram à sede concelhia para tratar da epidemia que invadiu essas localidades, a fim de ser incluída nas contas do concelho.

12 Mapas anuais e mensais de doenças infecciosas. Relatórios de estatística sanitária dos diversos concelhos do distrito: 25-1-1902 a 31-12-1927. 
Estava-se em 29 de novembro de 1918 e o delegado de saúde da Guarda informou o subdelegado que, até àquela data, as despesas com os epidemiados orçavam os $1.045 \$ 00$.

O último ofício foi de 31 de maio de 1919, no qual o delegado de saúde da Guarda remeteu um cheque no valor de $174 \$ 00$ para pagamento dos serviços prestados pelo médico Francisco Maria Manso, na epidemia da gripe pneumónica, em outubro e novembro de 1918, e também pelo aluguer de duas cavalgaduras ao mesmo médico, que as cedeu durante 18 dias para transporte de outros facultativos às diferentes localidades do concelho.

A opinião pública vertida na imprensa periódica nem sempre era consensual, dando-se o caso de no mesmo jornal, como $O$ Século $^{13}$ de 2 de outubro de 1918, se escrever que a epidemia decrescia, era mais benigna e mais circunscrita, e se relatar na mesma página que «(...) Arronches estava sem médico, no Sabugal havia mais de 1.500 enfermos, que aí a hospitalização se fazia nas escolas, que em Mira tinham falecido já 150 pessoas» (Garnel, 2009: 224).

A publicitação de medidas higienistas fez parte do combate epidemiológico, que travava uma guerra hercúlea dificultado pela extensão de muitos concelhos e dispersão geográfica, como a área composta pelo distrito da Guarda, de que não podemos dissociar a carência de transportes.

Em síntese, entre finais de setembro e de novembro de 1918, com especial incidência no mês de outubro, a gripe pneumónica infetou e matou na Beira Alta, deixando uma vaga de desolação e de luto, parecendo atacar menos na capital do distrito, por razões várias, a que não seriam alheias as melhores condições de saúde e de higiene.

Qual terramoto demográfico, a gripe pneumónica matou muitos e prostrou no luto inúmeras famílias, fosse no meio rural ou urbano, e o silêncio pareceu até há bem pouco tempo estar associado à gravidade da situação que então se viveu ${ }^{14}$.

\section{CONSIDERAÇÕES FINAIS}

O diálogo institucional entre o poder central e o local através da Direção Geral da Saúde e das delegações de saúde não foi uma falácia, bem como a mobilização da Igreja através do seu representante no distrito, com um papel de relevo do designado, na época, trabalho de consciencialização

\footnotetext{
13 Ver no n. ${ }^{\circ}$ 13.224, de 2-X-1918, o título «A epidemia», citado por Maria Rita Lino Garnel (2009: 224)

14 Veja-se Álvaro Sequeira (2001: 149).
} 
da população por parte dos sacerdotes, em alinhamento com as diretrizes do seu prelado, a exemplo do que aconteceu noutras zonas rurais do país, como nos indica Paulo Girão para o Algarve, em estudo de 2003. Pese embora esta ação, a que se juntou circunstancialmente a intervenção das forças da sociedade civil, designadamente a das comissões de benemerência, o país e a região em apreço não tiveram capacidade suficiente para combater a epidemia, registando-se o espectro da morte em muitas famílias, traduzido por uma assinalável quebra no crescimento demográfico. Num quadro de enorme morbilidade e mortalidade, a pandemia exigia recursos que não existiam, conhecimentos médicos que não havia, com uma etiologia da doença ainda desconhecida e uma consciência sanitária por parte dos cidadãos muito longe do necessário.

O cataclismo demográfico vivido em Portugal, resultado da epidemia gripal de 1918, parece gritar pela memória a que se julga com direito, pois contribuiu para a mudança de paisagens, para a alteração da pirâmide demográfica, para a reconfiguração de uniões conjugais, para a orfandade, entre outras.

\section{Fontes manuscritas}

\section{Arquivo Distrital da Guarda:}

ACD/DSG Delegação de Saúde da Guarda 1877/1933.

Correspondência Recebida e Expedida 1901/1933.

Estatística Sanitária 1902/1927.

Mapas anuais e mensais de doenças infecciosas. Relatórios de estatística sanitária dos diversos concelhos do distrito: 25-1-1902 a 31-12-1927.

Governo Civil da Guarda: Assistência e saúde pública, 21-2-1863 a 3-5-1977.

Decreto n. ${ }^{\circ}$ 4891, 12 de outubro de 1918, Diário do Governo, I Série n. $\stackrel{0}{2} 23$, suplemento, pp. 1.791-2.

\section{Fontes impressas}

Jornal A Guarda, janeiro de 1918 a maio de $1919^{15}$.

\section{Bibliografia}

$\overline{15}$ O periódico esteve suspenso de 4-1-1919 a 19-4-1919. 
CORREIA, Ana Maria Diamantino (2018). A resposta em Coimbra à epidemia de pneumónica de 1918-1919 sob o olhar de um periódico local. História, Ciências, Saúde, 25, n. ${ }^{-}$ 3, jul.-set., pp. 679-694. Acedido a 9/06/2018, em http://www.scielo.br/pdf/hcsm/v 25n3/0104-5970-hcsm-25-03-0679.pdf

ESTEVES, Alexandra (2014). O impacto da pneumónica em alguns concelhos do Alto Minho. CEM-Cultura Espaço Memória, 3, pp. 165-181. Acedido a 20/8/2018, em ler.le tras.up.pt/uploads/ficheiros/12847.pdf

GARNEL, Maria Rita Lino (2009). Morte e memória da pneumónica de 1918, in J. M. Sobral et al. (org.). A pandemia esquecida. Olhares comparados sobre a pneumónica 19181919. ICS, Lisboa, pp. 221-235.

GIRÃO, Paulo (2003). A pneumónica no Algarve (1918). Caleidoscópio, Casal de Cambra.

JORGE, Ricardo (1918a). Influenza pneumónica: nova nota apresentada ao Conselho Superior de Higiene em 24-IX-918. Portugal Médico, 3. ${ }^{\text {a }}$ série, vol. IV, n.ํㅜ 9, (Set.), pp. 575577.

JORGE, Ricardo (1918b). A influenza: nova incursão peninsular. Imprensa Nacional, Lisboa.

JORGE, Ricardo (1919). La grippe: rapport préliminaire présenté à la commission sanitaire des pays alliés dans sa session de mars. Imp. Nationale, Lisbonne.

SEQUEIRA, Álvaro (2001). A pneumónica. Medicina interna, vol. 8, n. ํㅜ 1, pp. 149.

SOUSA, Paulo Silveira; CASTRO, Paula; LIMA, Maria Luísa; SOBRAL, José Manuel (2008). Responder à epidemia: estado e sociedade civil no combate à gripe pneumonica (19181919). Revista de História das Ideias, vol. 29, pp. 469-500. Acedido a 25 de fevereiro de 2019. 


\title{
ECOS DA PNEUMÓNICA NA MARGEM SUL DO TEJO
}

\author{
Manuela Soares Ventura ${ }^{1}$
}

$\overline{\text { Investigadora do CITCEM } \mid \text { FLUP }}$ - Grupo de Populações e Saúde, mmanuela.ventura@gmail.com 



\begin{abstract}
Resumo
O objeto da presente comunicação consiste na análise da repercussão da gripe espanhola de 1918 no atual concelho de Montijo, ao tempo, Aldeia Galega do Ribatejo, território localizado na margem sul do rio Tejo, com base em dois jornais locais republicanos, $A$ Razão e $O$ Domingo, e em fontes demográficas. $\mathrm{O}$ cruzamento das diversas fontes procura estimar a dimensão que alcançou a epidemia na população local. A área em estudo compreende duas zonas distintas, uma, mais urbana, localizada em frente a Lisboa, na margem esquerda do rio Tejo, outra mais rural e no interior.
\end{abstract}

Palavras-chave: Pneumónica, Gripe espanhola, Montijo, Canha, Aldeia Galega.

A pandemia de gripe espanhola, influenza ou pneumónica encontra-se habitualmente descrita como a mais letal enfermidade que varreu o século XX, propagando-se em vagas com impacto diferenciado, que atingiram com grande violência a população mundial, tendo provocado idêntico efeito arrasador em Portugal. Apesar dos terríveis efeitos demográficos que a epidemia originou, é notório o esquecimento a que tem sido votada, presumivelmente devido a ter ocorrido durante a I Guerra Mundial, no terrível contexto de fome, carestia de vida e conflitos sociais, embora a tenha ultrapassado em mortandade (Sobral et al. 2009). Mesmo sem unanimidade quanto ao número de óbitos, os dados demográficos indicam que a epidemia de 1918 provocou em Portugal uma inversão relativa das taxas de mortalidade e natalidade, ímpar no período entre 1886 e 1993.

O objeto da presente comunicação consiste na análise das repercussões da gripe espanhola de 1918 no atual concelho de Montijo, ao tempo, Aldeia Galega do Ribatejo, ou Aldegalega, baseando-nos, em dois jornais republicanos locais: A Razão e O Domingo. Ensaiamos cruzamentos com outras fontes, sobretudo demográficas, procurando estimar que proporções alcançou a epidemia na população local. 
O concelho de Montijo situa-se no extremo norte do distrito de Setúbal, faz parte da área Metropolitana de Lisboa, estendendo-se por uma área geográfica de $348,4 \mathrm{~km}^{2}$. A zona Oeste do concelho situa-se à beira do rio Tejo, sendo parte integrante da chamada Margem Sul do Tejo, em frente à cidade de Lisboa. O território Este faz fronteira administrativa com os concelhos de Benavente, Palmela, Coruche, Montemor-o-Novo e Vendas Novas, estando já muito próximo das planícies alentejanas. A área concelhia apresenta-se separada e, consequentemente, formada por duas partes geográficas distintas. Esta singularidade ultrapassa a separação territorial e as diferenças paisagísticas, atingindo o tipo de povoamento, as influências climáticas, a concentração populacional e as atividades socioeconómicas desenvolvidas em ambas as partes. Tal descontinuidade explica-se pelas diversas alterações que a configuração do concelho passou. A partir de 1838, praticamente até finais do séc. XX, o concelho era formado por três freguesias: Aldeia Galega, Sarilhos Grandes e Canha. Esta última tinha perdido a categoria de sede de concelho durante o liberalismo e integrou, com a categoria de vila, o concelho de «Aldeia Galega do Ribatejo», atual Montijo, tal união nem sempre inteiramente pacífica.

Usamos como fonte principal, para compreendermos a dimensão da gripe espanhola na área em estudo, o jornal $O$ Domingo, que começou a publicarse em 21 de julho de 1901, proclamando-se «Semanário noticioso, literário e agrícola». No sétimo ano da sua publicação, o jornal identifica-se como «Semanário Republicano Independente». Em 1911, o jornal assumiu-se como «Semanário Republicano Radical». Até 15 de Agosto de 1920, data do último jornal publicado, foi seu proprietário e editor, José Augusto Saloio, figura proeminente do Partido Republicano Português local. A coleção completa do jornal foi adquirida pelo município montijense aos descendentes do seu proprietário. O jornal A Razão - Semanário do Partido Republicano Português, publicou-se, pelo menos, entre 1916 e 1923, não chegando aos nossos dias todos os números publicados. Procuramos cruzar a informação jornalística com fontes demográficas, nomeadamente dados censitários, Estatística do Movimento Fisiológico da População Portuguesa de 1918 e registos paroquiais. Para a vila de Canha, contamos com o Livro de entrada e saída dos doentes do Hospital da Misericórdia de Canha, relevante, e inédita, fonte manuscrita.

Para além da análise sobre os dados demográficos, procuramos referenciar também as providências sanitárias tomadas a nível concelhio. A virulência da epidemia fez despertar respostas da sociedade civil, sendo relevante 
compreender as medidas tomadas para minimizar o flagelo em comunidades relativamente pequenas.

Procurámos, através do estudo das notícias e comentários do jornal $O$ Domingo, abarcar o impacto que esta epidemia teve na área geográfica em foco, analisando todos os números deste semanário saídos entre 1917 e finais 1919. Até julho de 1918, não é publicada qualquer notícia ou comentário relativo a casos de gripe. Contudo, a questão da falta de limpeza da vila de Canha é referenciada mais que uma vez e, sobretudo, há alusões a inúmeras reclamações sobre a falta da vacina contra a varíola (soro antivariólico) que, apesar de repetidamente pedida, tardava a chegar à comunidade. Noticia-se, igualmente, que havia escassez de géneros alimentícios, tendo o açúcar e o petróleo desaparecido do mercado.

Em 7 de julho, surge a primeira notícia sobre a epidemia, na secção Comentários $\&$ Notícias, surpreendendo, contudo, pela ligeireza, tom jocoso e brejeiro da sua prosa. Diz o articulista que a doença, embora ligeira, era incomodativa, podendo ter consequências graves, mas não parecia coisa para sustos, terminando da seguinte forma:

Toda a gente adquiriu o hábito de dizer que A ou B está com a espanhola isto quando se dá o caso dos esposos se distanciarem e ela é ciumenta e de cabelinho na venta é o diabo, a confusão provoca escândalos. E depois... elas têm tanto salero $^{2}$.

Em julho, 14, noticia-se que se vai manifestando com intensidade a epidemia de varíola, alertando-se que todas as crianças devem ser levadas à vacinação, não se alvitrando nada sobre a gripe. Em final de setembro, o jornal alerta que a higiene do concelho continuava a não ser feita de modo conveniente, nomeadamente que havia óbitos de tuberculosos, cujas casas e roupas não tinham sido desinfetadas.

Só a 20 de outubro se destacam novas sobre a pneumónica, salientandose que a epidemia se desenvolve assustadoramente, provocando alguns óbitos na vila de Aldeia Galega. Realça-se a falta de higiene na vila e a inexistência de preparativos para a montagem de um hospital. A farmácia local transformara-se em hospital, tal era o número de doentes que ali ocorriam em busca de tratamento. Recomendava-se que cumprimentos de «apertos de mão» e «beijos» se evitassem, enquanto a epidemia durasse.

Presume-se, com base nas informações de $O$ Domingo, que a primeira vaga da epidemia de gripe espanhola tenha sido bastante benigna para esta comunidade, pois só a partir do final do mês de outubro as notícias se tornam preocupantes, embora com caráter completamente diverso na vila sede do

2 O Domingo, $7 / 07 / 1918$. 
concelho, à beira Tejo, «não é ainda a mais queixosa da pneumónica»e, na vila de Canha, situada no interior na fronteira entre Ribatejano e Alentejo.

Em 27 de outubro, diz $O$ Domingo, «Vai fazendo das suas a maldita doença que num sobressalto traz, assim se pode dizer, a humanidade inteira». A situação na vila de Canha é descrita como alarmante, noticiando-se o número de óbitos, o nome das vítimas e o número de órfãos que deixam. Naquela data, o jornal indica existirem 41 óbitos, mas os números serão crescentes: a 3 de novembro, os óbitos sobem para 71; no dia 10, anuncia-se um total de 85 vítimas; na semana seguinte, a 17 de novembro, anunciamse 98 mortes. É referenciados um total de 97 órfãos, muitos de pai e mãe. Publicam-se os nomes das vítimas e a indicação dos casos em que a doença afetou todo, ou quase todo, o agregado familiar, falecimento de ambos os cônjuges ou de um progenitor e seus filhos.

A Razão, outro jornal republicano publicado no concelho, confirma, em 7 de novembro de 1918, as informações sobre os danos em Canha. Um correspondente local do jornal descreve a gravidade da situação, "A epidemia atual, trouxe a dor, o luto e o desalento a toda a parte», poucos eram os que trabalhavam, as sementeiras estavam a um terço do habitual, o preço dos géneros alimentícios e outros artigos disparavam. Resumia o jornalista: «O pânico que se apoderou desta pobre gente é indescritível. O leitor não pode calcular o terror que por aqui vai. Meia dúzia de pessoas conseguiram escapar que a pneumónica lhes batesse à porta» ${ }^{3}$.

O Livro de entrada e saída de doentes do Hospital da Misericórdia de Canha, fonte que tivemos oportunidade de consultar, parece atestar a informação jornalística sobre o embate da gripe espanhola na localidade.

Em 1916, deram entrada no hospital 80 doentes; em 1917, o número desceu para 46; em 1918, chegou aos 113 doentes; rondando 62 e 80 entradas, nos anos de 1919 e 1920, respetivamente. Verificamos que o número de internamentos foi bem mais significativo durante o ano de 1918 (Figura 1), sobretudo de homens. As admissões de doentes, em 1918, concentraram-se em outubro e novembro, com a de entrada 50 doentes. Foram diagnosticados com gripe 43 pacientes e, destes, 20 vieram a falecer no hospital.

3 A Razão, 7/11/1918. 
Fig. 1 - Número de internamentos no Hospital da Misericórdia de Canha (1916-1920)

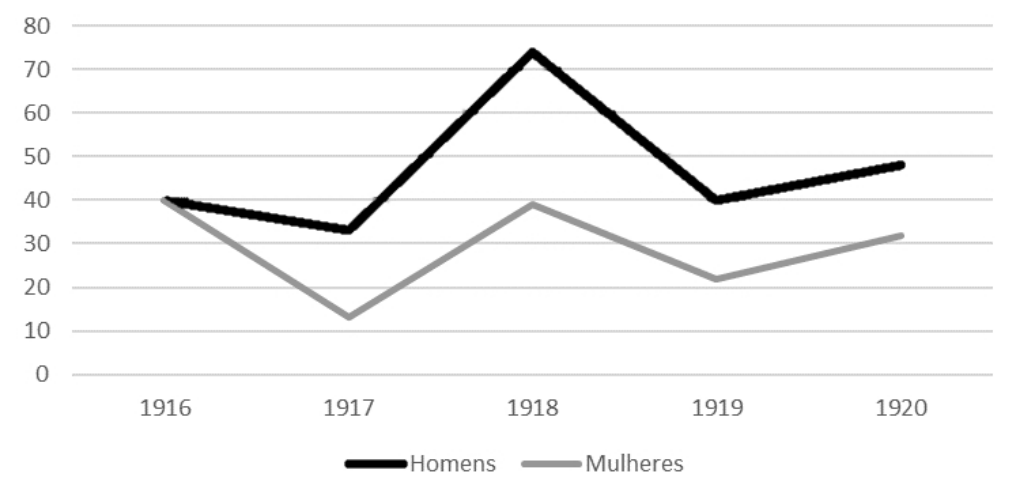

Fonte: Livro de entradas e saídas de doentes do Hospital da Misericórdia de Canha.

Outras informações jornalísticas configuram um quadro social de calamidade:

- A administração da Misericórdia solicitou um subsídio ao Dr. Ricardo Jorge para que a instituição pudesse resistir à adversidade, o qual chega em pouco tempo;

- Os proprietários e lavradores enviam donativos;

- O coveiro não consegue dar conta da sua tarefa, havendo necessidade de contratar um ajudante, inclusivamente alargou-se o cemitério;

- Distribuição gratuita de medicamentos aos pobres internados;

- A Sociedade de Beneficência Mário Salgueiro constitui uma comissão para angariar donativos;

- Foi suspenso o funcionamento da Sociedade Musical;

- As autoridades locais, acompanhadas pelo médico realizaram vistorias aos domicílios e quintais, intimidando os proprietários a removerem os lixos.

Obviamente que todo o envolvimento social inerente à vaga epidémica não esteve isento de conflitos políticos, sendo relatados diversos focos de discórdia entre as autoridades do concelho e as da freguesia de Canha. A questão da proibição do toque dos sinos ou a distribuição de açúcar aos 
infetados com a pneumónica geraram polémica na comunidade. Neste último caso, a resolução da comissão de abastecimentos local, determinando que o açúcar só fosse fornecido a quem apresentasse receita médica, provocou conflitos com os médicos, que a consideraram tarefa extra e complicada de levar a cabo, segundo os relatos jornalísticos.

As informações publicadas pelo semanário $O$ Domingo e também pelo periódico $A$ Razão suscitam algumas questões relativamente à incidência da gripe espanhola em Canha e nas restantes freguesias do concelho. São bastante destacados os efeitos da epidemia na localidade de Canha, contudo poucos infetados se mencionam na sede do concelho. Quando se começa a noticiar, em final de outubro, a situação calamitosa que a epidemia assume em Canha, refere-se que Aldeia Galega não se encontra muito afetada pela doença e, ironicamente, sugere-se que a falta de limpeza desta última localidade serviria para meter «medo» à gripe.

A Estatística do Movimento Fisiológico da População Portuguesa, em 1918, refere para o concelho de Aldeia Galega os seguintes óbitos causados pela gripe: 109 homens e 83 mulheres, correspondendo a $35 \%$ do total dos óbitos. Acreditando-se nas informações dos jornais, em Canha teriam falecido 98 indivíduos. Questiona-se: os restantes 94 falecimentos não mereceram praticamente tratamento jornalístico? Admite-se que o impacto das mortes em Canha, zona predominantemente rural, seja proporcionalmente muito maior, considerando o número de residentes. Segundo o Censo de 1911, o concelho tinha 11.167 habitantes, distribuindo-se da seguinte forma: 1.093 habitantes em Canha; 8.460 em Aldeia Galega e 1.616 em Sarilhos Grandes. A análise futura do registo civil dos óbitos ocorridos em 1918 poderá clarificar as diferenças descritas.

A sociedade civil respondeu localmente, a exemplo de grande parte do país, com diversos movimentos de apoio às famílias carenciadas dos epidemiados, nomeadamente recolhendo donativos para apoio imediato às vítimas $\mathrm{e}$ para a construção de um orfanato:

- Organizou-se a «Comissão de Assistência às vítimas»;

- Há subscrições abertas na vila para os pobres do concelho, cujas listas de donativos são semanalmente publicadas;

- Subscrições públicas a favor do Orfanato de Aldegalega do Ribatejo, iniciativa do médico César Fernandes Ventura, inaugurado logo em 1919, presumivelmente para acolher crianças órfãs de pais vitimados pela pneumónica. 
A análise destes jornais locais que, apesar da censura, noticiaram a gripe, promoveram subscrições de dinheiro e campanhas de auxílio aos doentes e seus familiares, releva o seu ativo papel cívico no seio das comunidades que os viram nascer.

Em conclusão, embora com uma primeira vaga benigna, a pneumónica teve efeitos devastadores no concelho do Montijo, principalmente durante o final de outubro, evidenciando uma maior incidência, na vila de Canha, comunidade mais rural e interior.

\section{Fontes}

Livro de entrada e saída de doentes do Hospital da Misericórdia de Canha. Arquivo da Santa Casa da Misericórdia de Canha.

A Razão, 31 de outubro de 1918, nº 147.

A Razão, 7 de novembro de $1918, \mathrm{n}^{\mathrm{o}} 148$.

A Razão, 15 de novembro de 1918, nº 149.

A Razão, 21 de novembro de 1918, no 150.

A Razão, 31 de outubro de $1918, \mathrm{n}^{\mathrm{o}} 147$.

O Domingo, 6 de janeiro de 1918, nº 859.

O Domingo, 16 de junho de 1918, no 881.

O Domingo, 7 de julho de 1918, no 884.

O Domingo, 14 de julho de 1918, nº 885.

O Domingo, 21 de julho de 1918, nº 886.

O Domingo, 28 de julho de 1918, nº 887.

O Domingo, 9 de setembro de 1918, nº 896.

O Domingo, 13 de outubro de 1918, no 898.

O Domingo, 20 de outubro de 1918, no 899.

O Domingo, 27 de outubro de 1918, no 900.

O Domingo, 3 de novembro de 1918, nº 901.

O Domingo, 10 de novembro de 1918, no 902.

O Domingo, 17 de novembro de 1918, nº 903.

Estatística do Movimento Fisiológico da População de Portugal de 1918, (1922). Lisboa, Arquivos do Instituto Central de Higiene, Imprensa Nacional. 


\section{Bibliografia}

CASTRO, P.; LIMA, M.; SOBRAL, J.M.; SOUSA, P.S. (2009). Perante a Pneumônica: a epidemia e as respostas das autoridades de saúde pública e dos agentes políticos em Portugal (1918-1919). Varia Historia, vol. 25, no 42, pp. 377-402.

FRADA, J.M. (2005). A Gripe Pneumónica em Portugal Continental (1918): estudo socioeconómico e epidemiológico, $1^{\mathrm{a}}$ edição. Sete Caminhos, Lisboa.

ESTEVES, A. (2014). O impacto da pneumónica em alguns concelhos do Alto Minho. CEMCultura, Espaço, Memória, no 5. Acedido a 20/04/2018, em http://ler.letras.up. $\mathrm{pt} / \mathrm{uploads} / \mathrm{pdf}$

REGO, Maria Aurora Botão Pereira (2013). De Santa Marinha de Gontinhães a Vila Praia de Âncora (1624-1924). Demografia, Sociedade e Família. Vila Praia de Âncora: Junta de Freguesia de Vila Praia de Âncora.

ROLLO, M.F. (2008). 1918. Pneumónica, ou a Gripe Espanhola. Ingenium, n. ํ 105, Maio/Junho. 


\section{La Pandemia de Gripe en la Provincia de BADAJOZ}

Antonia $\mathrm{M}^{a}$ Durán Herrera ${ }^{1}$ 



\section{Resumo}

Antecedentes: Em Espanha, a pandemia de gripe de 1918-1920 apresenta características heterogéneas de acordo com as regiões.

Objetivos: Determinar o impacto da pandemia na província de Badajoz numa época em que estava a acontecer uma transição demográfica; analisar as diferenças entre as áreas rurais e urbanas e observar os diferentes comportamentos sociais nesta situação tão grave.

Fontes e Métodos: Juntaram-se várias fontes para conhecer o excesso de mortalidade nas 163 localidades da província, de maneira a estimar a mortalidade específica por idade de todas as doenças, tal como a gripe e outras doenças relacionadas. Os jornais e documentos oficiais informam-nos da situação social.

Resultados: Rho de Spearman $(-0,318)$ mostra uma correlação inversa negativa entre as cidades, vilas, aldeias e a capital. O topo de mortalidade durante a segunda onda aconteceu em Outubro-Novembro de 1928. A taxa de mortalidade por gripe $(5,33 \%$ ) foi $629,66 \%$ maior do que em 1915-1917. A esperança de vida diminuiu $14 \%$.

Conclusão: Nas áreas rurais, a pandemia foi mais forte que na capital. O impacto da gripe interrompeu momentaneamente a transição demográfica. Em geral, houve uma sobre-mortalidade masculina, mas as mulheres sofreram mais com a pandemia. Os jovens e idosos tiveram as maiores taxas de mortalidade. No entanto, em 1919, a população continuou a crescer como resultado das medidas higiénicas e sanitárias tomadas. Os comportamentos sociais eram complexos. Houve ações de xenofobia contra cidades, vilas e aldeias vizinhas, enquanto um sentimento de solidariedade e fraternidade cresceu noutras.

Palavras-chave: Badajoz, Pandemia, Gripe, 1918, Mortalidade, Extremadura.

\section{INTRODUCCIÓN}

En 1918, el mundo estaba en guerra deseando una paz que llegaría precisamente en uno de los momentos álgidos de la expansión de una pandemia 
llamada «gripe española» ${ }^{2}$. A los millones de muertos en guerra se añadió otra mortandad provocada por el «soldado invisible», un microbio entonces desconocido más mortífero que la propia guerra con una mortandad calculada en más de 50 millones de personas, que podría llegar hasta 100 millones. La imbricación paz y pandemia parece clara (Crosby, 1918) porque ambos hechos provocaron una catarsis que no solo afectó al espectro demográfico sino a una multiplicidad de aspectos, entre los que destacamos los nuevos retos científicos y sanitarios generados por la misma pandemia, económicos, modificación de estructuras sociales, cambios ideológicos que determinaron acciones políticas-administrativas que han quedado explicadas como consecuencia de la gran mortandad pero en cuyo fondo está también latente la gran mortandad pandémica que operaba subrepticiamente al igual que las pestes medievales.

La aparición de la primera mortandad por el virus identificado como H1N1 en los campamentos militares estadounidenses se extendió rápidamente tanto a los soldados en las trincheras de los países en guerra en Europa como a los campamentos de otros continentes como Australia, Japón, India y países iberoamericanos que no estaban en guerra. España no estaba en guerra. Mientras en Europa se silenciaba la muerte de los soldados por esta enfermedad, fue precisamente la libertad de prensa lo que permitía informar sobre un nuevo tipo de mortandad relacionada con enfermedades respiratorias, especialmente la neumonía, que se denominó «gripe española». La entrada de personas procedentes de Francia y en muchos casos con destino a Portugal fue el cauce de expansión de esta pandemia en territorio español. En 1920, la población española era de 20 millones, de los cuales se calcula que 8 millones fueron infectados y 300.000 murieron a causa de ella.

Badajoz, región situada al sudoeste de España, provincia fronteriza con Portugal, tenía 644.625 habitantes (censo de 1920), con una densidad media de 29,78 ha./km. El grado de urbanización era del 35\%. De los 163 municipios, solo 15, incluyendo la capital, se reconocen como tales ciudades más por el número de habitantes que por grado de industrialización y servicios apenas reseñables, ya que su economía era fundamentalmente agrícola-ganadera.

La heterogeneidad de situaciones y resultados según regiones española en cuanto al exceso de mortalidad generado por esta pandemia expuesta por B. Echeverry (1993) y Chowel (2014) nos anima a estudiar la situación en la provincia de Badajoz. El objetivo primordial es analizar el número de

2 Aunque la formalización de los acuerdos de paz no se firmaran en Los Tratados de París (1919-1920), el 11 de noviembre de 1918 se firmaba el Armisticio de Compiégne por parte de Alemania y Francia. 
personas que efectivamente murieron como consecuencia de la gripe y de las tipificadas como enfermedades relacionadas con la misma. Así mismo tratamos de dar respuesta a algunos de los muchos interrogantes tales como ¿Cuándo se iniciaba exactamente la gripe? ¿Cuál fue realmente ese exceso de mortalidad? ¿Se presentan las olas con la misma temporalidad que en otros puntos de España? ¿Realmente afectó densidad de población determinó la gravedad de la pandemia? ¿Cuáles fueron las personas más afectadas según la edad y el sexo? ¿Cómo se refleja esta mortandad en el territorio? ¿Qué medidas políticas, sanitarias y sociales expresas se tomaron para paliar su contagio? ¿Cuál era el sentir de las gentes ante esta pandemia? Otras muchas cuestiones quedan abiertas a futuras investigaciones.

\section{ANTECEDENTES. FUENTES Y MÉTODO}

Desde sus orígenes, en que se consideró que la bacteria Heamophilus influenzae era la causante de la gripe hasta hoy día, son innumerables los trabajos de genética para identificar su verdadero origen. Ya en 1917 A. Abraham y otros (1917) constataron casos de muertes entre los soldados británicos por bronquitis purulentas difíciles de identificar. Son muchos los estudios filogenéticos realizados, especialmente los de J. Taubenberger (Taubebberger, 2006) y A. Reid (1999) los que tras el análisis del ADN de los fallecidos identificaron el virus A (H1N1) como el causante de la gripe, así como las mutaciones que se producirían en décadas posteriores. Esto ha dado lugar a la creación de posibles parámetros de transmisibilidad a nivel clínico por parte de A. Ganit (Gani et al., 2005), o conocer el grado de rapidez con que pueden producirse (Oeppen et al., 2010) e incluso creación de una modelización computarizada de posible transmisión de la gripe (Ruiz Bargaño, 2002).

Todos los investigadores apuntan la dificultad de establecer un punto de origen definitivo porque prácticamente aparecía de forma casi simultánea en Estados Unidos, Europa y Asia (Jordan, 1927). En unos casos se piensa que su origen estaba en China siendo exportado a Gran Bretaña y Francia a través de las tropas coloniales por lo que es comprensible su difusión por el ejército, de hecho en Europa se desencadenó antes en los ejércitos aliados que en las naciones centrales (Oxford y Gill, 2018). El primer caso de mortalidad se localiza en Estados Unidos, para unos en el campamento militar de Funston en Arkansas, para otros en Fort Rileys en Kansas (Murillo Godínez, 2011). La realidad es que a partir de marzo de 1918 se extendía por todo el mundo, especialmente por los campamentos militares, siendo especialmente mortífera 
en Estados Unidos. En España se reconocía públicamente su aparición en Madrid el 22 de mayo de 1918 (Echeverri Dávila, 1993), sin que esto significase que hubieran ocurrido antes en otros lugares o campamento militares.

La pandemia se presenta con variaciones en cuanto a su temporalidad e intensidad e incluso se advierten zonas climáticas más propensas, por lo que hay una gran variabilidad de resultados. En España es comúnmente aceptada que la pandemia se desarrolló a partir de la segunda quincena de mayo de 1918 pero no hay unanimidad de criterio ni identidad de situaciones para decir que finalizó en 1920. B. Echeverri considera la primera pandemia entre mayojunio de 1918, una segunda oleada a partir de septiembre, con un máximo en octubre desapareciendo en diciembre, la tercera oleada la sitúa en los meses de enero y junio de 1919. En el caso de Madrid, I. Porras (1994) mantiene la misma temporalización para la primera oleada, encuentra indicios de un segundo brote en el mes de agosto que llegaría al cenit en Octubre y el tercer brote lo sitúa en los meses de febrero-marzo de 1919. A. Erkoreka (2010) sitúa las dos primeras oleadas en mayo-junio y octubre-noviembre de 1918, la tercera en los primeros meses de 1919 y una cuarta en los primeros meses de 1920. A. Trilla estima que el $75 \%$ de la mortalidad ocurrió durante la segunda ola y de ellas, el $45 \%$ en el mes de octubre (Trilla et al., 2008). Con una temporalidad similar, en el caso de Madrid, L. Cilek, G. Chowell y D. Ramiro (1918) consideran cuatro oleadas marcadas por diferentes estaciones climatológicas: primavera y otoño de 1918, la tercera en el invierno de 1919 y una cuarta en el invierno de 1919-1920. En Portugal, la distribución del exceso de mortalidad atribuida a la pandemia también revela 4 olas: verano de 1918, otoño-invierno de 1918-1919, primavera de 1919 e invierno de 19191920 (Nunes et al., 2018).

En el caso de Extremadura, Carlos M. Neila Muñoz (2014), refleja diferencias entre Cáceres y Plasencia. En Plasencia la mayor virulencia estaría en el mes de octubre de 1918, pero en 1919 la pandemia fue mayor en Cáceres. Las dos primeras olas de gripe tuvieron lugar en junio y octubre de 1918, la tercera en marzo-junio de 1919. En el caso de algunas poblaciones del partido judicial de Llerena, Silva Ortiz (2018) sitúa entre abril y agosto de 1918 la primera ola y la segunda en octubre-diciembre. Según B. Díaz y B. Miranda (2014), en Campanario se produjo una concentración de defunciones entre los meses de Agosto y diciembre de 1918. En el caso de Montijo, Lobón y la Puebla, M. García Cienfuegos (2018) también encuentra la concentración de la mortandad en Octubre y Noviembre. Otros muchos estudios locales de diferentes provincias marcan reseñables diferencias en cuanto a temporalidad y gravedad de la pandemia (Férnández Fernández y Veiga Ferreira, 1995; 
Herrera Rodríguez, 1996; Álvarez et al., 2008; Gondra Rezola y Erkoreka, 2010; García-Consuegra García-Consuegra, 2013).

\section{Fuentes}

Los Censo de Población de 1910-1920 y los Movimientos Naturales de Población (MNP) de I.N.E. de los años 1915 a 1923 han sido imprescindibles para el conocimiento de la población, nacimientos, defunciones y matrimonios de España y de las demás provincias. Específicos de la provincia de Badajoz han sido los Modelos de Hojas Auxiliares de Nacimientos y Defunciones de 1915 a 1923 que mensualmente elaboraba el Instituto Provincial de Estadística (IPE) con las Cédulas de los Juzgados Municipales en donde quedaban anotados los números registrales de nacimientos y defunciones de todas las poblaciones a partir de las inscripciones realizadas en los Registros Civiles de todos los Ayuntamientos ${ }^{3}$. Para conocer la mortalidad por edad y sexo se han consultado los resúmenes anuales de las Estadísticas de las causas de mortalidad combinada con la edad de los fallecidos (1915-1923), las Hojas Auxiliares de Defunciones según edad del IPEB (1915-1923) y los Boletines Estadísticos de la D.G.E.G.E. de 1918.

De carácter administrativo se ha consultado el Boletín Oficial de la Provincia de Badajoz que nos ha dado una valiosa información no solo de la mensualidad del movimiento demográfico, sino de toda la normativa que se tuvo que desarrollar durante los momentos álgidos de la epidemia. A esto se añade la consulta de periódicos que al final han quedado focalizados en el periódico que se publicaba de forma continuada en esos años, el Correo de la mañana, periódico pacense que refleja la vivencia de la pandemia desde las autoridades y desde el pueblo.

\footnotetext{
3 Se da el caso de Campanario en donde en 1916 y 1917 es mayor el número de defunciones que figuran en el Archivo Parroquial que en las Hojas Auxiliares del IPE, pero en 1918 es todo lo contrario. Hay que considerar que en aquellos municipios donde había minorías protestantes, como es el caso de Santa Amalia, estas personas no aparecen en los Registros Parroquiales pero sí en los Registros Civiles.
} 


\section{Método}

A partir de la información censal municipal de 1910 y 1920 se ha calculado la población anual (Livi-Bacci, 2007: 35-55) . Dado que el resultado es una progresión continua de crecimiento y esto no se correspondería con el retroceso general de la población en 1918, se ha aplicado el diagrama de Lexis ${ }^{5}$ para 1917-1919, que por otra parte permite conocer exactamente la estructura etaria de dichos años ${ }^{6}$. Dado que los censos de 1910 y 1920 no ajustan la estructura etaria quinquenal, se ha procedido a la aplicación de los coeficiente de interpolación de Sprague (Shryock et al., 1976). Cuestión importante en este caso es conocer hasta qué punto hay un exceso de mortalidad pandémica o simplemente irregular, por lo que se ha seguido la formulación simple de Murray et alii (2006). Para el cálculo de los estadísticos básicos relativos tasas brutas de mortalidad, tasas específicas y estandarización de las mismas, tablas de supervivencia y esperanza de vida se han aplicado las técnicas y estadísticos comúnmente utilizados (Livi-Bacci, 2007; Vinuesa, 2007; Martín Martín et al., 2008).

Ante la excesiva particularización que supone la evolución de la mortalidad de los 163 municipios desde 1915 a 1923, se ha procedido a la categorización de los mismos en función del número de habitantes: la capital, ciudades $^{7}$ y espacio rural, el cual queda subdividido en tres grupos: poblaciones entre 5.000 y 9.999 habitantes, entre 2.000 y 4.999 y los que tienen menos de 2.000 habitantes. La geo-referenciación se ha realizado en función del nivel de exceso de mortalidad que pudiera haber en cada municipio.

Cuestión importante es la clasificación de las enfermedades. Por una parte se ha considerado la de M. Bertillon tal y como constan en las Esta-

4 La formulación utilizada ha sido la siguiente la tasa de crecimiento geométrico: $P_{t}=$ $o P e^{r t}$. De donde ${ }_{\mathrm{t}} \mathrm{P} /{ }_{\mathrm{o}} \mathrm{P}=e^{r t} ; \log (\mathrm{tP} / \mathrm{o}) /=\mathrm{rt} ; \mathrm{r}=\log \left({ }_{\mathrm{t}} \mathrm{P} /{ }_{\mathrm{o}} \mathrm{P}\right) / \mathrm{t}$.

5 Hay varios manuales sobre esta técnica de ajuste de datos: Livi-Bacci, M. (ed.) 2007. Introducción a la Demografía, Barcelona: Ariel, Vinuesa, J. P. D., 2007. Técnicas y ejercicios de Demografía, Madrid, I.N.E.

6 La población calculada según el método regresivo de Lexis, nos da una población total en 1918 de 632.849 a fecha de diciembre de 1918, lo cual es coherente por una parte con el crecimiento interanual en 1919 y 1920 del 0,93 con la población del censo de de dicho año de 644.621 y también es coherente con el crecimiento calculado según fórmula de Livi-Bacci (2007: 35-55) por el que se obtiene un crecimiento interanual para 1917 de 1,01. No obstante, dada la población que la Estadística Provincial atribuye a la provincia a 1 de enero de cada año, según movimiento natural de población, se ha hecho la media entre ambos datos para hallar las tasas de mortalidad tanto general como específica.

7 Se considera como tales a las poblaciones de más de 10.000 habitantes. Hay algunas que en 1910 no lo eran, otras lo eran en 1918 y otras dejaban de serlo en 1921. En todos los casos se ha hecho la media del trienio correspondiente. 
dísticas oficiales, ahora bien, teniendo en cuenta que se trata de estudiar una enfermedad de transmisión aérea, se ha buscado la correspondencia entre las rúbricas de Bertillon y el tipo de enfermedades según transmisión de acuerdo a lo establecido por McKeown (1976) (Tabla $\mathrm{n}^{\mathrm{O}}$ 1).

Tab. 1 - Correspondencia de la Clasificación de M. Bertillon y McKeown

\begin{tabular}{|c|c|c|c|c|c|}
\hline \multicolumn{2}{|c|}{ McKeown } & \multicolumn{2}{|c|}{ Bertillon } & \multirow[t]{2}{*}{ Enfermedad } & \multirow{2}{*}{$\begin{array}{l}\text { Agrupaciones } \\
\text { para el análisis }\end{array}$} \\
\hline Grupo & Subgrupo & Grupo & Rúbrica & & \\
\hline \multirow{18}{*}{ 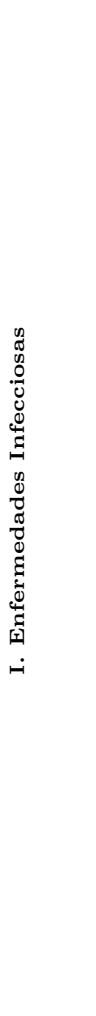 } & \multirow{16}{*}{ 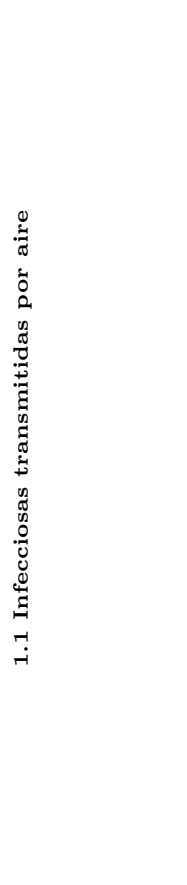 } & & 10 & Gripe & $\operatorname{GRIPE}(\mathrm{G})$ \\
\hline & & & 9 & Difteria y Crup & \multirow{11}{*}{ RESPIRATORIAS (R) } \\
\hline & & & 89 & Bronquitis aguda & \\
\hline & & & 90 & Bronquitis crónica & \\
\hline & & & 91 & Bronco-neumonía & \\
\hline & & & 92 & Neumonía & \\
\hline & & & 93 & Pleuresía & \\
\hline & & & 95 & Gangrena del pulmón & \\
\hline & & & 96 & Asma & \\
\hline & & & 97 & Enfisema pulmonar & \\
\hline & & & 8 & Tosferina (Coqueluche) & \\
\hline & & & 98 & $\begin{array}{l}\text { Otras enfermedades del } \\
\text { aparato respiratorio }\end{array}$ & \\
\hline & & & 28 & & \multirow{4}{*}{ TUBERCULOSIS (T) } \\
\hline & & & 29 & $\begin{array}{l}\text { Tuberculosis } \\
\text { pulmonar y las que se } \\
\text { originan o afectan a }\end{array}$ & \\
\hline & & & 30 & las vías respiratorias & \\
\hline & & & 35 & & \\
\hline & \multirow{2}{*}{$\begin{array}{l}1.2 \\
\text { Transmitidas } \\
\text { por agua y } \\
\text { alimentos }\end{array}$} & & 104 & $\begin{array}{l}\text { Diarrea y Enteritis } \\
<2 \text { años }\end{array}$ & \multirow{2}{*}{$\begin{array}{c}\text { ENTERITIS } \\
\text { DIARREAS (ED) }\end{array}$} \\
\hline & & & 105 & $\begin{array}{l}\text { Diarrea y Enteritis } \\
>2 \text { años }\end{array}$ & \\
\hline \multirow{3}{*}{\multicolumn{2}{|c|}{$\begin{array}{l}\text { II. No atribuibles } \\
\text { a microorganismos }\end{array}$}} & & 79 & $\begin{array}{l}\text { Enfermedades orgánicas } \\
\text { del corazón }\end{array}$ & \multirow{3}{*}{$\begin{array}{c}\text { RELACIONADAS } \\
\text { CON LA GRIPRE (RG) }\end{array}$} \\
\hline & & & 19 & Nefritis aguda & \\
\hline & & & 20 & Enfermedad de Bright & \\
\hline
\end{tabular}

$\mathrm{Al}$ ser la pandemia de «gripe española» una enfermedad de transmisión aérea, todas las enfermedades respiratorias, las tuberculosis relacionadas con el pulmón y otras enfermedades que se relacionaron en su momento con la 
pandemia tales como, orgánicas del corazón, o nefritis también se vieron afectadas. Caso peculiar eran las diarreas o enteritis, aunque su transmisibilidad no fuera aérea, si es infecciosa y en muchos casos los diagnósticos eran de «enteritis gripal». De hecho las diarreas y enteritis eran la máxima causa de muerte entre población infantil y que continuó siéndolo durante y después de la gripe (Gómez Redondo, 1992; Ramiro Fariñas, 1998a; Pérez Moreda et al., 2015).

\section{ANÁLISIS DE RESULTADOS}

Durante el primer tercio del siglo XX, la provincia de Badajoz, al igual que toda Extremadura y España estaba en el proceso de transformación demográfica caracterizado por el declive de mortalidad. Al iniciarse el siglo XX, la Tasa bruta de mortalidad (Tbm) $)^{8}$ provincial era de 28,4\%o, 26,9\% , en la capital, 28,5\%, en las ciudades y $29 \%$, en el ámbito rural. En 1914 la Tbm. había descendido al 20,43\%. El ritmo de descenso interanual hasta 1917 había sido de 2,6\%. En dicho año 1917 hubo un incremento de mortalidad debido a las enteritis y diarreas, especialmente en la capital que revierte la situación continuándose durante el trienio de 1918-1920 en que la Tbm ascendió al 27,6\% debido a la pandemia de gripe. Superada la crisis el declive fue permanente hasta llegar a una Tbm de 16,16\% en 1935 (Figura 1). La irregular evolución de la capital contrasta con la regularidad descendente en el ámbito rural y en las ciudades.

8 Para reducir las irregularidades, la Tbm se ha calculado por trienios. 
Fig. 1 - Declive de la Tasa bruta de Mortalidad en la provincia de Badajos. 1900-1935 y Porcentaje de descenso

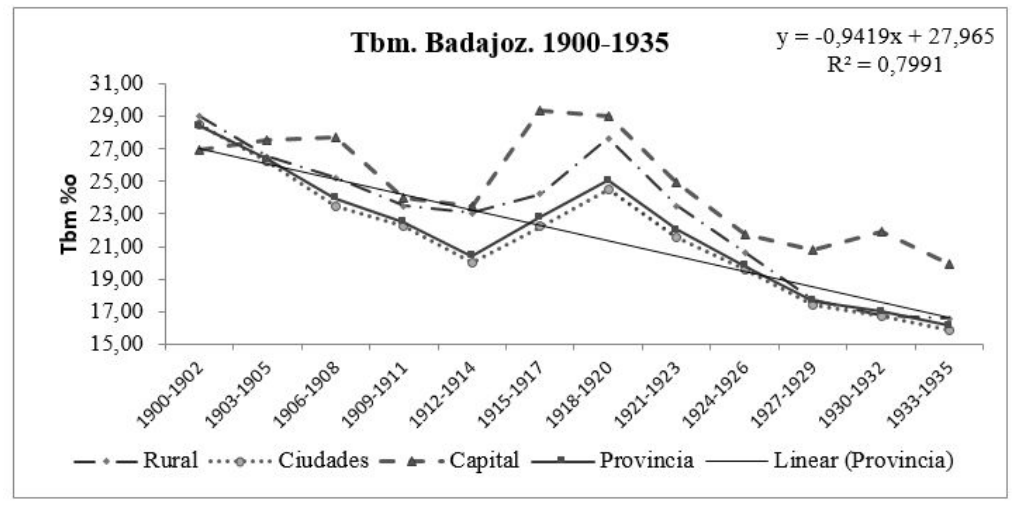

Fuente: MNP.1915-1923-MHA.1915-1923. Elaboración propia.

El coeficiente de regresión lineal demuestra diferentes ritmos de descenso según ámbitos rurales y urbanos (Gráfico 2.2.). En el ámbito rural el coeficiente de determinación es alto $\left(y=1,0038 x+29,39 / R^{2}=0,7548\right)$ al igual que en las ciudades, $\left(y=0,9539+27,731 / / R^{2}=0,8031\right)$ debido a su tradicional forma de vida carácter agrícola-ganadero, sin embargo en la capital el coeficiente es bajo e irregular $\left(\mathrm{y}=0,6408+28,95 / / R^{2}=0,4945\right)$, lo cual es atribuible a la fluctuación del movimiento migratorio en determinados años. La media provincial es prácticamente coincidente con la de la ciudades como podemos observar en la figura 2 .

Fig. 2 - Porcentaje en el ritmo de descenso de la mortalidad en la provincia de Badajoz. 1900-1935

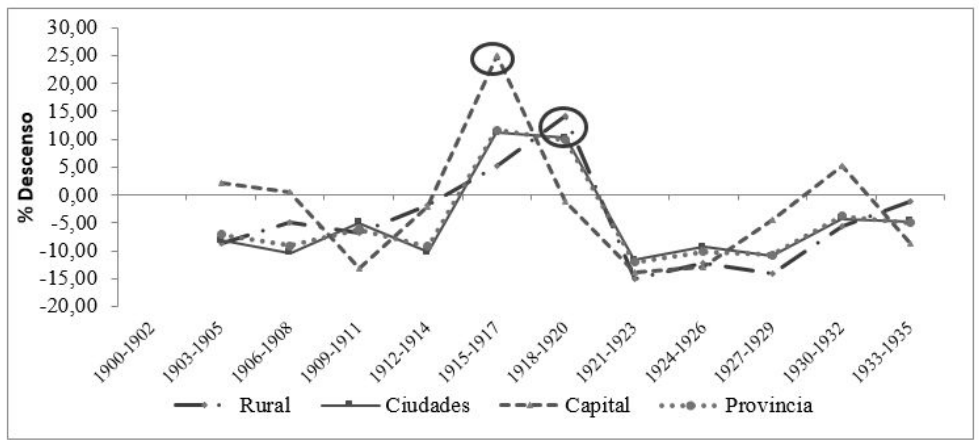

Fuente: resultados calculados a partir de los datos del MNP.1915-1923MHA.1915-1923. Elaboración propia. 
Tab. 2 - Sobremortalidad masculina

\begin{tabular}{lrrrr} 
Trienio & Rural & Ciudades & Capital & Provincia \\
\hline $1900-1902$ & 106,5 & 112,6 & 103,9 & 110,9 \\
$1903-1905$ & 104,4 & 106,6 & 104,2 & 106,1 \\
$1906-1908$ & 105,4 & 108,0 & 117,2 & 108,6 \\
$1909-1911$ & 105,3 & 109,0 & 117,2 & 109,3 \\
$1912-1914$ & 108,1 & 109,9 & 115,8 & 110,2 \\
$1915-1917$ & 105,9 & 111,7 & 112,4 & 111,4 \\
$1918-1920$ & 106,8 & 111,1 & 117,4 & 111,3 \\
$1921-1923$ & 106,1 & 112,2 & 125,3 & 112,3 \\
$1924-1926$ & 110,4 & 113,4 & 116,6 & 113,4 \\
$1927-1929$ & 109,7 & 112,2 & 128,2 & 113,2 \\
$1930-1932$ & 110,3 & 109,2 & 129,8 & 110,7 \\
$1933-1935$ & 106,8 & 109,5 & 137,1 & 111,0 \\
\hline
\end{tabular}

Otras de las características de esta evolución es la permanente sobremortalidad masculina en correlación con el grado de urbanización como se constata en la tabla 1. Siendo la media de todo el periodo de 1900-1935 de 107 en las zonas rurales, 110 en las ciudades, 118 en la capital y 110 en toda la provincia.

\subsection{El exceso de mortalidad en medio del proceso de transición demográfica}

La evolución del exceso de mortalidad presenta diferentes perspectivas. Hay un exceso de mortalidad general del 21,33\% del trienio de 1918-1920 con respecto a 1915-1917. Al contrastar mortalidad de 1921-1923 con respecto a 1918-1920, el proceso se han invertido, hay un declive del 11,33\%, continuando con la tendencia descendente que había predominado hasta 1917. Focalizando la sobremortalidad en 1918, el incremento con respecto al trienio anterior fue del $57,9 \%$, llegando al 85,9\% en los pueblos. En relación de la sobremortalidad de 1918 con respecto al trienio posterior significó un declive del 33,3\% lo que nos indica que el impacto de la sobremortalidad de 1918 era temporal y no marcaba un cambio en los patrones de mortalidad.

En lo que se refiere a la capital, polarizar el incremento de la mortalidad en 1918 no parece ser del todo exacto porque en 1917 hubo un incremento mayor que en 1918 debido a un fuerte brote de enteritis/diarreas que afectó especialmente a los menores de 2 años (Figura 3).

Se ha analizado en qué medida el incremento de mortalidad pudiera estar determinado por el volumen de población para comprobar si hubiera 
Fig. 3 - Porcentaje de variación de la sobremortalidad según tamaño de las poblaciones. Badajoz. 1915-1923

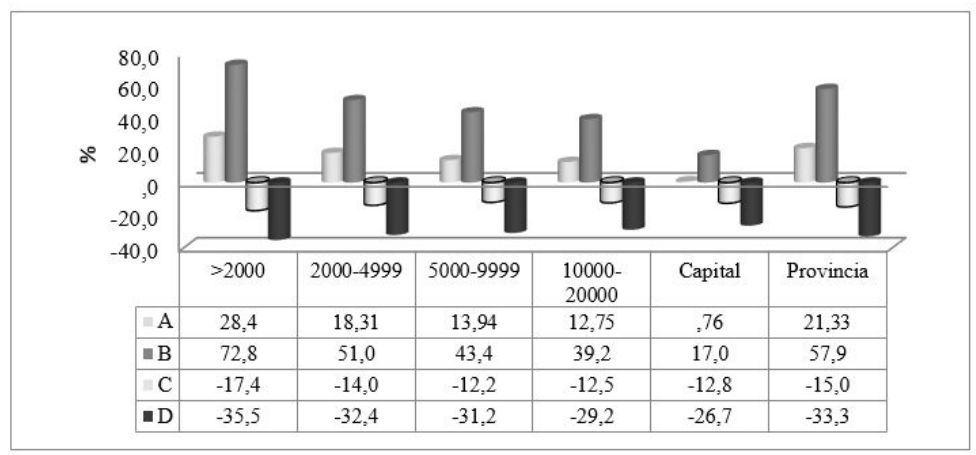

Fuente: Calculado a partir de los datos del MNP.1915-1923-MHA.19151923. Elaboración propia. A: Contraste entre 1915-1917 con respecto a 1918-1920; B: Contraste entre 1915-1917 y 1918; C: Contraste entre 1918-1920 y 1921-1923; D: contraste entre 1921-23 у 1918.

diferencias entre la capital, las ciudades y los pueblos. Los resultados obtenidos, de Pearson $=-0,303 /$ Rho de Spearman $=-0,318$, nos indican que hay una correlación significativa de carácter negativa en sentido inverso al grado de urbanización, los municipios con menor número de habitantes tienen un mayor porcentaje de incremento de mortalidad que las ciudades y la capital, si bien el coeficiente de determinación es muy bajo $(\mathrm{R} 2=0,0377)$ debido a la heterogeneidad de situaciones, a posibles inconsistencia de datos entre los pequeños municipios y a la polaridad entre dichos municipios (Figura 4).

Fig. 4 - Correlación entre el incremento de la mortalidad en relación al tamaño de la población. Badajoz 1915-1917 con respecto a 1918

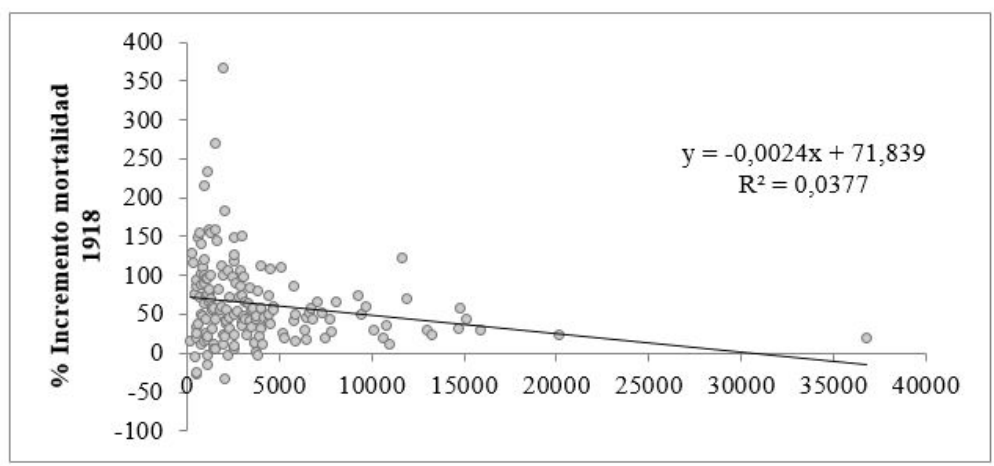

Fuente: MNP.1915-1923-MHA 1915-1923. Elaboración propia. 
Tanto los máximos como las mínimos incrementos de mortalidad quedan localizados en las poblaciones con menor número de habitantes, dichos contrastes son atribuibles a múltiples factores tales como las condiciones y educación higiénica de la población, la salubridad de las aguas y del medio ambiente proclive a ser zonas más o menos húmedas, la atención médica e incluso grado de comunicación o aislamiento con otras poblaciones lo que jugaría a favor o en contra de la expansión de cualquier epidemia De esto deducimos que si bien el impacto pudo ser más profundo en los municipios pequeños, las particularidades son tantas como municipios como se observa en el mapa municipal provincial (Figura 5).

Fig. 5 - Porcentaje de sobremortalidad de los municipios de la provincia de Badajoz en 1918

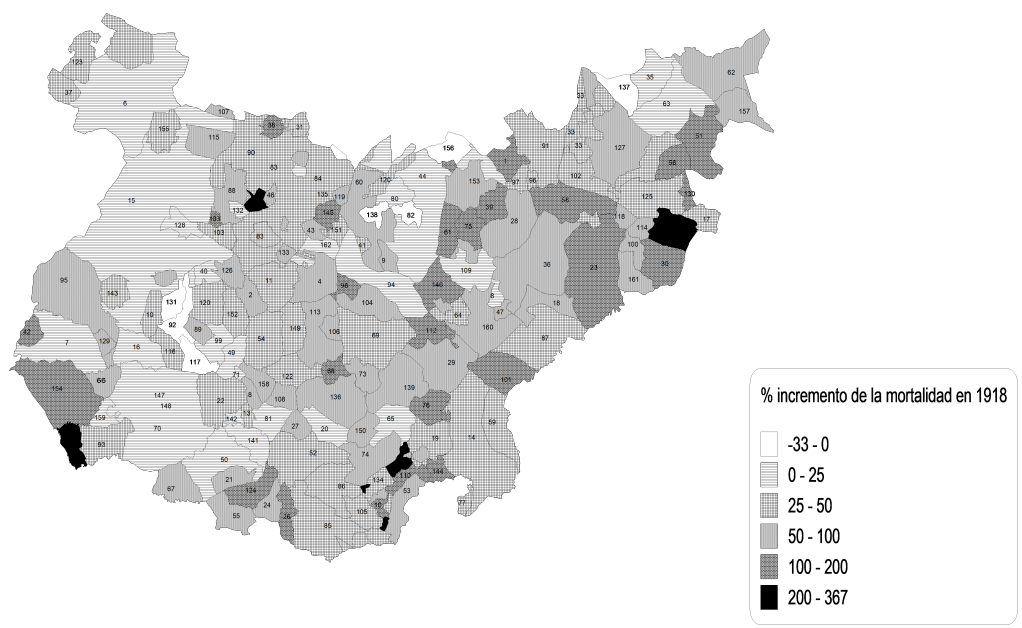

Fuente de datos: MHA. 1915-1918. AHPB. Elaboración propia. 
Según el porcentaje de descenso ó incremento de la mortalidad durante 1918 con respecto a la media de 1915-1917 se clasifican los siguientes grupos:

\begin{tabular}{|c|c|}
\hline Porcentaje & Municipios integrados en dichas categorías \\
\hline $4,9 \%$ & $\begin{array}{l}\text { Municipios que mantuvieron el declive de la mortalidad, in- } \\
\text { dependientemente de la pandemia de gripe: Mengabril, Nogales, Salva- } \\
\text { tierra de los Barros, Torre de Miguel Sesmero, Salvatierra de los Barros } \\
\text { Valdecaballeros Valdetorres y Villar de Rena. }\end{array}$ \\
\hline $18,5 \%$ & $\begin{array}{l}\text { Incrementan la mortalidad hasta el 25\%: Alburquerque, Al- } \\
\text { conchel, Badajoz, Barcarrota, Bienvenida, Carrascalejo, Castilblanco, } \\
\text { Corte de Peleas, Don Benito, Feria, Fregenal de la Sierra, Herrera del } \\
\text { Duque, Higuera de Llerena Jerez de los Caballeros, La Lapa, Malpar- } \\
\text { tida de la Serena Medellín, Medina de las Torres, Mirandilla, La Nava } \\
\text { de Santiago, Oliva de Mérida, La Parra, Quintana de la Serena, Tala- } \\
\text { vera la Real, Torremayor, Valencia del Ventoso, Valverde de Burguillos, } \\
\text { Valle de Matamoros, Zahinos, La Zarza (junto Alange). }\end{array}$ \\
\hline $25,9 \%$ & $\begin{array}{l}\text { Incrementan la mortalidad entre el 25-50\%: Almendral, Almen- } \\
\text { dralejo, Arroyo de San Serván, Atalaya, Azuaga, Baterno, Berlanga, } \\
\text { Burguillos del Cerro, Carmonita, Casas de Don Pedro, Cristina, Fuente } \\
\text { de Cantos, Fuente del Maestre, Granja de Torrehermosa, Higuera de } \\
\text { la Serena, Hornachos, La Codosera, Lobón, Malcocinado, Mérida, Mo- } \\
\text { nesterio, Montemolín, Monterrubio de la Serena, Navalvillar de Pela, } \\
\text { Oliva de la Frontera, Orellana de la Sierra, Orellana la Vieja, Puebla } \\
\text { de Alcocer, Puebla del Maestre, Salvaleón, San Vicente de Alcántara, } \\
\text { Santa Amalia, Santa Marta, Santos de Maimona, Siruela, Trasierra, } \\
\text { Valle de Santa Ana, Valverde de Leganés, Villafranca de los Barros, } \\
\text { Villagonzalo, Villalba de los Barros, Villar del Rey. }\end{array}$ \\
\hline $31,5 \%$ & $\begin{array}{l}\text { Incrementan la mortalidad entre 50-100\%: Aceuchal, Ahillones, } \\
\text { Alange, Albuera (La), Alconera, Aljucén, Benquerencia de la Serena, } \\
\text { Bodonal de la Sierra, Cabeza la Vaca, Calamonte, Calzadilla de los } \\
\text { Barros, Campanario, Campillo de Llerena, Castuera, Don Álvaro, } \\
\text { Esparragalejo, Esparragosa de la Serena, Fuente del Arco, Fuentes de } \\
\text { León, Guareña, Helechosa de los Montes, Higuera de Vargas, Higuera } \\
\text { la Real, Llera, Llerena, Manchita, Montijo, Morera (La), Olivenza, } \\
\text { Peñalsordo, Puebla de la Reina, Puebla de Obando, Puebla de Sancho } \\
\text { Pérez, Puebla del Prior, Retamal de Llerena, Ribera del Fresno, Risco, } \\
\text { Roca de la Sierra (La), San Pedro de Mérida, Sancti-Spíritus, Solana } \\
\text { de los Barros, Talarrubias, Táliga, Torremejía, Usagre, Valencia de las } \\
\text { Torres, Villagarcía de la Torre, Villanueva de la Serena, Villarta de los } \\
\text { Montes, Zafra, Zalamea de la Serena, Zarza-Capilla. }\end{array}$ \\
\hline
\end{tabular}




\begin{tabular}{|c|c|}
\hline Porcentaje & Municipios integrados en dichas categorías \\
\hline $16,7 \%$ & $\begin{array}{l}\text { Incrementan la mortalidad entre } \mathbf{1 0 0 - 2 0 0 \% : ~ A c e d e r a , ~ C a b e z a ~} \\
\text { del Buey, Capilla, Cordobilla de Lácara, La Coronada, Cheles, Espar- } \\
\text { ragosa de Lares, Fuenlabrada de los Montes, Garbayuela, La Haba, } \\
\text { Hinojosa del Valle, Magacela, Maguilla, Palomas, Peraleda del Zaucejo, } \\
\text { Puebla de la Calzada, Reina, Rena, Retamal de Llerena, Segura de } \\
\text { León, Tamurejo, Trujillanos, Valverde de Llerena, Valverde de Mérida, } \\
\text { Valle de la Serena, Villanueva del Fresno. }\end{array}$ \\
\hline $2,5 \%$ & $\begin{array}{l}\text { Incrementan la mortalidad con más de } \mathbf{2 0 0 \%} \text { : Casas de Reina, } \\
\text { Garlitos (La) y Valencia del Mombuey. }\end{array}$ \\
\hline
\end{tabular}

Tanto los máximos $(<200 \%)$ como los mínimos $(-32,5 \%)$ son poblaciones con menos de 2.000 habitantes, exceptuando Nogales, Torre de Miguel Sesmero y Salvatierra de los Barros.

\section{2. ¿Que significó de la pandemia de gripe de 1918 en el proceso de transición epidemiológica?}

Proposition One: The theory of epidemiology transition begins with the major premise that mortality is a fundamental factor in population dynamics. (...) Proposition Two: During the transition, a long-term shift occurs in mortality y disease patterns whereby pandemics of infection are gradually displaced by degenerative y man-made disease as the chief form of morbidity y primary cause of death (Omran, 1971: 733 y 737).

Tradicionalmente se ha considerado que el proceso de transformación demográfica se iniciaba con un descenso de la mortalidad (Thompson, 1929; Landry, 1934; Notestein, 1945). Fue A. R. Osram (1971) en su teoría de la transición epidemiológica quien consideró que el primer estadio de transición era la erradicación de las tradicionales pestilencias de cólera, peste, hambrunas, etc. que en la mayoría de los estados europeos desaparecieron en el siglo XIX, reflejadas en una esperanza de vida entre 20-40 años. El segundo momento estaría caracterizado por la eliminación de las pandemias infecciosas con las cuales se iniciaba el verdadero declinar de la mortalidad y la esperanza de vida se ampliaba hasta los 50 años; la tercera fase se caracterizaría por bajos nivel de mortalidad, una esperanza de vida superior a los 50 años y gradualmente las enfermedades infecciosas como la tuberculosis y enteritis darían paso a enfermedades degenerativas, cáncer y enfermedades cardiovasculares. Teóricamente en España durante este primer tercio de siglo se producía la transición epidemiológica y se iniciaba la sanitaria, ambas marcadas por la progresiva desaparición de las enfermedades epidémicas y 
reducción de las infecciosas por una parte (Robles González, 1996; Bernabeu Mestre, 1998) y por otra, la organización de los servicios sanitarios con una legislación adecuada para mejorar tanto la higiene pública como la asistencia a enfermos, dotaciones hospitalarias, servicios médicos y personal sanitario en general como lo demuestra una amplia literatura sobre el tema (Robles González, 1996; Barona Villar y Bernabeu Mestre, 2008).

En la provincia de Badajoz, teniendo en cuenta la clasificación de las enfermedades de Bertillon (1903, VV.AA, 1995) el conjunto de enfermedades infecciosas suponían el 39,9\% de la mortalidad en 1900. Progresivamente habían ido decreciendo hasta que en 1918 la pandemia elevó la mortalidad infecciosa al 46,3\%. Desde 1919 hasta 1930 descendieron al 30,8\%. Este declinar quedó también interrumpido entre 1931-1935 lo cual demuestra la inestabilidad de ese segundo estadio de transformación epidemiológica (Figura 6).

Fig. 6 - Evolución de las causas de muerte de 1900 a 1930 según grupos de enfermedad

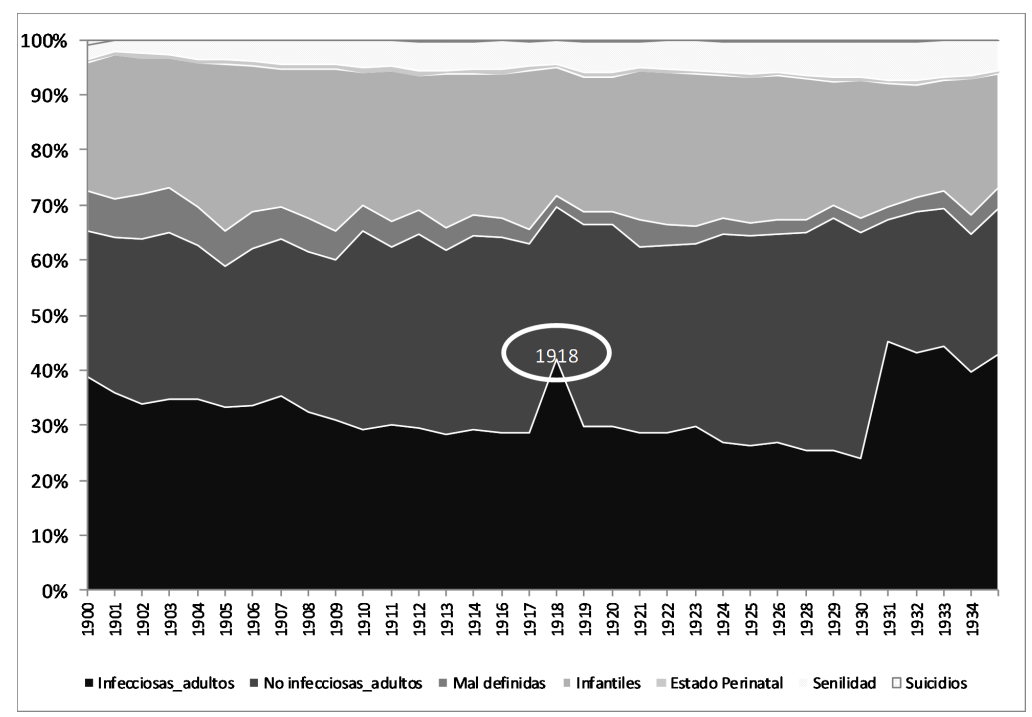

Fuente de Datos: MHA no 7, 11, 37 y 39: Estadística de las causas de mortalidad según clasificación aprobada por la Comisión Internacional desde 1900 a 1935. Tomado de Durán Herrera (2015).

Durante el primer tercio del siglo XX, el descenso de mortalidad obedecía básicamente al declinar de la mortalidad infantil como se ha demostrado en multitud de investigaciones a nivel nacional, regional, y provincial (Ramiro Fariñas y Sanz Gimeno, 2002; Leasure, 1963; Gómez Redondo, 1992; Blanco Carrasco, 1995; Ramiro Fariñas, 1998b; Durán Herrera, 2015). Hay 
que considerar que en buena medida la modificación de la mortalidad afectaba a la reducción de enfermedades mal definidas que al ser identificadas con la nueva nomenclatura de 1931, incrementaron tanto las infecciosas como no infecciosas. Por otra parte, el incremento de la mortalidad senil refleja el incremento de la esperanza de vida. Siguiendo la clasificación de las enfermedades en función del modelo de transmisión (McKeown 1972; 1976) se han analizado seis grupos de enfermedades según especificamos en el apartado anterior: en primer lugar la gripe como la causa principal de tan elevada mortalidad, en segundo lugar las respiratorias, por estar directamente afectadas por su transmisibilidad aérea que en muchos casos no solo se intensificaron sino que pudieron soslayar la gripe, en tercer lugar las tuberculosis de origen pulmonar, algunas enfermedades orgánicas que se consideraron también relacionadas con la gripe, y por último, las diarreas y enteritis que aunque no eran de transmisión aérea, las causantes de la mayor mortalidad hasta ese momento.

Teniendo en cuenta la situación de estas enfermedades antes, durante y posterior a la pandemia se especifica el incremento general de la mortalidad durante el trienio de 1918-1920 y de 1918 en particular con respecto al anterior 1915-17 y el posterior declive a partir de 1921, lo que se confirma que la provincia estaría en el segundo estadio de la transformación epidemiológica con la reducción de enfermedades infecciosas. Los efectos de la pandemia se extendieron a otras enfermedades infecciosas, tanto de transmisión aérea como por agua y algunas enfermedades orgánicas relacionadas. En las Figuras 7. a, b, c y d, podemos comprobar cómo se incrementan dichas tasas siendo diferente la situación a nivel provincial con respecto a la capital y en la provincia sin la capital. La gripe y enfermedades respiratorias afectaron más al espacio rural que a la capital, mientras las tuberculosis afectaron más a la capital que a la provincia en general. Por otra parte, tanto en la capital como en la provincia hay una sobremortalidad masculina especialmente en las enfermedades respiratorias. Según el tipo de enfermedad, el incremento de la mortalidad afectó de diferente manera a los pueblos con respecto a la capital (Tabla 4). 
Fig. 7 - Tasas de mortalidad $(\% 0)^{9}$ según causas en la provincia de Badajoz de 1915 a 1923

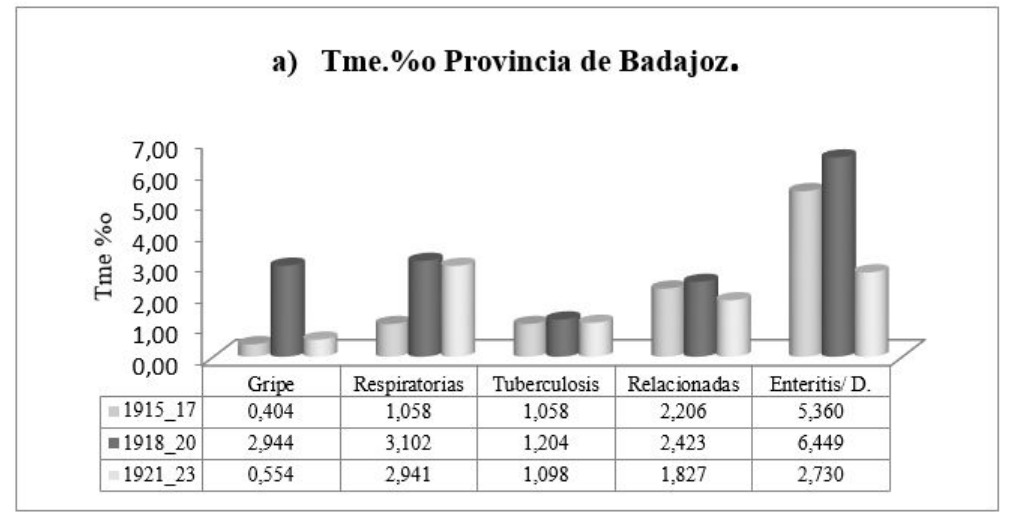

9 A nivel mundial las Tasas por causas de enfermedad se calculan en relación a 100.000 personas. Dado que la población total de la provincia en estos años oscila aproximadamente entre 626.100 y 658.500 , se ha optado por hacer los cálculos en relación a 1.000 personas. 

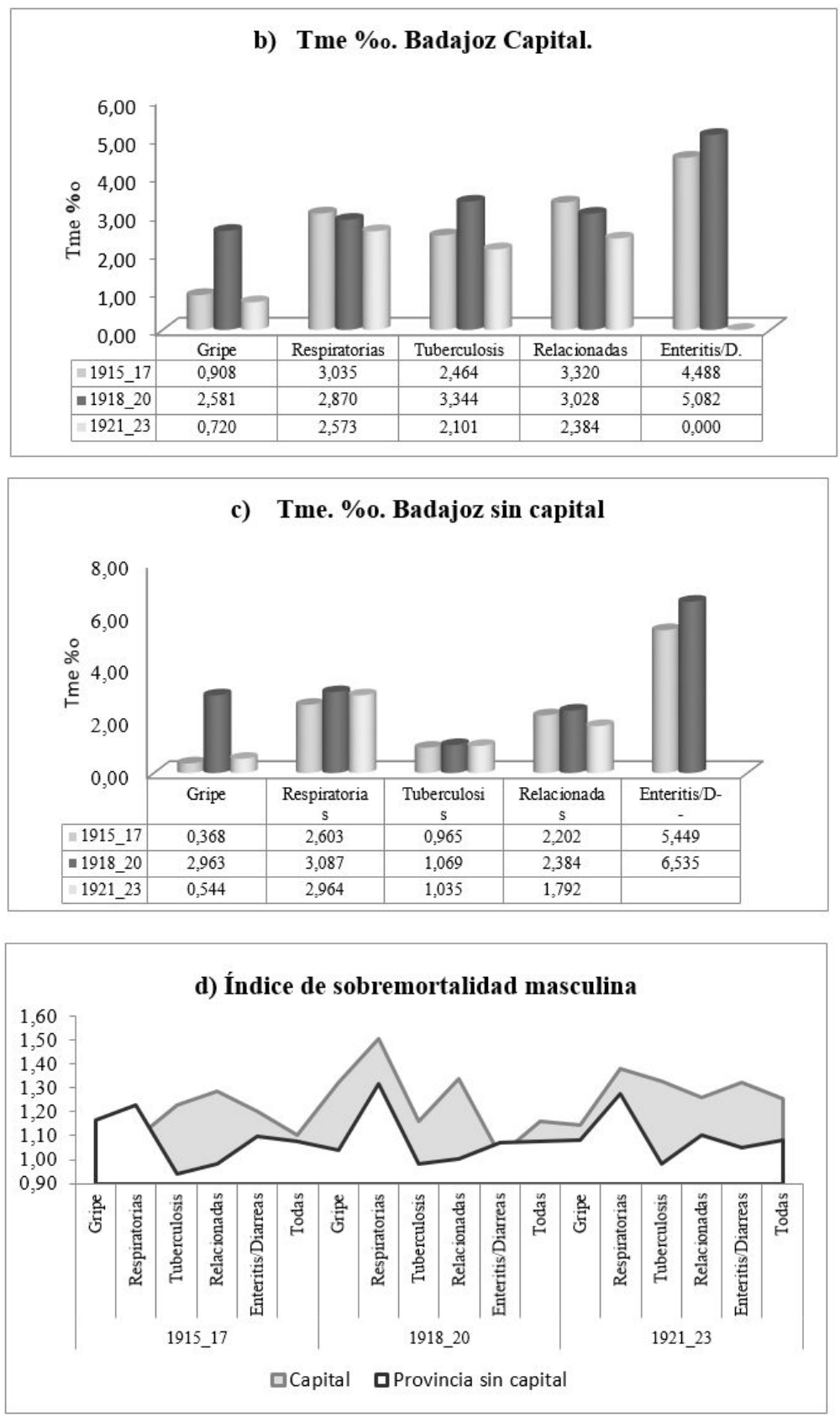

Fuente de datos: Estadísticas de las causas de mortalidad combinada con la edad de los fallecidos (1915-1923). 
Tab. 4 - Incremento de la mortalidad durante el trienio de 1918 con respecto a $1915-1917^{*}$

\begin{tabular}{lrrr}
\hline Enfermedades & Provincias & Capital & $\begin{array}{l}\text { Provincia } \\
\text { sin capital }\end{array}$ \\
\hline Gripe & 629,65 & 184,24 & 705,73 \\
Respiratorias & 18,24 & $-5,43$ & 18,58 \\
Tuberculosis & 13,83 & 35,71 & 10,71 \\
Relacionadas & 9,78 & $-8,80$ & 8,28 \\
Enteritis & 20,31 & 13,25 & 19,93 \\
\hline
\end{tabular}

* $\overline{\text { Porcentaje (\%) variación de } 1918 \text { con respecto a 1915-1917 }}$

Fuente: Estadísticas de las causas de mortalidad combinada con la edad y sexo de los fallecidos. 1915-1923. AHPB. Elaboración propia.

Mientras los efectos de la pandemia, enfermedades respiratorias y enteritis son más fuertes en el ámbito rural que en la capital, mientras las enteritis, las tuberculosis sufren un mayor incremento en las ciudades. No obstante, las enfermedades respiratorias descienden en la capital en los momentos de pandemia de gripe.

\subsubsection{El impacto de la pandemia de gripe y otras enfermeda- des infecciosas en 1918}

Ante la epidemia de tifus exantemático procedente de Portugal que en esos momentos estaba afectando especialmente a Oporto y se pudiera transmitir a través de la frontera de Caya y la existencia de casos de viruela procedentes de Córdoba, el gobernador de Badajoz reiteró las órdenes de carácter sanitario que ya se había dado en el mes de abril ${ }^{10}$ a fin de evitar un posible contagio. De cualquier manera, la expansión de la gripe era una realidad. Durante los meses de mayo y junio se habla en la prensa de la gripe como «la enfermedad de moda» de carácter benigno, ${ }^{11}$ que es padecida en la ciudad por numerosas personas pero sin que se contabilice una mortandad. El Correo de la Mañana del 28 de Mayo informaba de la enfermedad del rey, de varios diputados y numerosas personalidades en Madrid. El día 30 de mayo se publicaba un caso de mortandad muy cuestionado en La Codosera ante las sospechas de que pudiera ser gripe o tifus exantemático procedente de Portugal. El dictamen de la Inspección sanitaria provincial fue de pulmo-

10 BOPB. N.o 73 del 12/04/1918, Circular 19, Boletín Extraordinario del 6/04/1918 y BOPB n. ${ }^{\circ} 104$ 25/05/1918. Circular del Gobernador civil. Ante el temor de la expansión del tifus exantemático se decreta se instalen locales de aislamiento, se obligue a todos los alcaldes que los mendigo, vagabundos, gitanos y trabajadores que vengan en las cuadrillas a trabajar en la siega sean despiojados y desinfectados.

11 Correo de la Mañana (CM) 23/05/1918, n. ํ 1.495 , p. 1. 
nía. Ese mismo día, el Gobernador declaraba que la gripe se había extendió por la capital aunque los atacados por esta enfermedad no se encontraban graves $^{12}$.

Fig. 8 - Evolución mensual de la mortandad por gripe en la provincia de Badajoz de 1918 a 1920

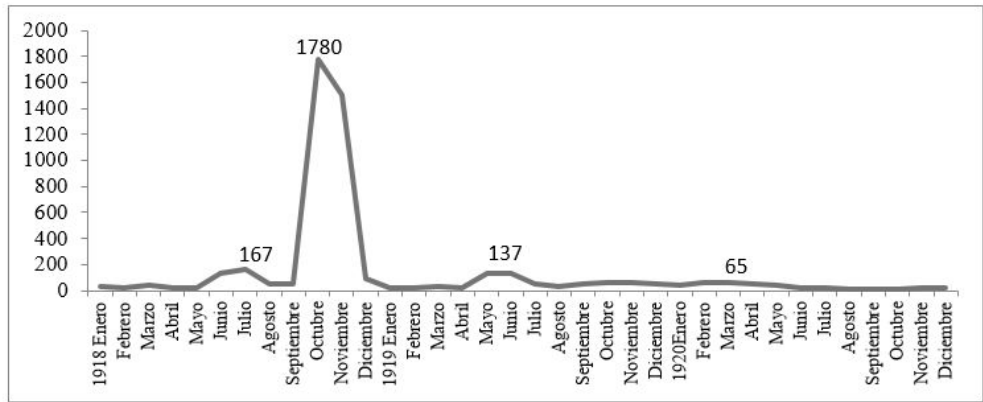

Fuentes: Estadística del Movimiento Natural de Población, Provincia de Badajoz (1918-1920). BOPB. 567, 569, 570, AHPB. Elaboración propia.

En el mes de mayo se contabilizan tan solo 19 casos de mortandad por gripe en toda la provincia lo cual no era significativo teniendo en cuenta que en el mismo mes de mayo de 1917 habían acaecido 31 decesos por gripe. (Figura 8). Oficialmente tampoco no se reconoció que la gripe fuera grave en el mes de Junio porque las muertes registradas eran pocas pero en la prensa se comentaba que la morbilidad afectaba a todos los sectores sociales. Esta escasa mortandad fue atribuida a las medidas sanitarias que se habían tomado en previsión de la extensión del tifus exantemático procedente de Portugal $^{13}$ unido al hecho de que el 5 de Junio se informó del cierre de la frontera francesa ${ }^{14}$. Las estadísticas nos dicen que en los meses de Junio y Julio se produce una sobremortalidad con respecto a años anteriores con un máximo de 167 casos en Julio, por lo que hay que considerarlo como el primer brote significativo de pandemia gripe. La Tasa de mortalidad específica por gripe (Tmgr) acumulada entre los meses de Junio y Julio fue del 0,469\%0 15 . En los meses de agosto y septiembre, la mortandad por gripe es más elevada que en años anteriores, pero reducida $(0,08 \%)$.

\footnotetext{
12 C.M. 30/05/1918, n. ${ }^{\circ} 1.411$, p. 2 .

13 C.M. 20/6/1918, n. ${ }^{\circ} 1.429$, p. 2.

14 C.M. 5/06/1918, n. ${ }^{\circ} 1.416$, p. 1.

15 En las tasas de enfermedad mundial sería 46,8 por cada 100.000 habitantes en los dos meses de Junio y Julio y de 5333,6.
} 
Durante el mes de septiembre las autoridades tomaron conciencia de la importancia de la epidemia ordenando a los alcaldes tomaran las medidas prevención necesarias e informaran inmediatamente en caso de gripe epidémica. ${ }^{16}$ A través de la prensa el Gobernador seguía declarando que no existía epidemia gripal en Badajoz y que hasta ese momento la salud pública en la provincia era inmejorable pero al mismo tiempo se revisaba la nueva instalación de un pabellón sanitario construido en el fuerte de Pardaleras por si fuera necesario ${ }^{17}$. Ante el incremento de la mortalidad a finales de septiembre, el Gobernador Civil y la Inspección de Sanidad terminan por reconocer la epidemia y tomaron serias medidas para evitar «tamaña calamidad» ${ }^{18}$. Desde al 11 de Octubre hasta el 16 de Diciembre se fueron declarando oficialmente en el BOPB los pueblos que iban sufriendo la pandemia ${ }^{19}$. Varios casos fueron tan caóticos que aparecen mencionados en la prensa, es el caso de Maguilla ${ }^{20}$ que con 1.800 habitantes hubo más de 500 afectados, entre ellos el médico, y el farmacéutico o el de Garrovilla ${ }^{21}$ con más de 400 afectados. Durante todo el mes de Octubre se fue incrementando el número, llegando a su cota más alta entre el 24 y 31 de octubre con 977 decesos. El punto de inflexión lo marca el 1 de Noviembre, aunque con cierta irregularidad, a partir del día 4 ya no superan los 100 fallecidos diarios. A finales de Noviembre ya hay poblaciones en donde tal epidemia ha quedado superada y el 16 de Diciembre extinguida la epidemia levantándose todas las medidas restrictivas que se habían dado ${ }^{22}$. La Tmgr. acumulada de Octubre a Diciembre fue de $5,33 \%$. Era el segundo brote, el de mayor morbilidad y el más mortífero. En 1919 apenas hay un repunte en la primavera en los meses de mayo y junio con Tmgr acumulada fue de 0,42\%. Posteriormente, encontramos meses aislados, noviembre de 1919 y marzo de 1920 donde la Tmgr fue de 0,1\%o por lo que realmente pueden considerarse como restos de la pandemia en poblaciones que no habían quedado inmunizados durante los brotes anteriores o gripe normal. En este acaecer no hay un comportamiento homogéneo en toda la provincia ni en la evolución de la pandemia de gripe ni del resto de

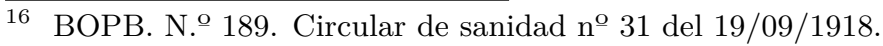

17 C.M. 26/09/1918, n. ${ }^{\circ} 1.513$, p. 2.

18 BOPB. N..$^{\circ}$ 198. Circular n. ${ }^{\circ} 33$ del $3 / 10 / 1918$.

19 Circular n. ${ }^{\circ} 36$ del 11/10/1918; Circular n. ${ }^{\circ} 39$ del 18/Octubre; circular n. ${ }^{\circ} 43$ del 4/11/1918; Circular n. ${ }^{\circ} 44$ del 22/11/1918.

20 C.M. $19 / 10 / 1918$, n. ${ }^{\circ} 1.533$, p. 2.

21 C.M. 11/10/1918, n. ${ }^{\circ} 1.526$, p. 2. Se produjeron de 10 a 11 defunciones diarias en la semana del 7 al 15 de Octubre (C.M. 15/10/1918, n. ${ }^{\circ}$ 1.529. p. 2.).

22 Circular n. ${ }^{\circ}$ 47. BOPB. N. ํ 250, 16/12/1918.
} 
enfermedades relacionadas. Los patrones de mortalidad son diferentes en la capital con respecto al resto de la provincia.

\subsubsection{Efectos de la pandemia según edad y género}

Ni toda la población sufrió de igual manera la pandemia, ni hubo regularidad según edad y ni de género en la mortalidad, ni todas las enfermedades respiratorias se incrementan de igual manera según la estructura etaria. A nivel provincial el mayor porcentaje de población afectada por la gripe corresponde a la población adulta joven que correspondía a las mujeres entre los entre los 20 y 34 acumulando el $35,6 \%$ del total de decesos en el género femenino y a los varones entre 25 y 39 años con el 33,6\% de la mortalidad total. Los menores de cuatro años son poco afectados por la gripe, sin embargo el porcentaje de enfermedades respiratorias significó el $46 \%$ del total de decesos en los niños y el $51,5 \%$ en las niñas. A medida que se van cumpliendo años, decrece el impacto de la gripe y se incremente la muerte por las tradicionales enfermedades respiratorias propias de los meses de otoño e invierno.

Fig. 9 - Porcentaje de mortandad por gripe y enfermedades respiratorias según estructura etaria y género en 1918. Badajoz capital y provincia sin capital

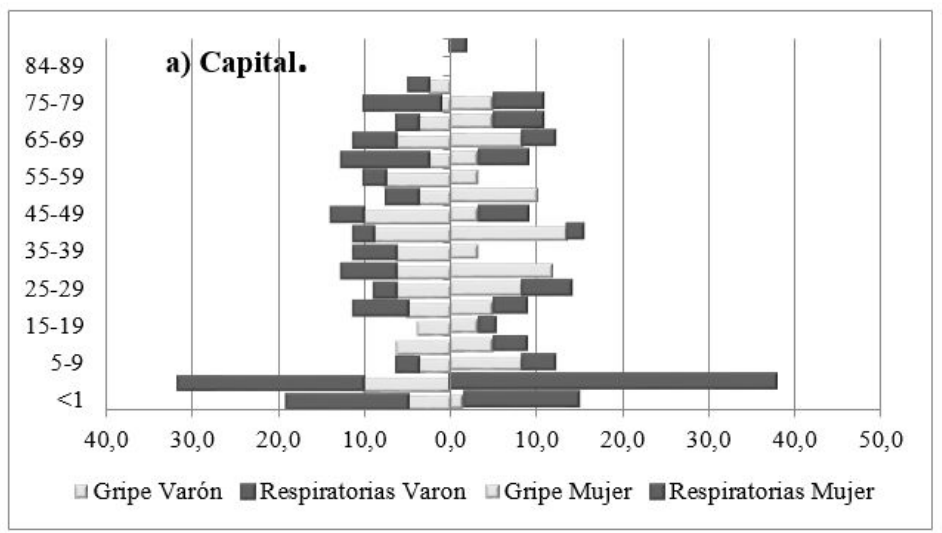

El desarrollo de la pandemia en la capital refleja una realidad diferente (Figura 9.a). En los menores de 4 años el 15,1\% de los niños murieron por gripe, mientras en el género femenino solo se vio afectado en un 1,7\%. En la población adulta se repite el mismo patrón que el resto de la provincia pero la distribución etaria difiere. Los varones entre 25-44 acumularon el 37,1\% 


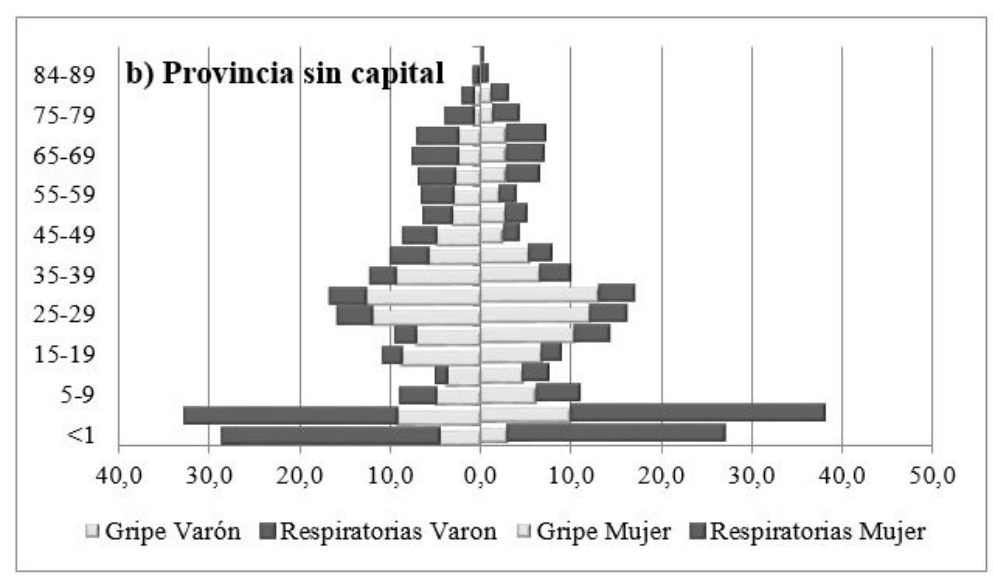

Fuente: Estadísticas de las causas de mortalidad combinada con la edad de los fallecidos. 1915-1923. AHPB. Elaboración propia.

de las defunciones por la pandemia, siendo la generación entre 45-49 años la mayor de todos ellos (10,1\%). Las mujeres entre 25-54 acumularon el 50,8\%, siendo la generación entre 50-54 las que concentraron el 10,2\% de decesos. A partir de los 60 años en ambos casos eran mayores los decesos por causas respiratorias (Figuras 9.a y 9.b).

En la provincia sin la capital, se repite el mismo patrón que en la media provincial aunque hubo mayor mortalidad. En los menores de cuatro años la gripe afectó al 13,8\% de los niños y 13,2\% de las niñas, mientras las causas respiratorias eran del 47,3\% en los varones y $51,5 \%$ en las mujeres. La máxima mortandad por gripe en los varones se concentra entre los 25-39 años $(34,2 \%)$ y en las mujeres entre los 20-34 (35,9\%). A partir de los sesenta años, en ambos géneros es mayor la mortandad por causas respiratorias que por gripe.

Las tasas de mortalidad por gripe muestran también las diferencias entre la capital y el resto de la provincia. En 1918 en la Tmgr en la provincia fue de $7,22 \%$, en la capital de $5,45 \%$ y en la provincia sin capital de $7,34 \%$ o (Figura 10). Las tasas más elevadas están en las generaciones de mayores de 80 años y entre 70-74, en segundo lugar entre 25-34 años y en tercer lugar los menores de 1 año. En la capital las más elevadas están a partir de los 65 años, en segundo lugar los menores de 1 año y en tercer lugar la generación entre 40-44 año. El incremento de la Tmgr de 1918 con respecto a 1915-1917 fue de 508,11\%. En 1919 la Tmg había descendido en más de un 82,4\% con respecto a 1918 y en 1920 en un 90,1\% con respecto a 1919 de tal manera que en 1920 hubo 374 decesos por gripe casos mientras en 1917 habían sido 377 , por lo que realmente la pandemia de gripe la tenemos que focalizar en 
1918 con algunos casos en los meses de mayo y junio de 1919 y prácticamente inexistente en 1920.

Fig. 10 - Tasa específica de mortalidad por gripe. 1918. Badajoz

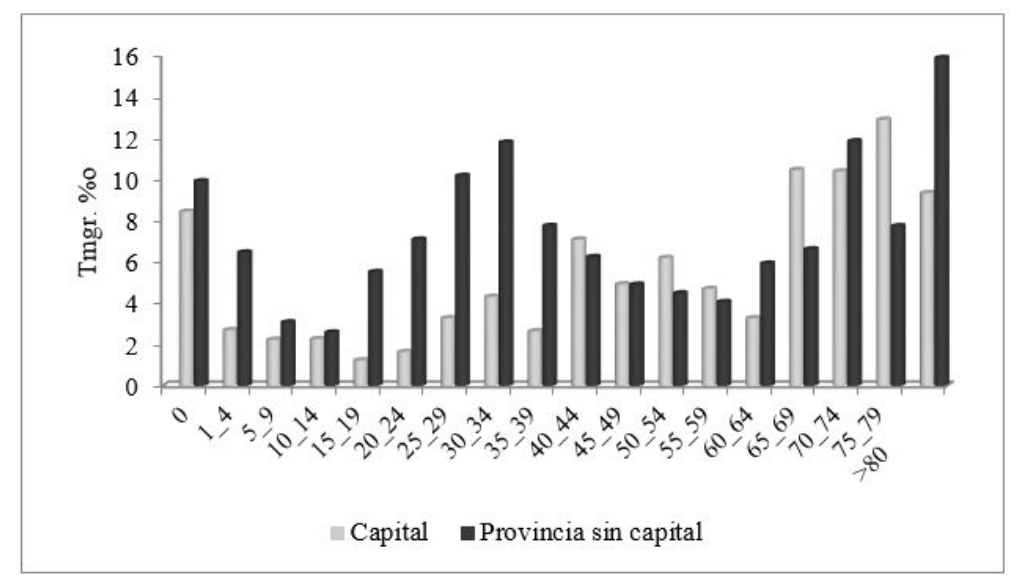

Fuente: Estadísticas de las causas de mortalidad combinada con la edad de los fallecidos. 1915-1923. AHPB. Elaboración propia.

La pandemia de gripe conllevó el incremento de la mortalidad en otras enfermedades de transmisión aérea como las respiratorias así como infecciosas de transmisión por agua, orgánicas relacionadas con la gripe y en menor medida las tuberculosis. En conjunto, el máximo incremento se concentra en jóvenes adultos entre 30-34 años y los menos afectados los mayores entre 75-79 años. Las enteritis/diarreas, se incrementaron en un 31,4\% de hecho algunos diagnósticos médicos se firman como «enteritis gripal». Tradicionalmente esta morbilidad afectaba especialmente a los menores de 4 años y a partir de los 60, pero en 1918 el mayor incremento se centra en adultos entre 25-29 años y entre 35-39, coincidentes con la mayor mortalidad etaria por gripe. Las enfermedades respiratorias se incrementaron en un $20,1 \%$, con respecto al trienio anterior, a pesar de que el mayor número de decesos por causas respiratorias fueran los menores de 4 años. Es importante señalar que en determinadas edades se produjo un retroceso en compensación con el incremento de la mortandad gripal (Tabla 5). Las enfermedades orgánicas del corazón y del riñón se vieron incrementadas en un 16,3\%, concentrando dicho incremento entre los 30-34 años y retrocediendo en edades tempranas. Los niños y jóvenes de naturaleza débil ya habían fallecido en 1917 por el incremento de las enteritis por lo cual, la gripe de 1918 proyectó una menor repercusión en la estructura etaria que habían tenido mayor mortalidad el año anterior y en los sobrevivientes que habían superado tales dolencias. Aunque 
el incremento de las tuberculosis fue menor que otras enfermedades $(10,8 \%)$ es significativo entre 1-4 años y en mayores de 70-74, cuando normalmente a estas edades había pocos casos de tuberculosis por haber fallecido en edades tempranas. En conjunto el incremento de la mortalidad en dicho año fue de un $34,3 \%$, siendo las edades más afectadas las comprendidas entre los 10 y 39 años, lo que indudablemente tiene su efecto en los índices de supervivencia.

Tab. 5 - Porcentaje de incremento de la mortalidad por gripe y enfermedades relacionadas de 1918 con respecto a 1915-1917

\begin{tabular}{|c|c|c|c|c|c|c|}
\hline Edad & Gripe & Respiratorias & Tuberculosis & Relacionadas & Enteritis & Todas \\
\hline$\overline{<1}$ & 462,9 & 37,2 & $-9,3$ & 25,1 & 37,7 & $\overline{36,9}$ \\
\hline $1-4$ & 1673,3 & 86,0 & 81,1 & $-9,6$ & 22,3 & 46,3 \\
\hline $5-9$ & 1941,5 & 122,5 & 8,6 & $-3,3$ & 45,0 & 57,7 \\
\hline $10-14$ & 3633,5 & 334,7 & 31,2 & 36,0 & 107,6 & 106,5 \\
\hline $15-19$ & 4308,1 & 174,1 & 8,4 & 32,0 & 79,3 & 142,3 \\
\hline $20-24$ & 3698,4 & 193,3 & 4,2 & $-3,0$ & 49,9 & 137,3 \\
\hline $25-29$ & 5406,7 & 266,5 & 18,0 & 4,0 & 168,2 & 176,9 \\
\hline $30-34$ & 7992,1 & 179,1 & 24,3 & 103,4 & 56,9 & 210,3 \\
\hline $35-39$ & 2165,1 & 93,4 & 48,2 & $-5,1$ & 140,9 & 126,7 \\
\hline $40-44$ & 1430,8 & 148,4 & $-10,3$ & 21,4 & $-13,6$ & 76,9 \\
\hline $45-49$ & 1234,2 & 79,7 & $-6,0$ & $-15,4$ & $-44,7$ & 49,4 \\
\hline $50-54$ & 726,0 & 38,6 & 11,1 & 12,7 & $-39,8$ & 36,8 \\
\hline $55-59$ & 383,6 & $-16,7$ & 39,2 & 2,9 & $-2,7$ & 23,7 \\
\hline $60-64$ & 337,4 & $-5,4$ & 16,9 & 6,1 & $-8,5$ & 10,8 \\
\hline $65-69$ & 230,8 & 1,8 & 25,9 & 8,3 & $-25,2$ & 13,3 \\
\hline $70-74$ & 289,7 & 0,1 & 68,1 & 14,9 & 24,2 & 27,6 \\
\hline $75-79$ & 80,0 & $-11,1$ & 6,6 & 19,3 & 61,7 & 20,3 \\
\hline$>80$ & 206,3 & $-18,7$ & $-78,7$ & 25,7 & 21,1 & 27,1 \\
\hline Total & 508,1 & 20,1 & 10,8 & 16,3 & 31,4 & 34,3 \\
\hline
\end{tabular}

En la capital el efecto de la crisis fue menor, el incremento de mortalidad por gripe fue del $145,3 \%$ y en general la mortalidad se incrementó en un $19,1 \%$, siendo las enteritis las que crecieron en un $22,6 \%$ con la particularidad de inexistencia por tal causa entre los 35-39. Las diferencias con el resto de la provincia se concentran en el mayor incremento de las enfermedades orgánicas con respecto a las respiratorias, que en las edades entre 50-74 presentan un declive a costa del incremento de los decesos por gripe. De nuevo se confirma la diferente repercusión que tuvo la pandemia en la ciudad.

Las diferencias entre el impacto de la gripe en la capital y el resto de la provincia creemos se debe a varios factores: en primer lugar la profundidad de la mortalidad infantil por enteritis/diarreas en 1917 afectó más a la capital que a la provincia con lo cual personas proclives a enfermedades infecciosas ya habían fallecido cuando irrumpió la epidemia gripal en la primavera de 1918. En segundo lugar, desde el mes de abril se emitieron varias circulares de carácter higiénico-profiláctico que fueron aplicadas especialmente en la frontera 
de Caya y en la capital ante el temor de una expansión del tifus exantemático procedente de Portugal, de hecho en septiembre de 1918 se había construido un pabellón sanitario en el fuerte de Pardaleras con carácter preventivo. En tercer lugar, había más personal sanitario, recursos farmacéuticos, recibió las ayudas de la Cruz Roja ya lo que se añade la llegada de un batallón militar para reforzar la frontera con el personal sanitario adecuado. Estas medidas pueden que no redujeran la morbilidad pero sí la mortalidad. En contraposición, los pueblos sólo disponían de sus propios recursos, en algunos casos sin médico y dependieron de la ayuda que pudieran enviar el Gobernador. La propia prensa se hizo eco de la dureza de la gripe en los pueblos en relación a la capital. A esto hay que añadir la insalubridad de las aguas y malas cosechas en las pequeñas poblaciones.

\subsubsection{Repercusiones demográficas de la pandemia de gripe}

La expansión de la epidemia afectó demográfica y socialmente a toda la población. El impacto en otras variables demográficas fue diverso. Durante el trienio de 1918-1920 la natalidad se redujo en un 0,4\%, produciéndose una recuperación en el trienio de 1921-1923 con un incremento del 2,1\%. El número de matrimonios se incrementó en un 0,14\%. Los descensos son significativos en la temporalidad anual siendo de diferente signo en la capital y en el resto de la provincia. En las ciudades y ámbito rurales los matrimonios descendieron en un 6,5\%, mientras en la capital aumentaron en un $26 \%$. Al año siguiente, la situación se invirtió, mientras la capital tuvo un descenso del $6,3 \%$ como si fuera un efecto diferido, las ciudades y ámbitos rurales se recuperaban en la misma proporción en que había retrocedido. En 1920 se advierte un incremento general de los matrimonios (Tabla 6).

Tab. 6 - Porcentajes de incremento y descensos en el número de matrimonios. Badajoz. 1915-1920

\begin{tabular}{lrrrr}
\hline & $\begin{array}{l}\text { De 1918-1920 } \\
\text { respecto a } \\
1915-1917\end{array}$ & $\begin{array}{l}\text { De 1918 } \\
\text { respecto a } 1917\end{array}$ & $\begin{array}{l}\text { De 1919 } \\
\text { respecto a 1918 }\end{array}$ & $\begin{array}{l}\text { De 1920 } \\
\text { respecto a 1918 }\end{array}$ \\
\hline Rural & 0,14 & $-6,59$ & 6,99 & 20,57 \\
Ciudades & 0,13 & 0,24 & 6,90 & 7,37 \\
Capital & 0,14 & 26,86 & $-6,31$ & 14,86 \\
Provincia & 0,14 & $-3,49$ & 6,31 & 16,57 \\
\hline
\end{tabular}

Fuente de datos: MHA. 1915-1920. AHPB.

La mayor trascendencia de la epidemia a largo plazo se advierte en el descenso del los índices de supervivencia con respecto a 1917 y 1920 y en 
la reducción en la esperanza de vida. La probabilidad de sobrevivir según la edad siempre fueron mayores los nacidos y población viva en 1917 que en 1918. Acorde con lo expuesto anteriormente, a nivel provincial, a partir de los 5 años la probabilidad de vivir va siendo menor, en este caso se acentúa a partir de los 5 años al tiempo que el porcentaje de regresión con respecto a 1917 también se va acentuado. En 1920, superada la crisis se incrementa la probabilidad de vida con respecto a 1917 en todas las edades, lo cual nos reafirma en la crisis temporal de 1918 pero que una vez superada, se continúa con el declive general de la mortalidad en este segundo estadio del proceso de transformación de la población. En la capital el retroceso, siendo menor, comparativamente con respecto a 1917, no hay homogeneidad en cuanto a la evolución etaria. El retroceso queda sobre acentuado en las edades de 5-30 años y especialmente a partir de los 60 años, cuestión que también se refleja en el descenso en la esperanza de vida (Figuras 11 a y b).

Fig. 11 - Índices de supervivencia de la provincia de Badajoz y capital
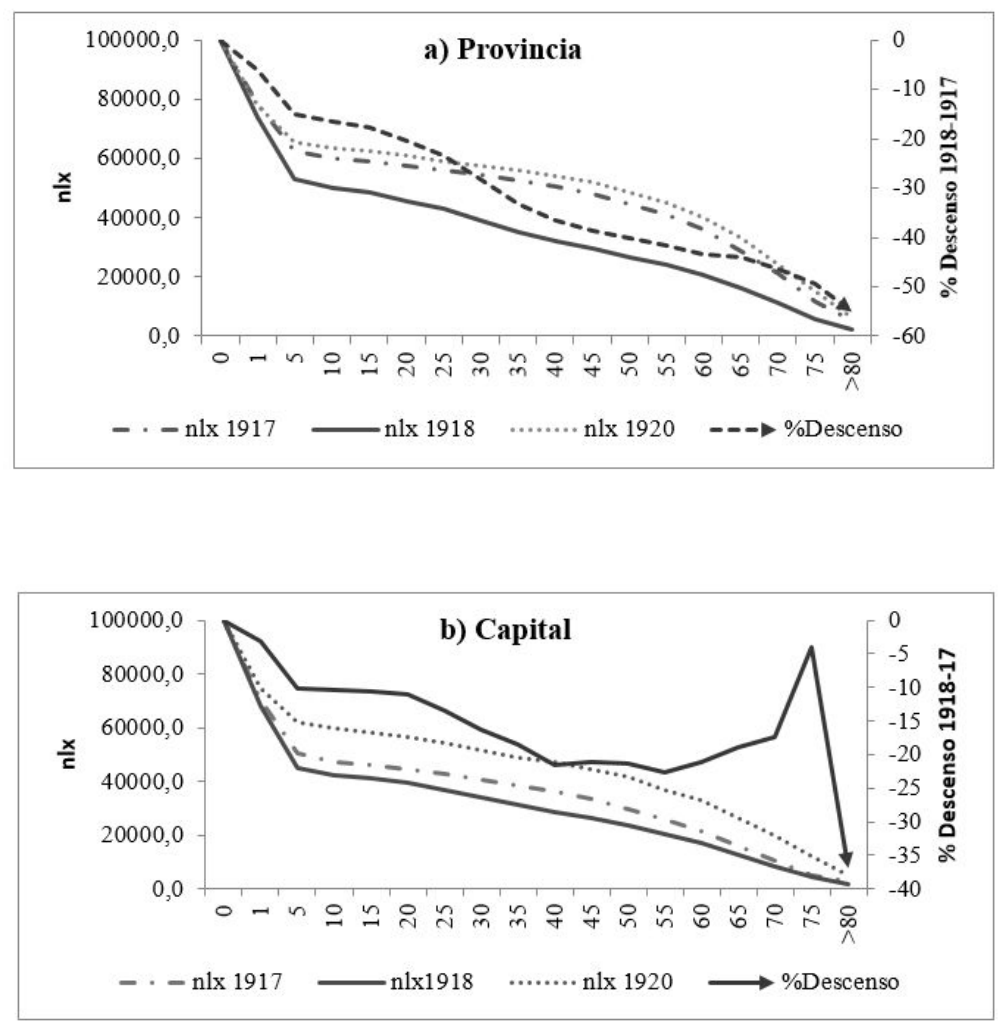

Fuente de datos: MHA. 1915-1920. AHPB. Elaboración propia. 
La esperanza de vida al nacer $(e x)$ en 1917 presenta diferencias en el ámbito rural y urbano así como entre los géneros. En la provincia los varones la ex de los varones era de 36,5 , la máxima era de 52,8 a los 5 años y para las mujeres era de 37,5 al nacimiento y de 53,6 a los cinco años, a partir de dicha edad la esperanza de vida siempre es decreciente. En 1918 la reducción fue significativa, siendo para los varones de 26,1 para los nacidos en dicho año, y máxima de 43 a los cinco años. Las mujeres también redujeron la ex siendo de 27,6 y de 43,2 a los cinco años. En general se pasó de una ex de 37 años en 1917 a 26,8 que en 1920 llegó a ser de 40,7 años (Figuras 12 a y b).

Fig. 12 - Contraste de la Esperanza de vida de los años de 1917 y 1918 en la provincia de Badajoz y en la capital

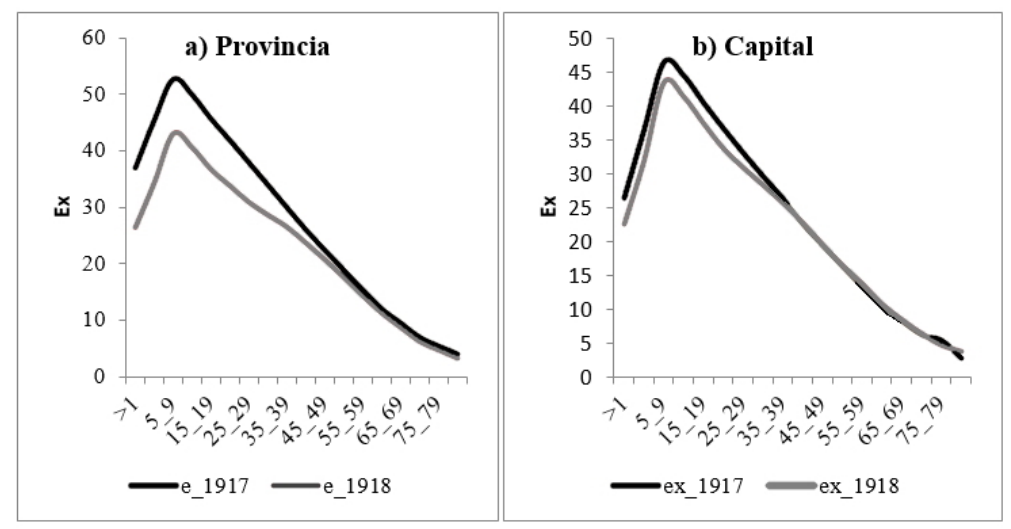

Fuente de datos: MHA. 1917-1918. AHPB. Elaboración propia.

La esperanza de vida de la capital era menor que en los pueblos pero al ser menor el impacto de la gripe, también se redujo la diferencia de la ex de 1918 con respecto a 1917. Los varones nacidos en 1917 en la capital, dada la alta mortalidad infantil, tenían una ex de 24,6 años y el máximo era de 43,8 a los 5 años. En las mujeres la ex era de 28,41 y el máximo de 49,3 a los cinco años. En 1918 la ex de los varones descendió a 20,7 y las mujeres a 24,4. De esta manera la secuencia en 1917, 1918 y 1920 fue de 26,35, 22,4 y 34,8 años respectivamente. Esto nos demuestra que las medidas higiénicas y sanitarias impuestas con motivo de la pandemia repercutieron positivamente en los años posteriores. 


\section{LA VIVENCIA DE LA PANDEMIA EN LA SOCIEDAD}

En el momento en que el día 23 de mayo el Correo de la Mañana publicaba la existencia de una epidemia de gripe en Madrid nadie podía pensar en los estragos que podía hacer ni como el dolor iba a provocar en todas las familias sin distinción de clases sociales ni lugar de residencia. Muchas cosas cambiaron no solo desde el punto de vista demográfico, sino a nivel sanitario, administrativo, político, económico y social.

\subsection{Medidas higiénico-sanitarias}

La inestabilidad política que se estaba viviendo en España ${ }^{23}$ impedía la modificación y mejora de la Ley de Sanidad de $1904{ }^{24}$ por la que se crearon las Juntas Provinciales de Sanidad e Inspecciones de Sanidad Municipal entre cuyas funciones estaba la «extirpación de los focos infecciosos... los relativos a higiene municipal, epidemias, epizootias y enfermedades infecciosas ${ }^{25}$ y se explicitaban los medios de desinfección, aparatos y condiciones que deberían tener los centros sanitarios según el número de población ${ }^{26}$. A partir del mes de Abril de 1918 los diferentes Gobernadores ${ }^{27}$ de la Provincia fueron dando sucesivas circulares para evitar el contagio del Tifus exantemático procedente de Portugal, obligando a tomar medidas profilácticas que debían seguir tanto los alcaldes como, médicos y personal sanitario. Estas medidas produjeron algunos cambios en las costumbres higiénicas comunes y sanitarias del momento.

Las primeras medidas sanitarias se dieron a partir del mes de abril para controlar la entrada de gente procedente de Portugal ante la expansión del tifus exantemático ${ }^{28}$. Durante los meses de mayo y junio se reiteraron las medidas de desinfección y despiojamiento de mendigos, vagabundos y trabajadores portugueses que vinieran a trabajar en la cosecha, creación de

\footnotetext{
23 Recordemos en 1917 España atravesaba una profunda crisis política, seguida de los que se llamó el «trienio bolchevique» o revolucionario de 1918-1921 por la extraordinaria conflictividad laboral, política y social.

24 Durante el de A. Maura (1903-1904) se aprobó la Ley de Sanidad, 13/01/1914. Gaceta de Madrid. Año CCXLIII, n..$^{\circ} 22$, pp. 273-275 y n.ำ 23, pp. 290-295. Gobiernos posteriores prepararon otros proyectos que no llegaron a aprobarse.

25 ART. 54. Ley de Sanidad Gaceta de Madrid. Año CCXLIII, n. o 2, p. 275.

26 Anejo II. Ibídem. p. 294.

27 Durante 1918 hubo varios Gobernadores: Juan Polo de Bernabé, Buenaventura Ma Plaja (Mayo-Julio) Ricardo Aparicio (Julio-Octubre) y Antonio Acuña.

28 Circulares del 12/04/1918, s.n., BOPB n. 73 .
} 
servicios higiénicos y lugares de aislamiento en todos los pueblos, obligatoriedad de vacunación y revacunación de viruela, y control de epizootias ${ }^{29}$. Estas órdenes se ampliaron en al mes de Julio se reitera la obligación a los alcaldes de tener lugares de aislamiento y despiojización de transeúntes ${ }^{30}$. A partir del segundo brote de epidemia en Septiembre y desde octubre a Diciembre se fueron dando sucesivas normas para controlar la epidemia, tales como evitar las aglomeraciones en lugares cerrados, obligación bajo pena de multa al alcalde correspondiente si no notificaba la epidemia, extensivo al vecindario, obligación de tener un local apropiado para aislamiento de enfermos, obligación de limpiar los lugares públicos y privados, patios, corrales, cuadras con zotal o creolina, mantener limpias los manantiales y fuentes de agua potables, no permitir la salida y entrada de cerdo, desinfección de cafés y tabernas con vapores sulfurosos, mantener los lugares públicos aireados, prohibición para los médicos ausentarse más de 48 horas del lugar de trabajo, y prohibición de de venta e importación de trapos en toda la provincia ${ }^{31}$.

La actitud oficial frente a la sociedad era ambigua, por un lado se emitían las circulares de obligado cumplimiento para ser aplicadas por los alcaldes en los municipios, por otra parte, en la prensa el Gobernador declaraba que el estado sanitario de la provincia era inmejorable e incluso se negó a retrasar el curso en la Escuela de Arte y Oficios por el gran número de enfermos ${ }^{32}$. En pocos días la epidemia explotó de tal manera que el día 10 de Octubre se declaraban los primeros pueblos oficialmente epidémicos ${ }^{33}$ y el 13 se decretó la clausura de los establecimientos públicos y privados de enseñanza de la provincia y espectáculos públicos, casas de recogimiento, supresión de procesiones, ferias y mercados en toda la provincia ${ }^{34}$. En la prensa se recomendaba la desinfección de hoteles, fondas, casas de huéspedes, cafés, bares, tabernas y de todos los locales municipales y oficinas así como estaciones ferroviarias. El Gobernador rogaba a la prensa que hicieran constar en un lugar preferente de sus ediciones el peligro de contraer o llevar la enfermedad por todo aquel que visite enfermos de gripe ${ }^{35}$, se regularon los enterramientos y se prohibió

\footnotetext{
29 Circular n. ${ }^{\circ} 19$ (25/05/1918), BOPB n. 을 105; Circular 21 (10/06/1918), BOPB n. ${ }^{\circ}$ 115; Circular $22(19 / 06 / 1918)$.

30 Circular n..$^{\circ} 25$ (24/07/1918), BOPB n.ํำ 148 , p. 1.

31 Circular 31 (19/09/1918), BOPB n. ${ }^{\circ}$ 189, p. 1; Circular 32 (27/09/1918), BOPB n. ${ }^{\circ}$ 194, p. 1; Circular 33 (03/10/1918), BOPB n. ${ }^{\circ}$ 198, p. 1; Circulares 34, 35, 37 (10 y 11/10/1918), BOPB n. $\stackrel{\circ}{203, \text { p. } 1 .}$

32 Correo de la Mañana: 1/10/18, p. 2.

33 Circular 36 (10/10/1918), BOPB n.ํㅜ 203, p. 1.

34 Circular 38 (14/10/1918), BOPB n. ${ }^{\circ} 205$, p. 1.

35 C.M. $13 / 10 / 1918$, n. $^{\circ} 1.528$, p. 2.
} 
la visita a los cementerios ${ }^{36}$. Desde el 16 de octubre hasta el 15 de noviembre un total de 138 municipios fueron declarados epidémicos ${ }^{37}$.

A partir del 20 de noviembre la epidemia fue remitiendo por lo que las circulares dejan de ser restrictivas y se permitieron la apertura de locales públicos si en siete días no había ningún caso nuevo de gripe ${ }^{38}$, se limitaba la inspección médica en la frontera permitiendo la entrada por todos los caminos que unían con Portugal ${ }^{39}$. El 14 de Diciembre se declaraba extinta la epidemia y se permitieron abrir las escuelas y teatros poniendo fin a todas las prohibiciones dictadas anteriormente y normalizando la vida de la provincia $^{40}$.

\subsection{Actuaciones oficiales con respecto a la frontera}

Aunque la pandemia surgió en marzo y en España no se declaró como tal hasta mayo, en abril se dieron órdenes específicas para controlar el paso de la frontera con Portugal debido a la epidemia de tifus exantemático ${ }^{41}$. A partir de septiembre, se pusieron en prácticas los análisis bacteriológicos, se exigía la desinfección y en el caso de padecer enfermedad sospechosa, se decretaba su aislamiento ${ }^{42}$. El recrudecimiento de la pandemia en octubre y la permanente comunicación de viajeros por la frontera las medidas de control se incrementaron en un doble sentido. Por un lado solamente se permite la entrada en nuestra población por los sitios donde están funcionando los puestos sanitarios de Caya y Estación del ferrocarril, los cuales funcionaban a la hora de llegada del tren portugués, de nueve a once de la mañana y de cuatro a seis de la tarde, quedando terminantemente prohibido el paso por la frontera a otras horas que no fueran las indicadas. Sólo se permitía la entrada a los ciudadanos españoles previo reconocimiento facultativo y patente de sanidad expedida por los médicos encargados de las referidas estaciones. Aquellos viajeros que habitualmente hacen cortos y frecuentes viajes a Portugal, no se les permitía regresar a no ser que se que se repatriaren. También

\footnotetext{
36 Circular 42 (20/10/1918), BOPB n.o 214 , p. 1.

37 Circular 39 (16/10/1918), BOPB n.o 208, p. 3; Circular 40 (20/10/1918), BOPB, n.o 210, p. 2; Circular 43 (3/11/1918), BOPB n. ${ }^{\circ} 220$, p. 1.

38 Circular 45 (20/11/1918), BOPB n.을 233, p. 1.

39 Circular 46 (5/12/1918), BOPB n. 을 243 , p. 2

40 Circular 47 (14/12/1918), BOPB n.o 250, p. 3; Correo de la Mañana 21/11/1918, n.o 1.561 , p. 2.

41 Op. cit. 6 .

42 C.M. 14/09/1918.
} 
se establecieron puestos de desinfección en los demás pueblos fronterizos con idéntico sentido restrictivo ${ }^{43}$.

Por parte de la opinión pública, aunque la expansión de la epidemia venía desde Francia, achacan a la Diputación y al Ayuntamiento no haber actuado a tiempo, que hubiera olvidado sus obligaciones y mostraban desconfianza ante las medidas que se estaban tomando en aquel momento por lo que pedían el cierre de la frontera ante el temor de las enfermedades contagiosas ${ }^{44}$. El 15 de Octubre se ordenó el acordonamiento de la frontera por fuerzas del ejército con la llegada del Regimiento de Gravelinas, dividiéndola en tres sectores, desde San Vicente de Alcántara al Bado de las Mesas, el segundo hasta Olivenza y el tercero hasta Valencia del Mombuey ${ }^{45}$.

Las actitudes ante la estancia de portugueses en la provincia fueron diversas. En el caso de no tener los documentos sanitarios firmados y hubieren entrado de forma clandestina eran arrestados y llevados a la cárcel; en el caso de estar infectados eran ingresados en el Hospital Provincial al ser pobres y escasos de recursos se les daba comida. Dos casos especiales llaman la atención en Zafra y en Villanueva del Fresno. Dadas las ferias de San Miguel en Zafra, muchos ganaderos portugueses venían a hacer negocios sin cumplir los requisitos por lo que 20 portugueses fueron devueltos por no tener documentación según la Ley de extranjería ${ }^{46}$, pero uno de ellos, el Sr. Antonio Ignacio, explicando la importancia de sus negocio y el beneficio para la feria, se le permitió quedarse previa donación de 100 pesetas ${ }^{47}$. En Villanueva del Fresno las cuadrillas de trabajadores portugueses fueron bien acogidas. En los días festivos celebraban sus propias fiestas que compartían con la población. Se narra el caso de un portugués que murió por la epidemia y el propio alcalde y el médico llevaron la camilla del difunto al cementerio ${ }^{48}$.

\subsection{Situación económica durante la pandemia}

La crisis epidémica afectó hondamente en múltiples sentidos a toda la provincia. Los agricultores de Badajoz, se vieron en un primer momento favorecidos por la subida delo precio del trigo que se enviaba a Barcelona ${ }^{49}$,

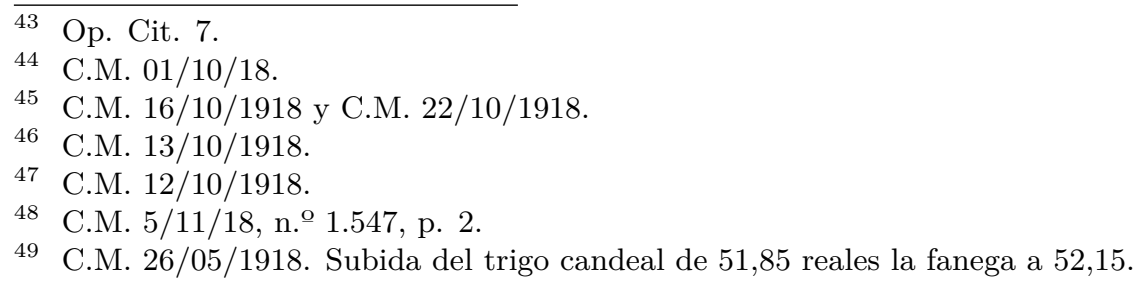


pero esta situación duró poco. Pronto hubo problemas tanto en la capital como en los municipios por temor a una falta de abastecimiento. En el mes de agosto, ante la subida de precios, la Junta de Abastecimiento que fijaba unos precios determinados se enfrentó a los agricultores que pedían se les permitiera exportar el trigo ${ }^{50}$. La ocultación de la producción dio lugar a que se abriera una investigación por parte de la Junta de subsistencia. En la capital, el presidente de la Cámara Agrícola, Sr. Carapeto, acordó con el alcalde de Badajoz que los agricultores proveerían del trigo necesario para el consumo de la población ${ }^{51}$. Esta subida de precios repercutió en el precio de la harina, creando conflicto con los panaderos por la subida del precio del pan, en los pueblos algunas fábricas de pan tuvieron que cerrar.

En la capital el alcalde tuvo varias reuniones con una comisión de dueños de ultramarinos y salchicheros para tratar de los abastecimientos y el control de precios, en caso contrario se vería obligado a utilizar todos los medios que le permite la ley. Pero de nada sirvió que la Junta de Abastecimiento fijara los precios, así por ejemplo la docena de huevos paso de costar 2 pesetas a 4,5 debido a que no llegaban de Portugal y los productos necesarios para el sustento diario también se duplicaron al controlar el mercado de ganado ${ }^{52}$. En la provincia la precariedad era doble, por una parte en algunos pueblos tuvieron males cosechas como en Maguilla y plaga de langosta declarada en Llerena y por otra, la imposibilidad de que llegaran alimentos por el cierre de mercados. La precariedad de la situación se refleja en las peticiones de ayuda económica para el abastecimiento diario ya que en muchos pueblos se cerraron mercados, ferias o se prohibía la entrada de mercancías. Son muchas las poblaciones que solicitaban ayuda o que tenían que cerrar las fábricas. En Castuera se cerraron las fábricas de pan por carecer de trigo ${ }^{53}$. También hubo casos de abusos y robos de cosechas: los transportistas de Berlanga pedían 3,95 pesetas por los portes de ferrocarril de la caja de latas de leche enviadas por el Gobernador, la Comunidad de Labradores de Villafranca de los Barros denuncia la venta de aceituna en los molinos sin que se supiera la procedencia y más de 25 de hurto de frutos $^{54}$.

\footnotetext{
50 C.M. 30/08/1918.

51 C.M. 17/11/1918.

52 C.M. 1/11/1918; C.M. 5/11/1918; C.M. 23/11/1918, n. o 1.563, pp. 1-2; C.M. 1/11/18, n. ${ }^{\circ} 1.544$, p. 2 ; C.M. $30 / 10 / 1918$, n. ${ }^{\circ} 1.542$, p. 2. El cocido que era la comida diaria se encarecía notablemente con el precio del tocino añejo, a 5 pesetas, el fresco a 4,50, la morcilla entre 5,5-6 peseta y el chorizo a 7 pts.

53 C.M. 6/11/18, 1.548 .

54 C.M. $1 / 11 / 18$, n. ${ }^{\mathrm{o}} 1.544$, p. 2.
} 
Reflejo de esta situación son las peticiones que hacían al Gobernador. Son muchísimos lo pueblos que pidieron auxilio urgente como es el caso de Villanueva de la Serena que lo hace en términos realmente penosos como «el pueblo carece de alimentos adecuados y de medicinas; se pide suero antidiftérico» ${ }^{55}$ Desoladora las noticias de Maguilla donde el problema sanitario va unido a la carencia de alimentos por la pérdida de 30.000 fanegas de trigo, declaraban estas sin leche, huevos, carnes, sin jamones para cuidar a los y confección de caldos para los enfermos o de La Garrovilla: «aquí reina un pánico extraordinario, por ser unos 400 atacados de gripe, aunque graves solo hay 15 o 20. Entre los atacados se encuentran los médicos no habiendo quien visite a los médicos ni despache los medicamentos (...). Todos los empleados del Municipio están enfermos al igual que ocurre en el Juzgado municipal $\aleph^{56}$. Situaciones similares se dieron en Campanario, Esparragosa de Lares, Higuera la Real pedían leche, medicamentos, desinfectantes. Se envían socorros a Calera de León, Magacela, Valencia de las Torres y Villanueva del Fresno, Cabeza del Buey o se envía dinero a Jerez de los Caballeros, Campanario ${ }^{57}$. Situaciones extremas son las peticiones y los correspondientes envíos de leche condensada y alimentos para Monterrubio, la Garrovilla, Fuente del Maestre, Los Santos de Maimona, Burguillo del Cerro, Berlanga, Castuera y Cabeza del Buey.

Las situaciones más traumáticas son aquellos pueblos que pedían se les enviara algún médico como Maguilla, Calzadilla, Segura de León, Burguillos del Cerro entre otros ${ }^{58}$. Para combatir la epidemia se envió quinina y material desinfectante y donativos a otras tantas poblaciones: Almendral, Cordobilla, Higuera de Vargas, Sancti Spíritu, Segura de León, Los Santos de Maimona, Fuente del Maestre, Benquerencia, Valencia del Mombuey, Trujillanos. Usagre, Herrera del Duque, Guareña, La Morera, Olivenza, Talavera la Real, Hinojosa del Valle, Guareña, Valle de Matamoros, y Cheles ${ }^{59}$. En Badajoz capital se recibieron tiendas de campaña y 100 jergones para establecer el pabellón para enfermos en Pardaleras y en La Estación. Las ayudas económicas procedentes del Ministerio de la Gobernación llegaron en el mes de diciembre que fueron repartidas entre algunos pueblos ${ }^{60}$.

\footnotetext{
55 C.M. 30/10/1918, n. ${ }^{\mathrm{o}} 1.542$, p. 2.

56 C.M. $11 / 10 / 1918$, p. 2.

57 C.M. 18/10/1918; C.M. 6/11/1918, n. ${ }^{\circ} 1.548$, p. 2.

58 C.M. $29 / 10 / 1918$, n. ${ }^{\circ} 1.541$, p. 2.

59 C.M. $15 / 11 / 1918$, n. ${ }^{\circ} 1.556$, p. 2.

60 C.M. 5/12/1918, n. ${ }^{\circ}$ 1.573; Palomas: 350; Talavera la Real: 250; Mérida: 500; Puebla de la Calzada: 300; Don Bnito: 300; Medellín, Valdetorres: 200; Burguillos del Cerro, Los Santos de Maimona, Villagonzalo y Manchita: 300 cada uno, total 3.200 pesetas.
} 
Todas estas noticias reflejan una realidad económica compleja, pueblos en donde la cosecha fue favorable, tienen un obligado control de precios y no pueden exportar, cosechas que son robadas, frente a un número importante de jornaleros que no tienen recursos para vivir y unos mercados cerrados. Desoladora la situación de Ante esta situación la reacción de la sociedad es muy diversa.

\subsection{Actitudes sociales}

En unos primeros momentos, durante los meses de mayo a agosto, como ya comentamos anteriormente, ni las autoridades ni la sociedad dio mayor importancia al problema, considerando que era una gripe benigna y el mayor problema en la provincia era la entrada de cuadrillas de portugueses para recoger la cosecha y que podrían traer el tifus exantemático. La situación cambió notablemente a partir del segundo brote cuando en poblaciones como Cabeza del Buey de 12 al 17 de octubre fallecieron 60 personas o en poblaciones de apenas 2.000 habitantes los infectados se contaban por cientos y entre ellos estaban el médico y el farmacéutico.

El temor a la muerte y al contagio creó actitudes xenófobas. Algunos casos son reveladores de esta situación. Es el caso de los Santos y Maimona y Fuente del Maestre (antes de ser infectados) negaron la entrada a la población procedente especialmente de Zafra y de pueblos ya epidémicos. En Cristina, se solicita al Gobernador que permita el tránsito de vecinos entre poblaciones ya que era imposible el abastecimiento dada la orden del alcalde de Guareña que prohibía el paso a los vecinos de Cristina ${ }^{61}$. Esta situación dio lugar a una nueva Circular ${ }^{62}$ por la que prohibía se negara la entrada a otros viajeros. Se decretó que, para conocer el origen del que llegare enfermo y vigilarle sanitariamente se le mantuviera en observación durante un periodo de siete días, como viene haciéndose con los españoles procedentes de Portugal cuando atraviesan la frontera. En otros casos se negaban a dar sepultura a los fallecidos que venían de los cortijos, lo que generó otra orden expresa ${ }^{63}$ en un doble sentido, por un lado prohibía que se negara la sepultura nadie, por otro se dictaban una serie de normas a fin de proceder en estos casos. Ante un excesivo celo por cumplir con las normas sanitarias, algunos alcaldes obligaban a someter a desinfección con vapores de azufre a todos lo que llegan de otros pueblos, lo cual era no solo contraproducente, sino cruel e

61 C.M. 24/10/18 n. ${ }^{\circ} 1.537$.

62 Circular 41, BOP n. ${ }^{\circ} 210,21 / 10 / 1918$, p. $1-2$.

63 Circular 42, BOP n. ${ }^{\circ} 222,6 / 11 / 1918$, p. 1. 
ineficaz, provocando catarros agudos que favorecía gripe y se convertía en un elemento más de morbilidad y mortalidad. De este modo también se defendía al viajero al decretarse que cualquiera que se viera sometido a ese procedimiento de desinfección u otro análogo, debe protestar, resistirse y dar cuenta al Gobernador civil de la provincia o a la Inspección sanitaria ${ }^{64}$.

En la mayoría de los casos la propia sociedad tomó actitudes de ayuda y generosidad para los epidemiados. Fueron innumerables las modalidades de ayuda a nivel individual, institucional y de asociaciones agrarias y especialmente las Juntas de Socorro que se formaron en la mayoría de los pueblos. En el primer caso el doctor Salazar, donó 10.000 vacunas gratuitas para los pobres para prevenir la difteria; en Badajoz otro doctor puso a disposición del Gobernador 300 cajas de cloruro de quinina, e innumerables donativos personales ${ }^{65}$, o el párroco de Usagre, D. Esteben Rodríguez quien socorría de su propio peculio a los enfermos y los visita o el caso de D. Julio Soares no cobró por confeccionar 25 cajas para el envío de medicamentos a los pueblos al conocer el destino de las mismas ${ }^{66}$.

En Villafranca de los Barros la Comunidad de Labradores hace una donación de 250 pesetas para ayudar a los gastos para controlar la epidemia. Dan un crédito de 100 pesetas en las 5 farmacias para los enfermos que ajuicio de los médicos no puedan comprar las medicinas; por su parte los farmacéuticos ofrecen las tarifas de beneficencia a los pobres ${ }^{67}$. En Segura de León donde la epidemia había afectado a 2.000 vecinos, el Sindicato Agrícola, cuyo presidente era D. Rodrigo Montero Espinosa abrió una suscripción que llegó a 7.247 pesetas para atender a muchos abandonados y enfermos ${ }^{68}$.

Las donaciones institucionales del Gobernador y del Obispo fueron constantes a multitud de pueblos. Especialmente citadas en la prensa son las del obispo para Berlanga, Los Santos de Maimona, Almendral, Valencia de Mombuey o Fuente de Cantos $^{69}$, las de Villalba de los Barros, Cabeza la Vaca y Barcarrota $^{70}$. Casos especiales también especiales fueron el Valle de Valle de Santa Ana y Valle de Matamoros y Ahillones, donde además de la gripe, había casos de difteria ${ }^{71}$. Estas donaciones eran seguidas con la formación de Juntas de Socorro en el caso de que no se hubieran formado ya.

\footnotetext{
64 C.M. 25/10/1918, n..$^{\circ} 1.538$, p. 2.

65 C.M. 30/10/1918, n. ${ }^{\circ} 1542$, p. 2.

66 C.M. $15 / 11 / 1918$, n. ${ }^{\circ} 1.556$, p. 1.

67 C.M. 30/10/18, n. ${ }^{\circ} 1.542$, p. 2.

68 C.M. $15 / 11 / 1918$, n. ${ }^{\circ} 1.556$, p. 2.

69 C.M. 5/11/18, n. ${ }^{\circ} 1.547$, p. 2.

70 C.M. $12 / 11 / 1918$, n. ${ }^{\circ} 1.553$, p. 2.

71 C.M. $13 / 11 / 1918$, n. $^{\circ} 1.554$, p. 2.
} 
Lo más destacado es la cooperación y solidaridad en los pueblos con la formación de las Juntas de Socorro. Estas Juntas eran iniciadas con alguna aportación importante del Gobernador y del Obispo recomendándose que se hicieran formaran dichas asociaciones para socorre a los pobres que no pudieran ni comprar medicinas ni alimentos. Es el caso de la que en una primera suscripción llegó a 1.067,75 pts., siguen otras muchas como las de Maguilla, Palomas, Fuente del Maestre. Esparragosa de Lares, Usagre, Benquerencia, Berlanga, Los Santos de Maimona, Almendral, Santa Marta ${ }^{72}$. En Puebla de la Calzada los más adinerados y el alcalde socorrían los enfermos sin recursos repartiendo diariamente 300 litros de caldos sustancioso gratis a todos los enfermos pobres mediante receta médica y los propietarios de vacas y cabras pusieron a disposición del Alcalde, las reses paridas de las que se pudieran sacar leche. Sin embargo, a pesar de todos los esfuerzos, los artículos de alimentación escaseaban ${ }^{73}$. Otras muchas poblaciones formaron estas Juntas de Socorro como Monterrubio de la Serena, Valencia de Mombuey, Palomas, Olivenza, Santa Marta de los Barros La Morera, Talavera la Real y Cabeza la Vaca ${ }^{74}$ y otras que se formaron pero no aparecen en la prensa. En Badajoz capital también se crearon Juntas de Socorro para familias necesitadas del Gururú y la barriada de la estación ${ }^{75}$. Si hay una crónica emotiva y real de lo que se vivió en esos momentos nada mejor que la crónica de Antonio Márquez en el Correo de la Mañana el 23 de Noviembre una vez que se consideraba superada la epidemia en Cabeza la Vaca.

\section{CONCLUSIONES}

Durante el primer tercio del siglo XX se producía la transición demográfica unida a la epidemiológica y sanitaria, donde las enfermedades infecciosas empezaban a desaparecer y precisamente la pandemia de 1918 obligó a poner en vigor las medidas sanitarias e higiénicas para mejorar la salud pública y el bienestar social que tendrían efectos positivos en los años siguientes por lo que se constata que la provincia se encontraba en el segundo estadio de la transformación demográfica. En cuanto al exceso de mortalidad provincial en 1918 hay una relación inversa en relación al tamaño de la población. Son las poblaciones pequeñas las que más sufrieron el impacto de la crisis.

\footnotetext{
72 C.M. 5/11/1918, n. ${ }^{\circ} 1.547$, p. 2 .

73 C.M. $26 / 10 / 1918$, n. ${ }^{\circ} 1.539$, p. 2.

74 C.M. 28/11/1918. Llama la atención los humildes donativos de 0,5 y 0,75 pesetas. Daban lo que podían.

75 C.M. $12 / 11 / 1918$, n. ${ }^{\circ} 1.553$, p. 2.
} 
En relación a la temporalidad de la pandemia se podrían considerar tres momentos importantes: el primero entre mayo-julio de 1918 aunque no fuera percibido como tal por las autoridades, el segundo brote tuvo lugar entre septiembre a diciembre de 1918, fue el momento más acuciante y significativo y el tercero, de apenas intensidad entre abril-mayo de 1919; los casos de gripe de 1920 fueron menores que en 1917 y no podemos especificar si su origen era de gripe común u otro origen.

Las tasas específicas de mortalidad por gripe en la provincia fue de $7,22 \%$, en la capital de $5,45 \%$ y en la provincia sin capital de $7,34 \%$. Las enfermedades respiratorias tuvieron unas tasas mortalidad de $6,86 \%$ en la provincia, $9,68 \%$ en la capital y $6,84 \%$ en la provincia sin la capital. No obstante las enteritis y diarreas seguían siendo las mayores causas de mortalidad: $12,61 \%$ en la provincia, $14,16 \%$ en la capital y $12,54 \%$ en la provincia sin la capital. Todas las demás enfermedades infecciosas se incrementaron. El mayor porcentaje de mortandad por gripe se concentra en las mujeres de 20 a 34 años $(35,9 \%)$ y varones de $24-39(34,2 \%)$. Según tasas brutas de mortalidad específica por gripe las más elevadas corresponden a mayores 70 años $(11,8 \%$ ) , en segundo lugar a población adulta entre $25-34(11 \%$ ) y en tercer lugar a menores de 1 año $(9,9 \%$ ).

Desde el punto de vista demográfico no se alteraron los patrones de fertilidad ni matrimonios, pero sí afectó a los índices de supervivencia y esperanza de vida que pasaron de 26,35 en 1917 a 22,4 según nacimientos en 1918, aunque en 1920 ascendió a 34,8 años.

La epidemia afectó a todos los sectores de la vida diaria. En el ámbito político, se aplicó una política de control militar y sanitario de la frontera con Portugal, se desarrolló toda una serie de normas que desarrollaban una política social de prevención y regularización sanitaria para el desarrollo de una infraestructura de atención a los enfermos. Desde el punto de vista económico, la subida de precios de productos básicos incrementó el estado de precariedad y enfrentamientos entre los diferentes sectores económicos y la Junta de Abastecimiento. Desde el pueblo surgía una reacción compleja y contradictoria, xenofobia frente a cualquiera foráneo susceptible de estar contagiado al mismo tiempo que una fuerte solidaridad interna con la formación de las Juntas de Socorro trataba de socorrer a todos los necesitados. 
La pandemia fue un impacto tremendo pero momentáneo, una vez superada la crisis, la provincia recobró el ritmo iniciado de descenso progresivo de mortalidad y la modernización de la población.

\section{Bibiografia}

ABRAHAMS, A.; HALLOWS, N.; EYRE, J. (1917). Purulent bronchitis, its influenza y pneumococcal bacteriology. Lancet, 190, pp. 41-46.

ÁLVAREZ, P. E.; FERNÁNDEZ LÓPEZ, A.; GONZÁLEZ TABOADA, F.; HÖFER, J.; GÓMOEZ GÓMEZ, P. (2008). Mortalidad en los concejos de Oviedo, Gijón y Aviles durante la epidemia de gripe de 1918. Revista miscelanea de Investigación, n. 22, pp. 93-106.

BARONA VILLAR, J. L.; BERNABEU MESTRE, J. (eds.) (2008). La salud y el Estado: el movimiento sanitario internacional y la administración española (1851-1945). Universitat de Valencia, Valencia.

BERNABEU MESTRE, J. (1998). Transición sanitaria y evolución de la medicina (diagnóstico, pofilaxis y terapéutica), 1885-1942. Boletín de la ADEH, XVI, pp. 15-38.

BERTILLON, J. (1903). Nomenclatures des maladies. Typographique de L'Ècole D'Alembert, Montévrain.

BLANCO CARRASCO, J. P. (1995). Agotamiento y crisis del modelo de alta presión demográfica extremeño: la trayectoria de la mortalidad infantil y juvenil. Norba. Revista de Historia, 15, pp. 143-158.

CHOWELL, G.; ERKOREKA ANTÓN; VIBOUD, C.; ECHEVERRI-DÁVILA, B. (2014). Spatial-temporal excess mortality patterns of the 1918-1919 influenza pandemic in Spain. BMC Infectious Diseases, 14, 371.

CILEK, L.; CHOWELL, G.; RAMIRO FARIÑAS, D. (2018). Age-specific Excess Mortality Patterns During the 1918-1920 Influenza Pandemic in Madrid, Spain. American Journal of Epidemiology, 187 (12), December 2018, pp. 2511-2523. Em https://doi.org/10.1 093/aje/kwy 171

CROSBY, A. (1976). Epidemic and Peace, 1918. Greenwood, Westport.

DÍAZ DÍAZ, B.; MIRANDA DÍAZ, B. (2014). RE: La pandemia de 1918. Su repercusión en Campanario (Badajoz). Actas de los VII Encuentros de Estudios Comarcales Vegas Altas, L.S.Y.L.S.

DURÁN HERRERA, A. (2015). Población y territorio en Extremadura. Siglos XVIII-XX. Doctora, UNED.

ECHEVERRI DÁVILA, B. (1993). La Gripe Española. La pandemia de 1918-1919. C.I.S, Madrid.

ERKOREKA, A. (2010). The Spanish influenza pandemic in occidental Europe (1918-1920) y victim age. Influenza y Other Respiratory Viruses, 4 (2), pp. 81-89. https://doi.or $\mathrm{g} / 10.1111 / \mathrm{j} .1750-2659.2009 .00125 . \mathrm{x}$ 
FÉRNÁNDEZ FERNÁNDEZ, C. M.; VEIGA FERREIRA, X. (1995). La «gripe» de 191819 en Betanzos. Anuario Brigantino, 18, pp. 143-158.

GANI, R.; HUGHES, G. H.; FLEMING, D.; GRIFFIN, T. M. J. L. S. (2005). Potential impact of antiviral drug use during influenza pandemic. Emerging Infectious Diseases, 11, pp. 1355-1361.

GARCÍA-CONSUEGRA GARCÍA-CONSUEGRA, M. (2013). Una tragedia olvidada: la pandemia de gripe de 1918 en Daimiel. Vínculos de Historia, núm. 2, pp. 331-350.

GARCÍA CIENFUEGOS, M. (2018). La repercusión de la epidemia de la gripe en Montijo. Año 1918. Em https://www.academia.edu/21738134/La_repercusi

GÓMEZ REDONDO, R. (1992). La mortalidad infantil española en el siglo XX. Siglo XXI, Madrid.

GONDRA REZOLA, J.; ERKOREKA, A. (2010). El cuerpo médico municipal (1897-1937) y la pandemia de gripe española en Bilbao (1918-1920). Bidebarrieta: Revista de humanidades y ciencias sociales de Bilbao, n. ${ }^{\circ}$ 21, pp. 139-152.

HERRERA RODRÍGUEZ, F. (1996). Incidencia de la gripe de 1918-1919 en la ciudad de Cádiz. Llull, n. ${ }^{\circ} 19$, pp. 455-470.

JORDAN, E. (1927). Epidemic influenza:a survey. American Medical Association, Chicago.

LANDRY, A. (ed.) (1934). La revolution demographique: Etudes et essais sur les problèmes de la population. J. Bière, Paris.

LEASURE, J. W. (1963). Factors involved in the decline of fertility in Spain 1900-1950. Population Studies, 16, pp. 271-285.

LIVI-BACCI, M. (ed.) (2007). Introducción a la Demografía. Ariel, Barcelona.

MARTÍN MARTÍN, Q.; CABERO MORÁN, M. T.; DE PAZ SANTANA, Y. D. R. (2008). Tratamiento estadístico de datos con SPSS. Thomson, Madrid.

MCKEWON, T. (1976). El crecimiento moderno de la población. Antoni Bosch, Barcelona.

MCKEWON, T.; BROWN, R. G.; RECORD, R. G. (1972). An Interpretation of the Moderns Rise of Population in Europe. Population Studies, 26, pp. 345-382.

MURILLO GODÍNEZ, G. (2011). Recordando a la gripe española. Med Int Mex, 27 (5), pp. 463-466.

MURRAY, C.; LÓPEZ, A.; CHIN, B.; FEEHAN, D.; HILL, K. (2006). Estimation of potential global pandemic influenza mortality on the basis of vital registry data from the 191820 pandemic: a quantitative analysis. The Lancet, volume 368, pp. 2211-2218.

NEILA MUÑOZ, C. M. (2014). RE: La epidemia de gripe de 1918 y 1919 en las ciuddes de Cáceres y de Plasencia (Extremadura). Extremadura, C. H. D.

NOTESTEIN, F. W. (1945). Population - The long view, In SCHULTZ, T. (ed.). Food for the world. University of Chicago Press, Chicago. 
NUNES, B.; SILVA, S.; RODRIGUES, Ana; Rouquette, Rita; BATISTA, Inês; REBELO-DEANDRADE, Helena (2018). The 1918-19 Influenza Pandemic in Portugal: A Regional Análysis od Mortality Impact. Am. J. Epidemiol, Aug 7. Emhttps://doi.org/10.1093/aj e/kwy 164

OEPPEN, J.; RAMIRO FARIÑAS, D.; GARCÍA FERRERO, S. (2010). Estimating Reproduction Numbers for the 1889-90 y 1918-20 Influenza Pandemics in the city of Madrid. Seminario - Barcelona 8-9 Julio 2010, Salud Y Ciudades En España, 1880-1940.

OMRAN, A. R. (1971). The epidemiologic transition: a theory of the epidemiology of population change. Milbank Mem Fund Q, 49, pp. 509-583.

OXFORD, J. S.; GILL, D. (2018). Unanswered questions about the 1918 influenza pandemic: origin, pathology, y the virus itself. Lancet Infect Diss. June 20, em https://do i.org/10.1016/S1473-3099(18)30359-1

PÉREZ MOREDA, V.; REHER, D.-S.; SANZ GIMENO, A. (eds.) (2015). La conquista de la salud. Mortalidad y modernización en la España contemporánea. Marcial Pons, Madrid.

PORRAS GALLO, M. I. (1994). Una ciudad en crisis: la epidemia de gripe de 1918-19 en Madrid. Doctor, UCM.

RAMIRO FARIÑAS, D. (1998a). La evoluación de la mortalidad en la infancia en la España interior, 1785-1960. Doctorado, UCM.

RAMIRO FARIÑAS, D.; SANZ GIMENO, A. (2002). Infancia, Mortalidad y niveles de vida en la España interior. In MARTÍNEZ CARRIÓN, J. M. E. (ed.). El nivel de vida de la España rural, siglos XVIII-XX. Universidad de Alicante, Salamanca.

REID, A.; FANNING, T.; HULTIN, J. A.; TAUBENBERGER, J. (1999). Origin y evolution of the 1918 «Spanish» influenza virus hemagglutinin gene. Proc Natl Acad Sci USA, Feb 16; 96 (4), pp. 1651-1656.

ROBLES GONZÁLEZ, E. B. M.; J. BENAVIDES, G.G. (1996). «La transición sanitaria. Una revisión conceptual. Boletín de la ADEH, XIV, pp. 117-144.

RUIZ BARGAÑO, J. (2002). Modelización de la epidemia de la gripe A (H1N1) mediante redes aleatorias en un entorno de computación distribuida. Universitat Politécnica de Valéncia.

SHRYOCK, E. G.; SIEGEL, J. S.; ALII., E. (1976). The methods y materials of demography. Academic Press Inc, San Diego, California.

SILVA ORTIZ, L. (2018). La pandema de gripe española de 1918 en el partido judicial de LLerena. Un estudio de caso. Revista de Historia de las Vegas Altas, pp. 35-52.

TAUBEBBERGER, J. K. (2006). The Origin y Virulence of the 1918 «Spanish» Influenza Virus. Proc Am Philos Soc, March, 150 (1), pp. 86-112.

THOMPSON, W. (1929). Population. American Journal of Sociology, 34, pp. 959-77.

TRILlA, A.; TRILlA, G.; DAER, C. (2008). The 1918 «Spanish Flu» in Spain. Clin Infect Dis, Oct. 1; 47 (7), p.987. 
A Gripe Espanhola de 1918

VINUESA, J. PUGA, D. (2007). Técnicas y ejercicios de Demografía. I.N.E., Madrid.

VV.AA (1995). Historia del desarrollo de la CIE, in Org. P.A.H. (ed.). O.M.S, Ginebra. 


\section{AMADEO E A «PNEUMÓNICA»: REQUIEM PARA UM MODERNISTA}

Luís Pimenta de Castro Damásio ${ }^{1}$

$\overline{\text { Investigador do CITCEM|FLUP }}$ - Grupo de Populações e Saúde, luispcdamasio@gmail.com 



\begin{abstract}
Resumo
Não há dúvida de que Amadeo de Souza-Cardoso (1887-1918) ocupa - entre as figuras portuguesas de maior projeção intelectual, cultural e artística do século XX - um lugar cimeiro. Desde os fins de setembro de 1918 que os jornais davam notícias de uma «epidemia que zomba da medicina», mas já havia populações dizimadas em várias comunidades nortenhas, particularmente no concelho de Amarante, onde se chegaram a esboçar movimentos de revolta. O surto de pandemia trazia uma particularidade: ao contrário do habitual, os casos mais graves e mortais atingiam a população jovem. Desde agosto de 1918 que Amadeo de Souza Cardoso se encontrava em Espinho, na casa dos pais, a passar as férias de verão. Nos primeiros dias de outubro, Amadeo começa a manifestar os indícios de doença gripal epidémica e, no dia 25 do referido mês de outubro, pelas nove horas da manhã, depois de uma noite de grande aflição e sofrimento, o artista modernista amarantino faleceu, vitimado pela "gripe espanhola» ou "pneumónica», com a idade de 30 anos. A envolvência da família de Amadeo no seu universo pessoal e artístico esteve sempre presente até aos últimos suspiros da sua morte.
\end{abstract}

Palavras-chave: Amadeo, Espinho, gripe espanhola e morte.

Não há dúvida de que Amadeo de Souza Cardoso (1887-1918) (Figura 1) ocupa - entre as figuras portuguesas de maior projeção intelectual, cultural e artística do século XX - um lugar cimeiro.

De facto, é hoje consensual que Amadeo foi não só um dos maiores pintores do seu tempo, mas também o grande pioneiro do Modernismo em Portugal, no que diz respeito às artes plásticas.

A viagem pelo universo humano e artístico de Amadeo, ao longo da sua vida, torna-se um desafio e um fascínio cada vez mais aliciantes.

Esta comunicação foca e contextualiza a última etapa dos últimos meses do percurso de vida e arte de Amadeo de Souza Cardoso.

Inicia nos primeiros dias do mês de julho de 1918, com a estadia na estância das termas das Taipas (Guimarães), para tratamento dermatológico, acompanhado pelo irmão mais novo, António. 


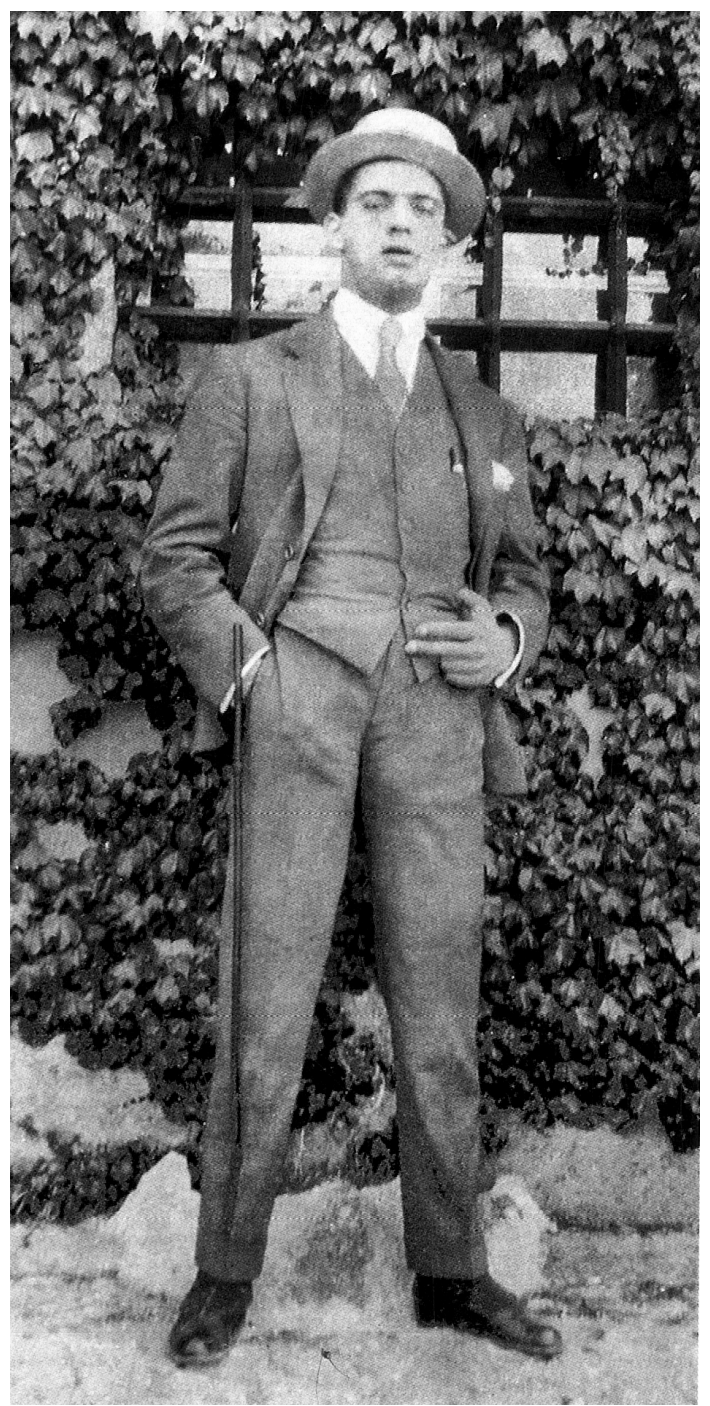

Fig. 1 - Amadeo de Souza Cardoso c. 1918.

(Arquivo Privado da Família Souza Cardoso). 


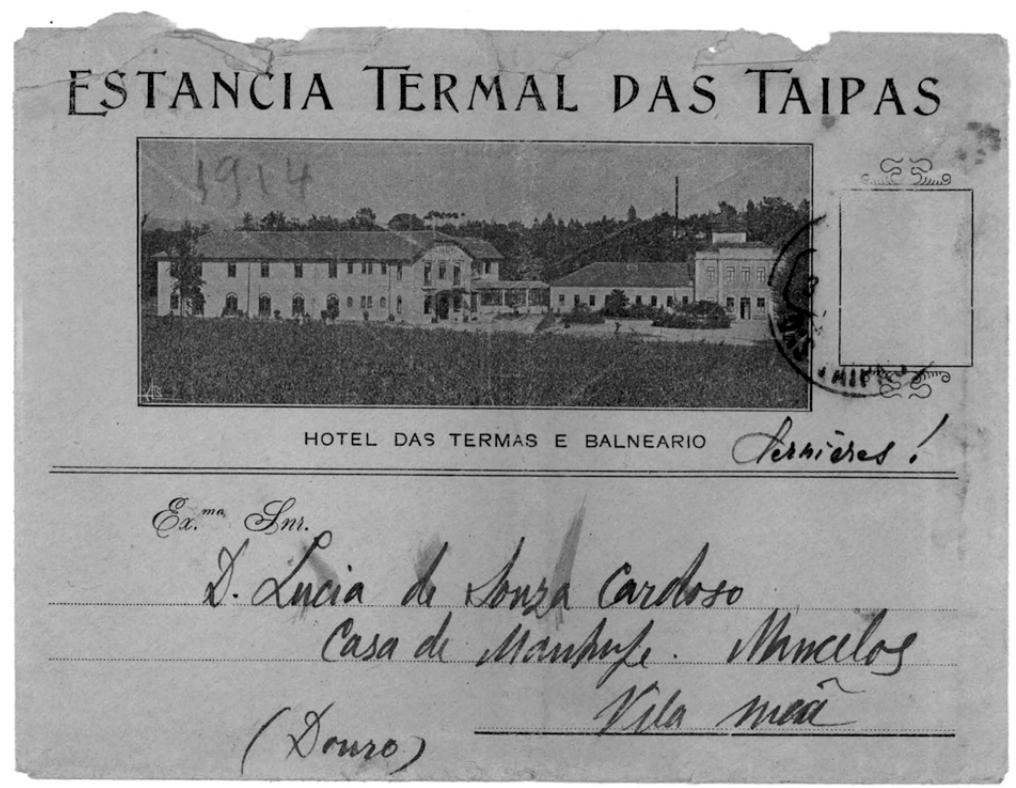

Fig. 2 - Sobrescrito da carta, com timbre «Estancia Termal das Taipas», dirigida a «D. Lucia de Souza Cardoso», 1918.

(Cortesia: Espólio Amadeo de Souza Cardoso da Coleção da Biblioteca da Fundação Calouste Gulbenkian).

Este problema de saúde foi recorrente desde finais de 1907, mas acentuouse nos últimos anos de vida do pintor, a partir de 1915 e 1916, na sequência da preparação para as exposições do Porto e Lisboa. Refletiu-se na dificuldade de escrita, recorrendo muitas das vezes a Lucie para redigir as cartas por ele, como se constata em algumas fontes epistolares, que mostram claramente uma caligrafia diferente, mas com a assinatura do pintor. Por esta razão, em princípios de julho de 1918, os dois irmãos, Amadeo e António, iniciam tratamentos de saúde na estância das Caldas das Taipas (Figura 2), em Guimarães, ficando instalados no «Hotel Vilas» (Figura 3). Estas termas eram consideradas «as únicas do país para a cura das doenças de pele», abertas de 1 de julho a 15 de outubro.

No dia 1 de agosto de 1918, ainda nas Caldas das Taipas, Amadeo escreveu a Lucie, para Manhufe, a combinar a partida para Espinho.

Nos primeiros dias de agosto, Amadeo partiu diretamente das Taipas para Espinho (Figura 4). Lucie deveria ir ter com ele e levar, do atelier do Ribeiro, todos os pincéis, espátulas, frascos de verniz, caixa dos tubos de cores, a palete e a caixa de transporte. 


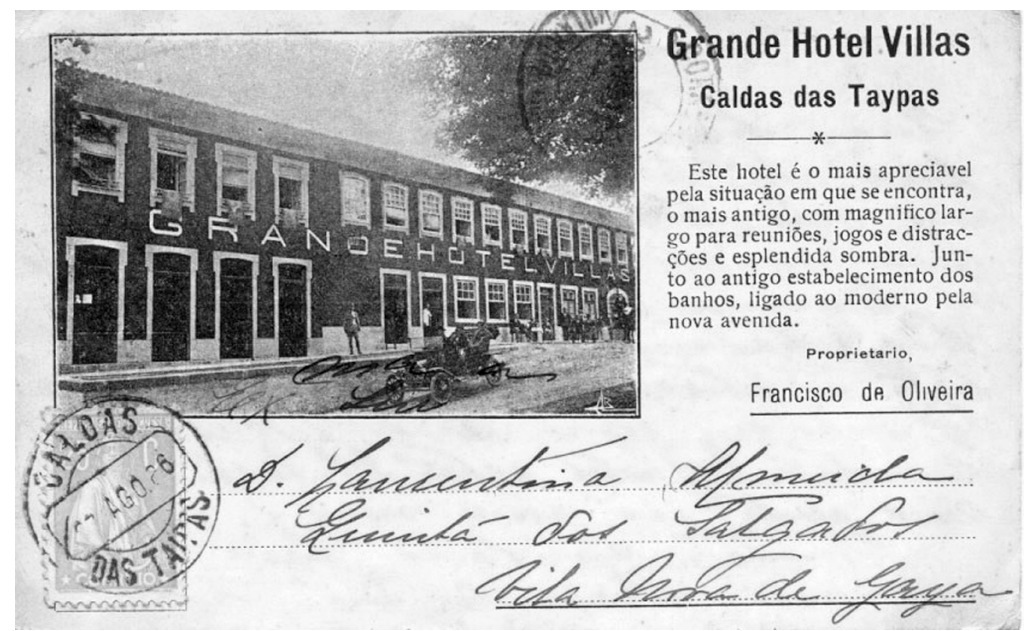

Fig. 3 - Taipas. Grande Hotel Villas, agosto de 1926. (Col. particular de António José de Oliveira).

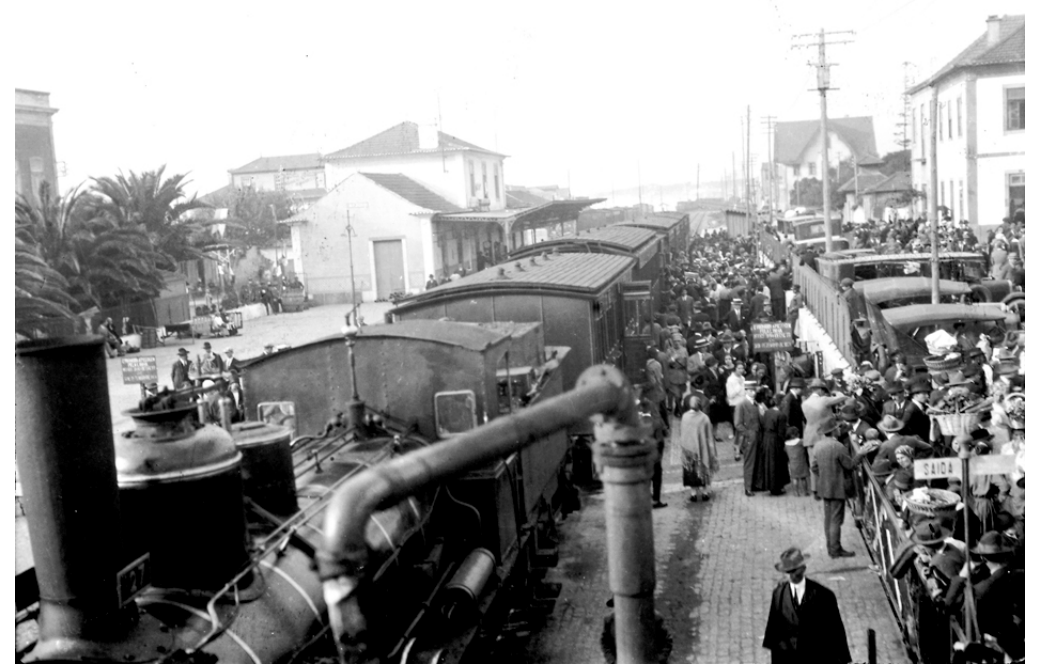

Fig. 4 - Espinho. Estação do caminho de ferro, fotografia de c. 1918.

(Arquivo Privado da Família Souza Cardoso).

Em Espinho, com todo o material de pintura, Amadeo vai aproveitar para se dedicar à pintura, escolhendo o mirante da casa dos pais (Figura 5) como espaço de eleição, não só pelo local ter bastante luz, mas, principalmente, pela privacidade que este oferecia, além de possuir «boas vistas» para o mar, paisagem que muito o inspirava. Um dos hábitos de Amadeo, 


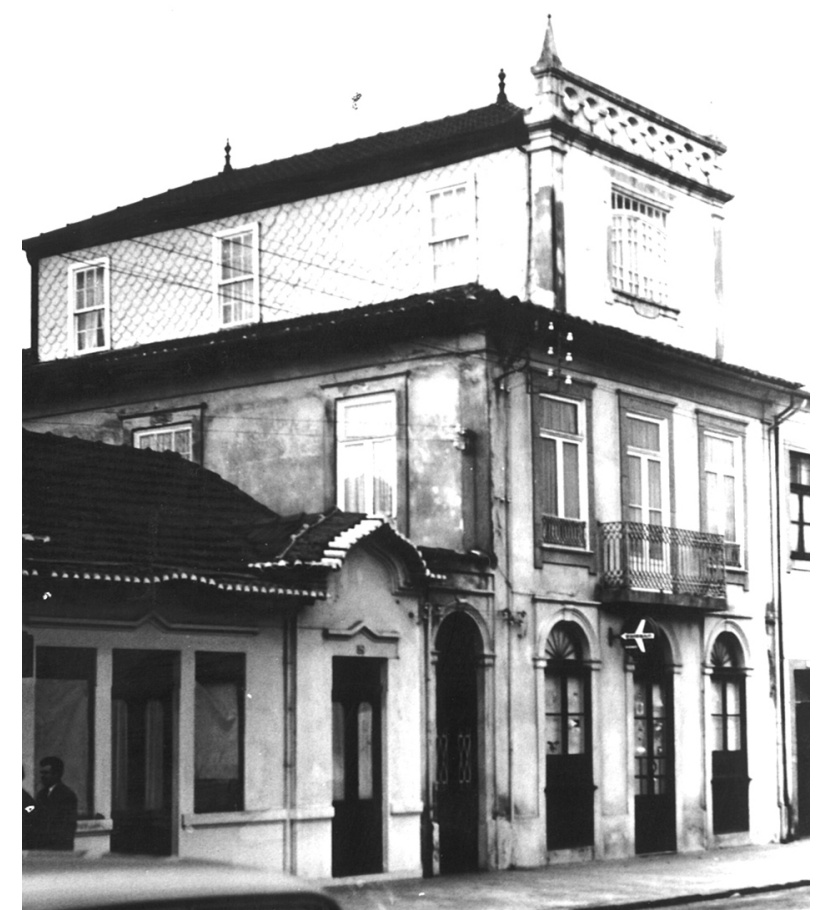

Fig. 5 - Espinho. Fachada da Casa dos Souza Cardoso, c. 1968. (Col. privada).

quando estava em Espinho, era passear pela areia da praia e deslumbrar-se com o mar. Em várias fontes epistolares encontramos referências do pintor a observar o mar.

Foi durante a estadia em Espinho, entre agosto e princípios de outubro de 1918, que Amadeo pintou as últimas obras. O «mirante» da casa foi um dos seus locais preferidos, cheio de luminosidade - «sol»-, que sempre o fascinou. Conseguiu «colocar» essa luz - «este nosso sol tão português»-, e as suas cores, em muitos quadros.

Na paleta de Amadeo vemos Espinho: as janelas e os postigos, as varinas, o pescador, a chalupa, os barcos dos pescadores, a praia e o mar.

Em várias fontes epistolares encontramos referências do pintor a observar o mar: «[...] em seguida fui ver o mar. [...]».

Quanto aos barcos dos pescadores desta região costeira, Amadeo refere nas cartas/postais o quanto os apreciava: «[...] Este postal que te mando 
é um dos barcos de pesca que se usam aqui são de uma linha elegantíssima $[\ldots] \gg$.

Foi durante a sua estadia em Espinho que pintou os últimos quadros, intervalando com muita regularidade os diversos passatempos que muito apreciava - leitura, cavaquear, passeios pela areia e banhos na praia, frequência do Casino, passeios pela Avenida 8, nas esplanadas do «Café Chinez» e viagens pela região.

Entretanto, o jornal periódico de Amarante, Flor do Tâmega, de 22 de setembro de 1918, noticiava a presença de seu pai, José Emygdio de Souza Cardoso (1856-1925) e família, em Espinho: «[...] Continua na Praia de Espinho, o senhor José Emygdio de Souza Cardoso, illustre Presidente da Comissão Administrativa Municipal [...]».

O mesmo jornal, insere um artigo com o título «A gripe Pneumónica», que é muito esclarecedor sobre a tragédia que começava a assolar a vila de Amarante:

[...] esta epidemia foi trazida por soldados de artilharia, que foram as primeiras vítimas, em número superior a vinte, incluindo três sargentos, alastrandose rapidamente na villa de Amarante e na maior parte das freguesias do concelho, onde só pessoas válidas, de 20 a 40 anos, foram irremediavelmente e rapidamente ceifadas pela morte [...]. Na primeira semana os caixões para casa dos armadores, cruzavam-se nas ruas; os sinos quasi todos os dias dobravam a finado [...] algumas casas fecharam as portas [...] só na antiga rua do Porto, adoeceram 39 pessoas [...] de 1 a 19 de Setembro faleceram no concelho 226 pessoas. [...].

No dia 24 de setembro de 1918, o Presidente da «Nova República», Sidónio Bernardino Cardoso da Silva Pais (1872-1918), visitou Amarante. Nesta altura, saiu uma notícia que informava que a gripe parecia estar a desaparecer: «Esta epidemia parece ter abandonado a villa [...]».

Em 27 de setembro, o seu pai, José Emygdio, e família, ainda continuavam em Espinho. Sabemos isto através de um bilhete-postal que Amadeo enviou à prima e cunhada Carolina. No bilhete-postal, ilustrado com a imagem da Quinta de Manhufe, tratou de assuntos pessoais, mencionando a terrível pneumónica, e convidava as filhas de Carolina, da Casa da Pena, para passar uns dias de descanso em Espinho.

Amarante encontrava-se sob a égide da reação conservadora e, ao mesmo tempo, sob os efeitos dos flagelos da fome, da crise de subsistências, de abastecimentos e das epidemias - o tifo exantemático e, sobretudo, a gripe pneumónica, popularmente conhecida como 'gripe espanhola' (porque veio de Badajoz, Espanha), que teve na vila e seu termo trágica incidência, tendo ficado 
também conhecida, em diversas comunidades nortenhas, por «epidemia de Amarante».

Desde os fins de setembro que os jornais davam notícias de uma «epidemia que zomba da medicina», mas já havia populações dizimadas em várias comunidades nortenhas, particularmente no concelho de Amarante, onde se chegaram a esboçar movimentos de revolta. O surto de pandemia trazia uma particularidade: ao contrário do habitual, os casos mais graves e mortais, atingiam a população jovem.

Nos meses de agosto e setembro, na casa dos Souza Cardoso, em Espinho, tudo parece sereno, num cenário totalmente oposto ao horizonte que paira para os lados das terras do Marão.

Em Espinho, nos primeiros dias do mês de outubro, a casa estava repleta, com exceção dos irmãos Laura e António, que se encontram em Manhufe. Entretanto, começam a surgir alguns indícios de doença.

Em carta dirigida ao irmão António, que se encontrava em Manhufe, Amadeo, na primeira semana de outubro, já descrevia alguns sintomas de mal-estar, referindo-se a uma grande constipação, e que em casa se encontravam já vários 'gripais' mais fortes, como era o caso das irmãs Maria da Graça e Maria Helena, e também de Lucie.

Em várias situações da vida, Amadeo põe sempre a última decisão na mão de Deus. Nesta carta não foge à regra: «Seja o que Deus quiser!». Amadeo, que amava muito a vida e estava cheio de projetos, tinha medo de morrer, fez tudo para se livrar desta pandemia e tentou todos os tratamentos que se pensava serem os mais eficazes.

O seu objetivo era regressar, no mais breve espaço de tempo possível, a Paris, para onde tinha enviado, meses antes, uma grande parte da sua obra, chegando mesmo a reservar o atelier do n. ${ }^{\circ} 27$ da Rue de Fleurus.

A tragédia começou logo no início do mês de outubro de 1918, com a morte de sua avó materna, Ana Cândida Ferreira (1827-1918), na Casa do Ribeiro, em Manhufe.

Em Espinho, os sintomas gripais de Maria da Graça agravaram-se, ao ponto de cair numa broncopneumonia, no dia 8 de outubro. Dois dias depois, 10 de outubro, pelas 13 horas, a «Gracita», acabou por morrer com 29 anos de idade.

Em terras de Amarante, pela mesma altura, Laura, em Manhufe, e Francisco Cardoso «Paco», em Fregim, começavam a apresentar os primeiros sintomas de gripe. Três dias depois de Maria da Graça, a 13 de outubro, morreu Francisco Cardoso, vitimado com a mesma idade e pela mesma epi- 
demia. Em Espinho, morria uma das empregadas de Alice Souza Cardoso, vitimada pela mesma doença.

Pouco tempo depois, em Espinho, no dia 25 de outubro, sexta-feira, pelas nove horas da manhã, depois de uma noite de grande aflição e sofrimento, morreu Amadeo de Souza Cardoso, vitimado pela gripe espanhola ou pneumónica, com a idade de 30 anos e 11 meses. Ao seu sofrimento, no leito de morte, assistiram os entes mais queridos.

O último desejo de Amadeo foi receber os últimos sacramentos, pedindo para comungar, o que foi conseguido junto de um sacerdote da terra, a pedido dos pais, e in articulo mortis.

Nas memórias de Fernando Cardoso (1888-1952), da Casa da Pena, seu primo, recordam-se os últimos momentos de Amadeo: « [...] meu cunhado Amadeu [...] n'uma luta feroz em que por fim foi vencido, [...] coitado morreu $[\ldots] \gg$.

Nas memórias da viúva Lucie, transpostas para uma carta de 25 de maio de 1987, os últimos dias de Amadeo ficaram registados: «Estando eu já doente várias vezes vi passar o Amadeu, no meu quarto, protegido com o seu cachecol em lã dos Pirenéus para evitar apanhar alguma constipação que o fizesse cair à cama. O vinho do Porto não foi suficiente para evitar esse perigo tão grande [...]» (Macedo, 1993: 120-121).

Em Espinho, durante o mês de outubro de 1918, morreram 32 pessoas e, destas, a maioria rondava a casa dos 20-30 anos de idade. No total, durante o ano de 1918, morreram 78 pessoas com a mesma doença epidémica, o que significa que em outubro ocorreram $41 \%$ dos óbitos registados no ano.

Amadeo nunca foi, fisicamente, um homem muito robusto, tendo sido essa uma das razões da sua dispensa militar (1916) - por incapacidade física. O exercício da pintura, nomeadamente o contacto permanente com as tintas, provocou-lhe algumas alergias que prejudicaram o estado de saúde da sua pele, levando ao agravamento de um eczema. Para o solucionar, Amadeo frequentava com alguma regularidade as estâncias termais das Caldas do Gerês, de Canavezes, de Vizela e, por último, as Caldas das Taipas (Guimarães).

Alguns amigos artistas de Amadeo - pintores, músicos, escritores e poetas - foram também vítimas do conflito da Primeira Grande Guerra, como o escritor francês, poeta, crítico e teórico de arte, Guillaume Apollinaire (18801918) que ficou gravemente ferido, mas que acabou por morrer de pneumónica, 15 dias depois da morte do pintor amarantino, a 9 de novembro de 1918 e o compositor espanhol, pianista, professor e crítico musical, Buenaventura Santiago Blanco López (1883-1919), amigo de Souza Cardoso desde os tem- 


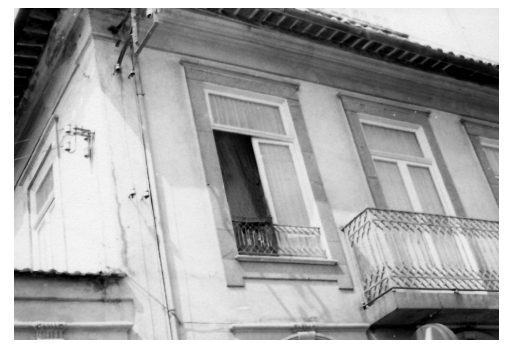

Fig. 6 - Espinho. Fachada da Casa dos Souza Cardoso, 1.ำ andar, c. 1970. (Col. da Família Ramos Pereira).

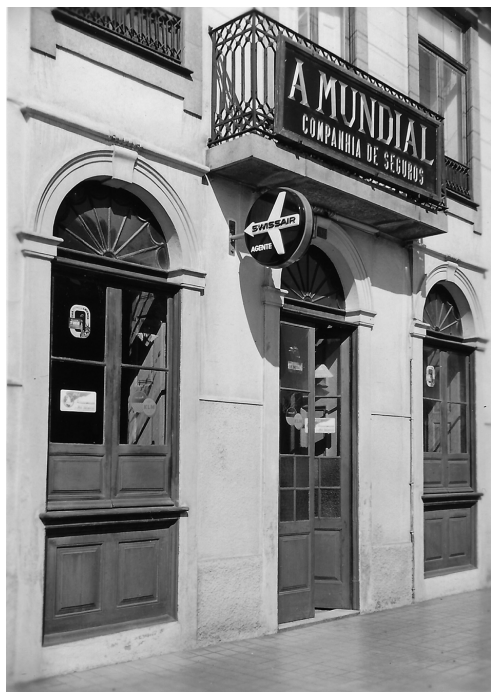

Fig. 7 - Espinho. 1. piso da frente da Casa dos Souza Cardoso, década de 60 do século XX. (Col. da Família Ramos Pereira).

pos da adolescência, nos verões de Espinho, morre a 1 de maio de 1919, com 35 anos, vítima da mesma epidemia, na cidade do Porto.

A obra de Amadeo de Souza Cardoso vai ficar um tanto ou quanto esquecida para o público em geral. Os pais e Lucie conservaram o seu espólio «religiosamente». Contudo, apesar do seu desejo de destacar o pintor, não foram bem-sucedidos. O pai, José Emygido de Souza Cardoso, morre em 1925, em Manhufe; a mãe, Emília Cândida Ferreira Cardoso (1861-1934), morre em 1934, em Manhufe; o tio materno, Francisco José Ferreira Cardoso (1865-1947), morre em 1947.

Outros entes queridos morreram sem verem reconhecido «o seu Amadeu» como um dos grandes vultos da pintura portuguesa de todos os tempos.

Com todos estes desgostos, os pais resolveram vender a casa de Espinho. Em 5 de janeiro de 1922, em Espinho, José Emygdio, com uma procuração da mulher Emília Cândida, vendeu a casa a um amigo e comerciante local, Fernando Ramos Pereira, pelo valor de dois contos. Anos depois, este comerciante, no rés-do-chão do prédio, abriu uma agência de viagens, «Agência de Ramos Pereira» (Figuras 6 e 7), que manteve atividade até abril de 1972.

A casa dos pais do pintor e todo o quarteirão (Figuras 8 e 9) foram demolidos (Figura 10) durante os meses de maio e junho de 1973, por iniciativa da Câmara Municipal de Espinho. No seu lugar, hoje, com os n. ${ }^{\text {os }} 436$ 


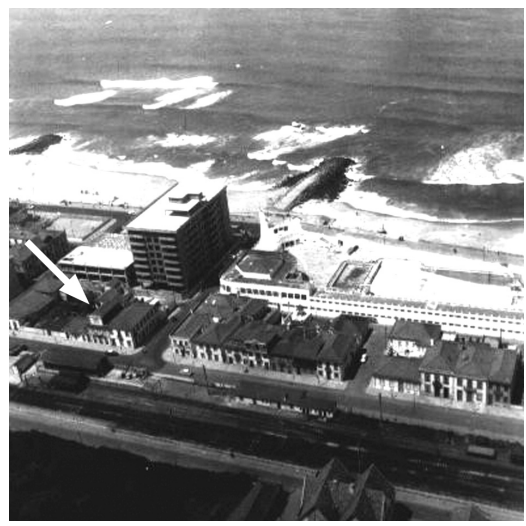

Fig. 8 - Espinho. Vista aérea. Casa dos Souza Cardoso, assinalada com seta, c. 1970. (Col. particular).

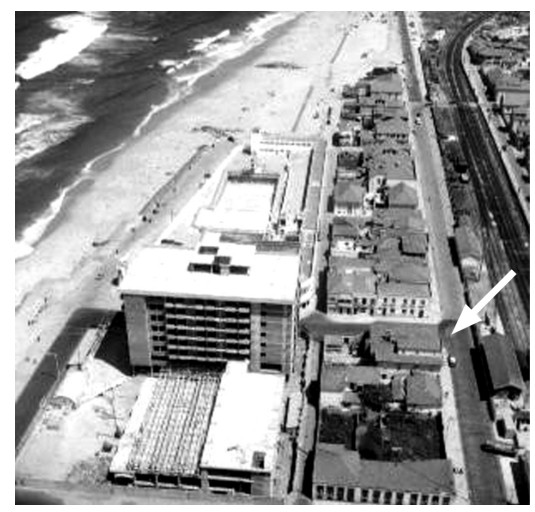

Fig. 9 - Espinho. Vista aérea. Casa dos Souza Cardoso, assinalada com seta, c. 1970. (Col. particular).

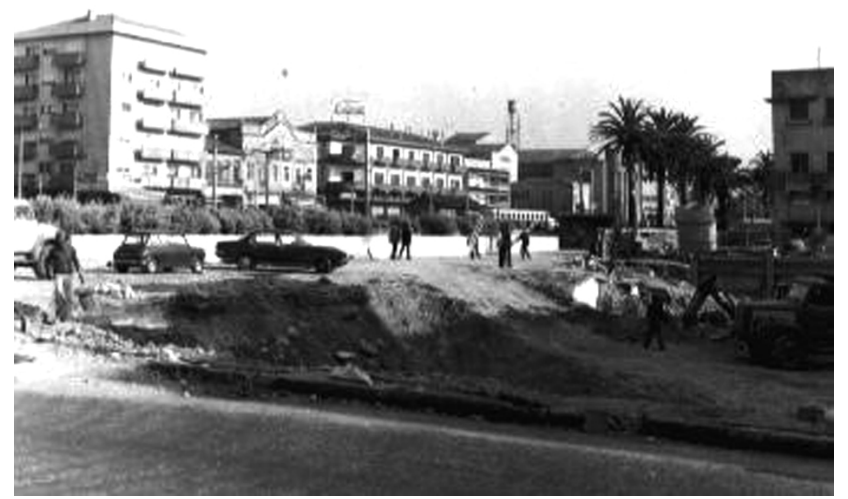

Fig. 10 - Demolição do quarteirão onde se situava a Casa dos Souza Cardoso, maio-junho de 1973. (Col. particular).

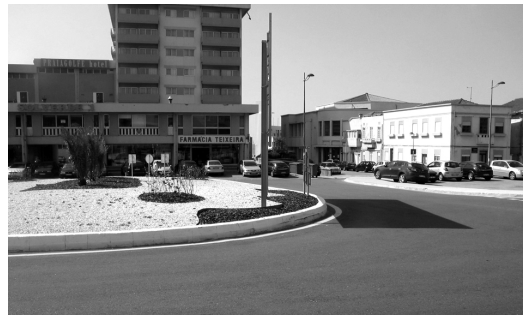

Fig. 11 - Espinho. Atual local onde se situava a Casa dos Souza Cardoso, fotografia de junho de 2011.

(Arquivo Privado da Família Sousa Cardoso).

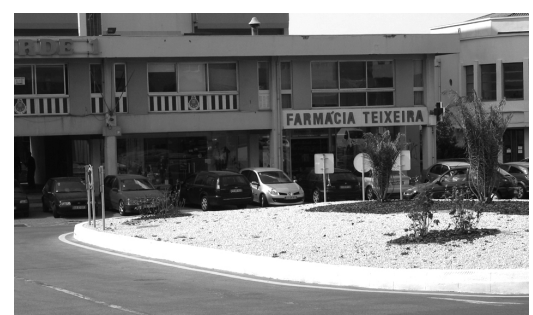

Fig. 12 - Espinho. Atual local onde se situava a Casa dos Souza Cardoso, fotografia de junho de 2011.

(Arquivo Privado da Família Sousa Cardoso). 
e 442, encontramos uma farmácia («Farmácia Teixeira») (Figura 11) e uma loja comercial (Figura 12).

É relevante evocar o centenário da morte de Amadeo de Souza Cardoso (1918-2018), mas, mais importante é pôr o pintor amarantino na História da Arte Universal.

Embora tenha deixado uma obra considerada notável, tendo obtido sucesso no seu tempo, portanto ainda em vida do pintor, foi sendo progressivamente esquecido, apesar de, nestas últimas décadas, terem sido realizados alguns eventos para promover e divulgar a sua obra, com destaque para o próprio Município de Amarante, que criou um museu com o seu nome e mantém uma exposição permanente de obras de Amadeo durante todo o ano.

É útil também referir o papel notável da Fundação Calouste Gulbenkian, que recebeu grande parte do espólio do pintor, através da viúva, com o objetivo de promover e divulgar a obra. No entanto, ainda falta um longo caminho a percorrer.

É necessário e de toda a justiça apresentar Amadeo na sua pluralidade e equipará-lo aos maiores do seu tempo, nomeadamente Picasso, Matisse, Braque, Kandinsky, Juan Gris, entre outros.

Souza Cardoso privou com alguns deles - Amedeo Modigliani, Brâncuşi, Brunelleschi, Sonia e Robert Delaunay, Otto Freundlich, Archipenko, Apollinaire, Max Jacob (poeta), Marc Chagall, Boccioni e Walter Pach. Este último foi uma das figuras que pôs Amadeo na ribalta do mundo artístico.

Não nos esqueçamos que, em 1913, Amadeo foi convidado a participar na Internacional Exhibition of Modern Art (Figuras 13 a 18), mais conhecida por «Armory Show», que se realizou nos Estados Unidos da América, em três cidades (Nova York, Chicago e Boston). Souza Cardoso, a partir desta data, consagrou-se como um dos grandes modernistas da pintura e o $1 .^{\circ}$ modernista Português.

Este acontecimento artístico, no seu tempo, foi ignorado em Portugal. 


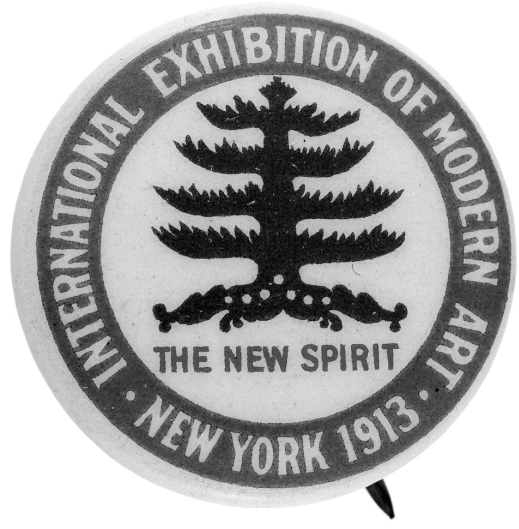

Fig. 13 - Cartaz da International Exhibition of Modern Art, 1913, USA. (Col. particular).

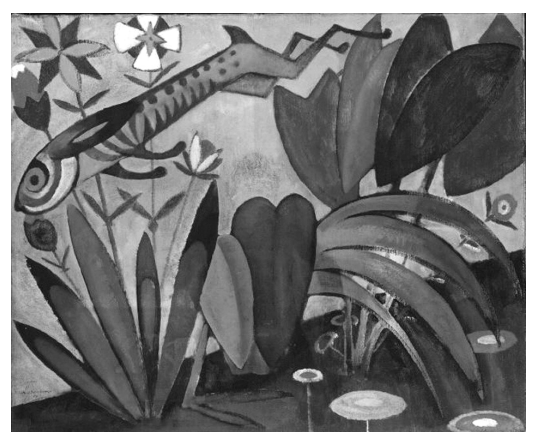

Fig. 15 - Pintura de Amadeo, Saut du Lapin, óleo sobre tela, 1911. (Cortesia: Col. The Art Institute of Chicago, Arthur Jerome Memorial Collection, USA).

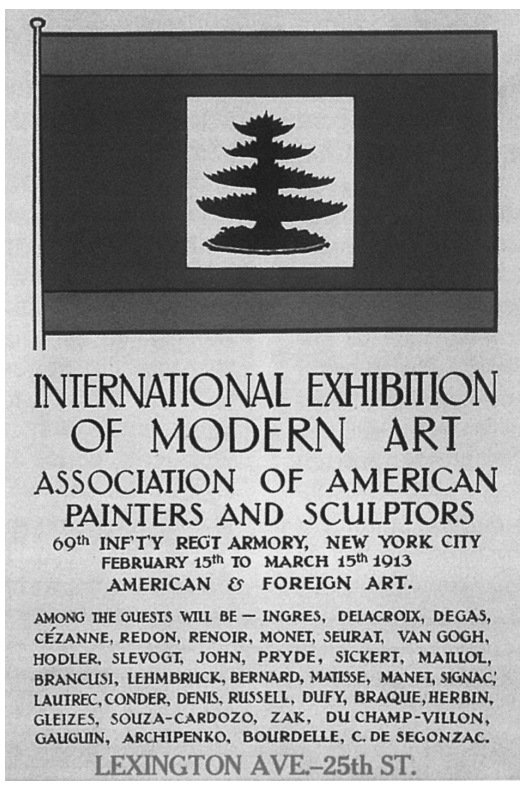

Fig. 14 - Cartaz da International Exhibition of Modern Art, 1913, USA, onde consta "Souza Cardoso».

(Col. privada).

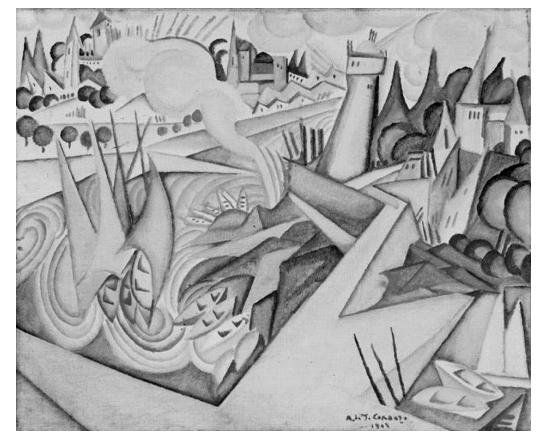

Fig. 16 - Pintura de Amadeo, Paisagem, óleo sobre tela, 1912.

(Cortesia: Col. The Art Institute of Chicago, Arthur Jerome Memorial Collection, USA). 


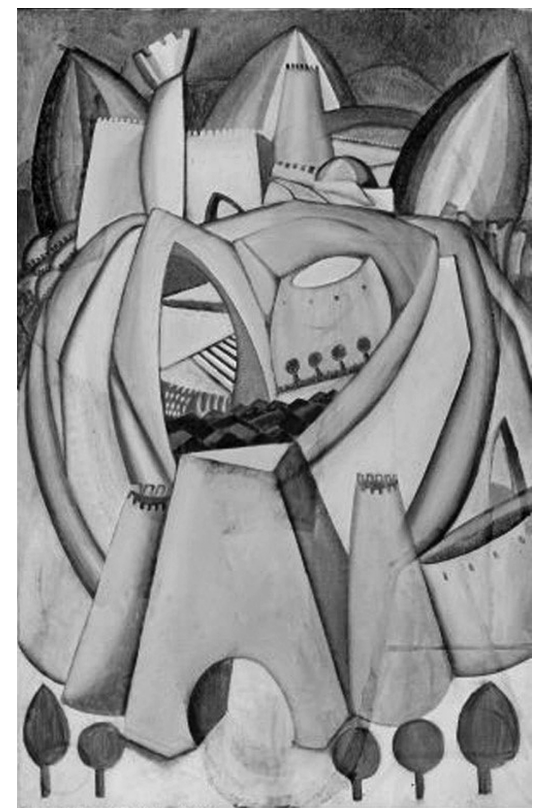

Fig. 17 - Pintura de Amadeo, Château Fort, óleo sobre tela, 1912.

(Cortesia: Col. The Art Institute of Chicago, Arthur Jerome Memorial Collection, USA).

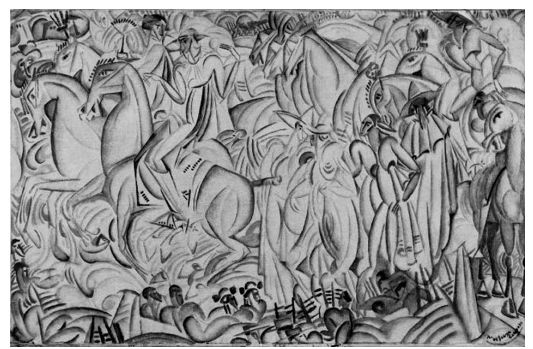

Fig. 18 - Pintura a óleo sobre tela de Amadeo, Avant la Corrida, de 1912. (Cortesia: Museu da Fundação Calouste Gul-

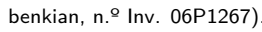

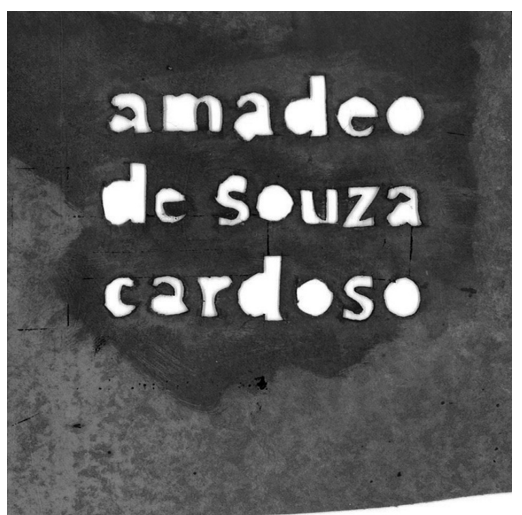

Fig. 19 - Pochoir (original) de Amadeo de Souza Cardoso, c. 1915.

(Arquivo Privado da Família Souza Cardoso).

Saibamos que em menos de 10 anos, Amadeo (Figura 19) obteve o reconhecimento dos maiores artistas na cena internacional do seu tempo, o que é um caso único na História da Arte Portuguesa. 
Não nos esqueçamos que o maior comissário que tivemos até hoje de Amadeo de Souza Cardoso foi o próprio pintor.

Temos que colocar definitivamente Amadeo de Souza Cardoso no lugar da História de Arte Universal, lugar que há muito lhe é devido. É uma figura Nacional. O seu rasto fixou-se no firmamento dos maiores criadores do século $\mathrm{XX}$.

A célebre frase de Pablo Picasso «eu não procuro, encontro», também se adapta a Amadeo, ao colher uma matriz de referências que se encontra naturalmente na sua vida.

\section{Bibliografia}

MACEDO, Luís Van Zeller (1993). Pequena História de Amarante, 2. ${ }^{a}$ edição. Edição do Autor, Amarante. 


\section{N. DeZembro de 1918 \\ Biografias, Memórias e Histórias DE FAMÍlia EM TORNO DA PNEUMÓNICA}

Rosalina Pisco Costa ${ }^{1}$

1 Universidade de Évora e CICS.NOVA. UÉvora - Centro Interdisciplinar de Ciências Sociais, rosalina@uevora.pt 

À avó.

Por todos os Janeiros.

\begin{abstract}
Resumo
A gripe é um fenómeno clínico sazonal que nos é familiar. Porventura, demasiado familiar para que o possamos olhar com o distanciamento e a cautela devida. Este texto procura aprofundar o conhecimento em torno da gripe espanhola de 1918-19 em Portugal, nas suas múltiplas dimensões, inclusive no rasto que, decorridos cem anos, a liga ao tempo presente. Partindo da história de família da autora, neta de uma sobrevivente da gripe pneumónica, nascida em Dezembro de 1918, em Évora (Alentejo, Portugal), são explorados alguns aspectos do contexto histórico, demográfico e social que permitem enriquecer o conhecimento sociológico do fenómeno epidémico e suas múltiplas repercussões. Fazendo uso da autoetnografia, combinam-se contributos metodológicos vários, que triangulam o conhecimento ganho por meio da história e memória familiar, passada de geração em geração, com fontes pessoais e evidências sociodemográficas que compõem a historiografia portuguesa do século $X X$, e resultados de uma incursão exploratória sobre jornais da época e outras fontes manuscritas e impressas actualmente à guarda do Arquivo Municipal da Câmara Municipal de Évora. Cem anos depois, equaciona-se, por fim, o lugar que as várias histórias em torno da pneumónica podem ocupar no modo, tempo e propósito com que se (re)conta o passado.
\end{abstract}

Palavras-chave: gripe, autoetnografia, família, gripe espanhola, storytelling.

\title{
UM SÉCULO DE VIDA, CEM ANOS DE GRIPE ${ }^{2}$
}

Neta de uma mulher nascida em Dezembro de 1918, cresci a ouvir contar histórias em torno da "pneumónica». Mas foi somente mais tarde, durante o ensino secundário, e muito particularmente a partir das aulas de geografia, que tomei consciência que essas histórias familiares, contadas e recontadas num misto de tristeza e distância eram, afinal, uma parte tão real quanto trágica da história mundial. E que aquele proeminente pico estatístico na linha do gráfico referente à mortalidade em Portugal na primeira metade do

$\overline{\text { Este texto é dedicado a Teres[z]a }}$ de Jesus, nascida «ao nascer do sol» no dia 28 de Dezembro de 1918, no Monte da Carrasqueira, extinta freguesia de São Marcos da Abóbada, Évora, Portugal. 
século XX não era formado por números sem rosto, mas sim por personagens com nome próprio e histórias de vida concretas. Algures, a história da minha família sobrepunha-se com aquela linha, ligando-se a muitas outras famílias e histórias espalhadas por todo o mundo em torno da gripe espanhola de 1918-19.

Terá havido outros surtos, mas, no ano de 1918, uma epidemia gripal de dimensão não antes vista foi responsável pela morte de milhões de pessoas em todo o mundo (Barry, 2004; Bristow, 2012; Killingray; Phillips, 2003). Conhecida em Portugal principalmente como «a pneumónica», é referida na maior parte dos países como «a gripe espanhola» (spanish influenza) ou a «senhora espanhola» (spanish lady) (Sequeira, 2001). A «influência» dos astros, do frio (George, 2014) ou, de um modo mais amplo, dos céus (influenza coeli) (Sobral; Lima, 2018), que o vocábulo italiano lhe perpetuou no nome, só em 1933 ficaria completamente esclarecida pela ciência, altura em que o vírus influenza foi isolado em laboratório.

Apesar de não existir consenso absoluto entre os autores sobre a cronologia exacta das diversas vagas da doença que grassou entre 1918 e 1919, reúne unanimidade a ideia de que foram três os principais surtos de manifestação da doença durante esses dois anos (Echeverri Dávila, 1993; Honigsbaum, 2013). Uma primeira vaga epidémica surgiu entre Março e Agosto de 1918 em várias zonas do globo. Uma segunda vaga ter-se-á verificado entre Setembro e Novembro do mesmo ano, esta com consequências severas em praticamente todos os continentes. Nalguns locais, terá ainda ocorrido uma terceira vaga entre Dezembro de 1918 e Março de 1919, embora sem a dimensão da anterior.

Em Portugal, há evidências de que a epidemia da gripe ter-se-á manifestado igualmente nas mesmas três vagas (Sousa et al., 2008). Uma primeira vaga vinda de Espanha, de difusão rápida mas pouco perigosa, ocorreu entre finais de Maio e Junho de 1918; uma segunda vaga com início no final do Verão estender-se-ia até Novembro, esta com consequências mais nefastas, originando casos graves de broncopneumonia e lesões pulmonares. Terão sido justamente estas características ligadas à última vaga que levaram o então Director Geral de Saúde, Ricardo Jorge, a classificar a doença de «gripe» ou «influenza pneumónica», termo pelo qual a epidemia ficaria conhecida em Portugal (Girão, 2003). Por fim, uma terceira vaga viria a registar-se na Primavera de 1919, entre os meses de Abril e Maio, esta já sem o impacto, em termos de mortalidade, da anterior (Sobral et al., 2009).

Desfeitos os equívocos que erroneamente conduziram ao entendimento de que a «gripe espanhola» teria tido origem em Espanha, mais de um século volvido, a localização geográfica do paciente zero da gripe 1918-19 permanece envolta em interrogações (Echeverri Dávila, 2018; Spinney, 2017). Em 
situação de neutralidade perante o conflito bélico de então, a imprensa espanhola terá sido a primeira a dar conta da situação (Crosby, 1976), facto que explica o qualificativo atribuído à gripe como sendo originária daquele país. Não obstante, em contexto português, a origem espanhola parece indubitável desde 1919, altura em que o Director Geral de Saúde reconhecia no relatório intitulado «La Grippe» que desse país recebemos a primeira infecção da doença (Jorge, 1919). Como descrito pelo médico e especialista Arnaldo Sampaio, acredita-se que terão sido os trabalhadores agrícolas portugueses quem, em finais de Maio de 1918, trouxe a gripe da Estremadura espanhola (Sampaio, 1958). Os primeiros números terão surgido precisamente em Vila Viçosa, Alentejo, a escassos quilómetros da fronteira que o rio Guadiana ali impõe entre os dois países.

O número de vítimas mortais da gripe espanhola tem tanto de elevado quanto de dramático. Apesar das controvérsias sobre as cifras exactas, o impacto da gripe é notório quando comparado com o da mortalidade provocada pela Grande Guerra de 1914-18 (estimada em 16 milhões de mortos, militares e civis) ou com a Segunda Guerra Mundial, que se estima ter provocado entre 50 a 85 milhões de mortos, entre militares e civis (Sobral; Lima, 2018). Calcula-se que, entre Março de 1918 e Março de 1920, terão sido entre 50 e 100 milhões as vítimas da pandemia da gripe em todo o mundo (Honigsbaum, 2013; Johnson; Mueller, 2002; Spinney, 2017). Com um comportamento semelhante ao verificado no resto no mundo, embora com ritmos e intensidades distintas, em Portugal estima-se que em pouco mais de um ano, e no conjunto, a gripe tenha infectado entre um quinto e um terço dos cerca de seis milhões de habitantes que então compunham a população residente (Abreu; Serrão, 2018), e que cerca de 50.000 pessoas terão sucumbido à doença (Rollo, 2008). Cálculos efectuados por David de Morais (2012) permitem mesmo aproximar estes números dos 100.000 indivíduos.

Apesar da magnitude dos números, «[t]erminada a epidemia nos princípios de 1919, uma cortina de silêncio desceu sobre o acontecimento», assim afirmou Álvaro Sequeira (2001: 49). Genericamente, sabe-se e fala-se pouco sobre a gripe espanhola. Por todo o mundo, prevalece um certo entendimento segundo o qual a pandemia de 1918-19 é uma «nota de rodapé» (Spinney, 2017) da 1. ${ }^{\text {a }}$ Guerra Mundial, sobre a qual houve um esquecimento generalizado (Crosby, 1976). Esquecimento ou silenciamento, as razões para tal constituem, ainda hoje, tema de interesse renovado com explicações inconclusivas. Desde logo, pela acentuada pequenez do número de vítimas da Primeira Guerra Mundial ante a grandeza dos efectivos que sucumbiram à gripe espanhola (Honigsbaum, 2013). Ainda assim, o espectáculo de morte e 
destruição provocado pela guerra, a urgência por reconstruir uma Europa devastada (Spinney, 2017), a impotência da medicina que se revelava «enferma» (Bertucci, 2004) para solucionar a crise epidémica e salvar vidas numa altura em que se celebravam as grandes descobertas da bacteriologia e da microbiologia, a incapacidade dos poderes políticos e administrativos fazerem frente à pandemia (Barry, 2004), o trauma provocado nas famílias que assistiam a uma morte próxima, «dentro de portas» (Milne, 2018), ou o receio de um novo castigo divino (Rollo, 2008), são algumas das razões apontadas para esse silenciamento entre os vários autores que o têm assinalado.

Na Nova Zelândia, um levantamento efectuado em 2017 a memoriais publicamente acessíveis relativos à pandemia da gripe deu conta de um número considerado pequeno (sete), sobretudo quando comparado ao número de memoriais dedicados a desastres ou catástrofes naturais e à guerra (Wilson et al., 2017). O mesmo estudo identificou uma realidade semelhante para outros países, desconhecendo-se à data qualquer trabalho publicado sobre memoriais dedicados à pandemia da gripe de 1918-19. Excluindo lápides tumulares ou estátuas de homenagem a figuras de relevo no combate à doença, os memoriais especificamente relacionados com as vítimas da gripe espanhola são relativamente recentes e estão localizados em cemitérios (e.g. NZ Influenza Epidemic Memorial (1988), Waikumete Cemetery, Auckland, Nova Zelândia e The Regina Spanish Flu Memorial (2017), Canadá).

Portugal parece não ser excepção a este cenário de desconhecimento e invisibilidade no que à gripe espanhola diz respeito. Do ponto de vista científico, para além dos escritos da época, a produção sobre o tema tem sido parca e até muito recentemente centrada quase exclusivamente nas ciências médicas (Abreu; Serrão, 2018). A própria historiografia portuguesa do século XX parece não fazer jus ao devido lugar deste evento no curso dos acontecimentos no país (Silva, 2018). No que respeita à memória colectiva inscrita na vida de todos os dias, estão também por identificar quaisquer monumentos (Sobral; Lima, 2018) ou outros memoriais dedicados à gripe espanhola em Portugal $^{3}$.

Este texto procura aprofundar o conhecimento em torno da gripe espanhola em Portugal, nas suas múltiplas dimensões, inclusive no rasto que 100 anos depois a liga ao tempo presente. De entre as várias abordagens possíveis, nomeadamente as epidemiológicas, históricas ou demográficas, insignemente

3 Uma pesquisa exploratória no motor de busca Google e Google/Imagens com os termos «gripe espanhola» + «memorial» + «estátua» + «lápide» + «Portugal», efectuada em Setembro de 2018 permitiu identificar em Sesimbra uma placa toponímica a recordar Aníbal Esmeriz, médico municipal entre 1914 e 1918 e que aí faleceu em 1918, infectado com o vírus que contraiu a tratar doentes da pandemia da gripe. 
levadas a cabo por outros autores em contexto português (Frada, 1998, 2005; Rebelo de Andrade, 2001; Sobral et al., 2009), adopta-se um ponto de vista diferente, embora complementar. A autoetnografia é um método de pesquisa qualitativa emergente, onde o autor parte da sua experiência pessoal para ampliar a compreensão sobre um determinado fenómeno social (Ellis; Bochner, 2000; Wall, 2006). Usualmente redigida na primeira pessoa, adopta um estilo de escrita altamente personalizado, o que faz com que esta não seja apenas uma forma de «contar» uma história, mas, sobretudo, de «conhecer», um «método de descoberta e análise», como refere Laurel Richardson (1994). No caso concreto, tomando a história de família da autora como ponto de partida, procura-se daí destacar os aspectos do contexto histórico, demográfico e social que permitem enriquecer o conhecimento sociológico do fenómeno epidémico e suas múltiplas repercussões ${ }^{4}$.

Empiricamente, combinam-se neste texto contributos metodológicos vários, que triangulam o conhecimento ganho por meio da história e memória familiar, passada de geração em geração, com fontes pessoais e evidências sociodemográficas que compõem a historiografia portuguesa do século XX. Adicionalmente, foi levada a cabo uma consulta exploratória de jornais da época e de outras fontes, manuscritas e impressas, incluindo correspondência trocada entre os serviços sanitários e administrativos da região e diversos outros documentos elaborados à data por entidades oficiais que permanecem actualmente à guarda do Arquivo Municipal da Câmara Municipal de Évora. No final, espera-se contribuir para aprofundar o conhecimento em torno da pandemia da gripe espanhola em contexto português e, muito particularmente, na região Alentejo, aperfeiçoando o ainda incompleto retrato do país nessa matéria, como aliás ficou demonstrado nas Jornadas de População e Saúde «A Gripe Espanhola de 1918», realizadas em Outubro de 2018 na cidade de Guimarães.

\section{O CICLO INTERROMPIDO E A RODA DA VIDA}

O que é que os nossos nomes dizem de nós? De quem somos? Da nossa família? Da nossa história? Em 1918, durante a gravidez da minha bisavó, uma sobrinha sua faleceu, vítima da pneumónica. Essa jovem rapariga, nos

\footnotetext{
4 A adopção do pronome pessoal «eu»sustenta de forma inequívoca a implicação da autora na história que se conta, mas também no modo como essa história é contada. E se é certo que a história que se conta denuncia uma motivação eminentemente pessoal para a redacção do texto; já o modo como se conta essa história não deixa de fora a curiosidade científica e o olhar sociológico, marcas idiossincráticas de quem conta, escrevendo, a história.
} 
seus vinte anos, não sobreviveu à epidemia que, em Portugal, vitimou milhares de pessoas. A rapariga chamava-se Teresa e a criança que viria ao mundo ao nascer do sol do dia 28 de Dezembro recebeu esse mesmo nome como um tributo à sua memória. Deste modo, a história da sua curta e trágica vida seria para sempre recordada na nossa família. Edviges da Conceição e ti' Rosária foram as duas únicas grávidas das redondezas a sobreviver à letalidade da doença. Para isso terá valido o repouso permanente a que estavam aconselhadas e a toma de pequenas doses de aguardente, a qual teria sido prescrita pelos médicos e adoptada pela população como forma de combater a doença. Morriam casas inteiras de famílias. Eram três irmãs que andavam sempre juntas: a guerra, a peste e a fome.

Vista de perto, a perpetuação geracional do nome Teresa ${ }^{5}$ inscreveu na história da família a memória da gripe, ao mesmo tempo que a narrativa oral, contada e recontada em seu redor, ajudou a sedimentar conhecimentos e representações em torno da pandemia, dos seus contextos e impactos, os quais vão muito para além da (aparente) banalidade de um nome próprio. Visto ao longe, o confronto entre a realidade próxima da história de família e as evidências sociodemográficas disponíveis para aquele período têm tanto de confirmatório quanto de revelador sobre o cenário descrito a partir da metáfora fortemente enraizada no imaginário popular, revelado pela trilogia tétrica das três irmãs que andam sempre juntas.

Procuremos, no contexto de então, as evidências da trilogia descrita que, de forma tão evidente, surgem na representação gráfica da evolução da mortalidade em Portugal, no primeiro quartel do século XX (David de Morais, 2002). Segundo Mário Leston Bandeira, não obstante a observação estatística não merecer, pelo menos até 1911, «inteira credibilidade», facto que dificulta a análise rigorosa dos fenómenos demográficos durante o início do século XX, «[...] parece claro que até aos anos 20 a estabilidade parece ter dominado a linha global de tendência da mortalidade e da natalidade. Enquanto a mortalidade mantinha valores relativamente moderados, à volta de $20 \%$, a natalidade situava-se cerca de 10 pontos acima deste nível. Esta diferença traduzia-se numa taxa de crescimento natural média de cerca de 1\%» (Bandeira, 1996: 161). O ano de 1918 vem interromper violentamente esta situação. Neste ano a taxa de mortalidade alcançou os 41,40\%, quase duplicando os valores do ano imediatamente antes e depois, nomeadamente 22,33\% em 1917 e 25,38\% em 1919 (Bandeira, 1996: 429). No contexto dos vários distritos portugueses, Évora registava uma taxa de mortalidade de 44,10\% em 1918, um valor superior à média nacional para esse período (Bandeira, 1996: 429). A tendência relativamente ao ano anterior e seguinte

5 Teresa (avó, n. 1918), Teresa (neta, n. 1973), Ana Teresa (bisneta, n. 2001). 
foi idêntica à verificada no conjunto do país: em 1917, a taxa bruta de mortalidade no distrito de Évora foi de 24,50\% e, em 1919, de 20,25\%o (Bandeira, 1996: 429). Para lá das taxas de mortalidade, as taxas de crescimento natural revelam bem o impacto da gripe de 1918. Portugal, em 1917, teve uma taxa de crescimento natural de 9,04\%o, em 1918 de -11,69\%o, em 1919 de $2,21 \%$ e, em 1920, de 9,95\%, aproximando-se dos valores anteriores à gripe de 1918 (Bandeira, 1996: 473). No distrito de Évora, a evolução foi bastante semelhante: em 1917, a taxa de crescimento natural foi de 8,22\%, em 1918, de $-12,09 \%$, em 1919, de 9,54\%o e, em 1920, de 12,93\%o (Bandeira, 1996: 473).

Uma interessante e detalhada análise levada a cabo por João David de Morais, em torno da mortalidade por anos, sexos, idades, meses, distritos e grandes regiões, ajuda a aprofundar a leitura e interpretação destes números (Morais, 2012: 98 e ss.) $^{6}$. A análise dos dados traduz de forma evidente o surto epidémico de gripe pneumónica em 1918, com um total de 53.975 óbitos declarados nesse ano (David de Morais, 2012: 98). O mesmo autor refere que se se restringir a análise à década em que surgiu esse surto, 1915-1924, observa-se que 81,0\% (LC: 81,0-81,3) dos falecimentos por gripe ocorreram em 1918. Dos 53.975 óbitos por gripe registados em 1918, 46,6\% (LC: 46,2-47,1) eram do sexo masculino e $53,4 \%$ (LC: $53,0-54,0$ ) do sexo feminino, embora não tenham sido encontradas diferenças estatisticamente significativas. $\mathrm{O}$ número de óbitos mostrou uma evolução decrescente com a idade, a partir dos 40 anos, verificando-se que a maior mortalidade ocorreu nas crianças e nos adultos jovens até aos 30-39 anos de idade. No ano de 1918, 90,0\% dos óbitos (48.565) ocorreram nos meses de Outubro e Novembro, com especial relevância para Outubro. Em relação ao número total de óbitos, o distrito de Lisboa assumiu a posição cimeira e o distrito de Portalegre foi o menos penalizado. Finalmente, no apuramento global por grandes regiões, verificouse a seguinte distribuição dos 53.975 óbitos de 1918, em valores decrescentes: Região Centro, Região de Lisboa e Vale do Tejo, Região Norte, Região Sul. Analisando a sobremortalidade segundo a incidência por 100.000 habitantes encontrou-se, por ordem decrescente de importância, a Região de Lisboa e Vale do Tejo, Centro, Sul e a região Norte como a mais poupada.

É preciso, no entanto, referir que os números da mortalidade por gripe surgem num contexto mais amplo, onde interagem outras doenças com particular incidência à época. Na leitura desses números, David de Morais su-

6 Segundo o autor, «Dado que a mortalidade por gripe pneumónica se revestiu nas Ilhas Adjacentes de fraca acuidade quantitativa [...]», esta análise incide apenas sobre Portugal Continental. 
blinha especificamente a co-morbilidade gripe/tifo/varíola. Como descreve, «[...] afinal, em 1918-1919 não se abateu sobre Portugal Continental apenas uma epidemia, mas sim três, concomitantemente (facto que, em geral, passou despercebido aos estudiosos): gripe pneumónica - situação já sobejamente conhecida -, tifo epidémico e varíola.» (David de Morais, 2012: 103).

Laura Spinney (2017) salienta que a pandemia da gripe foi moldada pela interacção de um vírus com os seres humanos que encontrou. Também em Portugal, a história da gripe «deve ser contada considerando o contexto do País que éramos» (Rollo, 2008). A enunciação dos factores que, em solo português, terão contribuído para o carácter extremamente violento da epidemia gripal são relativamente consensuais entre os autores que têm estudado este período, muito embora o peso exacto de cada um desses factores e o seu alcance esteja por determinar. Terá havido, isso sim, uma combinação de factores de natureza social, económica, política, nutricionais e sanitários «que interagiram entre si e se potenciaram» (David de Morais, 2012: 103). A literatura histórica e epidemiológica permite concluir que a generalidade da população portuguesa de então gozava de um baixo nível socioeconómico e que o estado de saúde era precário, com deficiências assinaláveis ao nível alimentar, sanitário e de higiene (Sousa et al., 2008). A rede hospitalar era deficiente e as dificuldades de cobertura médica e assistenciais notórias, sobretudo em zonas rurais e de difícil acesso. Em Portugal vivia-se uma crise económica, acompanhada de agitação social e política fortíssima, que, aliás, viria a culminar no assassinato do então Presidente da República, Sidónio Pais, em Dezembro de 1918 (Sobral et al., 2009). A estes factores ter-se-ão juntado outras razões propiciatórias à fácil disseminação da doença, nomeadamente a movimentação populacional, fosse a decorrente da sazonalidade agrícola, como as ceifas ou vindimas, fossem as feiras e romarias, deslocações de e para estâncias balneares e termais e outras actividades típicas dos meses de Verão, fossem, por fim, as movimentações de soldados no período em que se desencadeavam as últimas ofensivas militares (Girão, 2003). O cenário adensava-se: «A Guerra, a Fome, a Morte, concertaram-se em cortejo fúnebre, ao rubro em 1918» (Rollo, 2008: 89), daí resultando uma imparável «marcha da morte», como Paulo Girão (2003: 5) habilmente a apelidou.

\section{O PASSO DESCONTINUADO E A MARCHA DA MORTE}

Em noite de Santo António, uma mulher mais velha encarregar-se-ia de passar, em forma de cruz, um ovo pela fogueira, para depois o partir para um copo de água que repousaria ao luar até ao dia seguinte. O resultado, acreditava-se, 
constituía um presságio sobre a vida futura das raparigas solteiras, particularmente sobre a sorte ou o azar que as esperava no casamento, sobretudo das já comprometidas, como acontecia com Teresa. O amanhecer do dia de Santo António não terá trazido um bom augúrio para o promitente casal. A forma desalinhada que o ovo assumiu terá levado as mulheres mais velhas a acreditar que algo de mau estava para acontecer. Como o namorado de Teresa integrava o Corpo Expedicionário Português, todos pensaram que o pior haveria de suceder ao jovem soldado mobilizado para combater em França.

Como lembra Jacques Le Goff (1985: 7-8), «a doença pertence não só à história superficial dos progressos científicos e tecnológicos como também à história profunda dos saberes e das práticas ligadas às estruturas sociais, às representações, às mentalidades». Numa sociedade rural e pouco escolarizada, superstições e crenças populares como as aqui descritas, preceitos religiosos, saberes e práticas enraizadas na tradição das famílias e das comunidades faziam parte imbricada do contexto sociocultural que haveria de receber - não sem ilusões e resistências várias - o conjunto de medidas profilácticas de combate à gripe que emanavam das várias autoridades administrativas e sanitárias regionais e locais, mais tarde também da sociedade civil e igreja (Sousa et al., 2008).

À semelhança do que aconteceu nos outros países, também em Portugal a gripe pneumónica suscitou intervenções diversas de prevenção e combate por parte das autoridades administrativas e sanitárias. Para o efeito foram mobilizadas as delegações regionais de saúde e respectivas subdelegações, governos civis e câmaras municipais, que em articulação com Lisboa e as autoridades centrais tentavam combater os avanços da epidemia. No entanto, como afirma Paulo Girão (2003: 60), «[...] a luta iria revelar-se demasiado desigual». Vários foram os factores que contribuíram para essa situação, desde logo, «[...] o carácter violento e rápido que caracterizou o aparecimento da gripe pneumónica em Portugal» (Girão, 2003: 13). Para além disso, «o desconhecimento dos processos clínicos no tratamento da doença, a deficiente rede sanitária, as dificuldades de comunicação e de transporte, a escassez de recursos financeiros, humanos e materiais e a lentidão burocrática na aplicação de medidas concretas» (Girão, 2003: 79), foram algumas das condicionantes que contribuíram para diminuir a eficácia das medidas de prevenção, tratamento e apoio às vítimas e suas famílias. Um dos principais obstáculos no combate à doença estaria, aliás, contido em si própria. Para a população em geral o quadro clínico associado a esta doença do aparelho respiratório, marcado por febre, arrepios, dores musculares, sinais de coriza e prostração, pode facilmente confundir-se com o de outras afecções, como o resfriado comum (a vulgar constipação). Do ponto de vista dos serviços de 
saúde, o facto de a gripe ser causada por um vírus que viria a ser descoberto apenas em 1933 é um factor frequentemente esquecido na compreensão das dificuldades de luta contra a doença enfrentadas uma quinzena de anos antes pela ciência em geral, e pela medicina em particular (George, 2014).

As dificuldades sentidas no combate à doença e na ajuda às populações foram situações comuns em praticamente todos os países atingidos pela epidemia de 1918 (Girão, 2003) e o quotidiano da cidade de Évora não terá sido excepção. Uma pesquisa exploratória por diversas fontes manuscritas e impressas encontrou sinais avulsos embora impressionistas da forte presença e impacto da gripe no quotidiano da cidade de então.

No jornal Notícias d'Évora, edição de 29 de Dezembro de 1918 (anno XIX, n. ${ }^{\circ}$ 5:391), é apresentada uma lista de enterramentos relativa ao mês de Outubro. No dia 31 de Outubro, foram nove os enterramentos na cidade, todos por gripe pneumónica. Quando recuamos a esse mês, encontramos entre a correspondência da Câmara, com data de 26 de Outubro de 1918, uma carta da casa Achon \& Du Roveray, L. ${ }^{d a}$, que se dispunha a fornecer, «a retalho ao preço de $\$ 70$ por cada quilo», uma remessa de alcatrão vegetal, «o melhor desinfétante no momento epidemico que atravessamos - o qual temos fornecido ás diversas Camaras Municipais do País [...]»7 .

A 7 de Outubro de 1918, a Misericórdia de Évora escreve à Câmara Municipal de Évora. Porque o hospital se preparava para «receber os doentes atacados da ipedimia gripe-pneumonica» e, porque, «consoante indicações do Ex. ${ }^{\circ}$ Delegado de Saude e instruções das competentes autoridades, em tudo deve existir a maior higiene», chamava a «especial atenção» para o facto de que «uma das ruas de principal acesso ao hospital - a do Dr. Joaquim Henriques da Fonseca - não tem sido convinientemente varrida e lavadas as suas regueiras o que determina a acumulação de porcarias á porta do edificio, exalando por vezes extraordinario cheiro.» $\mathrm{O}$ então provedor da Misericórdia de Évora dirigia-se ao Presidente da Comissão Administrativa da Câmara Municipal de Évora «rogando-lhe a fineza de determinar que a aludida rua seja convenientemente limpa e desinfectada».

Em carta datada de 5 de Dezembro de 1918, dirigida ao Presidente da Comissão Administrativa da Câmara Municipal de Évora, o Delegado de Saúde do Distrito de Évora afirmava que «oficialmente considera-se extincta a epidemia desde os fins de novembro». Porém, num outro registo, esse relativo à correspondência do Governo Civil, encontra-se, com data de 22 de Maio de 1919, uma carta do Delegado de Saúde à época, José Lopes Marçal, dando conta da persistência dos sintomas: «Tenho informado a Direcção

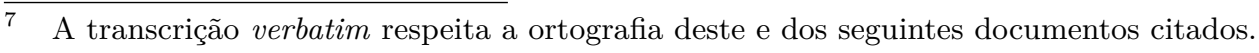


Geral de Saude da actual evolução epidemica neste districto, continuação não interrompida da epidemia outonal do anno findo, - que agora se agravou, com demonstrações de casos fataes no começo de abril ultimo, e que não pode actualmente ser proclamada epidemia de caracter benigno, em vista dos elementos estatisticos que as subdelegações de saude estão enviando». Por isso, afirmava, «[...] é necessário manter [sublinhado original] as providencias sanitarias que com bastante intensidade foram atendidas e executadas pela Camara, pelo Comissario e Administração do Concelho na epoca do fastigio d'esta mesma epidemia».

Do que fica exposto resulta claro como o ciclo interrompido de tantas vidas pela gripe de 1918-19 só pode ser cabalmente entendido quando se toma como lugar de análise o contexto mais amplo dessa «morte anunciada» (Trindade, 1998). Os anos em que se assinala o centenário da gripe espanhola devem, pois, servir também de estímulo a pensar o lugar que as várias histórias, não somente a história escrita, pública ou oficial, mas as múltiplas histórias orais, privadas e pessoais, podem ocupar no modo, tempo e propósito com que se (re)conta o passado.

\section{UM SÉCULO DE GRIPE, CEM ANOS DE HISTÓRIAS}

A muitos quilómetros de distância, o jovem soldado estranhava a ausência de cartas de Teresa. Um dia, apercebeu-se que os companheiros de combate comentavam algo a seu respeito. "Se ele soubesse o que aconteceu...", diziam. Insistentemente perguntou o que se passava. Suspeitava que o vaivém interrompido de correspondência seria um sinal de que Teresa se tinha cansado de o esperar e que outro, mais próximo, lhe teria roubado o coração que julgava pertencer-lhe para sempre. Perante tal desespero, o companheiro de caserna viu-se então forçado a revelar a triste notícia que por carta lhe tinha chegado. Não fora outro homem que lhe roubara Teresa, mas sim a pneumónica que sem piedade lhe ceifara a alegria e a juventude.

Cem anos passados sobre a pandemia de 1918-19, esta podia bem ser a história do presente. Muito embora a memória da gripe possa efectivamente estar longe da história de muitos de nós, o vírus influenza atravessa o nosso quotidiano. A gripe é um fenómeno clínico sazonal que nos é familiar. Porventura, demasiado familiar para que o possamos olhar com o distanciamento e a cautela devida. De facto, durante as épocas mais frias do ano, nomeadamente no Inverno, a gripe continua a matar. A intensidade desses números varia de ano para ano, ainda assim, estima-se que anualmente o influenza seja responsável por mais de 500.000 mortes por todo o mundo (European Comission, 2007). 
Depois de 1918-19, outras pandemias de gripe ameaçaram a saúde pública internacional. Em 1957, foi a chamada «gripe asiática»; em 1968, a «gripe de Hong Kong»; mais recentemente, em 2009, a Pandemia de gripe A (H1N1). Porque se trata de uma doença infecto-contagiosa, rapidamente transmissível por contágio directo pela via oral ou nasal; porque o vírus da gripe se encontra em constante mutação, o que faz com que facilmente deixe de ser reconhecido pelo sistema imunitário humano; porque o vírus sobrevive fora do hospedeiro, encontrando nas aves um reservatório privilegiado, o influenza constitui uma ameaça real e uma preocupação séria para entidades médicas e serviços de saúde à escala global.

Precisamente no ano em que se assinalaram os 100 anos sobre a gripe espanhola, a Organização Mundial de Saúde (OMS) apresentava como primeira ameaça à saúde global em 2018, no topo de uma lista de dez ameaças, o vírus influenza. Na página dessa organização podia ler-se:

Outra pandemia de influenza é inevitável. Neste mundo interconectado, o próximo surto global de gripe é uma questão de «quando», não de «se» - com consequências de longo alcance. Uma pandemia grave pode resultar em milhões de mortes e destruir mais de $1 \%$ do PIB global.

Percorremos um longo caminho nos cem anos desde que a gripe espanhola matou cerca de 100 milhões de pessoas. Agora temos os meios para detectar e fazer face ao influenza quando este ataca. Todos os anos, a OMS recomenda a vacinação para proteger as pessoas da gripe sazonal em todo o mundo. Mais de 150 instituições de saúde pública em 110 países trabalham em conjunto na vigilância e resposta global. Mas nada sobre a gripe é previsível, incluindo como e onde a próxima pandemia irá emergir ${ }^{8}$.

A Organização Mundial de Saúde é peremptória: uma nova pandemia de gripe surgirá (OMS, 2018; 2019); é uma questão de «quando» e não de «se» ${ }^{9}$. Romper com a «cortina de silêncio» (Sequeira, 2001) que desceu sobre a gripe espanhola é tão importante quanto necessário para preparar as gerações actuais para um eventual futuro ${ }^{10}$. Mas como fazer isso? Como desviar essa espessa e densa «cortina de silêncio» a que a gripe espanhola parece ter sido votada? Que histórias devemos contar? Como podemos fazê-lo?

8 Tradução da autora. Original disponível em 10 threats to global health in 2018 (OMS, 2018).

9 Orig. «the next global flu outbreak is a matter of 'when' not 'if'» (OMS, 2018).

10 Consciente desta ameaça global, a Comissão Europeia estabeleceu pela primeira vez no 7.ํㅡㅁo Quadro Comunitário de Apoio (FP7, 2007-2013) fundos próprios direccionados ao tópico «Emerging Infectious Epidemics», os quais explicitamente focam o influenza. Um catálogo publicado em 2007 reúne informação detalhada sobre 39 projectos financiados entre 2001 e 2007 pela Comissão Europeia nesse domínio (European Comission, 2007). 
Na Irlanda, a historiadora Ida Milne entrevistou sobreviventes da gripe espanhola e, através da história oral reconta-nos como foi, na primeira pessoa, sofrer dessa doença (Milne, 2018). No livro Empilhando os Caixões [Stacking the Cofins], há também excertos de entrevistas a familiares dos enlutados que falaram das suas memórias de criança ou adolescente, do que ouviram e do que foram ouvindo ao longo do tempo, e do impacto dessas histórias e recordações nas suas vidas.

No Canadá, a propósito da comemoração, em 2017, dos 150 anos sobre a assinatura do Acto Constitucional de 1867, a gripe espanhola foi incluída no rol dos momentos-chave da história do país. No âmbito do projecto $D e$ fining Moments Canada (2018), participantes oriundos de escolas, museus e parceiros diversos da sociedade civil foram chamados a contar a história da sua família e a partilhá-la digitalmente. Recorrendo às estratégias narrativas do storytelling, os participantes escolheram uma pessoa ou evento com significado pessoal especial e exploraram a pandemia da gripe espanhola a partir da perspectiva dessa pessoa ou evento. Um conjunto de histórias anónimas, pessoais e necessariamente singulares foram então recuperadas, construídas e contadas como parte da história do Canadá. O objectivo último foi o de envolver a população na história do seu país e, ao mesmo tempo, estabelecer entre essa história e o século XXI relações que vão para além dos círculos restritos impostos pela família, escola ou comunidade local.

Em Portugal, a pneumónica de 1918 foi, em termos de mortalidade, «a maior tragédia do século XX» (Sequeira, 2001). Há evidências e testemunhos vários da dimensão pública da gripe que um pouco por todo o país fechou escolas, abriu enfermarias e obrigou a enterrar dezenas de cadáveres num só dia, inclusive à noite (Rollo, 2008). Algumas personalidades de relevo sucumbiram à doença (e.g. Conde de Almeida Araújo, um neto do visconde de Alvalade, os compositores António Fragoso e Pedro Blanco, os pintores Amadeo de Souza-Cardoso e Santa-Rita, e também os videntes de Fátima, Francisco e Jacinta (Sobral; Lima, 2018), e a doença parece ter afectado todos, ricos e pobres, enfermeiros, farmacêuticos e até médicos.

No plano privado da vida das famílias, pouco ou nada se sabe. Mas a efeméride de 2018-19 pode constituir-se numa oportunidade para saber mais sobre como no espaço privado, em casa, nas famílias e ao longo das gerações, este tema foi tratado. As experiências retratadas na Irlanda e Canadá permitem antecipar um desenho de investigação que combine, de forma criativa (Kara, 2015), as técnicas da entrevista qualitativa em profundidade (Mason, 2002) com a estrutura narrativa subjacente ao storytelling (Berger; Quinney, 2004; Gough, 2008), possibilitando assim a escrita de uma história privada da 
gripe espanhola em Portugal. Se é certo que os sobreviventes (centenários) da gripe espanhola serão hoje pouco numerosos, dificultando a tarefa de replicar em Portugal o trabalho que Ida Milne desenvolveu há anos na Irlanda, será ainda possível ouvir os familiares desses sobreviventes e recolher, junto deles, as histórias sobre a gripe espanhola que foram passando de geração em geração. Na verdade, o aumento da longevidade acarreta a possibilidade de encontrar, a um mesmo tempo, indivíduos da mesma família que pertencem a várias gerações diferentes e que coexistem durante um período substancialmente grande das suas vidas. Porque bisavós, avós, pais, filhos, netos e bisnetos convivem mais tempo uns com os outros, seria interessante compreender qual o impacto dessa coexistência nas histórias que geracionalmente as famílias contam a si mesmas sobre a gripe espanhola e no modo como as contam.

Para além das fontes oficiais, das estatísticas e dos documentos públicos, é possível recorrer às pessoas para, à micro-escala, encontrar indícios que permitam compreender como e se a gripe espanhola foi efectivamente esquecida no plano privado, como no plano público parece tê-lo sido (Sobral; Lima, 2018). Por um lado, tais histórias poderão dar-nos pistas sobre o modo como as famílias esquecem. Por que o fazem? Quais são as estratégias e processos que usam para tal? Por outro, essas histórias permitem também compreender quem são os guardiães da memória familiar. Para quem e como é que a transmissão das memórias é feita? E como são essas memórias reconstruídas? Finalmente, como pode tudo isto ser importante para lidar com eventuais novas pandemias da gripe?

Como afirma a Organização Mundial de Saúde, «outra pandemia de influenza é inevitável. [...] Mas nada sobre a gripe é previsível, incluindo como e onde a próxima pandemia irá emergir»(OMS, 2018). As muitas dúvidas que temos em 2018-19 não são suficientes para abalar as certezas de 1918-19. Definitivamente, é urgente fazer subir a «cortina de silêncio» de que falava Álvaro Sequeira. Só assim conseguiremos procurar a resposta às questões que colocámos e compreender como podemos aprender (mais) com o passado para pensar e antecipar o futuro, prevenindo no possível as consequências de um ataque epidemiológico similar. Se é certo que o curso da história não poderá livrar-nos da vulnerabilidade biológica, deve em tudo contribuir para atenuar a ingenuidade sociológica.

\section{AGRADECIMENTOS}


Uma versão deste texto foi inicialmente apresentada como comunicação oral com o título «The Centenaries of the Spanish flu. Biographies, Memories and Family Stories» no Workshop «The social impact of epidemics: A workshop marking 100 years of the Great Flu Epidemic of $1918 »$, entre os dias 3 e 5 de Setembro de 2018 na Oslo Metropolitan University (Noruega), organizado pelo Centre for Welfare and Labour Research, Oslo, Akershus University College, The Norwegian Demographic Society e The EAPS (European Association for Population Studies) Working Group on Health, Morbidity and Mortality (HMMWG). Agradeço a todos os participantes desse workshop, particularmente aos organizadores, Svenn-Erik Mamelund e Yonathan Anson, os comentários e sugestões que sabiamente me fizeram tendo em vista a publicação do texto. Agradeço igualmente a Antero Ferreira (ADEH - Associação de Demografia Histórica; Casa de Sarmento) e a todos quantos participaram das Jornadas de População e Saúde «A Gripe Espanhola de 1918» (Guimarães, 25 e 26 de Outubro de 2018) as observações e incentivo a integrar este livro. Por fim, agradeço a Maria da Graça David de Morais as valiosas sugestões de leitura e a instigação a procurar na imprensa coeva os sinais quotidianos da gripe de 1918 em Évora, e a Maria do Rosário Piteira Martins o imprescindível apoio na identificação de algumas dessas evidências junto do Arquivo Municipal da Câmara Municipal de Évora.

\section{Bibliografia}

ABREU, Laurinda; SERRÃO, José Vicente (2018). Revisitar a pneumónica de 1918-1919: introdução. Ler História, 73, pp. 9-19. Em https://doi.org/10.4000/lerhistoria. 3944

BANDEIRA, Mario Leston (1996). Demografia e Modernidade - família e transição demográfica em Portugal. Imprensa Nacional Casa da Moeda, Lisboa.

BARRY, John M. (2004). The Great Influenza: The Story of the Deadliest Pandemic in History. Penguin Books, New York.

BERGER, Ronald J.; QUINNEY, Richard (ed.) (2004). Storytelling Sociology: Narrative as Social Inquiry. Lynne Rienner Publishers, Boulder.

BERTUCCI, Liane Maria (2004). Influenza, a medicina enferma: ciência e práticas de cura na época da gripe espanhola em São Paulo. Editora Unicamp, Campinas.

BRISTOW, Nancy K. (2012). American Pandemic: The Lost Worlds of the 1918 Influenza Epidemic. Oxford University Press, New York.

CROSBY, Alfred (1976). Epidemic and Peace 1918. Greenwood Press, Connecticut, Westport.

DAVID DE MORAIS, João Augusto (2012). Surtos epidémicos ocorridos em Portugal na primeira metade do século XX: abordagem histórico-epidemiológica. III - Gripe pneumónica. Medicina Interna, 19, pp. 97-104. Acedido a 31-08-2018, em http://www.spmi.pt/revista/vol19/vol19_n2_2012_097_104.pdf

DAVID DE MORAIS, Maria da Graça (2002). Causas de Morte no Século XX. Transição e estruturas da mortalidade em Portugal Continental. Edições Colibri, Lisboa. 
DEFINING MOMENTS CANADA (2018). The Spanish Flu Pandemic 1918-1919. Acedido a 31-05-2019, em https://definingmomentscanada.ca/the-spanish-flu/

ECHEVERRI DÁVILA, Beatriz (1993). La Gripe Española. La Pandemia de 1918-1919. Centro de Investigaciones Sociológicas, Siglo XXI, Madrid.

ECHEVERRI DÁVILA, Beatriz (2018). En el centenario de la gripe española: un estado de la cuestión. Revista de Demografía Histórica, 36, pp. 17-42.

ELLIS, Carolyn; BOCHNER, Art (2000). Autoethnography, personal narrative, reflexivity, in DENZIN, Norman K.; LINCOLN, Yvonna S. (eds.). Handbook of qualitative research. Thousand Oaks, CA, Sage, pp. 733-768.

EUROPEAN COMISSION (2007). Influenza Research - EU Funded Projects 2001-200\%. European Comission, Luxembourg.

FRADA, João (2005). A Pneumónica de 1918 em Portugal Continental. Estudo sócioeconómico e epidemiológico com particular análise no concelho de Leiria. Sete Caminhos, Lisboa.

FRADA, João José Cúcio (1998). A pneumónica de 1918 em Portugal continental. Estudo socioeconómico e epidemiológico, com particular análise do concelho de Leiria. (Tese de doutoramento). Faculdade de Medicina da Universidade de Lisboa, Lisboa.

GEORGE, Francisco (2014). História da Gripe. Direcção Geral de Saúde. Acedido a 30/08/2018, em http://www.dgs.pt

GIRÃO, Paulo (2003). A Pneumónica no Algarve (1918). Caleidoscópio, Casal de Cambra.

GOUGH, Noel (2008). Storytelling, in GIVEN, Lisa. M. (ed.). The SAGE Encyclopedia of Qualitative Research Methods. Thousand Oaks, Sage, pp. 832-833.

HONIGSBAUM, Mark (2013). A History of the Great Influenza Pandemics: Death, Panic and Hysteria, 1830-1920. I. B. Tauris, London and New York.

JOHNSON, Niall Philip; MUELLER, Juergen (2002). Updating the accounts: global mortality of the 1918-1920 «Spanish» influenza pandemic. Bulletin of the History of Medicine, 76, pp. 105-115. Em https://doi.org/10.1353/bhm.2002.0022

JORGE, Ricardo (1919). La Grippe. Rapport préliminaire présenté à la Commission Sanitaire des Pays Alliés, dans sa session de Mars 1919. Imprensa Nacional, Lisboa.

KARA, Helen (2015). Creative research methods in the social sciences. A pratical guide. Polity Press, Bristol.

KILLINGRAY, David; PHILLIPS, Howard (dir.) (2003). The Spanish Influenza Pandemic of 1918-1919: New Perspectives. Routledge, London.

LE GOFF, Jacques (org.) (1985). As doenças têm história. Terramar, Lisboa.

MASON, Jennifer (2002). Qualitative researching (2nd ed.). Sage, London.

MILNE, Ida (2018). Stacking The Coffins. Influenza, War And Revolution In Ireland, 1918-19. Manchester University Press, Manchester. 
OMS (2018). 10 threats to global health in 2018. Acedido a 31-08-2018, em https://medium.com/@who/10-threats-to-global-health-in-2018-232dafObbef 3

OMS (2019). 10 threats to global health in 2019. Acedido a 31-05-2019, em https://medium.com/@who/ten-threats-to-global-health-in-2019-fbe019ca7edf

REBELO DE ANDRADE, Helena (2001). Aspectos Epidemiológicos e Virológicos da Gripe: Desenvolvimento de um sistema de vigilância. (Tese de doutoramento). Faculdade de Medicina da Universidade de Lisboa, Lisboa.

RICHARDSON, Laurel (1994). Writing: A method of inquiry, in DENZIN, Norman K.; LINCOLN, Yvonna S. (eds.). Handbook of qualitative research. Thousand Oaks, CA, Sage, pp. 516-529.

ROLLO, Maria Fernanda (2008). 1918: Pneumónica, ou a Gripe Espanhola. Ingenium, 105, pp. 74-76. Acedido a 01-09-2019, em http://www.ordemengenheiros.pt/pt/centrode-informacao/dossiers/historias-da-engenharia/1918-pneumonica-ou-a-grip e-espanhola/

SAMPAIO, Arnaldo (1958). Subsídios para o estudo da epidemiologia da gripe. (Tese de doutoramento). Faculdade de Medicina da Universidade de Lisboa, Lisboa.

SEQUEIRA, Álvaro (2001). A pneumónica. Spanish influenza. Medicina Interna, 8, pp. 49-55.

SILVA, André Filipe Oliveira (2018). Epidemias e Historiografia em Portugal: Uma Reflexão. Comunicação oral nas Jornadas de População e Saúde "A Gripe Espanhola de 1918». CITCEM, ADEH, APD e Sociedade Martins Sarmento, Guimarães.

SOBRAL, José Manuel; LIMA, Maria Luísa (2018). A epidemia da pneumónica em Portugal no seu tempo histórico. Ler História, 73, pp. 45-66.

https://doi.org/10.4000/lerhistoria.4036

SOBRAL, José Manuel; LIMA, Maria Luísa; CASTRO, Paulo; SOUSA, Paulo Silveira (2009). A Pandemia Esquecida, Olhares comparados sobre a pneumónica 1918-1919. Imprensa de Ciências Sociais, Lisboa.

SOUSA, Paulo Silveira; CASTRO, Paula; LIMA, Maria Luísa; SOBRAL, José Manuel (2008). Responder à epidemia: estado e sociedade civil no combate à gripe pneumónica (19181919). Revista História das Ideias, 29, pp. 469-500. Acedido a 31-08-2018, em https://doi.org/10.14195/2183-8925_29_17

SPINNEY, Laura (2017). Pale Rider: The Spanish Flu of 1918 and how it changed the world. PublicAffairs, New York.

TRINDADE, Luís (1998). A epidemia da gripe pneumónica. A morte anunciada. História, vol. XX, 8, pp. 36-45.

WALL, Sarah (2006). An Autoethnography on Learning About Autoethnography. International Journal of Qualitative Methods, 5, pp. 146-160. Em https://doi.org/10.1177/160940690600500205 
WILSON, Nick et al. (2017). Remembering the 1918 influenza pandemic: national survey of memorials and scope for enhancing educational value around pandemic preparedness. The New Zealand Medical Journal, 130, pp. 53-70. 



\section{c) \\ casadesarmento}

